$x^{2}$

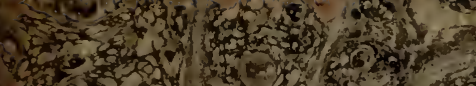

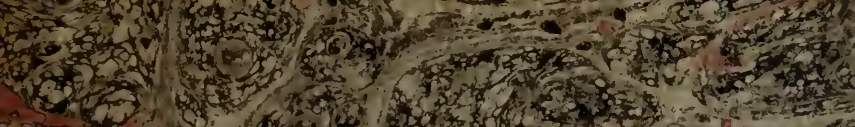

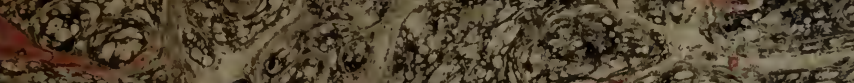

-1
B

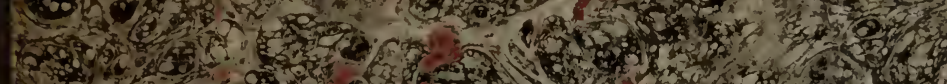

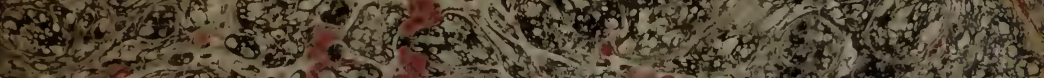

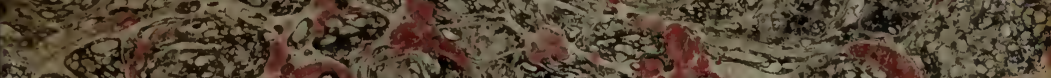

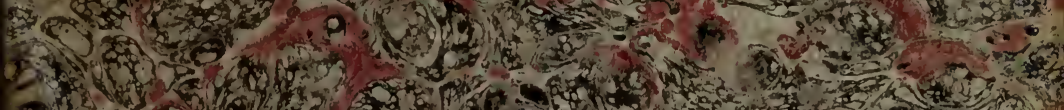

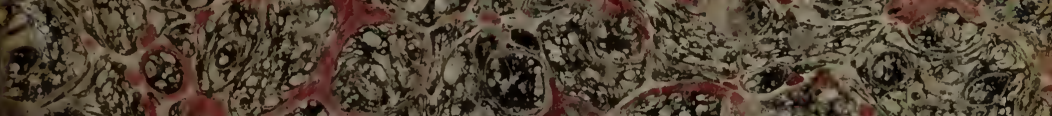

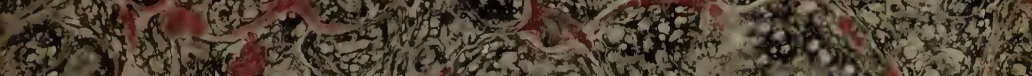

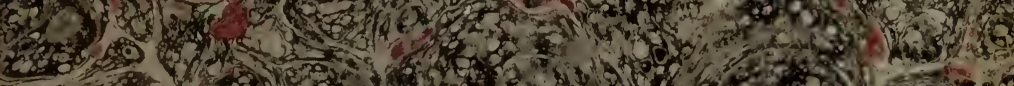

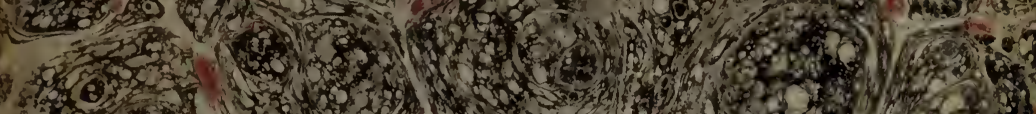

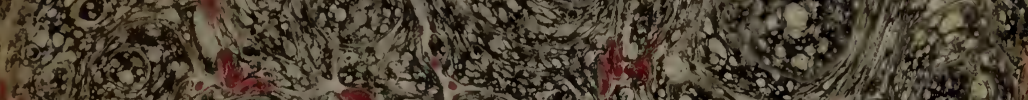

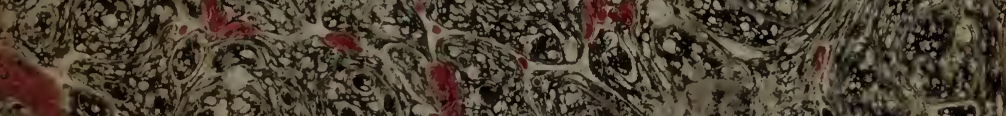

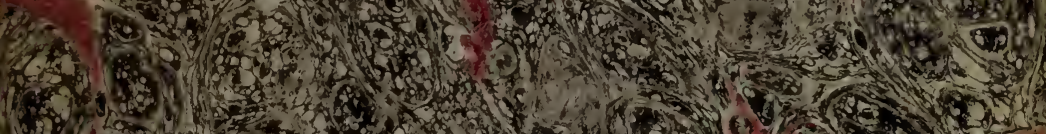

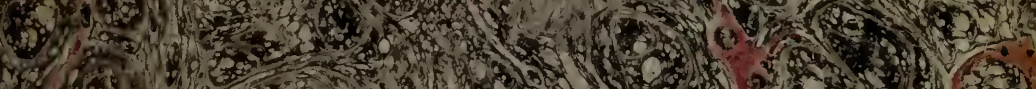

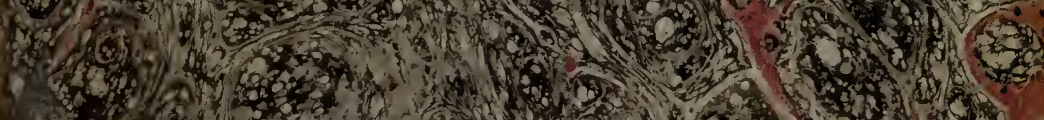

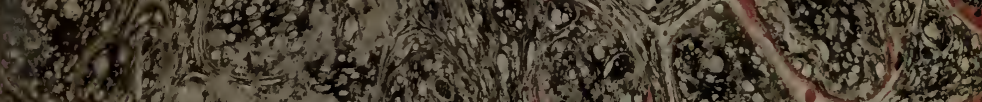

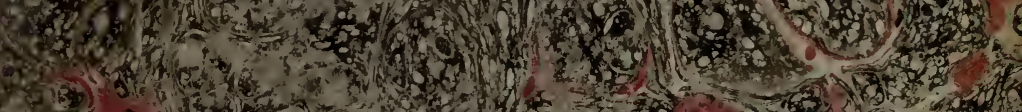

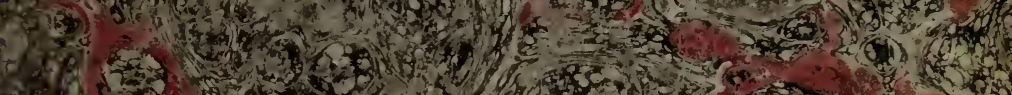

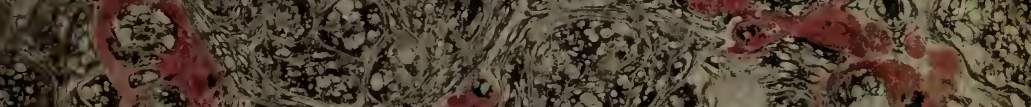

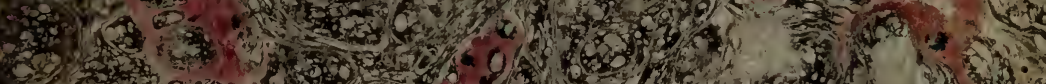

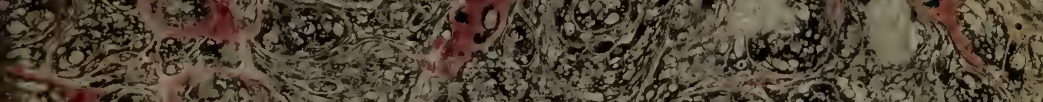

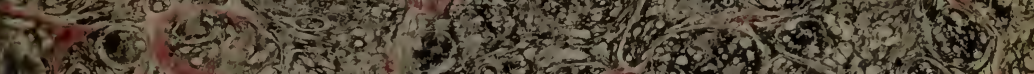
1.7.

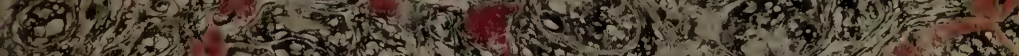

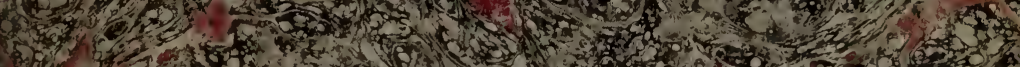

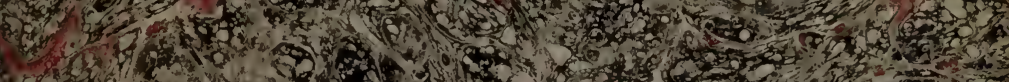

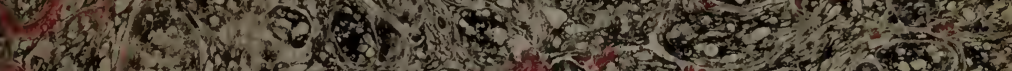

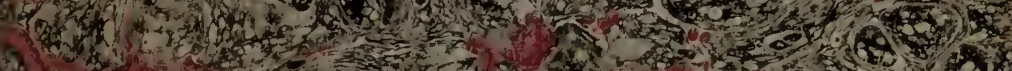

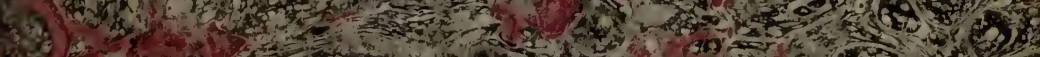

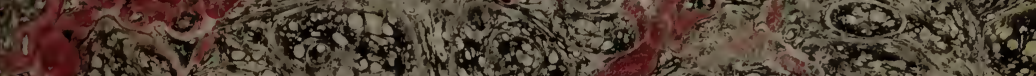

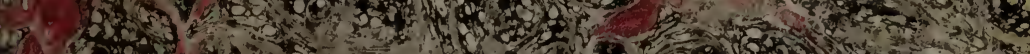

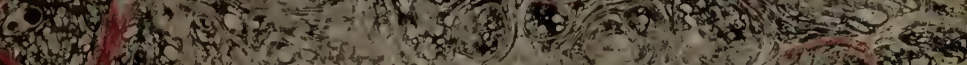

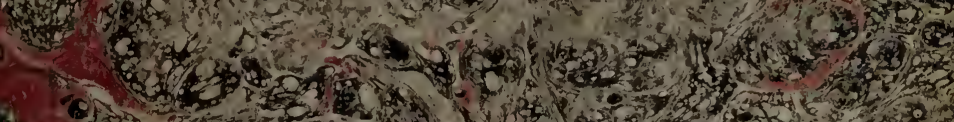

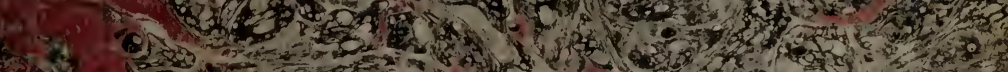

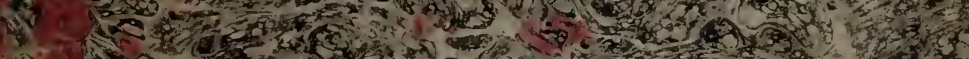

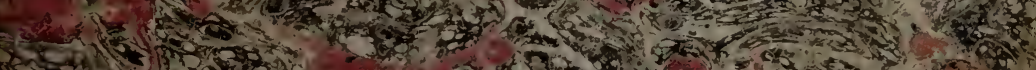

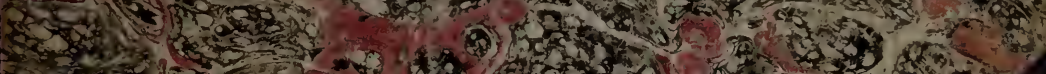

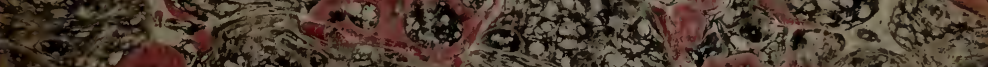

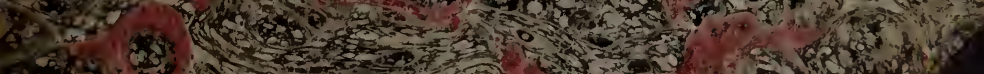

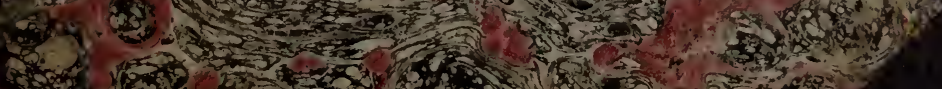




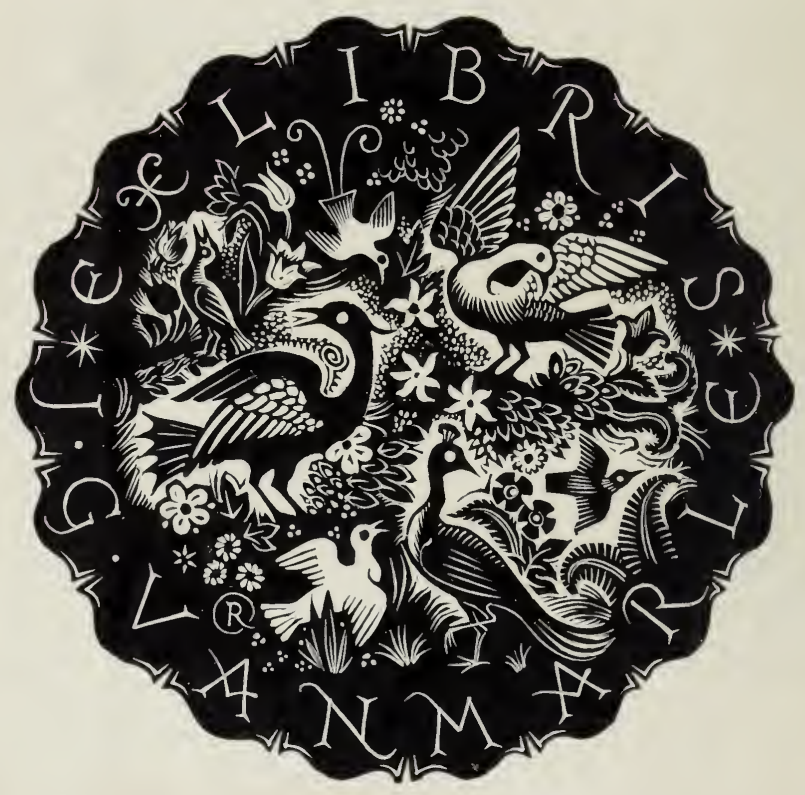




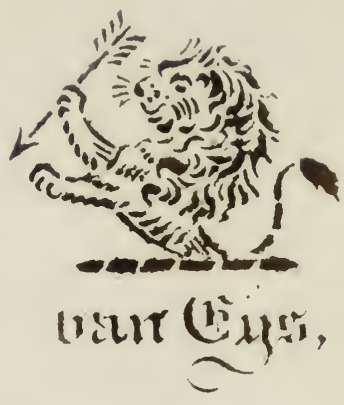


NATUURLIJKE HISTORIE

\author{
VAN \\ H O L L A $\mathrm{N}$ D. \\ V IJ F DE DEE L。
}




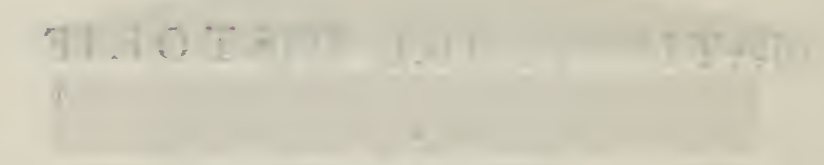

Digitized by the Internet Archive in 2016

https://archive.org/details/natuurlykehistor05fran 


\section{N A T U U R IJ K E}

$\begin{array}{llllllll}H & I & S & T & O & R & I & E\end{array}$ VA $N$

\section{H O L L A N D,}

D $000 \quad$ R

F: LE FR ANCQ VAN BERKHER.

gated. Docior en Pralector in de Natumrlijke Hiflorie ans

's Lands Univerfịteit te Leyden, Lid yan verfcheidene zoo Uitheemfibe ais Vaderlandfohe Matfchappijen der Natuur - en Dichtkunde.

$$
V \text { If } F \text { D E D E E L. }
$$

ATE T NOODIGE AFEEELDINGE NG

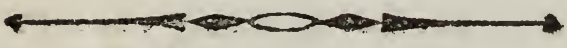

$$
\begin{aligned}
& \text { T E L E Y D E N, } \\
& \text { Bij } \quad D_{0} \quad H_{0} \quad T \quad R \quad A \quad P_{0} \\
& \mathrm{M} \mathrm{D} \text { C C C V. }
\end{aligned}
$$




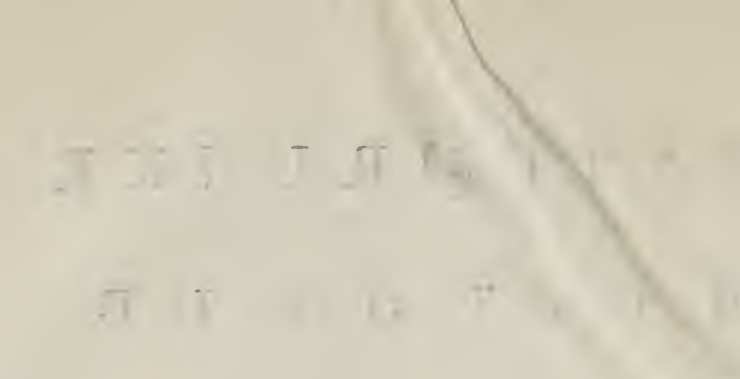

a $\mathrm{NA}$ A 


\section{IIORTE I NHOUD:}

D E R

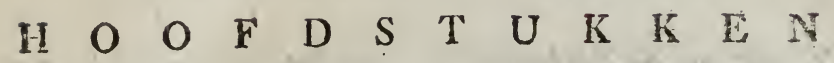
VA N HE T

$V$ If $F \quad D \quad E \quad D, E, E: L$.

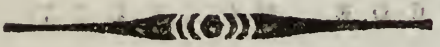

HE.T RUNDVE E.

TWE E DE A F DEELI N G。

E E R T E II O OF DST U K.

Befchrijving yan de Beenvording, het Rif, Geracmis en Beendergeftel der Koeijen. • • Bladz.. I

T W E E D H HO F D S T U K.

Behelzende de uitwendige kenbare gédeelten der Lem ciemmaten, Spieren en verdeelingen eener Koe, mitsggo ders derzelver benamingen in de huishoudelijke fpreek. wijzen der Vleeschhouwers en Landlieden. Bladz. 62

D I R D E HOOFDST.UK.

Befchauning yan het Hersfengeftel der Koeijen, desm zelfs yaten, zenuwen, aderen en fagaderen, boew zem en mergdeelen, mitsgaders het gan/che zentwgeffel door het. geheele ligchaam der Koeijen, yolgens THOMAs Wildis; met verbeteringen. Bladz. 133 


\section{K O R T E I N H O U D.}

VIER D E HOON D S T U K.

Vervolg op de verhandeling over het hersfengefuel, zoo als wit deszelfs verlengdmerg, het ganfclie weeffel der zenuwen, door de uit- on inwendige declen en ingewarden zich verfpreidt. . . . Bladz. 163

$$
\text { VIJ IDE HOOFDST U K. }
$$

Waarin, yolgens de waarnemingen en afbeldingere yan J. Casserus placentinus en anderen, inet yrimoedige verbeteringen, het gelicoi der Kociicn uitwoerig wordt befchreven. - . . Bladz. 196

\section{Z E S D E H O O F D S T U K.}

Vitvo'ige en meest. vermietwite Ontlecklunde van bet oog en de gezigideclen der Kocijen: - Bladz. 270

B V V E N D E H O O F D S T U K.

Ontyouwende en befolrijycnde de bijzonderheden yan de roukdeelen der Koeijen, nuct gehcel nieuwe if beclängen. . . . . . . . Bladz. 343

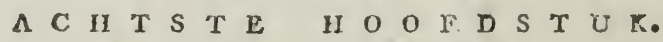

Ilandelende over de zinurigelijke declen yan den Smaak, de chijlmaking, het gebit, de tong en het verhemelte der Runderen. . • . Bladz. 593 
K $O R T E I N H O U D$.

N E G E N D E H O O F D S T U K.

Behelxende nadere bijzonderheden over het sintuigelijk gevocl der Runderen, met vergelijkende aanmerkingen op dat yan den Mensch en andere Diesen. . . . . . . . . Bladz. 452 
BERIGI A AN DEN BINDER? wegens hei placten der Platen, in dit Vijfile Deel.

Plaat VI te plaaten tcẹcn over bladz. Go
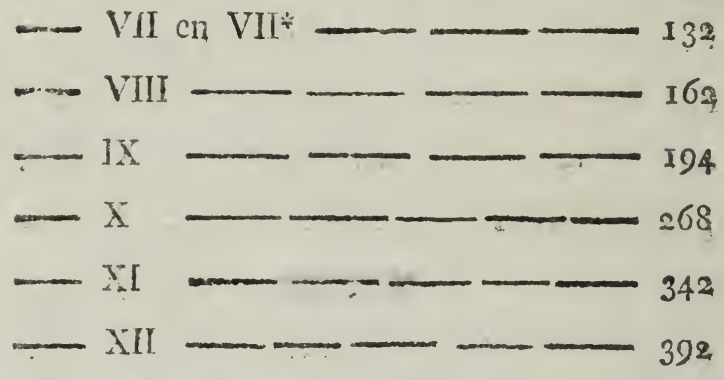

$-X I I I--\longrightarrow-45^{\circ}$

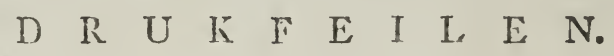

Bladz. In? regel 24 , ftaat: fmarting, moet zijn: finetting; 323 resel 4, ftaat: wer $\quad-$ de 


\title{
NATUURLIJKE HISTORIE
}

\author{
$\checkmark A N$ HET
}

\section{R U N D V E E}

IN

$\mathrm{H} O \mathrm{O}$ L $\mathrm{L} \quad \mathrm{A}$ N $\mathrm{N}$.

TWEEDE AFDEELING.

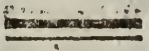

EERSTE HOOFDSTUK.

Befchrijying yan de Beenwyording, he

Rif, Geraminte en Beendergefiel

$$
\text { der Koeijen. }
$$

D

at het Beendergeftel in aile Dièren de fundamenteele gewrichten zijin, waar aan al-RUNDVRE。 le beweegbare fpieren en peezen zijn inge- il. Af lijft, alle zenuwen, -bloedvaten en ingewan-1. Hoodds, den zijn gehecht of omgevlogten, en zich in het beenmerg verliezen, behoefr geen bewijs , nademaal alleDieriijke wezens deze eigenenfchap: pen hebben, en de Mensch, het heerfchappij befenend, het vernuftigst wezen yan die alII. STUK.

A .. len 


\section{NATUURLIJKE HISTORIE}

get len, dit allezints ervaren is. Het is imeundver- mers het vernuft, de handigheid, de opmerII. Afd. king van den Menfch, die de Beendergeftel1. Hoofdrt. len der Dieren nict alleen kent en nagaat, maar dezelven door kunstbereiding en vlijt, van alle fpieren ontbloot, in het beendergeraamte zet en bewaart, on vervolgens de zamenvoeging der gewrichten, knokken, beenderen, ribben en hoofdbeenderen eigenaardig onderfcheid, en clk ccro noam naar zijnen aard geeft. De Ouden hebben voorlang veel werk gemaakt van het bereiden der geraamten en beenderen: zij hebben dezelven zeer wel gekend, doch or zijn tusfchen - eeuwen geweest, warrin die kunde zeer verwaarloosd is geworden; altans de afbeeldingen, in die tijden vervanrdigr, zijn, bij mangel van naauwkeurige Teekenaars, zeer gebrekkig; hier en daar is er fomtijds een eenige, ' $t$ wclk door den beugel kan. $\mathrm{Er}_{\mathrm{r}}$ is een boekje bekend van zekeren $\mathbf{V A N}$ DIjK, over de Geraamte der Dieren, vol Beenken-platen, doch alleronachtzaamst on flecht. De Dis.

Duitfchers hebben in de vorigc eeuw begonnen, vooral omtrent de geraamten der vogelen en visfchen, eenige vrij goede afteekeningen te geven. De Italianen, als EuSTACHIUS, EABRITIUS, CASSERI, VALESNERI, VALENTINUS: ook de Erggelfche MALPHIGrus en verfcheiden anderen, gelijk ook de beroemde Nederland/che vesalius, en de Fphemeridis, en vele Academifche Verhandelingen, hebben insgelijks de Beenkunde der Dieren toegelicht, doch van deze allen ziin het meestal of gedeelten of enkele ge- 


\section{VA N H O L LA N D.}

heelen, die deze of gene befchreven heeft. De Leydrche Hogefchole heeft bij hare eerfte ${ }^{\text {RUNDwre }}$ oprigting evenwel Ontleedkundigen opgele- II. Afd. verd, die hun work gemaakt hebben om ge-1. Hoofdr. raamten van allerlei Dieren te bereiden en te bewaren, en daar mede het Theatrum Anatomicum te verfieren; doch heden, ik weet niet door welk een toeval, zijn dezelven meest weg : er waren Paarden, Koeijen, Schapen, Bokken, Hertebeesten, Honden, Katten, Tijgers, Leeuwen, kortom, aller lei Vee in volkomene geraamten, en dat wel met ongelofelijk geduld met ijzer - en koperdraad aan een verbonden; en vooral mer opzigr tot den Mensch, durf ik zonder fchroom roem dragen op de heerlijk bereide leenderen van HEURNIUS, RAUW en BIDLO, welke door de zorg van den Hoogleeraar SANDIEORT gelukkig de verwoesting ontrukt en vermeerderd zijn, terwijl dezelven door des. zelfs uitmuntende Befchrijvingen en Afbeeldingen van Zieke Beenderen, in dic vak, boven eenige zijner Tijdgenoten uitmunteden, en gewisfelijk in dit vak den roem van Leydens Hooge Schole bevestigt heeft, als waardig navolger van zijnen grooten voorganger ALBI- Nus, die de Beenkunde der Mentchen to een non plus ultra gebrage heeft. Nu evenwel in mijnen tijd, is ook dat nuttig gedeelte van de Beenderkennis der Dieren weder ontloken, fints de beroemde DE BUFFon en DaUbenton, met behulp van hunne Leer. lingen, genoegzaam van alle bekende, zoo Inlandfche als Uitheemfche Dieren, zeer

$$
\text { A } 2 \text { naมพ- }
$$




\section{NATUURLIJKE HISTORIE}

BET naauwkeurige afbeeldingen van Dierlijke deeR UNDVEE. len, maar vooral geramtens gegeven hebben;

II. Ad. een wonderwerk, hetwelk zeker de vorige 3. Hoofdr. eeuwen befchaamt, en in de volgende de nagedachtenis dezer groote Mannen, nog in het waardig overfchot hunner eigen gebeenten zal doen eerbiedigen. Wat ons betreft, de befchouwing en opmerking dezer zaken, hadden zelfs in de eerfte jeugd, toen wij weinig dachten tot een dergelijke taak gefchike te zijn, ongevoelig onze bijzondere natuurdrift opgewekt, om zonder onderrigting of de minste kunde van ontleedkundige regelen, allerlei Diertjes te ontleden; op te zetten en er geraamten van te makerr, waarin wij zoo gelukkig flaagden, dat wij er eene goede verzameling van bezaten, die bijzonder den Hoogleeraren gaubius, albinUs, ALcalMand, en ook de Engelfche Monro der befchouwing waardig achtten, en mij zelfs, alrede tot den middelbaren ouxderdom van dertig jaren gekomen, gehuwd en in een ander beroep geplaatst, overhaalde om mif hier verder op, toe te leggen, gelijk ik dan ook eene verzameling van dierlijke beenderen, geraamten en vergelijkende Natuurkunde bijeen had, zoo ik nederig meene, in dien tijd in Leyden of in Holland, behalven die van den grooten CAMPER, niet bekend, maar toen de woedende burgertwisten het lie. ve Vaderland begonnen te fchokken, en dezel. ven zich ook uitftrekten onder den geleerden Itand, ben ik, die met leedwezen deze $t w i s$. ten zag aanbreken, en mijne vaderlandfche 
gevoclens wilde handhawen, in onaange- $\mathbf{R R T}$ naamheden gewikkeld, waar door ik deze RunDveE. verzameling mij heb moeten afhandig ma- II. Afd. ken, gelijk dezelve ook dan opentlijk tot ${ }^{\mathrm{L}}$ Hoofdr. Amfterdam verkocht is, en de Catalogus daar van nog in wezen is; evenwel de Natuurlijke Hiftorie der Koeijen, daar ik mij wel het meest op toegelegd had, lag mij nog te na aan het hare, zoo dat ik de voornaamfte tcekeningen, deelen en gedeeltens daar van, benevens her beendergeftel, meest bewaard had, en bijzonder de geraamtens en afbeeldingen, die ik u, geachte Lezer! thans in de naastbijgevoegde Plaat mededeelen en befchrijven zai. Vooraf evenwel, oordeelen wij het noodig eenig begrip van den aard der Beenzelfftandigheden in eene Koe of een Rund te geven.

Het is bij de Natuurkenners, vooral bij Zelfftan: de Ontleedkundigen overbekend, dat de digheid hardheid, weekheid, bonkigheid, kraakbee- beenderen. nigheid, enz. in de Dieren merkelijk verfchild, ja dar meer is, in een en hetzelfde Dier, naar gelang der jaren, arbeid of andere bijkonende oorzaken; er is zelfs een kennelijk en wel degelijk regelmatig verfchil in de Dieren zelve, die zulk een trap van verandering ondergaan, dat de ge. flachten als in een fmelten; de wormen hebben geene beenderen, maar daar die halfflachtig beginnen te worden, bekomen zij fteun. felen (osfa (aepiae) enz. de infekten heb. ben de beenderen buitenwaarts, en de fpịeren

$$
\text { 4. bin. }
$$




\section{NATUURLIJKE HISTORIE}

RET binnenwaarts; de visfchen en kruipende dic* UNDVE. ren hebben graten, welker zelfitandigheid mer-

II. Afd. kelijk van het beenachtige verfihilt, of 700 3. Hoofdlt. zij daar na hellen, naderen zij an het halfflachtige, als de kraakbeenige Cartilagineuze, de Steur, de $\mathrm{Rog}$ enz. doch alle deze gratachtige becnderen zijn dige, dat is zonder merg of porien, zoo dat zij geen lucht in. laten, ten minften nict 200 als de beenderen der Lucht - en Landdieren, het geen natuurlijk ook hunne gefchiktheid. om in het water onder de aarde te wemelen en te zweeven, nict vereischt; daarentegen zijn de beenderen der vogelen allen meest hol, en in ftaat om lucht te bevattén, en dat wel zoo wonderbaarlijk, dat die vogelen, dic zeer hoog in de lucht vliegen, als Adelaren, Duiven, Kraaijen enz. tot in de klein. fte beenderen lucht hebben, en dus, als voor het lucht-element gefchikt -zijnde, rogelen des Hemels genoemd worden. Men kan gemakkelik zich een befpiegelend vermak ver-

knnst- fchaffen. Laat ik mijnen Lezer dit kleine greep kunstgreepje leeren. Men neme eene volluche in de wasfen Duif, niet al te oud, en houde die

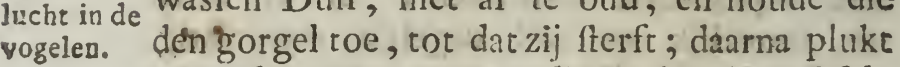
men de veeren weg, die onder den okfel, ain het fchoudervleugelbeen leggen, ontbloot dan omzichtig het fchouderbeen, en makt er met de punt van een fchaar, elst of mesje een gaatje in: daar na fteekr men een koper buisje, of om de gereedheid, een rabakspijp, door den bek in de longpijp, 


\section{$\checkmark A N$ H O LLAN D. ?}

en blaast dan de longen ftêrk op, houdt de HET andere hand over het gaatje, in het afinbeen gemaakt, en gij zult met verwonde- II: Afd. ring de lucht of de wind nit het been voe. . Hoofats $^{\text {. }}$ len uirblazen, en daar door overtuigt zijn . vain de onnafpeurlijke wijsheid des Scheppers, om aan de in het lucht-element levende Dieren, zulk eenen verbazenden invloed der lucht te hebben ingefchapen; maar daarentegen be. fchouwt men wederom gevogelte, dat niet hoog vliegt, en meest langs of op de aarde leeft, gij zult er te vergeefsch die holle gebeenten en fubtielen invloed zoeken, als bij voorbeeld, de Hoenders, Kalkoenen, Strand. duikers, Meerkoten, Waterhoenders enz. welker beenderen, alhoewel ook hol, nogtans altijd vol merg en dik bloed zijn, ei daarom minder luche doorlaten.

Deze verfchillendheid brengt ons nu dan Porien juist daar wij moeten zijn, dat is, bij onze der B. Koeijen, als behoorende tot de viervoetige Dieren: onder dezen kan men zonder be. risping voor vast ftellen, dat derzelver beenderen, het zij dezelve teeder en ligt, of kraakbeenig, of grof en knokkig zijn, altoos porieus, dar is, fijn, of jong zijnde, eenigfins brijzelig zijn, of vast en hard, dat is beenachtig, als zij ouder zijn, of zonder porien, ten minfte zonder merg, fteenachitg aan de tanden, als ijvoor enz. Dat de beenderen der Koeijen, ten minfte de kleine beenderen, niet van den allerharditen aard zijn, blijkt uit het verteren derzelven in de mang der Honden, die ze diktwijls geheel

$$
\text { A } 4 \text { in- }
$$


WET inflokken, daar ze meestal de PardenbeekUNDVEr. nen laten leggen; dat vervolgens alle been:

II. Afd. deren uit afzonderlijke beenmakende ftoffen, L. Hoofdrt angroeijen, uitdijen en volwasfen worden; weike ftoficn uit het merg, het inwendig. pit der bẹcnderen aanzetten, naar den aard van het dier, dẹszelfs ouderdom en geftalte, Naar den aard van het dier, on dat een Muis, een Hond, ecne Karat, een Konijn euz. dieren zijn van ligte beweging, dus zijn hunne beenderen ook onder de ligtfte en holite. De Kemelen, Paarden, Olifanten, Ezcls, in één woard, alle Lastdieren hebben de beenderen vaster en $z$ waarder, weinig hol; oude Paarden hebben de beenderen of fchonken als toegewasfen, waarom men ook de beenbreuk in een Paard veela! voor ongencesfelijk houdt, herwelk evenwel zoo vast nier gaat, alzoo $i k$ meer dan één Veulen of Paard gekend heb, wiens bęenbreuk genęzen was.

Het is evenwel bewezen, dat de beenderen der Kaeijen eene ivoorachtige polijsting. annemen, het geen overbekend is door de been-kunstwerken, die men van Koeijenen Schapen - fchenkelen maakt. Hier te Lande worden de afgeknokte Koefchenkels op. de Lijmmakerijen hageiwit gebleckt, en ann de Beenen-knoopmakers verkiocht, waar van zot Oudewater, zoo ik meen, de voornaamfte Fabriek is. Hct bruinmaken van Koebeenen of beenen-knoopen door branden of anderzins, is bekend, dan de kunst hoe, boop ik nader te onderzoeken.

Maar 


\section{Xa HOLLAND.}

Maar tot de Koeijen: zoo er eenig dier hET is , welks beendergeftel bijzonderheden RUNDvEn: heeft, die het alleen eigen fchijnt te zijn, Ir. Afd. is het eenc Koe: men vindt in alle de been-1. Hoofdho deren van eene Koe, een Stier of Os, fpons- Koeijen achtige holligheden, of zecr zigtbare po-Beender. cien, als eene fpons, welker tusfchenruim-groei. tens met fappen, mergfappen, gevuld zijn; maar bovenal zijn de groote beenderen, als daar zijn, de fchouderbeenderen, heupbeenderen, armbeenderen, en vooral de hoofdknokken, hol en vol merg, dije daarom ook den bijzonderren naam yan merg, mergpijpen bekomen, weike mergpijpen bij de Boeren pen.

Mergpiji:

murfpijpen, murfbeenderen genaemd worden, waar door zij iets weeks of zachts. vertaan: het is zoo gaar als murf. Dat deze beenderen bijzonder gezocht worden om er krachtige faepen en bouillions van te koken, behoeft men aan de Koks en Keukenmeiden flechts te vragen. Dit merg wordt zelfs uit de opgekookte beenderen als, eene lekkernij op den disch uitgeftoten, en op brood gegeten; deszelfs zelfitandigheid kan men niet zeggen vet te zijn, men kan het ook geen vleesch noemen, noch ook'zenuwachtig, evenwel fchijnt het iets van beiden te bezitten: tot nog toe, zoo veel mij bekend is, zijn er geene afzonderliike Chemifche proeven op deze bijzondere ftof genomen; en wat het Ontleedkundige betreft, zoo eindigt hier, even als in het herfenmerg, de fchranderheid en het vernuft wan den kundigften Anatomist; het is en

$$
\text { A } 5 \text { blijf }
$$




\section{ro NATUURLIJKE HISTORIE}

ивт bliffe cere bijzondere merg-weeke ftoffe, RUNDVEE. welker uitwerking wij zien, doch de be-

II Afd. werking daar van niet kennen; want, gelijk 2. Hoofdrt wij de zenuwen wel kunnen nagaan in derzelver gevormde taaiheid, aantrekking en elastiek vermogen of gevoel, zoo kennen - wij derzelver anngroei en hoofdftoffelijke $z a-$ menweving en gevoeligheid nog niet volkomen, als. zijnde dit als nog de voornaamfte ewistappels der geleerden, 'te weten, op het zenuwvocht (Liquidum Nerveum), en der. zelver gevoeligheid (irritabilitas), of het Enormon Hypocratis, zijn (impetum faciens) nog onbeflist. Iets dergelijks, en, naar ons inzien, niet minder moeijelijk te bepalen, is er in de kennis van het beenmerg, de bijżondere aangroeijingen bij het herftel van gèbroken en afgefcheiden beenderen, opgefloten: Geene beter voorbeelden echter, meenen wij, kunnen ten minfte een weinig licht aanbrengen, dan de mergpijpen der Koeijen. Men vindt, en een iegelijk, die nechts een gekookte runderfchonk of mergpijp op tafel krijgt, kan het nagaan: men vindt, zeg ik, in de mergknokken en pijpen der Koeijen inwendig, tusfchen het merg, uit de wanden der beenderen, zekere fpietsachtige fijne vezelen, die allengs beenachtig worden, of die bij-toeneming van den ouderdom der Koeijen zelfs tot vast been aangroeijen, dermate, dat die vezelen in eene tweejarige Koe reeds been zijn: deze fijne beenvezelen vertoonen zich als een geheel weeffel van rag, zoo als in Plaat VI.

Fig. 


\section{จ N H OLLA ND: BI}

Fig. I. naar het leven is afgebeeld, in den doorgezaagden knop of het hoofd (Condy- RuNDves. lus ) van een mergbeen. De rand of de Ir. Afa. beenachtige zelfitandigheid zelve, vertoont $\mathbf{I}$. Hoofdrt: zich insgelijks porieus, en vervolgt zoo het geheele been langs: hier uit kan dan oncegenzeggelijk bewezen worden; dat althans in de Koebeenderen het merg niet alleen de voedifer der beenderen is, maar ook wezenlijk de beenftof zelve wordt.

Maar nu fla men het oog eens op Fig. II., hier ziet men een ftuk van een doorgezaagd been van eene zevenjarige Koe, hier ziet men wijders met verwondering bladachtige getakte bladeren midden in het gebeente; deze bladeren zijn zelfs zoo hard en vast, als het been zelve; zij zijn niet zeldzaam te ontdekken, fchoon in het eene been meerder en breeder dan in de anderen: deze af beeldingen, op drie vierden verkleind geteekend, zijn met het bloote oog te ontdekken, gelijk men kan nagaan; maar om eens een fraai levensgroot gedeelte te vertoonen, is Fig. III.' gefchikt: dit fragment is een der fraaiften, die ik onder een goed antall dergelijken der af beeldinge waardig gekeurd heb: men ziet er onbetwistioar, als 't ware, een yegeterenden, plantaartigen, takachtigen wasdom in, volmakt als dat foort van fteenachtig zeegewas, dat men Water-coraal (Millepora foliata) noemt, en uit een zeker fteenmakend đlijm, zoo an. deren willen, dieren - cellerjes, geboren wordt. Geen ei gelijkt meer een ei dan dit foor: 
BtT fórt van zeegewas, en dit beentakje uit gundVEE. een Koeijenbonk. Ik heb meer dan eens II. Afd. met dit ftukje en andere dergelijken, de I. Hoofdr. liefhebbers van zeegewasfen verfchalkt, en hunne kunde getoetst, en waren er die het als cen nieuw fpecimen aanzagen, die waanwijzen liet ik even wijs, doch de doorzigrigen, die wat nader keken dan op goed geloof, hielp ik op den weg, met hun aan te toonen dat het been was, en deed hen letten op de porien van het water-koraal, bekend bij den naam van duizend porien (Millepora voormeld), en op de effenheid van het been, waarmede dan de zaak be nist was, door het onderfcheid der porien. Bij deze gelegenheid kan ik niet voorbij, iets, dat hier bij behoort, in te lasfchen. Ik heb bij zekrere gelegienheid van de zeer loffelijke en doorgeleerde Heeren JAN en ADRIAAN ESURE, beide voorbeeldige lichten en Doctoren in de Philofophie en Wiskunde, een zeer groote kop bekomen van een Walvischdier, bekend onder den naam van Bons$k o p$, bijna vijf voeten lang: dit geweldig hoofd, te groot zijnde om in mijne verzameling te plaaten, befloot ik hetzelve in deelen te laten doorzagen, het geen, door de hardheid, niet zonder zwaren arbeid kon gefchieden: onder het doorzagen en verwringen der gewrichten, wrong ik digt tegen het fteenbeen (Os petrofa) een ftuk been daar uit, hetwelk tot mijne verbazing volmaakt een zeegewas verbeeldde. Dit ftuk plaatste ik onder mijne verzameling 
van Zeegewasfen, alwaar dit altoos als een Heт ongemeen foort doorging, ten ware ik de RUNDVEE kundigen onderrigtte. Zeker neuswijs ken- II. Afd. ner van rang bood er goed geld voor, om I. Hooidita het in zeker vermaard Mufaeum te plaatfen; ik toonde hem zijn lompheid aan, en heb naderhand dir ftuk bij mijne verzameling openlijk laten verkoopen voor het geen her was.

Ik laat dit daar; doch ik breng dit voorbeeld alleen alhier te berde, om daar door aan te toonen, dat er in het beenmerg der dieren, in eenen vollen zin, in de beengroeis jing, een foort van uitbotting, takfchieting, beenkalkachtige aanzerting plaats heefr, gansch niet ongelijk, aan de aangroeijing en uitbotring die in de Prantdieren, Koralen, Steenen Zeegewasfen: door aanzetting plaats heefr; vooral in de Millepora en Corallia; als ook de Gorgonia, echter zonder hier de werking van kleine polijpjes te erkennen. Ik verfta door aanzetting hier ftremming, verharding, beenwording. Dan, dir flechts eene problematieke vooronderftelling zijnde, laten wij dit tot nader onderzoek over, en volgen liever, tor nog toe, het zekere, hetwelk Fig. IV. ons zal leren. Dezelve verbeeldt eene diametrale doorgezaagde fchijf van een pijpbeen van een Kalf van 10 weken oud, gedeeltelijk inwendig nog kraakbeenig, en uitwendig het been nog niet tot volkomen hardheid: de buitenkorst van dit been was vrij kennelijk afgefcheiden van de binnenfte bekleedfelen, dar 


\section{I4 NATUURLIJKE HISTORIE}

wer is, het zoogenaamd periofium (beenylies)

aUNDVEE. ( zie a a $a$ a, ) dat aan alle dierlijke beenderen

II. Afd. annkleeft, was nog week; onder dit lag de [. Hoofdst beenachtige zelfsftandigheid der pijp zelve, doch die zich nu als een ring vertoonde, $($ zie $b b b b$, ) en als ' $c$ ware den wand vau het been formeerde, waar uic dan onmiddelijk een zeker foort van beenweeffel volgde, hetwelk val fponsachtige porien was, (zie ccc $c, y$ welke porien eindelijk in den cirkel der inwendige wanden de holte van her been formeerde, (zie $d d d d$,) zoo dat deze drie nu nog in het kalf onderfcheiden beenwanden, eindelijk bij meerder ouderdom, geheel en al tot een groeijen, tot dat dezelve volkomen been zijn; maar nu ziet men bij e eee, in het midden dezer holle beenfchijf, het merg natuurlijk leggen : dit vertoont verfcheiden rondachrige bollen in de door. fnijding, doch, in het been overlangs doorgefneden, fchijnen het langwerpige klieren; alle deze klieren, laat ik liever zeggen,

Merg- mergkleinzingen, hebben wederom ontelbare bijkliertjes en vezelen, die onmiddelijk aan den binnenwand van de pijp verbonden zijn, doch niet te min, allen als in flijm. achtige bekleedfels opgefloten, 200 en in dier voegen, als de uitpuilingen der weeke hersfenftoffen, onder, om, en door humne zelfitandigheid. Als men nu deze geteekende voorbeelden toepast op onze opgave, te weten, dat het merggeftel der Koeijen buitengemeen gefchikt is tot het fpoedig formeren van een bijzonderen aard van gebeente, dan 
zấ er, naar mijn vermoeden, geene reden van нะт twijfel overblijven, of ook in dit opzigt RUNDVRE verfchilt de beengroeijing vrij wat van den II. Afd. Mensch, want daar cen Kalf van een tot I. Hoofda Ewee a drie jaren, zijn volwasfen beendergeftel heeft, is de vastheid der beenderen niet volwasfen in den Mensch tot beftendige hardheid, voor zijn zestiende of achttiende jaar, waar van het zeikerlijk moeijelijk is om re. den te geven, even $z o 0$ min als wij dit wegens de vroege teelkracht der Runderen kunnen doen; of nu de Itoffen der beenwording in onderfcheiden Dieren, cenigermate verfchillen, ftat nog te onderzoeken: intusfchen blijft er niet te min eene overeenkomst in de oorfprong dier groeijing uit het beenmerg zelve. Deze onze gedachten en ondervindingen bevestigen het gevoelen van den Italiaanfchen Natuuronderzoeker GAGLIIRDI, welke lieefe opgemerkt, dat de beenplaten of beenftof- Beenplav fen, fchelfers, indien men die dus gelieft te tjes. noemen, geformeerd worden door klcine ye- schelfers. zelachtige beentjes, die nu regt, dan f́chuins door elkander heen dringen, en de zelfftan. digheid van been uirmaken. In onze voorbeclden in de Kocijen houden wij het voor bewezen; doch hier moet ik al wederom, ter nadere ontdekking, den leergierigen een handgreep leeren, die niet algemeen bekend is, namelijk, om door de porien der beenderen de mergvaatjes te kunnen zien. De Heer MONRO, thans beroemd Hoogleeraar: oxfort, in de bloei mijner ondleedlie$\cdots$ : :

yen- 


\section{NATUURLIJKE HiSTORIE}

nะT vende uitfpanningen met mij omgang hetb. SUNDVEE bende, teekende ik uit. vriendfchap veel

II. Afd. voor hem; hij had verfcheidene fraaije jon: I. Hoofditt ge kinderbeenderen in Liquor hangen, die zoo doorfchijnend warcn, dat men het beloop der met roode wasch opgefpoten vaten tot het merg doorzien konde: ik verzocht om het geheim te mogen weten; dit vlotte eerst niet gemakkelijk; doch de reuk van het Liquor beklapte het eenvoudig geheim: het Liquor was een zeer helder wit overgehaalde geest van Terpentijn, waar door de porien der beentjes doorweekt zijnde; dezel. ve helder doorfchijnend vertoonden. Naderhand heb ik verfcheiden beentjes van eerstgeboren of ongeboren dieren, op nader onderrigting van den geleerden MONRO, aldus doorfchijnend gemaakt, gelijk ook alzoo de beroemde van DOEveren op deze wijze zeer fraaije voorbeelden gemaakt, en in zijne verzameling nagelaten heeft. Wil men nu deze kunstgreep nader weten? zie daar; ik deel die gulhartig mede: dan moer men dit meest in den zomer doen, en aan beenderen van jonge of eerstgeboren voorwerpen, die men dan fpoediger ent best kan macereren, zoo echter, dat de kraakbeenige geleden meer of min verbonden blijven; hier toe behoort oplettendheid, om het tempo te treffen: deze been. deren afgewasfchen zijnde', droogt men omtrent half, en befmeert ze dan met $S p i$ ritus Salis of getemperd fterk water, tor een kleine fchuiming, als wanneer het $\mathrm{Pe}_{\mathrm{e}}$ 
fioferim en het vet der porien verteerd; HET daar na weekt en hange men de beentjes in RUNDvEe. overgehaalde Spiritus. Therebenthinae, en II. Afd. men zal van tijd tot tijad de voorwerpen door- I. Hoofdat. fchijneuder zien worden. Wat voor het overige de kunst van opfpuiten der bloedvaten aangaat, hier in kan men bij RIGER Introd. ad Mat. Medicam te rege komen, die deze kunstbehandeling van den beroemden FREDRIK RUISCI, uitvoerig befchreven heeft; en wat hẹt gebruik van de Spiritus Salis of het fterk water betreft, welks zachte befproeijing en gesting het vet of vliesachtige der beentjes en opgefpoten vaten wegbijt, dezé kunstgreep is men, meen ik; aan den keurigen Anatomicus Meckes verfchuldigt; althans zeker vermaard Menfchenhoofd, met de allerfubtiellte hersfenvaten, thans in han. den van den Heer Doctor J. A. BENNET, en door MECKEL alzoo bercid, getuige van dcze bijzondere kunstbehandeling, die mij ook door wijlen den Heer HENDRIK FEITH, mijnen bijzonderen vriend en Mecenus is medegedeeld. Deze was een onderzoeklievend Wijsgeer, die MeckeL perfoonlijk gekend, en ook in zijne eigene kunst-ontleding van eer Menfchen-oog dien kunst beoefend heeft; als ook het geheim van F. RuIsCH, om geheele Lijkjes en gedeelten van Menfchen eenigzins voor verderf te bewaren in het afgefpoelde water der Suikerraffinadeurs, waar van dat bijzender helder Limpide Liquor komt, dat een bijzonder geheim was, en aleen door dit overgehaald vocht mer Campher B 
HET getemperd, bereid wordt. Hoe dit zij, ik meen zUNDVEE dan ook geen ondienst ann jonge Leerlingen

II. Afd. gedaan te hebben, door hun bij deze gele1. Hoofdift. genheid te herinneren, en nog met een woord te melden, dat men ook op deze wijze die fraije verzamclingen van de ontlecdide aderen in allerlei boom - en kruidbladeren, na cenige maceratie, kan maken. Wijders dient nog tot narigt, dat, danr men de bloedvaten in zulke groote dieren als de Koeijen, behalven de kostbaarheid dẹr materien, ook niet gemakkelijk, zelfs niet mogelijk cen $z o 0$ groor ligcham, of zelfs gedeeltens, in warm water kan opfpuiten, dat men dan zich zeer wel, zoo als ik dit beproefd heb, van eene koude ftoffe kan bedienen, ten welken einde men flechts cen gedeelte Vischlijm in water weeke tot fmeltens toe, en daar na in dit afweekfel we. derom een goed gedeelte zuivere Arabifche Gom fmelte, en met water zoodanig ver. lenge, dat het eene lijmachtige weekheid verkrijge, en daar na dit met fijne vermiljoen, of welke kleur men verkiest, vermengd, en alzoo deze ftoffe koud en zoo $\mathrm{zi}$ j $i s$, in de bloedvaten indringe, dezelve alsdan met nog verdikter ftoffe fuit of afbindt, en alzoo eenigen tijd dezelve ftil laat droo. gen, als wanneer vooral in de fijne haarvarjes deze gemengde ftoffe zoo hard, ja harder opdroogt als de weeke vliesachtige materie, en ook de Gom tegen de inbijting van her fterk water beftand zijnde, de drooging en vastheid der opgefpoten varjes be- 
vordert: vcle, ja zeer vele dergelijke waar- HET nemingen zoude ik hicr kunnen bijvoegen; ${ }^{\text {RUNDVEE }}$ don, daar ik dic in het vervolg, daar het Il. Afd. te pasfe komt, zal opgeven, wil ik hier I. Hoofdt. niet verder uitweiden, maar liever overgaan tot nog gewigtiger anduidingen van het beendergeftel zelve:

Hier toe heb ik de zoo na mogelijke nanuwkeurige Afbeelding van een volwasfen Geraamte van een tweéjarig Vaars in Plaat VI. Het geraam. Fig. V: gefehikt om die met de hier volgende te. verklaring en aanwijzing der Becnderen, vat baar voor onze ${ }^{\prime}$ Lanidgenooten voor te ftellen; hebben wij daarom dezelve verdeeling in het oog gehouden, die wij op Plaat III. in het III. Hoofdituk dezes werks hebben voorgefteld, en oov in de afbeeldingen van de uitwendige en alle andere verdeelingen zullen volgen, te weten het voORSTEL, het MIDDEN. STEL en het ACHTERSTEL; met dit onder. fcheid, dat wij hicr, als eigen aan een tif of geraamte, verkiezent te ftellen, het yoorrif, het middenrif; het achterrif of geraamec, om reden, dat her naamwoord rif voor geraamte; hier de verftanbaarite benaming is.

Doch eer wij tot de befchrijving daar van overgaan; zij den Lezer onderrigt, dat hij dit Scelet hebber te houden als buiten de ligamenten, peezen of bekleedfclen, dewel$\mathrm{ke}_{\text {, }}$ alhoewel wij de voormamfte zullen noemen; niet wel in die allertiitgeftrektfe zin, in zulk een kort beftek, konden worden afgebeeld, en veellicht ook juist nict zoo t 2 isoo: 
HEx noodig zijn, of men kan er wel cenige fut. tiliteiten door laten glippen, vooral om dat het cns vuornaam doel niet is deze hier aan te wijzen.

\section{HET VOOR S TE L.}

Het hoofd dan, is het eirfe en voornammfte van her voorrif. Het hoofd der Koeijen, Stieren of Osfen, is boven alle andere hoofden in de geraamten van Dieren, zeer kenne. lijk aan de plat - en breedheid van het voorhnofd, de ftar of kol, darrenboven ann de kruin van het horenbeen, geliik dit alreale bij het verhandelen dier declen van het horengeftel betooge is: voorts is het geheele beendergeftel breeder en plaster, tot aan de neus en onderkaak, zoo als in het Paard niet alleen, maar zelfs als in alle ander herkaauwend Vee, want een Schaaps-Rams - of Hertenhoofd is altoos zeer veel fpitfer aan het eind en fmaller aan de kaken Het ge . raamte var een Koeijenkop, vlak op de kqken nedergelegd, vertoont zich zecr vcrheven. Wanneer men er een Paarderhoofd naast legt van gelijken ouderdom, zal de kroon ran den Koeijenkop zeer verre boven uitfe. ken, hetwelk daar van daan kome, dat de underkaken der Koeijen grooter en hoo. ger in het bovenhoofd influiten, behalven cat de kruin of het horenwortelbeen hier ook bijkomt; ook buige de Koeijenkop aan zijne wervelen meer nederwares dan in een Paard, gelijk dit onze figuur annduidt; doch wij gan over tot de verklaring. 


\section{$\checkmark A N \quad H O L L A N D . \quad 2 I$}

De kroon of kruin, bij $\mathrm{N}^{\circ}$. I aangeftipt, нЕт is het eerfte, waar aan wij beginnen: dit RUNDVEe been is fteenhard, en is bijzonder in de II. Afd. Koeijen boven andere dieren uitftekende : het I. Hoofdft. bevat en omvange de horenwortelen, die De krmon aldaar ingelijfd zijn, en als uit eene bijzonde- van 't re inwendige mergftoffe geformeerd worden, hoofd. zoo als hier voren befchreven en afgeheeld is $\left(^{*}\right)$; deze inworteling alrede verhandeld, is hier in Plaat VI. bij $N \bullet$. 2. 2. aangeduid, gelijk ook de horentoppen bij $\mathrm{N}^{\circ} 3.3$; bij $\mathrm{N}^{\mathrm{O}} .4$. ziet nqen den naad van de voorhoofdbeenderen, of de ftar, almede hier boven befchreven; deze farbeenderen liggen vlak, en breiden zich uit tor aan de oogkas, waar van zij het bovendekfel uitmaken, ( $z$ e No 5. .) kolbeen. hier zijn zij allerbreedst, doch daarentegen verfmallen $z \mathrm{ij}$, tot omtrent onder de kroon, en maken aldaar eene foort van holte onder het fteenbeen, 't welk men oorhol noemt, hetwelk wij boven hebben aangeteekend, en hier bij $N$. 6 . angeduid is; deze holte is eren als den flaap des hoofds in den Mensch: zij is in alle Runderen buitengemeen ken. Slaap des nelijk; in oude Kocijen worde zij holder en knokkig; in de Hartebeesten wordt deze hol. te even boven het oog als een bijzonder kenmerk dezer dieren aangemerkt; bij de Schapen teekenen dezelve insgelijks fierk door. Het is in den naad van cit flaapbeen, dat het gedeelte van dien oogkas wordt vervangen. Men noemt den oogkas die hollig heid, die men in her aangezigt vau alle ge- Ooghase

raan.

(*) Zie IV, Hoofit. en Plaat V.

B. 3 


\section{NATUURLIJKE IISTORIE}

HET ramtens aanmerkelijk zict in jefneit, en wel. Q UNDVEz. ker holte duidelijk de plaats $\mathrm{N}^{\prime}$. 7. aan:

II. Afd. toont, waar in den oogbol gelegen heef: 2 . Hoofdit. de Vertaler van DE BUFFon noemt het verkeerd oogput." De oogput is de holligheid traanklier, die in de hoeken van het ogghol gevonden worden, als het dier gefpierd is;

ooghol. in het geraamte noemit men het aoghol met regt oogkas, als de kasfe, waar in de oogbol, het oog zelve bewaried word, ook wel oogkuil, waar van bij her verhandelen over het gezigt der Koeijen nader zal gefproken worden. Het ooghol, de oogkuil, of oogkas, vertoont zich in de Kocijen zijlings, niet vlak van vo:en, zoo als in den Mensch, de Apen en veiè dieren, ja van vele dieren, zijn de oogkasfen in 'de Koeijen het meest zijdelings replatst: deze oogkasfen hebben hun gewelf van her voorhoofdsbeen, hunne zijlinglche wanden van hec flaapbeen, en den rand van den bodem van het jukbeen of de onder-bov'inliak; deze maken te zamen een zeer therken beenachtigen rand, doch inwendig worken deze beenderen vereenigd met de fponsachtige bladeren der neusbeenderen, en dat wel zoo fijn en bladachtig, dat zij op de minfte harde druk: king breken. Deze inwendige beenbladeren laten in hunne zamenvoeging de groote ge: zigtszenuw door; er zijn verfcheiden openingen en fpleten, dic andere gemeenfchap: pelijke zenuwen en vaten doorlaten, "en hie. en daar de inlijving der oogfpieren antoo? nen; alle welken in dit klein bettek nie 
wel zoo onderfcheiden kunnen angewezen, maar bij de verhandeling over her gezigt der RUNDvez. Koeijen breedvoeriger zullen uitgelegd wor- II. Afd. den.

I. Hoofáit:

Bij $\mathrm{N}^{\circ} .8$. is het jukbeen (Os jugale) aangewezen : dir is dat gedeelte, 't welk Jukbeen。 aan de reeds befchrevene holte des zijlingfchen voorhoofds begint. Hier onder bij No. 9. begint de eigenlijke verbreeding van de bovenkaak, waar op de wangfpieren leg. gen: dit gedeelte heeft eene zekere holligheid, waar door dit been de tusfchenruimte tusfchen den oogrand en het kaakboord aanduidt; het is bij de Koeijen uitwendig zeer kennelijk, en duidt volkomen de achtergroef, mitsgaders het oppergedeelte der bo. venkaak aan, vooral daar het dikker wordt en de inlijving der kiezen aantoont, ter plaatfe daar de laatfe kiezen in hunne groe. yen (alveolae) ftaan; ook zijn er aldaar gaarjes, waar daor de Smaakzenuwen en K wijlvaten loopen, in 'c vẹrvolg nader te ver. klaren bij de fimaakdeelen. Dit been verfmale en verlenge zich vervolgens nederwaarts bij № 10, en formeert aldaar de geheele kiezunkast der bovenkaak, en eindigt fpitsach. tig in de lipbeenderen of neusgroeven, zon. der eenige verdere rand - of tandreekenen, waar in dit been, zoo aan deze als het te. genovergeftelde aan de andere zijde, afwijkt van de gedaante der bovenkaken in alle andere viervoetige Dieren, om dar, gelijk het kenmerk der Koeijen leert, dezelve geene boventanden hebben, en de inlijving van dit been dus eindigr aan de voarte boven.

$$
\text { B \& kies? }
$$


Heт kies, bij No. 10, alwaar de neusbeenderen RUNDVE. insgelijks cindigen; ook zijn hier kennelijké II. Afd. gaatjes, waar door de kwijl- cn reukvarjes 1. Hoofdit. loopen.

Weusbeen. Bij No. I r. ziet men de naden van de deren. boven - neusbeenderen, die aldaar uit twee fpitfen allengs verbreeden, tot hunne einden aan de punten der bovenlip, alwar zij rondachtig uitloopen, tot fompe uiteinden: In Paarden en dergelijke Dieren worden deze beenderen het bovengebit in de grocven der boventanden, doch in de Kocijen is er niets dergelijks; deze becnderen zijn minder hard dan de voorhoofd - en kaakbeenderen; integendeel teeder en dun. fomwijlen in jonge beesten, vooral in de Kalven, half: doorfcbijnend, waarom de Koeijen ook zeer. gevoelig zijn an en omerent deze beende. ren. Een Paard liat zich fomtijds nog al bij de neus betasten, en zelfs gaarne, niar. eene Koe nooit zonder mocite; warem de Runderen dan ook geen breidel noch muil. band kunnen velen: eenen Os, zegt men', zult gij niet muilbanden, als hij dorscht: hetwelk zoo veel betcekent, dat een Os; gemuilband zijnde, de vrijheid moct hebben om den neus en de bovenlip te bewegen, wanneer hij dorscht, (dat is, arbeidt, ) en hem vrijheid laten on fomwijlen een weinig dorschitroo te rapen; anderszins is het althans bij ons bekend, dat men de al te wilde Stieren of Osfen een ring in den neus of muil flaat; voorts is het overal buiten gebruik, een $\mathrm{O}_{s}$ of eene Koe te muilban$\therefore$ den, 


\section{* A HOLIAND. $\cdot 25$}

den, dat is, een gebit in den muil te leg- Her gen. - Gelijk er nu twee van deze neus- Rundve: beenderen wederzijds van beneden de juk- Ir. Afa. beenderen afloopende verbreeden, zoo wor-l. Hoorda den deze beiden vervangen door zeker middenbeen $\mathrm{N}^{\circ}$. II, welk been - eigenlijk het bovenlipbeen is, en allengs opwaarts verdunnende, eindelijk in de twee zijlingfche infchiet; deze beenderen gezamenlijk, fcheiden zich gemakkelijk, doch kunnen ciarentegen, uit hoofde vain hunne teederheid, zoo gemakkelijk nict in een ontleed hoofd, 't welk van een gefcheiden (gedisfolveert) is, worden zamengevoegd. Het valt ondertusfchen niet moeijelijk voor een iegelijk, deze deelen te kennen, zelfs onder het $\mathrm{Hol}$ : landsch tafelvermak, waar bij men elkander op een Kalfskop noodigt, als wanneer men onder her kluiven zeer gereedelijk dere beenderen kan leeren kennen; dan, daar wij in een afzonderlijk Hoofdfuk over de reukdeelen der Koeijen zullen handelen, Sparen wij de wonderbare gefteldheid der neusbeenderen tot daar, waar de nagelbeentjes, verhemelte en fponsbeencjes te berde zullen ko. men.

$\mathrm{Nu}$ komt de onderkaak in aanmerking. De onderkaak, (kakement, zeggen de Boe-kaks, ren) rekent men te beginnen an deszelfs achterfte uitftek, hetwelk het fteen - en flaap. been in zijn fcharnier of tusfchenholte fluit: (zie No. 12.) van daar verbreed de onderkaak in eene Koe geweldig, in vergelijking van het Paard of andere Dieren : het farmeert 


\section{NATUURLIJKE HISTORIE}

HET een geheele vlakke driehoek, en ontvangt de RUNDVEE. $z$ ware werking der kåauw- en-herkaauw-

II. Afd. fpieren (Masfeteres) ook eene zeer fterke 1. Hcofdit, zenuw, die aldaar zijne fpruchtels fchiet, naar de ondertongfche fpieren en kwijlklieren; dit been doorgezaagd zijnde, vertoont ook inzonderheid inwendig die beẹnachtige fponfigheid, waar van wij hier boven gefproken hebben, doch die vaster wordt, naar mate hetzelve an de kiezen en tanden verfmalt. Dit been noemt de Boer en de gemeene Man kinnebakken, het geen zoo veel zeggen wil als kinnebekken, als ware het eene

- holte of bekken, waarin men iets bevat: dat kinnebakken is een zeer hart been, en weerftaat het hakmes al vrij fterk. Simsom nam een Ezels kinnebakken en verfloeg de $1 \%$ : liftijnen; een Koeijen kinnebak in een fterke boerenvuist, is geducht genoeg. Bij $N^{\circ}$. I3. ziet men deszelfs groatfte breedte: bij N?. I 4. deszelfs middelbare breedte, en de plaatfing der kiezen; dit gedeelte is doorgaans holachtig: - bij No. I5. cindelijk de dunfte en fmalite eindens, alwaar bij $\mathrm{N}^{\circ}$. 16 . de onderfte fnijtanden zich bevinden, van alle welke deelen nader berigt bij het ftuk der herkaauwing, en de befchrijving van het verhemelte, de fimaakdeelen, tandwisfeling enz. zal volgen.

Halswer. Het Hoofd dus verre afgehandeld zijnde, velen. volgen nu de Halswervelen, als ook tot het voorftel of voorrif behoorende. Hier ontmoet men eerst en vooral de hoofdwervel, 


\section{$\because A N$ I O L. I. A N D. 27}

gelijk wij die noemen; de Boeren zeggen nokof nekwerwel; deze is hier bij $N^{3}: 17$. maar even gedeeltelijk zigtbaar, om dat zij II. Af. daar in de afbeclding achter cie kroon fchuilt; I Hoordge het is niet te min de voornaamfte, die het hoofd beftuurd, nademaal alle de bewegin: gen van het hoofd op derzelver fpil draaijen, en wordt daarom den Atlas genaame; deze wervel is in de Kocijen ongemeen trerk inge. wikkeld, bijna niet, dan met groote kracht, of door lange afkooking of rotting af te knotten. Het fchijnt dat de kracht van het horengeftel, de kroon en de kruin, tegen dit been eenen magtigen wederftand heeft, althans het lijdr geen tegenfpraak, dat men dit uit het geftel der Koeijen kan opmaken, want daar het Paard, de Schapen, Bokken en Hertebeesten,"in één woord, "meest allé - viervoetige Dieren, hat hoofd met de kin tegen den bovenhals kunnen krommen, kan dit de Koe niet doen," want altijd fteekt dezelve het hoofd voor uit, en zoo dezelve al cens de kin tegen den krop aanwrijft, ge: fchicdt zulks altijd bezwarlijk: all' het welk oubetwistbaar veroorzaakt wordt door de vastheid en onbuigzaamheid dezer wervelen en de verdere cusfchenbeenderen der hals.

MIen telt zeven Halswervelen, hier bij N. 17, 18, 19, $20,21,22$ en 23 aangeduid. Zij hebben allen ftompronde geledin. gen boven op, daar integendeel die van de ruggegraat en lendenen, fcherpe uittekken hebben; derzelver inwendige inledingen zijn insgelijks ftomp, doch ontziggelijk vast in 


\section{NATUURLIJKE HISTORIE}

ABT en gewrocht; in jonge Kalveren zijn hiep ZUNDVEE kraakbeenige middenfchotten (inter/titiale),

II. Afd. doch in oude Koeijen worden zij been; zij 2. Hoosdito verfchillen in lengte en dikte, naarmate dat zij van het hoofd verwijderd zijn. Het eerite No. $1 \%$ is het gedrongenfte, het tweede N. 18. is het langfte, en formeert het begin van de hals: het derde $N^{\circ}$. 19 en het vierde $\mathrm{N}^{\circ}$. 20. zijn omtrent van eenerlei gedaante: het vijfde $N^{\circ} 2 \mathrm{i}$. wordt eenigzins bochtiger : het zesde $\mathrm{N} \bullet$. 22. verfmalt iets: het zevende $\mathrm{N}^{\circ} .23$ verlengd wederom eenigzins in de groeven, hetwelk veroorzaakt wordt doordien het aan het laatfe No. 24, alwaar de vereeniging is der ruggewervelen en het nokbeen, eigenlijk fchoftbeen, begint; men moet hier door nok niet de nek, die ook wel eens bij vergisfing nok genoemd wordt, verftaan, maar de nok van den fchoft, die naar de nok van een dak den naam heefr, welk onderfcheidsteken ook kennelijk wordt door dien de laatfte wervel $N^{\bullet} .24$. een klein doornachtig uitfteekfel voorwaarts heeft, en als 't ware daar door de overgang der halswervelen tot de ruggewervelen afperkt.

Rugge- Thans volgen dan de Ruggeweryeler, wervelen. die de ruggegraat voornamelijli nitmaken. Men ftelt dit getal gelijk aan dat dẹr ribben, te weten dertien. Derzeiver gedaance, groot* heid, verandering van groeven, beantwoord ook juist an dat der ribben; dat is die der lange ribben verfchillen van de korte. Alte deze ruggeworvelen hebbon boven op den rug 


\section{$\checkmark A$ HOLLAND. $=9$}

rug beenachtige uitfekken, die men doorn. HET achige noeme. (Zie $\mathrm{N}^{\circ} 25$ tor 36 ) Deze RunDver $_{i}$ doornige uitfrekken zijn platachtige, doch II Afd vrij fterke beenderen. $Z$ ij formeren van I Hoofdts; $N^{\circ}$. 25 tot 29 , zijnde de rijf eerfte en langfte, de nok of de voorfchoft, van No. 29 tot 36 . de achternek of achterfchofe, de fchouder, en worden aldaar korter, zoo dat zij zelfs, naar mate dar zij aan de len. denwervelen naderen, allengs eene kleine buiging of kromte achterwaards bekomen.

Alle deze wervelen zijn inwendig rond en ontvangen als in eene pijp het ruggenmerg, waar van ftraks nader. De kundige vleeschhouwers zijn zeer kiesch op de kennis der doorhakking dezer wervelen De Boerenflagters zijn er zoo keurig niet op, maar hakken maar regt toe regt ant, doch een kundige verftat de geleding der wervelen, en weet naar dat beloop de ruggegraat, nu lings, dan regts, 200 juist te fcheiden, dat cen Ontleedkundige er over verzet ftart. Ik ten minften houde het fchier voor cen kenmerk ven een kundig vleeschhouwer, als hij de wervelen naar het beloop der geledingen, zindelijk doorhakt: evenwel behoort -er voor eenen Ontleedkundigen iets meer toe, en het moet zijne aandacht niet ontglippen, om op te merken, dat het beloop der wervelen van eene Koe veel verfchilt van die in anderen Dieren, waarom wij, eer wij van de wervelbeenderen aftappen, ons deze volgende aanmerking niet laten oniglippen, namelijk: dat daar men in meest alle andere

Die. 


\section{3ó NATUUURLIJKE HISTORIE}

IIET Dieren; de Schapen, Herten en de meestê Rundve. herkauwende Dieren uitgezonderd; de wer-

II. $\Lambda \mathrm{fd}$. velbeenderen der ruggegrant zeer vast in eeri 1. Hoofdt. fluitende, toi lastdragen gefchikt ziet, als in de Paarden, de Ezelen, Kemelen enz. in anderen viervoctigen Dieren de beweging der ruggregraat en wervelen losfer è bewegelijker is, cn bijzonder in den Mensch en de. Apen, in allerlei bogten bewogen worden, dat daar en tegen het Rundvee de ruggegraat niet zoo leenig en willig buigen kan; en veel min eenigen last kan dragen, het welk dan ook natuurlijk bewezen wordt zoo uit de gedaante der wervelen voorfchreven, als bijzonder uit hunne fchier volkomen horizontale ineenfchakeling; van den kop af tot den ftaart toe, als cen regten lijn makende, en dus de ruggegraat of de lendenen, zeer zclden of nooit ingebogen nog gebult zijn, ten zij bij wanftaltige misgeboorten of groeijing: daar en tegen weet men, dat de Paarden door last dragen, vooral de Ruiterspaarden, ingevallen lendenen, die men zaalrig noemt, bekomen:- dat wijders de Koeijen op verre na zulk eene vrije beweging van hunne rugge. graat en andere ledematen niet maken als de Paarden; kan men ligt na gian; daar men de parden, vrij in de weide loopende, dikwijls zich zelven om en wederom op den rug ziet wentelen en fpartelen, het geen men al. - thans, zoo veel ik weet, nooit eene Koe; Os, Stier noch Kalf zal zien doen, maar in tegendeel wel luchtige regt op en neder gierende fprongen, waar van men zegt: het Kalf 


\section{VA HOLLAND. $3^{i}$}

Kalf komt altijd op zijn pooten neder. HET Evenwel, fchoon wij in onze Provintien de Rundve:? Koeijen of Osfen niet tot lastdragen of ploe- II. Afd. gen bezigen, en zij, zoo veel ik weet, ook I. Hoofdr; in Duitschland en andere Europefche Landen, mede niet dan tot het voorttrekken van den ploeg, of fomtijds van een kar. re of wagen gebezigd worden, zoo was dit in de Oosterfche Landen oudtijds gemeen, althans de Arke des Verbonds wierd bij de Israëliten door Runderen getrokken. In de Aziatifche en Africaanfche "Gewesten is het nog vrij gemeen, dat men inzonderheid de Buffels tot lastdragen bezigt, zoo dat zelfs de Bramins, Mandarijns en ftatelijke vrouwen der Chine en, op rijkgezadelde Buffels rijden, hetwelk de menigvuldige afbeeldingen der Reizigers, en de Fapansche tekeningen op papier of porcelein, mitsgaders een menigte van fpekfteenen, Buffels of Osfen, met een daar op rijdende Chinees vertoonen; doch daar de Buffels, inderdaad grover en fteviger zijn dan onze Runderen, is dit eene uitzondering.

Wij vervolgen met de Ribben: deze al De Rik. mede de voornaamfte deelen van het geraam- ben. te zijnde, volgen hier het gefchiktfte, alfchoon dezelve meest tot het middenftel behooren, even als de ruggenwervelen, zoo kunnen dezelve hier niet wel anders, om den zamenhang niet te verliezen, geplaatse worden. De dertien ribben aan de dertien ruggenwervelen verbonden, verdeelt men gewoonlijk in lange en in korte ribben. De lange zijn de voortic, doch zij verichillen mer- 


\section{NATUURLIJKE IIISTORIE}

fict kelijk in lengte, naar mate zij aan de borse cundere. achter de fleuteibeenderen liggen, of in het

iI. Afu. micidenrif verlengen. $\mathbb{N}^{3} \cdot 37$. is de voorfte i. Hoofdr. on de kortfie: $\mathrm{N}^{\circ} \cdot 38$. is iets langer: $\mathrm{N}^{\circ} \cdot 39$. nog langer. Op deze drie ribben rust het fchouderblad $\mathrm{N}^{\circ}$. $5^{6}$. zij zijn de fterkfte; en derzelver wervelen: $\mathrm{N}^{0} .25,26$ en 27 . het $z$ warllie gedoomt, zoo dat men deze ribben met regt de fchoft of fchouderribben noemt: hicr aan volgen nu de langfte ribben, $N^{\circ}$. 40, 4I, 4,2 en 43 : alle deze zijn zeer rondachtig gektromt tegens de ruggewervelen, alwaar zij fijn en dun van gebeerte zijn, doch in het midden worden zij plat. ter en breeder, rond uitzctteride, tot zij ein. delijk wederom met dunne uiteindeńs om. krommende, in het borstbeen $\mathrm{N}^{\circ} .50$ or. denlijk verbonden worden aan en in bijzordere groeven en gewrichten. Dat de Koekjenribben ecne kromme fchateswijze geduante hebben, behoef ik niet te melden, nade. maal de jongens al fpeelende van Koeijenribben fchaaten maken.

Achter de lange ribben, volgen de korte ribben; DE BÚFFON noemt de eerfte ware, de tweede valfche ribben; misfchien daaron:, om dat de eerfte in het borstbeen ingroeijen, en de laatfte niet dan door eene peesachtige verlenging daar aan verbonden zijn; deze onderfcheiding is niet te min bij de Anatomis. ten ook bekend. Natuurlijk evenwel, is de onderfcheiding in lange en korte ribben Men telt acht lange en vijf korte: ik tel even. wel liever negen lange en vier korte, om 


\section{$\checkmark A N$ II OLLA N D. I3}

dint de negende ribbe als ' $t$ ware een middelfte is tusfchen beiden, en dezelve ook nog RUNDVEE. gemeenfchap met het borstbeen heeft, daar II. Afd. de overige vier, althans in een geraamte, I. Hoofdit: volkomen los zijn; ik ftel dus $\mathrm{N}^{\circ}$. $4 \sigma$, 47,48 en 49 . voor de regte korte ribben: zij zijn inderdand ook kort, en ontbreken, althans in de Koeijen, die groote bogt en knikking, die in de groote of lange ribben is; ook is het acnbingfel (cippendix) der fpierzenuwen, hier alleen' het verband aan den glooi der lange ribben. Dit anhangfel verliest zich bij de ontleding geheel, zoo dat men moeite heeft om den ftand dezer ribben, in ecn geraamte wel te bewaren, gelijk bij $N^{\circ}$. 49 . blijkt, als zijnde deze laatfte, korrfte, allerkortfte ribben los en onaangehegt. Deze korte ribben, alfchoon maar vier, (anderen, gelijk gezegd is, tellen vijf in getal, ) verkorten zoo fchielijk achter den anderen, zoo dat zij eene eironde gedaante ann het ribbengeftel geven. Dit geftel nu, is dat geene, dat wij bij de nitwendige deelen het keffer noemen. Het is eigenlijk den romp, dat is, her geheele voorfte deel van het middenttel, dat de edele ingewanden, het hart, de longen en de voorname werktuigen der ingewanden bevat. Alle deze ribben nu, worden vereenigd, en aan het borstbeen, (Aternim) No. 50 verbonden. Dit Borstbeet. borstbeen is, gelijk in alle viervoetige Dieren, plat, doch bij de Koeijen is deze platte gedaante bij uirftek breeder : in den mensch zeker is na proporcie dit been insgelijks zeer 


\section{NATUURLIJKE HISTORIE}

нет plac en fterk; zelfs houde ik het daar voor,

RUNDVER dat hetzelve een der breedfte is onder de

I1. Afd. Dieren, met opzicht tot de proportie, ge-

I. Hoofdrt. lijk dan ook doorgaans een forsch wel gefchouderd IVtan een platte breede borst heeft. De Koe, een groot dier, heeft het ook vrij breed, doch minder breed dan het paard. Dit been beftaat in jonge Koeijen, uit zeven geledingen: in nuchtere kalveren is het niet alleen kraakbeenig, maar heeft zclfs zeer dunne kraakbeenige tusfchenledingen, die dan nog flijmig zijn. In oude Koeijen vergroeijen deze geledingen ligtelijk tot een, als wanneer dit been manr een enkel been wordt; gelijk dit ook bij hooghbejaarden menfchen gefchied. Tusfchen elk dezer zeven geledingen, die hier niet dan flauw angewezen ziju, is de grocf of geleding der lange ribben, zoo dat de eerfte en achrfte of negende ribbe, het voor - en achtereinde van het borstbeen bepaald; allen de. ze geledingen van het borstbeen verfmallen naar achteren, het voorfte is het breedite en platfe, ook het hardfte: het tweede en vervolgens het derde, tot het zevende, verfimalt vrij fchielijk, en eindige in een zekcr uitfiek, dat .zich bij $\mathrm{N}^{\circ} \cdot 5^{\mathrm{I}}$. van den band der ribben affcheid, en deel ncemt aan de buikfpieren; dit uitftek $\mathrm{N}^{\bullet} \cdot 5^{\mathrm{I}}$ noemt men het zwaardvormig (falciforme) uitftek van het borstbeen, en voorwaar niet oneigen, nademaal her als een krommend zwanrd zich op doet. De gefteldheid van het Ribbengeftel tor hier toe aangewezen zijnde, vol- 


\section{$\forall A$ IN H OL LA N D. 35}

ǵén de Sleurelbecnderen; N. 53 en 54. нет Deze beenderen, tevens met de allervoorfte ${ }^{\text {RUNDVEe. }}$ ribben, verbinden zich ten fterkften aan het II. Afr: vobrite gelici van het borstbeen; en dat wel $\mathrm{I}$. Hootdit. zoơ fterk; dat aan dit gedeclte de krachi sleutelvan de geheele börst afhangt. Wij Menfehen beenderen. weten dit in ons eigen geltel; in de Paarden lige de kracht van zwaar te kunnen trek ken; in de mage dezer geleding; de Krijgshelden wachten de geduchte fchokken af tegen de borst en het borstpanfier, hetwelk vooral de fchouders, de fleutelbeenderen en het borstbeen dekr; de Ko'eijen' hebben de fleutelbeenderen insgelijks vrij zwaar, doch na gerade van de grootte van het Dier, nict bovenmatig; beiden de fleutelbeenderen hebben groeven in de banden en holten van de 24 fte halswerwel (zie $\mathrm{N}^{2} .55^{\circ}$ ) ) en van onderen in de voorfte groef van' het eerfte gelid van het borstbeen; bij: $N^{\circ} .54$. is het fteunfel dezer beenderen, zoo dar, indien een dezer borstbeenderen breekt of gekneust wordt, is de hals als verlamd, en zelfs de beweging der voorpooten onmartig; het is hierom, dat men eene Koe of een Os niet lige in een haam of gareel kan fpannen; angezien deze beenderen zoo merkelijk vooruit fteken en teeder zijn, dat zij lige gebrooken kunnen worden. In Duitschland zorgt men daar ook voor, door lederen-hamien of jukken voor de Paarien, of ook voor de Jok - Osfen te maken, op dat deze fleutelbeenderen nier verwringen, Na deze beeilderen kom het Middenftel in asnmerking.

$\mathrm{C} 2$ IIET 


\section{$3^{6}$ NATUURLIJKE HISTORIE}

\section{HET
BUNDVE.

I1. Afd. Dit worit gerekent te beginnen aan den I. Hoof tt nek en de voorfchouder, tevens de voorpoten bevartende, on eindigt aan de laarfic ribbenwervel. De ruggewervelen en de rib. ben behooren dus mede tor het Middenftel, Fnaar zijn, om eierzelver onmiddelijk ver. bandaan de nekwervelen, benevens het borstbeen, afzonderlijk, hier voren, op bladz. 28 tot 35 onder de gebeenten van het voorftel befchreven. Dus komen dan eerst schou voor de fchouderbladen, (Scapulcue), No. derb!ade- 56. de fchildbeenderen, volgens den landzen. naam. Dit been noemen onze Hullander's

schild het fchild, fchildbeen, en dat zeer cigenbecnderer aardig, dewijl het als een fchild op zijde, de romp of voorfchoft befchermt. Het fchildbeen of fchouderblad, is het platte, en na gerade op zijn platfte, het dunfte been in het rif der Koeijen: in de jonge Kalven, ja Pinken zelve, is het als doorfchijnend: het fchijnt geene inwendige fponsachtige holten of bladeren te hebben, ten ware aan des7elfs knokken; het heeft een waaijerachtige gedaante, van boven breed en bladachtig, waar van blad, fchouderblad: het is van onderen ftomp, in het midden is het gegroefd; deze groef loopt met een puntige lleuf bij $\mathrm{N}^{\circ}$. 57. te zamen. Hier is de plaats, alwaar de grove fchouderfpieren hun; ne pcczen inlijven, gelijk ook de fpieren der borst zich van onderen hier in dit figuus niec zigtbaar inenten, zoo dat dit been, als een geheel afgezonderd beendeel, door 


\section{y A N HOL L A N D. 37}

gecue andere ingroeving of gewrichthollig- $\mathrm{IEF}^{\mathrm{s}}$ heid, aan de wervelen; borst of fleutelbeen- RUNOVEe: deren verbonden is, dan enkel en alleen door II. Afd. de fpieren, gelijk dit alzoo aan alle dieren $I_{\text {. Hoof }} \mathbf{t}_{t}$. eigen is. Het ftrekke hierom den jongen, Liefhebberen, om geraamten of feletien te maken, tot cene les, dat zij in het fceletteren alleraandachtigst zijn, om zoo lang mo. gelijk de anhlegting der onderfpieren te bewaren, en vooral de plaats, waar de kom of de pan, zoo men dit noeme, yan hẹt fchouderblad gelegon hecf, hetwelk doorgans an de eerfte en tweede ribbe is, dan vooral houde men het ligament of de beenderen van het fleutelbeen aan het fchildbeen verheeld, dan zal men zelden den waren fțand verliezen. Aan hẹ ondereind is minder zorg benoodigt, vermits het fchouderblad aldaar, zie $\mathrm{N}^{0} \cdot 5^{8}$. tcn fterkften verbonden is aan her bovenarm - of fchouderbeen, en dat wel zoo fterk, dat er, behalven de holten in het bekken an het achterbeen, geen fterker groef of holte in eenig gewricht der Koeijen is, te meer, daar de hoofden of opperknok. ken, zie $\mathrm{N}^{\circ} .59,5 \%$. zoo fterk en grof uitftekcn, dat men $z e$ in her uitwendig geftel cener Koe duidelijk ziet, het geen bij het vcrklaren wat mẹn door eene bonkige Koe to verftaan hebben, allede verklaart is Deze bonkige uicftek wordt ook wel elleboogsknok genaamd; dan de elleboog is een an der been, hetwelk op dit volgt: natuurlijk is hẹt de armknok, gelijk dit been ook het ware armbeen is, en bij de Vlcesch. houwers het ichouderbeen genaand wordt.

$$
\text { C } 3
$$




\section{$3^{9} \quad$ NATUURLIJKE HISTORIE}

нат Wijders kennen onze Boeren de plaatruNDVEe. fing en de gezondheid van het geftel ce.

II. Afd. ner Koe, uit deze "fchouderfchilden "zeer

I. Hoofunt. wel, en vooral de vleeschhouwers weten wel wat een beste fchildribben is, waar van ftraks nader. Voorts vind men dikwijls Koeijen, die deze fchildbeenderen zeer gedrongen en zijdelings plat hebben", dat doorgaans fchrale dieren zijn, even zoo als een Mensch, die de fchouderbladen plat en f́chrial heeft? voor een fluikfchouder te bock 'taat, ook wel eens voor een goze plattenden.' 'Bij No. 6o. is eindelijk de ware elleboogknok of de elleboor. Deze naam van elleboogg is oorfpronkelijk van de vademen der Mc̉n' fchen op en om den elleboog. Elle is een zekere maat, waar door men ecne algemeen aangenomene mat meet. Dc Latijnon noemen het cubus, cubitiss, dat zekere voctmaat betekent, zoo als nog heden de cubifche voetmaat bekend is; dera maatrekening leert de natuur ann den Mensch, door het meten op den amm, van den fchouderknok af, tot aan het gewrich: van hetzelve aan het armbeen. De Duitche vrouwen, en bijzonder de Hollandfche, hebben dit 200 grif, dat zij op den vouw en den vadem van de armen en ellebogen veel al zoo juist meten als de geeikte ellemant of elleroede. De Koeijen, die geene klecderen of lijwaten me: ten, hebben dit gebruik niet benoodigd: niet te min is de naam van ellcboogbeen hier. van oorfpronkelijk, vooral dat van elleboog. kusfen, 'chat is dat kootachtig uitftek," dat den ellcboog, den bocht der elleboog uit(1.... 


\section{VAN HOLLAND. 39}

makt, zie N'.60. Dit elleboog kusfen is overbekend geweest, en is het nog bij onze fnakfche Landzaten, want als men iemand zijn ongenoegen te kennen geeft, zegt men : I. Hoofdrt. $^{\text {. }}$ kuscht mij den elleboog. Het vooruitftoten van den elleboog, is een teken van wrevel in de kinderen als zij nier gehoorzamen willen; hier van het fpreukje:

Stout Marchie dout haar armen voor, en laat den elleboog kusfchen.

Dit uitftek van het elleboog kusfen, is stranbij de Koeijen ongemeen fterk, doch hetbeen. behoort eigentlijk aai het gewricht van het ftraalbeen No. Gr. Dit ftralbeen is het ach. terfte van de twee beenen, die het armbeen Armbesn. uit maken, en is bij de liefhebbers van de deien. jage op de Hazen, bekend onder den nam van Hazen/prong. Deze armbeen. deren, fchoon twee in het getal, vereenigen zich echter in oude Koeijen, en worden als cen been. Zij zijn zeer onderworpen aan die aangroeijing, vooral van onderen. Het eigenlijk armbeen is dat, het geen men de pijp noemt. Het is inderdaad ook een foort van eene mergpijp, en aan de bovenfte en onderfte uireindens verbreedende, in her midden dunder, zie No. 6r. 61. naar de onderfte zijde verbreedt het meerder, en formeert aldaar de groeven des kniegewrichten van ęene Koe, zie N 62. doch in den Mensch cic buiging der arm, zoo dat men bij vergelijking k.n ftellen, dat de kniẹën der koe en van alle and we

$$
\text { C } 4 \text { viera }
$$


RUNDVEE. viervoetige Dieren, in dit gedeelțe, dat gec:

II. Afd. ne is, het geen men in den mensch her

I. Hoofdit. armgewricht noemt. In de achterpoten is verfchil, doch deze zullen bij het achterftel volgen, om hier niet te verwarren. Net het dijbeen en het fcheenbeen, blijven wij bij de voorvoet of de hand, zoo als de vertaler van $\mathrm{DE}$ : BUFFon dit ook zeer wel heeft overgezet. Hier komen dan voor, de kniefchijven of armgewrichten, deze beltann uit krakbeenige tusfenlagen cn kootjes, dic schotel-men om hunne holle gedaante, fchotelbeenbeenderen. deren ( (cutella) noemt. Mẹn vind er żes, zie No. 63. vier in de boventte en twee in de tweede, zoo dat de zamenvoeging van de vier bovenfte twee, en twee in de onderfte fluien, en deze twee onderte wederom het handbeen omhelzen. In jonge Kalveren ziju zij alle kraakbeenig;, in oude Koeijen zelfs blijven deze beenderen alioos meer of min kraakbeenig; worken zij verluard, dan bckomt de Koe een kniegezwel of mokpont, dat al vrij gemeen hanr kwal wordt. Die weten de Boeren, en zorgen darom dat de koes of de laapplaats der Kocijen op de ftallen, daar zij nederknielen, wel vlak en met zagt ftroo beftrooid word De Koe zelve is zeer omzigtig in zijn necierkniclen en in het oprijzen : zij zorgt altijd om zacht op deze gewrichten neder te komen, zij lekt en ftreelt dezelve als zij nederligt, en zijn deze knieën wel in rust, dan herknauẉt zij genoegelijk. Onder de knicfchijtbcenderen volyt het

Handbcen handbeen, dat in de Koeijen gedceltelijk hot armpijpbeen heet; dit becil is het dunfte, zoo in 


\section{$\forall \triangle N$ H O L L A N D.}

in de voor - als achtervaet. Het is in de Hex viervoetige dieren de fehenkel, doch in der RUNDVEE. daad, niet dat gene hetwelk in den Mensch、 II: Afd: het handbeen uitmaakt, men noemt het pijp-I, Hootdit. been, om dat het als een dunne pipp uit- schenkel. loopt, zie $N^{2} . \sigma_{4}, 6_{4}$. dit been is vrij vașt, doch niet te min hol, men draait er beenen. knoopen uit, of brand het door tot klosfen, doch dit zijn meesc kalven - of fchapenbeenderen. Deze Fabriek is, zoo als boven is z̧angeftipt; bijzonder in de StadOudewater. Montfoort enz. een beftaan, in welke Stad de ftapel is van dit knoopen draaijen; men draait er de witte knoopen als ijvoor, grelijk overvloedig bekend is. Deze ijvoorachtige witheid der knoopen, hangr af van den aard, en vooral van her zuiveren der beenderen: dir gefchied op de Lijmmakerijen, alwar de koepooten tot een trap. van verrotting worden gekuilt, daar na opgekookt, on van de zenuwen, horenklaau. wen, kooten enz de lijm af te kooken, en daar na in kalk relegt, en dan in de luche gebleekt, worden zij zoo wit als ijvoor; terwijl de kunst on uit dezelve zwarte of agaatachtige glanzigc knoopen te draaijen, eene bijzondere kundigheid van branding is. en wordt bij de beenen - knoopendraaijers voo ẹen geheim gehouden; wij melden dit te ge, reder, om de beenkundige Ontleders gelegenheid te geven dit nader na te fpooren om de beenderen der Menfchen , in hunne kunst: verzamelingen, wit en als ijvoor te maken, eene kunde of handgreep is, die velen ont. breekt, en ool voor als nog geen regel

$$
\text { C } 5 \text {. }
$$

heeft. 
Mex heeft. Bartholinus befchrijft deze manier IUNDVer in een Stukje, getijteld: Methodus dealbandi

11. Afd. osfa, dat is, de wijze om beenderen wit te t. Hoofdrt. maken, voornamelijk hier in beftaande, om dezelven op hooge daken of gooten, in de fchaduw te laten bleeken, na bevorens gemacerecrd of opgekookt te zijn. "De be. roemde Profesfor RAU is, blijkens de onvergelijke verzameling van beenderen op 's Lands Univerfiteit alhier, er zeer ervaren in geweest. De groote albinus had er ook zetten op, en ook cAmper, zijn Discipel. De Hoogleeraar FolKert sNip en ik, hebben er al vrij wat in gewroet, en het ver gebragt, en bevonden, dat het wit maken der beenderen door kooking minder gelukt, dan door zekere trap van rotting, om dat het vet en merg, vooral in beenderen van ouden, dan wel uitkookt, maar gedroogd zijnde, verhard, dic heeft green plaats bij eene langzame verrotting, tot eigen flijm, zondcr veel afwasfen, wanneer men na zeker tempo, net een mesje of met cen kwast, het periostrum er als nijm af̣egen kan, daar na de beenen op een dak, vlak of loode goor, tusfchen droog zand, ter blecken gelegt, worden zij zeer wit, velen gebruiken kalk: een wei. nig kan geen kwaad, maar tc veel of te fcherpe kalk, make wel wit, doch neem de ijvoorachtige gladheid, of zoo men zegt, het levendige weg; de grootfte zwarigheid evenwel is omtrent Dicrengeramtens, die men, volgens de alge meene hedendangfche maniẹ, inde banden (ligamenten) opzer, craan 


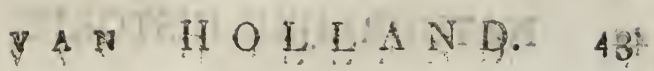

geen opkcoling of verrotting bloot kan ftel: HET len, of de beenderen worden lof en uit een, RUNDveE. waarom men zelden zulke Sceletten zoo wit II.Afd. kan krijgen als anderen, evenwel is er eenig lotioofdro hulpmiddel, hier in beftaande, althans ik heb dit dikwijls gedaan, om na de ontlee: ding en ontblooting van de fpieren en be: kleedfelen, de voornaamfte ' der geledingen," die het meest aan ontflooping onder: worpen waren, met een linnen doekje, in olie en wasch gedoopt, te-omwinden, en daarna het feeletje in water en zand te la. ten weeken, en eenige tijd in de fchaduw, aan de lucht bloot te ftellen, dan met eenig kalkfop overgewreven, en luchtig afgefchrapt zijnde, neemi men warm of heet water, en ontbindt door fmelting de olie en wasch, teyeus met de doekjes, men flaat er dan klei om, deze trekt de olie weg, en laat dan het rif droogen in dien ftand', zoo als men het wil ftellen. Ik heb boven dit alles bij toevallige ondervinding gezien, dat zelfs beenderen, na de verrotting der fpieren, of zoo als cen rif van ingewanden, huid enz. ontbloot is, en na dat de beenen tusfehen klei en zand, wel door een gemengd, gelegd, - en daar na afgewasfen en gebleekt waren, zeer levend wit wierden. Zie daar, ontleedlievende Jeugd! voor $u$ in het voorbij gaan deze uitftap." Wij keeren weder tot het Pijpbeen: pijpbeen. In Noordholland, en ook elders in Zuidholland, zange men de kalveren - en fchapenpooten door, of men knot dezelven af an den onderknok, alwaar zij den kooten of bikkels ontmoeten, en men flat dezelven? 


\section{NATUURLIJKE HISTORIE}

axx dan naast elkander in den grond, zoo dat de RUNDVEE, bikkelknoppen boven komen, alzoo dat dc.

II. Afd. ze pijpbeenen vast tegen elkander ingeflagen, I. Hoofdrt. een aardig plaveifel op den ftoep of drempel der voordeur maken; zulke drempels zijn dikwijls met figuren, ronden, vierkanten, heele en halve cirkels, en ook wel naam. vlechtingen, tusfchen de voorftraten ingeflagen, en geven door de witheid en gladheid, die zij door het geftadig fchrobben en fchuren met kalk en zand ondergaan, cen zonderlinge netheid en vertooning. Nog is bekend dat men van zulke pijpbeenen van jonge Koeijen wel fluitjes maakt, gelijk dat van de Ezelsbeenen in Spanjen overockend is, waarom men zegt dat een Ezel na zijn dood nog nuttig is, om dat men van ziin beenen fluitjes maakt. Bij $\mathrm{N}^{\circ} \cdot 65,65$.

\&ooter. doen zich de koatbeenderen op, deze, die in den Mensch, en in de viervoetige genagelde dieren, de voorbcenderen der vingeren, (Tar/s en Metatar/i) uitmaken, zijn in de Runderen en in het herkaniwend vee in het algemeen, grooter en kootachtiger. Hun, getal is ook zoo veel niec, want danr de vingers, eigentlijk dẹ hoeven of gekliefde klaauwen, maar twee zijn, zoo zijn er ook ninder geledingen of vingerkootjes. Men verdeelt dezelven gevorgelijk in twee of drie affcheidingen: de eerfte zijn de twee groote kootbeenderen, warr mede de jongens kooten, het geen nader zal worden aangemerkt als wij de inlasfing dẹr fpieren, in het volgende Hoofdituk, gaan verklaren; hicr aan Zado volgen de kleine becențes, die mẹn zaad- 
Becrtijes noemt, en tusfchen de kooten en HET de pijp, of ook de kleine kooten inliggen, RUNDVEE. dezen zijn in de jonge kalveren en pinken II. Aff.

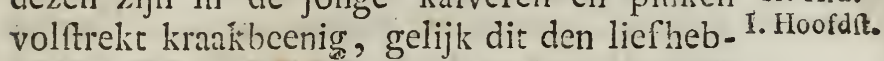
beten die gaarnê een kalfspootje, met peper en azijn kluiven, overbekend is; dc. że beentjes zijn veelal gehecht aan de peezen der hakken, die aldaar tevens aan de kooten, de fpoorhak formeren, doch dit zijn voornamelijk de beentjes van den tweeden rang, dat de bikkels zijn, die tusfchen de groote en kleine kooten in leggen. Deze bikkels zijn insgelijks genoeg bekend, vooral bij onze jonge meisjes, die nog het ouderwets bikkelfpel kennen; van dit bikkelfpel, of het werpen met de b:kkel's, is bij ons en bij de Ouden, het teerling of dobbelfpel oorfpronkelijk; dit is in onze $\mathrm{Na}$. tuurlijke Hiftorie yan Holland nader aan. gevoerd. Deze bikkcls zijn ook in de Koeijen als kleine kootjes $\mathrm{N}^{\circ} .66,66$. zij vervangen eincelijk en fluiren aan de uirerfte beentjes, die in den hoef of fchoe fluiten, welka beenen den form van den fchoe als dan aannemen, zij zijn de uiterften aan de pooten, en als het ware, het uiterfte vingerbeentje vinger- der Kocijen $N^{\circ} .67,67$. Deze beenderen zijn beentjes. doorgaans niet zeer hard, en zoo vast niet als de kooten. Zij fchijnen zelfs een zeker foort van weeker zelfitandigheid of gevoel te hebben, althans voor zoo veel ik heb kunnen nagaan, bij het afpeilen dor horenige hoeven, heb ik dezelve altoos weekachtig, ten minsten fponsachtiger dan de kooten Bikikels. 


\section{IV NATUURLIJKE HISTORIE}

HET bevonden, zij hebben veel van den and der horenpit, die, 700 ais gezegd is, bijzonder

II. Afi. is, en daarentegen zijn de kooten altoos het 1. Hoofdit. hardfte, zoo dat de kooten uit oude Koeijen niet allecn ficenhard; maar zelfs een ijvoorachtige vasthcid hebben.

Deze beenen zijn twee in getal, te weten, in elkon fchoe of horenigen hoef, No. 68. In hee Paard, 'c welk maar één hocf heeft, is ook maar één zulk een vin. gerbeen: dit been is het titerfte der pooten, en 700 ook in de Koeijen. Men moer het annmerken even als het uiterfte beentje aan den vinger der genagelde Dierer, zijnde de hoeve of fchoe, ook niet anders aan te merken dan als een foort van nagel: deze hoef of nagel wordt na de dood van het Dier afgerukt of gepeld, en dian tevẹns met de horenen an de Lijnmakers on Horengläs - bereiders verkocht; ook worden zij wel tot drinknapjes of fmeerkoppen gebeziggd. Deze hoeven zijn zeer onderworpen aan fcheuren en fchubachtige aanwasfing, fomwijlen zeer plat en breed uitwasfende, $z 00$ zelfs, dat zij in oude Koeijen omkrommen, even als in alle oude Dicren, zelfs ook in dien Mensch beginnen de nagelen te verharden en te fchelferen; doch hier van nader bij de ziekten en gebreken der Koeijen.

HET ACHTERSTEL.

Het Voorftel en Mfiddelfel dus afgehandeld zijnde, gaan wij over tot het Achter- 


\section{VANGHOLIAND. 4\%.}

fel. Dit rekenen wij te beginnen ann den eerften der lendenwervelen ( No.69.), aan RUNDVE. de laatfe ribbe, $\mathrm{cn}$ te eindigen aan de ftaart wervelen. Wij onderfcheiden deze lenden-I. Hoofdefo wervelen van die der ribbewervelen, die de voorfte zijn en minder buigen, daar de lendenwervelen meerder buigen, en in dien zin de buigzame lendenen genaamd worden: hij boog de ruggraat zijner lendenen. Deze wervelen maken wederom twee verdeelingen: de eerfte zijn de eigenlijke lendenwervelen, die anneenfchakelen van het voor. rif en de korte ribben, tot het achterrif, aan het bekken en de heupbeenen; de tweede zijn die, welke van het bekken tot aan het uiteinde der ftanrt volgen. Men telt zes lendenwervelen, (zie No. 69, 70 , tencien$7 \mathrm{I}, 72,73,74$ ); deze wervelen verfchil- w: veleen. len daar in van de voorwervelen der geheele ruggraat, dat zij geene doornachtige uitftekken hebben, maar in frede van dien breede platte wanden, die even als hanckammen uirffeken; weçerzijds hebben dezelven brcede platte vleugels, die, gezamenlijk in één grocvende, de zeer kennelijke platheid, die mess op de lendenen der Koeijen ziec, uitmaken, vooral in zeer magere en oude Koeijen is dit overbekend; men ziet dezelve kennelijk doorfteken, en de huid van den buik of het achterwand er als een fchrale lap aanhangen; inwendig zijn zij insgelijks rond, gelijk de ribbewervelen, zoo dat het beest opengehakt zijnde, de geheele ruggraat aan éñ verbonden is, nog- 


\section{NATUURLIIKE HISTORIE}

MET tains wordt de tronk der ruggraat iets breeQ UNDVEe. der naar achter, gelijk ook de vooifte kam-

II. Afd. men en vleuggels dezer wervelen breeder zijn 1. Hoofalt, dan de achtertte, té weten, No. 69 en 70 allerbreedst, de daaranvolgende iets fmaller, eindelijk de achterite nog fmaller, doch niet te min vaster, das zij in het heilig.

Heilig. been (Os Sacrum ) cindigen; dit been is, gebeen: lijk in alle Dieren, bijzonder: het beftaat uit vijf wervelen, dic. men vaifche weryelen noemt; in onze figuur niet zichtbaar, om dat het zijlings geteekend is, en deze ze valfche wervelen achter het heupbeen (No. 79.) fchuilen. Bij No. 75 cvenwel is het begin anngewezcr: deze beenderen zijn plat, ongedoornt, in oude Kocijen meestal aan één gewasłen, zoo dat zij; dus veree-

stuit. nigd, ook de fuitbeenderen genaamd worseenderen. den; de doornachrige uitftekken zijn zeer flaauw en flechts in de ecrite, zij vormen als ' $t$ ware cene bogt, en zijn zamengenomen kennelijk aan vier gaten, twee an twee tci wederzijden; in jonge Kalveren fchijnen er meerder; deze gaten laten zekere fpierpeezen door, dic inwendig gemeenfchap hebben met de banden der teeldeelen en der barmoeder; bij de verhandeling: der vroed. kunde nader te verklaren; zij formeren in der daad ook de bogt der zoogenamde walegreep, elders vermeld, of ook het holle verhemelte Stuitbeen. van het bekken; dan, daar in den Mensch deze beenderen inkrommen en het ftuitbeen (os Coxygis) formeren, zoo loopt de feha. kel dezer wervelen door tot de wervelen der ftaart, ( $\left.\mathrm{N}_{0 .}, 6,77,79.\right)$ men tclt er 
Whoorgaans dertien tot aan de vlok of ftart- HRT. pluim, doch ik fta voor derzelver juist ge. RunDVRe: tal niet in, om dat ik vermeen in verfchil- II. Afd. lende Kalveren de uiterfte beencjes verfehil- I. Hoofdifto lend gezien te hebben; men noemt dezelven yalfche weryelen; zij kunnen dien naam dra- Staare. gen; ik zou dezclven faartbeenderen noe wervelen. men : zij zijn het in der daad, of licver valfche bewegende wervelen, om dat de Koeijen, geliik alle geftarte Dieren, dezelven fterk bewegen, krommen en heen en weder kwispelen. Hot rugmerg zelve vermindert in derzelver aandoenlijkheid fterk in deze wervelbuis, nademaal het prikken, fteken, llaan of andere wonding, zelfs het af hakken van den ftaart, zoo als in de Paarden, niet doodelijk is, ja fomtijds nuttig in fchurfeziekten, daar integendeel een wond of eene kwetfing aan het lendenmerg of voorrif, vooral den hals en nek, doodelijk voor her Dier is.

$\mathrm{Nu}$ komt het kruis in anmerking. Men Het kruis: noemt het kruis in de Koeijen, dat bovenfte platachtige gedeelte, ' $i$ welk tusfchen de twee groote beenhoofden of bonken der heupen zigtbaar is, doch waar van hier om het profiel niets is aangewezen dan alleen de zijbeenderen, die hetzelve uitmaken. (zie No. 79.) Deze beenderen zijn de groote wanden van hec bekken, en fteken vrij kennelijk uit ; zij vervangen in het midden de laatfe lendenwervelen, en vooral de banden en fpieren van het lendenkruis, derzelver verhevenheid vertoont zich duidelijk door den huid, aan 


\section{0}

NATUURLIJKE HISTORIE

HET de walegreep om den ftant: de tusfcherto a undver. ruimte is platter en breeder dan in het Paard,

II. $\Lambda \mathrm{fd}$. en daarvan is het kennelijk onderfcheid ir 15 Hoofdrt, de rondheid en fraaiheid der billen en het kruis der Paarden, zeer verfchillend met de platheid en vlakheid van het Koekruis. De Boer houdt zelfs de platheid van her kruis voor een kenmerk van eene fraaije Koe, waarom men op de Koopbrieven dikwijls leest : beste platte Vaarzen of Koeijen, Groninger plat enz., elders reeds aangemerkt. Dit kruisbeen nu verdunt eenigzins in het midden en kromt zijlings uit,

Fet doch inwendig formeert het eene holte, die bekken. men het Bekken (Pelvis) noemt, te weten, als beide de kruisbeenderen tegen over elkanderen die holligheid formeren, (zie No. 80,80 . en in het vervoly, alwaar een Kalf in de gebuorte van dit bekken is afgebeeld.) Dezelve opgemelde bekkenbeenderen, gelijk zij inwendig, als hol zijn, zijn uitwendig bol, dat is, de holte van binnen maakt de bogt van butiten; ein. delijk rijst dat been weder op. (zie N.. 81.j en formeert den volkomen knok van het bekken: dit noemen de KoemeesDe brug.ters de brug, om dat, als het Kalf in de geboorte over deze brug of de bogt van dit been is, acht men het behouden, welke fpreekwijs ook bij de Vroedvrouwen bekend is. Deze beenderen zijn evenwel niet aan het bekken of het kruis vastgegroeid, maar niet te min zeer naauw ingelijfd: het zijn De heu-eigenlijk de heupen, de heupbeenderen der Dะn. Koo 


\section{A N IO OLLAND. 5L}

Koe. Deze zijn allerkennelijkst in déze Die- nst ten, en misfchien wel het allerkennelijkst RUNDVEEG in eenig dier, gelijk zoo even wegens het II. Afd. knokkige en platte reeds gezegd is; zij for-l. Hoofdts: meren van achter dic fchaambeenderen, en schaam. vereenigen van wederzijden tot één; in ou teenderens de Koeijen zijin zij vergroeid, doch in Vaarzen en jonge Kalfikoeijen bewegelijk en tusfchen gefctioten met kraakbeenige gewrichten. Deze beenderen zijn aldaar het flot van het geheele rif, der teeldeelen en fchaamdeelen, hetwelk bij het verhandelen der voortteling nader zal betoogd, mitsgaders de werking der banden aangewezen worden.

Deze fchaambeenderen nu yijlings zich uitbreidende, hebben ter wederzijden eene zeer anumerkelijke hoiligheid, waarin her hoofd of de bol van het dijebeen fluit en als in een fcharnier draait, waarom het ook wel het fiharnier heet: deze hoofden noemen de gewone Landlieden of Vleeschhouwers bonken, knokken, ook wel heupbonk; en na gerade dat dezelven in oude of magere Koeijen uitfteken, is de Koe een bonk, een ouden bonk, een mageren bonk: het zijn de'ze bonken, te weten, de hoofden, in welker holligheid men die fraaije beenwordingen kan nagaan, in . Fig. I, II. en III. afgebeeld; men noeme deze knoppen ook draaijers, en zeker zeer eigenaardig, vermits de Koeijen zoo wel als de Mensch en andere Dieren, de heupen mitsgaders de dijebeenderen' in - en uitwaarts kunnen draai. jen. Het is aan den zwier dezer beweging, dat de fraaiheid en vlugheid van cene $\mathrm{KOC}$ 
geт en een Paard, een Hond, of andere vaatRUNDVRE, dige Dieren erkend wordt. Hoe de vlugII. Afd. heid van eene fchoone Vrouw aan dezen 1. Hoofdrt: draai der heupen kenbaar is, wist ons SALOMON in zijnen tijd wel te zeggen, en het behoeft bij elk Man, die een welgefchapen Vrouw met een Schilders of Dichters oog befchouwt, geen bewijs, wijl zij nimmer eene die aan de heupen verminkt is, tot een onderwerp hunner bewonderende befpiegeling zullen uitkiezen.

Men onderfcheidt in de hoofdknop (Condylus) van het dijebeen tweederlei invoeginHet hoofd gen: de eerfte noemt men den grooten, de van het andere den kleinen draaijer, welke onderdijebeen. fcheiding de figuur bij $\mathrm{N}^{\circ} .83$. «anwijst.

Draaijers. Het dijebeen der Koeijen vervolgt uit deze ledenmaten in een vrij langen pijp (zie $\left.N^{\circ} .84,84.\right)$ eenigzins bogtig. Dit been is zeer zwaar, doch inwendig altijd hol, vol merg, waarom het den' naam draagt van groote mergpijp. Dit been wordt daarna van onderen weêr dikker, en verbreedt der. mate, dat het de hoofden van het fcheenbeen ontvangt; (zie $N^{\bullet} .85,85$. ) hier is eene zeer fterke peesband: men noemt de beenderen $\left(N^{\bullet} .86,86.\right)$, te regt fcheenbeenderen, om dat het hetzelfde in plat-

scheen. fing is als de fcheenen in een Mensch, Dsen. en wel moet onderfcheiden worden van het armbeen in den voorvoet der Koe: en dit vereischt hier oplettendheid, om dat men het geen men in de voorvoet der Koe kniebeenderen noemt, in der daad niet zijn dan de ellebogen: bij vergelijking met Dieren die 
die overeind kunnen gaan of ftaan, dit been oefent eigenlijk door de jbuiging der fcheen-Rundveg: beenen het knielen der achterpoot uit, zoo dat II. Afd. men de gewrichten der voorvoeten in de Koe I. Hoofdita als de armen en handen moet aanmerken, die der achterfte daarentegen als de dijen, fchenkelen en voeten, hetwelk vatbaar genoeg voor een doorzigtig Mensch is, want de Mensch knielt met de knieën der achtervoet, en de Koe met de knieën der voorvoet, waarom wij het ook daarlaten; alleen dient in 't voorbijgaan opgemerkt te worden, dat er in de Koeijen ook een foort van ftraalbeen is, doch kort en als aanééngegroeid. - Wij gaan over tot het hielbeen $N^{\circ} .87$.

Het hielbeen (Talus) is dat zelfde ge. deelte, ' $t$ welk bij de befchrijving van het uitwendig geftel de hak genoemd w'ordt, en breeder verklaard zal worden in her vol. gende Hoofdfluk: hier evenwel ziet men bij uitnemendheid deze hak, in de achterpoot der Koe, uitfteken, het is een dergelijk uitftek als meest alle Dieren aan de hielen hebben, waarom het met rege Hielhak: de hielhak genoemd wordt, gelijk ook hiel het achterfte uitftek van den voet beteekent. Het is aan het achterfte uitftek van dit been, dat de zware pees, die men in den Mensch de pees yan Achill's, bij de 'Vleeschhouwers de hakpees noemt, is ingelijfd, en die de Indianen in de Buffel. jagt doorhakken, om het dier ter aarde te doen nederftorten. Welk een kracht deze fpier heeft, en hoe men het voor on" geneesbaar houdt als een Mensch hier aan D 3 ver-

Hielbeen: 


\section{NATUURLIJKE HISTORIE}

RET veriamd is, dit weten de Heclmeesters alo lerbest.

II. Afd. Aan de binnenzijde der hak, alwaar de 7. Hoofalt buiging is, (zie $\mathrm{N}^{\circ}$. 38.) wordt het hielbeen vervangen door twce voorbeenderen, die even als de handbeenderen, hier het yoetbeen ontvangen, en twee onderbikkels. Deze voetbeenderen, laat ik eens yoetteener zeggen, nocme men piipachtig in de voor pooten, zijnde dezelve bij N. 64. befchreven. Her eenig onderfcheid der achterpijpen is, dat zij iets langer zijn en de bikkels graver, gelijk ook de achterkooten aan de achterklaauwen altijd zwarder zijn, het geen de liefhebers van kooten zeer wel weten. $\mathrm{Bij}, \mathrm{N}^{3}$. 89. ziet men derzelver geleding, tot an het uiterfte hoefbeen, $\mathrm{N}^{\circ} \cdot 90$, mede gelijkvormig an de voorpooten, hier voren befchreven. Zoo dat het gene hier nog met opzigt tot de achterfchoemen of horenklieven diende, die men om de gelijkenis van eene fchoe of voetzool, om de voeten der Koeijen, ook de horenklaauwfchoenen noemt, gereedelijk uit de vergelijking der voorpooten is op te maken, en alzoo ook het meest overeenkomende, waarbij wij dan ook van dit Hoofdftuk affeappen, $\mathrm{Na}$ dat dan aldus ook het Beendergeftel der Koeijen in het volle geramte is afge. beeld en befchreven, vermeenen wij onze Lezers tot hier toe genoegzaam te hebben overtuigd, dat wij geene moeite, noch op: lettendheid gefpard hebben, am de 200 gewigrige kennis van het rif of geraamte van dit 200 nuttig Vaderlandsch Dier varbaar.

voor 


\section{VAN H OLLAND. 55}

voor den Landzaat te maken, en de ver- HRT klaringen en benamingen der gewrichten daar RUNDVRE. van zoodanig voor te dragen, dat onder ver- II Afd. vrolijkende en voor den Hollanderen be I. Hoofds: grijpelijke woorden, deze anderzins ftroeve Itoffen is voorgefteld, en nagenoeg aan de Theoretifche vergelijking mer den Mensch voldoet. $\mathrm{Nu}$ gaan wij over tot nog ingewikkelder, maar niet te min nuttige zaken, die tot nog toe, zoo ik zeer wel meen te wheten, in onze Moedertaal alzoo nict verhan. deld zijn, namelijk, de werktuigelijke deelen der titwendige ledenmaten, zoo als die het vatbaarst voor den Landzaat kunnen befchreven worden, zoo dat wij, daar wij nu het beendergeftel en derzelver aaneenfchakeling hebben befchreven, het fpiergeftel ook zoo vatbaar :mogelijk zullen voordragen, en wel zoodanig, dat deze gegeven befchrijving van het beendergeftel of het geraamte als bij vergelijking het fundament is, waarop de andere weekcre deelen rusten en ingelijfd zijn.

Doch eer ik tot dit onderwerp overga, dien ik in opmerking te geven, dat gelijkerwijze ik in het nu befchreven Beendergeftel, niet in afbeeldingen van afzonderlijke gedeeltens, noch derzelver befchrijving getreden ben, als, bij voorbeeld, het hoofd inwendig, de wervelen, de afzonderlijke ge. wrichten, derzelver banden en aanhegtingen, dit insgelijks in het fpiergeftel niet verder zal worden aangewezen, dan voor zoo verre dit op het uitwendig beloop der kenbarfte 
нer en voornaamfte bij den Landman in het huise houdelijke bekende deelen zijn, hetwelk, II Afd. zoo men die anderzinis in alle derzelver laI. Hoofdet. gen op en onder, dwars, fchuins en overlangs op elkander, wilde befchrijven, dit: eene menigre afbeeldingen zouden vereifchen, dic dus gevolgelijk onnoodige kosten zouden veroorzaken, onnoodig zeg ik uitdrukkeliik, om dat alles wat op het bijzonder werktuigelijke van de afzonderlijke beenderen, Ifpieren, zenuwen, bloedvaten, ingewanden enz. betrekking heeft, in het vervolg bij elk gedeclte afgebeeld, en in derzelver platzing en werking befchreven zijnn, als bij voorbeeld: die van het hoofd en hersfenen bij de zintuigelijke deelen, als het gehoor, gezigt, fmaak, gevoel en reuk; in de. ingewanden van de borst en de buik, het. hart, de longen, milt, maag, lever, de darmen, teeldeelen, en de blaas, met een woord, allen deze met derzelver fpieren en plaatzing in het rif, zullen duidelijker in alle derzelver bijzonderheden, op zijne regte plaats worden opgehelderd, en van zelven het ware oogmerk van den beoefenaar tot kennis, zoa in de veeartzenij- als dierkunde, doen bereiken, zonder dat hiertoe cene geheele volle. dige ontleedkunde benoodigd is, 200 dat wij. er niet meerder van zullen zeggen, dan hes geen ononcbeerlijk is tot het ware nut van ons bedoeid ontwerp; volgende nu eerst op de befchreven gedeelten van her beenderge. ftel, eene aancengelchakelde verklaring van Plaat VI. 
v A N H OLLAND. 57

\section{VERKLARING ${ }_{\Omega}$ VAN PLAAT VI. II. Afdo}

Afbeeldingen yan de Beenwording en hat

Geraainte oener Koe, yolgens het na. tuurlijke yoorbeeld.

Fig. I. vertoont een doorgezaagde knop of hol, veeltijds den draai genaant, van het Mergbeen eener Koe, dat men de Mergpijp. noemt, waarin inwendig de beenwordende takfchieting, en alrede beenachtig rag of weeffel zich duidelijk vertoont, daar beneven het porieus inwendige vann de beenpijp zelve.

Fig. II. ftelt voor een doorgezaagd knokof beenhoofd van een mergpijp, uit eene Koe van zeven jaren, waarin de mergvezelen alrede bladachtig verhard zijn. Men ziet hierin eenige takachtige bladeren, die als tot een middenpunt zamenlaopende, uit het merg hun voedfel ontvangen, en allengs den rand van het been verdikken, terwijl dezelve rand, of liever de zelfftandigheid, dat poricuze niet meer heeft, dat in jongere beenderen zich ver. toont, te vergeliiken met Figuur I. Dẹe Figuur is zeer verkleind geteekend.

Fig. III. is een uitmuntend levensgroot voorbeeld van eene fraaije Takfchieting in het mergbeen, of het hoofd (Condylus) van den grooten draaijer, inwendig afgefcheiden, juist zoo als men die takfchieting of beenwording tusfchen het merg ingegroeid ziet, volmaakt gelijkende naar het Zeegewas ' $t$ welk men $W a$ ter-Coraal noemt.

Fig. IV. is eene op drie vierde verkleende Afbeelding van een doorgezaagde Mergpijp,

$$
\text { D } 5
$$




\section{NATUURLIJKE HISTORIE}

HET waarin men de natuurlijke gedaante van het RUNDVE. merg, en tevens de randen-der beengroeijing

II. Afd. kan zien; het is dat van een tuveejarige Koe, 1. Hoofdrt Waarin de, beenderen nog niet tot hun volko. men vastheid $z i j n$, en even als de ftam van eenen boom allengs ineen groeijen.

a $a$ a $a a$ is de aanwijzing van het beenvlies (perioftrium.)

$b b b b$ de eerfte ring van het been zelve. $c c c c$ de fponsachtige porien midden in het been. $d d d d$ de inwendige beenrand, die tegen het merg ligt, en waaruit, bij verderen aanwas, de beenvezelen en bladachtige uitwasfen, zoo als Fig. I, II. en III. vertoont, fpruiten.

ceceece zijn de Mergbolletjes of Kliertjes, zoo als die in de been - of mergweke ftoffen leggen, in en nevens hunne kleinere mergkliertjes.

Fig. V. ftelt voor een volkomen Rif of ge. raamte van eene Koe, van een eenjarigen Pink of Kalf, in alle zijne ledematen zoo veel mogelijk proportionaal gevolgt, als de zamenvoeging en Teekenkunde heeft toegelaten. Dezelve is in drie perken verdeeld, en bij Nommers aangeftipt.

\section{A. HET VOORSTEL OF VOORRIF.}

No. I. De kruin of kroon.

2,2. De inworteling der horenen.

3, 3. De horentoppen.

4. De ftar, de kol of dol.

5. De oogkas.

6. Het oorhol, of ook kakengroef, hoofdnaap.

7. Uitwendige oogkas.

8. Het jukbeen.

9. De bovenkaak met de kiezen. 


\section{VA $\mathrm{HOLLAND.} \mathrm{50ं}$}

No, 10. De kiezcnkast der bovenkaak.

11. De naden der neusbeenderen, en RUNDves; deszelfs middenbeen en bovenlipbeen. II. Afd.

12. Het fcharnier der onderkak.

13. De breedte of fcherpen hoek der onI. Hoofdif: derkaak, het kinnebakken.

74. De middelbare breedte, waar in de kiezen der onderkaak in hunne kasfen nuiten.

15. Is het uiteinde der onderkaak, of het eigenlijke kinbeen.

16. De plaats der fnijtanden, in een der volgende Platen levensgroote afgebeeld.

17. De nekwervelen:

$18,19,20,21,22,23$. De halswervelen.

24. De doornwervel.

B. HET MIDDENSTEL OF MIDDENRIF.

No. $25,26,27,28,29,30,31,32,33$, $34,35,36$. De voorfte nok of ribbenwervelen.

37. De eerfte kortfte ribben onder het fchiidbeen.

38. Niet zigtbaar in de teekening, als wordende door het fchildbeen geheel gedekt.

$39,40,41,42,43,44,45$. Zijn de lange ribben.

$46,47,48,49$. De korte of valfche ribben, waar van 49 de bijribbe genoemt wordt.

49*. De borstkrop van het borstbeen.

50. Het plat van het borstbeen.

51. Uitftek val het borstbeen, of het zwaardbeen.

52. Plaatzing, waar aan de buikfpieren aan het borstbeen hechten.

53. Dẹ Sleutelbeenderen. 


\section{NATUURLIJKE HISTORIE}

HBT No. 54. Het gelid of het fteunfel van de fletyRUNDVEE. telbeenderen op de voorvoet.

II. Afd: I. Hoofdr.

55. De opening tusfchen de fleutelbeenderen, waar door de ftrot loopt.

56. Het breed gedeelte van het fchildbeen of fchouderblad, of de pan.

57. Het fmal gedeelte van het fchildbeen, aan zijn holte, daar de fchildfpieren aan vast zijn.

58. De iugroeving van het fchildbeen aan het arm - of fchouderbeen.

59,59 . Het fchouder - of elleboogbeen.

60,60 . De elleboogknokken of gewrichten, of elleboogkusfens.

6r, 6r. De ftraalbeenderen.

62,62. De kniegewrichten of de kniebeenderen.

63,63. De fchotelbeentjes.

64,64. De arm - of pijpbeenderen.

65,65. De kooten.

66, 66. De bikkels.

67,67. De horenklieven.

68,68. De zoolhakken, fpoorhak'ken.i

C. HET ACHTERSTEL OF ACHTERRIF.

No.69, 70, 71, 72, 73, 74. De lendenwervelen.

75. Het hoofd van het heiligbeen.

76, 77. De ftaartwervelen.

78. Het eind der ftaart of pluimbeentjes.

79,79 . Aanwijzing van het kruis.

80, 80. De inlijving van het bovenbekken.

$8 \mathrm{I}, 8 \mathrm{I}$. Het eigenlijk bekken of de walegreep, de brug.

82. Het onderbekken, de bonken, eigenlijk de fchaambeenderen. 


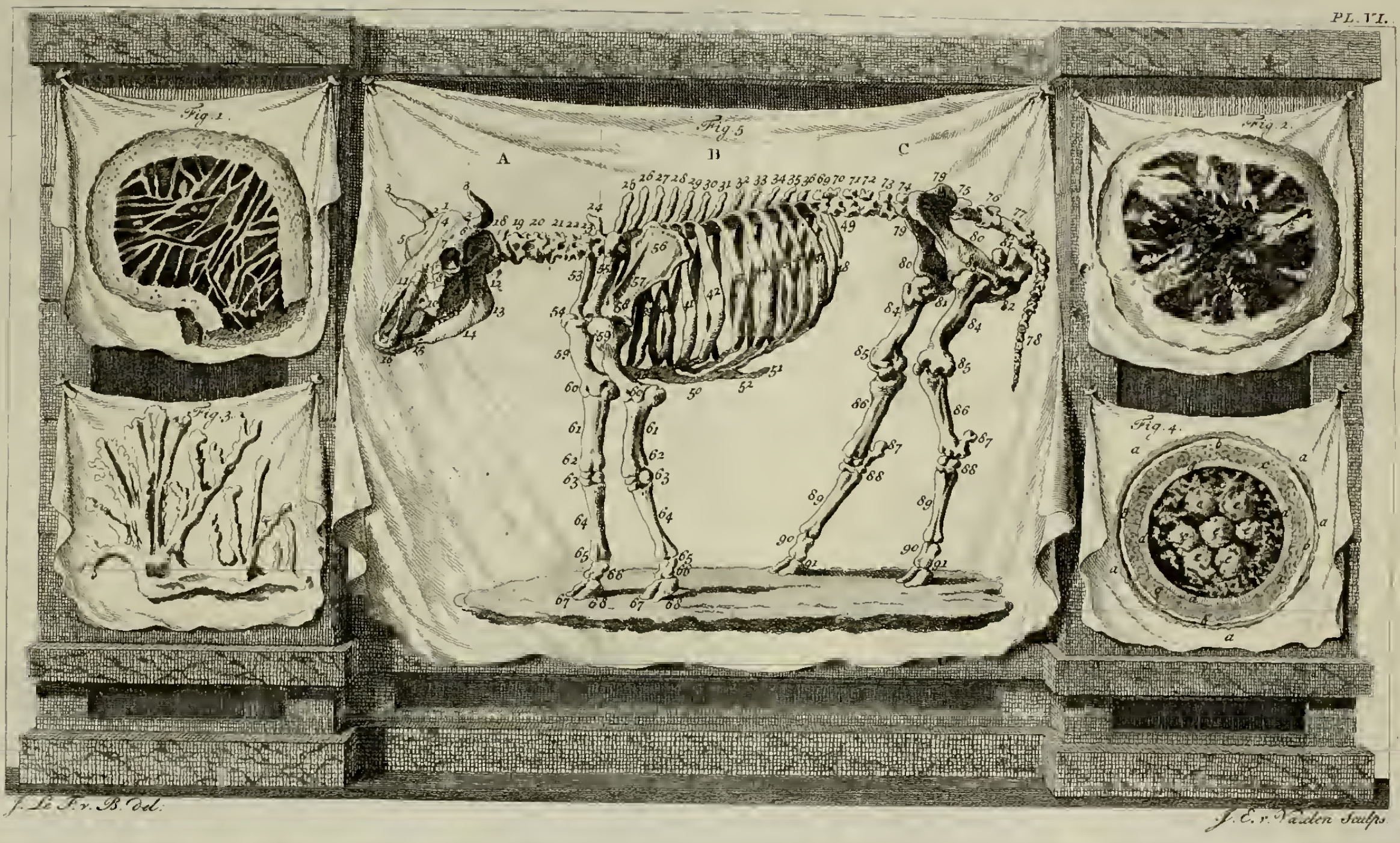


- 5

$x_{1}$ 
VA N HOLLAND. 6I

No. 83, De inlijving van de hoofden der bon- $\mathbf{H E T}$ ken of heupbeenderen, of het fchar- RUNDVE ; nier of de draaijers.

84,84. De heupbeenderen, eigenlijk de II. Afd. dijebeenderen.

85,85. De tusfchenbeenderen van het dijeen fcheenbeen.

86,86. De fcheenbeenderen.

87,87 . De fchijthakbeenderen, de hakker of hielbeenderen.

88, 88. De achter fchotelbeenderen.

89,89. De hakpijpen.

90,90. De achterkooten.

91,91. De achterklaauwen.

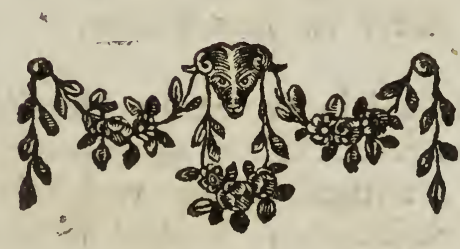

TWEE 
6. NATUURLIJKE HISTORIE,

\section{TWEEDE AFDEELING。}

\section{TWEEDE HOOFDSTUK.}

Behelzende de viitwendige kenbare gedeelien der Ledenmaten, Spieren en verdeelingen eener Koe, mitsgaders derzelyer benamingen in de huishoudelijke Spreekwijzen der Vlecschhous. wors en Landlieden.

RunDVEe $\frac{1}{\text { van de cerfte Afdeeling de algemeene be- }}$ II. Afd. namingen, mitsgaders het verfchillend ras II. en bont, de horenen, huid en het haar, ent Hoofdrt. in het eerfte Hoofdituk van deze Afdeeling, het geraamte, de beenwording en beenderen der Runderen befchreven heb. ben, gaan wij thans over tot derzelver uitwendig fpiergeftel, en de verfchlllende zamenftellen der meest uiterlijke tastbare deelen: meest tastbare, zeggen wij, om dat het juist wel niet ondoenlijk is, om alle de fpieren in hare natuurlijke zamenvlegtingen en inlijvingen naar te vorfchen, eren 200 als wij die van den MIensch 


\section{$\nabla A N$ HOLLAND. 63}

alrede tor den hoogften trap kennen, in de onnavolgbare werken van EUSTACHIUS, VE- ${ }^{\text {RUNDVER。 }}$ SALIUS, en de voortreffelijke afbeeldingen II. Afd. van een eenigen WANDELAAR en ALBINUS; maar dewijl tor zulk eene uitgebreide kenII. Hoofdr. nis eeuwen noodig zijn, en eens Menfchen leeftijd te kort is, om alles tot die juistheid te brengen in de fpierkennis der Dieren, en het daarenboven tot onnoemelijke kos. ten zoude ftijgen, eer zulk eene fpierkunde (IMyologic ) der Koeijen in het licht kwame, en zoo vervolgens alle andere onderwerpen van dien aard, als: de volkomen beenderkennis (Ofteologia), de zenuwkunde (Neurologia), de kennis der ingewanden (Spnergnologia) enz., zoo heeft dit echter ons niet afgefchrikt om het geene men reeds algemeen genoeg weet en kent, en het geen door weergadeloze Mannen, ten anzien der Runderen en Koeijen, aan ons is overgeleverd, in vatbare en geregelde verhandelingen voor te dragen, en zoo nabij als het ons doenlijk was voor te ftellen, door hetzelve met onze eigene ondervindingen, navorfchingen, vergelijkingen en verbeteringen tot zulk een regelmatig begrip yoor onze Vaderlanders te brengen, dat zelfs de onbedrevene in de Ontleedkunde, de Boer, de Burger, de Landheer of Edelman, een goed begrip kan bekomen van de uit - en inwendige geftalte van hec Wonderdier, ' $t$ welk wij befchrijven en gedeeltelijk reeds befchreven hebben', en nu verder gaan ontleden: ten dien einde zijn dan 


\section{NATUURLIJKE HISTORIE}

HEт de volgende Hoofdftukken gefchikt, en door RUNDVE. onze eigenhandige teekeningen, meest alle naar

II. Afd. het leven, opgehelderd; zoo dat wij cerst de

II. Spierkennis en het uitwendig zigtbaar fpierge Iloofdrt. ftel zullen verhandelen; daarna het zenuwgeltel en de zintuigelijke deelen, en eindelijk de inwendige deelen der ingewanden, elk in hun bijzonder geftel en werking, laten volgen, voornamelijk dezulken, wier gedaante en natuur alleen aan de Koeijen of het Rundvee eigen is, namelijk: de herkaauwing, de vooreteling, de teetdeelen, en wat dies meer $2 \mathrm{ij}$.

De oppervlakkige fpierkunde dan alhier ons eigenlijk ontwerp zijnde, komt eerst voor

HET UITERLIJK SPIERGESTEL DER KOEIJEN.

Het vit- Dit geftel verdeelen wij ten vatbaarfte wendig begrippe in drie voorname onderfcheidin\{piergeftel. gen : de Anatomisten verdeelen dus den Mensch in het hoofd (Caput), het rif (Truncus), de ledenmaten (Artus); maar wij verkiezen tevens het naar den aard der zake en het vatbare voor den Landman, en onze bevorens aangenomene ftelling. wederom te verdeelen in het VOORSTEL, het MIDDENSTEL en het ACHTERSTEL, zOO als dit in Plaat VII. duidelijk is verdeelt.

verdee- Men ftelt dus in het yoorftel, het Hoofd ling.

of den kop, de hals, de kossem of de Borst, tot aan de yoorbeenen of de yoor. kwartieren.

Het middenftel, dat men ook wel het kof: 


\section{$\checkmark \AA N H O L L A N D .65$}

koffer nocimt; zoo als in de Paarden, be. Hist gint aan de nok of diefchoft, yoorfchoft, en ${ }^{\text {UNDV }}$ bevat den rug, de fchbuderbläden, de ribben iI. Afd. en voorpooten; en eindige aan het lenden. kruis, tegen de achtetfchoft of de bonken Hoofdet: der achterdijen, of achterkwartieren.

Het achterftel wordt van het kruis tot aan den fuit gereekent, en bevat de heupen, de dijen of billen, de teeldcelen, de vijers, de ftaart, de achterpooten enz.

Alle de deelen nú, die tusfchen elke ver. deeling inleggen, en uitwendig van onder dèn huid kenbaar voorkomen, zullen nu in onze Plaat verklaard worden, niet zob zeer Ontleedkundig als wel volgens de benamin gen die de Landlieden, Veehouders, Vetweiders en Vleeschhouwers daar aan geven: hier en daar zullen wij er het onze bijvoegen.

\section{HET VOORSTEL.}

Men zict dan in de eerfte verdeeling het Hoofd, eigenliijk is hei de kop, koekop, osfenkop, ftierenkop; enz. volgens de verfchillende kenteckenen, alrede in Plaat V. afyebeeld.

in het Hoofd kome dan eerst voor: Het hoofd. $N^{\prime \prime}$. x de kuif of kroon. Dit gedeelte is De kroos. in hec horengeftel alreeds verklaard; hardbeenig te zijn, vol en dik met haar bezet, in zomnige Kocijen zeer zwaar, in andere dunner. De horenwortel verklaart zich zel ven. (Zie ook Plaat V.')

De horenkrappen, mitsgaders derzelver verifchillende aanwas, zijn ook reeds be-

Het vooge itel. 


\section{NATUURLIJKE HISTORIE}

Hex fchreven, en in Plaat V. afgebeeld, doch NUNDVEE hier bij $\mathrm{No}$. 3. angeftipt.

1I. Afd. Hier komt nu voor de kol of dol, de

II ftar enz. Deze konden in onze Figuur niet Iloofdrt. wel aangewezen worden, om dat de kop meer op zijde vertoond wordt, dơch in Plaat V. is dit rijkelijk vergoed, alzoo men aldaar wel in zeven verfchillende koppen de kol en de ftar kennelijk verbeeld zię. De nadere befchrijving evenwel volgt hier.

De kol. De kol is eigenlijk bet voorhoofdbeen; dat onder de horenwortel onderfcheiden worde, alfchoon het daar aan verheeld is. Het is het platte en vlak gedeelte van het voorhoofd, de plaats daar de flachters de Koe dollen en in zwijm flaan, hicrom ook dol genaamt. De uitwerkitug der dreuning van den dolflag, is op die plaats zeer gevoe: lig voor dit fterke dier, dewijl het plotfe. ling na den flag neder valt: er zijn er echter, wier kol, of dolbeen zoo hard is, dat men door dollen en flagen het dier niet kan doen vallen. Dat de Koeijen, Osfen of Stieren in dit beengedeelte natuurlijk eene meerdere gevoeligheid hebben, dan in andere harde beenderen, blijkt daar uit, dat zij in dit gedeelte onderworpen zijn aan dolligheid of kolziekte; ten aanzien van het eerfte, zegt $\mathrm{men}$ : de koe is dol, zij is horendol, (hier van zal nader bij het verhandelen der ziekten gefproken worden, (zie ook hier vooren: Hoofdit. IV. Afd. I. ) het geen te kennen geeft, dat de Koe kwijnt, borenwee heefe aan den dol, die aan den horenwortel verknocht is, en tegen de hersfenen aanlegt. De 


\section{$\checkmark A$ iv $H O L A N D$.}

Boeren kunnen aat het hangen van het hoofd, het geftadig fchudden van den kop, het blikken der oogen, dit horcndol dra ontdekken.

De beteekenis kolzierk komt op hetzelfde uit, alzoo kolderien zoo veel zegt als zinneloos, dol zijn. Het is hierom gemeen dat men, van een Koe die mijmert, lustelogos enz. is, even als men van een Paard zegr: hij kobdert, hij is kolderziek; wil iemand nu doh of kol van her dollen der vleeschhouwers, of vath den zin met iemand te dollen, te follen, dac is hem voor den gek te houden, afleiden, hij dolle er dari mede zoo het hem goed dunkt. Maar iers naders: deze kol of do verkrijgt nog eene meer bijzonderen naam, den Koeijen eigen, te weten die van ftar. De $f a r$ is eigenlijk die vlokking var haar, die ftars- De ftat: gewiize vlokkende, onder, om, op en tegen den kol, tot an de hieusbeenderen glooic, en als gehogen ftralen, eene ftarachtige gedaante heeft. Deze vlokking begint vit een middenpuat, dat zich in alle Rundereti zeer kennelijk vertoond, en ook in de harvlokking der Menfchen bekend is. Dit mid; denpunt is in de Koeijen juist de plates, atwaar de oog - en neusbeenderen zich in de voorhoofdbeenderen ingroeven en famenvoegen. $Z_{\mathrm{ij}}$ zijin dat gedeelte, dat in den Mensch die kennelijke ingroeving tusfchen biet voorhoofd, neus en oogen vertoont; en niet zelden de Phifionomie der Menfchen ontdekt; waar van men thans zoo veel ophef maakt in de harsfen - of fchedel. leer, door GAL opgehaald; in de Koeijers echter, is het vlak en plat, evenwel in fom:

$$
\text { E } 8
$$

HET

RUNDVEE: II. Afd. II. Hoofdrt.

Kolziex: 


\section{NATUURLIJKE HISTORIE}

нет migen, vooral in oude Koeijen, eenigzins RUNDVEe ingedruke. Het is eigenlijk deze ftar, of

11. Afd. dat punt, daar den dol-of kolnag op moet

II. vallen, om wel te treffen; en dit is natuur

Hoofdit. lijk, want om dat het gemeen zenuwgeftel der neus-, oog - en tongzenuwen, ja ook der gehoorzenuwen aldaar famenlopen tot het algemeene levensgevoel, (Senforium commune) zoo is dit ook de oorzaak van de

Dolnag. bezwijming, die de Koe ondergaat, door den flag of dol op de ftarre. Tot het dolle of in zwijm flaan van eene Koe of een Stier, behooren mannelijke krachten, of na mijn gevoelen, cene zekere beliendigheid of bedrevenheid, om den flag met ecne zekere dreuning, op her midden der ftarre te doen nederkomen. Zulk eene kracht en behendigheid bezat de beruchte ENTELLU's, in het ftrijdperk tegens DAREs, op het Feest, het geen eneas ter gedachtenis van zijn vader ancHISEs vierde, wanneer ENTELis a overwinnaar, met zijnen met lood gevulden osfenledere handfchoen, den Prijsttier voor den far floeg, dat hij dood neder viel. Men hoore hier weder VONDEL en VIRGILIUS:

Zoo fprak hij, ftaande voor den Woudftier, hern gegeven', Ten prijs van 't veldgevecht, on hief met kracht de hand? Bekleed met dit geweer en Buffels leere want,

Tot driewerf toe omhoog, en, mikkende op de farre; Des Wouditiers, kloak met kracht en al zijn magt dets - Varre

De hersfens in, dat hoofd en harsfenbekken kraakt, En de Os ter aarde plort, en lilleboent, en raakt Aan cene korte dood.

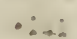




\section{VAN HOLLAND。 6}

Dit versje toont duidelijk, dat ENTELlus HET zeer wel het punt van de ftarre wist te tref Rundver, fen, zoo door zijne bijzondere kracht, als II. Afd. door zijne kennis aan de dreuning van het hersfengeftel. Ik erken dus in dit verwon. II. derend verhaal van de krachten van ENTELLUS wel iets bijzonders, maar ook niet meer als het geen men in de krachten en het beleid van geoefende vleeschhouwers erkent. Ik heb met eigen oogen gezien, dat. een forsch karel, met eene bijlknop eene Kae de ftarre doorfloeg, dat er de knop inzonk. Ik heb daarentegen gezien, dat een fchrandere handige jongeling, zoo juist was op het mikken van hegt centrum der farre, dat hij nooit misten om den Os te doen vallen, zelfs als forfche karels tot drie maat toe hunne kracht beproefd hadden. Ik voor mij, om dit in het voorbijgaan aan te merken, houde de kracht van eNTELi,us niet voor zulk eene groote bijzonderheid, als wel voor eene bijzondere bedrevenheid in het treffen, vooral als men anmerkt, dat het gebruik van dien țijd, om met $z$ ware osfenledere, of zoo als yONDEL het vertaalt, Buffelsledere handfchoẹnen, met lood en ijzer beklẹed, hetzelfde uitwerkfel had in den dol - of ftarreflag, als nu een bijlknop of dolhamer; dan dit flechts eene befpiegelende aanmerking zijnde, doet dit niets ter zake, gelijk ook niet, zoo ik denk, de billijke berisping, waarom vonDEL hier een Varre, een Woudftier, een Buffel en een Os, voor ẹen en hetzelfde Dier neemt, en dus in zes

$$
\text { E } 3 \text { a }
$$




\section{to NATUURLIJKE HISTORIE}

ser regels rijm, vier onderfcheiden Dieren voor zundViz. eeen en hetzelfde neemt; eene Dichterlijke II. Afd. vrijheid, dic zeker, als iemand dezelve in 1I. deze eeuw nam, veellicht den Dichter zou Hoofdrt. angewreven worden als of hij kolderde of fuifebolde, even als den Stier die gedold wierd. Dan 'al genoeg hier van, wij treden wat verder, en willen het Rund eens achter de ooren tasten, daar zal ons iets nader voorkomen, dat op het reeds gemel: de betrekking heeft, naamlijk de fteekspier.

sicelspier. De fteekjpier, of derzelver plaats bij No. 4. aangeltipt, is eigenlijk de fteekze. nuw, deze is nier algemeen bekend; alleen bij fommige Boeren en Vleeschhouwers in Zuidholland, bijzonder binnen de Stad Dordrecht, alwaar het vrij algemeen is om de Koeijeñ, Osfen en Stleren, niet te dollen, maar met een fcherp puntig mesje of vlijm, achter de kroon of horenwortel, tusfchen de ooren in te fteken, en aldaar de zenuw, die aan het begin van het ruggemerg, bij de cerfte werveibeenderen, die men den atlas noemt, af te frijden of te kwerfên, waárop het Dier dadelijk nederftort, en dodelijk in zwijm geraakt, waar na het dan verder gebloedrist wordt. Deze manier is wiskunstig genoeg, als zij wel be. ftuurd wordt, doch eischt, gelijk in alle za. ken, kundige ervarendheid; zij is zeker niet algemeen bekend; de foden, die de oudfre aan ons overgeleverde manier van flagten nog behouden, weet men, dat het flacht. dier de pooten, vastgebonden, van onder het 
lijf halen, en daar na den kop achter over dranijende, het beest keelen. De oude $R o$. meinen en Grieken, zoo als uit het aangehaalde van ENTELLUS en andere omftandigheden is betooge, dolden de Dieren met RUNDVER: een hamer of ander inftrument voor den kop: dus fchijnt het zenuwfteeken van ouds onbekend; echter is er een fpoor te vinden in de otde manicr der Stieren - of Buffeljachten, vooral bij de Indiaanen; deze wilde volkeren, hebben, wanneer zij op de Stieren - of Buffeljachr gaan, eenen taaijen ftok, aan welkers einde aan eene zijde een ijzeren bijl of puntig ijzer geklonken is, zoo als onze oude enterbijlen waren, en die aan de andere zijde een fcherpe lange punt heeft: wanneer zij nu een Buffel of wild Rund ontdekken, zoeken zij het op, en vertoor: nen het Dier, terwijl zij zelven zich achter een dikken boomftam verfchuilen, als wan. neer het Dier, naar zijn gewoonte dom toe. ftorende, op den boom aanftoor, terwijl den Jager behendig van op zijde den boom, zijn ijzeren punt achter de horen en het oor in flaat, zoo dat, indien hij wel treft, het Dier terftond valt, en dit tijdftip waarne. mende, keelt hij hetzelve en hakt het met den bijl den hielzenuw en daarna den kop af. Deze freekzenuw nu ligt tusfchen het ackter oor, de eerfte wervel en het achterfte gedeelte van het fteenbeen, zoo dat, wanneer de vlijm doortteekt, ook de oorfpieren gekwetst worden, de plaats dezer oorfpieren, is bij No. 5. aangeltipt, tevens met het oor, welker fpierwerking

II. Af 3. II. Hootdft. 
H? $x$ en ontleding zal volgen, bij de verhandeling. a.undver. over het gehoor der Koeijen, in een afzon. II. Afd. derlijk Hoofdftuk. Evenwel moet ik hier II. met een woord aanftippen, dat alle de RunHoofdf: derdieren, het zij Stier, Koe of Kalf, altoos de ooren zijdelings hebben uitfteken, nimmer, althans zeer zeldzaam, hangende, $z 00$ als de $Z$ wijnen, nog fteil opftekende, als de Paarden, evenwel gebeurt het, dat de eene Koe de ooren meer ftrak en ftijf, ook borsteliger heefft dan de andere; men vindt er ook wel die korter, langer en zelfs ftomper zijn. Er zijn ftreeken, daar men veel houdt, om de Koeijen, ter voorkoming van eenig ongemak, als de blaer, fchurft enz. in de ooren te fnijden, of er lappen af te fnij:

- den, dit misvormt dan het oor, en is onnatuurlijk. Wij gaan over tot het oog.

Het oog: Het oog wordt bij No. 6. anngewezen, over hetwelk wij insgelijks in het Hoofde ftuk, 't welk over hẹt gezigt der Koeijen zal haudelen, uitvoeriger zullen fpreken; men fla hier bij voopraad in deze Figuur fiechts gade', dat het oog of de oogen der Koeijen, gelijk in vele andere Diẹren, niet vlak vooruit, maar zijdelings in de oogkas ftaan, oogleden. gelijk cok de oogleden bij No. 7. de ba: ren zijdelings en vrij uitftekende vertoonen, in zoo verre, dat dẹ haren der oogleden van eene Koè, eene merkelijke borsteligheid hebben.

Ooghol. ' Het ooghol, dat bij No.8. is aangewezen, is niet het beene ooghol, waarin de bol van het $00 \mathrm{~g}$ in het hoofd ligt: dit is eigenlijk 


\section{Y A N HOLLAND. 73}

¿e oogkas, bij het beendergeftel verhandeld, maar het ooghol, dat hier wordt aangeduid, RUNDver: is zekere holligheid, die in alle Koeijen zeer kennelijk, zijdelings, even boven het oog, te zion is; het is dat gene, dat men II. Afd, II. in den Mensch, en in ander viervoetig. Gedierte, den flaap noemt, en gelijk in alle deze Dieren, door magerheid en ouderdom, den flaap des hoofds zich holder vertoond, $a$ 's in den bloei des levens, zoo is het ook met de Kosijen, doch veel fterker als in eenig ander mij bekend Dier, uitgenomen het Paard, doch al mede in een minder trap, behalven in ftokoude Paarden; dit ooghole is fomwijl zoo diep, dat men er een kindervuist in kan fteeken; het is dikwijls vol vuil, ftof en zweet, waarom een zindelijk Landman zo:gt, dat het gereinigd wordt. De Veekenners letten insgelijks op dit oog. hol, of het min of meer knokkig of diep is, of de huid aldaar leenig en het haar zacht is, of het rappig is enz. waar uit zij dan de gezondheid, vetheid, vooral den ouderdom en andere teekenen affeiden.

$\mathrm{Nu}$ komt de neus, of eigenlijk de nezus. De Netss. gaten, in aanmerking. De neusgaten, bij Neusga. $N^{\circ}$. 9. aangeduid, zijn in de Kaeijen zeer ten. verfchillende van die van andere Dieren. In de Paarden zijn zij zeer bewegelijk; in de Konijnen alleriterkst; doch in de Koeijen en de Honden fchijnt de natuur een vaster eeitgeftel aan de neusgaten gegeven te hebben: doch daar wij over het reukgeftel der Koeijen, 200 wel als over de andere zintuigen, naauw. E $5 \quad$ kets. 


\section{Y4 NATUUURLIJKE HISTORIE}

HЕт keurig zullen handelen, zijn deze aanduidinRUNDVRE. gen genoeg om aan te toonen, dat de neus. II. Afd. gaten der Koeijen, even als de oogen, in I. eenen zijdelingrchen afftand van elkander Hoofdr. ftaan, in diervoegen, dat de tusfchenruimte tusfchen de twee neusgaten niet uitftekende is, maar zijdelings plat en zenuwachtig, waar door dan dat gedeelte, hetwelk men in den Mensch en bij andere Dieren neus noemt, in de Koeijen den fnoet, den muil, den fmoel (probofcis) genaamd wordt.

De muil. Deze muil of fmoel is bij $\mathrm{N}^{\circ}$. 10. aan. geduid, $\mathrm{en}$ is eigenlijk de bovenlip der Koe, die onmiddelijk de Neus zelve uitmaakt; men kan en moet evenwel de neus bepalen tot dat bekleed gedeelte van het neusbeen, dat zich van onder de ftarre of kol, tot aan den bovenlip of muil uitftrekt, het geen men duidelijk ontwaar word in de fcherpe hoeken, die het neusbeen tot op den muil doorteekent, zoo dat de bovenlip te. vens met de neusgaten vereenigt, den eigenlijken nuil uitmaakt, en nademaal deze neusgaten deels de ademhaling bevorderen, en zij met de bovenlip grazen of het voedfel zoeken, zoo is eene Koe nooit vatbaar om een gebit in den muil te dragen, gelijk dit in de Heilige Schrift bedoeld wordt: eenen Os zult gij niet muil banden als hij dorst. De Schapen, Bokken en Geiten gedoogen fomtijds een gebit doch ook hunnen muil, hun bovenlip is fpitfer, evenwel kunnen zij geen tongItammen velen. Doch niettegenftaande dit, 
is er evenwel iets vrij algemeen bekend, zoo нЕт wel bij de Oosterfche volkeren als bij ons, RUNDVEE: te weten, dat daar men Osfen, vooral Stie- II. Afd. ren of wilde Koeijen, door geen muilband kan bedwingen, dat men dit doct door midII. Hoofds: del van eenen koperen of ijzeren ring door de neusgaten te flaan, dat zeker het fterkite middel is om deze ontzagchelijke Dieren te beteugelen. De Egijptenaren en andere volkeren, beftuurden de krachten der Kamelen, en de Afrikanen hunne Elephanten door haken in de neus te flaan; hier van: ik zal mijnen hake in uwe neuze leggen, en u leiden den weg, dien gij gaan zult. Dit alles famen genomen, houden wij voar verklaard, wat eene neuze en muil of fimoel der Koeijen zij; zullende het overige bij het zintuig der reuk verklaart worden; eer ik ech. ter hier van afftap, wil ik nog kortelijk aanmerken, dat de Hollanders bijzonder hee woord muil bezigen, in afleiding van der Kioeijen muil of fmoel, nademaal men van iemand die een breeden uitftekende lip, met een platte neus heeft, zegr: hij heeft een muil, een koeijenmuil, dit gaat zoo ver, dat de Phij. fionomiekundige LAVATER, en voor hem an. deren, hier uit een dom verftand anteiden; doch dit kan wel misfen, door dien Ezopus en socrates zulke dikmuilen, doch geenzints botmuilen waren. Voorts kan en mag men de bovenlip of muil ook wel fnayel (probofcis) noemen, zoo als in de Elephanten en Kamelen, om dat de bovenlip eener Koe ook in het annfokken van kruidẹn dezelfde werking doet.

Snavel::

De 


\section{NATUURLIJKE HISTORIE}

rex De onderlip, bij No. II. aangeduid; is RUNDVEE. meest los hangende, en niet zoo hard of II. Afd. fteekelig als de bovenlip, zij is harig, doch II. zachter van haar, daar de bovenlip borsteHoofdft. liger is. Deze onderlip is vrij bewegelijk , Onderlip. en omvat de tanden, voornamelijk de voortanden, waar over breeder gehandeld zal worden.

De kin. De kin, N: I2. is onmiddelijk het ondergedeelte van den onderlip, onder het uiterfte einden van het kinnebakken. Deze kin is in vele Koeijen ruig en harig, in fommigen, vooral bij oude Stieren, is het kinhaar langer en fchijnt een lange baard te worden, veeltijds is dezelve witharig; men vindt er, welker kin kennelijk gebaard is. De kin der Koeijen is voorts breeder als in de Paarden, en fchijnt als een bak of geul, die in de breedte zich uitbreidt, en als tot opfcheppen gefchikt is; misfchien daarom bakhuis en kinnebakken genaamt. Ziẹ hier boven bij kinnebak.

Kinnebak. De kinnebakken, N?. I3. zijn eigenlijk de onderite kaakbeenderen, met hunne fterke kaauwfpieren bezet; deze is fomwijlen fterk gehaard en heet dan kinnebaart, $\int k$. kebaart; deze beginnen aan de inlijving van het kakenbeen, in het hoofd tegens de groeve van de bovenkaak, 'zij bevatten de kieder. de in den bak van het kaakbeen of kinne. bakken; dit kinnebakken is bekleed met een zeer fterke zenuwachtige onderlip, vol met een foort van lepels bezet, en inwendig met 


\section{$\forall A N H O L L A N D$ D}

de baktanden of kiezen, welkers befchrijving it th en afbeelding, bij het verhemelte en de her-RUNDVEE, kaanwing nader zal voorkomen, gelijk ook II. Afd.

De boventaakpieren $\mathrm{N}^{\circ}$. 14 , welker onderfcheiding duidelijk in alle Runderen zigtbaar zijn, door den inval der tusfchen- Boven. ruimten van de geulen der onder. en bo-kaakSpievenlip, br̈zonder door de affcheiding der gaping van de lippen bij het einde van derzelver zamenvoeging, maar allerbijzonderst door de herkaauw-fpieren $N^{\circ}$. I5, die al. daar als de wangen der Koeijen uitmaken, en zeer veel toebrengen tot het fraaije hoofdftel eener Koe, even als de wangen of koo- Kaaknen in het aangezigt van een Mensch. In wanger. der daad, dir aanzien verfchilt mede merkelijk in de Koeijen, want men vindt er, die deze wangen, kaak - of ' kaauwfpieren (Masfeteres) merkelijk gezwollen en vet hebben, anderen daarentegen doorteekenend: men vergelijke in Plaat V. de hoofdfiguren of Koekoppen, daar zal men den eenen vet en bol gedrongen, en der anderen fchraal en mager zien.

Het yoorhoofd of de bovenkaak aan de Het vooro neusbeenderen $\mathrm{N}^{\circ} .16$, is hier eyen ange- hoofd. wezen in tegenftelling van de onderkaak, gelijk ook bij $N^{\circ}$. 17. de plaats der kol of Itar, 200 even breeder befchreven.

Het hoofd tot dus verre in alle deszelfs voornaamfte uiterlijke deelen befchouwd zijnde, volgt hier op deszelfs verknogtheid aan het overige gedeelte des ligchaams, on wel an het vooritel. Hier komt dadelijk voor:

De 


\section{NÀTUURLIJKE HISTORIE}

set De nek, bij No: 18: sangुefipt. De nels RUNDVEz. begint eigenlijk aan her achtereinde van het

II. Afd. kroonbeen of de horenwortel, alwaar het II. eerfte wervelbeen den atlas in de groeven van het achterhoofd draait; bij het been-

De nek. dergeftel reeds nader verklaart $\hat{s}$ alwar men zien kan hoe verre de wervelen van den nek zich uitbreiden. Men rekent uitwendig de nek, van het achterhoofd af, tot langs en aan den achter-bovenhals of nok $N^{\circ}$. 19. Dit woord nok vereischt hier eenige nadere

De nck. opheldering. Nok is eigenlijk het oorfpronkelijk namwoord; en beteekent eene zamenloopende hoogte, als s bij voorbeeld: de nok yan het dak; in dient zin is dari de nok juist zulk eene zamenloopende fchuinfche hoogte, die als ' $t$ ware het dak van dein hals aan de fchoft maakt, waar van de benaming

Haarnok: van haarnok komt : zijnde de haarnok juist het harig gedeelte dat van den nek langs tot deń nok den hils van boven volgt. De Biscaijers, zelfs de Vrouwen, hebben doorgaans zeer ruige zwarte haren aan den nek of nok, gelijk ik dic bij zekere aanzienlijke Biscaaifche Spaanche Princesfe bij ge legenheid aan haar toilet heb waargenomen. NIen verdeelt dan den hals in den haarnok en nek No. 19; dit is zoo veel als' in de Paarden de manen, het zijn in der daad de manen der Koeijen; de haren dezer nokker zijn dikwerf vrij lang en ruig, altoos on. derfcheiden van het ander haar; men vindt zelfs haarnokken die geweldig uitfteken en als openvallen, dat men fpothals noems. 
De haarnok is altoos duidelijk te onderkennen, langs den geheelen bovenhals tot aan den fchoft bij No. 26, daar eigenlijk de nek eindigt, ziet men dit duidelijk aange. toond; ondertusfchen zijn er vele Koeijen, RUNDVRE: die deze nok vrij fcherp en fmal toeloopende hebben, dat geene goede gedaante is, nademaal een Veekenner gaarne een hoogen ronden nek ziet. Deze nek is eigenlijk in de Osfen de bast of jok, in de Paarden de zadelnok, lastdrager, zadeling; veeltijds is deze nok kaal en glad, door het fchu. ten aani de hekken, boomen en fchurkpalen; dit noemt men dan kaalnok, fchuurnok, jeuknok, waar over hier in 't voorbijgaan eene kleine annmerking, namelijk : dat juist alle viervoetige Dieren, ook vooral de Mensch, ja de meeste Vogelen insgelijks, omtrent dit nok - of nekbeen aan den flag met eene zekere jeukerigheid geplaagd worden, en niet zelden met ongedierte, waar - van men wel eens anleiding tot een verwijt neemt: bij de verhandeling over de zickten der Koeijen zal ik dit nader ophelderen. Eindelijk wordt deze nok of nek bij uifftek ook fchoft genoemd, daar men die II. Afd. II. Hoofdis: in het nekbeen atlas noemt, om dat de fterkte van ATLAS, die men de wereld dra. gen doet, daar in gelegen is; waarom de Dichters zeggen:

Daar atras, forsch en fterk, de nek voorover dofe; Torscht hij den wereldkloot op zijaen breeden f́hofto 


\section{0}

Het $\mathrm{Nu}$ volgt de ftrot of gorgel $\mathrm{N}^{\circ}$. I9, die AUNDEE. ook frothals of de keel genoemd wordt; 11. Afd. naar de benaming van de longpijp, die men II. frot of gorgel noemt; dezelve begint aan Hoofdit. het ftrottenhoofd of het keelhol, de keel. De ftrot put, en is het begin van de keel, in alle of gorgel. Koeijen zoo kenbarr, dat men door de huid heen de werking vant de fpieren in het doorllokken zien kan. Hierom wordt dit gedeelie ook fokkecl, flokftrot, Rokdarm genaamd: De Koeijen zijn zeer gaarne aan dat gedeelte gekrouwd en geftreeld; de ontembaarfe Koe wordt mak, wanneer men flechits dit gedeelte kan te ftreelen krijgen! zij fteekt lijdraam den kop vooruit, en gedoogt het gieftreel langs' den geheelen halsvang.

Halsvang. De hals of de halsvang en deszelfs fpieren $\mathrm{N}^{\circ} .20$. begint onder dit gedeelte: men verftant èr het gedeelte door; dat van achter de kaken onder langs het ondergedeelte der hals loopt; het is de halsyang, die men ook noeme keelhals, keelftrot; want deze wordt tevens met de ftrot en de bloedaders in het keelen of bioedritfen der Runderen doorgefneden; wijders wordt den hals of den halsvang ook schothals. wel genoemd fchothals, fchurklials; de Schurk- Ouden noemden dit gedeelte wamme, de bals. koewam, dát zoo veel is als een kwab (palend), die onder de kin af hangt en de krop uirmaakt, dus ook wam, kwabwam. kosferm enz.; doch zij dient hier van onderfcheiden te worden, gelijk duidelijk blijkent zal, ook van yleeschkwab, kwab, knobbelkwab, als de kosfem knobbig en klierig 


\section{VA N HOL L A D. $8 \hat{\mathrm{I}}$}

is; niettemin zijn de keelkwabben niet ongemeen bij de Kocijen; vooril onder aan $\mathbf{R}$ Uwbvéz: de keel - en kaakfpieren, even als de zoo- 1I. Afd: senoemde wenners.

Schothals wordt de hals in 't algemeen genoemd, om dat om den hals de touwen schothats: en gcfpannen geflagen worden, waar mede de Koeijen op de ftallen tusfchen de fchotreepen en tan het fchot gelloten worden; hetwelk voornamelijk om het hoogfte gedeelte van den hals gefchiedt, war van hee woord fchothals komt, ook wel om dat, wanneer de Koeijen dikwijls genegen zijn de flooten over te $z$ wemmen of te wild in de weide zijn, men dezelve een houten fchor om den hals doet, waar door den hals of kaal of ingebogen wordt:

Schurkhals is al mede eene bijzonder- schuifs: heid, reeds angeltipt bij nokhals. Dezen hals: naam geeft men aan Koeijen, die door de jeukerigheid geplaagt, zich voornamelijk met den hals tegen boomen, palen, hekken of iets anders wrijven, zoo dat zelfs de huid kaal wordt; men vindt daarom tot gerief der Koeijen overal in. de weiden palen gezet, die men fchurken noemt, fchurkpaal, denkelijk van fchurf, fchurfpaal. Se. derc langen tijd heeft men bijina algemeen in Noord - en Zuidholland de ontzaggelijke kakbecnderen en ribben van Walvisfchen tot zulke fchurken in de weiden geplant? herwelk voor vreemdelingen een bijzonder verfchijnfel is, als ongewoon aan deze gebruiken, vooral als men bij de zindelijkè

$$
\text { F Nória }
$$

II. Hoofdit,

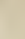


nRT Noordhollanders deze kaken fierlijk befchifRUNDVEE, derd ziet. Voor het overige fchurken vele

II. Afd. Koeijen zoo fterk aan deze palen of ook. II. wel aan de fchotten, dat zij den hals, halsHoofdrt. vang of het halsftuk genoegzaam kaal maHalsftuk. ken, en dan is het cen regte fchurkhals; maar integendeel, als de Koeijen de hals vet en harig hebben, gelijk meestal het voornaamfte gedeelte van den hals zoodanig Halsplooi-is, dan onderfcheidt men die in halsplooiien. jen, althans daar deze plooijen het meese zich vertoonen, zie $\mathrm{N}^{\circ} .22$, daar is eigen. lijk de halsyang, welke naam bij de Vleeschhouwers het meest in zwang is, vooral ook halsftuk, onder welke namen zij dit gedeelte verkoopen; ook wel $k o p$. ftuk; onder dit gedeelte liggen de zoogenaamde keuvel - en neusfpieren, hegt-en vezelfpieren van den hals.

Ondertusfchen, welke benamingen of verdeelingen men van eenen Koeijenhals make, dit is algemeen, dat aan de fraaiheid, fijnheid, zachtheid en welgemaaktheid van eenen Koe -, Osfen - of Stierenhals, genoegztam de volmaaktheid van het gehecle Dier, bijzonder van het hoofdtel, en vooral de kunde van deszelfs gezond of ongezond geftel onderkend wordt, gclijk hier dan ook inzonderheid bij behoort de fraaiheid van den kosfem, borst en fchoft, die nu voorkomen.

Dekrop. De bovenkrop of de krop, kropftuk, wordt aan het einde van den ftrot gevon: den, en is het begin van de borst, van de keelput af, die tusfchen de gewrichten van de fleutelbeenderen geformeerd wordt. Hier be- 
begint eigenlijk de borst of bovenborst, terwijl de onderborst aan den kosfèm lige. Dit gedeelte is bij $\mathrm{N}^{\circ} \cdot 23$. aangewezen, hetwelk, alhoewel hetzelve tor den kosfem onmiaddelijk betrokken wordt, evenwel door

eene zekere infnijding of fpierplooi kenbaar is. Ingevalle men een $O s$ in het gareel fpant; om den ploeg of wagen te trekken, is het hier de plaats daar het haam voor gefpannen wordt, en is dit gedeelte de borst van de Koe, welk deel ook bij het flagten het eerst wordt doorgehakt, te weten, het voorfte van het borstbeen, waar men dan zeker kliergeftel tusfchen het geele ver vindr, dat men borstje, veelal zwezerik noemr; onder dir gedeette liggen de II. Afd. II. Hoofdsh groote en kleine borstfpier, zaagfpier en fleutelfpier: dit deel is het geen men ook anders glandula Thymi noemt, ook wel kropktier, dan, deze is geheel iets anders, en beftaat eigenlijk uit eene vergroeijing der onderkaakfche ftrot - of kwijlklieren, en behoort tot de ziekten dor Koeijen : men noemt het daarom ook kwijlkrob, kwijl. balg.

Aan de borst nu volge dat zonderling en eí- De kos? genaartig geftel van den kosfem No. 24. Deze kosfem is voorzeker als eene bijzonderheid aan te merken, nademaal mén in geene viervoetige Dieren iets dergelijks vindt, althans niet zoo uitwendig; het is eigenlijk eene kwabbe of wamme, zoo als KILIAAN die te regt noemt, want door eene kwabbe, ook wel eens borstlelle, yetkwab, yleesch. rwab of wamme, verftaat men eenig velI? $2 c t-4$ 


\section{\%4 NATUURLIJKE HISTORIE}

HЕт achtig bijhangfel, vooral aan de onderkin *undver of de borst; wij weten, dat men iemand, II. Afd. die een $z$ ware onderkin heeft, een $k w a b b e$

II. nocmt, vooral als het in Vrouwen zich verHoofdr. toont, en de kwab of wam tot aan den boezem hangt, dan zegt men: ' $t$ is een kwabbe. Deze kwabben zijn in den mensch als een gebrek, en dikwerf oorzaak van eene flijmerige aandrang op de tongklieren en kwijlvaten, zelfs zoo, dat de meesten zwaar en belemmerd van fpraak zijn, als wanneer men ze kwab-en babziek noemt. In Zwitferland is, een zeker geflacht bekend, waat van ik een Man en eene Vrouw gezien heb, die zulke keelkwabben wel ter grootte van een vollen geldzak hadden hangen. In de Koeijen, die deze kwabbe of kosfem bovennatuurlijk zwaar hebben, heeft ook doorgaans iets dergelijks plaats. Ondertusfchen hangt deze kosfem, wamme of kwabbe van de onderborst tusfchen de voorpooten der Koe, en kan tot zulk eene ontzaggelijke zwaarte in vet aangroeijen, dat zij tot op de fchenkelen doorhangt. In vette Koeijen; vooral Queën, heb ik er gezien. die bijna tot op den grond hingen; de Osfen hebben ze minder zwaar. In de tafereelen de Gild-Osfen, boven vermeld, ziet men die doorgaans. Het is ook op den kosfem, dac de Vetweiders letten: als men eene Koe koopt, betast men altoos den kosfem, waar bij dan komt de gevoeligheid die eene Koe aan dit gedeelte heeft, zoo als vermeld is: niets kan eene Koe meerder lokken tot ftil- 
ftaan en betasten, dan het ftreelen aan den kosfem, hetwelk reeds meermalen is aan RUNDVE, geftipt. Zoo ftreelde inachus zijne Doch- II. Afd. ter Iö, welke in eene witte Vaars veranderd was; maar natuurlijker drukt ovidius dit II. Hoofdf: uit, in her geval van JAson, die de woedende Stieren onder het juk bragt: zijn gezegde komt hier net ter fnede; zie hier hetzelve, bij verkorting, aldus:

"JAsun ftapt de Stieren te gemoet, die ", met een wreede en vervaarlijke greins "met verijzerde horenen en 'gekloofde hoe"ven moedig op hem aantreden en loei" jen, dat het aardrijk allerwege vol damp ", en rook is; de Tesfaliers hadden den ", dood op 't lijf. Maar hij komt haar on", der het gezigt, blijft ongedeert door mid", del van zijne krachtige toverkruiden, van " dien vurigen adem, freelt onbefchroomd ", den KWABBIGEN KosSEM, dwingt haar on" der 't juk en gewone ploeg," enz.

Van dit treelen van den kosfem vindt men bij denzelfden Dichter nog gewag gemaakt in de Fabcl van europa, die den witten Stier aan den kosfem ftreelde: dus is dan dit geftreel der Koeijen, aan den kosfem. $k$ wabbe, zoo als VALENTYN te regt vertaalt, eene overoude kundigheid van alle Veekenners, en gevolgelijk ook nog bij onze Boeren overbekend, in zoo verre, dat het als nog het eerfte en genoegzaam eenig middel is, om eene jonge dartele Koe, een Stier of Os, tot ftaan te brengen, en dan met eenige jeuking aan de kruin het touw F 3 om 


\section{$80^{\circ}$ NATUURLIJKE HISTORIE}

He: om de horenen te laan, zoo als hier vorọ - undVE. betoogd is.

II. Afd. Ondertusfchen is er nog eene nadere on-

II. derfcheiding bij onze Hollcndfche Koeijen, Hoofdit. tusfchen de borst en den kosfem: zij noemen de bovenkrop kosfem, ook krop, bovenvoorborst. en onderkrop, bovenborst, voorborst. (zic No. 23.) door de onderkrap begrijpen $z i j$ den kosfem, of dat gedeelte dat voor de voorpooten zich vertoont: mạar het achterfte gedeelte van den kosfem, dat achter de dijen der voorpooten zich vertoont, noemen $z i j$ Naborst. de naborst, nakosfem, (zie $\mathrm{N}^{\circ} .2^{25}$ ) deze naborst bekome vervolgens nog den naam van

Voorvang. yoorvang, in tegenftelling van den achtervang, ook wel zwezerikyang, waar van reeds gefpraken is; er zijn er dic den kosfem ook yetlok noemen; doch dit is zoo nict, yetlok is een vette haarlok aan de hakken der Paar. den, en op de Koeijen niet toepaslelijk. Eindelijk is er nog een merkelijk onder. fcheid tusfchen cen ruigen cn gladden kosfem : de gladde is altoos fijnharig en vellig, doch de ruige is in fommige Kocijen zoo langha. rig, dat de haren tot op de kooten necrhan. gen, gelijk in de wilde Koeijen. ( Zie Plaat I.)

Tot hier toe het voornaamfe van het hoofd, den hals, de borst enz. aangewezen zijnde, vervolgen wij met het Middenftel, doch dienen vooraf te melden, dat hier eene bijzondere verdeeling plaats heeft, die meren. deels van de vleeschhouwers oorfpronkelijk

$\mathbf{K w a r t i e}$ is: $\mathrm{zij}$ verdeelen de Koe in kwartieren, het reṇ. yoor - en achterkssartier: onder het voorkwar: 
kwartier rekenen zij het hoofd, de fchoft, HET nek of nok, de kals, de borst en de voor- Rundvre. pooten, tot midden in het middenrif, aan de korte ribben; onder het achterkwartier, het kruis met de achterbillen, pooten en II. ftaart, en zoo vervolgens weder elken poot met zijn aanhang in een kwartier, dat dan de vier kwartieren van eene koe zijn, gemeen. lijk bekend bij de linker - en regter voorvoet, of de linker- en regter achtervoet, waar nit dan het volgende geestig raadfeltje ontftaan is: bij voorbeeld, men vraagt: als een yoet vleesch twintig guldens kost, op hoe veel koint cen kalf te faan? iemand die nu de kneep niet verftaat, gaat aan het berekenen der waardij van een Kalf tegen eene Koe; doch hij is mis, want de vraag ingewikkeld zijnde: op hoe veel yoet of yoeten komt een Kalf te ftaan, dat is: op hoe yeel yoeten of pooten fiaat een Kalf, zoo is het antwoord natumrlijk, dat een Kalf op yier yoeten of prioten fiat.

Tot het yow wartier komende, (want Voorkwar: hier moeten wij het gebruikwoord volgen, $)$ tier. Hoofde: komt hier eerst in aanmerking de $\int c h o f t$ - of jokfchouder, an de nok vereelt. ( $\mathrm{Zie}$ Jokfchou. $\mathrm{N}^{\circ}$. 26.) Er is reeds bij $\mathrm{N}^{\circ}$. 21 . melding der. gemaakt van den nek - en den haarnok, doch hier komt in tegenftelling van den haarnok, de fchoftnok voor: hier eindige de haarnok tegen het heuvelachtige of liever de bultachtige verhevenheid, die zich zoo kennelijk in alle Runderen vertoont, zelfs kennelijker dan in eenig ander Dier; 200 dat men $\mathrm{F}_{4}$

er 
MEx er onder dit geflacht vindt, die dezen nok of zuNDVER fchoft als vereeld hebben; het geen fam: II. Afd. mige Natuurkundigen toefchrijven aan de II. verwenning of vergroeijing, die deze Dieren tyoofdrt. zouden aanneemen, doar het dragen van het jok, gelijk zij willen dat dit bij de Zebu, die een aanmerkelijke bult heeft, plaats heeft; zelfs zijn er, die de kemelsrug aan diergelijke oorzaak toefchrijven. Het lust mij niet hier over in gefchil te treden, terwijl er te voren al iers van gezegd is; dan ten opzigte van de Koeijen, ontken ik het volftrekt, en wel om deze bondige redenen: die in weinige woorden dit vertelfel zullen ontzenuwen. Ik redeneer dus: indien het vergroeijen van dezen nok of bult oorfpronkelijk is van hec jok dragen of den ar: beid der Koeijen, en door voortteeling veranderd, dan moeten die Dieren, die voort: teelen, aan dezen last en vervolgens aan vergroeijing onderworpen zijn geweest ; maar. nu wordt altijd tot het jokdragen en ploe: gen de Os gerchikt, en nimmer of zelden de Koe, het Vaars of de Melkkoe; dewijl nu de Os niet voortteclen kan, en de Koe niet gebruikt wordt tot lastdragen, is die veronderftelling van vergroeijing, een louter verdichtel van hersfenfchimmige inbeeldingen, om de vaste natuurwetten, aan elk Dier ingefchapen, uit te leggen volgens. menichelijke begrippen, die nooit tot het Goddelijke Albeftuur kunnen indringen, en derhalven door geene vernuftige wijsgeeren te verklaren zijn. Dus komt de nok hier voor. 
voor in her eigenlijk begrip van $\int c h o f t$. De HET beteekenis van fciroft, "is alzins in den zin RUNDVRE: van den bult of de hoogte van het nek- II. Afd: been, waarop alle de Dieren de lasten dragen. Zoo wordt aan Atlas, die den Aardkloot II. op zijn nek en fchouders torscht, eenen De fchofs: groven fchoft toegefchreven : hij draagt de wereld op zijn fchoft; van een boutigen kaerel, die lasten op zijne fchouders draagt, zegt men: hij heeft een breede grove f̧hoft. De fchoft is dan in het gemeen, dat uitftekend gedeelte van het nekbeen, alwaar de halswervelen eindigen, en de ruggewervelen beginnen, beteekenende nok of $\int$ chouder. Het wordt dan ook op de Koeijen toegepast, niet alleen als de fchoft, maar nader als de jok/choft, de jok- of jukfchouder, dat is Jokichors; dat gedeelte, waar op een Ploegdier het jok draagt; hier van jok-osfen, als zijnde deze inzonderheid gefchikt om her ploegjok of juk te dragen, zoo als het hier boven reeds is aangeftipt: dat JASON de Stieren, door ftreelen aan den kosfem, onder het jok bragt. Het leggen van het jok op dienstbare fchouders, is overbekend; het zinnebeeld van twee Osfen, die eenparig onder een jok trekken, het dragen van het melkjok, het huwelijksjok, en ontelbare zin. fpelingen hier op toepasfelijk, zijn overtuigelijk genoeg um te kunnen begrijpen, waarom men in de Koeijen een jokfchouder erkent, namelijk om dat het dat gedeelte van de ruggegraat is, dat het jok draagt. Onze Boeren kennen den zin van dezen naam F 5 zees 
w\$x zeer wel, want zelfs zeggen zij van eene zUNDVER. Melkmeid, dic het melkjok draagt, dat hare II. Afd. fchouders en boezem naar het jok ftaan:

II: Woofdn.

Haar fiere heupenzwaai, daar zij den emmer drazgt,

$Z$ wiert op den vasten tred: de fehouders van de Maagd Gekneld door ' $t$.juk, geeft kracht aan ' $t$ plegen en 't verrigten,

Van 't boter karnen, en der vrouwen zuivelpligten.

Maar alhoewel nu de naam van jokfchou. der, jokfchott hier mede verklaard is, zoo is deze benaming onder de Hollandfche Boeren op verre na zoo gemeen niet als chloft en $\int c h o f$ tnok, en de reden is natuur. lijk, om dat men in Holland, Vriesland en elders, ten minfte voor zoo ver ik heb kunnen nagaan, niet met Osfen ploegt, en gevolgelijk het jok minder bekend zijnde, de benaming van jok-os ook fchier niet gebezigd wordt. Alle de fpieren van den jokfchoft hebben gemeenfchap met de borst - en fchouderfpieren, door cene menigte vezelén en hechtingen aan de voorfte ribben en wervelen.

De jchoft, nok en jokfchouders daar la. tende, komen ons kennelijker voor de yoor-

voor:" fchouders, $\mathrm{N}^{\circ}$. 27. De voorfchouder is ichouders het hooge gedeelte van het voorkwartier aan beide de zijden, en' is dus of de regter. of de linker voorfchouder; de regter is hier bij $\mathrm{N}$. 27. aangewezen, het beloop daar van rekent men van den fchoft tot aan het voorgewricht; zij bevat het achter-borstbeen, en vooral het fchouderbeen, of ei- 
genlijk het fchouderblad, het fchildbeen HET ( $\left.\int c a p u l a\right)$, waarom het gedeelte dat door Rundver. de vleeschhouwers hier uit wordt gehakt, II. Afd. fchildribbe, ook fchouderftuk genaamd wordt.' Hoofdet Men noemt het ook platte fchouder, in tegenftelling van den fchoft, dat de ronde schildfchouder is, (in de Plaat van het Beender- Platte geftel kan men dit fchildbeen of fchouder- fchouder; blad nader leeren kennen). $\mathrm{Bij} / \mathrm{N} \cdot 28$. is de plaats waar men de fchildrib of de platte fchouder vindt, angeduid; bij $\mathrm{N}^{\circ}$. 29. eindigt, dat men fchouder, fchoêr, of het fchoêr- De fchoer: ftuk noemt, want aldaar begint, gelijk in Schoer: alle viervoetige Dieren, het armgewricht; het vleesch tusfchen dit gedeelte noemt men ook crhijfftuk: het is het beenhoofd van den voorvoet, hetwelk in de holle groef van het fchildbeen draait; dit been vervolgens verlengende, vorme bij $\mathrm{N}^{\circ}$. 30 . dat geene, dat men in den Mensch den elleboog uoemt. Alle deze beenderen zijn nader afgebeeld bij rif van de Koe in Plant VI. In de afbeelding, welke wij nu verklaren, zijn dezelven met de fpieren enz. bedekt, en deze worden alleen ter aanduiding van de uitwendige verdeelingen der Ledematen aang'ehaald. Zij zijn voornamelijk die genen, die men in den Mensch de driepuntige, de groote en kleine borstfpier, ruggefpier, ronde, ondergraatfche, ravenbekfche en onder - en bovenbladfche fchouderbladfpieren noemt: deze zijn alle de voornaamite deelen van het voorkwartier, en worden hierom bij de Xoekenners en Vleeschhouwers wel oplet- 


\section{NATUURLIJKE HISTORIE}

ив rUNDVIE. kelijk in hoogte, breedte en dikte of vezel.

II. Afd. achrigheid De nok of fchoft kan in de II. Koe of Os hoog en bultig zijn, en hard in het betasten, de andere in tegendeel zacht,

De borst. lenig en glooijende. Het borstbeen of de fchild, kan in de eene zeer beenig uitfte. ken, en in de andere zache en als in de kos. femfpieren zich verliezende. De fchouderfpieren teekenen in deze fterk, en in gene zijn zij als in een geweld, het is hier, daar ook het vet meestal te ondertasten is. Een kenner zal alcoos dit gedeelte met de vingeren zachtelijk prikkelen. In vette Koeijen befpeurt men hier bij eene zekere trilling, eene huiverigheid van den huid, hetwelk een goed teeken is, en waar door de vetheid en lenigheid der fpieren aangeduid wordt. Men zegt hierom wel dat de Koe trilt, of waggelt $y$ an het yet. Integendeel, als de huid hard is en men de beenen fterk door de fpieren heen bemerkt, dan zegt men hij tast fchraal, hij is bonkig, enz. dit vertoont zich ver-

\section{De} fchinkel, volgens fterker aan de elleboogknop No.29 en 30. alwaar de zoogenaamde fchink of het fchenkelbeen begint, die het tweede arm. been van den voorvoet uitmaakt, en bij $N^{\bullet} \cdot 3 a$. vervolgt tot an $N^{\circ} .32$. alwaar het kniegewricht begint; dit gedeelte wordt doorgaans de voorfie mergpijp, murfpijp genoemd, ook wel de fchinkel, fchenkel, en ook vleeschfchinkel, kalfs/chinkel, bout. doch dit zijn meest achter deelen. De fchenkxel is omringd van de meeste taaije zenu- 
wen en fpieren, die van den fchouder nederdalen, en aldaar zijn ingelijfd ter beweging van den voorvoet, deszelfs voornaamfte centrum, of liever zamenloop, is aan den knok No. $3 \circ$. die bij den Mensch den elleboog vitmaakt, en daarom bij de Koeijen insgelijks den fchinkelknop, den elleboogknok heet; wat nu wijders fchenk, fchink, fchin$k e l$ is, is genoeg bekend, doch het wordt wel eenigzins verward gebezigd, dewijl men ook een yarkensham fchink noemt. Ook een fchapenbout fchinkelbout, hetwelk gemeenlijk de achterbout is. De fchinkel, eigenlijk fchenkel, is het armbeen van de Koe, het zij voor of achter, hier van yoor - of achterfchinkel; de vleeschhouwers onderfcheiden het ook zeer wel in voor - of achterfchenkel, dat is die van den voor - of achtervoet. Gelieve nu iemand het ook fchonk te noemen, her een en ander zal doch op hetzelfde uitkomen.

Nog wordt het vleezigfte gedeelte boven de knieën, of ook de achterhak, wel eens fchijf genoemt, doch meest in Kalven, als kalffchijf enz. in welkers midden dan ook: altijd de mergpijp. zit. Nu volgt de kniefchijf of het kniegewricht, $\mathrm{N}^{\circ} .32$. dit is het gedeelte waar het armbeen door de knie. beenderen, kniefchijven, of fteenplaat enderzelver bekleedfelen, aan het pijpbeen of den: onderarm van den voorvoet gehecht wordt. Dit gedeelte is zoo kennelijk, dat het geene

HET

RUNDVER'

\section{Afd. \\ II. \\ Hoofdit:}

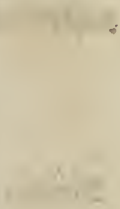
verdere verklaring behoeft, ten zij men kortelijk opmerke, dat dit gedeelte in oude. Koei: 


\section{NATUURLIJKE HISTORIE}

HET Koeijen eeltachtiger en harder is, dan in RUNDVEE. jongere, hetwelk her gevolg is van het veel

II. Afd. knielen, of de ongelijkheid van her plaveifel

II. der koes of de ftal, hetwelk oorzaak is . dat Hoofdrt. men al veel Koeijen vind, die dezen knieknok Stijffcheen verftijft, vergroeid en dik hebben, hetwelk men mokkig, eigenlijk koesḱnie noemt, als veroorzaakt door het leggen op den koes, koes. plank, doch hier van nader bij de gebréken

Pijprpier. Bij No. 33. zijn de pijp/pieren, eigenlijk de armpijpjpieren van den ondervoorvoet. Dit gedeelte wordt dikwijls vermengd met de fchink - of fchenkelfcheen; het kan doorgaan met opzigt tot de pooten der $\mathrm{Koc}$, nademaal men in den Mensch bij uitnemendheid de beenpijpen der voeten fchenkels of fcheenen noemt, anders is het de pijp, het pijpbeen, zie boven Plaat VI.

Dit pijpbeen nu eindigr of is verknogt aan dat gedeelte, 't.welk men de kroon der yoet of ook de koot noemt: de kroon of koot is bij $\mathrm{N}^{\circ} .34$ aangeduid; men noemt het ook wel den kogel, doch dit heeft meer betrekking tot de Paarden; het moet hier koot en kroon zijn; dadelijk bij den achtervoet, kroon en koot zal dit opgehelderd worden.

voor- De yoorklaauw, of de fchoenen, de klaaw. kliefklaauwen, ook de yoorfchoenen geKlief- naand, bij $N^{\circ}$. 35 aangeitipt, zullen ins Scheen. gelijks daar nader in aanmerking komen. been.

Eenige kleine aanftippingen dienen hier. echter niet overgeflagen; te weten, dat men, met opzigt tot de laatstgenoemde ge- 
deelten, eenige onderfcheidingen heeft, die aan de binnenzijde der voorvoeten herkend RUNDVEE. worden.

II. Afd.

Dus kent men de knielpees, bij No. 36. Hoofdt. aangeftipt: deze pees teekent geweldig fterk Knislpses. door in de voorpooten der Koeijen, even als de hakpees of fchijthak in de achter. pooten. Deze pees is voornamelijk kenbaar achter den bovenfchink, tegens den voorvang, en dient de Koeijen vooral in bet nederknielen en oprijzen, hierom kniebof kniepees.

Vervolgens is er nog de voorhak of yoor- Spoorhati: hielpees $N \bullet \cdot 37$ : dit is de regte hak van den voorvoet, en moet wel onderfcheiden worden van de achterhakken, bijzonder de zoogenaamde fchijthak. De voorhak, die hier. voorkomt, wordt ook wel spoorhiel ge- spoorhies? naamd, om dat dezelve den zred van. den Koepoot in het zand teekent, en men het fpoor der Koe daar aan erkent, gelijk men weet dat de Jagers zeer oplettend zijn on het voetfpoor der dieren te kennen. Immers weet men, dat men, het drukken van het fpoor, dat is, den indruk der yoet of voctzool nagaande, zegt: iemand op het spoor, op den yoet te volgen: het is zelfs in onze Dicht-eeuw eene foort van fierlijkheid, te zeggen, dat men het spoor van dezen of genen Dichter of Geleerden drukt. Spoorgezwel vind ik het bij. DE BUFron vertaald, doch de anderzins zoo keurige Verta. ler heeft hier grof misgetast, nademaal fpoorgezwel eene ziekte aan den fpoorhiel of hak beteekend, $z 00$ als blijken zal.

On: 


\section{NATUURLIJKE IHSTORIE}

IIET Onder dezen fpoorhiel bevindt zich nog nUNDVE. bij No. 38 . de binnenkroon of het kroon: II. Afd. hol, dat de holte van den voet-enkelfpoor II. is, men noemt het ook yoethoef, de horen. Hoofdit. spleet, oin dat de horenklieven, of hielen;

Binnen- fchoenen, horenklaauwen, zoo men die ge: sroon. lieft te noemen, hier zamenloopen en als de palm uitmaken; men noemt dit gédeelte ook de zool, de zoolgroef der gekliefdé klaauwien. Ook vind ik den fpleet der Koepooten keperbeen, keperklaaus genaamd; als zijnde gekeperd; doch dit fchijnt mij toe betrekkelijk te zijn tot dat foort vati klauwen, die buiten de geivone klieving, dè horenige fchoenen door vergroeijing fchelferig of met gebarsten nagels' hebben, hetwelk geen gering gebrek in de Koeijen is, vooral als de nagelhoef lang en plat is, dan zegt men: de Koe klepperbeent of hakkeneit, welk hakkenijen bij de Paarden bekend is:

Eindelijk worden alle deze opgenoemde deelen der voorvoeten, gelijk ook die der achtervoeten, onderfcheiden in binnen - of buitenhak: men noemt dien ook buitenyang buitenfchenkel, buitenpigp, zoo ook buitenborst, buitenyeer enz., alle gedeelten die naar buiten uitwendig zich opdoen, in tegenftelling van binnenwaards, als binnen. fchinkel, binnenvang, binnenbil, binnenyeer enz., al wat aan de binnenzijde zich vertoont, bij voorbeeld, - bij $\mathrm{N}^{\circ}$. 39 . de bin nenfchinkel, de binnenyang enz.

Alle de hier niet zigtbare Spieren hebben in de Koeijen ook hunne bijzondere namen;: 
als de armbeenfche, de groote en kleine bin- HET nen - en buiten elleboogfpier, de achter - en RUNDVEzo voorover kantelaar, de groote en kleine el- II. Afd. lefpier, de palmfpieren, de onderhuidfpier, de hak - en kootf́pieren, enz.

II. Hoofdr.

Wat nu de benamingen der laatstgemelde fpieren van het voorftel, bijzonder die der ruggegrat, het fchildbeen en de bijdeelen betreft, die onder deze deelen liggen, en op den huid in deze af beelding niet zigthaar doorteekenen, dezelven zijn de voordijbeenfpieren, de trekkers, de tusfclienbeenfche, de doorborende, de uitrekkers der kooten, de voorkootrpieren; deze allen behooren tot den voorvoet : als ook' aan het fchild en de borstwervelen de in - en uitwendige lendenfpier, de voorfpier, de onder - en bovenfchildfpieren, de buiten - en binnen - dikke fpier, de fchenkelfpier, de kniebuigfpier, de tweehoofdige fpier, de half en heele pees - en vliesfpier, de hazefpier; voorts die de voorpooten bewegen: de fcheenbeenfche, de hak, de buitenbeenfche fpier, de kroonfpieren enz., zijnde de overige op zijne plaats reeds aangeftipt.

Hier mede nu het Voorftel der Koeijen afgehandeld zijnde, gaan wij over tot

\section{HET MIDDENSTEL.}

Het Middenfiel der fpieren rekent men Het migo te beginnen, even als bij de beenderen, denftel. van den fchoft No. 26, tot aan het kruis N. 50, waar men eigenlijk de ruggegraac 


\section{NATUURLIJKE HISTORIE}

вет ftclt, dat is, alwaar de rugge - en fchouder a UNDVE. wervelbeenderen der ruggegraat met de len-

II. Afd. denwervelen vereenigt, en de achterlendenen

II. uitmaken; de fchikking dezer wervelen is, Hoofdit. zoo als reeds gemeld is, in de Koeijen doorgaans fchier lijnregt, en niet zoo ingebogen als in de Paarden, die men weet dat meerendeels meer of min een ingevallen ruggeftreng hcbben, die dikwijs ongeregeld doorzakt, en dien men zaalrug noemt. Het gebeurt echter, dat men Koeijen met een ingebagen ruggeftel vindt, doch zeldzaam, en als dit voorkomt, houdt men het voor eene zwakke Koe. Veel meerder is het der Koeijen eigen, 7,00 zij mager zijn en oud worden, dat aldaar de ruggegraat eene ongemeene fcherpe gedaante bekomt, doordien de opperbeenderen of doornen der wervelen fterker uitfteken, vooral bij de voorribben, het geen men in Plaat VI. in de afbeeldingen van het ge. raamte kan zien: deze ruggegraat, die men ook ruggeftreng noemt, heeft vervolgens ook hare verdeeling; de naams-reden verklaart zich zelve, naar de gelijkheid eener

Rugge- vischgraat: bij $\mathrm{N}^{\circ} .40$. is het middenpunt fpieren. daar van aangeftipt. Men volgt hier het beloop der ribben, en deelt die in de voorribben of lange ribben, (zie $N^{\circ} .4 I^{\circ}$ ) en in de achterribben of korte ribben; (zie N־. 42.) men ftelt wijders aan het fcheiden der lange ribben het middenrif, dat is: de plaats, alwaar de ingewanden der borst afgefcheiden worden van die des buiks, wel. 


\section{v A N H O L L A N D. 99}

welke plaats men omtrent op dezelfde hoogte ziet aangeteekend bij $\mathbb{N}^{\circ} .43$, en waar van bij het verhandelen der ingewanden nader zal gefproken worden.

Het beftek der voorribben wordt door de Vleeschhouwers genaand yoorribbe, de beste ribbe, of liever, zij verdeelen den ruggegraat in yoorribbe, achterribbe, fchild. ribbe, of beste ribben, paterftuk, doch dit zijn doorgehakte ribben, het lendenftuk enz., en de nicrharst klomp/tuk, en voor. waar natuurlijk, nademaal het eerfte en de meeste zekerlijk het beste vleesch bevat: het $r$ weede insgelijks de lendenen beflat, en daar in voornamelijk de inwendige lendenfpieren de zulken zijn, die men om derzelver malschheid wel den haas noemt: de nierhaist insgelijks, als bevattende het nier. De hasà geftel, is zeer eigenaardig dus genaamd; Nierharst. voeg hier bij, dat het woord harst eigen-

lijk gebraad beteekend: in welken zin dan Harst. ook onze Hollanders elkander noodigen op een gebraden harst, het zif het dan eene beste ribbe, lendenftuk, fchildribbe of nierharst $z i j$, aan welke laatfe evenwel bij uit. zondering dezen naam fchijat toegekend te zijn: KILIAAN noemt het bij uitzondering. nierbradd, nierherst, vooral kalfsharst (Lumbus Vitulinus.)

$\mathrm{Nu}$ volgt bij $\mathrm{N}^{\circ}$. 43. het eigenlijk middenrif, dit is het centrum van het geheele Middenrif. middenftel, alwar men de buikfpieren met die van den ruggegraat rekent zamen te

$G_{2}$ ver.

II. Afd.

Hoofdif.

Beste

ribbe. 


\section{NATUURLIJKE HISTORIE}

нЕт vereenigen, aan het middenrif en borstbeen. rundver. In de Paarden noemt men dit geheele middenII. Afd. ftel het koffer, in de Koeijen is dit zoo alge. II. meen niet; de naam van pens is genoegHoofdr. zaam algemeen, men zegt: de Koe is dik Koffer. yan pens, zij heeft een frikpens, dat is Pens. als de buik fluik is, en dus ook fmalpens, breedpens, vetie pens, magere pens, bonk. pens, en meer dergelijke bijvoegrels, welke benamingen in het vervolg bij de befchrijving der ware Pens of Mang zullen voorkomen. Maar boven dit, is er een nog algemeener benaming van koffer of te pens, te weten die van balg, balgh, eigenlijk op den buik toepasfelijk, den balg yol eeten, is den buik yol eeten, yol drinken, zoo ook balg yullen, balg mesten; onze Ouden berigde de beteekenis van quabbelbalg, zwelbaid, doch dit, meen ik, behoort bij den kosfem quabbe thuis, voor het overige is de beteekenis van balg, nnder de Menfchen genoeg bekend voor een yreetpens, fchrikbalg en balgzak. Ook is bij de Boeren en overal het gedeelte van den bovenbuik of pens, bekend bij den naam van het wand.

Het wand. Het wand, No. 48. wordt gefteld te liggen tusfchen den voorvang $N \%$. 44. en tus. fchen den achtervang, No. 45 . en vooral aan de melkaders $N^{3} \cdot 46$. tot aan den navel $N^{\circ}$. 47. Alle deze gedeeltens hebben hunne bijzondere oorfpronkelijke namen, naar den aard der zake, als daar is navelwand of buik, onderwand of buikkropwand, platwand, rondwand, dik in 't wand, dikyel enz. 
De yang, het zij yoor - of achteryang, $\mathrm{BET}$ wordt dus genaamd, om dat den Boer of Vet- Rundver: weider, de quabben der liezen, van den buik, II. Afd. of ook die des kosfems, als het ware, in de hand vangt, cndertast of grijpr, waarom

het elders ook de vanggreep heet. Bij De vang onze voorzaten is yang of yanck alrede bekend geweest voor eenen vetten vleeschklier, waar aan men de vetheid der beesten betasten kon, zoo als RILIAnN dit te regt aantekent. Het behoeft ook in de daad geen verder uitleg voor iemand, die ftechts eenmaal op eene vette of magere Beestenmarkt, in de weide of op ftal, met een Boer, Veehoeder of Vleeschhouwer geweest is. Het eerfte werk is doorgaans den kosfem te ftrelen, de lendenen te betasten, en den vang te grijpen, te ondertasten, onderflaan, zoo als men ook zegt; het is met dat al een' ieder niet gegeven het fijne van dit betasten, en den greep te kennen. Het is daarom moeijelijk te befchrijven, om dat het eene handigheid is die door ervarenheid geleerd wwordt, en geene regelen volgt, dan de begrippen van elk bijzonder vernuft. Ondertusfchen is dit algemeen waar, dat als de vang aan de liezen en aan den onderbuik lenig en zacht is, kwabbig doorhangt, en niet klonterig in het aantasten is, en vervolgens als in het wand verdwijnt, dat dit een goed teeken is van malsch vleesch en vet. Hier bij komen, ten opzigte van de Melkkoeijen, vooral in opmerking de melkaders en het uijer, want aan deze beiden $G_{3}$ heeft

II. Hoofdr: 


\section{NATUURLIJKE HISTORIE}

HET heeft de vang gemeenfchap, en meis nocme RuNDVEe. het dan ook uuryang. Bij No. 46 zier II. Afd. men derzelver beloop en fpruchtels, wan II. neer deze doorteekenen, en de vang en uurHoofdit. vang is lenig, dan is het doorgaans een goed melkbeest, maar voaial dient men te letten of de navel wel gefloten is, en nict doorzakt, want dat is al dikwijls cen ftil gebrek, 't welk men weinig telt, maar groote gevolgen hebben kan, orr dat daar uit of cen navelbreuk, of een doorzakking am en om de melkvaten, tot aan het rijer kan ontfaan, die $z 00$ geweldig groot kan uit: zetten en doorzakken, dat ik er gezien heb, die het gezwel langs den grond fleepten, en anderen die door een zeel en een zak moesten gefchoord worden.

Alle deze opgemelde onderfcheidingen nu worden in het algemeen betrokken tot het wand.

Nadere Het wand $N \bullet .48$. beteekent eigenlijk den befchrijving van het wand. geheelen middenhuid der Koe, vooral als hij welgehaard, ruig en vet is, dan zegt men: $2 \mathrm{ij}$ zit wel in het wand. De wand dan van eene Koe, of her wand, is de geheele huid, waarin het dier gefloten is; doch met bijzondere betrekking beduidt het wand bij den Boer den geheelen huid van het mid. denftel: daar is het, dat zij het wand betasten, bevoelen en beoordcelen, of de Koe dik en vet in 't want zit, dan of hij mager en bonkig, en gevolgelijk fchraal, kaal, ruig; rappig en blarig in ' $t$ wand zit. Het is wijders de plaats voornamelijk, daar die le: 
lenige en zachte tusfchenribbige fpieren uitwendig meer of min kenbaar zijn aan het vet of mager, taaiheid of weekheid: in éen woord, aan de kennis van het wand betasten, hangt een voornaam deel der KoeijenHET RUNDVEB II. Afd. II. kennis af, gelijk wij bij het vermelden van de Hoofde。 fijnheid van huid, haar en bont alrede betoogd hebben. Men houdt vervolgens ook dit gedeelte, daar het bij No. 48. is aangewezen, voor zeer fmakelijk vleesch, het welk an de beste ribben en het lendenftuk afgehakt zijnde, daarom den naam van $p a$ terftuk bekomt, om dat men zegt, dat het beste vleesch voor Pater en Mater is, en niet voor het geheele Convent. Deze ftukken fchikt men veel tot rookftukken, althans zulke gerookte ribben, en de paterftukken zijn bij uitftek vermaard, die uit Hamburg komen, alwaar dit artikel cen voorname tak van vleeschhandel uitmaakt, naardien zij van de beste Deenfche, Hol. feinfche en Altonafche Osfen gerookt wor. den. Voorts worden uit de Spieren van den buik veelijds huspot gehakt,; zoo als men het noemt, doch vooral klapftuken, dat vierkante ftukjes vleesch en vet, en zeer -finakelijk zijn.

Ondèr alle deze angewezen, uitwendige deelen van het middenftel, - liggen insgelijks aanmerkelijke fpieren, die tot deszelfs werktuigelijke bewegingen dienen, en al mede uitwendig niet zijn aangewezen, en voornamelijk tot de volgende betrokken wor-

$$
\mathrm{G}_{4} \text { den: }
$$

$1.2+2$

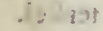




\section{NATUURLIJKE HISTORIE}

หrт den: als de groote en kleine middenriffpie. zunder ren, de driehoekfpieren, de lendenzaagfpieren

II. Afd. op de ribben boven en onder, de wervelfpieII. ren, de tusfchenribbige fpieren, de over. Hoofdrt. ribbige fpieren, die tegen den huid leggen en het wand uitmaken, zoo ook de onderribbige; voorts de borstbeenfche fpieren an de zamenvoeging der ribben, ook de drie. hoekfche genaamd, de lange borstfpier, de halve en heele graatfpieren der ribbewerve• len, de dwarsipieren van de nokrug, de groote en kleine vezelfpieren van den voorfchoft, en voorts alle anderen, die in het vak van den nok eene overgang tot het ach. terftel maken, en dus eene gemeene werking van alle de rug - en lendenfpieren oefenen.

Dit genoeg zijnde voor eene korte aanftipping; volgt nu

\section{HET ACHTERSTEL.}

Het ach. Het Achterftel begint, daar het miadenterftel. ftel eindigt, te weten, aan het kruis of len. denplat $N^{3} .50$, tot lijnregt door gerekend onder aan den liesvang van het voor-uur Het kruis. N9. 49. Het kruis ftelt men in de oppervlakce eenigzins bultig, daar het bekken aan den ftart of het ftaartfuk $N^{0}$. 5 I. doorteekent: het ligt tusfchen de heupbeenderen of bonken der achterpooten in, gelijk bij $N^{\circ}$. 52. het heupbeen van deze zijden te zien is: deze heupbeenderen zijn in alle Runderen en Koeijen boven eenig ander dier ken- 


\section{A N H OLLA N D. 105}

kenbaar uitftekende; de Paarden hebben de- HEx zelven altijd ronder en gladder, daar zij in RUNDVEE: de Koeijen eerder naar het vierkant hellen. II. Afd. (Zie Plaat VI.) Hierom zegt men wel: II. het is eene vierkante Koe, een drailje yan Hoofdr; cene $K o e$, gelijk men van een breed en forsch gefchouderd en fier geheupt Mansperfoon, ook wel Vrouwsperfoon, zegt: het is eene vierkante kaerel, het is een drailje, een talie van een wijf. Wat nu de naams-oorzaak van kruis is, weet ik niet, ten zij het oorfpronkelijk is uit de kruiswijze banden van de lendenen en de heu. pen, gelijk ook alzoo in den Mensch dit gedeelte het lendenkruis genoemd wordt, en zoo deze heupkruisfing fterk doorteekent, is het al wederom eene bonkige, dat is grofbeenige, grove Koe, in tegenftelling van een fijn gebeente. Als de Koe of Os oud of mager is, dan is het een oude bonk, een magere bonk; zoo dat het woord bonk, voorheen vermeld, in 't gemeen gansch geen gunftige naam is op de Beestenmarkten, vooral met betrekking tot de oppergewrichten der heupbeenderen en van het lendenkruis, dat de regte bonkbeenderen zijn, en gevolgelijk ook de fpieren en huid taai en grof uitwendig vertoonen.

Insgelijks is de plaats daar de ftaart be- Staare gint bij N9. 5I. veeltijds bonkig, om dat bonk. de ftaartwervelen aldaar uit het kruis uitfteken en eene merkelijke inbuiging ontvangen, die als in een groef invalt. $\mathrm{Zie} N \cdot 53 \cdot$ Deze groef is eene geheele holte, het zijn G 5 ei- 


\section{NATUURLIJKE HISTORIE}

нет eigenlijk de bandfpieren van het bekken, RUNDVEE. No. 57; men noemt ze daarom ook alzoo.

11. Afd. Het is op deze banden dat een Boer naauw.

II. keurig let, vooral in de Melkbeesten, want

Hoofdit. dewijl deze banden bij het kalven der Koe den.

De ban-ontfpannen en leeniger worden, hetwelk het cerfte teeken is dat zij op het kalven ftaat, of begint te kalven, zoo fpannen deze banden ook weer toe als de Koe gekalfd heeft, dat is, zij fluiten. Nademaal nu eene Koe, die veel gekalfd heeft, dęze banden allengs leeniger heefe, even als de Vrouwen, die veel gekraamd hebben, $z 00$ onderkent men hier aan, ook den ouderdom der Kalfkoeijen; vooral als de Koe ze al te flap heeft, oordeelt men dat $2 \mathrm{ij}$, vatbaar is om het Kalf te vergooijen. Voeg hier bij, dat, het zij door miskalven, of door al te fterke forfecring in het afhalen van het Kalf, deze banden verland worden, 't geen uitwendig zigtbaar genoeg is. Maar buiten dit kan het niet dan zẹer vreemd voorkomen, dat men dit gedeelte, namelijk de holte der Walegreep banden, walegreep en koekoeksgat noemt, bij welke benaming de Rhijnlandfche Boeren althans dit gedeelte erkennen. Het lust ons, dit, een weinig op te helderen. Zoa men het woord wale neemt vonr eene $W a_{a}$ le, Walon, welker Emigranten en gerefugeerde, Vlugtelingen, ten tijde van LoDEWYK de veertiende, in menigte zich in Leyden, Rhijnland en geheel Holland ter neder gezer hebben, en welke Menfchen zeer bedreven waren om uit de geringfte dẹelen

eener 


\section{VA N HOLLA ND. IOY}

cener Koe voedfel te bereiden, en dienvolgens ook aan dit gedeelte der Koe door RunDves; betasting de deugdzaamheid van het vleesch II. Afd. te onderkennen, zou het niet vreemd voorkomen, dat de betasting aan deze holligII. heid den naam van Walengreep, Wabenbe. Hoofdet: tasting bekomen had. Het komt mij evenwel natuurlijker voor, dat het eigenlijk moet zijn walgreep, dat is het betasten van den wal, of den rand of het boord van eenen greppel, floot of waterkant, althans $z .00$ noemt men wale eene holte of diepte van eenigen kuil of holte, gelijk dan in der daad de holte, die zoo anmerkelijk in de Koeijen zich vertoont, omringd wordt door eenen wal, eenen board van fpieren en banden. Gelieft iemand het van wallen, wellan, op. wellen af te leiden, ik heb er niets tegen, en het zal er ook weinig toedoen, indien men flechts toeftare; dat: uit deze boerenbenamingen zeer veel lichts aan de oude Landfpraak kan bekomen worden.

Met den naam van köekoeksgat ben ik Koekoeks. meer verlegen. : Mlen heeft meer benamin gat. gen van dien ard op andere zaken, als: koekoek, den draai op een fchoorften; ...an koekoek, zekere foort van blassbalg, allen evenwel daar op uitkomende, dat dezelve een bijzonder gat hebben, daar wind of geluid vitkomt, of dat wind doprlaat. Of nu misfchien dezen naam, die zeer gemeen is bij de Boeren, hier op zinfpelende is, om de poepering van den aars, dje onder dit koekoeksgat ligt, dan of er iẹts anders bij 


\section{NATUURLIJKE HISTORIE}

wx den fchertsachtigen aard der Hollandfche mundvez. Boeren bedoeld wordt, laten wij liever de II. Afd. nieuwsgierigen zelve vragen.

II. Eindelijk draagt de holligheid, die door Hoofdrt. deze, banden onder den ftaart geformeerd

Prikgat. wordt, de naam wel vals prikgat, de prik, om reden dat de Koekoopers en Vetweiders meest altijd, eer $2 \mathrm{ij}$ het wand of den vang betasten, aan deze holte mer den vin. ger prikken, en naar de banden voelen: dit noemt men prikken: men vraagt elkander: wel, heb je hem wel geprikt? hij prikt goed, dat is, het is goed vleesch, enz.; en hier van veeliigt prikkleteren, Prijklete-Schatten, waardig Jchatten, of prijkleteren. ren, dat is borg ttaan dat de Koe gezond is, gelijk dit overbekend is in de Koopbrieven der Koeijen, vooral in gebeterde, als de Verkooper de Koe prijkleteerd, dat is, inftaat voor alle perijkel der Veepest, als zijnde een gebeterd beest, al hetwelk dan uit de welgefteldheid dezer opgenoemde banden kennelijk is, dewijl de flappigheid of ongefteldheid daar van eenig gebrek of kwijning doet vermoeden.

De ftart. De ftaart, die bij No. 55. is aangewezen, glooit dan ook over deze banden, bekomt aldaar zijne kromte, en vervolgt zijne lenge tot aan den pluim $\mathrm{N}^{\circ} \cdot 5^{6}$. De ftarten der Koeijen, Osfen en Stieren verfchillen dikwijls veel in dikte, lengte, ruig. te of kaalheid. De gezondheid van den ftaart is al mede een gewigtig kenmerk: eene kale fchurftachtige ftaart is een flecht teeken van 
ongansheid, vooral als de haren bol ftaan, dan noemt men het ratteffacart; is zij heel ruig, dan is het een vosfeftaart; maar ftaan de haren levend en kwispelt de Koe frisch met de pluim heen en weder, dat is een goed teeken. Dar het flaphangen een flecht II. Afd. II. Hoofdift. teeken is, noemt men dit druipftaarten. Men ftelt de ftaarten doorgaans van eene goede lengte, als zij tot op of om den koothak neerhangen; er zijn er die ze veel langer hebben, en dikwerf tot op den grond flepen, vooral als de Koeijen zich uitrekken. De Landdichter viRgILius wil hierom, (zoo als in het voorbijgan reeds gemeld is, ) dat men Ploeg - Osfen of Koeijen opzoeke, wier ftaarten in de voor van den ploeg nepen. Onze Boeren houden de Koeijenftaarten gaarne rein, vooral op ftal, waarom zij dan om den pluim van den ftaart een touwetje binden, en dezelve aan een lang touw, welk men ftaartreep noemt, hechten, op dat dezelven door den drek niet befmet zouden worden. Wijders is er nog bij fommige Veekoopers een gebruik, om, als de Koe verkocht is, de hand op het kruis aan den ftaart te flasn, het geen zoo veel zegt, als dat de Koe zijn eigentom is. Ook fnijden zij wol cens een vlok uit den ftaart of in het haar, ten teeken; hier van het oude fpreekwoord: die de Koe zijn is, houdt hem bij den ftaart. Onder de Rhignlandfiche Boerenmeiden is een liedje of deuntje op de Koeftaart, en wel bijzonder op de berwegingen en het gekwispel der ftart. Zie eerite Afdeeling op Kwispelfactart.

Na 


\section{IIO NATUURLIJKE HISTORIE}

H.T $\mathrm{Nu}$ komen in het achterftel voor de achRUNDVEE. terkwartieren, de achterpooten: ieder poot

II. Afd. wordt voor een kwartier gerekend, en wel

II. voor de zwaarfte, dewijl zij de vleezigfte Hoofaft. en groffte fpieren der dijen en billen be.

Achter- vatten, deze noemen de Vleeschhouwers kwartier. ooki bilfukken, de yeeren of rookfukken: Bilftukken men kent een beste en een fchrale veer: of veeren. de beste is het dijfuk, het midden-bil. ftuk N.57. Nog is onderfcheid tusfchen den binnenveer of buitenyeer: de binnenveer is die, welke an den binnenkant der lies legt, de buitenveer legt aan den buiten. kant der billen, zie $\mathrm{N}^{\circ} .5^{8}$. Hier formeren deze veeren den fleuf der billen of der fchaamdee'en, en worden daar toe betrokken, gelijk ook tot den boven-uurvang; als deze billen, geliik veelal op morfige ftallen plaats heeft, dik met klonters en vuil bewasfen zijn, noemt men ze klonterbil.

Bilfpier. De eigenlijke groote bilfoier bij No. 57 ; is altoos de allerkennelijkfte in de Koeijen; zij formeert de rondte en uitgebreidheid der dijen en billen, als de gluteus in den Mensch. Zijn zij mager, dan is het fchraalbil, vet, yetbil, enz. Het dijt in de vette Koeijen en Osfen geweldig uit, en is in der daad het fchoone in eene Koe: men vindt er die zoo rond en vet zijn, dat zij niet meer doorteekenen; niet te min houdt men eene Koe met zware vleezige ronde billen voor minder welgemaakt, en zelfs flechte Mik. gevers en Vetwciders; men noemt ze bij onderfcheiding Varkensbil, Paardenbil.

Voorts 


\section{VA N. HOLLA N D. III}

Voorts zijn deze fpieren in de Mclkkocijen zeer kennelijk, zoo als onze Plaat VII doet Rundve: zien: in magere en fchrale beesten zijn zij II. Afd. åor en fluik, het geen overbekend is. Deze fpieren eindigen allen doorgaans genoegII. zaam in zware peezen, die naar de hakken loopen, zoo dat een Vleeschhouwer de fpieren naar het beloop dezer peezen affcheide, en misfchien om die reden dezelven yeeren noemt, als of de fpiervezelen gelijk een veer of vederpluin uit een fchacht zich uitbreiden. Deze peezen loopen allen te Peezen: zamen in eene geweldige $z$ ware pees uit, aan den bovenhak of fchijthak, alwar zij aan het beengewricht of de hiel is ingelijfd, zie $\mathrm{N}^{\circ} .59,59$. Men noemt dit gedeelte fchijthak, ook hangpees: de eerfte bena- Schijthak. ming is vrij natuurlijk, om dat de Koeijen, welker afgaug doorgaans week is, denzelven langs deze hakken laten loopen, en meest altijd deze hak bevuild is. Men moet ze evenwel onderfcheiden van den hielhak, die onder aan de kooten ligt, want deze draagt ook wel dien naam, doch regte kenners onderfcheiden die door den naam van fporrhak, fpoorliel, van fchijthak, fchijthiel. Wat aangaat de naam van hangpees, deze is niet Hangpees. minder eigenaardig, om dat de Slagters, wanneer de huid is afgevild, en de onderfchenkels afgeknot zijn, deze pees ontblooren en affcheiden van de fpieren, en dan tusfchen die affcheiding de fpanttok of de hangboom indringende, het ganfche dier door middel van touw en takel opgeheische wordt, 


\section{NATUURLIJKE HISTORIE}

нет worde, en zij het daar aan laten hangen, het nUNDVRE. geen een iegelijk, die flechts een Os aan den

II. Afd. haak heeft zien hangen, genoeg weet: deze II. peezen kan men begrijpen dat van eene buitengewone fterkte en taaiheid moeten zijn, nademaal daar aan eenen Os van over de tweeduizend ponden hangen kan; deze peezen zijn daarenboven in het levendig dier zijne forschfte krachten: als eene Koe of een Os zich fcherp zet, eu fchoort de achterpoot tegen de voorkracht der voorpoo. ten, kan geen geweld hem van zijn ftand krijgen. Het is ook meer of min gevaarlijk, eene Koe an deze hakken te tasten; zij laten het zelden toe, dan an de genen, die ze dagelijks hanteren; zij flaan vreesfelijk hicr mede achteruit, en niet zelden iemand de beenen aan ftuk, zoo als ik een Vleeschhouwer gekend heb, die het beftorven is, en verfcheiden anderen, die gekwetst zijn geworden. Onze Boeren zijn hier ook behoedzaam voor, en kennen onder hunne Koeijen zeer wel de genen, die achteruit flaan, vooral als het jong en dartel Melk. 'vee is: wachtje yoor den hak! is het waarfchouwings teeken op de ftallen: men bindt uit voorzorg hierom de Koeijen onder deze hokken om de pijp, als het melktijd is, met een touw, om het achteruitflaan voor te komen. In N'oordholland evenwel heb ik op vcrfcheidene platen dit niet gezien, maar wel dat de Koeijen met een touw om de horenen aan cen paalije gebonden ftaan, het geen ik niet zonder reden geloof te 


\section{$\forall A$ H}

giefchieden, om dát, als het hoofd der Koe in een divikenden ftand gehouden worde, RUNDVER: het Dier minder kracht op. de 'werking II: Afd: der achterfpieten heeft; dan; hier over nader. Voorts is deze hakpees van denzelf- Hoofdto den aard als de zoogenaamde pees yan Achilles in den Mensch (Tendo Achillis), die men weet dat de fterkfte van het ligchaam is.

Van de fchijthak afttappende, kome de. Achterachterfchenkel of pijp voor bij N॰.60, ichenkel. in beide de pooten lings en regts: er is niet veel op aan te merken; dar niet bijna overeenkomt met den voorfchenkel; het eenig zeer kennelijk onderfcheid is, dat de gewrichten der voorfchenkels No.32. de eigenlijke kniefchijven zijn, waarop het beest nederknielt, eer het gaat liggen, dus voorwaarts buigen of vouwen, daar de achterfte de hakken en fchenkelgewrichten achterwaards buigen, als het beest gaat liggen, in dier voege, dat, als hij gaat nederliggen, heeft hij bevorens op de voorfte geknield, eer de achrertte gaan liggen; daarentegen rigt hij in het opftaan de voorfte eerst op, eer hij de achrerfte opligt enz., men kan zeer gevoegelijk bij vergelijking de voorpooten yoor de armen van het dier; en de achrerfte voor de dijen en voeten houden; zelfs is de groorfte rusting in her geheel achterftel, dewijl er de Koe als op zit en rust onder het herkaanwen.

Deze achterpijpbeenfpieren zijn niet zeer Áchiêra tleezig, altoos fterk van peezen, en wel pijpex. 


\section{I4 NATUURLIJKE HISTORIE}

HeT zoo, dat zij zeer fterk doortcekenen. In RUNDVEE de eene zijn deze pijpen grover dan in de

II. Afd. andere, en al vrij gemeen lomp on dik; II. derzelver fijnhejd en welgemaaktheid is insHoofdft, gelijks ann de opmerking der kenners onderworpen.

Hielpees. Deze pijpbeenderen eindigen aan de hield pees, fomtijds verkeerdelijk hakpees genoemd, het is de achterfpoorhiel $\mathrm{N}^{\circ}$. 6\%: deze noeme men ook wel jpoorliak; deze hiel bevat den

xooten. kogel of de kroon, ook de kroonhol, doch voornamelijk de kooten of kootbeenderen, in het geraamte alrecie angewezen. Hier verdienen deze kooten weder eenigen uitftap,

Blaauwen, vooral als men die met de klaauwen $\mathrm{N} \cdot 62$. vêrgelijkt. Deze klaauwen zijn de hoeven of horenklaauwen der Koeijen, die men ook wel fchoenen noeme, twee ann twee aan elken voet, daarom gekliefde klaauwen genoemd, en hier van bij vergelijking zeker tweeklaauwig, breekijzer, koevoet, allen te wel bekend, om er hier op te blijven ftaan. Eenige bijzonderheden zullen hier volgen. Het is bekend, dat onze jongens' en kinderen her kootfpel oefenen: dit fpel: was voorheen bekend onder den naam van klaauwfpel, zOo als in BREDERODE's Spacnichen Brabander:

Aauwe, Aauwe, willen wij t'zamen klaauwen? Ik ra ftoof en Aauwe fchijt, Aauwe is zijn klaauwen kwijt. 


\section{ฟ $\mathrm{A}$ H $\mathrm{LLAND}$. It5}

Dit koorfpel heeft deels den naam van HET a achterkootbeenderen, die op de fchoe of RuNDve hoeven rusten, warrom mon dit gedeelte II. Afd bok koot of kooten noemt; bij voorbeeld: Hoofdf. de Koe flat fix op de kooten; die Meid is fix op de kooteri. Deze kooten uit de Kootipels beenderen gefcheiden zijnde, werden door de jongens tot dit fpel gebruikt: $z i j$ werpen die met een gier op den grond, valt nu de koot regtftandig en vlak neer, dan legt hij koot, dat is, hij that op de koot; maar blijft hij op ziide wentelen, dan legt hij fchijt. Dit fchijt nit is ontleend van de fchijthak of het achterfte der koot, dat aan de fpoorheil lige, boven vermeld, alwaar, gelijk als op den grooten fchijthak, den drek der Koeijen nedervalt, en waar van, waarfchijnelijk ook de niaam van kakhiel onder de Menfchen oorfpronkelijk is. Wat nu her kladuwen betreft, dir is, na ik heb kunnen opfpeuren, oudtijds bijzonder in gebruik geweest, om dat men de afgeknotte pooten aan de fchamele jongetis ten besten gaf, die dan dezelve door hunne Moeders lieten opkoken, en de kooten er uitnemende, om de klaauwen en de koot fpeelden, en dus was Aauwen ook zijn klaauwen kwije, even zoo als het bekend bikkelfpel, dat, 200 als boven gezegd is, meest meisjesfpel is, en met Schnpenkootbeentjes of bikkels gefpeeld wordt, zoo kennen ook de jongens in de koeklaauwen de kleine koorjes voor bikkelkooten. Het kootfpel is als nog virij $\mathrm{H}_{2}$ 


\section{II6 NATUURLIJKE HISTORIE}

HET algemeen, doch op verre na zoo fterk nict RUNDVEr meer in zwang als oudtijds, het wierd meest II. $\Lambda \mathrm{fd}$. door aankomende jongens gefpeeld, on dat II. $\mathrm{er}$ in de worp nog al overleg benoudigd is. Het algemeen genoeg bekend gezegde: het is beier yoorgekoot dan nagekoot, met opzigt tot een jongman, die in rijper jaren tot de losbandigheid der eerfte jeugd wederkeert, toone genoeg aan, welk een invloed dit koorfpel oudtijds gehad heeft. Wij flaan verdere aanmerkingen op her fchertfen van partijfchappen in ons Vaderland over, waarin de vergelijking van het kooten om de Hollandfche koe, of het klaauwfpel, niet zelden al vrij fcherp uitdrukte, en het liedje: Amfterdam op den Vijgendam, ftoof legt er mijn kootje, enz. hier uit ten tijde van vONDEL voor oor fpronkelijk uit Burgertwist wordt gehonden.

Tot de koot of de onderklaauw der Kos komende, noemt men de holligheid der kootgroeven ook verfenen. Men leest in Verfenen. den Bijbel van yerrenen tegen de prikkel te flaan: zulk een prikkel was bij de Ouden een ftok of ftaf, met ijzer beflagen of puntig gefneden, waarmede zij dan de Paarden of Ploegr Osfen tegen de hakken onder den fpoorhiel tegens de kooten aanftieten, om het beest tot trekken voort te drijven. De drijfftokken der Boeren zijn nog omtrent van dit gebruik, doch veel met een mikje of vorksgewijs; hier mede drijven zij de Koeijen voort, en prikken of daan de. 


\section{VANHOLLAND. I:?}

zelven ónder het drijven op de hakken. en tegen de verfenen. Zoo nog diijuen de RUNDVEr. jongens de Kalven voort, door het prikken 11. Afd. met een houten pen enz.

Wegens de klaauwen hebben wij al meII. Hoofdr: de iets bijzonders mede te deelen, dat, zoo Klaauwen. wij gelooven, geen onaangenaam nieuws in de Natuurkunde kan zijn. Buiten het gebruik dat men van de horenklaauwen of Koefchoenen, zoo men die noeme, makt, in het bereiden van lijm of horen, alvorens reeds in 't voorbijgaan aangeftipt, is ons het volgende in ervaring gekomen. Men kent bij de Natuurkenners zekeren fteen, die men flangenfleen (Lapis Cobra del Capello) Lap Conoemt : deze fteenen $\mathrm{kwamen}$ voorheen, en bra del $\mathrm{Ca}$. heden nog, uit China en ook uit bra-pello. zil. Dezelven bleven een geheim der Braminen, en hadden, zegt men, het vermo * gen, om te ontdekken of iemand vergift gebruikt had, maar voornamelijk om een vergiftigen flangenbeet te genezen, in welk geval de gebetenen den fteen op den wond legde, die daar dan eenen zekeren tijd op gekleefd bleef, tot dat hij van zeifs afviel. In der daad, de proef op deze fteenen is, dat men ze op. de tong legt, waar aan ze dan blijven hangen, tot zij fpeekfel genoeg ingezogen hebben, en daarna afvallen, zoo als ik dit menigmaal zelfs beproefd heb. De Hoogleeraar gaubius heeft in zijn leven veel werk gemaakt om dit ftuk Chemisch naar te.vorfchen, tot dat hij eindelijk hier in verlicht is geworden door een zijner Dis$H_{3}$

ci- 


\section{NATUURLIJKE HIISTORIE}

HE: cipelen, die, in Indiën gereisd hebbende, R UNDVEz. naderhand Lijfmedicus van Hare Rusch.

II. Afd. Keizerlijke Miajefteil elizaneth was. GeIt. melde Hooglecraar, mijn hooggeachten/MeesHoofdrt. ter, heeft mij in een eigenhandig briefje dit volgende medegedeeld:

Refert Cl. ribeiro sanches, Archiater. Rusfiae, Literis à me datis, fibi ex China relata effe A. P. SousA, hos Lapides a Brachmannis, qui traitu Indi, circa Dumum, habirant, ex tibiis boum combuftis fenfim in lac immer is, fingulari induftrico confici.

Dat is: "De geleerde RIBERIo SANCHES, "Lijfarts in Rusland, fchrijft mij in eenen " brief, dat hij uit het verhaal van A. P. ", sousa verftaan heeft, dat de Brachmans. " of Braminen, die langs de duinen wo" nen, deze fteenen met eene bijzondere " naauwkeurigheid bereiden uit gebrande "Osfenbeenderen, allengs in melk getem"perd."

Dit verhaal is mij naderhand gebleken echt te zijn, behalve dat de Reiziger niet bepaald heeft, welk gedeelte van beenceren der Osfen het geweest ziin; de tijd evenwel en toeval hebben mij hier in liche gegeven. Zie hier mijn berigt. Ik heb voorheen bij wijlen den Heer JAN COENRAAD) BRAND velerlei fteenen en kunstgreepen der Drogisten leeren kennen: dezen Heer had zekeren Portugee/chen Food an de hand, die onder ontelbare kunstgreepen ook de kunst bezat om deze fteenen te bereiden, doch 


\section{$\checkmark A N$ H OLLA N D. IIg}

wat moeite en aanbod dezen Jood gedaan HET wierden, om het te ontdekken, het was RuNDVEE. vergeefs; doch eindelijk oud en nooddruf. II. Afd. rig wordende, en genoegzaam zijn beftaan van dien Heer en deszelfs zoon BURGHARD BRAND hebbende, kreeg de laatfte kort voor zijn dood het er uit, en ik ook, namelijk, dat hij deze fteenen brandde uir de klaauwen en klaauwbeenderen der Koeijen, dezelven in melk temperde, en daar na oppolijstte; hij lict er verfcheiden na, en daar onder zeer fraaije, die eenen gloed hadden als de zoogenaamde paauwenfteen, of Labra d'or, hij fleep dezelven rond, en fomtijds wierden er van in gouden ringen gezet, hoedanig een ik bezeten heb, en naderhand zelve gebrand, doch hier toe moet men fijne horenklaauwen kiezen met ftreepen, zoo als die gemeen zijn in verfchillende Koeijen. Zoo nu iemand dit verder gelieve te onderzoeken, wij deelen het naar onze openinartige gewoonte gulhartig mede; gelijk wij nu nog eene niet minder opmerkenswaardige ontdekking gaan ontvouwen, die, zoo niet geheel, ten minfte zeer aannemelijk zal beflisfen de verfchillende gevoelens wegens de zoogenaamde nieuw ontdekte Elastieke Gam: Elastieke dit ftuk behoort al mede tor onze Koeijen-Gom. of Osfenpooten. Onze ontdekking is cieze: de Heer JOOST LODEWIJK WEIDEMAN, een mij al te ontijdig ontrukte vriend, neef en opvolger van gemelde Jas COENRAAD BRAND, had genoegzaam de geheele partij van Elastieke Gom opgekocht,

$$
\text { H } 4 \text { die, }
$$




\section{NATUURLIJKE HISTORIE}

HET die, gelijk men weet, meest allen tot kleiRUNDVER. ne zwaantjes, fleschjes, beestjes enz. ge-

II. Afd. vormd waren; maar onder allen waren er.

II. verfcheiden bolronde ballen en eenige figuren, die vast opgevuld waren en geen water inzogen: mijn Vriend en ik, die al dikwerf zamen knutfelden om icts te ontdekken, fneden eenen der bollen door, en ziet, tot onze verwondering was dezelve opgeprapt met half rotte of ofgekookte zenuwen en peezen, die zoo taai en lijmig waren als de bollen bekleedfels zelve, en alhoewel onrijper, genoeg vermoeden baarde, dat deze zoogenaamde Gom geen voortbreng: fel van het Rijk der Planten, maarvan dat der Dieren is, en niets anders dan een gekookt of door vertotting getemperde lijmftof was. Dit gevoelen werd gefterkt door het onderzoek van verfchillende fuorten van lijm, als na. melijk de Eingelfche, de Hollandfche en Duitfche. De Engelfche had den voorrang in fijnheid en elasticiteit, de Hollandfche in minder trap, maar de Duit/che boven al in hardheid; in dier voegen, dat ik zoogenaamde lijm - of foepkoekjes, "die in Duitsch: land uir koepoten bereid waren, bezeten heb, die zoo hard waren als ebbenhout, en zelfs tot plankjes of doozen konden gefchaafà worden; elk dezer ftoffen evenwel was vatbaar voor weking en fmelting, tot op zulk een trap. van uitrekking als men begeerde. Nade: maal nu de zoogenaande elastike Gom dezelve teekenen had, en tot zekere trap van uitrekking kan gebragt worden, zelfs, toi fmel: 


\section{$\checkmark A N$ HOLLAND. 124}

fmeltens toe, zoo blijft er ten befluite niets beredeneerder over, dan dat de zelfitandig. heid der zoogenaamde Elastike Gom, of zoo men wil, het Gomleder, niets anders is dan eene kundigheid, om de hoofuitoffen of H่อT RUNDVEB:

II. Afd, II. Hoofds: koeklaauwen of peezen, tot zoodanig eene weeking, pappigheid of zamenftolting te brengen, dat zij door weeking lederachtig, en door droogte verhard wordt, zelfs tot groote ftukken, gelijk er alzoo een geheele mans laars van Elastike Gom in het $\mathrm{Na}$ tuur Kabinet tot Leyden te zien is, die op eenige weeking zich ontlaat en week wordt, zoo dat die, uit dien hoofde, wel eenige gelijkheid ( analy/is ) met de gommen der boomen heeft, mar inderdand de zelfftancigheid van de horenige en peesachtige deelen eener Koe bezit, en dus verre af is van een vegetabicle gom te zijn, $z 00$ als vele Geleerden, en ook de beroemde camper hebben vermoed. Dat nu de peezen en de bekleed. felen der beenderen van eene Koe, eene eigenaartige eigenfchap hebben tot uitrekken en doorfchijnendheid, is mij gebleeken uit een zeker foort van worst, die enkel en al. leen uit de peezen der koepooten bereid wordt. Deze worst was voorheen bij de Walen en Franfchen bekend; velen dezer Natien, ten tijde der vervolging van LODE. wiJk de XIV. in Leyden zich nedergezet en den naam van Walen, Refugeés Wallons, verkregen hebbende, boven ook vermeld, brachten de kunde om van allerlei deelen der Runderen, fpijzen te bereiden, H 5 .

me: 


\section{(22 NATUURLIJKE HISTORIE}

mede, in zoo verre, dat men in dien tijd zUNDVEE. een bijzondere Penshalle oprigte, die nog II. Afd. heden bij oude Leydenaars de Wale Aca. II. demie genaand wordt. De voornaamite hloofdr. handel aldaar beftond in het verkopen van gekookten pens, maar vooral koepooten, kalfspooten en worsten van koezenuwen ge. makt; deze noemden zij endoulje, en wa. ren zoo doorfchijnde en taai als horenglas, en niet te min zeer fmakelijk op de tong. De Vleeschhouwer HUIBERT MASSAAR, heeft mij eens zulke worsten van peezen vereerd, die hij van een ouden Walon had leeren bereiden. Onze voorzaten hebben insgelijks zeer wel de krachten der zenuwen van koeen kalfspooten gekend, en nog zijn vele Boeren er niet vreemd van, om ter zalving van voetenwee, jichtwee en rheumatike pijnen, de voeten of handen in het afgekookte fap van koepooten, pens of knokken te weeken; al hetwelk zamengenomen, geen gering bewijs is voor de bijzondere eigenfchappen der koepeezen enz. Voor her overige weren velen, vooral Franfche Koks, de dikke zware peezen, door geftadig met een platten hamer te kloppen, zoo lenig te ma. ken, dat zij dezelven tot fmakelijke pastijtjes kunnen bereiden.

De fnakfche BREDERo fchetst deze knoken penskraam, in zijn Tooneelfpel : het Moortje, zecr natuurlijk. Laat ik er u, Lezer! mede vermaken: 
Van daar ben ik mooitjes naar de Gaarmarkt egaca, HBT $B i j$ 't volkje die daer voorftaen met heur jonge Beesten RUNDVEs. en nochtere Kalven,

Șiet dat 's een kruiffchonckje, dat is een koker/lukje, die yoorwoos om vier en ein halven,

II. Afd.

II. Hoofdn:

En die helf knoock derdalve ftuiver; wil je nou gheen pens noch koevoet?

Gien niersa, gien lever, gien middelrift, gien hoojtvleys, noch het fmaeckt foo foet,

Wilje gien warme beuling, leverling, bloeling, pie. perlingh hiel goet,

soekje fabberaen, Jasper gaetbloet, enz.

Dit fchetsje heldert veel op in het geen in dit Hoofdftuk hier en daar wegens de oude fpreekwijzen is anngevoert; als: de holsknook, (zie halsftuk, ) het middenrif, ( zie lendenftuk, ) pens, (zie ' $t$ wand, ). koeyoet enz.) en wat angaat leverling, voor leverbeuling, bloeling, voor bloedbeuling, pieperling, voor peperbeuling, en flabbe. raan, voor zeker foort van kabfslil enz.

Meerder aanteekeningen zouden wij hier kunnen invoegen, doch wij meenen met de. ze aangevoerde reeds te kunnen volitaan, en fpoeden tot het einde van dit nuttig Hoofdftuk, hetwelk wij thans gaan befluiten met de opheldering van de uitwendige teeldeelen en die der zooging.

Bij No. 64. is dus eerftelijk aangeduid het aarsgat, hetwelk zich dadelijk onder de banden $\mathrm{N}$. 54. boven den klink $\mathrm{N} \cdot 65$. bevindt. 


\section{I24 NATUUTRLIJKE HISTORIE}

1) $T$

XUNDVEE.

II. Afd.

II.

Hoofdrt.

Klink beteekent cigenlijk eene spleete ( $r i$. ma fisfura) volgens KILIAAN, men kent er ook lippen aan, en voorts nog andere deelen: dan vermits wij een afzonderlijk Hoofdituk over deze deelen befchreven hebben, en dezelve met levensgroote afbeeldingen opgehelderd zijn, laten wij dic hier berusten, tot dat wij uitvoerig over de teeldeelen zullen handelen: het zij ge. noeg hier in her voorbij gaan aan te teekenen, dat de Boeren en Vleeschhouwers door den klink de vrouwelijke uitwendige deelen eener Koe verftaan: ik heb dezelve elders ook wel queve hooren noemen, warom weet ik niet. Wat de teeldeelen der Stieren betreft, deze al mede in het vervolg. Met een woord moet ik hier evenwel aanmerken, dat men dezelve noemt dekoker, balzak, de klootzak, de mannelijke roede, zwengel enz. Het uur, de jadders of elders, de melkborsten en prammen der Koeijen vereifchen hier een nadere befchrijving.

Het uur. Door het uur, verftaat men de zoogborsten, de melkgevende vaten, eigenlijk de verzamelplaats van het zog voor de Kalven, de Melkgevende deelen eener Koe, het verkwikkelijk voedfel, zelfs voor de Menfchen. De naamsoorzaak van het uur is duister, het fchijne van Latijnfchen oorfprong (uri$\therefore$ na) pisfe, zoo als her Hollands woord elder in denzelfden zin genomen wordt. $\mathrm{K}$ - LIAAN noemt dus elder (uber ovilli peco. ris.) Dit zelve brengt men op uur over, 
จ N HOLLA ND. 125

zoo dat uUr dan zoude zamenloopen op HET den zin van pisfen, yocht loozen. In ${ }^{\mathrm{R}}$. zekeren zin is het uur het naast aan de II. Afd. pisleiders gelegen, maar het verfchilt hemelsbreedte in de uitwerking; doch om II. dat die deelen onmiddellijk bijeen leggen, is mogelijk de benamingen van uur, het uur, hier uit ontftaan, en veelligt is het zeer bekend onderfcheid dat de flachters maken in het uur en in uurboord, dat is de boord Uurboosti van het uur, of liever den rand, daar van die onder den klink an de pisleiders begint, (zie $N^{9} .66$. ) ein de eerfte bekleedfels van het uur worden. Hoe het $\mathrm{zij}$, men vergelijkt het melkgeven uit de fpeenen van het tur, de elder of de jadder, niet oneigen bij het ontlasten der pisfe, waarom het melkgeven van eene Koe ook bij pisfen vergeleken wordt, en de Friezen het woord jadder in dien zin nog behouden. Liefse ftappen wij van deze naamsoorzaken af, om dat wij in den eenen en in den anderen vele twijfelachtige dingen ontmoeten.

Door het uur verfaat men hetzelfde als dat van elder en jadder; de Friezen zegElder: Jaddex, gen het jaar, evenwel fchijnt het dat de latatte meest op de Schapen worden toegepast; immers vONDEL vertaald het dus, ten aanzien van de melkgevende Ooijen:

$\mathrm{Zij}$ komen onbedwongen

Ter Kooijen met den fleep van haar beminde jongen ; En kunnen van haar melk en jadder overlaên, Heel kommerlijk naar ftal den drempel overgaan. 


\section{NATUURLIJKE HISTOKIE}

HEт Dit Dichttafreel doet alles åf, en toont wendver aan, dat men door jadder hetzelfde melk:

II. Afd. gevend gedeelte moet verftaan, dat men

II. ivijers of elders noemt, zoo vindt men nog:

\section{Hoofdit.}

De melkvolle uijer, opgezwollen van het $z o g$, Vertraagt den lomen gang, de koe treedt traag en log Naar't melkveld, ginder loopt de ontlasten weder radder, En lekt al hupplende, de fpeenen vàn den jadder.

Hier uit blijkt dat de uijer voor het geheele borstgefiel, en de jadders voor de fpeenen genoomen worden. Het lijdt ook geen tegenfpraak, of het een en ander komt op een en hetzelfde uit.

Het uur of het jacr dan, is het geheele geftel dat tusfchen de achterpooten aan de liezen hangt, als de zoogborst der Koeijen Het geftel toont evenwel eene verdeeling, die men duidelijk an de uurpees of pispees ziet, waar de naat de fchutvliezen doorteekend, want alhoewel het uur of de elder eene zak fchijnt, beftaat dezelve inwendig uit twee kennelijke affcheidingen ( $z$ ie $\mathrm{N}^{\circ} \quad 67 \cdot$ ) die bij nader ontleding wel tot vier kunnen erkend worden, en geen gemeenfchap met de pisvaten hebben. Deze twee affcheidin. gen hebben elk hunne teepels, die men in de Koeijen fpeenen noemt, en die zoo wel als elder jadder, onder dezelve beteekenis leggen. Het fchijnt evenwel dat onze Boeren hier in onderfcheid erkennen, althans zoo zij zich in de wandeling uitdrukken, houden zij voor het uur eigenlijk bet uurs ftuk, 


\section{* A N II OLLA N D. I27}

Stuk, of de krop daar van, die zij verdeelen in het yoor - of achteruur, yoorus en RUNDVEE. snaunr (zie $\mathrm{N}^{\circ}$ 49. en $49^{*}$.), de elders "Ir. Afd. houden $z \mathrm{ij}$ voor het ondergedeelte, waar de fpeenen beginnen, dat dan de jadders worII, den, welke laatfte woordnaam evenwel thans weinig bij onze Hollanders gebeezigt worde, meestal is elder en fpeenuur de gemeene naam.

De speenen der Koeijen zijn genoeg be- Speenexi kend. Zij zijn bij een ieder kennelijk genoeg sls langwerpige runde teepels, waar uit de melk vloeit; men telt doorgaans vier fpeehen aan den elder, twee lingfche en twee regtfche, wanneer een van de fpeenen of wel twee verftopt raken, kruipen zij op of verlammen, dan zegt men dat de Koe driefpeen of tweefpeen is. Het gebeurt, dat de Koeijen fomtijds wel een bijwas of vrat aan her uur bekomen, of natuurlilk daar mede gebooren worden, dat noemt men dan bij. fpeen of yijffpeen, doch dezen geven nooit Bijfpees: melk. Deze fpeenen zijn dikwerf aan brandigheid en zwelling onderworpen, of aan zekere vurige fmerting, die men heden koepokken noemt, en die zoo veel gerugts door gantsch Europa maken, door inenting aan den Mensch, en waar van wij het onze in een afzonderlijk Stukje reeds gezegd hebben: er is geen artikel, waarop een Boer meer acht geeft dan op de fpeenen, ja er lige den Boer veel gelegen aan een kundigen knecht of melkmeid, die de fpeenen wel zachtelijk weet te behandelen: want het geheele behoud eener Koe hangt, zoo wel als bij 


\section{I28 NATUURLIJKE HISTORIE.}

ห६т eenes Menfchen moeder; van eene veritundige P. UNDVEe zoogvrouwe af. Er behoort cene vaste eti 11. Afd. kundige hand tor het melkén, en het be: II. handelen der uijers. Mooneri fchetst dit fraai: Hoofdift

't Gezwollen iijer wordt met volgenagen hand Gemolken.

$\mathrm{Er}$ is evenwel iets bijzonders, dat bij de melkers geen uitleg behoeft, maar bij onkundigen wel eenig onderwijs vereischt, te weten : dat de melkmeid of knecht altoos aan de regterzijde regts melkt, en nooit of zelden, dan bij bijzondere omftandigheid, links, fchoon er zijn kunnen, die links melken.

Melken. Regts melken is, als het regter achterkwartier aan de linkerhand der Melkers ftant, en dezelve dan regts met de regter: hand aan het uur, den clder, de jadders of de fpeenen flaan kan, en dus de regterhand eene geheel vrije beweging onder den buik der Koe heeft. Dit veroorzaakt groote abuizen in de ftukken der Beesten-fchilders, die hier van onkundig, de Melkboeren en Boerinnen links en regts fchilderen, en dus grovelijk dwalen. Dus verhaalt men van een Schilder, die cen zeer fraai koppel Koeijen in de melkbogt, en daar bij eene melkende Boerin gefchilderd had, doch de Melkmeid zat links. Een Boer bij den Schilder komende, wierd gevraagd om zijn oordeel, of de Koeijen niet fraai gefchilderd waren, en wat hem er van dacht? De Huisman bezag her 


\section{VA N HOLLAND. 129}

het, en zeide : de Kneijen zijn lijkewel HEт heel mooi; maar die Melkkoe deugt niet, RUNDves die ftat yerkeerd; men vroeg hem reden; II. Afd. wel, zeide hij, de Koe frat regts, en de Melkmeid zit links. De Schilder begreep het, en zcide tegen den Boer, dat hij her veranderen zoude, mits de Melkmeid hem eerst wel leerde, hoe men regts' melkt. Dit gebrek is buiten dit vertelfel algemeen genoeg in de Prentwerken, vooral in de overdrukken of het niet wel obferveren der teekeningen, dewijl men, gelijk dit in overvloed bekend is, links overdrukt, het geen de Teeknaar regts. cn goed geteekend heef : nu, dit zij een Schilders-lesje. Men zie de juiste af beelding van eene Melkfter op Plaat II. En daar mede laten wij de verklaring over het uitwendig geftel der Koeijen berusten, tor dat wij in het vervolg nader tor de bijzonderheden der invendige deelen zullen komen, als: de inwendige borst en buikfpieren, der herkaauwing, ademhaling -, hart-, long - en leverfpieren, die der maug, darmfcheil, middenrif en dar. men, der nieren en pisleiders, der inwendige teeldeelen, die van het bekken, den aars, die der baarmoeder en der klink, in één woord, allen die tot de afzonderlijke inwendige fpieren behooren, die hier uitwendig niet hebben kunnen befchreven noch figurlijk aangewezen worden; terwijl die geenen; welke nu nader tot het zenuw - en herfengeftel behooren, in de twee navolgende Hoofdftukken zullen voorkomen. 


\section{I3o NATUURLIJKE HISTORIE}

Waar in de uiterlijke deelen eener Koe worden afgebeeld.

\section{HET VOORSTEL。}

No. I. De kroon of kuif.

2,2. De horenen.

3, 3. De horenkrappen.

4. De fteekfpier.

5. De oorfpieren.

6. Het oog.

7. Het ooglid.

8. Het hol aan de flaap des hoofds.

9. De neusgaten.

10. De muil, fmoel of fnuit, bovenlip.

II. De onderlip.

12. De kin of baard.

13. Het kinnebak of kakement.

14. De bovenkaakfpieren.

r5. De herkaauw - of kaauwfpieren.

I6. De bovenkaak.

17. De plaat der kol of ftarre, zijdelings,

18. De nek.

19. De keel.

20. De ooren en de voorhalsvang, fchothals.

27. De fchoftnok, de fchoft.

22. Het halsftuk, de hals, fchurkhals.

23. De krop, de voorvang, voorborst.

24. De kosfem, ondervoorvang, borst, 5. De binnenkosfem, binnenvang, naborst, 


\section{VAN H O L LAND. I3I}

No. 26. De Schildfchouder, de fchoft - of jokfchouder, jokfchoft. Het voorkwar-RUndere, tier.

27. De voorfchouder, fchildftuk.

28. De plats der fchildribbe.

II. Afd.

29. De voorvoet aan het armbeen of de II. Hoofdita mergpijp, fchijf of klompltuk.

30. De cllebocg, fehonk of fchinkel.

$3 \mathrm{r}$. Het borstbeen en fpieren.

32, 32. De kniegewrichten, het eelt.

33,33 . De voorpijpen.

34,34 . De kogel en voorkooten.

$35,35$. De klaauwen of fchoenen.

36, 36. De knielpeezen, de voorbouten.

37,37 . De voorfte fpoorhielen.

33,38 . De voorachterkooten of het kroonhol, koothol.

39. De voorvoets, binnenveer, binnenfchenkel.

HET MID DENSTEL。

No. 40. De rugge en ruggefpieren, de haasfipieren uitwendig.

4. De lange ribbe, het beste ribbeftuk.

42. De korte ribbe, de plaats daar het paterftuk wordt afgehakt van de groote ribbe.

43. Het middenrif, de lenden, het lendenftuk.

44. Het voorwand, de voorvang, het koffer.

45. De achtervang, de buik.

46. De melkfpicren en aders.

47. De navel.

48. De pensbuik of het wand. 


\section{I32 NATUURLIJKE HISTORIE}

ตET RUNDVEE

II. Afd. II. Hoofdit.

\section{HET ACHTRSTEL.}

No. 49. Het uur, het vooruur, de uurvang. $49^{*}$. Het achteruur met de fpeenen of jadders.

50. Het kruis.

51. De ftaartbonk.

52. De heup, de heupbonk, de bonk.

53. De ftaartgroef.

54. De banden, mitsgaders de wal- of walegreep, het koekoeksgat.

55. De bovenftaart.

56. De ftaartpluim.

57. Het dijftuk, de billen, het bilftuk, de veeren en bilfpieren.

58. De achterbil, achterveer, rookftuk. 59, 59. De fchiiithakken, hangpces enz, 60,60. De achterfchenkels of pijpen. 6I, 6I. De achterfpoorhielen of hakken. 62,62. De achterkooteil. 63,63 . De achterklaauwen,

64. Het aarsgat.

65. De klink.

66. De boord van het uur.

67. De naat der fchutvliezen of affcheis ding in het uur.

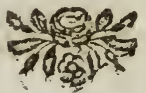




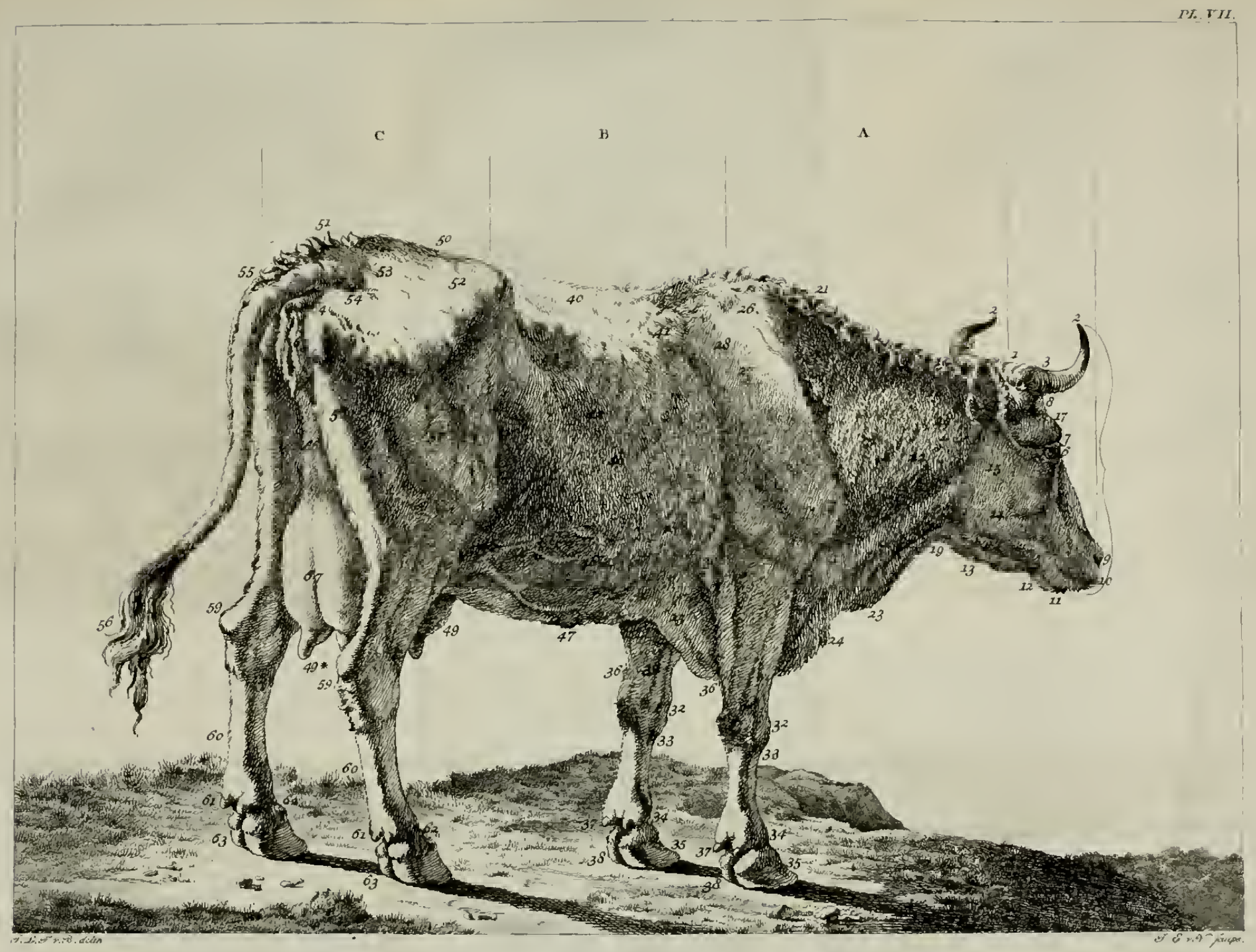


R

1

f

-

(1)

1 


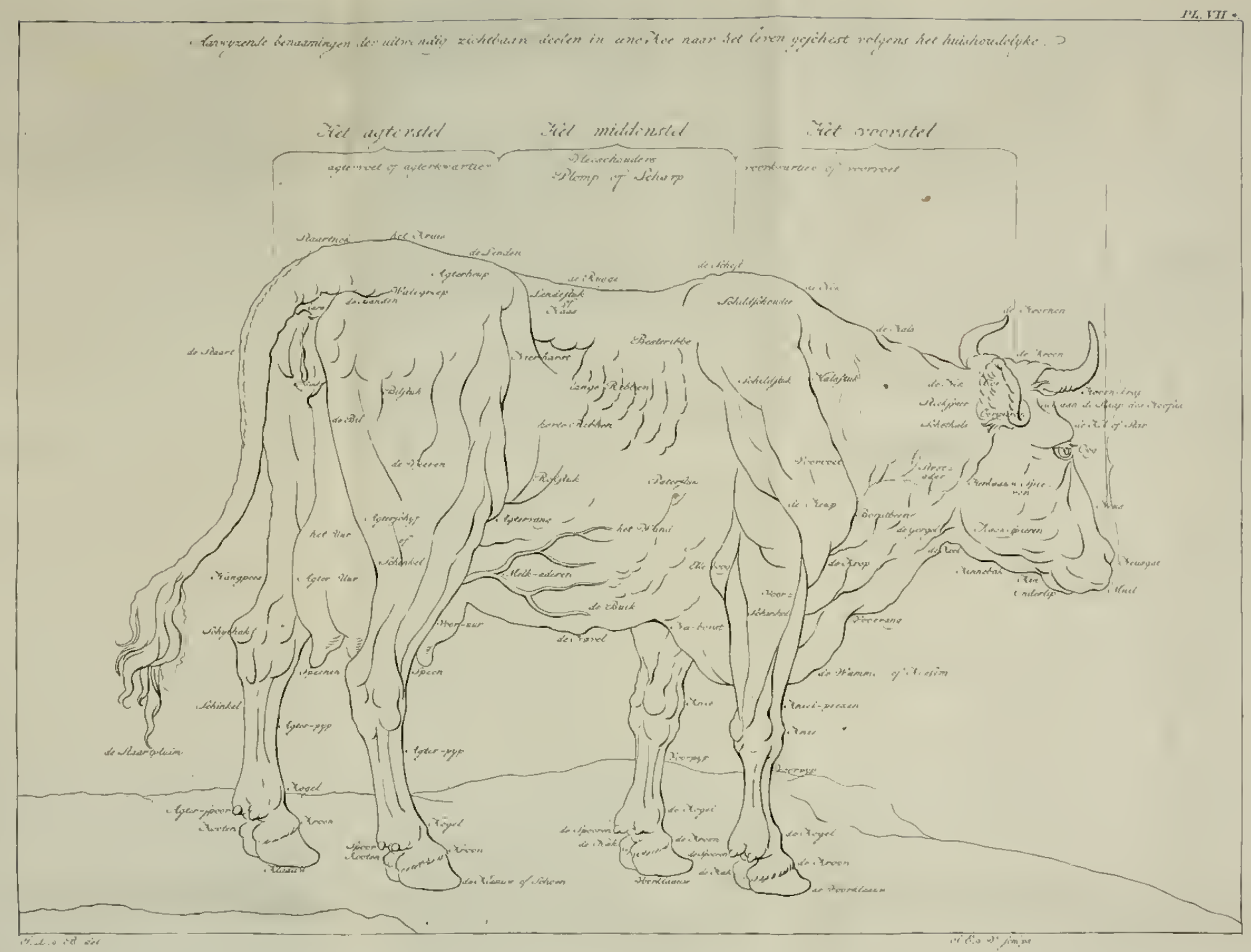




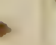


$\forall A$ N HOLLAND. I3

\section{TWEEDE AFDEELING.}

DERDE HOOFDSTUK.

Befcrouwing yan het Hersfengefiel der Koeijen, deszelfs yaten, zenuwen, ade. ren en flagaderen, boezem en mergdeelen, mitsgaders het gansche zenuwgeftel door het geheele ligchaam der Koeijen, yolgens

THOMAS WILLIS; met yerbeteringen.

$\mathrm{N}$

a dat wij tot hier toe in zoo verre gevorderd zijn, dat wij de platefing der RunDvize: beenderen en fpierdeelen in de Koeijen hebben voorgedragén, zal het hier niet dan zeer nuttig geacht kunnen worden, dat wij II. Afd. derzelver onderlingen zamenloop, die zij uit het algemeen hersfengeftel ontvangen, befchouwen, en nader ophelderen; te meer, daar derzelver maakfel in de Koeijen, aan 


\section{NATUURLIJKE HISTORIE}

Her den Ontleedkundigen den weg gewezen heef, RUNDVEr om die in de Menfchen te kennen: immers

II. Afd. de beroemde THOMAS WILLIS En BARTHOLINUS Hoofd. hebben hier in de voornaamften voorgegaan en de grootite opheldering, uit de Koeijen ontleend, gegeven, en de Geleerden zijn aanden grooten Amfterdam/chen Profesfor BLAsius en de pers van wETSTEIN, de uitvoerigfte uitgave verfchuldigd : men vindt daar in het hersfengeftel der Koeijen en Schapen keurig afge. beeld en befchreven, en nademaal wij niers willen achterwege laten, het geen ten aanzien der Koeijen of herkaauwende Dieren met oordeel is vonrgedragen, hebben wij ook deze bijzonderheden niet voor onze Landzaten willen verbergen, maar beflocen, om in onze Mocderfprake de befchrijving, en in afzonderlijke teekeningen die af becldingen mede te deelen; dezelven zijn meerendeels naar die van willis gevolgd, doch wel degrelijk door ons met de Natuur zelve vergeleken, waar door het komt, dat hier en daar, zoo in het beloop der vaten, als den omtrek zelve, vele verfchillendheden zich opdoen, het geen een kundige dra zal ontdekken. Het is wijders ons oog* merk niet, om breedvoerig uit te wijden in de ontelbare gevoelens over de fijne vezelen en vaten der hersfenen, over de klierachrige zelfftandigheden, die RUISCH en MALpHIGIUS 200 meesterlijk betoogd hebben, geiijk ook MORGAGNE; veel min over de eigenlijke werking van het zintuigelijke, of de denkwijze der Dieren, volgens DEsCAR. 


\section{A N H O L L A N D. 135}

TES, dat van anderen in de pijnappelklier; ja ook treden wij in de gevoelens van wiLLis niet, die de zitplaats der zinnen in her geftreepte merg; dat der verbeeldingskracht in het witte merg; het geheugen in de korst of HET RUNDVES:

II. Afd. III. Hootdft grijskleurde zelfitandigheid fchijnt te ftellen: neein! wij laten deze en ontelbare andere gevoelens berusten, zij loopen in het oneindige en in het onmogelijke; geene boekdeelen zouden voldoen, geene beflisfing volgen, en de Burger het niet verftaan; daar en boven zoude het ons niet alleen van ons waar oogmerk aftrekken, maar veelligt ons in fijne en uitgebreide overwegingen wegvoeren, die een fpitsvondige betwisten, en een bijgeloovige veroordeelen zou; want, indien ik uit de overeenkomst van het hersfengeftel der Koeijen, en dat van andere Dieren, met dat van den Mensch, eens wil de betoogen, dat, nademaal niets te ver. geefsch gefchapen is, de Koeijen, dic men voor 200 dom en onverftandig houdt, evenwel ook denken en redeneren, ja eene zintuigelijke ziel hebben, naar haren aard, ik liep zeker gevaar van verketterd te worden; ien evenwel meen $i k$, dat het tegen de gezonde rede niet ftrijdt, zelfs niet tegen den Godsdienst, als wij deze en velen anderen diefen eene redenering, geheugen en denkwijze naar hunnen aard toefchrijven. In de nog te betogene verhandelingen, over den aard van rieken, van hooren, van fmaken, van gevoelen en van zien, zal dit naauwkeuriger blij. ken; en wat hunne hartstochten van toorn,

$$
\text { I \& vrees? }
$$




\section{I36 NATUURLIJKE HISTORIE}

нгт vrees, haat, teeldrift, en vooral liefde tot RUNDVE. hunne jongen, tot gezelligheid en lijdzaam. II. \{Afd. heid betreft, deze allen zijn bij uitftek der III. Koeijen eigen, en deze kundigheden der

Hoofdrt. Koeijen waren den Ouden bekend: in de Heilige Bladeren vindt men het opgemerkt ten anzien van het geheugen: eer Os kent zijne kribbe; ten aanzien der lijdzaamheid: hij ging als een Os ter fachtinge, en dergelijke meer. Men zegge niet, dat dit een dom en onwetend inftinct is; ik beken, men ziet hun doodsangst zelden uirerlijk zoo kennelijk werken als bij den Mensch; maar wie hecf, wie zal ons ooit vertellen, wat eene Koe denkt, als $z i j$ den eenen makker na den anderen voor zich ziet wegbrengen, het bloed froomen, en de afgeftroopte huiden maast zich liggen? Zeker, dit is voor ons verborgen; maar let er ecns andachtig op, gij zult ze zien fnufielen, blazen, fommigen fchor locijen, anderen kregel worden, meest allen van angst afgaan en veel pisfen, dat ik vuor mij aanmerlk als een zincuigelijk gevoel van angst: en wat ảe vrees betreft, hier van zijn duiwende voorbeelden te vinden: als voor onsveier, voor kanonfchoten, voor flikkerend vuur, en dergelijke meer. Deze en ontelbare redenen leiden ons dan dartoe, om te befluiten, dat het hersfengeftel der Koeijen, en vooral het zenuwgeftel, in haar ook gefichikt is, om niet alleen op het geftel tan bet ganfche ligchaam, mar ook bijzonder op dat der fjijsvertering, voedfel, nood. 
nooddruft zoeken en voorttelingsdriften te werken en te gevoelen, naar hunnen aard RUNDVRE: en eigenfchap. En hier mede laat ik da I1. Afd. overige fijnigheden berusten, wijzende onze Lezers naar het onbetaalbaar werkje van III. Hoofdat? ReIMARUS, over de driften der Dieren.

Ondertusfehen is het hersfengeftel in de De hers: Koeijen, gelijk meermalen is opgemerkt, fenen. naar gerade van de grootte van het Dier, niet groot, althans in vergelijking met den Mensch; ook is de oppervlakte der hersfenen tegen het bekkeneel niet zoo, pherisch rond, maar langwerpig plat, volmaakt beantwoordende aan de platheid van de ftarre van het voorhoofd, en de drukking van den kruin onder de horenen, tot aan het nekbeen. Voor het overige beftaan de Koe. hersfenen mede uit eene grijsachtige korst, die allengs vermindert, en witter worit tot een wit merg, waarin de vezelen der hers* fenen tot zulk eene fijnheid van draden en weefrels verloopen, dat tot heden toe de fchranderfte Ontleedkundige dezelve niet heeft kunnen bepalen; en het is hierom, dat alle redeneringen, ten aanzien der zintuigelijke werking der ziel, of der dierlijke geesten, door geen fterveling kunnen ontwikkeld worden, het geen de fpitsvondige winsLow heeft doen zeggen, dat men nooit dit ftuk zal kunnen bepalen, om dat de vezelen in het hersfenmerg zoo week zijn als het merg zelve, en derhalve niet te be. handelen; waarom dan te wanhopen is, dat het menfchelijk vernuft derzelver verborgen

wer: 


\section{NATUURLIJKE HISTORIE}

HET werking ooit zal kunnen bepalen. Wij maRUNDVEE. ken 's Mans woorden de onze, met te zeg. II. Afd. gen: wij weten het niet. Wijders is ons

1II. niet onbekend, dat de Geleerden onzer daHoofdrt. gen niet veel meer ophebben met de af. beeldingen van wiLLIs, als, zeggen zij, te veel van hunne plaats geraakt door het al te fribtiel uitfpannen van dezelven: dit kan 200 zijn, maar waar zal men beter nabij de waarheid te regt komen? Doch dit raakt ons hier niet, nademaal wij hier niet redeneren met overbrenging op den Mensch, maar enkel ons houden aan het geen op de Koei. jen toepasfelijk is, en her zoude voorze. ker, naar ons inzien, onvergevelijk zijn, in. dien wij zulke uitmuntende voorbeelden aan onzen Landzaat onttrokken; en, vraag ik, waarom zoude een Boer, een Vetweider of Vleeschhouwer dit wondergeftel zoo wel nier eens mogen leeren kennen als een $\mathrm{Ge}$ leerde?

Derhalve, alle ingewikkelde redeneerkunde daarlatende, laat ik dan, mijne Lezers! zoo veel het onderzoek toelaat, uwe weetgierigheid voldoen, om het hersfengeftel, dat der zenuwen en het ruggemerg der Koeijen eenvoudig iaf te beelden, zoo als dit voor ons gedaan is, om aldus de deelen te verklaren, derzelver ligging, gedaante en natuur aan te toonen, die gij anders niet wist, en aldus bij wijze van aanwijzing in de bijgaande Plaat VIII. verklaren, alwaar wij van gedeelte tot gedeelte de gedaante der Koeijenhersfenen zullen leeren kennen. 


\section{A N HOL L A N D. I3?}

In de Plaat, waar wij de reukdeelen der Koei- иет jen zullen afbeelden, zal breed - en uitvoe- RUNDVRE: riger een groot deel van de beenachtige II. Afd. holligheid der hersfenpan vertoond en ver- III. klaard voorkomen; maar hier ziet gij bij Hoofdfs. voorraad dezelve vlak van onderen, mee alle de holligheden en cellen, die de hersfenen omvatten, zoo echter, dat er als een algemeen vlies tusfchen beiden is, dat de geheele weeke hersfenbol bevat, en om en Beenige door alle boltens en holtens doorloopende holtens der eindelijk als in een fchede het ruggemerg ${ }_{\text {kast of on }}^{\text {herfer }}$ en den rok der zennwen formeert, waarom derhoofd. men dit vlies het Moedervlies (pia Ma. Moederter) noemt: dit vlies moet men dan denk-hersfenbeeldig ftellen als nog in deze af beelding vlies. verheeld. Zie dan de verklaring hier vol. gen.

\section{VERKLARING VAN PLAAT VIII.}

Fig. I. Verbeeldende het hoofd yan een Verklaring Kalf, liggende omgekeert ylak op denvan Plaat kruin, half doorgezaagd, yan den nekwer-VIII. yel, tot tegen het bovenfte verhemelte. Fig. Is

$B \mathrm{ij} a$ is luchtig afgebeeld het eerfte wervelof nekbeen, dat men den atlas noemt, om dat hetzelve, bijzonder in den Mensch, met een uitfteekend beentje, als op een fpil, het hoofd of den hoofdbol draait, en voorts den draai der lendenen beftierd.

Bij $b$ ziet men aangeduid de beenderen van het 


\section{40 NATUURLIJKE HISTORIE}

HPT

RUNDVEE.

II. Afdi

III.

Hoofd?d

het verhemielte, ter plaatfe daar deżel:

ve van de hoofdkas affcheiden, en aan de bovenkaakbeenderen $c c$. worden ingegroefd. Ten begrippe daax van, zijn er de kiezen dd. bij afgebeeld.

e e e e duiden an die holligheden; waar in de fponsbeenderen van den reuk liggen, en die zeer breedvoerig en levensgroote in een volgende Plaat verbeeld, en aldaar tevens in alle deelen befchreven zijn.

If $\mathrm{fertoonen}$ de tepelformige beenderen, waar door de reukzenuw loopt, mede in een volgende Plaat afgebeeld en befchreven. $g$ is de plaats der gezigtzenuwen, daar zij vereenigt zijn. Nader verklaard bij een vol. gende Plaat.

$h$ is de $\mathrm{kwij}$ klier, uitvoerig met derzelver zenuwen afgebeeld en befchreven bij een volgende Plaat.

¿i zijn de plaatfen daar de Arteriae Car. roticies in de hersferien indringen.

$k k$ de z.nuwen, die de oogbollen bewegen, ter plaatfe daar a ij in de hersfenen dringen.

16 duiden aan die bewegende gezigtzenuwen; die onder het moedervlies als doorfluipen, en hier hun vitgang tot de oogen toonen. Het zijn deze zenuwen, waar aan willis de beweging en het gevoel der hartstochten in de zielen, door de aandoening van het gezigt, toefchrijft, het geen flechts eene gisfing $\mathrm{kan}$ zijn, maar wie zal het beflisfen?

$m m$ bet zesde paar zenuwen, die even als de vorigen, onder het moedervlies 


\section{$\checkmark$ A $\mathrm{HOLLAND.} \mathrm{I4I}$}

liggen, en door eene en dezelfde ope- HRT ning met de vorige, doorgaan naar de RUNDveE reukdeelen.

II. Afd.

$n n$ toonen her zevende paar zenuwen, die naar het fteenbeen loopen, en het geIII. Hoofdet; hoor uitoefenen.

00 het achtfte paar zenuwen, dat men verwijderend en bepaald ( yagum) noemt, om dat hetzelve zich met de andere ze. nuwen vermengt, doch eigenlijk is het dat paar, dat op den fmaak, het verhemelte en de longeklep, het meeste in vloed heeft.

$p p$ duidt het negende paar zenuwen aan, hetwelk zijn onderlinge werking op her gevoel heeft, gelijk ook

$q q$ het tiende paar antoont, hetwelk in de hersfenen verfpreid is.

or zijn de fteenbeenderen.

ss de jukbeenderen (osfa jugalia), in hunnen natuurlijken ftand. Hier in liggen de oogbollen.

tt zijn de holligheden van het onderbekkeneel, waar in de hersfens tegen het fteenbeen en het gehoor drukken.

u u zijn de groote holligheden, waar in de hersfenen tegen het verhemelte drukken.

y y zijn langwerpige geulen, die al mede de hersfenen ontvangen, in zoo verre, dat dit ganfche beendergeftel als de form is van den ganfchen bol, die de hersfenen in hunne vlięzen aannemen, en waar van de volgende Figurur een nader begrip zal geven. 


\section{I42 NATUURLIJKE HISTORIE}

Hex $\mathrm{Na}$ dat dan een begrip in Figuur $\mathbf{r}$. is zUNDVEe. gegeven van het Bekkeneel, voor zoo verre II. Afd. het beendergeftel betreft, en deszelfs hol. III. ligheden, benevens de uitgangen der zenuHoofdr. wen, uit het bekkeneel naar de zintuigen, en zoo door het verder ligchaamsgeftel; zal

Fig. 2. nu Figuur 2. ons de geftalte van de hersfenen zelve, zoo als dezelve in hun geheel zijn uitgenomen, doen kennen, en tevens geen klein licht geven van het beloop der bloedvaten in het hoofd, waar van nader zal gefproken worden. Wij merkten hier boven, in het voorbijgaan, aan, dat het hersfengeftel in de Koeijen, naar mate der grootheid van het hoofd, kleiner was dan in den Mensch, tevens dat hetzelve langwerpig was. Deze Figuur vertoond het duióelijk, want daar in den Mensch de twee

Hersfen-hersfenbollen, die men ook wel billen ( $p a-$ bollen. tes) normt, te zamen eene bijna volmaakte fpheerronden bol uitmaken, zoo zijn dezelven in de Koeijen en Schapen op zijde platter en meer gedrongen, en het middenfchotvlies, dat men, om deszelfs gelijkenis Seisvlies. naar ecne feis, het feisyliezig uitftek (proces/us falciformis) noemt, in de Koeijen ook langwerpiger. In deze Figuur kun. nen wij het niet wel vertoonen, on dat het hersfenftel hier omgekeerd voorkomt, en de billen of halve bollen hier flechts van op zijde zijn angeduid, gelijk dan deze Fi. guur 2. in dien fand moet gehouden worden. Zie hier dan 


\section{v N H OLLA N D. 143}

in Fig. 2.

a de plaats der fcheiding van de twee halve RUNDVE. hersfenbollen, door middel van het feis. II. Af. vlies.

b $b$ duiden aan de uirerfte wanden van de Hooldit. groote hersfenbollen, die anders in den De hers-

Mensch rond zijn, doch hier met infnij- fenwandingen vertoonen dat derzelver figuur ge- den.

rchikt is naar het beendergeftel der koekruin, die inwendig hier ingedrukt is.

ec zijn de linkfche en regtfche halffpherifche De linkhersfenbollen, van tegen het onderbek-fche en keneel te zien. regtfche hersfen.

d d zijn de uitpuilingen van de kleine hersfe-bollen.

nen (cerebelli), op zijde te zien, en zoo genoemd, om dat zij op zich zelven Dekleene twee kleiner bollen uitmaken, en als aanhangfels der grooten zijn. Het zijn dezen, waar van de liefhebbers van nlobbering in de kalfskoppen, een lekkernij maken.

oee is het verlengde merg (medulla oblon-Verlengdr. gata) daar het bij de twee $e e$, uit de merg. groote hersfenen allengs verfmallende, tot bij $e$ van onderen doorloopt, tot het door al de wervelholtens of wervelringen heen, aan den ftuit in de zenuwen zich verliest, te regt daarom verlengd genoemd. Onze Slagters en Boeren noemen het de pees, het ruggemerg, het nekmerg, zij rukken het altijd uir, om dat zij het fchadelijk achten, gelijk hier boven reeds gemeld is.

ff duiden de tepelachtige beentjes aan, waar De tepelsin wiize been. 


\section{NATUURLJJKE HISTORIE}

Hex in de reukzenuwen naar de hersfenen 100. RUNDVEE. pen en in het merg verdwijnen. In II. Afd. de Plaat waar in de reukbeenderen af. III. Hoofdit. zonderlijk ijin afgebeeld, kan men dit nader onderzocken.

$g$ zijn de gezigtzenuwen, of eigenlijk is hier een aanmerkelijke tweetakkige mergzenuw, die zich dikker dan eenige andere zenuw opdoet. In Fig. I. mede bij $g$, ziet men ze insgelijks duidelijk. Bij de verhandeling over het gezigt, en de daarbij gevoegde. Plaat is derzelver werking breeder betoogd. $h / 2$ duiden het derde paar zenuwen aan, die eigenlijk gefchikt zijn om den oogbol te bewegen, en de fpieren daarvan te befturen, ten wille van het Dicr. In het Hoofdltuk en de Plaat over het gezigt der Koeijen, zal deze werking zeer naauwkeurig worden vertoond, vooral met betrekking tot de Koeijen. Het verdient hier in het voorbij gaan opmerking, dat 200 wel in de Koeijen als in den Mensch en andere Dieren, uitgezonderd de Mollen, de zenuwen der oogbewegingen zoo afzonderlijk kenbaar zijn, daar die van het gehoor, de fmak en de reuk op verre na zoo zigrbaar niet zijn, waar van de reden is, dat de oor-, de neus, de rongfpieren en derzelver zenuwen, als fprugtels zijn van de fpieren en zenuwen, waarin zij gewikkeld zijn, daar de oogbol op zich zelve in zijn beenkas liggende, geene toevoer heeft, dan alleen het geen de oogleden van de voorhoofd: 


\section{VAN HOLLAND; 245}

hoofd- en wingfpieren uiterlijk beko- He: men; dus kan en moet men hier op RunDvire: deze fiuitreden maken, dat de Schepper Ir. Afd. gewild heeft, dat aan het gebruik der cogen eene vrije en gevoelige beweging III. wierd gegeven, om de oogenblikkelijke gewaarwordingen aan de ziele te bren. gen, waarom de wijsgeren wel te regt de oogen, de venfters der zielen noemen, en wat kracht en invloed dezélven op ons Menfchen hebben, weten de verliefden, de gramftoorigen, de droefgeestigen, de mededogenden, de hebzuchtigen, in één woord, de werking van alle onze driften, en ook hoe zij in de Koeijen werken, is voor ons onbekend, doch zal nader en zoo veel mogelijk opgehelderd worden in de verhandeling over het gezigt; mant het geen ten dezen opzigte nog meerder atdoet, zijn het vierde paar zenuwen, die bij Hoofdrt,

Het vier-

i $i$ zijn aangeftipt. Deze zenuwen behooren de paar ook tot de fpieren van den oogbol. WiL. zenuwen. LIS noemt dezelven Pathetici; eene bijzondere benaming, door hem an dit paar gegeven, oin daar door ann te duiden, dat dezclven het meest op de ziele der dieren werken. I $k$ wil hier wel inftemmen, voor zoo verre dit met de flelling van wiLtis waarfchijnelijk is, maar ik ben gantsch niet vreemd te geloven, dat de fpruchtels dezer zenuwen ook gemeenfchap !hebben op die van het inwendig gehoor en het flekkenhuis, en ook op de reukzenuwen, IJ om 


\section{NATUURLIJKE HISTORIE}

BET om dat dit vierde par onmiddelijk ann RUNDVEE, derzelver oorfprong begint; hoe het zij,

II. Afd. zeker is het, dat dit par zenuwen, tor

III.

Hoofdrt. nog toe, alhoewel bekend; en onderfcheiden genoeg bckend, niet te min in derzelver werking duister is.

Vijfde $k k$ is het vijfde paar zenuwen, zeer zigtpaar, de Imaakze. nuwen. baar in twee aanmerkelijke takken, wederzijds uit eenen oorfprong fpruitende. Wij houden het voor de wortels der fmaak - en reukzenuwen, om dat derzelver takken zig daar breed en wijd verfpreiden. Eene Plaat zal dit nader ophelderen, om dat derzelver takken al. daar zijn afgebeeld.

Zesde $l l$ teekenen wederzijds het zesde par, in paar, de longzenuwen. dezelfde rigting als de vorigye, en hebben ook dezelfde werking, ten ware zij, naar mijn vermoeden, ecne nog bijzon. derer uitwerking op don fmakk, en de inademing der verfijnde lucht in den ftrot, den flokdarm, de longpijp en ondertongfche klicren, ja ook de tanden en lippen hadden

Zevende $m m m m$ zijn de zevende paren, te weters, paaren, de gehoorzenuพen.

de eigenlijke gehoorzeruwen, in Fig I. bij $n n$ afgebeeld, die hier ook twee uitftekken hebben Vergelijk hier verder bij een volgcnde Plaat en het darbij behoorende Hoofdituk over het gehoor der Koeijen.

Achtfe $n n$ duiden het achifte paar zenuwen aan, parr, de - die men zwervend (yagum ) noeme. zwcrende, Zie de explicatic op Fig. I. in deze zenuwer. Plast bij oo. qo zijı 


\section{$\checkmark A N$ HOLLA N D. 147}

oo zijn de zenuwen die langs het rugge- Het merg, eigenlijk het verlengde merg, ont- RunDVRE: fpruiten en in de hersfenen tuitloopen, II. Afd wederzijds zeer kennelijk langs de wer- Hoofde: velen vervolgende tot aan het ftuitbeen.

$P$ P vertoonen de fpruchtels en takjes van het Negende negende paar zenuwen. Men ziet de- par,mergzelven hier in kleine takjes, doch eindelijk vereenigen $z \mathrm{ij}$ zich dieper, tot eenen fronk, hooger in de hersfenen.

99 zijnde het tiende par, insgelijks met Tiende fpruchtels te zien, als boven. paar, rug: zenuwen.

r $r$ Hier is de voorname bloedader, die van her hart uit deszelfs linker holligheid, fenbloed. langs den hals, in de hersfenen dringt; aderen, zij is hier afgefneden vertoond: anders naapade. zijn hare takken aanmerkelijk. Het is ren enz: door deze aderen, dat men de fijne harvarijes door de geheele hersfenbol en het moedervlies, overkennelijk kan op. fpuiten; het zijn dic uiteindens van de halsaderen en llagadereil, waar aan de Koeijen worden adergelaten: wanneer deze veritope zijn, kwijne de Koe, en raakt aan het kolderen, het geen de Boeren aan het kugchen, hangen en veel fchud. den van den kop ontdekken, vooral aan de flaperigheid, waarom dezelven ook flaapaderen (Joperiferae carotides) ge. naaind worden.

ss verbeeldt de kusfing (anaftomofis) van de beide takken van dezen gemelden ader.

s vertoont de vereeniging der beide groote takken der halsaderen. 


\section{$\$ 48$ NATUURLIJKE HISTORIE}

нет и zijn de takken der aderen die langs de eundVeE. wervelbeenderen loopen, en dic hier in

I1. Afd. de hersfenen invloeijen. Deze aderen III. vergezellen beftendig de zenuwen der Hoofdit. ruggegraat in alle hunne takjes.

Dewervel- $\boldsymbol{y} y$ vertoont de vereeniging dezer takken, aderen.

De fijne rakaderen. tot eenen zamenloop, opklimmende naar het bovendeel der hersfenen, met zeer kennelijke takken door, om en weder door de verfchillende holligheden en vliezen van het merg.

De $C_{a} . \Psi w$ vertoont de uitbreiding der zijtakjes rotis, de platte uitbreiding der bloedvaten. uit de Carotis, bij wijze van cene wederzijdfche zeer fijne uitbreiding van zeer fijne takjes, dat men in het Larijn plexus Choroidoni noemt, in het Nederduitsch niet mogelijk uit te drukken, ten zij men het eene platte uitbreiding van vaatjes noeme.

Halsade- $x$ vertoont de vereeniging der oorfpronkeren

lijke aderen, die ter wederzijden naar den hals, en de middenfte naar beneden naar de longpijp loopen.

Trechter. $y$ is de trechtervormige holligheid in de vormige

klier.

witte $z$ is die witte klier, die onder het opge. melde ligt, en als een bijzonder midden: punt der hersfenen gehouden wordt.

Hier mede Fig. 2. verklaard zijnde, zouden wij hier de bijzonderheid met betrekking tot de Koeijen kunnen voordragen; dan, dewijl wij dit verkiezen te doen na de ver- klaring der volgende Figuren, om des te klaarder begrip te vormen, volgt hier 


\section{VAN HOLLA N D. 148}

Fig. 3. Deze Figuur, die nabij komt нат aan die, welke willis uit het hoofd van Rundver een Schaap heeft afgeteekent, verfchilt eeni II. Afd. germate met die, welke wij bij het hers. III fengeftel uit een Kalf genomen hebben, en hier verkleind is afgeteekend. Het grootfte Verkla. verfchil is, dat onze figuur zoo langwerpig ring van nier is; dat wij den bovenrand van her hardachig deel (corpus callofum) wat vlakker en dooraderd geteekend hebben, behalve nog verfcheiden kleinere verfchillendheden, die naar onze teekenmanier veelligt anders voorkomen', doch hetzelfde beteekenen. Onze Figuur dan vertoont bij

Fig 3, het gedeelte van het hersfenge. Groot ftel, dat aan de bovenfte en grootfte bollen merg. gehecht was, en tegen het groote merg aan merg. deszelfs vezelen, die men geftreepte ( $f$ riatw) noemt, verbonden, thier daar van afge. fneden vertoond worden, tevens met deszelfs verband ann de kleine hersfenen, het verlengd merg, de deelen van den verhardenden korst, de billen, rondtens, holtens, zenuwfpieren enz., zoo als die natuurlijk liggen.

a a a a teekent aan de doorfnijding of af- Affcheit: fcheiding van dit gedeelte der groote ding. hersfenen, (zie Fig. $2 . b b$ en $c c$ ) juist ter plaatfe daar de vereeniging of het begin was van het verlengde merg, dat men hier draadachtig, geftreept noemt, om dat deszelfs vezelen langwerpig en fchier lijnregt nederloopend zigtbaar zijn.

$$
\text { K } 3
$$




\section{r5० NATUURLIJKE HISTORIE}

HET $b$ is de affnijding van eene holte, die zich RUNDVEE. Om en door het harde tusfchenmerg uit-

II. $\Lambda$ fd. breidt : wiLlis en anderen nocmen ze IIl. fornax, dat cene gaping als van een fourHoofdr, nuis beduidt; doch anderen, als winsLow. Het four noemen het eene trechterachtige holte: nuis, rech- deze, alhoewel hier flechts even ange-
terhol. wezen, is nogtans in eene Kochersfen zeer aanmerkelijk kenbaar, gelijk dit ook blijkt in de nederdaling van haar buis, - in het eigenlijk trechtertje bij

$c$, daar de ware bafis is.

Harde $d d$ is een gedeelte van de harde hersfenen, hersfencn, zoo als dezelven zich vol aderen, tusfchen de golvingen der hersfenen vertoonen, tegens den afgefneden korst $e e$, bij wiLl!s niet verbeeld.

Trechter-e e de doorgefneden rand, die als tittpruitbuis.

fels der ovenholte zijlings omloopt, en daar bij $f$ in de gemeene trechterbuis doorloopt, en tevens nog twee randen furmeert bij a ca, die de harde hersfenen influiten, zoo dat zij deszelfs rand formeert.

$f$ de lange trechterbuis,

Takjes. $g g$ zijn twee takjes van de trechterbuis, dic tusfchen het geltreept merg in lig. gen, in de Koeijen buitengemeen groot en zigtbaar.

Draad. $h h$ vertoonen twee zeer aanmerkelijke uithersfenen. weidingen van het hersfenmerg, daar het als ' $t$ ware de draadachige hersfenen omvangt, mede anmerkelijk groot in de Kocijen, 


\section{$\checkmark A$ in HOLLAND. 15}

$i$ is een anmerkclijke fleuf, die tusfchen, Heт den bafis der trechterwortels begint, en RUNDVEE. ann het veriengd merg eindigt.

II. Afd.

$k k$ vertoonen eigenlijk die deelen, welke men vezelige of dradige geftreepte lig. III. chamen (corpora friata) noemt; zij De veze. zijn fterk net aderen en lagaderen door-len of ge. weven; wij vonden de\%clve onmiddelijk ftreepte in de dikfte $z$ welling der hersfenbol $a$ a deelen. en als in een witten korst liggen, en niet 200 onderfcheiden in eene groote bol der hersfenbillen, als wiLlis die in een Schaap verbeeldt: mogelijk hangt dit af van eene hoogere of lagere doorfnijding,

1/l zijn de aanduidingen van de verharden- Zenum de hersfenen, of laat ik liever zeggen, bron. derzelver zcnuwachtigen bron, om dat het, naar mijn inzien, wel te betogen zij, dat de oorfpronkelijke takken der zincuigelijke zenuwen in den zamenloop dezer bron hunne vezelachtige en onzigtbare inwortelingen hebben; en hier uit het mergachtig voedrel uit beide de weeike hersfenbollen, door de menigte kronkels en golvende kwabben klieren. of klieren, zoo als maLpHigius ftelt, bekomen, 't geen nader te onderzoeken is, en zeker niet verre afwijkt van het geen CARTESIUS en WINSLOW hier over gedacht hebben; dan, dit zoude ons veelligt te verre brengen.

as $m$ zijn de uitfpreidende fchachten der ge- Schacks zigtzenuwen (Thalami neryi optici) ten der ge: 


\section{NATUURLIJKE HISTORIE}

IreT RUNDVEE。

II. Afd,

III.

Hoofdet?

De pijn $n n$ zijn de doorfnijdingen van den pijnapappelklier. pelklier (glandulus pinealis), dus genaamd om dat deze klier de gedaante van een pijnappel heeft : ttraks zal dezelve nader voorkomen.

De billen 00 zijn twee bolronde uitpuilingen, die, of geulen.

zoo zij natuurlijk zijn, bij en tegens een liggende, even als de rondten der Menfchenbillen, aan elkander zich vertoonen, waarom men ze bilklieren ( $n$ a tes ) noemt, gelijk dadelijk nadẹr $\mathrm{zal}$ blijken : hier vertoonen zij zich verwijderd, om des te beter de fleuf $i i$ en de geuien $s s$, die uit de Fornax en aan het geftreept merg ontfaan, te kunnen zien. Verlen $\not p \not$ zijn verlengingen van het verhard merg, ging merg.

Inwendi. 99 ge kleine hersfenen. die de rondę billen omringen.

vertoonen de inwendige gedaante van de kleine hersfenen, zoo als het witte merg op eene verbazende wijze als wittẹ take ken in den korst van het uitwendi fengeftel ligt, en welke takfchieting ten duidelijkfte aantoont, dat ook hier in eene onnagnanbare aaneenfchakeling is, die de zeṇuwvochten bereiden en affcheiden, en welker werking als nog onbe: kend is, om dat wij door de weekheid der vaarjes dezelve niet kunnen navor-

fchen, 
fchen, in zoo verre, dat de grootfte mannen hier ftilftann, en dit als nog het ftelfel van BOERHave over het zenuwvocht (Liquidum meryeum) tot een hevig gefchilpunt mankt, doch waar aan RUNDVER,

II. $\Lambda \mathrm{fd}$. ik voor mij gaarne mijn zegel hang, om dat al het werktuigelijke geftel der hersfenen alzins overeenkomt met die affcheidingen der vochten, die wii in de bloedvochten, wei - en chijlvochten erkennen, en men dus uit de vergelijking oordeelende, tot iets dergelijks kan befluiten. Blijvende voorts de fubtielheid en vlugheid der zenuw - en hersfengeesten voor ons onnagaanbaar, en het is dus beter te zeggen ik weet het niet, dan op probabiliteit te twistredenen.

$r$ het verlengde merg.

III.

Hoofdf:

Om nu nader begrip te erlangen van de anngewezene deelen in Fig. 2. en 3, vercoonen wij in Figuur 4. het ganfche geftel van de kleiner hersfenẹn, de gettreepte lig. . fche geftel chamen, benevens den oorfprong en den hersfenen. zamenhang van het verlengde merg uit een Kalf, en geheel afgefcheiden van de groote hersfenbollen. Dit gedeelte is van belang, on dat men daar in een aanmerkelijk verfchil vindt met dien in den Mensch, 't welk daar in beftaat, dat fommige deelen naar gerade veel kleiner, andere daarentegen veel grooter zijn; daarenboven zijn deze, deelen in de Kalveren, en vooral in de, Koẹijen, veẹl harder en handelbaarder voor

$$
\text { K } 5 \text { do }
$$

Verlengd merg. 


\section{NATUURLIJKE HISTORIE}

nET de ontleedkunde, waarom het dan ook niet Rundver te bewonderen is, dat de Koeijen en SchaII. Afd. pen-hersfenen zoo veel licht in de hers-

III. fenkunde der dieren verfchaft hebben, geHoofdrto lijk uit de werken van BARTHOLINUs, FABRICIUS ab Aquapendente, MaLPHIGIUS, CASSE I en wiLlis is gebleken, en waar aan ook niet weinig toebrengt de gelegenheid, om Kalfs -, Koeijen - en Schapenhootden dagelijks versch te bekomen, dat, gelijk men weet, zelden met Menfchenhoofden gefchiedt : één voorbeeld echter is mij bekend, dat ik bij deze gelegenheid in het voorbijgaan aanttip. Er was binnen Leyden een perfoon ter onthoofding veroordeelt; de groote albinus verzocht om het hoofd dadelijk $\mathrm{n}$ a de onthalzing te mogen hebben, het geen hem ingewilligd wierd, en zoo ik niet mis heb, heeft hij daar van die overheerlijke kunstftukken gemaakt, die nog heden door zijn Hooggeleerden Discipel SANDIFORT met zoo veel zorg en juistheid, tot luifter dezer Univerliteit bewaard worden. Het is ook bekend, dat - genoemde Profesfor albinus dikwijls Kalkoenen, Hoenders en andere Dieren onverhoeds den kop affloeg, om de werking der hersfenen op het gevoel te onderzoeken. Het is dus al mede van belang voor jonge Studenten, om uit verfche Schapen - en Koeijenhoofden te leeren, 't geen in Menfchelijke hoofden voor hun moeijelijk valt; doch dit in het voorbijgaan. Wij gaan over tot verklaring van Fig. 4. 
a a zijn "de geftrecpte eivormige ligchamen HET in hun ware gedaante, van het hersfen- kundvea. merg afgefcheiden, waar vin derzelver II. Afd. uitwendige gedanate in Figuur 5, te Hoofdrt. zien is.

$-6 b b 6$ het verharde hersfengedeelte, of de Geftreepte rand van het opgemelde. eivornige het fournuis, bij Fig. 3. verhandeld. ligchamen. $d d$ de uitgefpreide vlcugels van de plat-van 't verte rag - of vatwliezen (plexus Choroi-hard geftel. des), zoo ais dezelve op de geftreepte nuis. of gedraadde ligchamen liggen uitge- De vle! • fpreid. gels van

$e e$ is de flagadertak, die uit de vierde boe- het rug. zem ontfpruit, even zoo als deszelfs slägacezo ader in Fig. 2. vertoond is, en dus zijn tals. fpruchtels in de apgemelde raguliezen tweetakkig verfpreidende, door eene me. nigre bloedvaatjes zich onderfcheidt, zoo dat zich deze deelen in de Kalienhoofden, versch geopend, roodachtig vertoonen, gelijk ook deze gehecle figuur zeer fterk naar het roode helt.

$f$ de opening, die naar de trechterachtige Opening holte loopt.

$g g$ de vederwijze fchachtfpruchtel der ge- Vederwijo $\therefore$ zigtzenuwen, vloeijende over hunne hers-ze fchachto fenbollen.

$h h$ de mergachtige uitftekken, die een over- Mergach. gang hebben tot den weg der mergftof, tig uittek, fen en derzelver ronde en kronkelige bolrondten, en bijzonder in de bilvor. mige vitpuilingen. 


\section{I56 NATUURLIJKE HISTORIE}

Her $i i$ de bilvormige rondtens zelve, $z 00$ als die tegens een dringen.

II. Afd. $k k$ de ringen der opgemelde billen, die men III. ook fchelpvormig, fchelpdeelen (teftes) noeme.

Bilvormige $\ell$ de boogswijze halve mergring, die twee-

Deringen ledig uit de opgemelde deelen, als in der billen. de twee vleugelen van de kleine hersfeDe halve nen zijlings zich verfpreiden. boogring.

De merge boezem.

$m$ den boezem van het merg, 't welk onder de bilvormige rondtens en de boogswijze bogt $l$ zich met het verlengde merg vereenigt.

re gezigt. $n n$ de twee Pathetifche gezigtzenuwen, zenuwen. hier zeer duidelijk ontbloot.

Takaders. 00 de anmerkelijke mergtakken der kleine hersfenen aan deszelfs oorfprong, bij de gezigtzenuw.

ne halve $P P p$ de achterfte mergtak der kleine hersfering. nen, die zich onmiddellijk achter de vo. rige met het verlengde merg vereenigt, en tevens hare inworteling omringt, en eindelijk de boogswijze halve ring $l$ formeren

Hetderde $q$ het derde gedeelte van de kleine hersfedeel.

nen, ter plaatfe daar dezelve geheel in de ftaart van het verlengde merg wordt ingelijfd.

witte $r$ rr $r$ de witte mergtakken, zoo als dezelve mergtakker. in de kleine hersfenen zich vertoonen. $s s$ dezelve tak of bladwijze figuur, waar in de eerfte takken zeer breed zijn, en zich in drie a vier fpruchtels uitbreiden. Deze afbeeldingen dieper doorgefneden zijnde 
als in Fig. 3. 99 , zoo doen zich de HEx bloedvaatjes van de hersfenkorst hier RUNDvex: kennelijk zien.

- toont de indrukking of de geul aan, die zich in het aanhangfel van het gantfche Hoofdrd merggeftel, formeert tot een boezem, Het verwaar uit het verlengde merg uit de hers- lengde fenen tot de ruggegraat overgaat. II. Afd. III. $u$ is het verlengde nierg, gedeeltelijk uit graat. de wervelen genomen.

Deze Figuur verklaard zijnde, volge

Fig. 5, In deze Figuur vertoont zich Fig. 5: het hersfengeftel geheel van de bovenlig- Het boven gende deelen ontbloot, zoo en in dier voe- ontbloot gen, dat het geheele beloop en de ftructuur hersfenges dat het hersfenmerg op den oorfprong der zenuwen heeft, daar uit kan gekend worden.

a a zijn de holle uitftekken of zenuwachtige De tepel: buizen, die men de tepelachtige noemt, buizen. en betrekking tot de reuk hebben.

$b b$ vertoonen volmaakt het merg of de gol- De merg: ving van het merg, geheel op zich zel-golving. ven, zoo als het dwars door van de

- groote hersfenen gefcheiden is.

c $c$ de geftreepte ligchamen, die in de voo- De ged rige Figuren 3 en 4 reeds waren aan- ftreepte gewezen, vertoonen zich hier doorge- doorgefina: fneden, en volkomen de rigting der ftre- den. pen. Ik noem dezelve affcheidingen die elkander in hun middenpunt ontmoetende, als Itrepen voorkomen. 


\section{NATUURLIJKE HISTORIE}

tres $d d$ de regtfandige en uitfpreidende vezclen zundice. van de zoogenaamde vederzenuwen der

11. Afd. gezigtzenuw, zich naar de geftreepte ligIII. Hoofdr. chamen verfpreidende.

- $e$ de geul of boezem die naar de trechter-

reveder- wijze hoite loopt, of daar van ont'pruit. zenuwen. $f$ de roncie klier, omtrent gelijkvormig aan ne ronde de pijnappelklier. Deze klier is in de klier.

Kocijen en Schapen vrij groot en kennelijk, en niet tweeledig, 200 als in den Mensch.

De afge. $g g$ de afgefcheiden gezigrzenuwen, afzon fneden ge- derlijk afgefneden en zijdelings omge. zigtzenu.

we bafis $h h$ de groote en eerfte grondflag van het flagen. van ' $t$ ver- verlengde merg, waar in deszelfs vezelevgd merg. . len, al mede regiftandig zigtbaar voorkomen, zoo als dezelve naar de gefreepre ligenamen bij Fig. 3. loopen.

$i i$ de tweede afdeeling van het "verlengd merg, als boven.

Mergrin-kkkkk zijn die mergachtige ringen, die de gen. verdeelingen van het verlengde merg onderfcheiden, en zijdelings uit de groote hersfenen omloopen.

Enobbels. $l l l l$ de knobbelige kronkels der groote hersfenen wederzijde.

Mergring, $n i$ de groote mergring, die de kleine hersfenen van het verlengde merg fcheidt.

$n$ het verlengde merg, in her ruggemerg eindigende.

Het rug. 00 het begin van het ruggemerg. gemerg $p p$ de bladerachtige fchubswijze lagen van I) fchub- de kleine hersfenen, als zoo vele lobben wijze la. gen. 
op een liggende, van het merg gezuiverd: verroonende dezelven zich in de RUNDVEz: kalverhersfenen zeer aanmerkelijk.

II. Afd.

III.

Eindelijk, om ten overvloede het beHoofde: doelde der vorige Figuren, tot nog duidelijker uitleg te brengen, zal de fchets bij Fig. 6. kortelijk het eigenlijke nader ophelderen, te weten: de vezeldraden der hersfenen. De vorige Figuren dienden, om de voorname dcelen, zoo als dezelven allengs, door nadere en nadere opligting, zich vertoonen, te kennen; doch van de vezelen in het merg zelve, is niets dan ter loops gefproken, bijzonder bij Figuur 5. In deze luchtige fchets zal het denkbeeld opgehelderd worden, door dien voornamelijk de bilrondtens en de vederachtige gezigtzenuw, de geftreepte boltens, mitsgaders de randen en wanden, en de buiten of groote hersfenen der Koeijen, hier in hun waren ftand zijn vercoond.

Fig. 6. dan hier toegefchikt zijnde, zie Fig. 6: men bij

a a a a ter wederzijde de bollen der groote De hers: hersfenen, met derzelver kronkels, fenbol : doorgefneden verbeeld. Vergelijk doorgefne: Figuur 2. bij $b \dot{b}$, daar dezelven ins. gelijks in hun omtrek zijn anngeduid.

$b 6 b$ de fchelpdeelen tegens de bilrondtens. Schelpdee: c. $c$ de beide bilrondtens in hun waren ftand, len. tegens malkander dringende doorgefin Doorge: dringende doorgefne fneden den, warin men ontdekt hoe derzelve: bilrond: 


\section{NATUURLIJKE HISTORIE}

HET

mergveżelen, links en regts naar de groo.

RUNDVEe, te hersfenwegen invleijen.

1I. Afd. $d d$ zijn twee halve rondeens, mede doorIII. Gefneden, waar in men insgelijks de Hoofdrt. ftrekking der mergvezelen ontdekt, tor Doorge tegen de witte rand der geftreepte ligfneden chamen, en de mergranden der bilronden. halve rond. $e e$ vettoonen in hun ware gedannte de vetens.

roorge. fneden ve. derfchach. ten. derachrige fchachten der gezigtzenuwen. In de voorige Figuren vertoonden wij dezelven uirwendig en vol fijne vaatjes, maar hier doorgefneden zijnde, vertoo. nen zich deszelfs vezelen als uit een cen. trum van de merg - ronden fpruitende, en dus blad- en waaijerachtige en vedervormige ftreepen en vezelen vertoonende, juist zoo als de vezelen van een fchrijfveder zich uitfpreiden, waar uit dan gemakkelijk deszelfs vezelige ftructuur kan opgemerkt worden.

De merg. $f f$ is de mergachtige rand of de boord, rand. die de geftreepte ligchamen van onderen omringt, gelijk ook de vezelen van de vederachtige uitbreidingen van de gezigtszenuwen, en voorts vereenigt met de inergachtige randen.

nenboord $g g$ toont insgclijks den boord van de geftreepte ligchamen aan den bovenkant, of den bol der groote hersfenen.

Geftreepte $h$ is het eene decl der geftreepte ligchamen lígchamen in het geheel, en niet doorgefneden, om In ' $t$ ge. derzelver vaten, die er uitwendig omlo-
heel, pen, te zien. Zie Fig. 4. $a a$ en $b b$. Het ander $i$ is het ander gedeelte, doorgefneden, om deel. 


\section{N HOLLA ND. x6I}

derzelver frepen en zenuwachtig beloop HET te zien. Vergelijk hier bij Fig. 5. $c c$, Runders; alwaar zich dezelven in hun dubbele unt- II. Afd. moeting vertoonen.

III. $k k k k k k$ is de boezèm of het fournuis; Hoofdrt. met deszelfs zijdelingfchen ring, De bos die om het geheel binnen-hers zem. fenftel de fcheiding maakt van dè groote hersfenen.

I de gezigtzenuwen, met haar trechterbuis. m $m$ gedeeitens van den kleinen hersfenvleugel. $n$ het verlengde merg.

Hier mede dan de Figuren van de Vilft. Plaat verklaard zijnde, en de deelen der Koeijenhersfenen, zoo uit onze eigene vergelijking en ontleding, als onder de toelichting van anderen, bijzonder van wILtis, voorgefteld hebbende, zouden wij ntt tot nadere aanmèrkiingen̉ kunnen overgaan: maar om dat wij ons toegelegd hebben om zoo na mogelijk de ontleding der Koeijendeelen te verhaindclen, zoo zullen wij in de negende Plat een geheel en al nagevolgd mergftel uit een Kalf, in juiste afteekening en met behoorlijke anwijzingen afbeelden, en welke Plaat geheel en al ge- fchikt is, om de verdere kennis der zenuwen te verklaren, zonder ons in de nadere. redenkavelingen, die, als boven, meestal nog meer ingewikkeld zijn, in te laten. Alleen is ons doelwit, om onze Lezers ook te vermaken met de geheele befchouwing en aaneengefchakelde afbeelding van her merg - en ze-

ntix: 


\section{NATUURLIJEE HISTORIE}

Hет nuwgeftel in de herkaauwende Dieren, welRUNDVEE. ker verbazend weeffel niet kan nalaten om II. Afd: ons te doen ftilftaan in opgetogen verwonde. I:I! ring, hoe ook deze geduchte Dieren, die Hoofdat. wij gewoon zijn dom en redeloos te noemen, echter naar hun aard en natuur even zulk een kunftig zamenftel hebben als de Menfchen, hetwelk ${ }^{3}$, al valt het dan in vele opzigten voor den Landman buiten den kring zijner onderzoekingen, evenwel, zoo wij meenen, fiet kan misfen, om hein te verlustigen in befpiegelingen van her geftel van een Dier, ann welks kennis hem zoo wel gelegen lige als de geleerdfte Ontleedkundige.

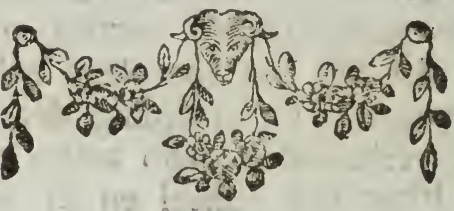




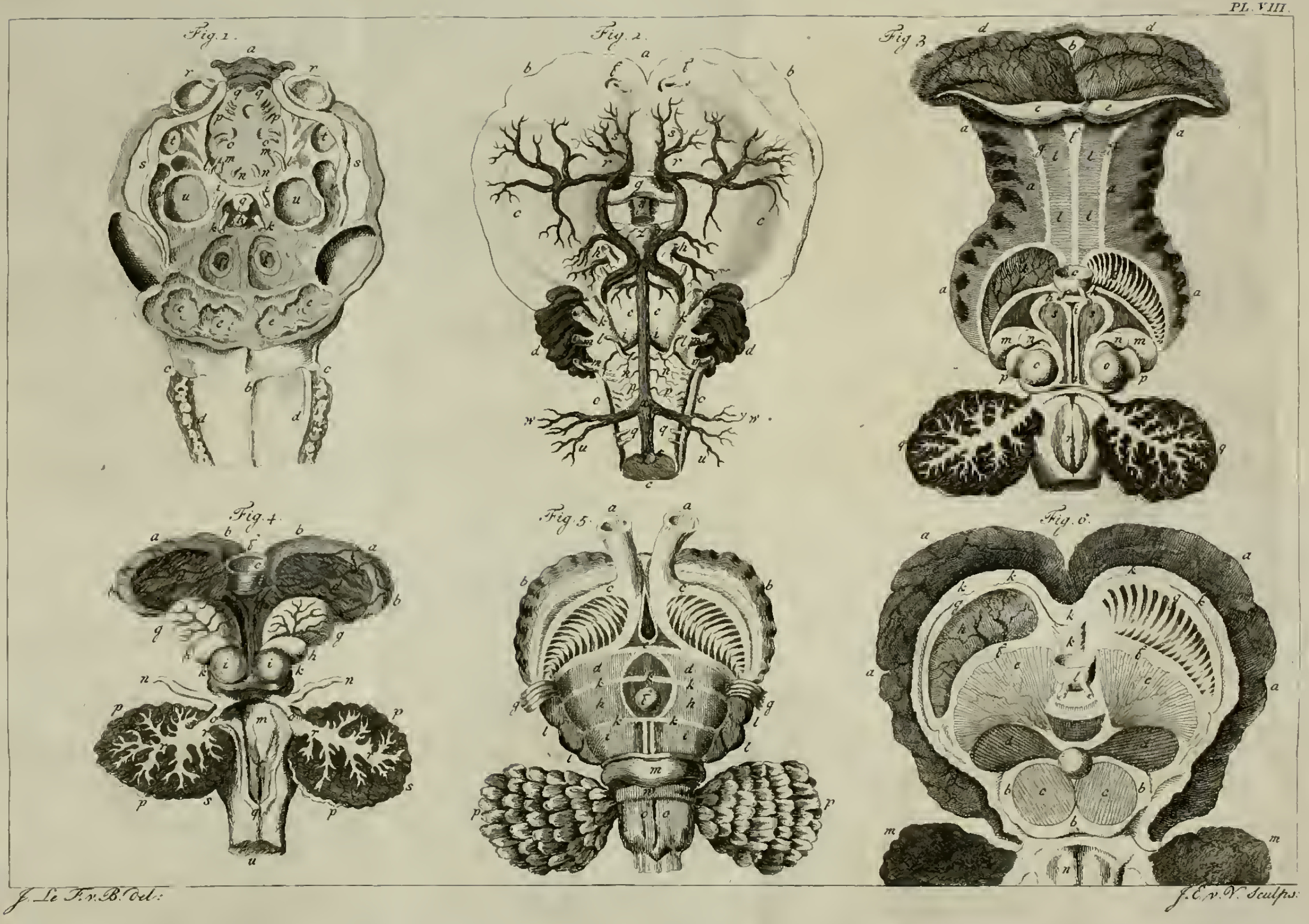





\section{TWEEDE AFDEELING。}

VIERDE HOOFDSTUK.

Veryolg op de verhandeling over het hersfen. geftel, zoo als uit deszelfs yerlengdmerg, het ganfche weeffel der zenuwen, door de uit-en inwendige deelen en ingewanden zich yerppreidt, met geheel nieuss afbeeldingen.

aar ik thans tot de uitgebreider af- HET beelding en verklaring van alle de uitbrei-RUNDvEs: dingen der zenuwen, door, om, en in het uit - en inwendig geftel overga, heb ik al II. Afd. wederom de moeite genomen, om een dui- Hoofdr: delijk begrip aan den min ervarenen, door eenige bijzondere afbeeldingen, te geven van het natuurlijk beloop van het ruggemerg, uit het hersfengeftel, langs de geheele ruggegraat, tot aan het uiterfte einde van den ftaart, waar door ik vertrouw, dat een Landman, Vee-Doctor of anderen, in het L 2 


\section{NATUURLIJKE HISTORIE}

HET fijne dezer zenuwkennis min bedreven, ge RUNDVEE. reedelijk tot eene vatbare kennis zullen worII. Afd. den toegelicht.

IV. In de vorige Figuren en verklaringen van Hoofdrt Plaat VIII. is zoo na mogelijk het hersfengeftel in het hoofd verklaart, hier nu volge noodzakelijk de verklaring: van deszelfs ver. lenging door de inwendige holligheden der wervelen, en de uitwendige verfpreiding der zenuwen door het ganfche ligchaam.

In de afbeelding on befchrijuing van het geraamte is naauwkeurig het getal, onderfcheid en beloop van de ruggegraat en derzelver wervelen verklaart, maar daar de klein. heid van die af beelding niet tocliet, om daar in de juiste aanwijzing van de zenuw - en bloedfprugtels te voegen, zoo dienen de volgende af beeldingen in cene grootere pro: portie ter nadere opheldering, zijnde dezelve op een vierde verkleind, naar de wẹvelen van een Mestkalf van 4 a 5 weken geteekend, en wel voornamelijk de wervelen die aan den nek tegen her hoofd lig. gende, aldaar het verlengend merg omhelzen, en alzoo in verfchillende ftanden, van voren, van achteren, op zijde en dwars doorgezaagd, afgeteekẹnd met de openingen der beenderen ter doorlating der zenuwen.

De wervelen op Plaat IX. Fig. 1, 2, $3,4,5$ en 6 atgebecld, zijn geheel en al afgefcheiden van derzelver kraak. beenige tusfchenvoegfels, mitsgaders van de anhechtingen der banden en fpierveze. len; zoo dat deze wervelen, in verfchillewden 


\section{$\checkmark \mathrm{A}$ HOL L A ND. 165}

Pen ftand, in haren waren omtrek zijn gereekend, ten einde des te duidelijker te

HET kunnen worden aangewezen, zoo als hier II: Afd. volgt:

IV.

De cerfte Figuur dan is de eerfte halsHoofdifta wervel, die men den Atlds noemt, om dat Atlase deżelve het hoofd draagt; de Boeren noemen wervel. het in de Koeijen het nekbeen, den hoofd/pil, Pl. IX: waarop het hoofd draait; zij kennen dit ge-Fig. I. wricht zeer wel, en weten, dat aan derzelver ontwrichting of kwetfing her leven der dieren hangt, waarvan het zoogenaamd nekflaan, nekomdraaijen, aan Konijnen, Katten, Honden enz. een bewijs is. Dit gebeente is ook van zulk een makfel; dat het $z 00$ juist en vast tegen den achterhoofdsfchedel Nluit, dat het niet dan met forsch geweld daar van kan worden afgefcheiden: het beftat alleen uit een rondachtig gevleugeld bec11, 't welk uit drie kraakbeenige tusfchenvoegfels in jonge Kalveren kan gefcheiàen worden, als een onder aan in ' $c$ midden bij $a$, en twee zijdelingfche bij $b b$ : dic been heeft wel geen uitftekende graat 200 als de volgende en alle wervelen, maar niet te min een knobbelig uitltek boven aan bij $c$ : voorts ziet men bij $d d$ wederzijdfche vleugels van binnen holachtig uitgefchelpt; zoo ook beneden dezelve wederzijds nog bij $f f$ grooter holle wanden, waar aan de banden zijn ingelijfd, die dit been aan het hoofd hechren.

Maar daar het hier zoo zeer niet aans komt om alle de bijzondere formen en fia

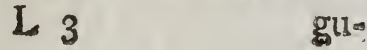




\section{I66 NATUURLIJKE HISTORIE}

ART. guren van dit en de volgende wervelen aan RUNDVEx te duiden, als zijnde dit bij het befchrijII. Afd. ven van het geraamte reeds gedaan, maar IV. voornamelijk dient ter verklaring van het Hoofde. beloop des lendenmergs en zenuwgeftel, zoo toont dan deze Fig. 1. in de holten $g g$ de wanden van het gewelfrond, waarin de eigenlijke koker $h$ is, warin het verlengdmerg (medulla oblongata) in Plaat VIII. vertoont, met het vlies in den ruggegraat invlecht, door de ringwijze holligheid $h$, terwijl de onderruimte in dezelve bij $i$ vervuld wordt door de vliezen, fpiertjes en bloedvaten, die uit het hoofd naast en om het merg omwonden zijn, en aldaar in dier voege liggen, dat een en ander den geheelen ring beflaan, en at$z 00$ de geheele ruggegraat langs. Buiten dat. zijn aanmerkelijke openingen aan dit achterbeen, waar door zeer aanmerkelijke zenuwrakken zijlings uit het merg fpruiten, doch dit is hier niet 2igtbaar, om dat dic been niet omgekeerd verbeeld is, maar ftraks bij Fig. 2. zal dit worden aangewezen. vel.

Halswer- Achter dit Atlasbeen volgt nu de tweede halswervel bij Fig. $2,3,4,5$, in verfchillende ftanden verbeeld, waar van Fig. 2.

Plaat IX. dezelve vlak van voren, de derde dezelve Fig. 2. van achieren; de vierde dezelve op zijde, en de vijfde dezelve doorgezaagd vertoont, zijnde allen in hun waren omtrek gefchetst: deze wervel is verfchillend in ftand vertoont, om daar door het waar beloop van den mergkoker, mitsgaders derzelver zenuwgaien, te kunnen bevarten: in de cweede Figuur 


\section{VAN HOLLAND. 16 ?}

regtftandig van voren, ziet üen bij $a$ de tandvormige fpil of liever knobbelachtige tandswijze graat - uitftek op den top des wervels; bij $b$ is eene holte, waarin de Atlaswervel fluit; $c c$ zijn de boventte been. HET RUNDVEE: achtige uitftekken, waar aan de nekfpieren gehecht zijn; $d d$ zijn de verfchillende gewricht-uitwasfen; $e e$ de onderfte beenige uitwasfen, die veel meer verwijderd zijn, dan de bovenfte, en al mede dienen tof inlijving der wervelfpieren, om die achter den anderen te verbinden, waarom men dezelve tc regt wervelbanden noemt. Voorts is bij ff het wervelgebeente met twee wederzijdfche inholingen die tegen den Atlas aan. dringen; eindelijk is bij $g$ een ovaal rond gebeente, 't welk hier regtitandig verbeeld is, en dus is de ring of buis van den mergkoker niet zigtbaar, dan alleen bij $h$, dat een gedeelte dier opening is, en waarvan de openingen bij $i \vec{i}$ wederzijds den doortoge van het cweede parar zenuwen aan deze zijde van dezen wervel aanduiden.

Maar nu vindt men in Fig. 3. dit zelfde P1. IX. wervelbeen omgekeerd afgebeeld, zoo als Fig. 3 . het zich wederom aan den volgenden wervel fluit, en zoo ook even dezelfde beenderen andersom aangewezen: $a$ het tandvormig uitftek, $b$ een ovaalronde holligheid, waar in het bolronde gedeelte in Fig. 2. g fluit; $c c$ de boven uitftekende beenderen in het verkort te zien; $d d$ de onderfte uitftekende beenderen; $e e$ aanmerkelijke holten tusfchen de uitftekken, war in de groote rug- of

$$
\text { L } 4 \text { nek: }
$$

II. Afd.

IV. Hoofdra: 


\section{NATUURLIJKE HISTORIE}

нгт nekfpieren zijn ingelijfd, die ook alzoo is aUNDVIx. alle volgende wervelen aan derzelver zamen-

II. Afd. voeging de gewrichten befturen; voorts is

IV. hier bij $f$ de ring van het ruggemerg meer-

Hoofdst. der zigtbaar, om dat de wervel in dezen ftand dezelve meer vertoont, gelijk ook de gaten der zenuwen bij $g g$ hooger ftaan, en daar door aantoonen dat aldaar de zenu. wen, in eene fchuine rigting, door dezen

Pl. IX. wervel loopen, hetwelk door de vierde Fi-

Fig. 4. guur duidelijker wordt angewezen, door dien dezelve wervel regtitandig afgebeeld, deze zenuwwegen op zijde duidelijk te ken. nen zijn, en tevens alle de opgenoemde uitftekken der wervelbeenderen, zich in een anderen ftand vertoonen: dus is bij $a$ het doornig of graatachtig uitfiek, hier tusfchen de twee uitltekken $b b$, ingezonken, en lager te zien, gelijk ook de uitftekken, die in Fig. 2 en $3 \cdot$ bij $d d$ zijn aangeduid, zich hier bij $c$ rond vertoonen, en bij $d$ het onderfte uitltek, weder fcharp ftoinp, mar het geen in deze zijling fche Figuur vooral dient opgemerkt te worden, zijn de twee ronde beendervlakten, die elk door eene juiste ineenfluiting, van wervel tor wervel, op elkander pasfen. zoo dat het bolrondachtige gedeelte bij $e$, juist beantwoord aan een dergelijk in den voorften wervel, en daarentegen het vlakke ovaal bij $f$, beantwoord aan een sergelijken in den derden wervel, en alzoo de opgemelde openingen bij $g g$, de fchuine doortogt der zenuwen zijlings vertoonen, waar toe ter nadere begrip, de gemelde wer: 
vel voor de vierde maal, in haar inwendig неx maakfel, op zijde doorgezaage, is afgebeeld. RUNDVRE; Bij Fig. 5 is hier bij a het doornig uit. II. Afd, ftek: bij $b$ het rond van den wervel: $c$ de holligheid, waar in de naastvolgende wervel fluit: $d$ het uitftek dat op de plaat der At- Pl. IX: las fluit : $e$ het doorgezangd ondergedeelte ${ }^{\text {Fig. }}$ 5* van den wervel: $f$ het midden fponsachtig deel van het wervelbeen: $g$ het onderfponfig beenftof : $h$ het hol of den boezem, waar door hee ruggemerg loopt: $i$ de weg der zijtakken van het merg.

Uit deze fchetfen meen ik kortelijk de kennis van eene der voornaamfte en eerfte wervelen, met opzigt tot de zenuwkunde, te hebben verklaart, maar om dit ftuk nu nog nader op te helderen, dient de 6. Fi- P1: IX: guur, waarin een viertal halswervelen aan Fig. 6 . den anderen fluitende, in hunnen waren ftand verbeeld $z \mathrm{ijn}$, en hier in verfchillende van den ftand der eerfte, tweede, derde, vierde en vijfde Figuur, die, ter nadere verklaring, regeftandig, en niet fchuins liggende, zoo als zij natuurlijk in de ruggegraat liggen, zijn gefchetst, zoo dat het diametraal of de middellijn, daar in regtftandig is, daar dezelve in deze Fig 6 . overhellende, eene fchuine rigting bekomen, 200 als dezelve in de natuur liggen, en in een fluiten. Alle deze wervelen zijn doorgezaagd, zoo dat het ganfche Mergftel geheel en al an de eene zijde ontbloot, in de holte of koker zigtbaar is, en te gelijk de daar uit fpruitende zenuwen, duidelijk

$$
\text { L } 5 \text { kun: }
$$

IV. Hoofde: 


\section{NATUURLIJKE HISTORIE}

HeT kunnen verklaard worden, en wel 200 , dac RUNDVER

zelfs een onervaren in de Ontleedkunde het

II. Afd. begrijpen kan, hetwelk ook in de daad mijn IV. oogmerk is, want anders had ik zeer wel

Hoofdrt. alle deze afbeeldingen en anduidingen kunnen achterlaten. Om dan aan dit oogmerk te voldoen, behoeft een Landman of Vlees? flagter, of wion het lust, fleches het halsftuk van een Kalf of Koc, van het hoofd tot aan den Nokwervel af te fcheiden; zoo dat de hoofdwervel, de Atlas, Fig. 1. aan den tweeden, en drie volgende verbonden blijft, te zamen vier wervelen, of zoo men wil, meerder daar aan volgende, dezelve gezamenlijk an een verbonden, opkoken, om, na dat het bekoelt is, het vleesch en overtollige daar van af te fcheiden, en aldus dit gedeelte ter befchouwing te bereiden, op gelijke wijze, als hier in Figuur 6. tot een vicrde verkleind, naar het leven naauw: keurig is afgebeeld. Men ziet dan in de. ze Figuur bij a a $a$ a, alle vier de eerfe halswervelen, aan de graatwijze, bulten en uitftekken, in den juisten natuurlijken ftand, zoo als dezelven langs den gehelen ruggegraat, tot aan het uiterfte van den ftaart, achter clkander volgen en aan een fluieen, zoo als ook de onderfte deelen, en de bafis der wervelen, onder aan bij $b b b b$, doorgezaagt, insgelijks op elkander fluiten, en allen bij $c c c c$ los, en alleen door kraakbeenige middelfchotten gefcheiden zijn, zoo dat men moet vooronderftellen, dat deze wervelen, alle vier, zonder eenige banden 
of fpieren, los an cen verbeeld zijnde, HET alleenlijk door de lenden-mergbuis, die bij RUNDVEz. het doorzagen, omzigtig in deszelfs ftand Ir. Afd. bewaard is, an een verbonden fchijnen, om des te beter het beloop des lendenIV. mergs, mitsgaders deszelfs takken te kunnen nagaan: dus is bij $d$ de affcheiding van het verlengd merg, ter plaatfe daar het door den eerften Atlaswervel inloopt, en bij $e$ wederom afgefneden, daar hetzelve van den vierden tot aan den vijfden wervel is afgefcheiden.

Maar nu ziet men bij ffff vier zijlingfche Takken, met hunne verwijderde fpruchtels, zoo als dezelve elk door de zijdelingfche tusfchenruimtens der wervelen, en veronderfteld dat de wervel niet doorgezaagt waren, als dan ook tusfchen de aangewezen openingen, in de wervelbeenderen Fig. 3 en 4. bij $g g$ aangewezen, doorloopen, in dier voegen, dat men moet begrijpen, dat gelijk in deze Fig. 6 . deze zenuwtakken ontbloot liggen, dat dezelve ook even zoo aan de andere zijde der wervelen, hier niet zigtbaar, liggen, maar nogtans als tweetakkig moeten begrepen worden, ter welker verklaring de volgende Fig. 7 . en 8. zullen dienen. Doch eer ik tot deze verklaring over ga, dient nog vooraf aangemerkt te worden, dat in deze vier wervelen, door de doorzaging, ook de inwendige zooge. naamde beenderfchelfers van GAGLIARDI, duidelijk te erkennen zijn, zoo als wij dit bij de inwendige angroeijing der beenftoffen hebben opgemerkt, en in deze wervel- 


\section{NATUURLIJKE HISTORIE}

is $\mathrm{T}^{\mathrm{f}}$ figuren, $z 00$ in deszelfs boven-als onder RUNDVE. gedeelten, $g g g g$ boven, en $\dot{h} h h \grave{h}$ onder,

II. Afd. duidelijk van den verharden beenrand te er-

IV. kennen zijn. Eindelijk, dat dit voorbeeld

Hoofdrt. van deze vier eerfte wervelen der ruggegraat, moet begrepen worden alzoo van wervel tot wervel te vervolgen in het geheel beloop der ruggegraat, met dit onderfcheid, dat de graatachtige uititekken, op den nek en de fchoft langer worden, en vervolgens wederom verkorten aan den kruin, al hetwelk in het Beendergeraamte op Plaat VI. duidelijk is verbeeld.

Tot dus verre het beloop van het rugge= merg door de wervelen der ruggegraat beroogt zijnde, zoo als hetzelve nog in zijne vliezen befloten is, zoo is er voorzeker nogi een nader opheldering benoodigd, om he: inwendig geftel te kennen, waar door men het ware begrip van het wonderbarlijk weeffel en verbreiding der zenuwtakken kan begrijpen, want daar het gantfche hersfengeftel en de hoofdfchedel, door een alge. meen hersfenvlies, pia Mater genaamd, omringd wordt, zoo volgt dit vlies, ook aan een verbonden, aan het ganfche merg. en zenuwftel, onder de naam van Mem. brana. Meninges, 200 dat, als men het inwendig merg wil kennen, men ook dit vlies moet doorfnijden, en om dit te doen zien, dient Fig. 7 en 8.

Pl. IX. In Fig. \% vertoont zich een ftukje, Fig. 7. merg, iets grooter in zijn doorgefneden vlies, natuurlijk liggende. $\mathrm{Bij}$ a a a $a$ is het door: 


\section{VAN HOLLAND. 173}

doørgefneden vlies kennelijk : bij $b b$ is het merg nog in zijn geheel kennelijk, zijnde de ftreep $c$, die perpendiculair doortokent de affcheiding van wedẹrzijde, terwijl onder aan bij $d$, het merg doorgefneden, en de innerlijke openingen, waar door de bloedvaten midden doorlopen, worden aangeduid, maar dat hier het voornaamfte dient opgemerkt, is de uitfpruiting der zenuwfpruchtels, uit bet merg zelve: deze ziet men bij $e e$, ter wederzijde uit de mergbuis uitvloeijende, binnen door het omgeflagen vlies, als tot een waaijerachtige famenloop vereenige, doordringen, 'tot daar zij wederom buiten hetzelve vlies, als ' $t$ 'ware, in eenen ring of knoop $f f$, omvangen, andermaal zig wederom door de nasstaanliggende deelen verfpreiden. Maar daar nu deze Figuur nechts de mergbuis vereenigd vertoond, is er nog eene nadere afbeelding noodig, om de fcheiding van het merg zelve te bevatten, want fchoon dit lendenmerg zich uiterlijk als een ronde pees of fpier vertoond, en alzoo doorgaans oppervlakkig befchouwd wordt, zoo is zij zulks in de daad niet, maar wel degelijk tweeledig, zoo dat zij duidelijk in het midden door eene bijzondere affcheiding, waar door de bloedvaten loopen, gefcheiden wordt, en tevens eene ontfpruiting daar van, uit een waaijerachtig , weeffel, wederzijds in elke afdeeling loopen, welke fpruchtels dan wederom, bij wijze van kusfing, (anastomofis) inet dergelijke tegenoverliggende fpruchtels yereenigende, wederom op eene tegengeftel-

II. Afd.

IV. Hoofdift.

He? UNDVEZ Hoofdr.

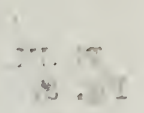




\section{NATUURLIJKE HISTORIE:}

HЕT de wijze; door het vlies dringende, eindeRUNDVE2. lijk buiten hetzelve, zich wederom in het 11. Afd. oneindige verfpreiden, zoo als in Fig. 6. IV. Hoofdrt. bij ffff is aangetoond.

Daar nu de gemelde Fig. 7. eene nadere opheldering van de vlechting (Plexus) der oorfpronkelijke zenuwvezels uit het merg

Pl. IX. aanduidt, is bij Fig. 8. een ftukje van hee Fig. 8. mergulies (membrana meninges), geheel glad en vlak uitgefpreid, en van al het merg ontbloot, afgebeeld, zoo dat alle de fijne waaijerachtige vezelen in hunne afwijkende en weder zamenloopende fpruchtels duidelijk zigtbaar zijn, en men de zoogenaamde kusfing (Anaftomofis) der varjes en fpruchtels duidelijk op het vlakke vlies ziet zamenloopen.

Dus is bij $a$ a $a$ a de vier hoeken van het vlies; bij $b b$ de middelfte mergbuis; $c c$ de wederzijdfche buizen; $d$ de middelfte uitfpruiting of vlechting; $e e$ de waaijerachtige kusfing der vezelen wederzijds; $f f$ de tweede zamenloop wederzijds; $g g g g$ verfcheidene fijne zenuwtakjes.

Gaarne had ik deze Figuur levensgroote medegedeeld, om dat dezelve zeer veel tot de kennis van het geheel-toebrengt, doch om de kosten te vermijden, heb ik dit gelaten. Ondertusfchen is niets gemakkelijker, zelfs voor min ervarenen, dan dit, volgens het leven, na te gaan: men behoeft flechts aan een Vleeschhouwer een ftuk van de lendenfpier te verzoeken, die zeer gereedelijk bij het doorhakken der ruggegraat kan worden 
uitgeligt: deze fpier fnijdt men' overlangs door, en fpreidt dezelve, op een plankje vitgerekt en met fpelden vastgeftoken, uit, II. Afd. en befproeit voorts het merg met water, en wascht het met een fpons, doekje of liever met een penfeel af, tot dat al het merg er af gezuiverd is, als dan zal men na een weinig droogens de vlechting der zenuwen en vaatjes duidelijk kunnen zien.

Daar nu alle deze Figuren van I tot 8 ingefloten, het maakfel der wervelen en rug. gegraat, benevens de plaatfing des ruggemergs hebben verklaard, en deze voorbeel. den tot het vervolg van de geheele lengte der ruggegraat betrekkelijk zijn, alzoo dezelve allen eveneens zijn, en alleen daar in verfchillen, dat, hoe meerder de wervelen in het achterftel, in het heiligbeen en in den ftaart verkleinen, alzoo ook de holtens van den mergkoker en de dikte van het merg verkleind, eindelijk in de ftart verdwijnen. Om ook dit wel te vatten, had ils bevorens eene afbeelding uit wiLlis overgenomen; dan, daar dezelve mij niet duidelijk genoeg fcheen, en ook andere kundigen dit nuttig oordeel. den, zoo heb ik met zeer veel moeite, gemerkt de kleinheid der proportie, hier toe eene geheel nieuwe afbeelding vervaardigd, waarin het ganfche beloop van het merg, van het hoofd af tot aan het uiterfte van den ftart, ontbloot vertoond wordt; met alle deszelfs zenuw - mergfpruchtels, na wederzijds op het omgeflagen mergvlies uitgebreid, en na dat dezelve, als vereenigt door 


\section{NATUURLIJKE HISTORIE}

HET hetzelve vlies doordringen, juist zoo als die rUNDVEE. van gedeelte, tot gedeelte aan het voor - mid. II. Afd: den- en achrerftel in takjes en fpruchtels

IV. zich verwijderen, afgebeeld, en wel zoo, dat Hoofdrt. dezelve telkens, naar mate, dat zij van de afzonderlijke gedeelten van den romp en ingewanden verwijderen, ook meer of min PI. IX fchuins of regtftandig uitloopen; al hetwelk Fig. 9.

dan ook in deze Figuur 9. is angeduid.

Eindelijk worden alle de zenuwen, die, tot 32 ingefloren, duidelijk zijn afgeteekend, door bijzondere letteren, op zijde en langs het ganfche merg - en zenuwgeftel angewezen, op de volgende wijze:

a a Het verlengd merg, van het weeke brein gefcheiden, als gefpleten, ter wederzijden op het vlies van de hersfenen afgercheiden, en aldus tot en in den ftaart eindigende.

$b$ De fleuf, waar door de aderen en חlagaderen loopen, welker kleene vaarjes $c c c c c$ hier om de kleinte niet wel hebben kunnen verbeeld worden, doch niet te min uit het beloop zeer wel te kennen zijn. $d d d d$ Het omgeflagen mergvlies, wederzijds, ontbloot van het merg, omgeflagen, tot aan het einde.

eeee De vier eerfte paren zenuwen van de hals en den nek wederzijds.

ff Twee paren fchouder-nokzenuwen aan het neutelbeen.

g gggg De vijf paren fchouder - en voorftukzenuwen wederzijds. 


\section{VA N HOLLAN D. 177 :}

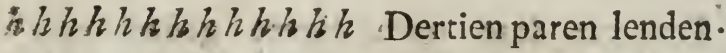

HET en ruggegraat-zenu RUNDVE wen, van den nok af 11 . Afd. tot het kruis, weder zigds langs het ganIV. fche middenftel.

iii De vier heupzenuwen van het voore kruis wederzijds.

$k k k k$ Vier paren ftuiizenuwen aan bet achterkruis wederzijds.

$1 / 16 \mathrm{De}$ achternok of bovenftarar-zenuwen wederzijds.

sn $m m$ enz. De ftaartzenuwen in ontel. bare takken verfpreid, eigenlijk de Paardeftaart (Cauda Equina) genaamd.

Alle deze zenuwen zouden voornamelijk op 36 à $3^{8}$ paren kunnen berekend worden, maar om dat de zenuwvezels tevens met de ftaartwervelen meestal in vezelen verdwijnen, $z 00$ worden dezelve ook zoo zeer afzonderlijk niet onderfcheiden, doch niet te min door ons bij $n n n n$ zoo na mogelijk anngewezen.

tn hier mede is deze Figuur genoeg verklaard; alleen is de doorboring der zenuwtakjes, binnen - het vlies afgebeeld, $z c 0$ als dezelven uit den rand van het ontbloote merg boogswijze uit een gefpreid zijn; hoedanig dezelve zich eindelijk tor een bundel en ring vereenigen, is in Fig. 7 en 8 vertoond en upgehelderd.

\section{M \\ Dus}




\section{NATUURLIJKE HISTOR PE}

nex Dus van deze onze eigene geheel ver.. zuNDVEE, nieuwde figuren afitappende, is hier ter vol-

II. Afd making van dezelve wederom bijgevoegd

IV. het zeer fraai en naauwkeurig geheel zcboofdat. nuwgeftel in de Herkaauwende Dieren, uic den beroemden thomas willis, de Anima Buclerum, overgenomen, en zoo naauwkeurig doenlijk in eene kleinere proportie gebragt, als, hetzelve bij ons cerfte ontwerp geteekend was; wij vermeenen dit, tot gemak der Onderzoekers, zoo klaar en duidelijk te hebben voorgefteld, als immer naar den aard van het onderwerp konde gefchieden. Ik twijfel ook daarom niet, hoedanig men dit ook, als aloud bekend zijnde, moge beoordeelen, of men zal mij toeftaan, dat er voor de vatbaarheid van den Landman, van Veekenners en Koemeesters als nog geen beter is, dat zoo duide. lijk het beloop der zenuwen en tevens. de bloedvaten aantoont, en vooral in het inwendige der ingewanden, wier hoofdzakelijke deelen hier zoo juist zijn aangeduid, dat men zelfs gedeel telijk en bijna geheel ook den omloop des blocds daar uit kan navorfchen, warrom ik dan ook de andere hier toe betrekkelijke af beeldingen van willis heb achter gelaten, berustende bij de volgende verklaring. 


\section{VA N HOLLA N D. 179}

Terilaring yan het ganche zenuwgeftel RUNDVE. in zijn geheel, benevens het beloop

yan het merg en deszelfs

yezelen.

Il $\mathrm{Afd}$ IV. Hoofder

Ever gelijk wij bij de verklaringen van P1. Ix. het geraamte en der uitwendige fpieren, de Fig. 100 vatbare verdeelingen in het voorftel, mid. denftel en achterftel hebben in acht geno: men, zoo zijn wij in deze af beelding van de manier van verklaring van Dr. willis afgeweken, en hebben de voornoemde af. deelingen wederom in acht genomen, en die zelfs naar den aard van het ontwerp nog al klaarder trachten voor te ftellen, in dier voege, dat een Landman, Veehoeder, Kocijen-Doctor of Vleeschhouwer, zonder zelfs ontleedkundige te zijn, met een opnag de plaatfing der zenuwen en bloedvaten in deze Figuren op eene Koe kan toepasfen, het geen eigenlijk ons oogmerk is, om, gelijk wij meermalen gezegd hebben, niet zoo zeer alleen voor de fijne en fchrandere vernuften, maar ook voor het gezond verftand van den Boer te fchrijven: ten dien einde zijn de verdeclingen, die bij de platfing van het rif en de fpieren regtftandig gelezen worden, hier integendeel zijlings gefchikt, om reden, dat men dient te veronderftellen, dat deze geheele afbeelding uit eene Koe genomen is, die, als op den rug liggende, van den top des hoofds tot aan den ftaart, in zijn zenuwen vatengeftel regtitandig en met wederzijd. $\mathrm{M}_{2}$

fche 


\section{NATUTTRLIJKE HISTORIE}

HET fche takken en fpruchtels ontleed, voors rundver. komt, dar wij in de vorige afbeeldingen II. Afd. niet dan zijlings onze Koe hebben kunnen III. afteekenen; buiten dit, zoo geeft deze afwoofdit. teekening gelegenheid, om de deelen, die in het eigenlijk voorftel uitwendig beperkt voorkwamen, hier in eene naauwere onderdeeling te brengen; want daar zon wel in het rif als fpiergeftel, het hoofd, den hals, de ftrot enz. afzonderlijk behandeld wierden, zoo loopen hier de deelen meer in éen, en het harr, de longen enz., die naar hune inwendige ligging eigenlijk tot het middenftel behooren, dat is, tot het gedeelte van den nok tot het kruis, liggen hier boven het middenrif; hicrom gelieve den nafpeurenden Lezer het een en ander met onderfcheiding gade te flaan.

De voornaamfte inwendige deelen, die boven het middenrif liggen, zijn: het hoofd en de hersfen - zenuwen - en bloedvaten; de hals of nek, met den gorgel, het frottenhoofd en longpijp; het hart en de longade. ren enz.

Die in het middenftel en onder het middenrif (Diaphragma) liggen, zijn : de maag, de lever, de mile en de nieren, me hunne zenuwen en bloedvaten.

Eindelijk zijn in her achterftel de kruis. vaten, de tceldeelen, zaad-bloedvaten en zenuwen, tot aan de ftuir of ftart.

Om echter de kortheid te betrachten, en al wederom niet in het ingewikkelde van her zenuwgeftel, met betrekking tot den Mensch, 
Mensch, te treden, zullen wij in deze overgenomen Figuur I ${ }^{\prime \prime}$. flechts dat geene aanwijzcn, ' $t$ welk eigenlijk tot het zenuwgeftel der Koeijen behoort, en de verklaring, zoo veel mogelijk, vatbar trachten te maken voor-den oplettenden Boer en weetgierigen Landzaat; derhalven zullen wij eerst de al. gemeen bekende deelen met groote Kapitale Letters, en de kleinere met curfijve letters en nommers aanwijzen, te meer daarom, om dat cen ongeftudeerde of min ervarene, aan dergelijke Plaatverklaringen ongewoon, het des te gemakkelijker zou kunnen bevatten In de verklaring der voorige Plaat is reeds genoeg melding gemaak van het eerfte, tweede, derde, vierde, vijfde, tot het tiende paar zenuwen: hier zal vit geftel nader begrepen worden, als men begrijpt, zoo als deze Figuur aanwijst, dat elke zenuw, tit zijn oorfprong, links en regts zijn takken uitfpreid, zoo dat zij bij paren telkens ter linker en ter regterzijden afwijken van het middenpunt van het hoofd, en zoo voorts langs de ganfche ruggegraac en lendenen, tot dat zij eerst in de voorpooten, daar na in de heupen, het bekken, tot de ftuit, in de achterpooten eindigen. Om dit nu regt te bevatten, zie men in Plaat IX. Fig. 10.. vooreerst: de aanwijzing der voorname dealen met Kapitale Letters, om dézelve, naar mate der voorgeftelde verdeelingen, van de kleine Curcijve Letters en Nommers te onderfcheiden, en $\mathrm{M}_{3}$

HeT RUNDVEA, I1. Afd IV Hoofdr. 


\section{NATUURLIJKE HYSTORIE}

ine dus vertoonen de volgende deelen zich al. Wundere' dus:

Ir. Afd.

IV.

Hoofdat.

A. De longenklep en het ftrottenhoofd, met de tusfchenringfche takjes.

$\mathrm{BBB}$. De longepijp, en de plaats der lon. genzenuwen.

CC. Het hart en deszelfs zenuwer.

D. De holle ader en zenuwen.

- E. De harcader zenuw, van de regterzijde, die naar de regter voorpooren loopt.

F. De hartader zenuw van de linkerzijde, die naar de linker voorpoot loopt.

De ligging dezer aderen en zenuwen, is den boeren en flachters wel bekend, zij weten, dat dezelve aan de linkerzijde lager ligt, en be. zasten de Koeijen daarom veel onder de oxelen, om te ontdekken of in dezelve ook fpatzen zijn, gelijk in de paarden : zij kennen hier ter plaatfe insgelijks den polsflag en de ze. nuwen, en letten of hier ook zenuwknopen leggen. De vetwijders, als zij magere bees. ten koopen, zijn ongeloofelijk ervaren, om uit het geftel der vaten en zenuwen, ondet de oxelen der Koeijen, de gezondheid en de voorfpelling van welgedijen te kennen; ook kennen zij zeer wel de lagerligging der bloedvaten an de linkerzijde, en het is hierom niet ve vergeefsch, dat wij bij ons het gemeen fpreekwoord hebben: de linker: hand is het naast aan het hart. a.d 


\section{- A N HOLLAND: I}

GG. Zijn de twee halsaderen en zenuwen, die, naar het hoofd loopende, dezen rundurn. vergezellen. Zie derzelver befchrijving Ir. Afd. en her beloop in de hersfenen, in IV. Plaar VilI.

Moofaft.

\& TI. Is de plaats van her miduienrif en deszelfs zenuwen.

Deze voorname deelen met Kapitale Letters aangewezen zijnde, vervolgen wijnu mes het Curcijf Alphabeth, om ordelijk het geftel der zenuwen te verklaren, doch hebben vooraf onzen Landman te onderrigten, dat alhoewel de bloedvaten hier telkens genoend worden, dit noodzakelijk is, om dat het gantfche zenuwftel, in alle deszelfs takken en fpruchtels, juist altijd naast aan, om en in het beloop der bloedvaten volgt, zoo dat er geen allerfijnst bloedvaatje is, of er is ook een zenuwfpruchtel naast aan: om dic duidelijker te -verklaren, volge hier de na. dere aanduiding met Curfive letters en nom. mers, en wel : 


\section{NATUURLIJKE HISTORIE}

\section{RUNDVER. \\ L. \\ 11. Afd. \\ IV. \\ Hoofdit.

\author{
IE T T VOOR S T EL
} \\ of yerklaring yon de Afdeelingen in he yoorfel, yan het hoofd tot an het mididenrif.}

De hoofd a a a a vertoont de vlechting der zenuwer, en hersfen. zenuwen. zoo als dezelven zich in de hersfenen verfpreiden.

b zijn twee aanmerkelijke takken van het zesde par zenuwen, hier afgefneden verbeeld.

oogze $6 C$ zijn de zenuw - en fpiervezelen van het muwen. $\quad$ oog, war in het vijfde paar zenuwen is ingewikkeld.

$d d$ is de ontfpruiting van het derde paar zenuwen.

Gehoor-ee de gehoorzenuw, die hier den kring en zenuwen. : den draai van het flekkenhuis volgt, en tevens den bogt van de omkromming, die deze tak makkt, duidelijk aantoont, en zich uitbreidt in de vlechting $a a a a$, hier boven angeduid, zoo als die zich in de hersfenen veripreid.

klierze $f f$ de klierachtige zenuwknoop, die hier zuwknoop om de tusfchenribbige zenuw lirult, en waar uit men kan leeren, wat eigenlijk een zenuwknoop is, te weten, als twee zenuwen, elkander ontmoetende; eene kronkel maken. De oude Hollanders

$\therefore$ noemden dic wel den nastelknoop, vooral 
als die in de onderdeelen viel, als wan- HET neer zij iemand voor onvruchtbaar hiel- RUNDVER. den. De Boeren zeggen het nug, als ir. Afd. zij in de Koeijen iets dergelijks bemer- III. ken.

$g g$ zijn de takken van het paar zenuwen, Dwalende die men-dwalende ( par yagum) on-zenuwen. zeker in hun menigte takken, noeme. Deze zijn het, waar in de Slagters met Prikzes een mesje fteken, kort achter de ooren, nuw. 200 als wij van de Slagters of Vleeschhouwers re Dordrecht gemeld hebben, en het welk ook door de Indianen wordt waargenomen, als zij op de Stieren - of Bulleniagt gaan, en als dan achter een boom het verwoede dier afwachtende, hetzelve aldaar mer een pijl of bijl treffende, het dier plotfeling ter aarde valt.

h $h$ cen dergelijke tak, die de halsfpieren Halsze. beftierä.

nuwen.

ii de zentwen, die naar het ftrottenhoofd, Strotzeloopen. nuwen.

$k k$ de tusfchenribbige zenuwen, uit hunne Tusfchenvlechtingen nederdalende, tevens mer ribbigé zehet dwalend paar zenuwen.

l $l$ takjes van het tiende paar zenuwell.

m $m$ de zenuwen, welker vlechting de: keel Keelze. en ondertongfche fpieren en klieren ${ }^{\text {nuwen. }}$ beftierd.

$n n$ de fchede van de zenuw, die uit de regt Longze.

2. i nederdalende tusfchenribbige zenuw, nuwen. ontfpruitende, met een bocht in de zijdelingfche longzenuw zich vereenigende, de borst inloopt, en aldaar met de andere zenuwen zich vereenigt.

M 5

oo de 


\section{NATUURLIJKE HISTORIE}

Hex 00 de vlechting der zenuwvezelen, ter plaat? andver. fe daar dezelve met eenen aanmerkelijken

II. Afd. is tak, naar het hart loope, en tevens met IV, Hoofdif.

Hartze. Buwen. twee fpruchtels wederkeert naar de ze. nuwen der oxelen of der voorpooten, en ook de borst regeren.

slagader- $p$ de ringzenuw, die zich om de liukerfag. zenuwen. ader vlecht.

$q$ de zenuw an de hartagader.

Inwendi- $r$ een ontelbaar getal zenuw'vezelen, die alge hartze. Ien naar de bekleedfelen van her hart, nuwen. en derzelver inwendige fpieren loopen. 1)eze zijn in de volwasfen Koeijen zeer aanmerkelijk te onderkennen.

Voor- ss hier ziet men de vijf rakken, of zeer

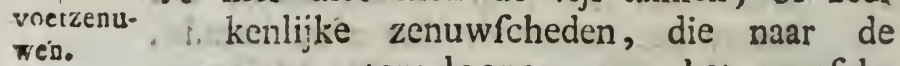
voorpooten loopen, en het gantfche beender - en fpiergeftel van het voorftel - vertr regeren. Her zijn deze zenuwen, die men in het vleesch der voorveren van het geflagte vleesch, zoo kennelijk zič, dat dit gedeelte hier van den naam van zenuwbonken ontleend heeft. Deze zenuwen zijn danrenboven in de Koeijen langer en veel lager geplaatst, dan in den mensch, daar men dezelve de arinzenuwen (neryi brachiales) noem, en dic is natuurlijk, nademaal de armen en oxelen in den mensch hooger geplaatst zijn, en de armen éene vrijer bewceging hebben. Dit merkt men ook op in de vijfvingerige dieren, wier armen of voorpooten nader aan den Mensch komen, daar de voorpooten en de ge. 
kliefde klaauwen in de Koeijen en hun RUNDvea, geflachtsaard, meerder tor fteunfelen die- Ir. Afd. nen, gelijk men in de Plat van het IV. Beendergeftel zien kan.

Hoofdr.

is zijn weder twee in een loopende zenuw. takken, die naar de voorpooten loopen en de voorige doorvlechten.

a \& zijn de zeer fterke zenuwen van het mid- Middendenrif, äie onder aan in drie takjes ein-rifzenudigende, zijlings zijn aangeftipt, doch die ongelooflijk fijn in her middenrif zich verfpreiden; in de Koeijen zijn de. ze takjes, volgens de waarnemingen der Ontleedkundigen, drie, daar, dezelven in den Mensch maar twee zijn, hetwelk dan aanlaiding geeft om te. ftellen, dat het middenrif in de Koeijen ook veel gevocliger is en fterker werkt.

y Voorts loope de groote tak dezer ze- schildzenuw, na een bogt gemaakt te hebben, nuwen. die achter de fchildbladen omloopt, lijnregt neder.

w het eind der opgemelde zenuw.

$x x$ zijn de takken der gebogen groote ze. Groote nuwen, die dadelijk nar her hart loo- hartzenupen.

y zenuwtakjes in ongelooflijke fijnheid om Fijne en in het hart gevlochten.

$z z z z z z z z z z z z$ de zenuwen die ter wederzijden uit de rugge- Ruggegraat uitfpruiten, en van nuwen. tusfchen de wervelen in de Spieren zich uitbreiden, welke uitbreiding door 


\section{8}

\section{NATUURLIJKE HISTORIE}

$\therefore$ HET

RUNDVEE。

ii. Afd.

IV.

Hoofdit. der zenuwen van den buik, volgens nommerletters, om de verwarring mer de alpha. betifche te vermijden.

I I zijn de beginfelen der zenuwen, die naar de maag loopen, welke, zoo men derzelver opklimming en oorfprong, digr bij de gehoorzenuwen, de gezigt -, reuken overige zintuigelijke zenuwen, gade. flaat, ons weldra een denkbeeld geven van de reden, warom in de Koeijen, als de herkaauwing en de magen ontfteld zijn, de gevoeligheid zich vooral in het kwijnen van het hoofd opdoet, even zoo als wij menfchen, als de mag on gefteld is, door de gemeenzamheid de. zer zenuwen, pijn in ' $t$ hoofd, oorpijn. kiespijn enz. krijgen.

Vereeni. 2 de vereeniging der groote takken tot gende ze. eenen tak, die van onder het middenrif ถuwen. naar de maag, lever enz. zich weder uisbreidt.

333333 de uitfchietende takjes, die tusfchen de ribben en de tusfchen. ribbige fpieren door, de uiteinden der, als 't ware, fpierpluimtjes aanwijzen.

Door alle de voorgemelde aanwijzingen tot dus verre, de zenuwen van het voor - en bo. ven. 


\section{$\checkmark A N$ HOLLAND. 189}

wenftel, die tot het hart, de borst, de longen, het middenrif en de armen of voor. pooten betrekking hebben, zijnde voorget'eld, volgen hier de vervolgen der zenuwen in den buik en de ingewanden, maag, lever, mile, nieren, en zoo vervolgens, die wij, alfchoon dezelven in eene afzonderlijke Plaat bij anderen zijn uitgebeeld, hier als voreenigd voordragen, om dat den min ervarene hier door een gemakkelijker denkbeeld van het geheel bekomen kan, gelijk wij ook voorbedachtelijk hier al de fubti. liteiten, die op dit gedeelte kunnen voorkomen, overlaan,

1I. Afd.

IV. Hoofds:

\section{B.}

\section{HET MIDDENSTEL.}

Dezè Afdeeling dan verbeeldt, als vervolg $o p$ de aaneenfchakeling der zenuwen van hee boven borstgeftel, tot aan en om het bekken onder aan het buik - of middenftel, voornamelijk de takfchieting der dwaalzenuw of liever de algemeene zenuwen.

4. Is de groote tak, die naar de bekleed- De grow: felen der maag loopt, en uit de veree te maag. niging der takken bij $\mathrm{C}$ voortfpruit. ${ }^{\text {zenuw. }}$ Deze zenuw met zijne takken fpreidt zich om. den grooten krop der eerfte maag of pens in de Koeijen; men noeme hem de onderite.

$$
\text { 5. Zijn }
$$




\section{0: NATUURLIJKE HISTORIE}

net ${ }^{3}$. Zijn de twee takken, die uit de takken der borstzenuwen nederdalen, en, zich

II. Afd. zamen vereenigende, de andere of bo-

IV. vendeelen der mag doorvlechten.

Hoofdit. 6. 'Toont derzelver vereeniging.

Magze 7. Derzelver fpruchtels om en door de ben nuwen.

kleedfels der maag.

Maagkrop. 8. De fijne vezelige vereeniging en vlech. ting der zenuwvezelen, on den krop der maag, bij wijze van netvormige doorvlochten draden: in de. Koeijen, zoo als ftraks zal blijken, hebben deze vezelen een bijzonderen invloed op den nokdarm en den krop der maag tot het her. kaauwen, en het oppersfen der fpijzen.

Leverze-9. Zijn de takken der zenuwen, die zich onnuwen.

middelijk met die der lever vereenigen.

Tusfchen-10, 10, 10, I0. Zijn de vervolgen der groote sibbige zenuwer. tusfchenribbige of rugzenuw, die tusfchen de wervelen door zich langs de ribben uitbreidi, en $z 00$ als boven, coor de zijlingrfche pluimvezelen de ftrekkingen aan. duiden.

I1. Een tak van de zenuw, dic zich uit de bovengemelde naar den ommeloop uitbreidt.

Orklim-12. De opklimmende zenuwtak, die met mende ze- eene menigte vezelen naar de milt nuw. loopt.

Ncderda-i3. De nederdalende tak der zijlingfche lende ze- 3 fpruchtels van de groote tusfchen๓uw. ribbige zenuw, zoo als die reg- 


\section{VA N H O L L A N D. ' 191.}

terzijde naar den ommeloop neder- nez
daalt.

14. De fplitfing dezer zenuw, zoo als de II. Afd. cene naar de levertakjes, en de andere IV. naar de nieren loopt.

15. De vlechting en het beloop der zenu- Splitfing: wen naar de bever en omloop

16. De vlechting der zenuwen, van het al-Aivleeschvleesch, mitsgnders die der zenuwen zenuw. vetvlies. van het netvlies. zenuw.

17, 17. Twee zenuwen, die al wederom uit Omme. de groote lendenzenuw voorname-loopzeaus: lijk, naar den ommeloop loopen.

I8. De ontzaggelijke waaijersgewijze, en zeer fijne vlechting der zenuwen, die uit den omloop zich door all' het gedarmte in oneindig fijne fpruchtels ver. wijderen.

19, 19 De nieren.

$20,20,20,20$. De bloedvaten en pisleiders Nierzo der nieren, mitsgaders de nuwen. fijne fpruchtels uit de nierzenuwen fpruitende.

2I,2i,2I, 2I,2I,2I. Zijtakken der groote lendenzenuw.

22. Den oorfprong der zenuw, die neder-en pisze: waarts nevens andere zenuwen door- nuweres dringt, tot in de zenuwen der ballen en der teeldeelen.

23. Vereenigende zenuwen tusfchen het netvlies, de maag, de lever en de milt

24. Vereenigde zenuwen of groote vaten tusfchen de nieren, de lever en het al. vleesch. 


\section{NATUURLIJKE HISTORIE}

मет' 25. 'Zijtakken van de zijkwabben der leverzenuwen.

Ii. $\mathrm{Afd}_{2} 26,26$. De lendenzenuweñ onder de nieren. IV. EHoofd.

\section{G.}

HET ACHTERSTEL.

De overige kleiner zenuwen, en die zoo op het onderfte gedeelte van den buik, als op het geheel achteritel betrekking hebbende, volgen hier wederom op de vorige mer nummers.

Zenuw. 27. De zenuwknoop die nit de zenuwen knoop van - van den omloop ontfprooten, naar on. it kruis. deren loopt.

28,28. Zenuwen die na het pancreas loo. pen.

Barmoe 29. De zenuwvlegten die nar de baarder-of ze. - moeder uitbreiden, of over het licht

nuwen val loopen.
het licht.

Blaasze- 30,3०. De fpruchtels uit die zelve vlechnuwen. ting, die naar de blaas loopen, en die omvlechten.

31,3r. De zenuwen, die naar de klieren

1. der proftatae, voorftanders der teelleden, loopen.

Aársze 32. De zenuwen die zich naar den aars nuwen. uitfrekken.

Zenuwen 33. De zenuwen die zich naar de mander Manno. nelijke teeldeelen verfpreiden. lijke en 


\section{v $\mathrm{N}$ II $\cap$ L I. A N D. 193}

34. Dezelven, die de fpieren der teeldeelen $\begin{gathered}\text { heT } \\ \text { RUNDVE. }\end{gathered}$ regeren.

35.35. De zenuwen die naar de vrouwe- II. Afd. lijke teeldeelen loopen.

36,36. De zenuwen die zich naar de eijer.

IV. ñesten of vleugels der baarmoeder Vrouwe: verfpreiden.

37,37. De zenuwen die zich in de heup- deelen. beenderen of het lendenkruis ver- nuwen. Ipreiden.

38,38 . De zenuwen die zich naar het hei- Bekken: ligbeen of het bekken verwijderen. zenuwen. 39, 39, 39, 39. Takken yan de lendenzenu- Heiligwen, die door de kromte van beenzenu. het heiligbeen loopen.

40,40 . Zenuwvlechten die zich in de liezen Lieszenuof de langen achtervang enz. ver wen. fpreiden.

4I. Het einde der zenuwen, die bij de Koei- Startze: jen in de ftaart eindigen, doch in den nuwen. Mensch om het os coxygis indraaijen, warom er hier de ftart is bijgefcherst.

42,42 . Zcnuwen die naar het uur loopen. Uurzent. wen.

Hier mede de vlechtingen der zenuwen zo.o, beknopt mogrelijk voorgefteld hebben. de, zoo als dezelve door het boofd, het voorftel, middenftel, buik en achterftel, in derzelver vakken elkander onderling ontmoeten, en daar tevens voornamelijk de rusfchenribbige zenuwen, zijdelings verfpreid, vertoond worden, zoo zijn daarmede de Figuren, op deze negende Plaat voorkomen.

$$
\text { N de, }
$$




\section{NATUURLIJKE HISTORIE,}

нЕт de, duidelijk aangewrezen, en behoeft hier ZUNDVER. geene verdere verklaring.

II. Afd. Ten befluite dan van al het geene wegens

IV. de zenuwen gezegd is, dient hicr met een Hoofdrt. woord nog gezegd, dat, wat belangt eene nog nadere kunde, in overbrenging en afleiding van het zenuwgeltel der Runderen van en $\mathrm{op}$ den Mensch, zoo als wij telkens, daar het te pas komt, in acht nemen, dit heeft in dit geval geene plaats kunnen heb. ben, uit hoofde van her groot verfchil in het geraamte en de ligging der teeldeelen. Wie er lust toe heeft, kan ten aanzien der Menfchelijke zenuwen, in de werken van EU.TACHIUS, VEZalius en anderen, het bijzondere van de voornaamfte zintuigelijke paren zenuwen nargaan, volgens de ver: deeling der ontleedkundigen, en $z 00$ als die bij opgemelde beroemde Mannen, langs het beloop van een geheel beendergeftel, verbeeld worden; hetwelk ook door fommige Dierkundigen, ten aanzien van eenige viervoetige Dieren, is naargevolgd, als door SAUNIER en Bourgelat van de Paarden, en door BL^zIUS van de Honden, elders van andere Dieren, in walke af beeldingen dan zulk cen Paard of ander viervoetig Dirr op den rug gelegd, met de voor - en achterpooten uitgereke, verbeeld was, met alle de takken der zenuwen en bloedvaten, even als de takken en fpruchtels van eenen. ongebladerden boom, manr om dat zulk foort van afbecldingen niet alleen aan ontelbare misteekening onderhevig zijn, maar ook 


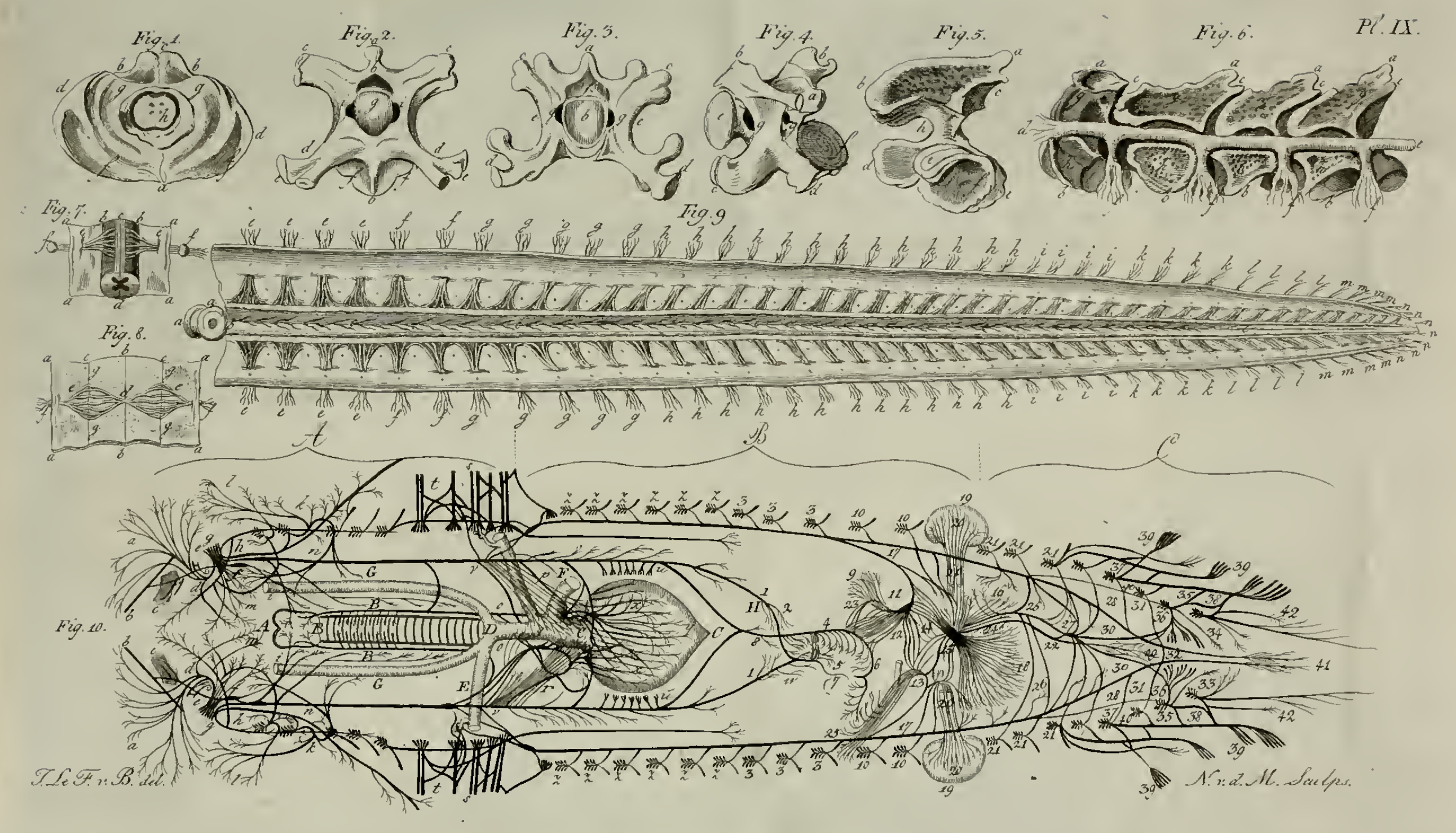





\section{VA N HOLLAND. 195}

cot eene vitgebreider behandeling behooren, en mij zeer zeker buiten mi n beftek zou-RUNDVEz. den verwijderen, heb ik foortgelijke afbeel- II. Afd. ding vermijd, en een beknopt en zelfs voor minkundigen begrijpbaar famienftel mede geIV. deeld, waar mede ik dan vertrouw tot dus verre te kunnen volftann, te meer, daar ik dit onderwerp met nieuwe afbeeldingen en verbeterde verklaringen, naar den aard der zaken, heb opgehelderd, en volkomen aan een' iegelijk de beoordeeling daar van overgelaten, in die verwachting, dat mijne Le. zers, overtuigd van mijnen ijver, geregelde ondervinding. en geduldigen arbeid, in de volgende Verhandelingen, over de zintuigelijke deelen, niet minder nuttige en te. vens vermakelijke zakelijkheden en nieuwigheden zullen vinden.

\section{Hoofdit.}

Hoofar 


\section{I96 NATUUREIJKE HISTORIE}

\section{TWEEDE AFDEELING.}

VIJFDE HOOFDSTUK.

Waarin; volgens de waarnemingen en af beeldingen yan J. CASSBRUS PLACENTI-

Nus en anderen, met yrijmoedigc.

yerbeteringen, het gehoor der

Koeijen uitvoerig wordt be.

fchreven.

HET

$\mathrm{D}$

aar het eene bevestigde warheid is, nundver. cat de eerfte beginfelen, ten grondlage van

II. Afd. eenige wetenfchap, altoos de moeijelijkite $v$. iijn, doch echter zoo onontbeerlijk, dat

Hoofdft. men zelden of ooit tor de volledige kennis, het nut en vermaak van eenig onderwerp kan komen, zonder eenen goeden grondling gelegd te hebben, waarop men verder kan bouwen. Daar ik nu ten aanzien van het beender-, fpier - en zenuwge. ftel, zoo veel mogelijk is, naar den aard der Koeijen, der Runderen of herkaauwende Dieren, het geheel geftel ontrouwd heb, 
zoo kunnen wij te gereeder tot het zakelijk ABT... en vermakelijk befchouwen van elk werktui- RUNDVE. gelijk gedeelte, in het bijzonder, overgaan, II . Afd. waarin dan naar de leiding der meeste en geTchiktfte Ontleedkundigen, aan de zintuigelijHoofdit. ke deelen de allervoor naaminte en eerfte plaats wordt gegeven, om dat dezelve in der daad de naaste aan de beftanbaarheid der levensgeesten of zielsvermogens komen, zoo dat wij zelfs door de kennis daar van in de dieren, en wel bijzonder in de Koeijen, ook die van ons eigen menfchelijk geftel leeren kennen. Deze zintuigelijke werktuigen wor'den' nu in vijf onderfcheidenen verdeeld, als: het gehoor, het gezigt, de reuk, de fmaak en her gevoel; deze nu, zullen het onderwerp van dit en de volgende Hoofditukken van dit Deél uitmaken en welke ik dan ook vertrouw, dat met zoodanige naauw: keurigheid tot eene geregelde vergelijking yan het Rundvee met den Mlensch en andere Dieren zullen bij een gebragt zijn, als mijns wetens tot heden gefchied is, waar van wij dan nu tot de befchrijving van het gehoor zullen overgaan.

Dat het zintuig van het gehoor in alle Het ge. Gierlijke wezens eene der voornaamfte is, hoor det die de gevoeligheid van hun beitaan tevens inet de gewaniwórding van alle itoffelijke zelfitandigheden buiten het ligchaam doen bekend worden, ontkent geen Wijsgeer, noch eenig fchel fel. Het verbazena en Goddelijk kunstftuk der werktuigelijke deelen 
ตะт van het gehoor, overtreffen bijna dic van undver. alle andere zintuigen, ten minften zijn zij 11. Afd. even zoo wonderbaar, als die van het ge-

V. zigt en de reuk, en zeer zeker nader bij Hoofdrt. an het gevoel, dan de overige; dit ftel ik uitdrukkelijk alzoo, om dat men overtuigelijk ziet, dat Menfchen, die of doof gebooren, of door roevallige oorzaken doof ge• worden zijn, altoos een zekeren invloed van het inwendig gevoel op dit zintuig, te weten het gehoor, werkende hebben: ik Gewijs het daar uit, dat, zoo al de fijne werktuigen van het gehoor, als de ftampertjes, het trommelvlies enz. buiten flaat zijn om de gehoorzenuw aan te doen, de trilling en dreuning der lucht echter de gehoorzenuw, door het gevoel kan aandoen, zoo zelfs, dat ik het daar voor houde, dat, zoo de gehoorzenuw geheel, wel te verftaan aan zijne inworteling, aan het hersfengeftel werg, verlamd of verzworen is, dat dan ook die des gezigts en der reuk weg is, en zelfs het gehcele guftel, als ' $c$ ware, een doodelijk vitwendig ongevoelig wezen wordt. Ik makk deze voorafgaande befpiegeling, om dat ik niet wel kan treden in het grevoelen der Wijsgeeren, die willen, dat een Dier zonder gehoor kan beftaan, gelijk zij ook erkennen, dac het even zoo met het gezigt en de fpraak is. Het fchijnt zoo, om dat wij dagelijks ongelukkigen zien, die doof, ftom en blind zijn geboren, dit is waar, maar ik ontken ftoutelijk, en mogelijk bij de Gelecrden wat 


\section{v A N H O L L A N D. 199}

àl te ftout, ik ontken, zeg ik nog eens, dat daarom de ziel die vatbaarheid verliest om te kunnen begrijpen, wat hooren, zien en fpreken is; dit overtuigen ons de hedendaagfche onbegrijpelijke vatbaarheden, die men ftommen, dooven en blinden in. prent; in zoo verre, dat zij lezen, fchrijven, rekenen, en, als 't ware, zien kun. nen. Het Groninger Inftituue doet in dic ftuk ons Vaderland eer aan, want het be. wijst; dat; al zijn de werktuigelijke deelen zonder werking, de ziel echter werken kan. Omtrent het gehoor of de onderfcheiding der geluiden hapert er echter iets meer: cen blindeman kan een treffelijk Organist en Murikant ziin, als hij llechts zijn gehoor heeft: hij kan door gevoel zelfs de kleuren onderfcheiden, zoo als ik eene blinde jonge Jufvrouw, de Dochter van een waardig Hoogleeraar, ken, die op het gevoel zwart, wit, rood, en vooral blaauw laken kan onderfcheiden Evenwel heef het gevoel met het gehoor eene naauwe betrekking, het geen hader zal bewezen worden; men kent ftommen, die op de beweging der lippen, vingeren en der gebaarimaking, met teekenen antwoorden; omtrent eenen doover wil men weinig denkbeelden hebben, en evenwel zijn zij zoo fterk kenbaar, als in eenig ander verminkt zintuig: men lette op een dooven, alfchoon zijn gehoordeelen in de uiterlijke gehoorwegen verftopt of niet aanwezig zijn, hij zal më open mond als gapende den fpreker aanzien: 


\section{NATUURLIJKE HISTORIE}

HeT hij zit als ' $t$ ware bedwelmd in zijne opmerRundve. king, en zeer zeker heeft hij gewaarwor-

II. Afd. dingen op de gehoorienuw, die an hec Hoofdi, gemeen zenuwgevoel (Jenforium commune) grenst; uit welke aanmerkingen dan dit do gevolgtrekking is, dat hét gehoor der die. ren, zoo wel als alle anderen, een wezenlijk zintuig is, zonder heitwelk geen dier leven kan, hoe verminki het ook moge zijn; en het ten miniten eene gewarwording behoudt, die door de dreuning op de zenuwen werkt.

Dan, Jaat ons nu eens zicn, waar in dit levensbeftaan van het gehoor noodwendig beftaat: door het gehoor wordt cen dier van verre, of van nabij, zijne mededieren gewaar; door het gehoor ondérfcheidi hij de geluiden en ftemmen der dieren, het zij dezelve de grimmighcid der brullence Leeu. wen, het gekrol der Tijgers, het giejank der Wolven, het gebas der Honden, het geloei der Koeijen, het geblaet der Scha. pen, in toorn en vrolijkheid, in één woord, in allerlei omftandigheden van geluid aanduidt; zoo ook onderfcheid meń, door het gehoor, het gekrasch der Nachtuilen, het gekràai der Haanen, het kwaken der Eenden, en vooril het uren verre aankondigend geluid der Ganzen, het geklepper Ider Ooijevaaren, en, o lieffelijke aandoe: ning voor het gehoor! die lieve melo. dijen van het fluitend gevogelte, het tjilpend Huis - Muschje, het fchertend Spreeuwtje, de fluitende Lijsters en Mere: 


\section{$\forall$ Á $\mathrm{N}$ HOLLA N D. 20 I}

laren, de roepende Kieviet, de zich zel- нет ven nóemende Koeklioek, en vooral die RUNDvEz: bekoorlijke zangfter bij de avondfchemerin- II. Afd. gen, de Nachtegaal; ja nog, op dat ik ook de wemelende Infekten niet overfla, het gekrijs V. Hoofdrt.

der Krekels en Kriekjés, het gefnor der Vliegen, Honigbijen en Hommels; in de Visfchen het gelluit der Tonijnen, Karpers en fommige Palingfoorten, in één woord, alle dieren hebben éen gehoor, an hun aard en geflacht bijzonder eigen: allen fpreken hunne taal door de geluiden der liefde of zamenleving; zoo dat van den Mensch af, tot het kleinfte infekt ingcfloten, elk hunner een werktuigelijk gehoorgeltel heeft; aan zijnen aard eigen; dit is zoo barablij kelijk in her onderwerp', dat wij behandelen, namelijk de Koeijen, dat, zoo er in eenig dier eene kennelijke ondcrfcheiding plaats heeft, het onbetwistbaar in her $R$ und: vee bijzonder, en in meest alle de herkaauwende dieren kenbar is, in zoo verre zelfs; dat de beroemdfte Ontleedkundige onderzoekers van het gehoorgeftel, de gehoordeelen der Koeijen tot een voorbceld nemen, naast die van den Menscli. De on . waardeerbare JuLIUS CAsSERUS PLACENTInus heeft inzonderheid deze taak volmaakt afgedaan; wij zullen zijh fpoor drukken, en zijne afbeeldingen ftiptelijk volgen, doch met vrijmoedige aanmerkingen voor onzen Landzaat verftaanbaar trachten voor te dra. gen, en, des noodig verbeteren; te meer, dart opgemelde Wijsgeer niet alleen de N 5 


\section{NATUURLIJKE HISTORIE}

HE: gehoordeclen der Koeijen, maar ook die nundver. van alle dieren, met die bijzondere oplete II. Afd. tentheid, de beroemde Italianen eigen,

Hoodd. in cene vergelijkende natuurkunde heef medegedeeld; wij durven des te meer dien grooten Man volgen, met zoo vele rondborstigheid, als den onfterfelijken ALBINUS de af beeldingen van eUsTACHIUS en VESALIUS gevol d heeft. Eene waarheid, eene nauwkeurigheid blijft altijd dezelfde; daarom, bevestigde overtuigende rchoonhe. den te willen verbeteren, is roekeloosheid, en het is altoos beter regt te doen aan de werken der, waarlijk eerwaardige, Ouden.

be ver- Dan ter zake. De ouden zoo wrel als de deeling der hedendaagfchen, onderfcheiden doorgaans de gehoordeeIen. gehoordeelen in uitwendige en inwendi. ge; de titwendige zijn die, welke men ooren, oorfchijyen, oorlepels, oorlellen noemt, de inwendige zijn de gehoorbeen. deren, zenuwen en fpicien. De uitwenDe uit. dige verfchillen zoo fterk in de fooren wendige der Dieren, dat er genoegzaam geen gegehoordee- flachtaard is, die niet een bijzonder ken.
len. merk aan de ooren heefe Alle de viervoe. tige Dieren hebben kennelijke oorlellen, dic uitwendig an het hoofd uirfteken. De vogelen hebben ze niet zeer uitftekende, ten zij in fommigen door pluimvederen, de nachtuilen evenwel uitgezonderd, welke verbazende groote oorlellen hebben, die zij naar willekeur openen en fluiten. De visfchen heb- 
hebben ze in het geheel niet uitwendig, ten HEr zij cenige kiewen. De infekten insgelijks RUNDVEE. minder of nooit zigtbaar enz.

Dit alles nagaande, zijn de viervoetige Dieren over het geheel uitwendig van oorlellen of oorfchijven voorzien, die zij naar verfchil willekeur beweegen of uitftrekken kunnen, der oorlel. om de geluiden te vangen: derzelver ver- len. fchil is echter aanmerkelijk in de beweeg. baarheid. De Mensch, alhoewel fijn luisterende of hoorende, heeft de oorfchijf of lellen minder beweegbaar dan eenig ander Dier. De Koeijen cn Paarden hebben dezelven daar en tegen allerbeweegbaarst; na. tuurlijk evenwel kan een Mensch de oorfchijven, oorfchelp en oorlel bewegen of rekken 200 men het noemt. (Arrige Aures, Pamphile! zegt plautus, die ooren heeft om te hooren rekke dezelve.) Onze voorouders, als zij een getuigen benoo. digd hadden, namen een jongen of getuigen, en trokken hem aan den oorlel, als om de ooren te buigen tot het hooren en het getuigen van het geene hij gehoord heeft, hier van oortuigen, oorkond enz. De Oosterfche volkeren en de Amerikanen, kunnen de oorfchijven bewegen, hunne oorfchijven of oorfchelpen ftaan ook uitwendiger gebogen dan die der Europeanen; onze Nederlanders vooral bewegen dezelve zelden zoo vrij, het geen veroorzaakt wordt door het fluiten van de hoofdfchedels der eerstgeborenen in platte flepjes cn mutfen, waar door de fijne fpieren als

II. Afd. V.

Hoofdit. \\ HOLL A N D. 203}




\section{NATUURLIJKE HISTORIE}

Het vergroeijen. Deze fpieren hebben groo kUNDVRE gemeenfcháp met de kaakfpieren, zoo dat;

II. Afd. wanneer het fchijnt dat iemand de ooren be:

$\mathrm{v}_{\text {. }}$ weegt, hij eigenlijk de kaken beweegt doorIooddr: hulp van de kaakfpier aan de oorlel; dai dit is de regte natuurlijke beweging niet, De groote albinds had door oefening het vermogen weder gekregen, om de oorfchijf, zonder de minste aandoening der kaaken, te beweegen, en de beweegfpier van de oorfchijf te doen werken. Dit deed dien Hoogleeraar telkens als hij over dit onderwerp handelde, aan zijne Leerlingen zien: $Z_{i j}$, die met mij; in dien tijd, 's Mans lèsfen hebben bijgewoond, weten, hoe dezen ftatelijken Wijsgeer bij die uitoefening, dikwijls de Jongelingen tot lagchen vérwekten; door dien elk dit willende naarvolgen, al vrij wat zonderlinge gelaatstrekken maakte. Er zijn niet te min hier en elderśs nog̣ Menfchen, inzonderheid onder de zeclieden en visfchers, die veel in allerlei weer en wind zijn, die ook de oorlellen beweegen, doch' met dat al, zoo komen deze beweegingen en cigenfchappen in geen vergelijking met andere Dieren, vooral niet met de kittcloorige Paarden, ook niet met die der Koeijen, welkers oorlellen zeer groot en breed zijdelings uitfteken, en boven eenig ons bekend dier beweegbaar zijn. De viervoetige Dieren in het gemeen, en de gehoefde in het bijzonder, hebben in der daad dit ook benoodigd, door dien zij hunne voorvóeten niet als handen gebruitken kunnen, nog eenig hulp- 


\section{* N HOLLAND, 205}

hulptuig bezigen, zoo als den Mensch, die, als hij alleroplettend hooren wil, de aundve: holte der hand aan den oorfchijf legt, om iI. Afd, des te naauwkeuriger te hooren, of bij gebrek, wel hulp-ooren gebruikt. Oudstijds fchijnt V. het, dat onze voorzaten wel oorlappen of oorholtens bezigden, waar van het aannacijen yan" ooren oorfpronkelijk is, als men zegt: gij zult mij geen ooren aamaaijen, zie winschoten, zeeman; ook op oorin. baar, een lompen fteiloor, die nog onbedreven is om te hooren enz. De opgemelde wezens dus deze en dergelijke middelen ontbrekende, heeft de wijze Maker ook hier voor gezorgt, dat zij door de vrije beweging der oorlellen: vooreerst, niet alleen op alle zijden de ooren konden wenden, maar ook daar door de ongevallen, die de koude, hagel, fneeuw en buitenlucht zoude künnen veroorzaken, af te weren; want men dient hier op te merken, dat de ooren der Menfchen en der naast aan hem grrenzende Dieren, als fommige Apen de óoren natuurlijk door het haar bedekken. In fommige Apen is de oorfchijf zelfs tot inwendig gehaard, eenige grove gehaarde mannen hebben inwendig; voor de opening der gehoorweg, insgelijks haartjes Vele der Honden hebben hangooren, die de gehooropening bedekken, en zijn het fteilooren, altoos zijn dezelve van binnen gehaard. Van de Katten, die altoos teilöoren hebben, zijn dezelve altoos inwendig als in digt wollig haar gedom- 


\section{NATUURLIJKE HISTORIE}

HET pelt; in een woord, elk Dier heefe hier in RUNDVEe. zijne bijzonderheid; maar laat ons nu de II. Afd. ooren van de Koeijen befchrijven.

Hoofdn. Hier doet zich een wonderbaarlijk geftel op, want de ooríchijven, die onze Boeren ook oorlepels, oorlellen noemen, zijn buitengemeen groot, en horizontaal wederzijds uitftekende, in zoo verre, dat men van.zeer verre af eene Koe hier aan kan onderkennen, zoo wel als aan de horenen. Het Paard en de Ezel daarentegen hebben fteilopitaande ooren. Deze zijdelingfche uitfteking der ooren van de Koeijen is algemeen. Men vindt genoegzaam nooit, zoo veel ik weet, hangooren, wel eens flappe ooren, dat men struiloor noemt; doch dan is het Dier hier of daar niet gezond, of ook kan het wel verftopt zijn in de ooren, of daor vliegen, rappigheid of fchurft geplaagd, en dit gebeurdt nog al, vooral door vliegen of wespenbeten, waar vaor eene Koe doodelijk beangst is, en hierom geftadig de oorlellen beweegt, om den aanval der Infekten te beletten, waar voor de goede Natuurfchepper dan ook gezorgd heeft, dewijl deze Schepfelen meest altijd in de opene en vlakke velden grazende, natuurlijk meerder aanval van dergelijke diertjes, mierties of torretjes, te duchten hebben. Dan laat ons ter ontleed. kundige befehrijving, een fchred nader treden, en onze aandacht vestigen op Figuur 1. in Plaat $\mathrm{X}$.

p1. $x, \quad H i e r$ is afgebeeld het oorlel eener Koe, Eig. 1. zoo als hetzelve achterwaards vleijende, door 


\section{Y N H O L L A N D. 207}

door de oorfpieren voorwaards bewogen wordt; hier boven is alreede telkens her- RUNDVRE. haald, dat de bijzondere mayt om de ooren te bewegen, en voor - of achterwaards te rekken, aan de Koeijen en het verder herII. Afd. $\mathrm{V}$. Hoofdif. kaauwend vee bijzonder eigen fchijnt; dit Befchrijbewijst het fpiergeftel der oorfchijf of oor-ving van lel. Onze Leidsman, de geleerde CASSERI, het ge: getuigt dit zelfs in de verklaring der Figuur die wij volgen, als hij zegt: teftatur etiam admiranda Brutorum animantium cum homine in yariis organorum typis convenientia, en vervolgens: cum grandiora fint hujus animalis auditus organa: majoresque musculos habeant, auriculam, SURSUM DEORSUM, RETRORSUM E' in gyrum rotantes. Hetwelk hier op uitkomt, dat def Koeijen fpiergeftel in het draaijen, bewegen, voor achter, op, ne= der, en in allerlei gieren en draijingen, ons ten voorbeelde ftrekke om de kennis van des menfchen oorfpieren toe te lichten.

Men zier dan in onze Figuur I. een Koeijenhoofd, waar van de huid bij a $a$ a $a$ is fpieren. geopend en omgeflagen, zoo dat de oorppieren daar onder bloot liggen en zigtbaar zijp, van het vet en de klieren gezuiverd. De eerfte en voornaamfte fpier, die zich boven allen kennelijk opdoet, is de horenfpier. Deze fpier $b b$, is ingelijfd aan den horenwortel bij $c$, en ftaat in tegenwerking met de kraakbeenigen rand of wortel van her oor, in den nek bij $d_{0}$. Deze fpier rekt en trekt de oorfchijf of de oorlepel van 


\section{NATULRLIJKE HISTORIE}

HET achteren na voren, of ook opwaarts naar. RUNDVER mate het Dier de beweging maken wil.

II. Aft. De fpier $e e$ is eigenlijk mecrendeels regt V. van het krakbeenig gedecle van het oor Hooldf. ter plaatfe daaf de gehoorweg beenachrig wordt. Deze fpier formeert met de angereckende bij $b$, een volkomen driehoek, welks lijnen aan het horengeftel boven, en aan het kaakgewricht benẹden inlijvende, die forfhe beweging veroorzaken, die aan de ooren der Kocijen eigen zijn.

Onder deze fpieren lige er eene nog bree. c̈cr, en alfchoon minder fterk, nogtans zich meerder uitbreidende, nadenaal dezelve in vier uitbreidingen zich verdeeld. Deze fpic. ren bij ffff aangeduid, regeren het oorftel. meerder inwendig, en hebben gemeen chap met de voorhoofdfpieren en die der nek, om het oor, derzelver werking oefent de mindere, en om zoo te fpreken, de fpelende bewegingen van het oor. De gemelde fpieren nu, zijn of zijdelings of op - en benedenwards, als door wegfmeltende vezelen, meer of min verknocht aan het kraakbeenig gedeelte, waar in de fpieren der oorlel zijn ingeworteld bij $g \mathrm{~g}$. Jjit kraakbeenig gedeelte moet men wel onderfcheiden van het oorlel zelve, nademaal zich aldaar de inworteling on vereeniging der zelfilandigheid, in elkander ver. liest; men noemt het dus oorlepel, de ruige hairige fchelp, die men uitwendig dik met haar bedekt ziet, en als met cen omgevouwen rand geplooid is, noemt men hierom ook helux, dat is: cen gerande fchelp eigen- 


\section{v $\lambda$ N $\mathrm{HOLLAND} \quad 209$}

cigenlijk oorfchelp, gelijk daarom zeker utw foort van paerlemocrfchelp, helix, o.or. RUNDves. fchelp heet; deze oorfchelp onderfcheide II. Afd vich van en eindigt in den mensch in zeker aanhangfel, 't welk men oorlel noemt, waarin onze v:ouwen de onrverfierfelen en juweelen dragen; in de meeste viervoetige dieren zijn $\checkmark$. Hoofdr: of fchelp zulke oorlellen, als in den mensch, onbekend; ten zij in de Aapen en Elephanten, welke laatften boven slle bekende dieren de ontzagchelijkfte oorlellen hebben; in onze Koeijen zijn dezelven in het geheel niet, maar darentegen is het begin van den gehoorweg en het einde der inworteling van den oorlepel geheel en al kraakbeenig en bol, gelijk dit de knobbel dàar van, bij $g g$ voor: noemd, aantoont, terwijl dit kraakbeen in der daad het oor zelve te dier plaate for: meert, zoo zells, dat, al waren de oorlellen afgefneden, de gehoorweg of kom nog in' zijn geheel bliift, hetwelk nader zal blijken bij Fig. 3 en 5 .

Onder dit kraakbeenig oorgeftel ligt eindelijk nog eene fpier, die final begint bij $\mathrm{g}$, en voorts, doch met teedere vezelen, als waaijerachtig zich uirbreidt bij $h$, en als met de kaakfipier of kaauwfpier (Mas 2 $t e r$ ) zich vereenigt; dit is de fpier die in het herkaauwen der Koeijen die lodderlijke en ftille beweging maakt, als de Koeijen, als 't ware fluimeren en de hazeीaap doen; zoo als MaEcenas zeide: non omnibus dor. mitat bonus Maecenas; men zou hem in dien zin den wachter kunnen noemen; zij 


\section{IO NATUURLIJKE HISTORIE}

MET loopt insgelijks om en op, ja is in de UUNDVER. breedte genoegzaam geheel ingelijfd aan het

in. Afd. fchildvormig kraakbeenig gedeelte, hetwelk $\mathrm{V}$. naar het inwendig oorgeftel tegen het fteenbeen aanloopt: zie bij $k$ de vlakte van het fteenbeen in zijne bekleedfels.

Wijders ziet men bij Fig. 1. de oorfchijf of het harig oor, ftaande op het geftel van alle opgemelde fpieren en deszelfs kraakbeen : dit oorftel algenneen genoeg bekend zijnde, vereischt hier niet veel omflag: al. leen willen wij ter opmerking aanbevelen, dat de ooren der Koeijen, boven eenige andere herkaauwende dieren, of die in het open veld grazen, ongenteen zwaar gehaard zijn, en veeltijds zelfs wolachtig en ruig. Het verdient, onzes bedunkens, opmerking, dat de Paarden gladharige ooren hebben, en dat de Schapen en Geiten, die anders de huidharen zoo dik, vol en wollig hebben, evenwel zulke gladharige, ja fomtijds kale ooren dragen. De Natuur, die doch niets onnut heeft gefchapen, moet hier zekerlijk redenen voor heb: ben. Wie verklaart dezelven? Ik voor mij beware het onder mijne befpiegelingen.

Het uitwendig oor dus in deszelfs beweging van achteren naar voren verklaard zijnde, volgt natuurlijk om ook deszelfs. werking van voren naar achteren te verklaren. Men heeft nu een begrip van de zonderlinge vermogens, die eene Koe bezit, om zijn oorlel of oorfchelp voorwaarts te bewegen: zie hier, Lezer! de tegenwerj....

keas: 


\section{VA N H O L L A N D. 21:}

kende evengelijke magt in Fig. 2. ver- üт klaart: gij ziet hier insgelijks een Koeijen- Rundve hoofd, waarvan de huid omtrent den om- il. Afd. trek van het oorgeftel is ontbloot en omgeflagen; de oorlel, of oorfchijf, vertoont V. zich omgellagen, en dus van achteren met haar bezer, de fpieren vertoonen zich dus ook van de achiterzijde eenigzins uitgerekt, ten verftande der zaak.

In Fig. 2. bij a a doet zich eerst en vooral eene lange fterke fpier op, die mede aan den horenwortel begint, en dus even Tegen200 als die in Fig. 1. aantoont, dat de der oorlel, kracht der oorbeweging als vereenigd is len. met die der horenen. Deze fpier eindigt in een vrij taaijen pees aan het oor zelve: het is cie zelfde pees en fpier, waar aan wij elders die gevoeligheid des levens toefchrijven, wat door de Vleeschhouwers de Koeijen met de prikfteek doodelijk treffen: hare kracht is fterk in de rigting van her oor, om hetzelve met kracht achterwaarts te trekken; onder deze fpier is eene kleinere, $b$, die, alhoewel van minder kracht. het oor in ftiller beweging zijlings trekt, evenwel zoo, dar dezelve an de peesachtige einden, juist zoo als die van de andere Fig. I, een driehoek formeert, met eeñe nog fterker fpier $c c$ : deze beide fpieren oe. fenen, even als de gemelde, de geweldigfte krachten in de beweging van het oor naar achteren; deze krachten zijn zoo fterk, dat eene, Koe met haar oor een tamelijk hars den flag kan geven wan den genen die haar

Plaat to: Tegen. 


\section{NATUURLIJKE HISTORIE}

EET al te veel oor - of horenkitteld; men kan RUNDVEE zelfs opmerken, dat, wanneer eene Koe II. Afd. graast, zij als dan geftadig de ooren be$v$. weegt en de vliegen of torren van zich wegHoofdt, flaat, terwijl zij met den neus blaast.

Deze beide fpicren glooijen over eene vrij breeder fpier, die als onder on tus. fchen die van Fig. I. en 2. ligt; deze fpier, bij $d$ aangewezen, hecht zich aan het kraakbeen $e$, onder deszelfs holligheid bij $f$, zij oefent eene horizontale kracht, en houdt het oor in dien ftrakken zijlingfchen ftaat, dic zoo aanmerkelijk in het uitrekken van de ooren der Koeijen ziğtbaar is, zoo dat, wanneer de Koe aandachtig luistert, dan is het deze fpier, die de ocrlepel ftil en ftrak uitrekt.

Onder- Onder deze ligt omtrent in dezelfde rigoorfpieren ${ }^{*}$ ting een dunner fpier $g g$ : deze begint uit dezelfde inworteling, doch eindigt onder aan den rand van de oorlepel, in dier voegen, dat, daar de fpier a a van boven den rand van het oor beftuurd, deze zulks van onderen verrige, en dus beiden het oor opof nederwaarts, zijlings of voorwaarts bewegen: deze beweging wordt geholpen, eerst door een fpierig annhangfel van de fpier $d$, uit wier inworteling zij ontfpruit, en daarna als inwendig induikt, om den bol van het kraakbeen, dadelijk nader te verklaren; zij wordt alciar, als met twee armen, vorksgewijze omhelsd door twee fpiereinden $h$ en $i$, die beiden om de kroon glooijende, aan het voorhoofd ingeplane 2ijiz- 


\section{VA N HOLLA N D. 2I3}

zijnde, aldaar dezelfde foore van fpieren нет ran het ander oor ontmoeten: deze fpieren RUNDVER: zijn het, die de oorfchelpen draaijen, en II. Afd. nu de holligheid der lepel opwaarts dan nederwaarts wentelen; zij werken zoo even- Hoofdit. redig op beide de ooren, dat derzelver be- Draaioor. weging meest altijd gelijkftondig gefchiedt, fpieren. hetwelk men duidelijk zier, als de Koeijen of ini rust of ftaande herkaauwen, als wanneer. het een oor even zoo als het andere bewogen wordt, en wel beiden op hetzelfde tijdftip, ten ware de Koe eenig zijdelings geluid aan eene of andere zijde gewaar wordende, als: dan de andere fpieren werkende worden.

Bij $k$ wordt de bolle bogt van het ne- De boge derkraakbeen aangewezen, hetwelk met een van het ronde gedaante eindigt, en van daar den kraakbeen hals of het midden verengd, dat wederom aan den kom van den bafis der oorfchelp of lepel eindigt: deze holte is de kom der oorlchelp of lepel zelve, zie bij $k$, alwaar zij voorwoarts in den harigen huid van het oor, of bij zekcre bijzondere oor-of huidfpier $l$, zich verliest in den rand of kring, die de haarwortelen van het achteroor aldaar heb. ben, en welker affcheiding zoo dadelijk bij het geheel oorgeftel zal voorkomen; wijders ziet men bij $m \mathrm{~mm} m$ den ongeflagen huid in deszelfs plooijen.

De horenen, de fnuit en kop verklaren zich zelven genoeg, en zijn door ons hier flechts ter aanwijzing der bijdeelen afgebeeld. Beide deze Figuren, 1 en 2 , geven dus een klaar denkbeeld van de be$\mathrm{O}_{3}$ we- 


\section{$2 I 4$ NATUURLIJIKE HISTORIE}

нет wegingen die de oorfchelp, lepel of oorlel, xundver zoo als men die verkiest te nocmen, door

II. Afd. middel van zijne cerfte fpierbekleedfelen der

V. Koeijen makt; nu volgr er ecne nog naHoofdr. der en duidelijker befchiiving van het ganfche oorgeftel in zijn gehrel verband, zoo als hetzelve in alle zijne wentelingen, theuven en holligheden, tor in het gebeente zelve is ingewikkeld, en waar van niemand, zelfs een kundige, zich nier wel eenig begrip kan vormen, zonder eene geheele ontbloating der kraakbeenige deelen en der fpieren, zoo voor als achterwaarts; ten. dien einde dienen nu voor eerst de Figuren 3,4 en 5 .

plaat x. Figuur 3 , de eerfte in rang, vertoont Fig. 3. dan het geheele oorgefrel met zijne fpieren Het kraak- en kraakbecnige deelen van achteren, áls beenig oor-' 't ware regtftandig; doch men gelieve te chteren. begrijpen, dat die regtftandigheid alleen zich hier dus vertoont, om dat men anders dezelve niet wel kan aanduiden, weshalve men diene op te merken, dat dęze deelen meer of $\min$ in de holligheden van het achterhoofd en die van den flaap des hoofds zijn ingebogen; deze Figuur evenwel is zoo. fraai en duidelijk, dat een oplettende de geheele zamenftelling genoeg begrijpen kan: dezelve is in de proportie wel iets groote dan Fig. I en 2 , doch niet te min in deszelfs gedaante geëvenredigd an het origineel van casserus.

Kraakbee- Men ftelt dan, dat bij a de achterlepel nige ach, van het gehaard oor, op de helft van desterlepel. zelfs 


\section{VA N H OLLA N D. 215}

zelfs kraakbeenig middenfchor, is afgefchei- нит den van het onderite gedeelte der oorhulte RUNDve. of oorkoker, zoo als ik die verkies te noe- II. Afd. men : deze koker vertoont zich bij $b$ ge- $v$. heel van den epperhuid ontbloot; op dit Hoofdn. gedeelte doet zich een afgefneden gedeelte Oorkoker. der fpier $c$ zien, die uit den hollen gehoorweg aan deszelfs kraakbeen bij $d$ begint, en aan de oorlepel eindige, gelijk die in $\mathrm{Fi}$ guur 2. bij $a$ is angeduid, en die hier bij d insgelijks de wcrking verklaart, hoe het oor, of, zoo als casserus zegt, de oor- Oorvlewvleugel (ala) achterwaarts wordt bewogen. gel.

Bij ee ziet men insgelijks wederom cis dunner fpier afgefneden, die bij wijze van een driehoek in Fig. 2. bij $c$ is aangeftipt, doch hier eenigzins buiten den natuurlijken ftand op zijde geflagen, om des te klaarder de hoofdzakelijke deelen te kunnen aanwijzen, terwijl even zoo bij $f f$ de beweegfpier van het vooroor uitgefpreid ge- Beweeg. zien wordt, welke fpier eigenlijk midden fpier, in de voorfte en achterfte beweegfpieren in ligt; deze worde in tegenoverftelling vervangen door eene zeer dikke en zware fpier $g g$, welker geheele werking de oorvleugel tevens met de kraakbeenige holte van den ge. hoorweg verbindt, dezelve is derhalve diep in de fleuf dezer deelen ingelijfd; $z i j$ fchijne dezelve geheel inwendig te befturen, en geholpen door de flaap- en kaauwfpieren $h$, die bij haar, en insgelijks in den bol van het kraakbeen ingelijfd zijn, heeft zij dus mede eenen invloed op meest alle gehoor. 


\section{NATUURLIJKE HISTORIE}

HEт hoorfpieren aan het kraakbeen gelegen, nundVez. en wel an dar gedeelte, alwaar hetzelve II. Afd. als eene fleschachrige gedaante aanneemt,

v. en met regt de verzamelfresch der lucht of Hoofdrt. luchtkamer genaamd kan worden, terwijl Luchtka- deszelfs vernaauwing bii $i$ als een aanhangmer. fel is, waarin de lucht meerder verfijnd door de eigenlijk algemeene gehoorweg tor de eigenlijke werktuigelijke gchoordeelen in het fteenbeen indringt, en welker beweging. yolmaakt beftuurd worde door eenen vrij langen fpier, bij $k$ afgefchotst, welkers tegenwerker is eene allergrnorfte, breede en waaijerachtige fpier $l l$, die, van den krop van het fteenbeen ontfpruitende, zich ten fterkfte om het achterhoofd orrviecht; boven

Flesch. dezelve op de fcheiding van het fleschror. yormig mig kraakbeen ontfpruit wederom eene nog kraakbeen. aanmerkelijker fpier, bij $m$, deze fpier eindigt in een zeker kraakbeen $n$, dac los en be= weegbaar is, en als de gedaante van een - fchild heeft, waarom het ook Clypeiforma schildge- ( (childgedaante) genoend wordt; men hoosbeen. houdt dit fchildbeen en deszelfs fpieren ge: fchilt om de enge gehoorweg. (Meatus ancufticus), die aan de inlijving zijner (pieren begint, te befchermen; waar van ftraks nader. De fpier $m$ verwijdert zich, uic het middenpunt, van dit fichildvormig: kraakbeen, en is in het fteenbeen zelve als ingelijfd, zie bij 0 ; zao dat deze fpieren, in eene driehoekfche riging ftaande, niet weinig aantoonen, welke krache zij kunnen uitoefenen: in der daad, zij zijn 200 


\section{$\forall A \times H O L L A N D . ~ 217$}

200 vast in eene zekere holligheid van het HET Ateenbeen ingegroefd, dat men met moeite Runvver. dezelven kan affcheiden, ja zelfs schijnen zij II. Afd. tot in het binnenfte in te dringen.

$\mathrm{Nog}$ is er eene, alhoewel kleinere, nog: V. Hoofdat tans zeer fterke fpier. die in zijne zelfftandigheid eerder krakbeenig fchijnt, zij is zigrbaar bij $p$, en fchijnt gemeenfchap to maken met het fchildvormig kraakbeen, en tevens mede te werken met het fchier regtlijnig fpiertje bij $q$, 't welk al mede op het fchildvormig kraakbeen eindigt, al hetwelk zamen genomen, overtuigelijk genoeg aantoond, welke werking dit fchildbeenig deel op het oor hebben moet, waarom men het misfchien wel bijoor noemen konde. Men kan herzelve inderdaad, als een kundige hand die betast, inwendig beweegbaar an de oorwortelen der lepels voelen; men voelt al: thans in eene levende Koe hetzelve als verfchuiven. I) Koeijen zijn er zeer jeukerig en worden kitteloorig, als men het tusfchen het einde van het groote kraakbeen en het gehemelte van het fteenbeen, fterk drukt, het welk bij $r r$, in deszelfs oppervlakte, van achteren zich klaar vertuone, en ftraks. in zijne gedeelten, zoo in - als uitwendig, nader zal verhandeld worden. De gedaante. waar in hetzelve zich vertoont, is, zoo als hetzelve natuurlijk uit de gewrichten der bijbeenderen $s s$, uit het hoofd is gewrongen, dat voorzeker geen kleine moeiten is, gelijk men uit de menigte groeven, hollig. heden; hoeken en rondtens, in het onderfte

O 5

ge- 


\section{NATUURLIJKE HISTORIE}

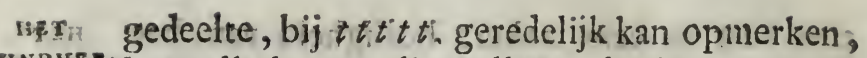
nundver, hetwelk boven dien alle ontleedkundigen te 15. Afd wel weten, oin er bewijs van te vorderen, Hoofdr. evenwel als iemand de inlijving der boofdbeenderen wel kan, en na eene weeking of verrotting, het bekkeneel, het veelvormig en flapbeen, juist kan affcheiden, volgt het nog al gemakkelijk. Dan laat ons nu het opgemelde oorgeftel eens oinkeeren, en hetzelve vạn de andere zijde befchouwen, na vooraf het geheele kraakbeen bij Fig. 3 . ontleed te hebben, is daar van eene nadere

Plaat $x$. afbeelding bij Fig. 4. Hier ziet men het geEig. 4. heele oorgeftel, van de helf der oorfchelp Inworte- of oorvleugel, tor aan de inworteling in ling in het het fteenbeen, geheel en al van fpieren, feenbeen. ver en klieren gezuiverd, in zijne ware gefalte., $\mathrm{Bij} a \mathrm{a}$ is de oorlel half afgefcheiden, zoo dar:flechts een gedeelte van den harigen huid er aan gehecht blijft. Bij $b b$ ziet men het krakbeen, of, zoo ik het noem, de oorkoker, geheel ontbloot. Men moet hier in aanmerking nemen, dat deze koker aan de onder - of achterzijde eene bul tige gedaante heeft, zie $c$. Deze bult is inwendig als eene kom of holte, en vangt de eerfte dreuning der luchtitroom, (zie dit nader in Fig. 5.) Casserus zoo wel als anderen, verklaren derzelver werking llechts flaauwrjes. Het ondergedeelte van deze kom of uitwendige knobbel $d$, vereenigd wederom dit gedeelte met, en wordt ingelijfd in de eerfte beginfelen van het fteenbeen $e$ e e. Eindelijk, om eçige nadere vatbaarheid van 
het bijoor of het fchildkraakbeenig gedeelte нет te bekomen, ziet men bij fff dit been in RUNDVEz. zijne volkomen ligging, en fluiting, op her kokerkraakbeen liggen, en, tevens hoe derzelver inlijving aan de oorvleugel bij $g$, II. Afd. v. Hoofdit. begint en eindigt aan de nok van het fteent been $\mathrm{bij}_{h} h$, van war hetzelve door eene yrij fterke Ipier $i$, eene zeer groote kracht oefent op het midden van het bultig ge, deelte van het kokerkraakbeen, bij $k$. Om, nu deze uitwendige gedaante verftaanbaarder kraakbeen: te maken, geven wij in Fig. 5. eene af, teekening van het oor, perpendiculair doorgefneden, het geen men bij casserus noch elders, niet vindt afgeteekend, en het geen wij echter zeer noodig oordeelen; om dat men noch zijdelings, noch regt- Doorfnijftandig, deze regte geftalte nier afbeel, ding van den kan; wij hebben dus bij Fig. 5. een het koei. dwarsduorgefneden Koeijenoor naar het le- jenoor. ven afgebeeld, en wel aan de inworteling fig 5. van den oorvleugel van het fteenbeen, welke gedaante een iegelijk gemakkelijk kan nagaan in een afgevilden koe - of kalfskop, en die mogelijk, om dat dezelve algemeen genoeg bekend is, dikwijls wordt overgefla. gen. Zij is nogtans zoo toepastelijk op ons onderwerp, dat zij met reden hier bij behourt, om dat alles wat wij door de voorfte deelen van de oorfchelp, mitsgaders derzelver fpieren, betoogt hebben, volftrekt niet kan verftaan worden, zonder deze Fi. guur. Men ziet dus bij a de eerfte holte, dia 


\section{NATUURLIJKE HISTORIE}

ner die de oorfchelp (helix) an de oorvleu Rundver. gel formeert, en waar uit de lucht in de

II. Afd. groote oorkom fluipt. Bij $b$ is de kleinere

Hoofdt. holte, waar in de lucht of het geluid ver. fijnt wordende, in de kromte of bult van het kraakbeen, (zie Fig. 4. bij $c$,) langs deszelfs wand bij $c$, insgelijls in de groore ge. hoorkom $d d$ eindigt, terwijl er dan nog een derde holte is, die in zijue groeve de tegenftuitende lucht vangt bij $e$, tot dat de geluiden in de groote kom geconcentreert, en de onzuivere dampen, of andere uitwendige beletfelen, in deze kommen hangen blijvende, in het aldaar verzameld oorfmout, de luchtftroom zuivert en verfijnt (purefactus), door de opening van den gehoorweg bij $f$, verder de andere deelen aandoet, en welk geftel nog nader zal voorkomen. Bij $g g g g$, zijn de randen en aanhangfels van de plaat $\mathrm{x}$. oorfchelp en deszelfs kraakbeen. $\mathrm{Na}$ het Pfg. 6. verklaren dezer Figuur, zal die van Fig. 6 . gemakkelijk volgen. Hier ziet den Lezer eene zeer fraaije afbeelding van het Koeijenoor van binnen, tot in de holte der lepel, oorfchelp of vleugel $a$, wanr in de luciut of het geluid, tot in deszelfs fluiting $b$, gevangen wordt, of liever eene wederkaatfing of dreuning maakt op de inwendige konsttuigen van het gehoorgeftel. Dit gedeelte is voornaamlijk gezuiverd van den uitwendigen huid, die aldaar den gehoorweg omvlecht; dus vertoont zich bij $c$ de ombuiging der oorfchelp, of den rand der aorlepel, die men helix noemt, en die in de

Koei- 


\section{A H OLLA N D. 29}

Koeijen altijd zeer aanmerkelijk groot is, AEt in tegenftelling van eenig ander dier, der- RUNDver, zelver omkrulling vertoont zicli daarom ook II. Afa. zeer aanmerkelijk in den kraakbeenigen omflag bij $d$, alwaar dezelve duidelijk doet zien, dat door deze feuf de eerfte en zwaar. Binnen. 1te luchtdrcuning invalt, en wel door de oor leuf。 groote holligheid, die uit de gemeenzame holte der oorfchelp, in het begin, of de eigenlijke opening des gehoorwegs, bij $e$, invalt, en voorts indringt door de treg- Tregrer: terwijze buis. $f$, alwar de cerfte gehoor-wijze geweg, of liever de luchtdreuning nader ver. hoorbuis.

fijnt wordt, even als het geblass op een trompet of waldhoorn, van den blaastromp af, in de buizen der trompet wordt voortgeftuwd, terwijl men, zonder van inbeeldi. ge vergelijking te kunnen befchuldigt worden, zeer wel de inwendige bultjes of kraakbeenige uitfekken, die men in alle ooren, aan het begin dezer trechterbuis vindt, kan vergelijken hij de lippen van een tromperblazer, die daar door de luche en zijn geblaas zoodanig moduleert, als de onderfcheiden geluiden vorderen, (zic Fig. 5.) en die eene Koe, of ook een Mensch zelve, zoodanig opent en fluit, als de geluiden door het gehoorlid gevangen kunnen worden, en dus op het zintuig. werken, te meer, daar het zeker is, dat alle geluiden of luchtdreuningen, die op het gehoor der Die. ren kunnen werken, niet alcijd door het dier gehoord worden, ten minsten indien dezelve onaangenaam, ja onnatuurlijk zijn, en het 


\section{NATUURLIJKE HISTORIE}

MET Dier als 't ware hier voor de ooren fluit? Q UNDVEE. doch hier van iets nader bij het verhandelen

II. Afd. over het geluid en de ftem der Koeijen.

V. Bij $g$ zier men aan de cene zijde de kraak. beenige oorfchelp in eene hoekige geủaante eindigen, welkers punten in de bovenverklaarde Figuur 4. de fpier van het fchildbeenig gedeelte omvangen... $\mathrm{Bij} h$, aan de andere zijde, eindigt dezelve oorfehelp an omplooi. het uiterfe der omplooi, insgelijks in een puntig gedeelte, waar aan èn aanhangfel van een kleine beweegfpier $i$ is, die naar het fteenbeen $k$ loopt. Eindelijk ontdekt Hetfteen.zich nu het fteenbeen (os petrofum) in been. deszelfs geheel ontbloote, en van fpieren gezuiverde gedaante bij $1 / l l l l l$, deszelfs Figuur is zeker zeer wonderlijk en van allerlei gedaante, nu knobbelig, dan pun. tig, dan hoekig, gekromd, doorboord enz dan vermits alle deze affcheidingen en ge. deelten nu afzonderlijk ftaan te volgen, is deze Figuur voldoende genoeg om het geheel te begrijpen. Alleen, eer wij tot nadere verklaring overgaan, dient men te letten op

Plaat X. Fig. 7. waar in de anmerkelijke gehoorFig. 7. Zenuw $a$, die uitwendig in het midden van

Gehoor de bolligheid van het fteenbeen te zien is, en bij voorraad hier te berde komt. Bij $b$ ziet men de holligheid van het aanmerkelijk gat, in het fteenbeen altoos bij uitnemendherd te zien. Dit gedeelte van het fteenbeen heeft, om zijne gedaante, den naam van teseen.

Tepel- pelbeen (os mammillare maftoides), gelijk 
dit de Figuur zelve bij $c$, wel aanduide, HeTWij vervolgen mee Figuur 8 .

Deze Figuur geeft thans eene nadere en II. Afa. nog duidelijker opheldering aan de hand, om de werking van het kraakbeenig oorgeftel, onderling met het bijoor, op het fteenbeen, in welkers holligheden de fijne gehoordeelen zijn opgefloten, te kunnen bevatten.

Onze aandachitige Lezers; door de vorige Figuren alrede op den weg gebragt, zullen weldra in Figuur 8. ontdekken, dat de oorfchelp of vleugel hier wederom ten halven afgefcheiden vertoond worde, en vervol. gens, dat bij $a$ het kraakbeenig gedeelte zich van achteren opdoet: deze gedeelten zijn hier voorgefteld; oin ons allengs tot de kennis der voornaamfte inwendige deelen te brengen, gelijk dan vooreerst het alrede vermeld fchildbeenig kraakbeen in deszelfs volkomenheid bij $b b b$ zich opdoet: het vertoont zich hier in der daad als een foort van fchild, de holligheid van hét bovenge- oorbeen. declte $c$, en de fleuf tusfchen het ondergedeelte, maken te zamen als een rondachtigvierkant uit, terwijl de bultachtige uitftekkẹn $\mathrm{bij}_{\mathrm{j}} d d$ de opperfte aanhangfels zijn, waar aan de tweefplitfige banden of fpieren - bij $e$ in en aan den engen gehoorweg, of de trechterwijze buis $f$ van het gehoor gehecht zijn, en dus hier duidelijk de werking van dit fchildbeen op den gehoorweg antoonen, terwijl in het eigenlijke fchild de fpier $g$ uitfpruitende, deze bij $h$ in en 


\section{NATUURLIJKE HISTORIE}

Hzt op de oppervlakte van het boverigedeelte nuNDVEe. van her fteenbeen ingelijfd zijnde, al\%oo het

11. Afd. fchildbeen op hetzelve zoo vast aan doet

V. fuiten, als twce oesterfchelpen door hunne pees doen, dermate, dat het bovengedeelte van het fchild-kraakbeen, van boven op de trechterwijze gehoorweg fluitende, het on: derfte en grootfte darentegen op het gat of de opening van her feenbeen $i$ fluit; ter plaatfe daar de eigenlijke inwendige lleks gewijze of horendraai begint, dat men in het

Horen- Latijn concha noemt, waar door men ver: diraai of kromme gehoorweg. ftaat, bij vergelijking, den draai of de wen: teling, die men in een zeekinkhoren of flek: kerhoren vindt, en die men wel degelijk moet onderfcheiden van de oorfchelp, die ook wel Concha, dat is fchelp, genaamd wordt, doch die zeer vernuftig. door de ouden in Helix, of ook Ala, dat is oorfchelp, of vleugel, ook oorfchijf, onderslekken. fcheiden is van de eigenlijke Concha of flekhuis. kenhuis.

De opening daar van ziet men nu bij $k$ duidelijk, gelijk ook de affcheidingen der wanden, die de wenteling van het flekkenhuis formeren, en inwendig de kleine opening, die verder inwenteld, en ftraks nader zal ontbloot worden. Om nu wijders eere volmaakte bevatting van deze zonderlinge en bij de Koeijen zeer opmerkenswaardige gefteldheid en werking te bekomen, dient men te letten, dat deze Figuur 8 het fchildvormig kraakbeen omgenagen vertoont, als een blad in een open boek, 't welk men 


\section{$\checkmark A N H O L L A N D .225$}

naar helieven om - en openflaat, waarom dit fchildbeen ook in zekeren zin draaibeen

(rotula) genaamd wordt, en zeker in de 11 Afd. Koeijen vooral zeer eigenaardig, vermits men het voelen, en zien kan in de opgeV. Hoofdif, melde beweging. Eindelijk vertoont het feenbeen zich alhier in zijne geftalte, zoo als herzelve an onderfcheiden 'beenderen des hoofds is gren'ende, als bij $l$ aan het jukbeen os jugale), bij $m m$ aan het veel. vormig been (os mulifforme), zijnde $l$ het uitftek of puntgewijs gedeele van het fteenbeen zelve; eindelijk ziet men in deze Figutur bij $n$ wederom de groote fpier die het boven-oor regeert, en bij de Figuren 1,2 , vooral bij 3 . is befchreven; voorts zijn bij $m m$ de hoeken des feenbeens.

Het geheele oorgeftel, in zijne vereenig. de geftalce met her fieenbeen, op allerlei wijzen en, rigtingen vertoond en beichreven ziinde, gaan wij nu over tot de afzonderlijke deelen der geheele zamenftelling, waarin men dan de yerbazendite wonde. ren zal ontdekken, wel waardig, dat on. ze weetgierige Landzaten dezelven kennen, om, al waren $z \mathrm{ij}$ geene Ontleedkundigen, uit het begrip onzer voordragten, in befpiegelende vermakeli,kheden, de groorheid des Makers te leeren kennen, waar toe zeker niet altijd zulk eene diepe geleerdheid behoort, als men voorgeeft: de Natuur is in alles klaar, eenvoudig en waarachtig, zoo dar een Mensch, mer na. 


\section{ص26 NATUURLIJKE HISTORIE}

FET tuurlijk en gezond oordeel begaafd, alles RUNDVEz. $z 00$ wel kan bevatten, als dikwerf groote II. Afd. vernufen.

V. Hoofdit.

Plaat X. gedeelte van het fteenbeen, omgekeerd, zoo Eig. 9.

als hetzelve met verfcheidene bogten, groe. ven en gewrichten, aan de inwendige beenderen des hoofds, eigenlijk den bodem van het bekkeneel, is ingelijfd, en waar van zoo dadelijk eene nadere verklaring zal volgen. Het hoofdoogmerk van onzen voorlichter CASSERUS is voornamelijk om aan te toonen, waar en hoe, of door welke deelen de Enge ge- enge gehoorweg ligr en beftuurd wordt: dus hoorweg. teekent hij bij $a$ een zeer dun fpiertje aan, hetwelk het bijoor, of eigenlijk het oortje of de opening van de enge gehoorwegbeítuurt, herwelk hierom Auricula genaamd word, Bijoortje. 't geen in onze fpraak bij vermindering oor. tje beteekent, als zijnde kleiner als het geheele en groote oor. $\mathrm{Bij} b b$ vertoont zich een velachtig, als 'c ware geplooid, bekleedfel, hetwelk inwendig het gedeelte van dezen gehoorweg als een kleed bedekt; bij $c$ vertoont men nu het cerst de opeTrommel-ning, die inwendig naar de trommelyliezer vliezen. of gehoortrompetien (Tympanumi). loopt:

Gehoor deze opening is hier half levensgroote uit eene Koe vertoond, gelijk ook verfcheiden der volgende. Bij d eene groote luchtholte van het fteenbeen, zoo ook bij $e$, en wijders bij $f f f$ verfchillende hoeken van hetzelve, die bij de volgende Figuren nu zullen voorkomen. 
Deze twee Figuren, 8 en 9, hoe zeldzaam derzelver maakfel ook fchijnen moge, zijn echter van zeer veel belang, om al het gene alrede verklaard is op te helderen; want daar alle de verhandelde afbeeldingen meest HeT
RUNDVES: allen de gehoorwegen van de oorlel of lepel af, tot in de omwinding der fpieren, en de inglooijing in het uitwendig fteenbeen vertoond hebben, zoo zijn deze Figuren dienende om den gehoorweg, de gehoorbuis, de gehoortrechter, en de overige holligheden. midden door hee fteenbeen te befchrijven. Bij Fig. 5. is de opening of liever de ingang van het gehoor verbeeld, dat wij gaarne het portaal wilden noemen, of de deur des gehoors, om dat Gehoos? de geluiden en de lucht die in de holte der gehoorvleugel of fchelp indringen $\downarrow$ door dit portaal, als door een bijzonderen ingang, in de binnenfte gehoorvertrekken of kameren moeten indringen, naar mate deze zich openen of fluiten, of open of verftope zijn, hetwelk men duidelijk ondervindt, als men den vinger in het oorgewelffel fteekt en deze opening drukt, als dan hoort men nier, ten minften zeer dommelig en bedwelmd; doch zoo dra neeme men den vinger niet weg, of men hoors weder even fcherp, zoo ook wanneer men als ' $t$ ware door eene echo of wederklank hooren wil, dan legt men de holte van de hand tegen het oor, of men buigt de oorlel, en men hoort door wederklank: er is in dit opzige onder onze Landzaten aan de Hoofdot portash. 


\section{NATUURLIJKE HISTORIE}

max franden een zeker kneepje bekend, om na. melijk de zee te hooren ruifchen, dan houdi

.13. Afd. men een zeekinkhoren aan het oor, en in

v. dér daad men hoort een geruisch, doch dit

Hoofdrt. is niets anders dan een wederwerking der luchifiroom en het zeegeruisch op den hijlen draai der flekhoren, even zoo als die, welke daar na in het gehoorgeftcl gehoord wordt; ondertusfchen, indien men een holle le. -pel, een theekopje, of een ledige flessch aan het oor brengt, zal men hetzelfde gewaar worden, dat genocg bekend is. Dit geruisch, of liever deze luchtfroomende dreuning, wordt eerst, zoo als betoogd is, gevangen in de gemeene oorfchslp, en de holle bogren, die de fleuf der omvouw aan den rand der lepel formeren, daarna - nuipt dezelve lucht door de openingen der inwendige fleuven, in Fig. 5 en 7 vertoond; dit gedeelte vervolgt zijne buis inwencig door het fteenbeen, en bekort taar den naam van de gehoortrechter of de gehoorTrrmpet weg, de trompetbuis; dit gedeelte komt buis. nu in Fig. 10 te voorfchijn: bij $a$ is de Fig. Ic. affnijding van het bovengedeelte, bij Fig. 5. door ons afgeteekend; dir gedeelte duid door kleine ftippen de fpruchrels van eenige haarftoppels aan, die men in alle dieren, doch inzonderheid in de Koeijen ziet : het is coor deze haartjes, dat het $z$ weet, de vogt van regen en andere ftofjes belet worden om in de gehuor: buis in te dringen, ja ook volgens ande= rèn zijn dezelve ook gefchikr om de in- 


\section{$\checkmark A N$ HOLLAND. 229}

inwendige uitwafemingen te vangen, waar HeT van dan het oorfmout of oorvuil altoos RUNDVEEs meest in de opening van deze buis legt. II. Afd. Deze buis nu wordt in Figuur 10. bij $b$ IV. vervolgt, midden door den hollen fleuf van Hoofdit. het fteenbeen zelve bij $c c c$, tot dat de-Oorfmoutzelve mat eene inkromining bij $d$ binnen-buis. waarts zich in de gehoorkamer tot op het trommelvlies verliest, alwaar de luchtdreuning door deze buis ingelacen, zijne veer. kracht oefent: het is deze buis, dic, als dezelve of verttopt of verzworen is, door kincierziekte of andere toevallen, de doofheid veroorzakt, alfchoon het inwendig gehoorgeftel nog in goeden ftaat is, warom men dit gebrek nog al met zekere horentuigjes verhelpt. Dan, dit in 't voorbijgaan. Deze buis, die meerendeels in den hollen neuf van het fteenbeen velachtig en viiesachtig is, en in het geheel niet hard kraakbeenig mar teeder en onifpannende eindigt bij $d$; voorts doen zich de wanden van den fteenbeenteuf doorge zaagd op bij e eeee, want men gelieve op te letten, dat deze gehoorweg, die men den engen noemt, hoorweg. niet uitwendig zigtbaar is, en niet kan vervolgd worden, dan door middel van doorzaging van het geheele fteenbeen, waarom dan ook de aangrenzende uitftekken van hetzelve in hun geheel aan hetzelve verknocht vertoond zijn, als onaffcheidelijk van het geheel.

Nu overgaande tot Figuur II, ziet men P 3 da2s 


\section{NATUURLIJIKE HISTORIE}

HVT daar dezelve enge gehoorbuis of gehoorweg RUNDver. (Meatus ancufficus) in eenen ongekeer-

II. Afd, den ftand, en tvel zoo, dat men nu des-

v. zelfs uitcinde van den gehoorweg zien kan Hoofdrt. te eindigen op en aan het zoogenaamd Plaat $\mathbf{X}$. trommelylies (Membranum tympanum), Fig. II. dus ziet men bij $a$ de trechterswijze Trommel buis of de opening van den engen gehoorslies. weg even als in Figuur 1\%, doch eenigzins meer gedrongen in den fleuf van het fteenbeen, tot daar dezelve bij $b$ als eene

- holle pijp afgefcheiden cindigt, gelijk de af beelding vertoont; deze holte nu fluit of ftuit op de bolle oppervlakte van het trommelvlies bij $c$, waar van men niet dan eenig aanwezen zien kan, maar hetwelk dadelijk nader zal vertoond worden; dit vliesje is meest altijd doorfchijnende en taai, doch niet te min teeder.

Steen- Wat nu aanbelangt de gedaanten van het fteenbeen zelve: deze geven in deze Figuur een voldoend licht wegens de ligging van den gehoorweg in de Koeijen; want gelijk in Figuur 1 en 2. de werking der bovenite gehoorfpieren en derzelver inlijving uit en aan de horenwortel en de kaakfpieren ver. toond en verklaard zijn, zoo geeft dit afgebeeld been een begrip van de plaatfing van het inwendig gehoorgeftel, insgelijks an de oorwortel: dus fchetst onze lieenfiguur bij $d d d d$ volkomen de holle groeven, waarin de horenwortelen of derzelver groeiftoffen leggen, en den horen gehecht is, en hetwelk men kan vergelijken met de be- 


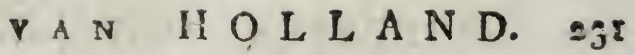

fchrijuingen en afbecldingen der horenen $\mathrm{BEx}$ in Hoofdltuk IV. der eerfte Afdeeling. Rundver: Hier moet en kan men zich dan gereede . II. Afd. lijk voorftellen, dat het beengedeelte $e$ het voorhoofd aan den horen, en $a$ het oor op Hoofda. zijde verbeeld, en dus gevolgelijk is bij $f$ het achterlte ondergedeelte van het hoofd, waarin de groevingen en inwrikkingen van het fteenbeen in her veelvormig been, en de aangewezen holligheden door $g g g g$ zijn aangeftipt; voeg nu bij deze twee op. merkelijke Figuren I0. en II, Figıur I2, Plaat $x_{0}$ dan zal men eene nog nader vatbaar-Fig. 12。 heid van het inwendig gehoorgeftel met opzigt tot de twcede befchouwing bekomen, om dat in deze afbeelding het begin van het flekkenhuis (Cochlea) met zijn fpier. tjes meerder ontbloot voorkomt: dus ziet men bij $a$ het inwendig fpiraal door de spiraal. ronde opening van het been als ' $t$ ware influipen naar her trommelvlies bij $b$, eigenlijk de draai of wentel van het flekkenhuis, ontbloot van het dunne gedeelte des fteenbeens dat het bedekte; bij $c$ doet zich eene kleine fpier zien, wier inwendige werking mede op het nekkenhuis andringt, $d d$ het tepelachtig uitftek van het fteenbeen, e eee de gewrichten van het fteenbeen inwendig aan de flaap - en jukbeenderen, $f f$ holte van deze beenderen of kameren der lucht.

Tot hier toe zijn nu meest alle de gehoorbeenderen, voor zoo verre die uit hunne gewrichten afzonderlijk gewrongen en afgefcheiden zijn, in allerlei vitwendige 


\section{NATUURLIJKE HISTORIE}

HEx gedanten vertoond, thans zullen wij de: XUNDVE zelve eens inwendig openen, als wanneer

II. Afd. het verbazend kunstwerk van het werkruiV. gelijk gehoor ten klaarfte zal toegelicht Hoofdit worden. In vele en wel de meeste befchrij. vingen der vorige Figuren, makkten wij telkens gewag van de gehoorwegen, vooral val het trommelvlies, doch nu volgen de ftampertjes, kloppertjes, hamertjes (Mallei); dit nu 2 al de zeer fraaije Figuur 13 . ons voor oogen brengen.

Plaat X. Men lette dan op deze Figuur; dan ziet Fig. 13. men het onderfte gedeelte van het fteenbeen, digt aan deszelfs tepelachtig uitftek doorgezaagd en uitgeveild, in dier voegen, dat het trommelvlies en deszelfs rand, mitsKlopper-gaders de kloppertjes, ongefchonden te voortjes. fchijn komen. Dit gedeelte is levensgroote uit een jong kalf genomen, en dus vertoond het zich in zijn geheel. Sla uw oog eens, onder oeklievende Lezer! op de aanduiding bij $a$, daar ziet gij een rond gefpannen vlies, hetzelve wordt omringt door

De trom, een beenen ring of rand bij $b b$; deze rand melring. en dit vlies behoeven geen bewijs van ver. gelijking met een gefpannen bereid perga. ment of kalfsvel over den rand eener trommel: de gediante beantwoord dus aan de gelijkenis eener trom, maar nademaal een gefpannen trommelvel geen geluid geeft, zonder de roering der trommelitokken, wie moet dan niet wegzinken van verwondering, als hij ziet, dat aan den beenachrigen trommelrand, een allerkonstigst beentje is, hetwalk 


\section{VAN HOLLA N D. 233}

welk op zijn eigen zenuw/pilletje en rondach- HET tig bolletje, door de luchtdieuning, die RUNDVE, door de gehoortrechter tot op dit, als 't wa- II. Aft. re, fcharniertje gebragt wordt, beweegt en op het vlies nu hard, dan zacht, dan fijn, V. dan grof tamboert, en zoo op het trom- Trommel. melviles werkt, zoo dat de aandoening der ftok-ze. geluiden, onder het trommelvlies, weder-nuwtje. om in de flekkendraai indringende, eindelijk de fijne gehoorzenuw aanprikkeld, en de zicle doet hooren. Bij $c$ ziet men bij voorraad, dit kloppertje of hamertje, omtrent levensgroote, op zijn bollerje afgebeeld, dadelijk zal het nader voorkomen. Voor het overige doen de bijdeelen bij $d d$, zeer fraai zien, hoe het repelachtig uittiek, (pro. cesfus Mammellares) hoe hard het uitwen. dig fchijne, evenwel van binnen zeer fraaije holligheden heeft, die warfchijnlijk het hunne toebrengen tot inwendige luchtcellen Luche of kamertjes. Bij $e e$ is het grootfte ge-celletjes. deelte van het fteenbeen, aan de bovenkant, insgelijks holachtig te zien, en het been zelve in zijn harde uitttek bij $f f$, dus dan geef deze Figuur 13. een nader en zeer goed denkbeeld van het geen bevoorens is voorgedragen, hetwelk bij vergelijking nader kan begrepen worden, als men het oog flat op Fig. I 4. alwaar hetzelve been, bij tegen Plaat $\mathbf{X}_{\text {: }}$ vergelijking, in zijn geheel voorkomt, en Fig. 14. voldoende is, als men bij a a den uitwendigen engen ingang der gehoorweg, (Meatus ancuficus,) ziet, die in Fig. 13. op het trommelvlies werkt, en wijders bij $b b b$ de 


\section{NATUURLIJKE HISTORIE}

HET invoegfels en deelen van het fteenbeen, die RUNDVEe. in Fig. I3. doorgezaagd zijn, zoo dat, bij

II. Afd. vergelijking, Figuur I4. de noot, en Fig. V. I3. als de kern vertoont. Bij $c c$ zijn de Hoofdro '3. Wanden van het fteenbeen.

plaat x. Nu komt bij Figuur 15. hetzelve tromFig. 15. melvlies andermaal voor in de holte van het reeds gemelde tepelbeen (os Maftoides), waar in naauwkeuriger deszelfs werking, door middel der fpiervezelen, de zenuw en de kloppertjes worden aangewezen. Deze fraaije Figuur verdient hierom al mede eene bijzondere opmerking, te meer, daar dezelve, in zijne natuurlijke grootte, uit een kalfskop genomen is, en ftraks de geheele - verklaring van het gehoor zal ophelderen, zoo dat wij hier flechts de aanduiding der deelen zullen aanftippen.

Verkla. Bij a ziet men het trommelvlies, als mee ring van fijne ftreepjes, in den ring, die hetzelve het klop omringt, in de holligheid van het tepelbeen.
pertje.

Bij $b$ het beenachtig ringetje om het gefpannen trommelvlies, vergeleken!bij Fig. 13 . Bij $c$ vertoont zich de ftaart van het kloppertje; dan onder dit kloppertje of hamertje moet men hier wel degelijk in opmerking nemen het eivormig fpiertje dat $\mathrm{bij} d$ is aangeftipt, als zijnde dit pierrje, tot nog toe, in de voorige Figuren niet vertoond; hetzelve re geert en beweegt volkomen het aangeduid kloppertje aan deszelfs gewricht.

Het ze. Bij $e$ ziet men een zeer klein takje oprijnuwboor: zen, dat men als een zemısskoortje (chorda) ๘je. 


\section{AN HOLLAND. 235}

aanmerkt. Dit zenuwkoortje is het, dat de aandoening der trilling van de lucht, op het RUNDVeE. trommelftokje of kloppertje overbrengt. On- II. Afd. der dit zenuwtje bevindt zich een hoekig beentje, hetwelk onmiddelijk aan het ach$\mathrm{V}$. terftel van het kloppertje gevoegd is: zie bij $f$. Dit beentje noemt men cambeeld Aambeeld.

(incus), en in dien zin bekomt dan ons tot hier toe genaamd kloppertje, den naam van hamertje (malleus), dat op her aambeeld tikt, even als een fimitshamer op het aam. beeld; zoo dra hetzelve in trillende'bewe. ging komt, en wel door de luchttroom, die in de hoiligheden van het tepelbeen bij $g$ verzameld zijnde, op deze teedere deelen werkt, dermate, dat dit geheele anmbeeld en hamerftel geheel en al omringd en gedrukt is door de lucht, die uit den engen gehoorweg, zie Fig. 10. en 11., in deeze holle ruimte geperst wordt.

$\mathrm{Bij} h h$ vertoont zich de bult of het uit* wendig gewelf van het tepelbeen op zijde, daar het anders, zoo als in Figuur $6, \mathbf{I} 2$. en 14, als regtftandig nederwaarts verroond is

Bij $i$ ziet men de bafis of het Jteunbeen- Steunbeeni ije van het hamertje, bij wijze van een tje. fchubachtig omflag. Voorts bij $k$ het gedeelte van het fteenbeen aan het tepelbeen verknocht, waar in op te merken is bij $l l$, de holligheden des beens. Bij $m$, de opperfte fchelp van het fteenbeen, waarin de enge gehoorweg influipt, gelijk bij $n$ de opening daar van zich opdoer. Bij 0 is de groef, 


\section{NATUURLIJKE HISTORIE}

Hет groef, in welker holligheid de fpier van het RUNDVEe. fchildwiis kraakbeen is ingelijfd, zie Fig 8.

II. Afd. Eindelijk doet zich bij $p$, eene inwendige IV. zenuw op, die, alhoewel zij veelal bij velen thoofdit. zcer onvoorzigrig van de gehoordeelen ge. fcheiden wordt, niet te min cenen ongemeenen invioed op de fluiting en ontluiting der gehoorbuizen heeft, zelfs, naar mijn inzien, zoo fterk, dat zeer dikwijls an her verlam. wen dezer Zenuw., de vollagen doofheid, tot een zekeren trap, zijn oorzaak heeft. Voorts is bij $q q$ de anwijzing van een gedeelte van het flaapheenig aanhangfel van het fteenbeen. Nu volgt nog duidelijker P'n $\mathrm{X}$. uitleg bij Figuur 16 , waar in nog eens afFig. 16. zonderlijk het trommelvlies met den hamer en het aambeeld voorkomt, hetwelk met dezen korten uicleg volftan kan: $a a$ is een gedeclte van het repelbeen, met verfchillende holligheden en draaijen zigtbaar, $b$ de been: achtige ring van het trommelvlies, $c$ het trommelvlies zelve, $d$ het klopperije of hamercje, $e$ het aambeeld (incus), $f$ de eivormige fpier, $g$ het zenuwtje, $h$ het holte van het fteenbcen.

Tor hier toe de voornaamfte gehoorbeen. deren en derzelver kleinere deelen verhan. deld zijnde, ontbreekt er nog een anmerkelijk gedeelte aan, namelijk dat gene, hetwelk aan het uitftek van het fteenbeen grenst, ter plaatfe alwaar hetzelve aan de gewrich. ten der kaaken en der inlijving van de geweldige kâuwfpieren, (Maxillares Masfe. teres) cnz. uitfteekt. Dit gedeelte is des 
aanmerkelijker, om dat hier vooral in ogen. fchiin komen het zoogenaamd fijgbeugieltje en he: pedunculus, het hamerkruis enz.

In Fig. 17. bij a a a a vertoont zich zeer fraai de inwendige zelfftandigheid van het fteenbeen, daar her een gedeelte van het flaapbeen (os temporis) omvangt; aan en Heltie. omtrent het kaakbeen: dit gedeelte is geheel kruis. inwendig vol holligheden als puimfteen, of, 200 als wij elders hier boven vermeld heb Plaat $x$. ben, als een koraalachtig zeegewas; men zoeke dit bij onze verhandeling over de Beengroeijing in Hoofdituk I. dezer tweede Afdeeling, hier in deze Figuur ontbreekt niets, om niet de puimfteenachtige gedaante, zoo als casserus wel zegr, te erkennen.

- Bij $b$ vervolgens vertoont zich hier nu den waren grondnag en inlijuing van den beenachigen ring van het trommelvlies, die anders in de voorige Figuren als losleggyende fcheen; $c$, het trommelvlies, of zeer dun gehoorylies (meninga), boven reeds befchreven; $d$ het hamertje of kloppertje (malleus); e het eenvormig fpiertje; $f$ het ambeeld van agteren, met zijne rwee zigibare ftanders; g het zoogenaamd ftijgbeugel. rje, zijnde een driekantig beentje, dat zoo genoemt wordt, om de gelijkheid van den ftijgbeugel aan een gezadeld pard. Voorts bij $h h$ wederom een gedeelte van het fteen. been, als boven; bij $i$ de bafis van het fponsbeen.

Nu komt in Figuur I8. nader voor een Plart $X$. afgefcheiden gedeelte van het inwendig ge Fig. 18. 


\section{$23^{8}$ NATUURLIJKE HISTORIE}

mET deelte, waar in de flekswijze draai in zijne sundver wenteling zich opdoet. Deze draai worde II. Afd. bij fommigen der nieuwere ontleedkundige $v$. gantsch niet oneigen, het doolhof (labyHoofdit. s-inthum) genoemt, om dat derzelver fpirale draai, als de wegen van de platre afteekening van een doolhof zijn. In de holle fpirale kringen, die deze draai uit zijn centrum maakt, loopt een fijn zenuwtje, als een draadje, welk zenuwtje, een elastik en inkrimpend vermogen hebbende, eindelijk in het hersfengeftel en de gehoorzenuwen; of liever het merg, zich verliest, en waar in dan alle menfchelijk londerzoek eindigt."

Men ziet dan nog bij $a$ het fubtiel oppertopje dezer draai, even als men op den top van de flekkenhoorn, die wonderlijk fubtielen draai als in een toppunt ziet eindigen.

Bij $b$ is de holligheid, waar op het eironde gehoorfpiertje van het aambeeld rust en ingelijfd is. Bij $c$ is al wederom de holligheid van het fteenbeen tegenwoordig.

Plaat X. - Maar nu in Figuur 19. Hier ontdek Fig. 19. zich nu geheel en, al, zoo nabij de tekenkonst dit met mogelijkheid konde afbeelden, en de lettertekening dit aanduiden. $\mathrm{Bij}$ a het fijne zenuwdraadje of peesje, dat

Doolhof. den draai van het doolhof, van deszelfs begin af, volgt. Dit geheele geftel is met alle omzigtigheid gezuiverd van flijm en andere ftoffen, zoo dat het hier geheel bloor voor oogen legt, en wel bijnaar leven!groote uit een Kalf genomen, want men gelievè op te merken, dat deze fijne 
deelen meest in jonge Kalveren, en in den Mensch in jonge Kinderen worden erkend en bereid, aangezien deze deelen in volwasfen Koeijen, Menfehen en alle andere Dieren, dermate verhard en fteenachtig zijn, dat het fchiel ondoenlijk is, om dezelve zonder kwetzing of misvorming voor te dragen, waarom dan ook, zon men al tor zoo verre, door geduld en oefening, komen wil, om dit geftel in oudere Dieren te ontleden, men als dan de toevlugt tot de vijl moet nemen, en door taai geduld, met allerlei foort van vijlen allengs de fteenbeenen afvijlen, tot op de fijne wegén van dit zoogenaamd doolhof zelve, waartoe waarlijk 'eene meer dan gewone handigheid vereischt wordt: eene eer die eenen VALSALVA in den hoogften trap toe. komt, en zekcr moet ik hier aan den beroemden Baron VAN ZWIETEN, mitsgaders deszelfs Zwager, den kundigen Doctor NOORDWIJK, zoo wel als den Hoogleeraar ALBINUS, regt doen, ten aanzien der bijzondere handigheid in het vervaardigen van deze gehoorbereidingen', welke na hunnen dood in de Kabinetten verfpreid; als nog in. 200 veel hoogachting onder de kenners der beenderen worden gehouden, als de bereidingen van RUISCH en LIEBERKUN ten aanzien der fubtiele opfpuitingen der bloedvaten, in net oog en andere. Onze CASSERUS zelfs, hoe getrouw zijne af beeldingen zijn, fchijnt deze manier van uitvijlen niet zoo

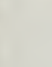

(1)




\section{NATUURLIJKE HISTORIE}

mex volkomen bekend te zijn geweest, althans RUNDVrr. wij vinden ze alzoo niet: gaarne zouden II. Afd. wij er eenige van voordragen, dan, daar

v. wij vreezen om te veel uit te weiden. en

Hoofdrt dezelve bij valsalva en anderen genoeg te zicn zijn, laten wij die berusten; on we af beelding kan volftaan, als men bij $b$ de wenteldraai van het beengeftel geopend op. merkt, $e n$ in deszelfs fleuf $c c$ lict \%e. nuwkoordje of draadje ziet, voorts bij d de groote geboorzenuw, die, hoewel grooter en meer uirwendig, evenwel onmiddelijk aan het fijne zenuwkoordje vorbonden is, en onzigtbaar goor de beenholte $e$ influipt.

Eindelijk, ter nadere herhaling on opheldering van de telkens aangehaalde kleine gehoorbeentjes, zijn bij Fig. 2ก, 21,22 en 23. de vier af beeldingen van casserus, van de klopperijes, het aambeeld en de ftigbeugel gevoegd, elk afzonderlijk in zijne $F_{\text {plaat }} \mathrm{X}$ gedanie: Figuur 20. vertoont dus bij $a$ ig. 24. het inwendige eirond fpiertje; $b$ het honfd van den hamer, herwelk door zekere luiting (gynglimoides) op de bafis van het admbeeld dringt; $c$ de ftart van den ha. Tikkertje. mer, eigenlijk het tikkertje, in zijn natuur. Dehamer.lijke gedaante; $d$ duidt de zenuw van den ftart. ftijgbeugel aan.

Figuur 21. doet al wederom het eivormig fpiertje $a$ aan de andere zijde zien, $b$ is het hoofd van het hamertje, zijncie het dikfte en ftomp einde van hetzclve, $c$ is de ftaart van hetzelve bij $d$, is het fijne pees- 


\section{VA H H OLEAND. 24:}

peesie, hetwelk van bet eivormig fpiertje zamenviocit, en aldaar in het been is ingelifits, $e$ het aambeeld; $f$ de ftijgbeugel.

Figutr 22: vertoont het aambeeld geheel afgemonderd van alle deelen: bij $a$ is deszelfs bolle oppervlakte; $b$ deszelfs uititek; c destelfs buik.

Figint 23. draage in een klein beftek de getaante van het ltijgbengeltje (ftapes). tets versroot, voor: bij $a$ is deszelfs op: pergedecle; $b$ de linker - en $c$ de regterhoekige uitftekken van onderen.

Dus hebben-wii, met alle mogelijke ge. trouwheid, de Figuren van casserus te. vens met vele onzer verbeteringen en bijvoeging van eenige nieuwe figuren, zoo wij vertrouwen, zeer ôphelderende voorgedragen; het zal nu aan den onderzoek. lievenden Lezer ftaan, om daar van gebruik te maken; ter volkomen bevatting van het gebruik het welk van deze deelen door de Koeijen gemaakt wordt, want dit ons doelwit zijnde, zal, zoo ik vertrouw, door het volgende de ingerogenheid, die ter befchouwing der afzonderlijke dee. len des gehoors ons een poos heetic opgehouden, weldra vetzoet worden door de aangename befluiten, die uit deze befpie; gelingen moeten voortvloeijen.

Bij de bijzondere deelen des gehoors it eene Koe, hebben wij tclkens de betrek: king, die ij tot dit dier bijzonder hadden, in onderfcheiding van die in andere dieren; opgegeven; hier nu is hec dé regre plaats Q

NET RUNDVEB! II. Afd, v. Hoofdá. 


\section{NATUURLIJIKE HISTORIE}

mat haar onze géwone wijze van voordragen, Rundver. om all' het bijzondere tot zijn greheel te

II. Afd. brengen: in dit opzigt is er een ontegenV. zeggelijk bewijs, dat en het gehoor, en de Hoofdrt. gehoordeelen der Koeijen veel verfchillen van die in andere dieren, en dus ten haren opzigte eigenaartig aan dit dier zijn.

De Ouden, en velen na hun, ftelden de gehoortuigen der Kocijen het naast aan die van den Mensch; doch de nieuwere en wij ook, erkennen er een' aanmerkelijk verfchil in. De gereedheid en geinakkelijkheid, om, als men maar wil, deelen van eene Koe of ook van eenen Hond te kunnen bekomen, in tegenftelling van die van een Mensch, heeft zeer zeker gelegenheid gegeven, dat door de kennis, die de onderzoekers uit de deelen der Dieren bekwamen, zij de\%elve overbrach. ten op die der Menfchen en dit is oorzaak geweest van gelijkenisfen, welker bevestiging anderzins moeijelijk was, alchans in ons $\mathrm{Va}$ derland, om redenen dat men hier minder gelegenheid had, om zoo gereedelijk de deelen van een Mensch te bekomen. Deze mogelijkheid was bij de Italiaan/che Ontleedkundigen grooter en vrijer, vermits zij ter voortzetring van hun onderzoek, zoo vele lijken of deelen daar van konden bekomen, als zij met befcheidenheid begeerden. Dit is dan ook de oorzaak waar aan wij alle die heerlijke ontdekkingen van casserus, EUSTÁ cHIUS, FABRITIUS, VESALIÚS en VALSALVA omtrent het gehoor verfchuldigd zijn: de 


\section{$\checkmark A N H O L L A N D .243$}

eerite heofe door vergelijking van die deelen in allerlei foort van Dieren het voerfpoor der Ouden, als: aristoteles, Galenus, hip. POCrATES, DEMOCKITES, DIOGENES, in één woord, van alle oude Ontleedkundige Grieken หอT RUNDYESo gedrukt: de tweede, namelijk EUST CHUS, alhoewel, hem de eer betwist wordt, heef ons de gehooritaafjes nader leeren kennen, en vooral die wonderlijke gehoorbuizen in den Mensch, die men naar zijnen naam de gehoorbuizen van etstachius noemt ( $T u b a e ~ E u$. fackianac), nok heeft FaloppIUs, insgelijks hieromirent ontdekkingen gedaan; eindelijk heeft VALSILV, alle de gehoordeelen, en inzonderheid de opgemelde buizen, wentelingen en doolhof beenderen allernaauwkeurigst afgebeeld, in 200 verre dat CASSERUS, hoe opletrend anders, die nier fchijnt ge. kend te hebhen, althans niet $z 00$ onder. fcheiden in de Koeijén. Wij hebben ons werk gemiakt, om in de Koeijen dergelijke deelen op te zocken, doch bekennen, dac door de moeijelijkheid van dit onderwerp, wij maar ten desle gellıgd zijn, waarom wij alleen herusten mocten bij eenige figuren, op Plaat X. afyebeeld; en verder nier willende treden in meerdere irgewikkelde kundigheden, vervolgen wij ons oncwerp.

Dus verfchilt dan her oor, de oorfchijf, Oorf́bijf. de lepel, de oorvleugel of oorlel, hoe men die gelieft te noemen, van die van alle an. dere viervoetige Dieren, buicen eenige herkaauwende, zoo als reeds gemeld is, in

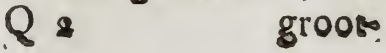

II. Afd V. Hocfda 


\section{NATUURLIJKE IIISTORIE}

BET grootte, ftand en gedaante, als zijnde zijonUNDVEE. lings geplaatst en horizontaal uitftekende.

II. Afd. Hier komt nu de vraag voor, of eene Koe

$\mathrm{V}$. hierom op eene andere wijze hoort of de Hoofdrt. geluiden vangt, als een ander Dier, in hetwelk dat zelfde foort van deelen of in gedaante of inrigting anders zijn geformeerd of geplaatst? De Naiuur fchept niets yergeefs, derhalve is dic geftel, in eene Koe, ook niet vergeefs zoo klaarblijkelijk onderfcheiden van andere Dieren; de Wijsgeeren houden het daar voor, dat de grootfte oorlellen, vooral als de inwendige deelen daar aan evenredig zijn, wel het zwaarfte geluid, maar niet het fijnfte ontvangen, en dit is niet-ongegrond, want als men her gehoor of wel de fijne gehoordeelen van een Paard, van eene Kat, van eenen Hond, volgens de tafelen van casserus, bij die van eene Koè vergelijkt, dan is hun zamenftel veel ingewikkelder, en althans ten anzien der werking op het trommelvlies, de hamertjes, het aambeeld en de wentelingen met bijzonderer werktuigelijke deelen voorzien, dan in eene Koe, ja in een Mensch; de zamenleving van den Mensch met deze Huisdieren leert dit zelve: een Paard, voor eerse, toont door die altoos werkende beweging zijner oorvleugels de gevoelige fijnheid van zijn gehoor; den Ezel, dic ongemeene groote ooren heeft, beweegt ze nog fterker, waar op de vernuftige ciss doelt, 2Is hij zijn Reiziger vermaant: 


\section{VAN HOLLA N D. 245}

Neemt vooreerst een Ezelsoor,

Dat is, past op uw gehoor.

II. Afd.

V.

Virgizius èn alle andere Latijnfche en Griek. fche Dichters, vereerden silenus Ezel met Hoofd?:

dien lof, dat, als de vette Baas door wijn bedwelmd was, zijn Ezel nog fijn hooren kon.

Maar wat leeren ons nu onze Honden? Zij fehijnen te llapen, zij fluimeren, ja, zeg ik, : zij llapen, maar ziet ze leggen aar den haard, onder het gerammel en gebroin van zainenfpraken, zingen, ja allerlei geraas, weten zij de ftem van een onverwache inkomende, het geluid op fraat, het minfte geritfel te onderfcheiden, en ontwaken, ftan op, loopen her - en derwaarts, zon. der dat men er reden van kan geven: vergelijk dit met eene Koe, met een Mensch zelve, wij zullen moeten erkennen, dat, hoe fijn ons gehoor is, hetzelve zeer zeker. tot zulk een hoogen trap niet werkt; wel. is waar, dat er Menfchen zijn die een buirengemeen fijn gehoor hebben, doch dir behoort tot zulk foort van gaven, die aan, elk geftel niet gemeen zijn, of liever het behoort tot een allergevoeligst zenuwgeftel, dat in het dierlijk leven in den eenen. gevoeliger kan beftaan dan in den anderen. Ik heb Vrouwen gekend, die zoo fijn van gehoor waren, dat zij woordelijk konden vertellen het geen verre af in een vertrek of in de, keuken ftil onder meiden of knechts gemom-s peld wierd; ik heb lieden gekend, die in den 


\section{NATUURLIJIE HISTORIE}

Het eenen hoek v̈an een vertrek aan den mur undver. luisterden, terwijl iemand van bet gezelfchap

II. Afd: aan de andere hoek binnens monds aan den $\checkmark$. muir fprak, on dat zij alles verftonden. Hoodd. Het is algemeen bekend, dat iemand vatbaar is tot flaaw wor 'ens toe, over het fijn gekners door het doorfnijden van eenkurk ver oorzaakt; ik zelve getuig, dat ik op het zien fnijden van een kurk altijd eene huiverion gevoel; men weet dat een fijn luifterend.Muzikant grillen kan als hij een wantoon hoort; men weet dat lieden, die-nimmen eenige regelen van maat of muziek gekend of geTeerd hebben, uic de nacuur de volmaakifte welluidendheden leeren en zeer groote $\mathrm{Mu}$. ziek-componisten kunnen worden.t..War is dit nu alles, "waar toe brenge gij, , vraage lige mijn Lezer, ditre berde?" kunnon Koeijên Muzikanten, Kapelmeesters, Componisten zijn? Ja wel, -zij zijn hër in hun foatt, niet om, even als de mensch, noten op te. teckenen, of muziek te ftellen die gefchike is voor den Mensch, maar haar geftel is

- naar haren aard varbaar voor geluiden, die. een ander wezen nict andoen : een Pard bemint het geluid van de trom en krompet, en wordt er moedig door; eene Koc integendeel wordt er angstig; dol, razend en woe. dend om, dermate dar als men iñode Stie. rengevegten een trom roert, dary worden de Stieren woedende. Men vindt gemeld, dar HANNIBAL en verfcheiden andere Vcla. bveriten, vooral de oude Germanen, do

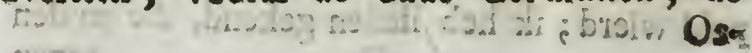
a.p.es 
Osfen en Koeijen in de fpitfen ftelden, en bij den annval met geweld van trommelgeluid en gefchreeuw, en ook met brandende toorten voor uit dreven, om in des vijands gelederen te vallen. Deze vrees voar $z$ waar HET: gebrom en geluid is, behalven aan de Koeijen, ook aan alle ander herkaauwend Vee eigen: de Duitfche Jagers jagen de angftige Herten een fchrik aan door den-trom en den toet-jagthoren. Het behoeft flechts een weinig opmerking, als men bij het exerceren onzer Soldaten in en omtrent eenig Kamp of Buurt, alwaar Koeijen zijn, er op let, zoo dra, hoort het Vee geen geratel van eenen trom en het afvuren der Pelottons, of alle de Koeijen loopen als ontzind en wild door een; de Paarden daarentegen ftaan er yeeltijds naar te luifteren; , evenwel bemint eene Koe het zachte zanggeluid, en dit fchijnt alle herkaauwende Dieren insgelijks eigen: de Arábieren geleiden en befturen hunne Kameelen door gezang en gefluit; de Hertebeesten zijn vatbaar voor en nieuws. gierig om naas flutgefpeel te luifteren. Men behoeft den Herders- dichteren -flechts te vragen of een fchoon Landgedicht zonder herdersfluit welluidend $z \mathbf{i j}$; de Koeijen zijn er zeer vatbaar voor; naar het. deunitje van de Melkmeid of Boerenknecht ftaan zij ftil te luifteren, voor het gebäf vani een hond verfchrikken zijor. In mijn buitenleven heb ik mij menigmaal vermaake, in den vroegen morgen of den vallenden zomeravond op de Q 4 dwars-

Il. Afd, V. Hoofdit: 


\section{NATUURLIJKE HISTORIE}

neт dwarsfluit te fpelen, wanneer een ganfrhe Qundver koppel Koeijen al zachtjes toetrad en ftilII. Afd ftond om dit aan te hooren, al herwelk v. dan met een wijsgeerig denkbeeld overgestoofdfe bragt, genoeg bevestigd, dat, hoe groot; breed en havig de uitwendige ooren der Koeijen zijn, zij echter zeer gevoelig - zijn voor al te fterke andoening, en aan hun dus een meer oplettend dan verfijnd gehoor is toe te kennen; dit zoo zijnde, zou het zeer wel met de Ariftotelifche gevoelens der Ouden, en de fpeculatien der Gelaatkundigen ( $P$ hy. fionomisten) overeenkomen, dewelke ftellen, I dat groore oorfchelpen of lellen een dommelig en dom gehoor, doch een goed geheugen teekenen; hierom wordt een Lzel om zijn groote ooren wel ech domine Ezel genaamd, maar om zijn geheugen; dat, gelijk men zegt, een Ezzel zich geen aweemaal aan énien fleen floot, ook teffens een goed verftand toegekend. $l k$ behoef niemand onzer Landzaten te verklae ren, wat men door een domoor verftaat, vooral ook door een ezelsoor, een dommen ezel, maar ook wie weet niet, dat men aan zeker foort van ftroeve, ftompe en breedgeporde Menfchen den naam geef van domioor, of buiffeloor.

Ir if : 0 , Heez wilt ons verlosfen

$\therefore$ Van deze Deenfche Osfen En brengt, ons, naar ons wenfchen, In Holland bij de menfchen. 


\section{VA H OL A D: 249}

was en is nog bij ons, 200 men wil, een Vondeliaanfchen inval op ftompe vernufeen en domooren. Dan, zoo dom en lomp men ook de oorlellen der Koeijen befchouwen wil, is er niet te min, beredeneerd befchouwd, in derzelver mnakfel wederom iets, waar in de wijsheid van den Maker toont, dat ook even dac geene zijn ncodza. kelijk nut heeft. De ooren der Koeijen niet gefchike zijnde om in de hoogte, met de verheffing van het houfd, de uitrekking van den hals, of in den vollen ren of loop de lucht te vangen, zijn dus natuurlijker gefchike om de lage luche, en gevolgelijk de meer geconcentreerde dampen re vangen. In holen of fpelonken verbergen zij-zich natuurlijk niec; op rotfen en hoogtens leven zij nier; en fombere digte kreupel: bosfchen niet dan doortrekkende ; leven zij derhalven meest altoos in beenden, valleijen en vlakke velden, alwaar de arond-en morgendaauw, de regen - en hagelvlagen vlak bp hun ligchaam en gehoor nederdalen, en dus is er geen twijfel aan, of de zijdelingfche platfing, gevoegd bij de groatheid en de harigheid der oorvleugels, even $z 00$ als wij van de oogleden opmerkten, dient haar om den invloed van regen, wing ên koude, te verhinderen, om eenig letfel aan het fijne inwendig geftel te doen, het kom mij zelfs, om evengemelde reden, voor, dat aok de hazen en konijnen, bijzonder de cerfte, zulJe lange ooren 'hebben, om dat $\mathrm{zij}$ mede Q 5 meesf

MET RUNDVEA 11. Afa. V. Hoofdit: 


\section{$25^{\circ}$ NATUURLIJKE HISTORIE}

42x meest op de vlakke velden leven. De muiQUNDVER: $z$ en en ratten daar en tegen, hebben kale II. Afd. korte ooren, en ook even daarom kunnen. $v_{\text {, }}$ zij geen regen of wind, of water velen; wij menfchen weten insgelijks, hoe lastig het is als de regen of hagel ons in de oorholte Alaat. De zwemmeis, als zij onderduiken, en daar na boven komen. fchudden de ooren, proesten of fniezen door de prikkeling en aandrang van het water, dat door den gehoorweg ingeflopen is, zij raken, zelfs zomwijlen an het fuifebollen. Iemand die tegen wind ingaat, gevoeld den invloed van den wind zoo fteik, dat hem de ooren gloeijen, en het gefuis van den wind hein uren lang in hẹt gevoel aankleeff, al het welk, zoo durf $\mathrm{ik}$ redekavelen, niet gefchieden zoude, ten minste in minder trap van andoening, indien ons geftel vorderde, dat wij koeijenof ezelsooren hadden; welk een zeldzaam figuur zou dan een welgemaakt mensch heb. ben, maar ook welke fchoonheid, welke yolmaaktheid moeten wij met ingetogen aandacht niet erkennen, dat wij menfchen, in tegenftelling van zulke grove dieren, onze gladde oorlellen, met fchoongekrulde haar: vlokken, die, toch de eerwaardigheid eenes mans, en de bekoorlijkheid eener vrouwe uitmaken, be dekt zien, welke den invloed yan weer en wind beletten, en dat wij na genoegen van cusfchen die natuurlijke gehoorkeeren, het lieffelijk zingend gevogelte beluisteren of of zelfs door zoete zanglust I2) 01 ? 


\section{$\checkmark A N$ H O LL L A D. 253}

of zedige liederen, het gehoor ftrelen, en boven alle andere dieren, van dit zoo wonderlijk geftel, ook een wonder en verheven gebruik makęn.

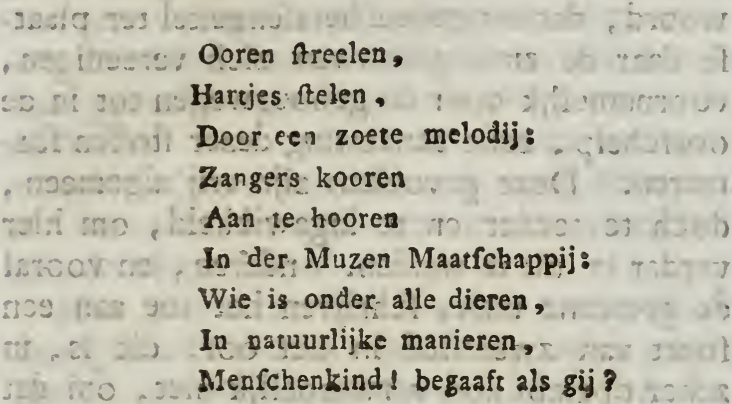

Eer wij evenwel hier affappen, hebben Oorfmoù wij ten flotte nog iets te melden wegens her meer: inwendige der opening, of eeriten ingang in hec oor, alrede befchreven en door ons in plaat $X$ bij Fig. 5. naar het leven afgebeeld. Hier alleen dient men nader te letten op het oorfmout, hetwelk in deze kom of holte van den oorfchijf, in meest alle dieren gevonden wordt, en aan ons smenfchèn niet onbekend is. Velerlei gevoelens en gisfingen zijn er over deze ftoffen, idie wij ter loops dienen aan te roeren, om des te klaarder onze zoo even voorgedragen gedachten wégens de Koeijen mede te decelen, te meer, daar an de kennis hief van, een zeer aanmmerkelijk deel der kennis van de) gezondheid eener troe af hange, Er zijn er die ftellen dat het oorfmou

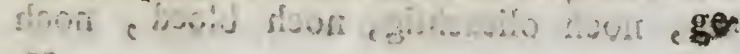




\section{NATUURLIJKE HISTORIE}

HET gedeeltelijk uitwafemende ftoffen der hersfeRuNover. nen zijn, gedeeltelijk uitlozingen van de

11. Afd reuk-: en fmaakdeelen, en zelfs veelal van Hoofdr. de traanklieren en zenuwen der oogen; in.énn woord, dat het geheel hersfengeftel ter plaat$\mathrm{fe}$ daar de zir tuigzennwen zich vereenigen, voornamelijk door de gehoorwegen tor in de oorfchelp, eene aanzecting dezer ftoffen formeren. Deze gevoelens zijn vrij algemeen, doch te teeder en te ingewikkeld, om hier verder in uit te weiden. Anderen, en vooral de gemeene man, fchrijven het toe aan een foort van zweetfof in het oor: dit is, in zeker opzicht zoo verwerpelijk niet, om dat het oorgeftel onder alle andere zintuigen, het minst uitwendig kan uitwafemen of zweeren; door de neus ontlasten de dieren de fnot, en bij fterk $z$ weeten druipt het zweet van de neus af. De mond ontlast zich door het fpeekfel, de oogen door de traanklieren, máar het oor kan het zweet, dat uirwendig uitvloeit, niet ontlasten, om dat het in de rchelp blijft hangen, en gevolgelijk aldaar éven 200 wel aanzet, als in alle deelen des ligchaams, al waar de zweetftoffen of uitwas femingen blijven zitten, bij voorbeeld: bij onreine menfchen in de hoeken der neus, an de teenen, en vooral achter de oor fchijven, zoo zelfs, dat het fomwijle tot veretteringen komt, dan, het $z \mathrm{ij}$ hoe het zij, deze ftoffe van het oorfmout is in al. lerlije dieren min of meer tegenwoordig, en van eèn bijzonderen aard; zoo dat het noch ret, noch olieachtig, noch bloed, noch 


\section{VA N HOL L A N D. $\$ 53$}

zenuw - noch fpierachtig, noch fpeekfel of ee. nige andere ftoffe gelijk is, het naaste komt het bij een zeepachtige ftoffe, die zich zoo wel met water als met olie laat ontbinden, zelfs kan dezelve met gom vermengd worden, waarom fommige waterverffchilders, als hunne met gomwater gemengde verwen, wat ftroef uitfmeren, een weinig oorfmout er onder temperen, als wanneer de verw zeer wel uit penceelt, ja zelfs eene zekere vastigheid aan de kleur geeft.

Het oorfmout der Kocijen evenwel, is doorgaans dikker en bruiner, zelfs groeit het als tot een zekeren korst aan, dic in oude Koeijen als ' $t$ ware, een inwendige huid wordt; $z i j$ is niet 200 overvloedig als in andere dieren, om dat de Koeijen over het gehel niet zoo fterk in de ooren fchijnen uit te wafemen en te $z$ weeten, ook minder ftof in de ooren vangen, dan de paarden, die door de roskammers veelal gezuiverd worden. Ook zijn de honden boven al bezet met oorfmout, hierom worden $\mathbf{z i j}$ dikwerf oorziek. Een hond is onder de $\mathrm{mij}$ bekende dieren wel het fijnfte van gehoor en reuk, maar tevens het teederfte aan deze deelen, en het vatbaarfte voor oorkitteling en oorfchurft. Een verkeerde klank of aanhoudende prikkeling, kan een hond doen huilen of janken, ja tot oordolligheid brengen. De Koeijen en Paarden fchijnen aan iets dergelijks onderworpen te zijn, want fom: wijlen ziet men de Koeijen het hoofd dikwijls fchudden, de ooren eenigzints flap en

HET RUNDVER:

II. $\Lambda \mathrm{fd}$ : V. Hoofdit: 


\section{NATUURLIJKE HISTORIE}

нЕт wapperende latende hangen, als wanneer men

a undver. er zeer wel op aan kan, dat het oorfmout ver.

II. Afd. hard of verftopt is, of anders dat er Ichurfe

$V$. achter de ooren zit, of dat infekten of wespen. hun gebeten hebben, gelijk dikwijls gebeurt. Men wil dat de Koeijen ook in het oorfmout wel wormpjes hebben, dac nier on. mogelijk is, doch het is ons niet gebleken, geli k nader hij de verhandeling over de gebreken der Koeijen zal verhand ld worden, onder het artikel van oorworm.

Wij laten dit verder berusten, en vervol. gen nog kortelijk met de volgende aanmer. kingen, te weten, dat 200 men alle de aftekeningen der gehoordeclen, zoo giove als fijnere, het zij denkbeeldig, of volgens de atbeeldingen bijecnvoegd, dan zal men overtuigelijk ontdekken, dat de ligging dezer deelen, in één woord, het gantfche gehoorgeftel der Koeijen, eene gantsch andere rigting heeft als in eenig ander dier, vooral de ongehorende, want in de meeste dieren, zelfs in de vogclen, zijn de ooren wel op zijde, ter wederzijde aan de llagen van het hoofd, doch de ingroeving van den gelioorweg loopt tegen het bekkeneel, mar in de Koeijen is de gehoorweg meer achterwaarts naar den nek, ter oorzake, dat hes horengeftel, of de horenwortel, de kruin uitmakkt en het oorbeen niet alleen onder den horen, maar ook achter dezelve is ingclijft. Het is dan hier door dat men de Koeijen een zeker foort van doofheid roekent, als den horen en vervolgens 
de vereeniging van de holligheden van het - fteenbeen-verwrongen is; dit erkent men doorgaans in de Koeijen, welker horenen 11 Afd. door het ftoeijen of ftoten verlamd zijn; zie hier voren Plaat V. Deze doofheid of verlamming is in de Koeijen kenbaar an de losheid van den oorlel, die als dan druilend hangt; hier van druiloor, ook dompoor enz." Men kan duidelijk aan die zelfde zijde, alwaar zulk een oorlel of vleugel, en den horen verlamd en verwrongen is, in het oog een flaauwer uitzigt befpeuren, zelfs tot dien trap, dat de oogfchel (cornea) verduistert, en de Koe als blind wordt. Dit is den Boeren en Veehoeders overbekend, waarom zij de oorlel aan die zijde, alwaar de verwringing en het ge. brek tegenwoordig is, doorfnijden, en zelfs een vrij groote lap van den oorlel affnijden en dezelve laten bloeden, om dus de verdervende en drukkende humeuren af te leiden; het een en ander wel opgemerkt, bewijst, dat in opzigt der doofheid, verftop. pingen van den gehoorweg, de Koeijen ook zeer vatbaar zijn, zelfs tot den trap van razernij, horendol, druildol enz. dan dit zal op.zijn plaats nader worden onderzocht.

Thans willen wij eenige oplosfingen inlas. fen, betrekkelijk den invloed der lache op het gehoor, en ook op het geheugen der Koeijen.

Ten aanzien van het eerfte, is alrede in de verklaring der luchtholen, in genoegzaam alle gehoorbeenderen, genoeg bewezen, dar 


\section{NATUURLIJKE HISTORIE}

*2x de invloed det lucht niet alleen op de hnlle aundrze kamertjes werkt, maar zelfs tot de andere zin11. Afd. tuigelijke deelen, voornamelijk tot de reuk$v$. en de fmaakdeelen invloeid. Maar ten aanzien Hoofd van het tweede, is nog al iets op te merken. Het is overbekend dat zoo wel de ouden, inzonderheid Ptinius, als ook de nieu. we ontleedkundige wijsgeren het daar voor houden, dat het gehour der dieren, het werktuig van het geheugen is. In den Mensch kan het volftrekt niet ontkend worden, want iemand die in zijne jeugd met een fchoolgezel, met zijne zusters of broeders, neven of nichren, dagelijks verkeerd heeft, zal in zijnen ouderdom, zelfs na jaren afzijn, en al ware hij blind, aan den ftem. klank en tongual, nog den perfoon erken. nen. Eene moeder onder een aantal kinderen, zal enkel op het gehoor; het gefchrei, het gelach, ja de zoete prevelarij, van elk bijzonder erkennen. Een klein kind, hoe onnozel, bekome door het gehoor ge. heugen, en dikwijls op dit inftinkt alleen, kan een Regter in duistere zaken, op het ge. hoor en geheugen van een onnozel kind, zeer wel aan. Te rege kome hier al weder mijn Vaderlands fprookje te pas.

Kleine potjes hebben ooren,

Kunnen zij niet zien, zij kunken toch wel hoores:

Dan, nademaal wij op dit onderwerp vath het gehoor, eenige nadere opheldering zul. 


\section{$\nabla$ \& N II OLLA N D. $25 \%$}

lẹn voordragen, ter platefe diar wij over het natuurlijk geluid, de ftem en onderfcheiden toonklanken der Koeijen; đoor middel der ademhaling, longpijp en de beweegfpieren der geluiden, afzonderlijk zullen handelen, en moeten het hier dus laten berusten, en alleen tot flot in korte woorden' melden, dat die zelfde luchtftroom, luchtdreuning, die eerst de uitwendige gehoordeelen of groote "oorlellen der Koeijen aandoet, daar na in de binnenkameren en fijne gehoorwegen verfijnd, het hersfentter en de algemeene zitplaats van het zielsgevoel indringt, dat, zeg $\mathrm{ik}$, die zelfde verfijnde lucht, door aandoening, ook de andere zintuigelijke zenuwdraadjes treffende, insgelijks, tot zelfs in en aan de luchtademing der longpijp, het gevoel der gezigt. en reuk - ja misfchien fmaakzenuwen, in. dringt, want gelijk het zeker bewijsbaar is, dat een mensch, vooral een paard, en nog: fterker een hond, door onregelmatige en ontijdige oorprikkeling; het gantfche zenuwftel kan berocren, zoo is dit ook waar in de Koeijen. Een mensch, bij voorbeeld, vooral in het linkeroor peuterende, zoo mẹn het noemt, en al te fterk het norfmout uitledigende, kan zulks niet lang uithouden, of hij begine te kugchen, te walgen, ja fomwijlen over te geven. Men kan een pard van angst doen pisfen, door hem inwendig in de ooren te flerk te jeuken, een kat zal het nooit gedogen, en meer andere dieren ook niet, maar vooral geen koe; de ftier, de os wordt er woedend door, datr

v. Hoofdit: 


\section{\$8. NATUURLIJKE IISTORIE}

สस: in tegendeel ber vitwendig jeuken hen be' Sundver valt. Dit zamen genomen, toont dan dat .11. Af fd. het gehoor zelfs zijn invloed tor de ingewar-

Hookdift. den en het geheele zenuwftel nitftrekt, en dit buiten maten meer annprikkeld dan -zulks door andere zintuigen gedaan wordt. De Boeren 'fchijnen, het zij dan door vooroordeel, of door wijze ondervinding, zeer oplettend te zijn op de gebreken der 'horenen els ooren, manr bijzonder op zether foort van kug of fchorheid der longenklep, insgelijks op het nekbeen, en de inwendige oorjeuk, fchurft enz., als wanneer zij fpoedig een lap van de oorvleugel fnijden, of met een fchaar er eene keep in knippen, zoo als gemeld is, ook fteken zij wel een dotje met olie ter verzachting in de lepellellen, hetwelk veeltijds een goed gevolg heeft, dan, ook dit behoor nevens nog vele andere zakien, bij de verhandeling over de gebreken der Koeijen en derzelvër genézing. - Hier mede dan befluiten wij onze verhandeling over het gehoor der Koeijen, hetwelk wij vertrouwen, dat na den aard deff zaken, met alle mogelijke klaarheid verftaan. baar is voorgedragen, vooral met ver. mijding van nog zeer vele wijsgeerlijke befpiegelingen, die vit dit onderwerp zouden zhunnen voortvloeijen, doch die wij ook juist om derzelver ingewikkeldheid en afgetrokken đenkbeelủen, laten berusten, terwijl wij deze onze befchrijving met alle eerbied onze Eezeren ter onderzock anbieden, en, wa de lorte verklaring: der af beeldingen van de gehoordcelen, op Plaat $X$, tot de gezigtdeelen zullen overgann. 
A H OLI A N D. 259

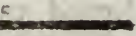

HET

RUNDVEE:

Verklaring yan de Gehoosdeelen op Plaat X.

II. Afd. V. Hoofdn:

Fig. 1. verbeeld een Koeijenhoofd; met de huid omgeflagen aan het oor - en horengeftel zijdelings, achterwaarts. aca $a$ de omflag der opengefneden huid.

$b b$ de horenfpier die het oor beweegt naar de horenwortel.

$c$ de inlijving van dezelve an de horenwortel. $d$ de tegenwerking in de nek.

$e e$ de fpier aan het kraakbeen der gehoorweg; in verband met $b$.

ffff vier uitbreidingen van fpieren, het oorftel inwendig bewegende in gemeenfchap met de voor hoofdfpier.

$g g$ het kraakbeenig gedeelte, waar in de fpieren zijn ingeworteld.

$\hbar$ onderfpier die zich aan de kaauwfpier aan het kakenbeen vereenigd, en de oorlel naat voren trekr.

$\because$ de oorlepel van binneri.

$k$ de vlakte van het fteenbeen in zijn be: kleedfels.

Tig. 2. Het Koeijenhoofd met de huid ongeflagen, het oor voorwaarts omgeflagen, en deszelfs ontbloote oorfpieren.

- $a^{2}$ de lange en fterke fpier ann de horenwortel en oorlepel.

$$
\text { B } 2 \text { blei० }
$$




\section{NATUURLIJKE HISTORIE}

ArFT $b$ kleiner fpier, breed onder dezelve uitgeRUNDVEE fpreid.

11. Afd. $C C$ nog fterker fpier, die in een drichoek

$\mathrm{V}$. met a a met kracht de oorlel naat achHoordit, ter trekken.

d Ppier die onder de gemelde bij ce legt,

- en zich aan het kraakbeen hecht.

$e$ het kraak - of kroonbeen.

$f$ inhechting van de fpier $d$, onder de holligheid van het kraakbeen.

g.g onderoorfpier van de oorlel of lepel.

$h$ opklimmende fpier die aan de krain ontfpruit, vereenigt met

$i$ de andere tak van dezelve om de kroon,

- het oor befturende, en doende voorwaarts draaijen.

$k$ de bolle bocht of kom van het nederkraakbeen aan de oorlepel.

$l$ bijzondere anduiding van de huidfpier.

min $m m$ de ongeflagen huid.

Fig. 3. Geheele ontblooting van de kraakbeenige oorkas, de fpieren achterwaars regeftandig van het hoofd gefcheiden, met een volmaakte aanduiding.

a de top van de oorlepel, met het haar van achtcren.

$b$ de oorkoker van de oorlepel, ontbloot

- van de huid.

c. afgefneden gedeelte van de fpier uit de

1 holle gehoorweg.

$d$ het kraakbeen en inenting der. fpier $c$, die, de oorlepel naar achteren trekt.

es medewerkende fpier uit dezelve rigting. 


\section{VA N HOLLA N D. $26 \mathrm{r}$}

ff de beweegfpier die de oorlepel naar vo- Het ren beftuurt.

$\S g$ fterke fpier die het geheele oorgeltel der II. Afd. oorlel befturr met de krakbeenige $V$. holte.

I2 flaap - en kaauwfpieren, aan het holle kraakbeen of luchtkamer verbonden.

$i$ deszelfs inlijving onder aan het aanhangfel der luchtkamer, hetwelk eene flesachtige gedaante heeft.

$k$ een lange fpier die de kraakbeenige holte of fles om doet draaijen, en met de fpier ll tegenwerkt.

Il groote waaijerwijze fpier, die uit de krop van het fteenbeen ontfpruit, en het flesvormig krakakbeen geheel helpt befturen.

s $M$ andere rterke fchildfpier, aan een beweegbaar kraakbeen, tegens de enge gehoorweg.

$n$ het beweegbaar kraakbeen.

0 inlijving aan het fteenbeen van de fpier $m$.

$p$ een fterke kraakbeenige fpier, aan het fchildvormig kraakbeen.

$q$ fpiertje, hetwelk bijna regtlijnig loopt en mede op het fchildvormig kraakbeen ein. digr.

or $\gamma$ einde van het groote kraakbeen aan het gehemelte van het fteenbeel, met zijne holligheder.

ss ankangfels of gewrichten, wanr het fteenbeen uit het hoofd an het veelvol. mig been gewrongen is.

tit tt hoeken on groeven van heezelve.

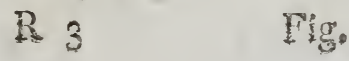




\section{NATUURLIJKE HISTORIE}

y2x Fig. 4. Het geheele flesvormig koker-kraakRUNDVER.

II. Afd.

$\mathrm{V}$. gehoorbeen; ontbloot van de bovenfte fpiern, tor deszelfs geheele inworteling.

Hoofdt: $a$ a de ruige oorlel afgefcheiden.

$b b$ de kraakbeenige oorkoker geheel bloot.

$c$ de bult of flesvormige buik.

d $d$ het ondergedeelte van hetzelve.

ce $e$ deszelfs inlijving in het fteenbeen.

fff fchildkraakbeen.

$g$ deszelfs inlijvingfpier an de oorlel of vleugel.

th nok van het fteenbeen.

i een fterke fpier, welke een groote kracht oefent op het midden van het bultig gedeelte van het koker kraakbeen bij $k$.

Fig. 5. Dwars doorgefneden Koeijenoor, om de inwendige ftand te zien. Dezè Figuur is nog door niemand afge: beeld, maar door ons bijgevoegd.

a eerfte holte van de oorlepel daar het oorfmout in ligt.

$b$ kleiner holte naast aan, langs de oorfchijf.

$c$ krakbeenige oorknobbel of bult.

dd gehoorkom.

e luchevang.

$f$ opening van de gehoorweg.

gggg kraakbeenige oorlel, dwars doorge. fneden.

Fig. 6. vertoont het geheel flesvormig kraakbeenig oorgeftel van de binnen - of tegenzijde van Fig. 3. omgekeerd. 


\section{VAN HOLLAND. 263}

de harige holite de! ooriepel of vieugel.

$b$ deszelfs fluiting.

ce ombuiging der oorfchelp of den rand.

d kraakbeenig omflag of fleuf.

$e$ gehoorweg.

$f$ tregrerwijze buis.

$g$ kraakbeenige oorfchelp aan de eene zijde.

$h$ einde van dezelve aan de andere zijde.

$i$ aanhangfel van een kleine beweegfpier.

$k$ fteenbeen.

$176 l l l$ het geheele fteenbeen vit zijne groeven, en van alles gezuiverd.

Fig. 7. vertoont afzonderlijk de groote ge. hoorzinuw door het fteenbeen loopende, welke figuur mede door ons is bijgevoegd.

$a$ de gehoorzenuw.

$b$ het holle gat, daar dezelve uit de hersfe. nen in het oor loopt.

c tepelachtig uitftek van het fteenbeen.

Fig. S. Nader verklarende afbeelding van de werking van het kraakbeenig oorgeftel, met het zoogenaand bijoor. a het kraakbeenig oorgeftel van achteren te zien.

$66 b$ fchildbeenig krakbeer.

$c$ bovengedeelte van hetzẹlvẹ.

$d d$ bultige uitftekken.

$e$ fpierbanden.

$f$ de gehoorbuis.

g groote fpier van het fchildbeen.

$\%$ inlijving in het fteenbeen.

i fteenbeen.

R 4 ops.

HeT

RUNDVEZ,

II. Afdo $\checkmark$. HoofdPo 


\section{NATUURLIJKE IISTORIE,}

uxt $k$ opening van den ingang tot het flekkenhuis. undvez. $l$ uitftek van het fteenbeen aan het jukbeen, II. Afd. $m m$ hoeken van het ftecnbeen, daar het aan v.

HoofdA. het veelvormig been grenst.

" de groote fpier die het bovenoor regeert.

Fig. 9. Een gedeelte van het fteenbeen, als leen omgekeerd met alle zijne groeven inwendig.

a Spiertje door welke de opening der enge gehoorweg beftuurd wordt.

$b b$ velachtig bekleedfel omgeflagen.

$c$ eerfte opening welke naar liet trommel. vlies of gehoortrompet loopt.

d luchtholte.

$e$ andere luchtholte.

fff verfcheiden hoeken van het fteenbeen.

Fig. 10. Afbeelding van de gehoortrompet, of tregter in het ftecnbeen.

a affnijding van de oorfchelp, 'met ecnige ftippen van haarftoppels.

$b$ gehoorbuis.

$c c c$ holle fleuf van het ftecnbeen waar doof de buis loopt.

$d$ inkromming van de buis.

e e e e wanden van het fteenbeen doorgezaagd.

Fig. I 1 . Dezelve afbeelding van de enge gehoorbuis of trompet, omgekeerd en duidelijker voorgefteld om het uiceinde vąn den gehoorwer te zien.

a de tregterwijze buis.

b deszelfs ondergedcclte ann de onkromming ? 
จa N HOLLA ND. =6́5

doorgefneden in de holte der buis, zigt- Hze baar in de fleuf van het fteenbeen.

- de holte van het fteenbeen tegen het trom. II. Afu. melvlies.

$d d d d$ de holle groeven waar mede het fteen. Hoofdax

" been aan den horenwortel vereenigd is.

$e$ het puntgebeente aan de kroon van het voorhoofd.

$f$ het achterfte gedeclte met de groeven van het fteenbaen.

$g g g g$ holligheden van het fteenbeen, dic an het veelvormig been fluiten.

Fig. 12. Nadere ophelderende afbeelding, om.den ingang van het Alekkenhuis en fpiertje meerder ontsloot te zien.

$a$ inwendig fpiraal begin.

$b$ influiping van heczslve naar het trommelvliesje.

$c$ kleine inwendige fpier.

$d d$ her tepelwijs uirftek van het fteenbeen, zie Fig. 7. met het overig gedeelte.

eeee inwendige bolachrigheid van het fteen. been.

ff kameren der lucht.

Fig. I3. De fraaije afbeelding van het trom. melvlies geheel ontbloot, en des-zelfs werktuiglijk geftel, geheel doorgezaagd.

$a$ het trommelvlies.

$b 6$ de rand of ronden ring waar over het gefpannen is.

c hat trommelltok zenuwrje of kioppertje.

$$
\text { R } 5 \text { d d l het }
$$




\section{NATUURLIJKE HISTORIE}

иex didd hét tepelachtig been doorgezaagd, vol aUNDEB. inwendige holligheden en celletjes.

II. Afd. ee het grootfte gedeelte van het ftecnbeen, v. aan de bovenkant.

Hoofda: ff harde kant van het fteenbeen, op zijde?

Fig. I 4. Het voorgemelde been an de ach- terkant, in zijn natuurlijke ge. daante.

a ingang van de gehoorweg, in het in. wendige.

$6 b 6$ invoegfels van het fteenbeen, met hunne holligheden.

c c de wanden.

Fig. I5. Keurige afbeclding van het-trommelvlies, in de holligheid van het fteenbeen of zijde te zien, duidelijk met de itamper.

a is het trommelvilies in de holte van het tepelbcen.

$b$ beenachtig ringetje van het rrommclvlics.

c de ftaart van het kloppertje, op het vlics tikkende.

d fpicrije dat dit beweegt.

e zenuwkoortjc.

$f$ hoekig beentje an het kloppertje, zijnde het aambeeld.

$g$ holtc van het tcpel- en fteenbeen, war in het trommelvlies befcherma worde.

$\hbar h$ het uitwendigc deel van het repelbeeng of het gewelf.

: de bafis of het fieunbeencje. 


\section{I HOLLAND. 267}

$k$ gedeelte van het theenbeen an het tepel. Hen? been verknoge.

Il holligheden in hetzelve.

m opperfte fchelp van het ficenbeen.

$n$ opening van de gehoorweg.

RUNDVEE.

II. Afd. V.i

Hoofde:

- groef van de fpier in het fchildwijs kraakbeen.

p voorname zenuw, die de fluiring en ont: fluiting van de gehoorwegen bevordert.

$q q$ flaapbeenig aanhangfel.

Fig. 16. Nader afzonderlijke uitleg van hee trommelvlies, met het hamertje en het aambeeld.

a $a$ gedeelte van het tepeibeen.

$\checkmark$ beenachtige ring van het trommelvliess.

$c$ het trommelvlies.

d het hamertje.

$e$ het aambeeld.

$f$ eivormig fpiertje.

$g$ het zenuwrje.

$h$ holte van het feenbeen.

Fig. 17. Afbeelding van de inwrendige zelfftandigheid van her ftecnbeen, met alle deszclfs wonderlijke verecniging aan het hoofdflaapbeen en kaakleden, yol holligheden.

s $a$ a $a$ het gemelde gedeelte als puimifteen.

6 de ware grondflag van het trommelvlies.

$c$ het trommelvlies.

ad het hamerije.

$e$ eivormig fpiertje.

$f$ het aambeeld. 


\section{¿68 NATUURLIJKE HISTORIE}

нет $\$$ het ftijgbeugeltje.

aundves. $h h$ gedeelte van het fteenbeen.

II. Afd $i$ bafis van het fponsbeen. V.

Fig. 18. Afgefcheiden gedeelte van het ge: beente, waar in het doolhof, flek. kenhuis, of deszelfs draai, kenbaar is.

a het doolhof.

$\checkmark$ het oppertopje of ingang in het doolhof, en inlijving van het eivormig fpiertje.

c holligheid van het fteenbeen.

Fig. 19. Het flekkenhuis of doolhof, gansck duidclijk ontbloot.

$a$ het fijne zenuwdraadje of peesje aan het begin van den draai.

$b$ den draai of het doolhof.

$c c$ de rand van het gewelf of de neuf.

$d$ groote gehoorzenuw.

$e$ beenholte.

Fig. 20. Afbeclding van het hamertje.

$a$ het eirond fpiertje.

$b$ hoofdje van den hamer.

c ftart van het hamertje.

d zenuw van het ftijgbeugelije.

Tig. 21. Hetzelve voorwerp omgekeerd.

a het eivormig fpierrje.

$b$ het hoofd van het hamerije.

$c$ de ftaare van hetzelve.

thet hijne peesje. 


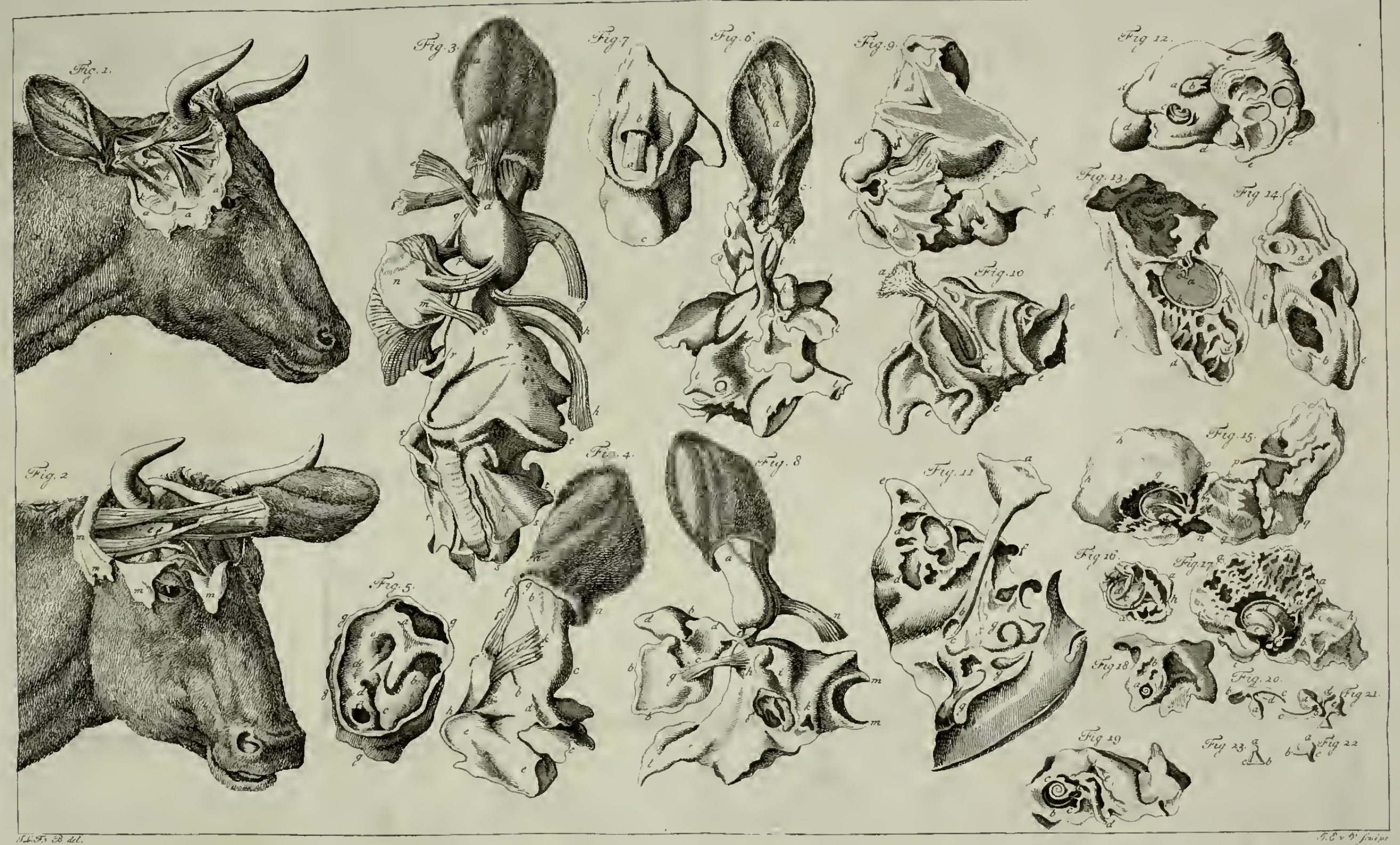


I N H OL LA N D. 269

$e$ het aambeeld.

$f$ de-ftijgbeugel.

RUNDVEE:

II. Afd.

Fig. 22. Het aambeeld afzonderlijk.

a oppergedeelte.

V.

Hoofdel:

$b$ deszelfs uirftek.

$c$ deszelfs buik.

Fig. 23. Het ftijgbeugeltje afzonderlijk.

$a$ het oppergedeelte.

b de linker beweging.

$c$ de regter beweging.

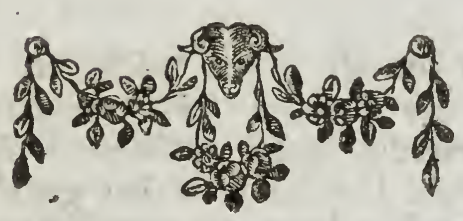

TWE E。 


\section{NATUURLIJKE HISTORIIE}

\section{TWEEDE AFDEELING.}

\section{ZESDE HOOFDSTUK。}

Uitvoerige en meest vernicuwde Ontleed-

- kunde yan het oog en de gezigtdeelen der Koeijen.

Hex 1 ven zoo als in het befchrijven van het RUNDVEE. Gehoor der Koeijen zcer wonderiijke en

II. Afd. wetenswaardige zaken verhandeld zijn, zoo vI. ook zál dit Hoofd́ftuk in het geftel van de Hoofdrt. oogen der Runderen, in vergelijking met die van andere Dieren, bijzonderheden opleve. ren, die in vele opzigten, voor zoo ver wij weten, niet algemeen bekend zijn, ten minften niet tot een geregelde befchrijving. bijeen verzameld zijn, en veel min door afbeeldingen, het zij die van oude of nieuwe Natuuronderzoekers; tot een zamenftel gebragt zijn. Daar wij dan, volgens ons tot hier toe reeds gevolgd ontwerp, dit tot cen regel hebber aangenomen; zoo volgt dan ook in dit Hoofultuk een geregeld zamenftel der afbeeldingen en befchrijving van het 


\section{$\checkmark$ a HOLLAND. $2 \%$}

oog; en gevolgelijk komen dar, de op Plaat Xi. geplaatste, afbeeldingen van de gezigt-RUNDVEE. deelen hier ter onderzock en verklaring in ii. Afd. aanmerking.

In dezclve ziet men in de eerfte plaats, Hoofdit: in negen voorname Figuren, allen naar het-leven, de oogen van een volwasfen Kalf, levensgrootte afgebeeld, waar van dadelijk den uitleg volgen zal. Vooraf dien men evenwel op te merken, en bij onze bitwendige befchrijving der oogdeelen te vergelijken, dat de Koeijen in het horenvlies der oogen, gelijk ook in het vlies dat Cristalij. het cristallijne vogt bevat, ja ook in of aan ne bol. de cristallijne oogbol (Lens Criftallina), in ftede van eene bolronde ftraalweg, zoo als in den Mensch en genoegzaam alle revingerde Dieren, dezelven integendeel in her Rundvee eene langwerpige of ovale doorlating der lichtfralen hebben: de Paarden hebben er ook iets van, doch op verre na zoo kennelijk "nict als in de Kocijen', her is nog fterker in de Schapen, en nog fterFer in de Geiten of Bokken, in zoo verre dat de Steenkundigen zeker foort van agaat $($ Ony $x)$, hier van daan den mam van bok. kenoog (Oculuis Beli), geven, gelijk ook weer anderen die naar het kattenoog, wiens pupil ook iets hier van heef, Oculus Catti-(kattenoog) nocmen; men weet dat de Katten de oogrtar of het cristallijnvlies kunnen als toeknijpen, iets dergelijks is ook de Koeijen eigen, gelijk dan ook alle de vliezen, waar uic het oog beftar, hier naar 


\section{NATUURLHIEE HISTORIE}

HET
RUNDVEe wijkende gedaante tegens die van andere die.

II. Afd. ren betreft, dit is in vele opzigten moeijelijk

VI. te verklaren: er zijn er, die willen, dat deze

Hoofdst, ovaalronde gedaante, die in Plaat XI. Fig. I, 2,3 cn 5 te zien is, eene vergrootender eigenfchap an het gezigt dezer dieren geeft, zoo dat, zeggen zij, eene Koe , den Mensch of kleinere dieren veel grooter, zoude fchij. nen, dan zij wezenlijk zijn, en dat dienvolgens hierom de groote dieren de kleinere dieren ontzag toedragen; dan, dit gevoelen begeere ik niet te beflisfen, veel min in den omflag van gezigtkundige regelen te treden, ten aanzien der ftraalbuigin. gen, in een langwerpig oval of bolronde gedaante van de oogrvliezen, dit zoude ons te veel afleiden, te meer, daar men, zoo veel ik weet, geen voldoende proeven met langwerpige ronde glazen heef, nogtans vermeen ik nier geheel mis te tasten, als ik ftel, dat dit oogftel in dit opzigt aan: deze dieien gegeven is, om dat zij onder het grazen het hoofd nederwarts buigende, en de oogen zijlings hebbende, aldus ook noodzakelijk meerder zijlings moeten zien, om de kruiden te onderfcheiden en op te zoeken, en dat dus deze dieren natuurlijk op zijde door de oogen zien, het geen wij menfchen en andere dieren niet dan met moeite kunnen doen. Dat dit mijn gevoelen geenszins op losfe gronden fteunt, meen ik te kunnen betogen uit de verfchillendheden in het menfchelijk gezigt, gelijk ook in dat 


\section{จ Aे HOLLAND. 273}

ఛan andere dieren: bij voorbeeld, mén weet tex. dac in een Mensch, die fcheel zièt, of bijziende is, de pupille, of eigenlijk in onze taal de oogftarre, meer of min is roegeknepen of langwerpiger wordt zamiengetrokken; iemand ; die loers, loerig ziet; dat is, die op Oogftarre' zijde zien wil zonder het hoofd te wenden, drukt insgelijks de oogftarre zamen; in de Katten, en in de Papegaaijen is de beweging van de oogftarie zoo kennelijk, dat men; zoo mer er op lette, derzelver beweging ziet; zij knijpen', als zij fcherp zien, zigtbaar de ftarre zamen in eene langwerpige of ovale rigting, en blijven in die geftalte; zoo lang: als hun andacht op eenig voorwerp is gevestigd; hier van zegr men: eer kat uit den boom kijken, zoo ook faroogen. Indien een mensch, die natuurlijk goed, en niet fcheel ziet, een fcheelziende wil naar bootfen, dän dringt hij door de ring - of $\mathrm{ka}$ trolfpier van het oøg, de beide oogen tor een centrum, en knijpt de oogftarre; dir kunstje is bekend genoeg, nogtans virdr men Menfchen, die dit naar eigen willekeur niet kunnen doen, maar als men den vinger vcor den neus hou'dt, en vestigt daar op de oogen tot op een zekeren afitand; dan. ziet men ook fcheel, en de oogftarre knijpt zich ook toe, hier van het fpreekwoord: hij kijkt langs ziju neus. Wanneer men dir nu: alles vergelijkt, en op her zeldzaam oog. geftel der Koeijen overbrengt; dan meenen wij, zonder verder in het wiskundige

II. Afta

VI. Hooldif: 


\section{NATUURLIJKE HISTORIE}

HET der gezigtkunde te treden, op eenvoudige RUNDVRr. en voor een iegelijk vatbare redenen te mo-

11. Afd. gen ftellen, dat de ovale eironde gedannte, VI. in deloogvliezen der Koeijen zoo kennelijk,

Hoofdft. aan deze dieren dienstig is, om zeer fcherp

Bijzon- zijlings af te kunnen zien, ja, ik ben zelfs derheid in niet vreemd, om te gelooven, dat dit oos bet gezigt der Ko eijen. genftel ook an deze dieren dienftig is om in het donker te zien; ten minfte dit is waar, dat de Paarden in ftikdonkere avonden, wanneer den IMIensch geen fpoor kan zien, echter den weg volgen en vooruit zien; meenig flapende Jagersknecht of vermoeide Voerman, wordt in den ftikdonkeren nacht door de Paarden t'huis gebragt; de oude Batavieren hielden de Paarden hierom als voorzienders, en eerden dezelven tot wichelarij : zoo vereerden ook de Egyptenaren hunnen $I / 2 s$, zijnde eene Koe of een Stier. Hoe het met de Paarden zij, zeker is het, dat de Koeijen bij nacht zeei fterk zien : men brenge leene Koe, in eenen ftikdonkeren nacht, eenige ftonden vit zijne weide, waarin hij met andere Koeijen gewoon is te grazen, hij zal gerust den weg vinden. Maar nog iets: als wij Menfchen en fommigen dieren in het duister zijn, zoeken wij licht, wij ontfteken toortfen en lampen, en verheugen ons, als wij licht zien; daar integendeel Paarden, Koeijen en Schapen des nachts voor het licht verfchrikken en van angst zweeten, en hierom is het, dat men sooit in Koeijen - of Paardenftallen meerder

liche 


\section{$\checkmark A$ H OLLA N D. 275}

Iicht aanfieekt, dan de Boer of Stalknecht benoodigd heeft um in de ftal te zien; ook is her bekes:d, dat men door vuur en lich tende fakkelen de Kocijen fchrik aanjaagt, immers 200 bedienden zich de oude Grie. ken en andere Volkeren van Osfen en Stieren, die zij in de Magordening der vijanden jocgen, door vuren achter haar an te ftefteken, waar door de Osfen en Stieren, wordende van angst, in de fpitze der vijanden drongen. DE BUFFon en anderen merken aan, dat de Koeijen een tegenzin tegens de roode kleur hebben; dit heeft ech. ter niet altoos plaats, want in Zuid-e12 Noordholland en elders dragen ineest alle de Boerinnen en Melkmeiden hoog roode onderrokken, en komen daar mede in het veld; 200 er dan fomtijds eenige tegenzin tegen de roode kleur plaats heeft, wijte ik dit aan de fchichrige afkaating der lichtftralen op het rood of fcharlaken, die hun buitengewoon voorkomen: hoe het zij, dit is zeker, dat het oog der Koeijen ten opzigte van de oogftarre of de vlieıen eene bijzondere ovale gedaante heeft, zoo als dit op Plaat XI. in Fig. 1. bij $a$ te zien is. Doch Plazt Isa het is nog dit alleen nier, dat de Koeijen bij- Fig. I. zonder hebben: in de befchrijving van het uirwendig geftel maken wij gewag van den ooghoek, oogkas, het wenkvlies, fuimerylies (Membrana nictitans): dit vlies fpruit voort op en om de traanklieren, en II. Afd. VI. Hoofdir:

HET RUNDVEE? (10) (1) 


\section{NATUURLIJKE HISTORIE}

zet van het oog, zie Fig. I. bij $b$, het gartRUNDVEE. fohe vlies is echter inwendig met het bo-

11. Afd. venfte ooglid vereenigd, en vonwt of plooit

vi. zich naar deszelfs beweging, zoo dat, als

floofdto het ooglid fluit, dit vlies ook ontfluit en: over de oogappel zich uitbreidt, echter zoo, dat het maar even over de pupible of oogappel vleidt, (zie weder Fig. I. bij b) zelfs zoo, dat al flaapt of fluimert de Koe, zij ecnigermate flaauwelijk ziet; want nooit valt eene Koe in zulk eenen dicpen flaap, dat zij niet meer of min luikt of loert, en waarfchijnlijk is dit aan dit dicr door den Schepper dus bezorgd, om dat zij natuurlijk noch in de holen der aar. de, noch in geboomte of eenige fchuilplaatfen, maar op het open vlakke veld wonende, moeten flapen of fluimeren, en dus voor alle bejegcringen des.nachts bloot. ftande, als ' $r$ ware flapende waken. Ondertusfchen kunnen de Koeijen de oogen fluiten, en hunne oogleden zijn hier ook toe gefchikt. Dezelven zijn voorzien van borstelige-haartjes, die vrij lang en hard zijn, in ecnen geregelden rei ftaan, en in hec midden allengs verlangende, meest alle halvemaanswijze ombuigen, ook fluiten die der bovenfte oogleden, als ' $t$ ware, in de De haar-haartjes der onderfte oogleden, zoo ziet. xjes der men in Fig. I. bij c.cc de bovenfte, bij $d d d$ oogleden. de onderfte dezer haartjes of borstelijes : zij zijn zeer fierlijk in de Koeijen, en geven or dat goelijke en cerwardige aan, dat die zelf- 


\section{VAN HOLLAND. 27 ?}

zelfde haartjes aan der Menfchen oogen doen, doch zij worden door nog andere haartjes fff, minder borstelig, gerugfteund, zoo dat het water der regenbuijen, of hagel - of fneeuwbuijen het oog niet deeren kan, gelijk dan het gemelde wenkvlies het oog insgelijks daar tegen verdedigt, vermits de Koeijen altoos met het achterfte tegens den wind ftaan, en dit opgemeld vlies ook achterwaarts in her oog ftaat; wanneer men deze haartjes uittrekt, of men ontbloot het oøg van de wenkbramen en de daar aan verbonden vetvliezen, ontdekt men zeer kennelijke groefjes en porien, waar in zij geworteld zijn. Deze haartjes zijn, gclijk ook in den Mensch en andere dieren, verfchillende van kleur, naar de kleur van het haar van den huid, gelijk dezelven dan ook gerugfteund worden door de haren van het geheele ooglid of wenkbramen, die tot ann den oogkas loopen, doch deze zijn zoo den en kennelijk niet, als in den Mensch, alleen wenkbrezijn er eenige zijlingfche kreuken, die men.

Afd Hoofdro uic de zijden der traanklier opwaarts vouwen in het uitwendige, zoo als in de afbeelding - van het Koeijenoog reeds geroond is; en dewijl de oogen der Koeijen zijlings ftaan, hebben hunne wenkbramen geene zoo fterke werkirig op het voorhoofd, op de ftarre of kol, als in den Mensch, in welke deze werking der wenkbramen, boven alle cieren 200 fterk plasts heeft, dat dcrzelver fpieren het S3. voore 


\section{NATUURLIJKE HISTORIE}

get voorhoofd rimpelen en fronsfen, zoo dat RUNDVEe een Mansperfonn dikwijls daar coor den

II. Afd hoed van de kruin fchuiven kan; de KoeiHoofdr. jen daarentegen werken meerder met de wenkbramen naar de ooren, en het is hierom, dat zij ook zijlings lodderachtig Pinkoog.zien. Misfchien is het pinkoogen wel ontleend van het zijlings of lodderachtig zien der Pinkvaarzen, gelijk de Dichters bij vergeliiking can eene lonkende Vrouw Osfen. en Kalfsoogen toefchrijven; immers wierd de Hemelkoningin Juno blaauwe Osfenoogen toegekend. HowirRUS doet haar voor haar Gemanl JUirtier verf́chijnen, als lonkende met hare lodderlijke wenkbramen en blaauwverwige Os,enoo. gen. In der daad de Kocijon hebben iets lodderlijks en goelijks in hunne oogen, vooral als zij in rust en vergenoeg herkaauwen. Onze Landicugd on Herderdichters weten ook ran het pinkoogen te fpreken; immers zeker Dichter van rozelijNs oogjes, voert zijn Herder dus, fpreken. de, in :

Als mijn ROzELIJNij lonizt,

En ee lijlings wenkje vonkr

Uit de bruine wenkbramboogjes,

Pinkende uir haar Osfenoogjes,

Dan verftaan wij allebei

Deze lieve lodderij. 


\section{VA N HOLLA N D. 279}

Tie daar, zoete Landjeugd! voor u ook een Vaderlands uitfapje. Wij vervolgen wijders, en zeggen, dat er in der daad in het pinkoogend en lonkend ooggeftel der Koeijen, te weten, dat van den langwerpigen ftraalweg en het fluweelvlies of het druivenvlies enz., iets is dat nabij met het wenken en lonken der Menfchen - oogen. in het wenkvlies zelve, in anmerking komt: willis makkt hier ook melding van, doch het is, in de Menfchen, zoo fijn en dun, dat het fchier het oog ontglipt, en men uiterlijk deszelfs werking niet ziet, daar men het in de Koeijen kennelijk ziet werken; ik merk in het voorbijgaan aan, dat de leepoogen in de Koeijen mij toefchijnen te ontftaan uit de verlamming en verfoppingen van, om en aan dit vlies. Wijders is het uit de oogen der Koeijen, waar door STENON, CASSERI, WILLIS en andere beroemde Ontleedkundigen de kennis van het oogenftel der Menf́chen hebben verlicht.

In Fig. 2. hebben wij de afbeelding over- Plaat XI. 'genomen, die sTENon van een kalfsoog, ${ }^{2}$ ontbloot van de oogfchellen, gegeven heeft. Nadere Hier in ontwikkeld zich alles, wat wij an befchrije ders door omfchrijvingen zouden dienen te het nuimelden : men zict er ten duidelijkfte in, mervlies. hoe de ligging is, en hoe de plaatfing zij der traanklieren en van het fluimervlies. Men moet vooronderftellen, dat in deze Figuur het geheele oog hier van het kraakbeenig, 


\section{NATUURLIJKE HISTGRIE}

Heт en inwendig beenbekleedfel der oogkas is afaundver. gefcheiden; dus vertoont zich hier bij $a$ de

II. Afd. ongẹnaamde oogklier, zọo genoemd, om

VI dat dezelve door geene Autheuren voor sTE-

roofdit. Non was wargenomen : men ziet, dat Ongenaam-dezelve zeer kennelijk verfcheiden kwabbede oogklier tjes of kliertjes heeft die tusfchen de grooran STE te en kleine ooghoeken $b$ en $c$ invloeijen. Deze kwabberjes zijn zes in getal, zie $d d d$ c)d $d$, en doen het traanvogt docr de buisjes eee eec, achter langs den rand van het opperfte ooglid $f$ invlocijen in de traanklieren $g g$, en achter het fluimervlies $h$. Alle deze kliertjes en vaatjes zijn in een zeer zacht vet bewonden, gelijik ook de ganfche oog: bol en deszelfs fpieren, in zulk een zacht vẹ liggen, indiervoegen, dat hec eete crvaren en geduldige hand moet zijn, die hier niet in dwale, om hetzelve van de vliezen en fpieren wel te onderkennen. Ondertusfchen geefr onze Figur, uit sténon overgenomen, een volmaak denkbeeld van het oog, 't welk van de oogleden ontbloot is, en kan vergeleken worden tegen onze Fig. I. dat

yerdere met de oogledien zich vertoont, on nog na: verklaring der in aanmerking moet komen, Straks zul. wan Plaat len wij de Leerlingen onze menigvuldige onXI. Fig. I. dervindingen, om oogen te ontlẹdęn, mede deelen; hier volgen nog eenige anwijzingen van het oog, ten aanzien van het fluim̧ervlieș; dus ziet men in Fig. I. bij $k$, de onderfte oogfchel, die ik de bak van het oog noem, hicrin cindigt dit gedeeltce zeer: ? 
iliezig, en formecrt daar het fluimervilies $b$, He' dat zich als 't ware dan eene vout of plooi RUNDVEz; formeert bij $l l$, en welke eigenlijk het zigt- Ii. Afd. bare nuimervlies is. Bij $m$ is de witte oog. VI. kring, of het geen men eigeniiijk het wit van Hoofdit. tuet oog of de fclerotis noeme, die als 't ware den rand van het hoornvlies uitmaake. Voorts ziet men om den rand van het bovenfte ooglid, de duidelijke inwortelingen der borstelige haartjes, die zig aan de oogleden der Koeijen kennelijk opdoen, doch om einde. lijk van dat gedecle van het oog, dat wij het fluimervlies noemen, een duidelijk begrip aan den eenvoudigen Landman, aan wien de ontleedkundige kunstwoorden onbekend zijn, te geven, heb ik ten overvloede in Fig. 3 een levensgroot kalfsoog, plaat $x_{\text {? }}$ Haar : het leven afgetekend, verbeeld; ont-Fig. 3 . bloot van alle klieien, viiezen en bekleedfelen, indiervoegen, dae men moet vooron. derftellen dat Figuur i. en 3 . in het hoofd van het dier ftaan, doch in deze laatfee, hee nluimervlies in deszelfs fterkfte uitrekking, zoo als die natturlijk ligt. Men ziet dus bij $a$ a a $a$ het gedeelte van het kraakbeenig. vlies van de oogkas. Bij $b b b b b$ de affcheid. fels van de afgefneden oogleden; bij $c$ de groote ooghoek; bij $d$ het nluimervlies, bij $b e$ de inentingen 'van dit vlies; bij $f f$ ziet men de kring van het ftarrenvlies, bij g $g$ het hoornvlies, zoo als de oogbol daar door, over het reivlies en het watervogt, zich als donker en zwart verroont; bij $h$ wordt S 5 het 


\section{NATUURLIJKE HISTORIE}

HeT het glasvocht angeduid, gelijk ook bij $i$ RUNDVEr. den ovalen kring van het vlies over het kris-

II. Afd. tallijn, of de lensvormige oogkern; alle vI. welke eenvoudige aanwijzingen op Fig. I. Hoofurt. en 2. overgebragt kunnen worden.

Plaat XI. Maar om nu alles nog duidelijker te Eig. 4, doen begrijpen, zoo nemen wij hier wederom eene Figuur over van stenon. In deze Figuur 4. ziet men bij a $a$ de ooghoeken aan humne kraakbeenige uiteinden of klieren; bij $b$ is dat gedeelte, dat men den kleinen ooghoek noemt. Ik noeme het den grootften of breedften, om dat aldaar het fluimervlies is ingelijfd, en het zig ook altijd zigtbarer vertoont; ja ook noem ik het den vlakken ooghoek, om dat dezelve zoo diep niet inloopt, en ook zoo kennelijk de traanklier niet vertoont, en het hier de plaats is, waar men in de Koeijen de brandige ontfleeking der oogen waarneemt; bij $c$ ziet men den kleinen ooghoek, waar in het bekleedfel der traanklier zig tterk doet zien, ondertusfchen moet ik hier niet overflaan, het gene de geleerde WARTHON in zijne Adegraphia aanmerkt, dat namelijk deze oog. klieren, traanklieren, traanpuisjes, (carunculae lachrymales), in de Koeijen nooit $z 00$ uitwendig gezien worden, als in den Mensch en andere dieren: maar, zegt hij, en onze eigen Fig. I en 3 bewijzen het ook, dezelve traanklieren zijn uitwendig bedekt door een fterk vlies of klier, inwendig kraakbeenig, 200 als dit in Fig. 1 . bij $g$ te zien is, 


\section{N HOLLAND. 283}

en welkers vliezen zich langwerpig en breed uitbreiden, en dit kraakbenig geftel helpt veel aan het uitfpreiden en uitrekken van het dekvlies, bij ons het Auimervlies genaand, het geen bijzonder den Runderen eigen is; voorts merkt wILLIS aan, en te regi, dat Tranklie. men deze plaatfing der ooghoeken nier vol- renvolgen ftrekt als een fcherpen wiskundigen hoek, maar STENONO als een ronde hoekachtigheid moet aanmerken, en dit herhaal ik te meer, om dat, zoo in eenig dier, dezelve voorzeker in de Koeijen het rondfte is, 't welk onze Figuur I en 3 aantoonen, en ook in Figuur 4 te zien is ij $a a$. Voorts ziet men in Figuur 4 bij $d d$ zeer juist aangewezen een omgellagen gedeelte van de bovente oogfchel, waarin door ftipjes de vereeniging aan den onderrand wordt aangeftipt, gelijk ook bij $e$, die van den bovenrand. Bij $f f$ ziet men wijders de holletjes, porien of groeven der haartjes of borsteltjes van de oogenleden, en vocral dient men hier bij $g$ g, op $d \varepsilon$ twee kleine gaatjes, door sTENoN ontdelit, te letten, waar door de traanvochten uitvloeijen: men noemt dezelve traanpunted (punctuli lachrimales), zij zijn in de. Koeijen zeer kennelijk. Wijders is bij $h h i$ het gedeelte van het doorgefneden hoornvlies. Met achterlating van verdere oogkundige aanmerkingen op de oogdeelen, die de Koeijen met andere Dieren gemeen hebben, kan ik nu niet voorbij, om nog iets te melden yan de bijzondere gefteldheid der fpieren, 


\section{NATUURLIJKE HISTORIE}

HET die den oogbol bewegen, en hier toe diene undvar. Figuur 5 , door ons naar het leven afgeteeII. Afd. kend, welke Figuur niet weinig zal toeVI. brengen tot de kennis van het geheele $\mathrm{za}$. Hoofdt. menftel van het Koeijenoog, want hierin Plaat XI. ziet men den ganfchen oogbol $a$, in zijne Fig. 5. volkomen rigting, geheel op zijde liggen, De oog. In de beenen oogkas $b b b b$ der hoofdbeenfpieren, deren: in deszelfs verlengd hersfenvlies, telt men, gelijk in den Mensch, zes fpieren, die den oogbol bewegen, waar van de twee voorfte $c c$, dienen om het oog naar boven te trekken; de twee achterfte $d d$, om het zelve nederwaards te trekken; de vijfde fpier $e$, om den oogbol achterwaards te beweegen en regtftandig te houden, doch deze fpier wordt als omwonden met fpiervezelen, die als een dunnen rok van de ge, zichtzenuw uitvloeijen; maar de zesde bij $f f$, is de bijzonderfte, om dat dezelve door eẹnen kraakbeenigen ring $g$ loopt, en door die middel, den oogbol regt voorwaards naar den neus trekt, daar deze fpier even als een touw door cen katrol loopt, draage

Katrol. zij den naam van katrolppier (muscit. \{pier. lus trochlearis); deze fpier werkt het fterkfte bij de Koeijen, om dat, gelijk meermalen gemeld is, de Koeijen dẹ oogen niet vlak in het voorhoofd hebben, en dus de oogbollen van beiden de oogen fterker naar voren moeten béwegen, om het gezigtpunt te treffen, het gene wij Menfehen, door beide de ocgen, door dezelve 


\section{IA H OLLA ND. 285}

Katrolfpieren, op een punt te doen ftaren, иeт gemakkelijker doen, bijzonder in het veraf RUNDVE: zien. Alle deze fpieren des oogbols, zijn II. Afa: in de Koeijen zeer fterk en verbreedend, en fpruiten allen ait een bekleedfel, dat VI. de gezigtzenuw zeer vast omvat, zoo dat de zenuw zelve hier op werkt, en cindigen in waijervormige vezelen, aan den rand van den oogbol, waar het doorfchijnend hoornvlies begint, in dier voege, dat zij gezamenlijk den oogbol omvatten en doen draaijen. De meeste ontleedkundigen vertoonen dezelve ook aldus: evenwel, zonder groote mannen te willen beris. pen, heeft de ondervinding mij geleerd, dat alle deze fpieren tor wel op "de helf van den oogbol zelve ingelijfd (geinfereerd) zijn, en dat $z \mathrm{ij}$ om den anderen lager of hooger toor hunne vezelen verbonden zijn, zoo als ik wel degelijk, niet alleen in de Koeijen, maar ook in Schapen, Paarden en Hazen ondervonden heb, gelijk ik dit bij $h / h$ heb aangeteekend. Ik heb opgemerkt, dat juist aan dezen kring de harde hoornigheid van den oogbolaffcheid, en de fclerotis zachter wordt , zoo dat het achterfte van den oogbol als een ronde zak hier aan vast is; de oorzaak der bovengemelde misflag, indien ik het durf zeggen, is, dat de Ontleders der oogen den weg dezer fpieren van het harde hoornvlies gemakkelijk affcheiden, om dat het vet (celluleus) ge: makkelijk fcheidt, en ieder ontlecdkundige weet, hoe omzigtig men moet zijn, om soch vooral de fpieren in hunne verbreeding niec 


\section{NATUURLIJKE HISTORIE}

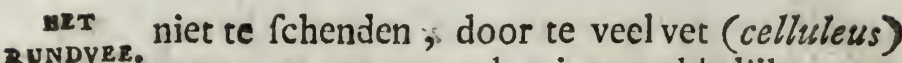
weg te nemen, want bet is gemakkelijker eene

11. Afd. fpier aan zijn oorfprong, dan aan zijn mid.

VI. den of uiteindens te kennen, en het is dus zeer Hoofdift. juist, ' $t$ geen GaLENUS heeft waargenomen, dat de reeds aangevoerde vezelachtigen en fpierachtigen rok, die de gezigtzenuw geheel omringt, en onder de zes voorgemelde, den oogbol van achteren regeert, als een Zevende zevende fpier is aan te merken. Deze fpier, o ogfier bekend onder de naam van de zevende oogvan GaLE fpier van Galenus, is in de Koeijen en Kalveren zeer kennelijk.

$\mathrm{Nu}$ dienen wij, eer wij van de bijzonderheden van dit ooggeftel der Koeijen affappen, nog eenige aanmerkingen van de inwendige vliezen en de vogten mede te deelen, voor zoo verre derzelver bijzonderheden tot de Koeijen betrekking hebben, want indien ik alles wat tot het gezicht betrekking heeft, wilde betoogen, zoude ik te verre uitweiden, en mogelijk, wel in ftaat zijn een geheel boekdeel te vullen met zeer vele ondervindingen wegens de oogen in verfchillende dieren, die gantsch niet gemeen zijn, voornamelijk in de verfchillende zamenftelling der oogen, in dieren die in het duister of in het licht, in het water of in de lucht leven, ongelooflijke verfchillendheden komen hier in voor, in zoo verre, dat ik kan aantoonen, dat er onder de kruipende dieren en onder de visfchen, die in lijk en altoos in het duister leven, gevonden worden, die geene oogfpieren en binnenvliezen hebben, 
maar alleen een enkelen zenuw en oogbol, нат zoo als in den Meerval en eenige Paling- Rundveq foorten; dan wij blijven bij onze taak.

II. Afd;

Men telt in den Iensch voornamelijk de volgende bekleedfelen, als: het harde of VI. Hoofdrs: het hoornvlies (Corneus), dat men weder De bedeelt in het doorfchijnend, dat eigenlijk het kleedrels bovenfte hoornvlies is, en voor op den of de vlie oogbal ligt, zie dit, in het Koeijenoog, in het Koei: Figuur 5. bij $i$, alwaar het den witten oog- jenoog. kring doorfchijnt, gelijk bij $k k k$. het donkere dat er achter lige, hetwelk men de fclerotis of het harde vlies noemt, wordt aangeduidt : het ontvangt of eindigt in en aan de gezigtzenuw; in de Koeijen is de plaatfing daar fchuins, dat is, het voorfte of doorfchijnend hoornvlies of de oogbol ftaat wel midden in de oogleden, en de achterfte donkere bol ook', doch de beweeg. fpieren lopen fchuins te zamen in de oogkas en op het dik hersfenvlies door, tot en om de gezigtzenuw, in zoodanige rigting, als in Fig. 5. te zien is; en deze gefteldheid is natuurlijk, om dat, gelijk meermalen gemeld is, de Koeijen zijlings zien, en den Mensch regt vooruit, en echter moet de zamenloop der gezigtzenuwen zich vereenigen op het middenpunt aller zenuwen in de hersfenen; hoe het zij, zoo wel CaSSERI als willis, hebben deze fchuine rigting als bijzonder aan de Runderen en Schapen erkend; maar het geen wij genoegzaam algemeen in de oogen der Koeijen gevonden hebben, is eene ongemeene blaau- 


\section{NTATUURLIJKE HISTORIE}

ixtr we glans, die fomtijds naar den groeneri RUNDVE. helt, en inwendig gevonden wordt; vooral

'Ir. Afd. als men het daar aan verknoche dun netvlies

VI. er ànlaat, men zie Fig. 8. met den uitleg van Hoofdit. hetzelve; in de Stieren is het fterker, en moDe ovale gelijk wordt hier door dien vonkelenden op'doorfchis. flag veroorzaakt, welke deze dieren in hunnen wendheid. toorn vertoonen; in de Bokken-en ook in de Kocijen-oogen is dit groen-blaauw zon fterk, dat de kleur in voorloop nier ver. bleekt; in deze inwendige gefteldheid des blaauwen kleurs ziet men insgelijks eene langwerpige ftreep, dic aan de ovale doorftraling, die hier boven befchreven, en in Fig. I. bij $a$, en in Fig. 3. bij $i$ te zien is, beantwoordt even als een weerkaatfende fpiegel, zoo dat ik met, reden befluit, dat deze holligheid als de holle fpiegel is, die de lichtftralen weerkaatst, en het ware toonbeeld in de gezigtkunde affpiegeld, en dus; $z o o$ als ik veronderftel, den Koeijen aient om in het duister en op zijde te zien, en waar van nu ók bij Fig. 6. eene juiste afbeelding volgen zal.

Het voor den Landman te moeijelijk zijnde, om het geftel dezer vliezen volgens de opgegevene kunstwoorden te begrijpen, fta men ons toe, om het ook naar hunne wijze van fpreken en vatbaarheid voor te ftellen. Het hoornylies dan, het $\mathrm{zij}$ men hetzelve doorfchijnend of hoornig noemt, is eigenlijk de uiterlijke uitpuiling van den oogbol, die zich altijd bloot vertoont, als de oogen open ftran; zij noemen het, het leven, de oog. glans, 


\section{$\checkmark A N \quad H O L I A N D . \quad 289$}

glans; het lioornvlies of oogglans is dus HET ook niet verder doorfchijnend, als hetzelve RUNDVEe uit de oogkas en worikbramen kan uitpuilen, II. Afd. rie Fig. I; men vindt deze vitpuiling in VI. fommige Koeijen zeer fterk, gelijk men dit in fommige Menfchen ook vindt, in dezulke Het hoorn: vertoont zich het eigenlijk oogwit fterker, den oog. en het hoornvlies, van alles afgefcheiden, appel. vertoont de bepaling daar van als in een kleineren en grooteren cirkel, zie Fig. I, 2 en 3 , het middelfte rond is allerdoorfchijnendst, zie Fig. 3 . bij $i$, en behoudt, hoe sterk gedroogd, zijn doorfchijnendheid: als men dit geheele vlies, na eenige weeking in water, wil fcheiden, kan men het wel tot driemaal toe van een pellen, althans in de Koeijen heb ik dit meer dan eens gedaan; de uiterfte fchel heb ik zoo doorfchijnend gemaakt als glas, en door een goed vergrootglas porieus bevonden.

Als men in eene pas gedolde Koe het vitwendig hoornvlies bezier, als de Koe nog bloedwarm is, ziet men hetzelve bloedig: dat het in ontfoken oogen of bij forcering van brakingen geheel bloedig en rood is, is algemeen bekend: in de ziekten der Koeijen is het volftrekt een tee. ken van inwendige ontfteking; een verftandige Boer merkt dit op, en doet ftraks het beest aderlaten: dit alles bewijst eene zeer fijne doorfijpeling der bloedvaatjes in het oogvlies, en vooral in het vlies, ' $t$ welk aan her hoornvlies verbonden is. Dic onderwerp is 


\section{NATUURLIJKE HISTORIE}

BET eene der vermakelijkheden in de ontleed. MUNDVEx. kundige opfpuitingen, zoo dat, als men de

II. Afd. roode ftoffe door dit hoornvlies in het oog-

vi. wit ziet doorgedrongen, dan kan men er Hoofdft. op aan, dat de opfpuiting van het geheele inwendig geftel, en vooral der hersfenen, volkomen geflaagd is; wij hebben eenige fpruch-

Plaat XI. tels er van in Figuur 6 . aangewezen. De groo-

Fig. $6 . \quad$ te RUISCH en LIEBERKLHN keurden nooit eene opfpuiting voor goed, ten ware de haarachtige bloedvaaties in dit vlies, vooral in deszelfs witte kring ( Fig 6. bij cccc), roodach. tig waren, en hier van is ook aan dit vlies den naam van het Ruisfiaansch gegeven; doch dadelijk zullen wij de nadere ontdckkingen van den beroemden Hovius in het netwijs adervlies befchouwen.

Ik heb het genoegen gehad, met den grooten MONRO, wiens Zoon in Edenburg de luifter der Ontleedkunde geworien is, deze opfpuitingen te doen, doch ben na dien «ijd nooit zoo gelukkig geflaagd; zoo veel vermag de hand van eene gcoetenden.

Ondertusfchen moet men opinerken, dat, alfchoon ik van deze vliezen en de afpellingen van dezelven fpreek, men in het eigenlijk midden ovaalrond, dat doorfchijnend is, geene bloedvaatjes, ten minften niet door opfpuicing, vinde, maar dat het middelrond, dat eigenlijk de doorfchijnende oogappel is, altoos doorfchijnend blijft: in het gedeelte van het hoornvlies, dat over de lens ftrekt, en de langwerpige ovale fleuf ( Fig. 6. bij d) 
bedekt, zijn door mij nooit bloedvaatjes gevonden; alle deze eindigen tegen den ring van de pupil aan de iris, als fijne haartjes, alwaar zij de wederkeerende naga deren kusfchen, dat men Anaftomofis noemt, en dit is fraai in de Koeijen te zien, in zoo verre, dat de bloedvaatjes en haarachtige fpiertjes tegens den rand van hetzelve ftuiten, en men zelden den geheelen uitwendigen oogbol meer doorfchijnend dan tweemaal met het vlies aan een verbonden kan affcheiden, om dat het doorfchijnend twee rokken heeft, het wit drie, en de vetvliesjes of klierrjes er onder geteld, men het fomwijlen wel tot vier kan brengen, doch dan komt het ook meer op de fijnheid dan op de warheid van de zaak.

Wij vervolgen: als men nu het opgemeld harde hoornvlies voorzigtig in de rondte doorfnijd, ter plaatfe, waar het inwendig donker vlies van hetzelve af hangt, en men ligt het op, dan vindt men daar onder het zoogenaamde reiylies: dit vlies heeft eene binnen - en cen buitenfcheiding, en ontvangt Het rei: vlies. verfcheiden vaatjes voorgemeld; dit vlies loopt den ganfchen oogbol om, en is met wwartachtige, fomtijds roodachtige ftoffen bezet, die echrer meerder verflaauwen naar mate dezelve aan her doorfchijnend hoornvlies komen; in de Koeijen is het vrij dik en zwart, doch helder op zich zelve, want de zwartheid worde veroorzaakt door het wa: tervocht, maar zoo dra fcheidt men het niet, $\mathrm{T} 2$

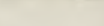




\section{NATUURLIJIKE HISTORIE}

A2T en fpoclt het af in water, of de zwarte en aunDVEe. fomwijl roodverwige ftoffe verwt het wa-

II. Afd. ter, en het vlies wordt helder, hierom ont-

VI. vangt het ook fomtijds den naam van drui. yenvlies, evenwel moet het er niet mede verward worden.

Het drui- In Fig. 6. ziet men hêt druivenvlies bij renvlies. $c c c c$, en bij $a$ a den afgefneden rand van het hoornvlies, en daar in de zwarte kring bij de waterkoin of den binnenkant daar van door het $z$ warte vocht bedekt, dat eigenlijk het reivlies is, hetwelk in opgefpoten oogen den indruk der vaatjes zelfs op het druivenvlies vertoont. Willis en /vele an. deren hebben den oorfprong dezer ftoffen niet kunnen vinden, en ik ook niet, doch dit heb ik bij ondervinding, dat, wellie dierlijke oogen ik ook heb doorgefneden, deze zwartachtige ftoffen er altijd uitvloeijen. zoo dat men er zeker op aan kan, dat deze lijmerige ftoffen altijd tusfchen het druivenvlies, het reivlies en de haarvezelen of de iris inleggen, en ik, voor zoo verre het mij vrij ftaat eenige gisfing te maken, voor vast geloove, dat het uitfijpelingen zijn uit de vaatjes van het netvlies en de roode bloedvaatjes der binnenbekleedfelen van het hoornvlies, zoo wel als van het reivlies, vermengd met die zwarte ftoffe, die men in het haarvlies vindt.

Doch om ons met deze aanmerkingen nies meer op te houden, beziet men andermal Fig. 6 : hier in ziet men bij a a den rand 


\section{VAN HOLLAND. 293}

rand van het hoornvlies, met den zwarten kring van het reivlies aan het hoornvlies verbonden, en bij $c c c c$ het druivenvlies met indrukfels van de Ruis/chiaanfche vaatjes, welk vlies zijnen naam bekomen heef van de doorfchijnende gedaante, die eene druivenbezie heeft, door welkers doorfchijnend vlies men de kern zien kan, gelijk dan ook door dit vlies de oogkern, of de pupit (oogappel) kan gezien worden, 200 als in Fig. 1. en 3 . is aangeduidt, alwaar men die langwerpige doorfchijning, den Koeijen eigen, vindt, welke echter, alfchoon de. zelve daar, als mede in Fig. 6, zich langwerpig of eirond vertoond, nogtans bij de affcheiding meer of min rond zamentrekt, en als dan open, dat is, zonder vlies is; fchoon ik vast vermoede, dat, als het dier leeft, hier over ook een vliesje ligt, dat zoo teeder is, dat het der kunst ontinapt, en hetzelfde is met het gordijnulies, over welks aanwezen, in pas geboren kinderen, de groote ALBINUS, HALLER en WACHENDORF getwist hebben, en dat ik vermoede in de Koeijen of Kalven wel nader te ontdekken zoude zijn.

- Wij vervolgen met Figuur 7 : hier ver- Plaat XI. toont zich de gedaante van het glasvogtvlies Fig. 7 . (humor yirteus) bij a $a a a$, den rand of Het glasring van het druivenvlies bij $b b b b$, en vogtvlies. de harribbetjes of oogftarre, van de iris of het regenboogvlies, 200 als dit naar het leven in een Kalfsoog is afgeteekend bij

$$
\text { T } 3 \text { c c c c , }
$$

II. Afd. Hoofdit: 


\section{NATUURLIJKE HISTORIE}

Hгт $c c c c$, en vervolgens het cristallijnvlies of RUNDVEB. bollerje, hetwelk door de opening van de

II. Afd iris of het regenboogvlies doorfchijnt, bij

Hoofdit. $d$, alwaar her zich nu rond vertoont.

Men ziet dan in deze Figuur den omtrek van den oogbol uit de hoornvliezen en het reivlies uitgenomen, zijnde het waterachtig voge (humor aqueus) weggelopen, en daar van, zoo wel als van het zwarte lijmig vogt, het geen uit de $i r i s$, of liever uit de harige buisjes vloeit, gezuiverd, en derhalven vertoont zich het glasachrig vocht in zijn eerfte vlies volkomen Dit vlies, dat de binnenrand van het regte druivenvlies is, hecf, aan zich en in zijn cirkel bij cccc, het regenboogvlies en de haarribbetjes, die als uit cen centrum ftarsgewijs uit?tralen; hierom bij de Boeren bekend bij den

Qogftarre. naam van oogftarre. Deze oogftarre is in het midden open, zoo dat deze opening vlak op \{het cristalijn volgt, of liever op het vergroot-oogglas, zoo durf ik het noemen legt, indiervoegen, dat de Koe hetzelve, insgelijks eivormig oval toeknijpt, offchoon het zich cirkelrond in de ontleding vertoond. Veel ware over deze $i 1$ is te zeggen, en velerhande gevoclens aan te vocren, doch dit wederom vermijdende, merken wij flechts aan - dat de naam

Iri of re van iris of regenboogulies, ontitaan is uit ge >b.og. de verfcheidene kleuren, die des\%elfs opperries. vlakte, vooral in levende oogen, heeft, want in doode oogen, ten minsien die eeni. 
gen tijd zijn dood geweest, of een langzame dood geleden hebben, verwelks die glans, en deze verwelking is dat. geene, dat men II. Afd. in ftervenden, verglaasde oogen noemt, dat is dac blaauwe, dat verwelkende, dat men VI. Hoofdit: in het verwelken van den glans ziet, en geen wonder! want de laatfte werking van de ziel is in dat tijditip in het oog, als de laatfte lichtftraal nog eenige invloed heeft, en het leven eindige, althans voor onze kennis, en ik voor mij twijfel niet, of de laatfte kennis der ziele van de ligchamelijke werking, ja zelfs de laarfte gedachten ligt in dit werktuig. De groote albinus, van wien wij in ons Verheerlijkt Leyden gezegt hebben:

ALbinUs dierbaar Lijk fchijnt, onder zijnen fteen, Zijn eigen deelbaarheid, nog in zijn ftof te ontleên.

Deze groote man had zoo veel op met dit laatfte inflinct der ziele, dat hij, waar hij gelegenheid vondt, bij den ftervenden dit laatite vonkje gade noeg: hij voedde zelfs kalkoenen op, dien hij onverhoeds den kop affloeg, om in de oogen te zien, en merkte op, dat de oogen zich nog eenige feconden bewogen en zagen. In onthoofde menfchen hebben fommigen opgemerkt, dat de iris in het oog nog toekneep en zich opende. In de Koeijen, die gedold en gebloedrist zijn, ziet men dit nog eenige kortftondige oogenblikken duidelijk verwelken, vooral, als de oogen uit de bedwelming die den dolflag $\mathrm{T}_{4}$ 


\section{NATUURLIJKE HISTORIE}

HET veroorzaakt heeft, uit den zwijm bekonen, Rundver. en dan vertoont zich vooral die ovale $z a$.

II. Afd. mentrekking, welke wij, als bijzonder aan VI. de Koeijen eigen, hier telkens in het oog Hoofdrt. houden, zeer kennelijk; voor het overigen hebben de Koeijen deze iris, of deze harribbetjes of ftarren, alle eenkleurig in de ontleding, zijnde de oogen van alle blaauw. kleurig. Eenige uitzondering nogtans is er in de witte Koeijen, die eenigzins bleeker zijn en naar het roode trekken. Hier boven heb. ben wij reeds aangemerkt, dat men funo, om deze blaauwheid der oogen, de blaauwoogige Funo met heur osfenoogen noemde. In: het voorbijgaan, fta men mij toe, an te merken, dat, (althans ik voor mij twijfel $\mathrm{cl}$ niet aan,) van de oppervlakte, zoo wel als van de ons nog onbekende fcheiding der vogten, en naar de temperamenten der bloed.. rijke , phlegmatieke, cholerieke of nielancholieke Menfchen, de kleuren dezer ir is of haarribbetjes verfchillen, en dus bruine, blaauwe, zwarte of bleeke oogappelen vertoonen, naar de meer of min verdikre vogren in de haarribbetjes; in de blaauwe oogen althans erkent men dit duidelijk bij trappen, want nu zal men dezelven flersch blaauw, dan met geele 1tarretjes, dan wederom met zwarte ftarre. tjes, dan weder twijfelachtig hevinden, en zeker is het, dat een donker blaauw ong met een $z$ wart ftarretje, ook zwarte haren aan de oogleden heeft, en deze foort van oogen zijn onder de Menfchen minst alge- 


\section{VAN HOLLAND. 29?}

meen, en teekenen altijd iets fchranders, нвт dan hier zouden wij mogelijk te veel Phij- Rundvrz: fionomiekundig worden, en kon men dit Il. $A \mathrm{fd}_{\text {. }}$ op de Koeijen toepasfen, hoe verre zou die kunst niet gaan? zeker is het, dat de Hoordt? oogen in de Kalveren altoos veel lichter zijn dan wanneer zij volwasfen Kocijen zijn, even als in den Mensch, waar van men weet, dat een jong kind dikwerf blaauwe oogen heeft, die in den ouderderdom donker, ja donker bruin worden. Uit alle welke aanmerkingen dan blijkt, hoe moeijelijk het zij, hier in iets zekers te bepalen, doch zeker is het ook, dat het ontleden van de oogen der Koeijen en Paarden, als zijnde groote Dieren, den gezigtkundigen veel lichts kunnen geven, althans het gene wILLIS en sTENON ftellen, wordt in der Koeijen oogen bevestigt, te weten, dat de in Figuur 7. bij c c c c naauwkeurig afgeteckende ribberjes, volkomen verdubbelde geftraal. de uitloopingen zijn, die als langwerpige op hunnen kant ltaande blaadjes, uit den omtrek van den kring van het cristallijnvlies, ontfpruiten, en aan het inwendig druivenvlies gehecht, in het reivlies eindigen, en, zoo ik vermoedde, aldaar als buisjes in de holle kamer des watervogts influipen, en aldaar ook, gelijk alle andere vogten des ligchaams, opflurpen en uirloozen.

Onder de opgemelde vliezen ligt nu einde. Het net: lijk het netylies (retina) zoo genaand, vlies. om dat deszelfs vezelen en vaten als een netT 5 ach- 


\section{NATUURLIJKE HISTORIE}

HET achtig weeffel zich vertoonen. Dit vlies Rundver. beftaat uit zeer teedere mergachtige vezelen,

II. Afd. die uit den ftam der gezichtzenuw voortVI. fpruiten, en welke vezelen begeleid worden

Hoofdit. door ongemeene fijne bloedvaatjes en vetklierrjes, die mede an den bodem des oogPlaat XI. bols invloeijen, zoo als in Figuur 8, bij a

Fig. 8. te zien is, alwaar de takjes van dit vlies uit de gezigtzenuw ontfpruiten, en zoo als zij gewoonlijk bij de ontleding bijeen loopen, vermits de kliertjes of het ftremfel dat de vaatjes verbindt, doorgaans wegvloeid. Alle deze vaatjes of vezeltjes eindigen, of liever vereenigen zich onmiddelijk met de uiterfle takjes der iris, of de haarachtige ftar revezeltjes. Dit vlies vertoont $\mathrm{zich}$ in de Koeijen aanmerkelijk dik, doch tevens als eene mergachtige ftoffe, die uit vele deeltjes beftaande, in bijzondere rigting aankleeven, even als de lbinnenfte hersfenvliezen, waar van het eene verlenging fchijnt te zijn, volgens stenoN; ondertusfchen, hoe dit ook fchijne, is er geene der vliezen, die de handigheid der Ontleders eerder ontfnapt, vooral als men het oog in water ontleed, want dan verfmelt en verdunt dit merg dadelijk zoo, dat men hetzelve in liquor of gedroogd, zelden geheel afgefcheiden bewaren kan, ten ware, dat er het reivlies of de geheele halve oogkom of oogbol aan vast is, evenwel zijn deszelfs oorfpronkelijke takjes en eenige fpruchtels, altijd aan de gुczigtzenuw inwendig zoo 1terk, dat zij 


\section{VAN H O EL L N D. 299}

als een klein boomtjc of koraaltakje aan een HET hangen, en in vogi zich uitfpreiden. Ik RUNDVEs? heb echter dit vlies uit een Koeijenoog ge- II. Afd. nomen, en in zijn ware gedaante gedroogd gehad, welke kunstgreep al mede zal volgen. VI. Meerder was er van dic vlies te zeggen, dan, ten aanzien der Koeijen, weet ik el niets bijzonders van, dan alleen, dat deszelfs inplanting midden in de ovale blaauwe 1cheiding, zijdelings naar den ingang der gezigtzenuw, in de hersfenen loopt, zoo als Fig. 8 bii $a$, alrede is angewezen, maar in deze Figuur heb ik nu nog aan te merken en ook afgebeeld, den bodern van het oog, waar op dit netvlies in de na. tuur legr, in de kom van den bol, op het onderdeel van het reivlies. In de Koeijen en Kalveren vertoont zich deze bodem, vooral in Bokken en Schapen, heerlijk weerfchijnend blaauw, hetwelk even als de zoogenaamde kattenoogen, boven vermeld, tegen het licht in verfcheiden ftral. buigingen weerkaast. Het vertoont zich vol vezelen, die naar het rond des oogbols zich rigten, en uit het centrum der yezigt zenuw zich uitfpreiden, zoo ais wij dit heb. ben afgeteekend, maar zeldzaam is het, dat midden in deze ftralen een zigtbare middenkring zich vertoont, zie Fig. 8 , bij $d$, deze kring is volltrekt ovaal, en loopt te zamen in zeer fterke blaauwe glinșterende ftralen, zoo dat daar uit dan bevestigd wordt, het geen het voornam doel van deze verhandeling 


\section{NATUURLIJKE HISTORIE}

HRT is, dat in dit geftel eene bijzonderheid is, den RundVEE. Runderen en andere herkauwende Dieren,

II. Afd. bijzonder eigen, en welkers verderen uitleg

vI. voor ons een diep geheim blijft, nademaal

Hoofdro eene Koe ons niet kan vertellen, hoe zij ziet; weshalven van deze vliezen afftappende, hebben wij, om onze verhandeling over het oog volledig te maken, hier nog bijgevnegt Het glas- de afbeelding van het flasachtig en cristalch cristal- lijn vogt in een Koeijenoog, zoo als het natuurlijk legt. Men zie op Plaat XI. Fig. 9.

Plaat XI. het glasachig vogt $a a a$, in zijne vliezen, 5ig. 9. in eenen natuurlijken ftand leggen, in de doorgefneden kom, of halve bol van het $\operatorname{oog} b b$, bij $c \hat{c} 2 \mathrm{ijn}$ de wanden van de reien druivenvliezen Dit glasachtig vogt is in de Koeijen, gelijk in alle andere Dieren, volkomen geleiachtig, doorfchijnend, indien hetzelve voorzichtig van het vlies of vliezen, die het omvat, gefcheiden wordt, vloeit het wel uit een, doch ftremt zeer fpoedig, het is kleeverig en hangt aan de vingers; indien het in de vliezen eenige tijd in de zonne gelegd wordt, blijft het dermaten aaneen verbonden, dat ik hetzelve door drooging in zijne volle doorfchijnendheid bewaard heb. Dit głasvogt wordt in twee dunne doorfchijnende vliesjes, die in de Koeijen wel te fcheiden zijn, bevat, echter kan men het eerder als vereenigde binnen - en buitenwanden befchouwen. Deze vliezen hebben tevens met de kleverige lijmigheid van het glasvogt, een kuil- 


\section{A H H L L A D. 301}

tje of kommetje, waar in het cristaliijne HET appeltje $d$, ten halve legr. De opper-RundveE: vlakte van dit vlies van nabij befchouwd, II. Afd. zict men er zeer kennelijk die fleuven en ftreepjes e e e in, die men met moeiVI. te in kleiner oogen ontdekt, aan den rand van dit kommetje zijn deze leuven ingelijf, zij beantwoorden en fluiten tegen de ftreepjes der oogftarre; de vertooning daar van in de Koeijenoogen is zeer fraai, want als men de druiven - en reivliezen afligt, dan ziet men om en op bet glasvogtvlies het tegenbeeld van de iris, of liever van de haarvezelige ftraalijes, doordien het $z$ wart lijmig vogt daar van in de geulen of fleuven insgelijks liggen blijft, zoo dat men het niet dan door geftadige afwasfing en verdunning daar van zuiveren kan, en als dan blijven de kenmerken der fleuven nog in deze glasvogtvliezen zigtbaar. Ik houde zelfs voor, vast, dat deze ribberjes aan een verbonden zijn, en in het levend oog buisjes zijn, die, bij de affcheiding der vliezen, van een gefoheurd worden, het geen de onregelmatigheid der ftraalranden klaar : antoont: de einden dezer fleuven, maken als eenen ring uit om het cristallijne gezigrbolletje, zoo dat men dezen kring kennelijk in der Koeijen oogen levend zien kan, gelijk ook in den Mensch, in het kommetje van dit leenig en geleiachrig glasvogt en deszelfs vliezen, legt eindelijk het cristallijn vergrootbolletje, zie Fig.9. bij $d$, Oogbol: 


\section{NATUURLIJKE HISTORIE}

HET cn hetwcik in Plaat Xí: Fig. Io afzonder RUNDVE: lijk is afgebeeld, dit wordt in het Latijn

U. Afd. lens genaamd, naar de gedaante cener Len-

vi. zenboontje. Dit bollerje is eigenlijk het Houfüt, geene men in de vergrootglazen ook lens plaat XI. noeme; het is in der daad ook als ' $t$ waFig. 10. re het vergrootglas, ten minste het ge: zichtpuntglas van het oog, en naar deszelfs meer of minder bolrondheid $7^{\circ}$ ziec men of grooter of kleiner door de vergrooiglazen; ik houde het daar voor, dat van de Figuur van dit bolletje, de meerder of minder fcherpheid, of ook bijzienend heid der Menfchen en Dieren afhangt. Dè groote LUBERKUHN moet dit cristallijne bolletje buitengewoon fcherpzienend gehad hebben, nademaal hij met het bloote oog de fatellieten van, Saturnus konde zien, ja volgens getuigenis van den groote Natuuron derzoekers, wijlend den Heer GEORGE CLIFFORT en den Hoogleeraar GAUBIUs, ontleedde hij eene vloo of luis op de punt van een naald, in alle deszelfs inwendige deelen, met het bloot oog, zoo als LEEcwENHOEK : dit door zijne vergrootglazen deed. In de Adelaren, Valken en andere fcherpziende vogelen is het altijd fpheerrond, in genoegzaam alle vistchen insgelijks, het geen men zien kan in de witte bollecjes, die men uit de oogen van fchelvis, baars, voorn en fnoek haalt. In de Koeijen echter is deszelfs oppervlakte wel bolrond, voor ar $\quad$ zoo vel het cristallijne bolletje uit het glasvogto 
vogtvlies uitpuilt, dan, voor zoo veel het in het glaskommerje ligt, plat en op zijde RUNDve : fcherp ovaalrond, gelijk Fig. IO, aanduidt: II. Afd. zoo dat ik hier al wederom uit vermeene te mogen vastftellen, dat de oogen der VI. Hoofdes: Koeijen veel meer gefchikt zijn om van nabij en in het duister te zien, dan van zeer verre. In den Mensch is ook dit bolletje doorgaans meer of min van onder platter, en hier uit leidde ik af, dat en den Mensch en de Koeijen, en alle viervoetige Dieren, de Mol uirgezonderd, altoos de voorwerpen in hunne eigen gcdaante en grootte zien, hetwelk in de Vogelen en Visfchen, die graan, infekten en voor ons oog onzigtbaar aas opfpeuren, gewisfelijk anders moet zijn, en ook is; want de Kwikftaárten aafen op dingen, voor ons onzigtbaar, en die bij haar nogtans eene merkbare grootheid fchijnen te bezitten, en waar van daan hebben de Rivier-meeuwen bij ons den naam van ikftarre, mikftarre, anders, dan van hun fcherp zien, zelfs door het water; men weet, dat de naam van faaroogen af komt van het Hoendergeflacht, en van meest alle Vogelen, die niet hoog vliegen en gelijk de viervoetige dieren op de aarde leven, deze hebben echter de ooglen. zen omtrent zoo als de Koeijen, ja zelfs platter, het geen ik mede als een bewijs aanmerk, dat aan alle dieren, die van ter zijde de oogen naar voren moeten bewegen, dit bijzonder eigen is: eindelijk wordt door 


\section{NATUURLIJKE HISTORIE}

HET WILis aangemerkt, dat men in het crisRUNDVER. talvogt in groote dieren cristalbuisjes

1I. Afd. vindt; men ontdekt ze in de oogen der

VI. Koeijen duidelijk, vooral als de lens in de zon wat opdroogt, of dat men dezelve opkookt; in de gekookte Schelvisch-oogen kan men de laagjes afpellen, en ook in de Koeijen, doch ik oordeele dit geene buis jes te zijn, maar veel eer zeer fijne ftraaltjes en cristallijne laagjes, even zoo als men die in cristal, ja zelfs in diamant befpeurt, en in het IJslands cristal dic zeldzame verdubbeling der voorwerpen vertoont; ja ik ftel vast met den Heer PETIT, die Ao. 1726 in de Akademie te Parijs betoogd heeft, dat de kleur en de zamenftelling van deze cristallijne lens in vastheid en hardheid mer de jaren toeneemt, dit vertoont zich in de Koeijen zelfs in den tijd van hun tanden. wisfelen, want als dan is deze lens veel blaauwer doorfchijnende en vuriger. Mcn kan het vlies van dit cristalvogt in de Koeijen zelfs fplitfen en er de lens vitpellen. men late de lens dan weder droogen, en al wederom zal er een vlies overkomen, waar uic blijkt, dat deze vliezen uit de zelfftandigheid van het cristalvogt zelve ontftaan, bij wijze van zamenftelling, en dus wordt ook het gevoelen van sTENoN en WILLIs omtrent de verdeeling dezer vliezen in Paarden - en Kocijen - oogen bevestigd, en het is hierom, dat de Paarden vooral vatbaar zijn voor het verdikken en aangroeijen dezer vlieg 


\section{v A HOLLAND. 305}

vliezen, en daar door veel aan blindheid on- нгт derhevig zijn, hetwelk men maanoog noemt; ${ }^{\text {RUNDVE. }}$ de Koeijen worden ook wel eens blind aan dit II. Afd. deel, doch op verre na $z 00$ veel nier als de Paarden, bij welken dic waarfchijnlijk VI. meer veroorzaake wordt door de mishan-Manoogi deling der Voerlieden, of door ongelukkige zweeplagen, en gansch niet onwaarfchijulijk door de ooglappen, die her gezigtpunt afleiden, en in oude hoofdiftellen den oogap. pel fchuren: voegt hier bij het ftof, dat op de rijwegen de oogklieren der Paarden verftopt; een verftandig Stalhouder en Voerman is op dit ftuk oplettend, en llaar nooit een Paard op de ooren en om het oog. De wijze Veehoeders blinden hierom ook de Koeijen niet gaarne, dan in hooge noodzakelijkheid, als dezelven veel afdwalen en bunne weiden verlaten, overzwemmen, of 2) te tochtig zijn, gelijk ook in het laatfe geval de Stieren fomwijlen geblinddoekt worden.

Hoe het $z i j$, zeker is het, dat het kristalvogt, en alle overige hier verhandelde deelen, een allervoortreffelijkst onderwerp opleveren, ter befchouwing, hoe de wijze Schepper in dit ontzagchelijke dier de oogen geformeerd heeft, 200 als het die tor aijn doeleinde, natuur, aard en levenswijze benoodigd heeft; terwijl de bijzondere invloed des gezigts, gelijk ook de uitwerking daar van op de ziel dezer dieren, voor ons een diep geheim blijft, en blijven zal, waarom wij hièr van dic 


\section{NATUIIRLIJKE HISTORIE}

H2x keurig onderwerp affappen, en nu onze zundvzE. belofte geftand zullen doen, om den leer1I. Afd. lingen of weetgierigen onze eenvoudige Hoofdr. kunstgrepen mede te deelen.

Gelijk dan de ondervinding in alle zaken de grootfe leermeesteresfe is, zoo heeft deze gezellinne der weetlust an mij verfcheidene handgrepen geleerd, die ik zonder dezelve niet geweren zoude hebbe.

Omtrent de manier, om oogen te onderzoeken en te ontleden, is algemeen genoeg bekend, dat hetzelve in water, brandewijn, azijn, genever of andere vogten gefchied, als waar in men de fijne vliezen gemakkelijk kan fcheiden en zuiveren; de infpuiting door waschmaterie is mede genoeg bekend; als mede de opblazing der vliezen en dergelijke fubtiliteiten meer: ook weet men, dat men de deelen der oogen, en de vliesjes in overgehaald vogt wel bewaren kan, als warin dezelve, vooral als dezelve volgens de manier van RuIsch zijn opgefpo. ten, aangename cieraden en genoegelijke herinneringen van welbefteden tijd, aan den beoffenaren geven. Ondertusfchen weet eik beoeffenaar, bij ondervinding, hoe moeijelijk het is, om de fijne vliesjes, de iris, het reivlies, het netvlies, het glas - en kristallijnvogt enz., in derzelver waren ftand te bewa . ren, zoo dat een geoefend en keurig onderzoeker, uit verfcheidene oogen, zich een ap. paratus moet verfchaffen, om dus de vliezen op den oogbol zelve in hunnen waren ftand te kunnen vertoonen. Nog is het bekend dat 


\section{IA HOLLAND. $30 \%$}

de Duitchers de kunstoogen in ijvoor maken; wormius makt in zijn Mufaeum gewag van konstoogen van leder gemaakt, en de meergenoemde Heer HENDRIK FRITH heeft er zelve een uit kunstvliezen bereid, waar mex RUNDVEE; II. Afd. VI. Hoofdrs:

van geen wedergade bekend is; maar, en hier op wil ik nederkomen, ik geloove, dac het nog niet algemeen bekend is, om de onderfcheidene oogkameren, vliezen en oog. rokken, zelfs het kristallijn - en glasvogr, door drooging zoodanig te bereiden, dat men het geheele oogengeftel, onderfcheiden in alle vliezen, op- en aan elkander kan voegen, even als een ijvoor konstoog, en dit is het gene ik heb mede te deelen.

Ik had het verdriet, dat de vliezen der oogen, wier deelen ik in vogt bewaar- greep om de, in een zakten, en terwijl ik dezelve ontleden droogde, plat wierden. Ik wist wel, dat en devlie: men wel eens glazen bolletjes bezigde, maar zen te dewijl tot allerlei oogen dan ook glazen bolletjes van allerlei grootte benoodigd waren, was dit gebrek, zonder groote kosten, niet zeer gemakkelijls te vergoeden; dan, eenigen tijd daar na, langs het Water te $\mathbf{A}$ mferdam gaande, en ziende daar voor een winkel marmeren knikkers en verglaasde ftuiters, van allerlei grootte, te koop ftaan, viel mij in, dat zoodanige fteenen of verglaasde bolletjes mij mogelijk zouden kunnen dienen, om daar op allerlei oogbolvlie. zen te droogen; ik fchafte mij dus eenige 


\section{NATUURLIJKE HISTORIE}

mxx dergelijke bolletjes van allerlei grootte aan : nuNDVEa en beproefde de uitwerking, die mij zoo I1. Afd. mede viel, dat ik met weinig moeite, al-

vi. lerlei foort en grootte van oogvliezen op dezelve bereiden en droogen kon. Laat ik de jonge Leerlingen zeggen hoe men doen moet.

Het eerfte is, om zich zoodanige fteenen of verglaasde bolletjes aan te fchaffen, en daar uit te kiezen, die met de grootte des oogbols best overeenkomen, dan nijpt men die bollerjes van onderen plat, zoo dat zij op dit plat half fpherisch kunnen ttaan, en dus onder het gebruik niet weg rollen, mas ftasnde blijven, wanneer men dan een oog, met of zonder fpieren en klieren, ontleden wil, zoo hebben men dic op te merken: men maakt, naar dat den oogbol uit de beenkas genomen en van den dikken rok van tet verlengd hersfenvlies en de fpieren gezuiverd is, met een fcherp fchaartje eene opening midden in den horifontalen diameter des oogbols, ter plaatfe waar het doorfchijnend hoornvlies aan de fclerotis zich met het donker binnenvlies vereenigd, zie Fig. 5. bij $h / 2$, dan pelt men het boven hoornvlies voorzigig af, en fcheidt tevens met het binnenvlies, het reivlies en watervlies aan een vereenigd, want deze vliezen moeten gelijkelijk doorgefneden worden, orm dezelve daar na, een voor een, in den onder - en bovenbol te kunnen ichoiden; men kan dadelijk derzelver affcheiding ontdekken, 200 dra het watervogt weg loopt, 
loope, want als dan is de ruimte der wan- Hxт den grooter en zigtbaarder, zoo dat men kundves: gerust toeknippen kan, terwijl zij alle nog II. Afd. eenigzins aan den doorfchijnenden ring vast zitten, daar na laat men den oogbol aan de VI. onderkom en gezichtzenuw nog vast, legt Hoofdise vervolgens het bovenfte gefcheiden deel in water, daar na frijdt men alle vliezen langs derzelver rondte door, tot aan het glasachtig vogtbeursje, dat vooral niet gekwetst moet worden, want daar van hangt alles af: wanneer gij dan deze vliezen doorge neden, of eene goede opening gemaaks hebt, zult gij dadelijk aan het waterachtig vogt zijn; dit kunt gij niet bewaren noch vermijden dat het weguloeije: het zal er $z$ wartachrig en morfig uirzien en $u$ belemmeren: darani als uwe fnede tot ruim over de helft gevorderd is, legt dan het oog in fchoon water, en ververscht dit telkens, zo'o lang tot het helder blijft, zagtjes het oog op en neder bewegende, tot de wanden van het watervogt inet helder water vervuld zijn, ga dan voort en fnij het overige midden door, doch alles in en onder het water, en vooral cirkelrond, als dan de bovenfte halve bol van de onderfte gefcheiden is, zal het geheele glasvogt en de kristallijnen lens er gemakkelijk uitvallen: verfchaft $u$ dan een hol horologieglas, waar van men een kleine voorraad bij de hand moet hebben: kies dan zulk een glas naar de grootte of holte van het glasvoge zakje, en fmeert het een weinig met witte oljjven - of 


\section{NATUURLIJKE HISTORIE}

wex amandel-olie, die vooral helder is: daarna RUNDVRE. fchept men het glasvogtbeursje en de kris-

II. Afd. tallijne lens in hetzelve, en fpoelt het V'. zagtjes en zuiver af, gij zult als om den Hoofdr: ring of den rand van het kristallijn, eenige 2 warte randjes en haarbuisjes vinden: neem dan een zagt penceel en zuivert die omziga. tig van het watervogt, zoo dat het watervogt helder en doorfchijnend blijfe, en nog. tans de fprugtels dezer buisjes er agnblijven, zoo als men dit in Fig. i9. bij e ee zien kan, daarna haalt gij het horologieglas uit he, water, en laat het water voorzigtig afzijpelen: plaatst daar na uw glas in den zonnefchijn, doch liefst des zomers, als de zonneftralen in de fchaduwe heeter zijn, dan zal het glasvogtvlies dadelijk drooger, en het vogt in het begin wel wat melkachtig worden, en ook inkrimpen, maar eindelijk taaijer, als een doorfchijnend gom droogen, vooral als het buitenvlies fchielijk droogt, bierom moet men het water, 200 veel men kan, met een penceel afvegen, op dat het vlies niet week blijft: hoe fpoedi. ger men dit glasvogt en kristallijn droogt hoe beter, want als men er lang mede vertoeft, gelukt het niet zoo zeker : dan neemt men zeer witte arabifche gom in zuiver water gefinolten, met een grijntje gekristallifeerde witte fuiker, 200 wit, als gij die kunt bekomen, en befmeert uw onderwerp er zeer dun mede, als het winddroog is, want dit belet het inkrimpen; dit glasvoge zal dan eindelijk handelbaar worden, maar 
dan moet men omzigtig zijn, om hetzelve HRT uit het glas te krijgen, vermits het wel ge- Rundves. beurt dat de bodem van het glas aandroogd, Ir. Afd. doch daarom moet men van tijd tot tijd hetzelve in het glas zagtjes verfchuiven, en vi. met witte olij fmeeren, om het los te hou. den, of zoo het al te vast zit, dan moet men het van verre over het vuur iets warm maken, dan worde de olie los, doch al te warm is gevaarlijk, om dat dan de doorfchijnendheid minder wordt : daarom moet men langs den rand telkens met een penceel met zuiver water ftrijken, dan raakt de kleverigheid los, welke, zoo dra gij er de bol vitligten kunt, ftraks weder opdroogt en doorfchijnend blijft. Insgelijks kunt gij als dan, of wel bevoorens, er de lens uitligten om deszelfs kommetje te zien, doch dit moet men niet doen, voor dat het waterachtig vogt en dcszelts rok geftremt is, anders verliest het zijn gedaante. Als dit nu gedaan is, gaat dan voort met het fcheiden der overige oogvliezen in het water, telkens dezelve met een zagt penceel zuiverende en fcheidende : men moet dit doen in een vlak teljoor, of op een wit Engelsch aardewerk foupbord, en is men er kiesch op, moet men zich een koper of blik vierkant bakje laten maken, dat wit geverwd is, en daar in een bodern van wir glas, die men er uit kan ligten: dan moet men telkens daar onder een natgemaakt wit papier leggen, om duidelijker de vliezen te kunnen onderfcheiden en te zuiveren. Ik gebruikte een fpiegelglas. Als. 


\section{NATUURLIJKE HISTORIE}

HET dan nu uwe vliezen gezuiverd ziju en in het RUNDVBe. water drijven, giet er dan een weinig witce II. Afd. brandewijn in, om dezelve te doen zamen-

VI. trekken: witte azijn is ook goed, en mogelijk Hoofdr. beter, dan neemt gij uwe tteenen of verglaasde bolletjes, naar de groote van de oogbol, lege die insgelijks in her water, en legt dan zagtjes en ftil, zonder het water veel te bewegen, elk vlies op een afzonderlijk fteenen bolletje, en frijk het in zijn 1tand met een penceel glad uit, als men de kosten wil doen, om zich ecn koper bakje te ver. zorgen, kan men under aan den bodem een kraantje of opening maken, die men kan toeftoppen, tot dat de vliezen uitgebreid zijn, en op de fteenen bolletjes plat leggen, waar na het water zagtjes wegloopende, de vliezen van zelve zich uitfprciden. Dit kunstgreepje is van een ongelooflijk nut, niet alleen om alle vliezen plat en ongekreukt te houden, maar inzonderheid oin aile fijne waterplantjes, zeewier, koralijnen enz: te droogen, zonder dat de incenigte takjes verwarren; als dan nu de oogbolvliezen dus op de fteenen bollerjes leggen, mak u dan tuitbolletjes van klei, en drukt die naâr den rang der vliezen op een plankje, of in een houren bakje, zoo diep, dai gij over de bollen een glas kunt leggen : neem dan met beleid uwe fteenen bolletjes, cen voor ecn, elk met deszelfs vlies, uit het wate:, of laat het water, zoo als gezegd is, van onderen afoopen, neem dan onzigtig hei fteenen bolleije met het vlies, en druk din deszelfs 
onderfte onbedekte deel op dit tuitkleibolle- ner tje, 200 dat het vast ftaat in dien ftand als Rundvzz: het $00 \mathrm{~g}$ is, en ftel daarna uwe vliezen on- II. Afd. der het glas alzoo te droogen, dan zult gij met vermaak oogenblikkelijk het genoegen vI. Hoofdar. genieten om uwe vliezen te zien opdroogen in hunne ware geftalte: maar de groote zaak. is nu om de vliezen wederom zonder kwetfen van de feenen bollerjes af te krijgen, en hier toe behoort voorzigtigheid en geduld: dan, om dit te doen gelukken, moet men dezelve, voor en aleer men die in het water legt, met een weinig, vooral helder, zeer flap gomwater of olijven-olie beftrij. ken, doch het eerfte is beter: wanneer uwe vliezen dan droog zijn, ligt gij zagrjes, met een fcherp mesje, de randen der vliezen op, en laat dan, met een penceel, er laauw water in wellen, dan wordt de gom ligtelijk los, zelfs al bevogrigd men het geheele vlies, hetwelk dan eindelijk gehieel los laat, en van het fternen bolletje affchuift: doch hierin moct men niet driftig zijn, want het vlies moet allengs bevagtigd worden, anders wordt het weder nap, dit dan wel gelukt zijnde, vernist dan uw vlies mer witte Spiritus vernis, en het zal volkomen doorfchijnend worden; plaatst het na de vernisfing weder telkens op uw fteenen bolletje, befmeer die dan met witte olijvenolie of water, dan zal de vernis niet meer aankleven, en eindelijk uw vliezen bereid zijn, zoo dat dezelve in eene voorzintige hand, volkomen handelbaar zullen zijn: vervigens 


\section{NATUURLIJKE HISTORIE}

MET knipt gij alle overtollige falbulas, vezeltjes aundver. enz. in de rondre af, en plaatse dan een II. Afd. voor een, naar rang uw vliezen, zet daar in VI. uw gedroogd doorfchijnend glas - en krisHoofdit. talvoge, en dekt dit dan wederom met de vliezen van den bovenbol, en gij zult het. genoegen hebben een natuurlijk gedrongd oogenpreparaat te hebben: doch let hier op, dat uw vernis wel droog zij, anders.loopt gij gevaar, dat de vliezen kleven, hierom moet men nooit terpentijn vernis bezigen, ten ware het allerzuiverst uit witte mastiek of gom dragacanthi beftaat: indien men de vliezen afzonderlijk wil bewaren, dit kan mede gefchieden.

Zie daar dan, Lezer! een eenvoudig kunstje, waar mede ik oordeel geenen ondienst aan jonge liefhebbers te doen: meerder kan ik er niet van zeggen, indien evenwel iemand de kosten doen wil, om glazen bolletjes van allerlei grootte te laten blazen, deze zijn nog beter, on dat het glas minder aandroogd, en zulke glazen bolletjes, aan een ftaafje, handelbaarder zijn.

Nu zal ik nog melden, hoe men diene te handelen, als men ook de fpieren van hét oog wil droogen en de oogkas er bij bewaren: de laatfte dient men uit het bekkeneel te zagen, en dan daar in de verlenging van het hersfenvlies luchtig te fcheiden en er aan te laten, en vooral den ring der katrolfpier (trochlea), zie Fig. 5. bij g. Voorts kan men ook, naar gerade der oogbollen, op ecnen grooter fteenen of glazen bol de oogleden : 


\section{- An HOLla}

den, wenkbramen en de traankliertjes bereiden, doch als deze bereid zijn, moet men dezelve op het oogenblik eerst met gomwater, en dan gedurig aan mer vernis befmeren, op dat ze hunnen natuurlijken wel. ftand behouden, en vooral ook zonder drukking op den oogbol fluiten; een weinig winddroog zijnde, zorge men om het lluimervlies van het hoornvlies te fcheiden, met er geolijd papier tusfchen te vieijen en het gedurig te rekken, dan blijft het in zijn ftand. Wat de fpieren betreft, deze moet en kan men gemakkelijk genoeg fcheiden en van het vet en het overtollige zuiveren, doch men moet vooral dezelven niet al te ver van derzelver waaijerachtige uitfpreidfels ontblo. ien; als men ze dan om den oogbol drooger wil, zoo als in onze Fig. 5. te zien is, neemt men wit fchrijf - of postpapier, dit befmeert, men met olie, terpentijn olie is het allerbeste, zoo lang tot het doorfchijnend wordt als glas en niet ankleeft, ook geen water antrekt, daar na maakt men daar van plaarjes, rolletjes, of zulke ftukjes, ais de omtrek der fpier vereischt, dan befmeert men dezelve met wat olijven-olie, en vouwe of fchuift de fpier daar op, zoo dat hee opgemeld papier als een fcheidsmuur is tusfchen de wanden van de fpier en de wan. den van den oogbol, het zij aan de gezige. zenuw of aan de fclerotis of het hoornvlies; begeert men de fpieren af te fcheiden en uit te fpreiden, zoo als men dezelve veelal bij de ontleedkundige af beeldingerz 


\section{NATUURLIJKE HISTORIE}

gzT ziet, dan moet mien zich glazen plaatjes zuNDVre. anfchaffen, wier centrum of onderbol tot

II. Afd. een cirkelrond is uitgefneden, zoo dat er Hoofdr. de oogbol in rusten kan, waar na men de fpieren in de rondte op het glas uitfprei. den en droogen kan; een geolied bordpa pier met het opgemelde doorfchijnend papier daar over, heeft dezelfde litwerking, verders moet handigheid en vernuft het ove: rige volmaken.

Ortdek. Maar ik heb beloofd, dat ik de onthiug van dekkingen zoude mededeelen van den zeer y. Hovius. geleerden Heere JAKOB Hovius, in leven Philofophiae en Medicinae Doctor te AmRerdam, een Man, wiens verdienften niet alleen in die wereldftad, maar ook bij de Hooge Scholen en Maatfchappijen van Europa als nog in hoogachting zijn. Wij Spraken hier boven reeds van de fijne infpuitingen van RUISCH en MONRO in de oogen, en behielden dien leiddraad der ontleedkunde tot hier toe in onze afbeeldingen en verklaringen; het kan dan hier niet onaangenaam zijn, dat ilk regt doe aan den roem van mijn Vaderland; in de nieuwe ontdekkingen wegens het oog der Koetjen. Het was in den jare 1740 , dat bovengenoemde JAROB HOviUs, deszelfs nieuwe ontdekkingen over het oog mede. deelde, bij zijn inwijdings-Redevoering, onder den titel: Trattatus de Circulari hu. moram motu in Oculis, dat is: Verhande. ling oyer de beweging der omloopende vogren in de oogen; welke Verhandeling na. derhand vermeerderd en verbeterd te voorfchiji 
fchijn kwam. Daar nu het Koeijen-ogs de eerfte en voornarmfte aanleiding tor deze nieuwe ontdekking gegeven heeft, en dezel. ve tevens eene bijzonderheid in het oog van dit dier heeft doen kennen, mogen wij HET RUNDVEZi niet voorbij, om deze in dien tijd zoo roem. rugtige nieuwe uitvinding mede te deelen, en te meer, daar deze ontdekking zelfs door de Leipziger, Parijsfche en Londenche Maatfchappijen genoemd wierd: Rete Novum bobus eft mirabile, dat is: het nieuwe netgeftel in de Koeijen is verwonderlijk; en in der daad het is zoo, gelijk de fraaije, en zoo naauwkeurig als ons doenlijk is, ge. volgde af beeldingen zullen getuigen; zij zijn zoo fchoon en klaar, dat onze Lezer, zoo wij vertrouwen, alleen door de verklaring derzelven, al het bevorens verhandelde ligtelijk nog beter zal begrijpen.

Bezie dan Figuur I1, verbeeldende het Plaat $\mathbf{X I}_{\text {: }}$ hoornig oogvlies uit eene Koe in zijn wa. Fig. 12. ren ftand, weike Figuur wij, fchoon dezelve bij dien Schrijver de laatfte is, verkiezen hier te laten volgen op onze laatfe Figuren van den oogappel en derzelver vlie. zen, zoo om den aard der zaak als om de geregeldheid der plaatsfchikking.

Men vergelijke dan de langwerpige witte ooghleuf met onze Figuur 1. en 6, alwaar wij denzelven hebben afgebeeld en befchreven; als bijzonder aan de Koeijen eigen, en ver. moedelijk zeer gefchikt om in het duister te zien; de onzen uit een Kalf genomen zijnde, 200 is de teuf kleiner, maar hier

II. Afd. VI. Hoofdra: 


\section{3: 8 NATUURLIJKE HISTORIE}

grt bij $a$ helder en duidelijker, zij ligt midden anDVER in het ontbloot druivenvlies bij $b b$.

II. Afd In Figuur 4. vertoonden wij de kleine Hoofdr. gaatjes, waar uit de ooghaartjes in de oog. leden fpruiten; in Figuur $\mathrm{s}$. ziet men de haren uic den rand op het uitwendig ooglid van ons Kalfsoog, maar hier, in Figuur II, ziet men bij c c c c ongemeen fraai de fijne bloedvaatjes en zenuwtjes in een gevlochien, ter plaatfe daar de ooglidhaartjes ziju ingelijfd, als aan, om en naast elkander gefchaarde tepeltjes den kring van het oog beflaan, en als onmiddelijk eindigen in het omgeflagen gedeelte van het inwendig vlies, $d d d d$; waar door dan, ten dezen opzigte, meest alle onze Figuren worden opgehelderd.

Plaat XI. Maar nu bezie men Figuur 12, zijnde de Fig. 12. vijfde Figuur van Hovius, eens tegen onze Figuren 1 . en 5 , mar vooral tegen onze Figuur 9, dan zal den oogbol, aldaar vertoond, in zijne onderfcheidene ontledingen duidelijk op deze Figuur van Hovius kunnen overgebragt worden, vooral indien men denkbeelcig de kristallijne vogten, het oogbolletje, het net en druivenvlies, bij Fig. 9. verbeeld, plaatfe in de kom van den oogbol, hier vertoont: alleen is opmerkelijk in deze riguur, dat hier de kronkelende nieuw ontuekte bloedvaarjes kennelijker zijn.

Mien ziet bij a den oogbol eener Koe afgebeeld, van achteren geheel van fpieren ontbloot; vergelijk Figuur 5, alwaar deze bol nog met zijne fpieren in de beenkas 


\section{VAN HOLLAND. 3is}

lige; bij $b$ doet zich de groote gezigtze- ngE nuw omgekeerd op.

RUNDVER'

Bij $c$ is de voorname fpruchteltak, wel- II. Afdi ke, volgens de nieuwe ontdekking van dien tijd, het aderlijk vat is, hetwelk uit het VI. Hoofded aderlijk vereenigd netsgewijs vat (Reticulum noyum Arteriofum ) ont(pruit, en om den oogbol loopt.

Bij $d$ ziet men deszelfs tweetakkige fcheiding.

Bij $e$ is angewezen de opklimming der tweeleedige vaten tegens en op het hoornvlies.

Bij $f$ ziet men den rand van het hoorn. vlies, waar op en om het kronkelend aderbuisje vloeit en ingelijfd is.

Bij g ziet men een zeker bloedvat, hetwelk uit de bekleedfelen van het hoornvlies corfpronkelijk : uit andere vaten in den rand van de omringende flangsgewijze vaatjes invloeit.

$h h_{2}$ zijn de wanden valn het druivenvlies, tusfchen den rand van het hoornvlies en de kronkeling der vaatjes in.

Bij $i i$ vertoonen zich de aderlijke kronkelingen, die bij wijze van eenen ring den oogbol omloopen: deze bloedvarjes zijn hẹt, die bij de ontfteking der oogen het eerst kenbaar zijn.

Bij $k$ is de voornaamfte kronkeling der adervaatjes, doch die fchier met geene mogelijkheid zijn af te beelden, ten ware mer het vergrootglas te hulp neemt.

Wij zullen nu tot de voornaamfte, zijnde de twee eerfte zeer annmerkelijke Figuren 


\section{0 NATUURLIJKE HISTORIE}

Het van Hovius, overgaan; waarin, in eene Rundve verikleinde oncrek van een ontleed Kalfs. II. Afs. hoofd, de nieuwe ontdekking van het wonVI. derlijk nersgewijs adergeltel in eene Koe is Hooldf. afgeneeld.

Plaat XI. Men befchouwe dan opletcend Figuur $13:$

8.g. 13. hier is eerftelijk een Kalfshoofd, waarin aan deze zijde des hoords her meergemelde aderlijk netsgewijs zamentel in deszelfs natuurlijke plaating zigtbaar voorkomt: men veronderflelle, dat bij a het uiteinde van het verhemelte in de bovenkaak eindigt, en dus de beenderen van het verhemelte wegge. nomen zijnde ter plater, alwaar de reuken fmakzenuwen zich met derzelver bekleedfelen als vereenigden, en dus hier al. leen de voornaamfte gezigtdeelen te voor. fchijn komen, om des te beter de nieuw ontdekte netsgewijze vlegting der adervaatjes te kunnen zien: in der daad vertoonen deze zich duidelijk ter linker - en regter $z i j$. de, zoo dat de eene hooger dan den anderen fchijnt te faan, gelijk dic ook in de volgende Figuur kennelijk is, en war van ik geene reden weet te geven, daar de ge. zigizenuwen en ook de grootere bloedva. ten rer wederzijden eenpurig evenredig geplaatst voorkomen; bij. $b$ ziet. men dan de linkir netsgewijze adervlegting in des. zelfs natuurlijke ftand, van de vliezen en klieren gezuiverd, even voorkomen; bij $c c c$, zijn de wederzijd/che fpiertjes, die hetzelve bedekten, omgeflagen vertoont; $d$ doet de aderlijke fpruchtel zien, die uit de nets. 
gewijze vlegting optwaarts loopt; bij e komt de afdaling van de halsader (Carotis) voor, waar uit de net gewijze vlegting ontfpringt; ff toonen de raksgewijze fpruchtels van dezelve aan; $g$ vertoont de regt che adervlegting zeer duidelijk tusfchen de omringende vaten, bijzonder bij $h$, alwar de halsader zich als verdeelt; bij $i$ ziet men twee tak. ken van het nieuw ontdekte aderlijk bloedvat, hetwelk uit de netsgewijze adervlegting ontfpruit, en welke takken om den oogbol loopen : vergelijk Fig. 12, alwaar dezelven, gelijk hier, on, het hoo:nvilies der oogbol omzwaaijen; bij $k$ zijn twee zenuwtakken van den oogbol; bijlvertoonen zich de beide gezigtzenuwen, evenredig tegen elkander ge. vleid en afgefneden, ter plaatfealwaar dezelven in het hersfengeftel inkrommen; bij $m$ ziet men een gedeelte van de halsader, die insgelijks in de hersfenen of liever in het moedervlies (pia mater) invloeit, bij wijze van een tweetakkig vorkje verfpreid; $n$ is de annwijzing van de plaats, alwaar de voorname bloedvaarjes en zenuwrjes invloeijen, welke men de bloedvaatjes en zenuwijes van $N u c k$ noemt, gelijk ook het beloop van deze vaarjes den rand van het netsgewijs gedeelte formeeren; bij 0 is de vereeniging der netsgewijze ringvaatjes, tusfchen de beide gezigtdeelen als tot een centrum zamenloopende: eindelijk ziec men bij $P P$ de oogbollen uitwendig geheel ontbloot; bij $q$ de fcheiding of her middenfchot van her verhemelte; $r r r r$ duidt een gedeelte van hec
HeT RUNDVEZ, II. Afd. VI. Hoofdfta 


\section{NATUURLIJKE HISTORIE}

нET beenachtig achterhoofd aan. Deze Figuur RUNDVEE. dan in zijn geheel verklaard zijude, worde

II. Afd. nict weinig opgehelderd door de volgende VI. Figuur 14, om dac in dezelve de netsgewijze Hoofdrt. vlegting allerduidelijkst en veel grooter uitPlaat XI. gebreid, in eenen omgekeerden ftand voorFig. 14. komt, vooral met deszelfs afleidende zoo wel als invloeijende vaatjes om en aan her gerigtgeftel.

Bij \& dan is wederom het uiteinde van het verhemelte, bij $b$ het middenfchot, bij $c c$ de achterwanden van hetzelve verhemelte (palatum); maar bij $d$ worden duidelijk en kennelijk, op den linker oogbol, de flagaderlijke vaten (yenofa) aangeduid, welke het bloed uit den omtrek van den oogbol weder nederwarts afleiden, en altoos zeer kennelijk tusfchen de fpieren en klieren of vetvliezen van den oogbol te zien zijn: doch hier ziet men dezelve in het netsgewijs ader. geftel zeer klaar achter ingloijen bij $e$; bij ff ziet men allerheerlijkst het netsgुewijs adergeftel voorkomen, zich zelve volkomen als een netsgewijze vlcgting vertoonende, terwijl de rand der flagaderlijke vaten, als in hunne vliezen leggende, zigtbaar is, en bij $g$, een kennelijke flagader, nog klaarder voorkomt; bij $h$ doet zich de llagaderlijke boezem, (finus yenofis,) zeer duidelijk onderkennen; terwijl niet minder duidclijk de aanvoerende aderen om den oogbol (bij Fig. 12. reeds verklaard) hier bij $i$, op den regter oogbol, wederom voorkomen; bij $k$ is de plaats der invloeijing van 


\section{VAN HOL L A N D. 323}

eenige flagaderlijke vaatjes; voorts ziet men bij $l$ wederom eenen der tweeledige fpieren omgeflagen, van het regter netgeftel afgefcheiden, terwijl dezelve nog om het linker leg. gen; $m m$ duiden de beide oogpunten, en $n n n$ het gedeelte van het achterhoofd aan.

$\mathrm{Na}$ dat wij alcus, in naarvolging des onderzoeklievenden Hovius, ook zijne twee eerfte Figuren hebben voorgedragen, en het netsgewijze adergeftel in de oogen in deszelfs natuurlijken ftand vertoond is, volge hier nu zijne heerlijke derde Figuur, (op deze Plaat Fignur 15), waar in het meer- Plaat Xr. gemeld netgef?el, afzonderlijk vertoond Fig. 15. wordt, met deszelfs afleidingen en invloeden op en om den oogbol, tor zelfs in de fijnfte fpruchtels van het druivenvlies en de overige oogbekleedfelen, in alle deszelfs wonderbare takverfpreidingen, draaijing en kronkeling, in en aan de kusfing (anaftemofis) der allerfijnfte llagaderlijke bloedvaarjes ingefloten, al het welk hier zoo duidelijk voorkomt, dat er niets meer behoef, dan op dien voet, de verklaring van den Autheur zelven te volgen, met overbrenging op de onze.

$\mathrm{Bij}$ a $a$ dan is eene der voornaamfte takfpruchtels van de halsader (arteria carro. tidis) van de benedenzijde tot boven roe, het aderlijk net omvangende: bij $b b b b b$ zijn deszelfs zijdelingfche fpruchtels aangewezen; $c c c c c$ nu is het geheele aderlijk net, zoo als hetzelve uit de halsader gevlogten wordt, plat uit geftreks; het ver$\mathrm{X}_{2}$

II. Afd. VI. Hoofdit. 


\section{NATUURLIJKE HISTORIE}

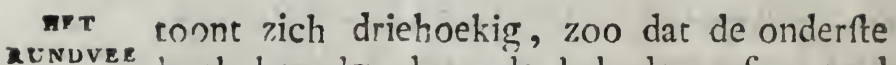
hoek heneden door de halsader geformeerd

II Afd. wordt, en de twee bovente door den rand VI van het net zelve. Uit alle deze zonderlinHoofdit. ge netgewijge vlegtingen vlocit nu het nieuw ontdekte aderlijk bloedvat bij $d$; dit varje n" vervolge tot om en aan de ge\%igtzenuw, gclijk dezelve dan vervolgens met twee aan$\pi$ erkeliike affcheidingen, bij $e$ te zien, zich vcrder over het hoornig oogvlies verfpreid, in zeer annmerkelijke kronkelvaarjes cn flingerrjes, bij. $f f$ allerduidelijkst te belihouwen; hij $g g$ ziet men wederzijds twee voorname fpruchtels, die door het hoornvlies, tusfchen deszelfs inwendige wanden oplopen, over het choreidevlies; bij $h h h$ zijn ontellijke fijne bloedvaatjes over den inwendigen bol loopende, meerendeels door vergrooting afgebeeld, alzoo zij anders, door derzelver fijnheid, bijna niet kunnen gezien worden. Wijders is bij $i i$ de grooten raind van dẹn oogbol omringd door een gemeenfchappelijken ader; $k k$ vertoon duidelijk al wederom die ongemeen fijne flangswijze kronkelingen der nicuw ontdekte vaatjes, op den rand $i i$, rondom den oogbol flingerende; bij $l / l l$ zijn de nog. fijnere fpruchtels aangeduid; eindelijk bij $m m$ is de vereeniging of kusfing der vaatjes op hun centrum aangewe. zen; voorts ziet men alle de fine bloedvaatjes die dnor het druivenvlies vlegten. (Vergeliik onze eisen Figuur 6. Hier mede nu is deze fraaije Af beelding der nieuwe ontdekking in een Kueijenoog, eenigzins als door 


\section{A N H O L L A N D. 325}

een vergrootglas opgehelderd, doch om dit нвт volkomen te beflisfen, is bij Figuur 16 , (zijnde dit 'de vierde Firnur van hovius), II Afd. merkelijk vergroot een gedeelte van het druivenvlies, vol van de allerfijnte vaatjes, verHontivit. toond, zoo als hetzelve tusfchen het hoorn- Plaat XI. vlies inlegt Dit vliesje, dat wij in Fig. G. Fig. 16. alreeds vol van fijne bloedvaatjes verroond hebben, wordt hier volkomen opgehelderd, door dien bij a a a de algemeene gekr onkelde aderkring gezien wordt; bij $b b b$ zijn oneindig fijne fpruchtels, die zich door het druivenvlies verfpreiden, in onderfcheiden takjes re voorf'chijn komen: dat nu deze fijne takjes aan het druivenvlies behooren, blijki uit het omgenagen vlies bij $c c c ;$ bij $d d$ is een gedeelte van het hoornvlies verbeeld. Alle deze $z 00$ aanmerkelijke ontdekkingen wegens het oog en gezigtgeftel, toonen aan, hoe genoegzaam alle voornaamfte Ontleedkundigen, dezelven aan de deelen der Koeijen verfchuldigd zijn, het is dan zeer zeker van geen klein belang, dat wij dezelven, zoo veel mogelijk, bij een verzameld en met onze warnemingen vereenigd, den Landzaat doen kennen, en aan hun, in onze landfprak, voordragen, het geen in onderfcheidene werken, in andere talen, niet dan bij gedeelten te vinden is.

Daar het nu uit alle de befchrijuingen der Figuren, op Plaat XI, blijkbaar is, dat de oogdeelen en het gezigt der Koeijen zulk een bijzonder maakfel hebbci, hen bijzonder eigen, zoo is het natuurlijk gevolg, dat de- 


\section{NATUURLIJKE HISTORIE}

HrT ze, volgens het reeds verhandelde, tot een unDVRe bijzonder gebruik dienen. Hier boven hebben

II. Afd. wij bij den aanvang van dit gedeelte, na ge-

VI. noeg bepaalt, dar het gezigt der Koeijen ge-

Hoofdr. fchikt fchijnt, om bij nacht of in de fchemering fterker te zien dan fommige andere Dieren: wij merkten aan, dat hun oogpunt een zekere andere rigting, of liever vermogen had tot het vangen der lichtftralen. Ten flote, en ten bewijs van dit ons gevoelen, hebben wij de laatfe Figuur 17 in deze Plaat gefchikt, als moetende dienen tot befuit van alle de overigen. Onze ftelling is, dat her oog der Koeijen, buiten het betoogde, om in het duister te zien, ook inzonderheid gefchike is, om op zijde en kort voor zich te zien. Men beziet eene Koe vlak voor den kop, dan ziet men, dat de neus, de ftarre of kol, eene vlakke gedaante hebben: men lette op de affanden der neusgaten: deze zijn beiden veel meer dan in eenig ander Dier verwijderd, zelfs meerder dan in de Schapen. Vergelijk dit nu eens met den mensch en met andere Dieren, vooreerst, in den Mensch zijn de oogen vlak in het voorhoofd geplaatst: hij kan dus met opgeregten hoofde zeer verre voor uit zien, en fchijnt gefchapen, om het hoofd hoog en opgeheven naar de lucht, te heffen, om dus ook met de oogen opwaarts en vlak naar de fterren te zien, dit is reeds door de oude Dichters opgemerkt, welke wegens de bijzondere befchikking des Scheppers, ten opzigt van den Mensch dus zongen:

Pro. 


\section{VA N H O L L A N D. 327}

Pronaque cum fpectant animantia caetera terram, Os homini fublime dedit, coelumque tueri Jusfit, \& erectos ad fidera tollere vultus.

Dat ik met vrijheid dus overbrenge:

II. Afd. VI. Hoofdî;

Daaral 't gedierte fteeds naar de Aarde neêrwaarts zię, Gaf Hij, die 't alles fchiep en alles wijs gebiedt, Den Mensch dat heerlijk en dat wonderlijk vermogen, Om opwaards 't Starrenheir te aanfchouws met zijne ongen,

En daar al het gediert' als kruipend ziet langs d'aard, Zoo gaat de Mensch regt op en 't aanzigt hemelwaard.

Ondertusfchen hebben de Apen, als over het geheel het naast aan den Mensch komende, de oogen nog digter bij cen, doch platrer neuzen, uitgezonderd de Hondskoppen (cynocephali, die fnuiten hebben: deze zien beiden regt voor zich uit. Het Paard heeft ook de oogen digter, evenwel eenigzins zijlings, als eene Koe, doch de neus finaller, zoo dat dit Dier ook in dit opzigt, fchoon zoo fterk niet als de Mensch, vooruit ziet. Onder de Visfchen zijn er, die volitreke de oogen boven op den kop hebben, als de Uranofcopus en de Anablebs, die ik in het werk van SEBA uitvcerig befchreven heb, dan dit gezigt is van eenen anderen aard. Intus?chen kan eene Koe meer over en op zijde van den neus zien, als eenig ander Dier, om reden dat de neus plat is, en dir Dier dus met het oogpunt over die platheid zien kan, het geen een Mensch volftrekt na. 


\section{NATUURLIJKE HISTORIE}

вะт tuurlijk niet doen kan, om dat zijn neus uit-

RUNDVEE ftekende is, en het linkeroog den regter wang,

II. Afd. gelijk het regter den linkerwang niet bereiken

VI. kan, nu leert de gezigtkunde, dat, zoo men

Hoofdft uit ieder oog van den mensch een lijn trekt, dịe beide de gezigtpunten tor een brengt, deszelfs afftandige zamenloop, zeer verre vooruit loopt, maar in eene Koe is dit geheel anders. Hare oogpunten uit beide de oogen, zijn kort en kort ziende, zie, bij

Plaat XI, voorbeeld, Figuur I7 bij $a a$, de twee oo-

Fig. 17. gen of oogappels, oogpunten, in eenen Koekop afgebeeld:, men trekke van $a a$, aan elke zijde eene lijn, van den hoek van her oog af, tọt over en tusfchen de twee verwij. derde neusgaten $b b$, war langs eene Koe nacuurlijk vooruit zien moet, dan zullen de twee lijnen elkander kruisfen en een oogpunt maken bij $c$, wel te verftaan, als de Koe met beiden de oogen te gelijk vooruit ziet, en dus volgt hier uit, dat eene Koe niet zeer verre vooruit kan zien. Dit, meenen wij, is al wederom cen bevestiging van de onbegrijpelijke wijsheid des Scheppers. Overweeg het, Lezer! en beoordeel het. Eene Koe heeft volftrekt een kort gezigt noudig tot zijn beftaan, om dat hij kor langs den grond zijn voedfel opfpeuren, al grazence de kruiden onderfcheiden en uitkiezen moet, van andere foorten, hem onnut, $z 00$ dat, indien hij een uitftekende neus had, hij volftrekt zoo nabij niet, zoude kunnen zien, en vooral niet zoo fijn grazen, noch het gras afkorten, om dat hem boventanden 
den ontbreken. Het paard heeft boventanden en graast ook, doch op veree na zoo RuNDVEs. fijn en kort niet als dé Koeijen. Men lette Ir. Afd. er op, een Paard zal veeltijds mei rukken het gras afbijten, eene Koe mee eenen geHoofdit. ftadigen eenparigen voortgang. Maar ik heb nog meer ondervindend bewijs voor het kortzien der Koeijen, wel te verftaan, vlak vooruit, want vain ter zi iden zien zij zeer verre, ' $t$ geen dadelijk zal blijken. Men lette eens op de Koe of Koeijen, als zij in het veld vrij en onbedwongen loopen, en zij ontdekken eenen hond of eenig ander dier, dadelijk geraken zij op den hol, en loopen in het wild als dolten den hond na; de hond natuurlijk van angst radder vooruit loopende, omringt hem de koppel Koeijen, zoo dat hij niet ontvlugten kan, en zie daar, alle Koeijen ftaan Itil, tor op eenen korten afftand van den hond, dan berieken $z i j$ hem : en vallen zij hem aan, dan fluiten zij de oogen, en ftoten blindeling toe ; nooir zal eene Koe aanvallen en toeftoten, zon der eerst een poos op eenen korten afftand te blijven ftaan; dit weten de Stieren - en Büffelvangers bij de lndianen, en ook onze Boeren en Jagers, die, geliik wij elders gezegd hebben, op dit oogfluiten letten: een verftandig Jager, als hij in her veld tusfchen de Koeijen is, laat ftil de Koeijen bij zijn hond naderen, laat hem berieken en bekijken, de Koeijen of Koe zal op een aftand blijven ftaan, en allengs vreedzaam worden; evenwe! zijn er, die volI $\mathrm{z}$ ftrekt 


\section{0}

NATUURLIJKE HISTORIE

Hет ftrekt niet zoo gedoogzaam zijn, maar, op a UNDVE. het minfie hard loopen, aanftonds weder

11. Afd. toefchieten, zoo dat er altijd meer of min VI. gevaar bij is, vooral bij de Osfen, die zeer vatbaar zijn om dom toe te ftoten; dan, ik behoeve dit niet verder uit te pluizen, nademaal er vele liefhebbers van de jagt zijn, die door de Koeijen in de floor gejaagd worden, als hunne honden kort op den mecster volgen, waarom den Jagers geraden wordt, humne honden niet kort achter hen, maar op zijde te laten loopen.

Maar lust het iemand eene nadere proef te nemen van het kort-zicn der Koeijen, men neme een matig groote fpiegel, en houde die van verre tegens de Koe, hij zal dadelijk, die op zijde ziende, er zijn tegenbeeld in zien en toeloopen, doch kort voor de fpiegel als verrast blijven ftaan.

Integendeel kan eene Koe vrij regturt zien, en is niet kortziende, wanneer elk oog op zich zelve langs den neus zijlings ziet, zoo dat de ooglijnen niet tot één punt zamenkruisfen, en de Koe den kop op zijde draait; bij voorbeeld: men volge uic de beide ooghoeken $a a$ de lijnen $d d$, dan ziet de Koe wel regtuit met beide de oogen, maar zijn oogpunt loopt nooit te zamen, en dus is elken oogftraal gefchikt om meer zijlings te zien dan vooruit, gelijk blijkt uit de Figuur, bij voorbeeld: wederom uit het oogpunt a a loopen de gezigtitralen of lijnen $e e$, deze, zich verfpreidende, on vangen in het ruim des halven cirkels van 
$d d$ tot $e e$ alle de gezigtlijnen, dis op zekeren afftand zijilings voor het oogpunt der RUNDVEB. Koe kunner komen, en wel nederwaarts II. Afd. langs den muil; maar nu itelle men dat de VI. liinen ffff regt wederzijds uit zien, en Hoofdrt. wederom in eenen halven cirkel, of zoo men wil, ook met de vorige lijnen def zich vereenigen, dan zal men ontdekken, dat het ganfche ooggeftel der Koeijen meerder gefchikt is; om op zijde dan vooruit te zien, en volftrekt niet om naar de hoogte te zien, want de ooren, de horènen en den nek beletten dit, gelijk dit overbekend is; maar daarentegen kan eene Koe en meest alle viervoetige dieren, door het omdraaijen der hals, vrij wel naar achteren zien, en zeker de Koe vooral, want men zal haar in de weiden veel den kop zien omdraaijen en over den rug zien: dit doen de Paarden ook veelal, ja her fchijne mij toe, dat een Paard insgelijks zeer fterk op zijde zien kan, yaarom men ook de hoofditellen met ooglappen dekt, om, zoo als men het roemt, het fchichtig worden, en op zijde uitfpatten te beletten: voor zulk eene fchichtigheid fchijnt eene Koe zoo vatbaar niet te $2 \mathrm{ijn}$; kortom, wij heb. ben uit dit alles geleerd, in hoe verre dat wonder gezigttuig in deze groote dieren al mede zijne bijzonderheid heeft, in onderfcheiding van dat in andere dieren.

Dus dan befuit ik mijne verhandeling over het inwendig ooggeftel en het gezigt der Koeijen, welke men voorts gelieft te 


\section{NATUURLIJKE HISTORIE}

HET vergelijken met het geen wij wegens het zunover oog gemeld hebben, in de befchrijuing, II. Afd welke wij van het geraamte en van het uitVI. wendig fpiergeftel, in de II. Afdeeling, Hoofdit. Hoofdituk I. en II., gegeven hebben; terwijl wij nu zullen overgaan tot de werktuigen der deelen van den reuk en het bijzonder geftel van de reukbeenderen, alles volgens geheel nieuwe ontdekkingen en door naauwkeurige afbeeldingen, opgehelderd, waar door dan het gebrek, dat in dit gedecle heerschte, vergoed zal worden; zijnde onzes wetens, tot nog toe, wegens het reukgeftel, aithans der Kueijen, geene zoo uitvoerige befchrijving bekend; en zullen hier nu, ten befluite van dit Hoofdftuk, nog laten volgen, eene verkorte verklaring van Plaat Xl.

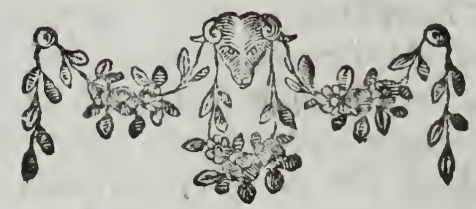




\section{VAN HOLLA ND. 233}

Fig. 1. vertoont een Kalfsoog, levensgrootte.

a de ovale doorfchijning van her kristallijn, leggende in den zwart-blaauwen kring van het doorfchijnend hoornulics, het rei. vlies enz.

$b$ het flitimervlies.

$c c c$ de borstelige haarties van $h t$ bovenfte ooglid.

$d d d$ de haarties van het ond arte oodil. $e$ de groote ooghoek.

fff de bijhartjes der oogleden.

$g$ de krakbeenige ongklier.

$h$ de ronde ooghoek.

$i$ de binnenrand van het boven - ooglid.

$k$ de onder - binnentand van het onder -ooglid.

II de inentingen van het fluimervlies.

$m$ den kring van het oogwir.

Fig. 2. Het oog van een Kalf, onhloot van deszelfs oogleden, volgens s'TENON.

$\varepsilon$ de ongenaamde oogklier, die de holligheid van het boven-ooglid vult en des. zelfs zachtheid veroorzaakt.

6 de fcherpe ooghoek.

c de breede ooghoek, ter plaate daar het 


\section{$23+$ NATUURLIJKE HISTORIE}

HEx ooglid, waar van men eenige overaundVEr. blijffels op zijde omgeflagen zier, is inII. Afd. geënt.

vi. $d d d d d d$ zes zakjes of kwabberjes van de Hoofdit. ongenaamde oogklier.

e e e ee e traanbuisjes, waar door de oogleden bevogrigd worden.

$f$ de binmenrand van het boven-ooglid.

$g g$ de traanklicren.

$h$ het nuimervlies.

i het oogwir.

$k$ de oogappel.

$l$ de doorfchijning van het reivlies en wa. tervogt.

$m m m m$ aanhangfels van den huid der oogleden.

Fig. 3. Het regter Kalfsoog, levensgrootte, van de oogfchellen en alle vliezen ontbloot, om het fluimervlies te kennen.

a a a a gedeelte van het kraakbeenig vlies van de oogkas.

$b b b b b$ de affichoidfels van de afgefneden oogleden.

$c$ de groote ooghock.

$d$ het fluimervlies in zijne breedfte uitfpan. ning, den oogbol half bedekkende.

$e e$ de inentingen van dit vlies.

ff de zwarte kring der iris of oogftarre, door het hoornvlies fchijnende.

$g g$ het reivlies en watervogt, door het hoornviies fchijnende. 


\section{v A N HOLLA N D. 235}

$h$ het glasvoge, door het hoornvlies fchij- нвт nende.

$i$ het ovale doorfchijnfel van het kristalvogt. II. Afd.

Fig. 4. vertoont het oog, dwars doorge. Hoofdit. fneden, volgens sTENoN.

aa de ooghoeken an hun kraakbeenige uiteinde of klieren.

$b$ de groote of breede inwendige noghoek. c de kleine ooghoek.

$d d$ omgeflagen gedeelte van de oogfchel. $e$ vereeniging aan den bovenrand.

$f f$ de buisjes der haarwortel rjes.

$g g$ de traanpuntjes (punctulae lachrymiales) van STENON.

hh h gedeelte van het doorgefneden hoorn. vlies.

Fig. 5. De geheele oogbol in de beenen oogkas, met de voornaamfte zijner fpieren, levensgrootte uit een Kalf. a de oogbol aan cie inenting der zevende oogfpier van Galexus.

$b b b b$ de kring van de beenen oogkas.

$c c$ de twee fpicren die het oog opwaarts bewegen.

$d d$ de twee fpieren die het oog nederwarts bewegen.

e de fpier die het oog regttandig houdt, met de zevende fpicr van GaLenus. ff de katrolfpier.

$g$ den ring der katrolfpier, aan het verlengd hersfenvlies verbonden.

th in inlijving der fpieren op de helft van den oogool, waar ook de fcheiding is 


\section{$33^{6}$, NATUURLIJKE HISTORIE}

HET van het doorfchignend hoornvlies van het RUNDV̈RE. zichie of weeke ongulies.

II. Afd. $i$ den ring van het oogwit.

Iloofaft. $k k k$ den ring van het zwart watervogt met zijne vezelen.

$l$ de iris.

$m m$ de opening van het reivlies.

Fig. 6. Her druivenvlics.

a a den omtrek van het hoornvlies, met den zwarten rand van het reivlies.

$b b$ de doorfchijuing van de iris.

c c c c het druivenvlies, met aarwijzing der vatjes in een opgefpoten oog.

¿ de ovale opcning, war door het netvlies fchijne.

Fig. 7. Het glasvogtvlies met de oogftarre. a $a$ a $a$ het Elasvogrvlies。

$b b b 6$ den rand van het druivenvlies.

c c c c de zwarte haarachtige oogbuisjes, in hunnen waren kring, of het farrenvormig haarvlies (trunca colearis.) $d$ het kristallijn bolletje.

Fig. 8. De halve oogbol met de plaats der gezigtzenuw en het daar aan nederhangend netvlies, mitsgaders de ftraling der blaauwe ovale glans in de oogen der Koeijen.

$a$ de plaats der gezigtzenuw eenigzins buiten het centrum, zoo als deze zich vertoont in de natuur.

$\vec{b} b$ de blaauwe ftraling van bet rei-en an- 


\section{A N II O L L A N D. 337}

dere vliezen, afgefcheiden van het net- $\begin{gathered}\text { Het } \\ \text { RUNDVE. }\end{gathered}$

c takjes van het netvliesje.

d de cubbele blaauwe ovale ftraling die op het licht weerfchijnt, en midden in de II. Afd. VI. oogkom zich vertoont.

Fig. 9. Het glasvogt en het kristallijn oogbolletje in zijn natuurlijken ftand.

a a $a$ het helder doorfchijnend glasvogt in het vlies.

66 de kom of halve bol van het oog, waar in het glasvogt ligt.

$c c$ de wanden van de rei - en druifvliezen.

$d$ de pupil of het kristallijn oogbolletje.

$e e e$ zeer fijne geultjes of fleufjes, waar in de ribbetjes van het haarftarretje gelegen hebben.

Fig. Io. Het kristallijn bolletje of de oog. lens.

a deszelfs bovenfte bolrond.

$b$ deszelfs onderfte platrond.

Fig. II. vertoont de hoornachtige oogbol eener Koe, met de omgellagen aanhangfels van het oogvlies, de fclerotis en de kliertjes der oogharen, omgekeerd te zien; vergelijk hier mede Fig. I en 4.

a de ovale oogfleuf, die zich hier zeer - kennelijk langwerpig, in het midden ingedrukt, vertoont.

$6 b$ het ontbloot druivenvlies. 


\section{$33^{8}$ NATUURLIJKE HISTORIE}

net c c c c de uitftekende tepeltjes van de aderRUNDVER.

II. Afd. VI. tjes en zenuwtjes, in een gevlogten, ter plaatfe alwar de ooglidhartjes zijn ingeliifd.

Hoofdrt. $d d d d$ de omgellagen bekleedfels van het hoornvlies.

Fig. 12. Een Koeijenoor, op zijde vercoond, in zijne bolronde gedaante, war in de bogtige kronkelingen der adertjes om her hoornvlies aan den oogbol zigebaar zijn.

$a$ a de oogbol van zijne fpieren gezuiverd. $b$ de groote gezigrzenuw.

$c$ het nieuw ontdekt aderlijk bloedvat van Dr. Hovius, uit de netswijze adervlegting gefproten, op zijde van de gezigtzenuw.

$d$ deszelfs verdeeling in twee fpruchtels.

e twee takjes van hetzelve, die op het $\because$ hoornvlies opklimmende, zich verfpres. den.

$f$ de rand van het hoornvlies.

$g$ de aderfpruchtel die in de flangsgewijze vaarjes, op den rand van hec hoornvlies, invloeit.

$\pi h$ de wanden van het druivenvlies, aldaar uitwendig zigtbaar.

$i i$ de kronkelingen van den ommekring der aderen.

$k$ de vooinaamfte kronkeling der adervaatjes, ists grooter dan natuurlijk, om derzelver kennelijke vereeniging' met de zenuwachtige watervaatjes te begrijpen. 


\section{v A N H O L L A N D. 339}

Fig. 13. Een gedeelte van een Kalfshoofd, waar in van de eene zijde, de door RunDveEd Doctor rayius nieuw ontdekte ader- II. Afd. lijke netsgetijze vlegting in zijne VI. natuurlijke fand vertoond wordt. Hoofdit.

$a$ het uiteinde van het verhemelte aan den fnuit.

$b$ de linker nersgewijze adervlegting.

ccc fpieren van hetzelve, omgenlagen vertoond. $d$ aderlijke fpruchtel die uit de netsgewijze vlegting opwards loopt.

$e$ afdaling der hals -ader (carotis).

$f f$ taksgewiize fpruchrels van dezelve.

$g$ de regtiche adervlegting tusfichen de omringende vaten.

th plaars alwaar de hals-arter zich als verdeeld.

i takken van het aderljk bloedvat, hetwelk uit de netsgewijze vlegting: ontpruit, en welke takken om den oogbol loopen.

$k$ twee zenuwtakken van den oogbol.

$l$ de beide gezigtzenuwen afgefneden, ter plaatfe alwaar dezelve in het hersfengeftel inkrommen.

$m$ gedeelte van den hals-ader, die mede in de hersfenen invloeit.

$n$ plaats alwaar de voorname bloedvaatjes en zenuwrjes invloeijen.

0 de vereeniging der netsgewijze ringvaatjes tusfchen de beide gezigtdeelen.

$p p$ de oogbollen uirwendig.

$q$ de fcheiding of het middenfchot van het verhemelte.

$r r r r$ ecn gedeelte van het beenachtig ach. terhoofd.

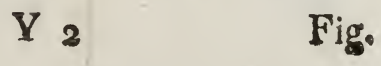




\section{NATUUURIJKE HISTORIE}

нет Fig. 14. Een gedeelce van hetzelve KalfsRUNDYRE.

II. Afd. VI. hoofd. warin de netsgewijze ader-

$a$ de fnuit.

$b$ de fcheiding van het verhemelte.

$c c$ de wanden van hetzelve

$d$ twee flagaderlijke vaten op den oogbol.

$e$ derzelver invloeijing in het adernet.

$f f$ het nieuw ontdekt adernet, breed uitgebreid.

g kennelijke flagader.

$h$ de flagaderlijke boezem (finus vena. fis).

$i$ vaten over de oogbol loopende.

$k$ flagadervaten naast dezelven.

$l$ gedeelte van een oogfpier omgeflagen.

$m m$ oogpunten.

$n n n$ gedeelte van het achterhoofd.

Fig. 15. Alleruitvoerigfte afteekening van het netsgewijs aderftel in het Koeijenoog, waar in hetzelve met alle zijne fpruchtels, kronkelingen, inen aanvlegtingen, bronnen en aderftukjes om en in den oogbol, her druivenvlies, hoorn - en giasvogtvlies, vertoond wordt.

a a de voornaamfte takken van den halsader (carotis), het netsgewijs aderweefrel omvattende.

$65 b b b$ zijdelingfe fpruchtels van hetzelve. 


\section{$\checkmark$ A N HOLLAND. 341 .}

c cc cc het geheel aderlijk net van alle be, свт klecdfels ontbloot.

RUNDVRE?

$d$ de groote adertak, die naar den oogbol loopt, om en naast de gezigtzenuw.

$e$ deszelfs affcheiding in twee takken.

Ii. Afd;

VI. Hnofdet

$f f$ de kronkelvaatjes, flangsgewijs den oogbol omningerende.

$g g$ twee voorname fpruchtels, die aan de wanden van het hoornvlies influipen.

$h h h$ ontellijke fijne bloedvarijes - over den inwendigen oogbol loopende.

$i i$ de groote rand der oogbol.

$k k$ kronkelvaarjes op den rand der oogbol.

llll nog fijner fpruchtels inwendig.

$m m$ de inlijving derzelver aan den rand der oogkom.

Fig. 16. Is een gedeelte van het druivenvlies, plat untgebreid en vergroot vertoont.

a a a algemeene gekronkelde flangsgiewijze adervlegting.

$b b b$ derzelver nederdalende fpruchtels of bloedvaatjes.

c c c het omgeflagen vlies.

$d d$ gedeelte van het hoornvlies.

Fig. 17. In deze Figuur is naar de regelen der gezigtkunde, het oogpunt der Koeijen afgefchetst.

a a duiden de twee Koeijenoogen aan, zoo als zij vlak op zijde van het hoofd ftaan en zien.

$$
Y_{3} \quad b 6
$$




\section{NAT. HIST. vaN HOLLAND}

Ex $b \cdot b$ zijn de neusgaten vlak voor den muil BundVEe, te zien.

II. Afd. $c$ het oogpunt der Koe, vooruitziende uit VI. beide de oogen.

Hoofdft: $d d$ de lijnen der oogpunten wederzijds regt nederwaards.

ee de lijnen der oogpunten meer zijwards uit.

ffff de lijnen der oogen wederzijds vlak op zijde zich zeer verwijderende. 


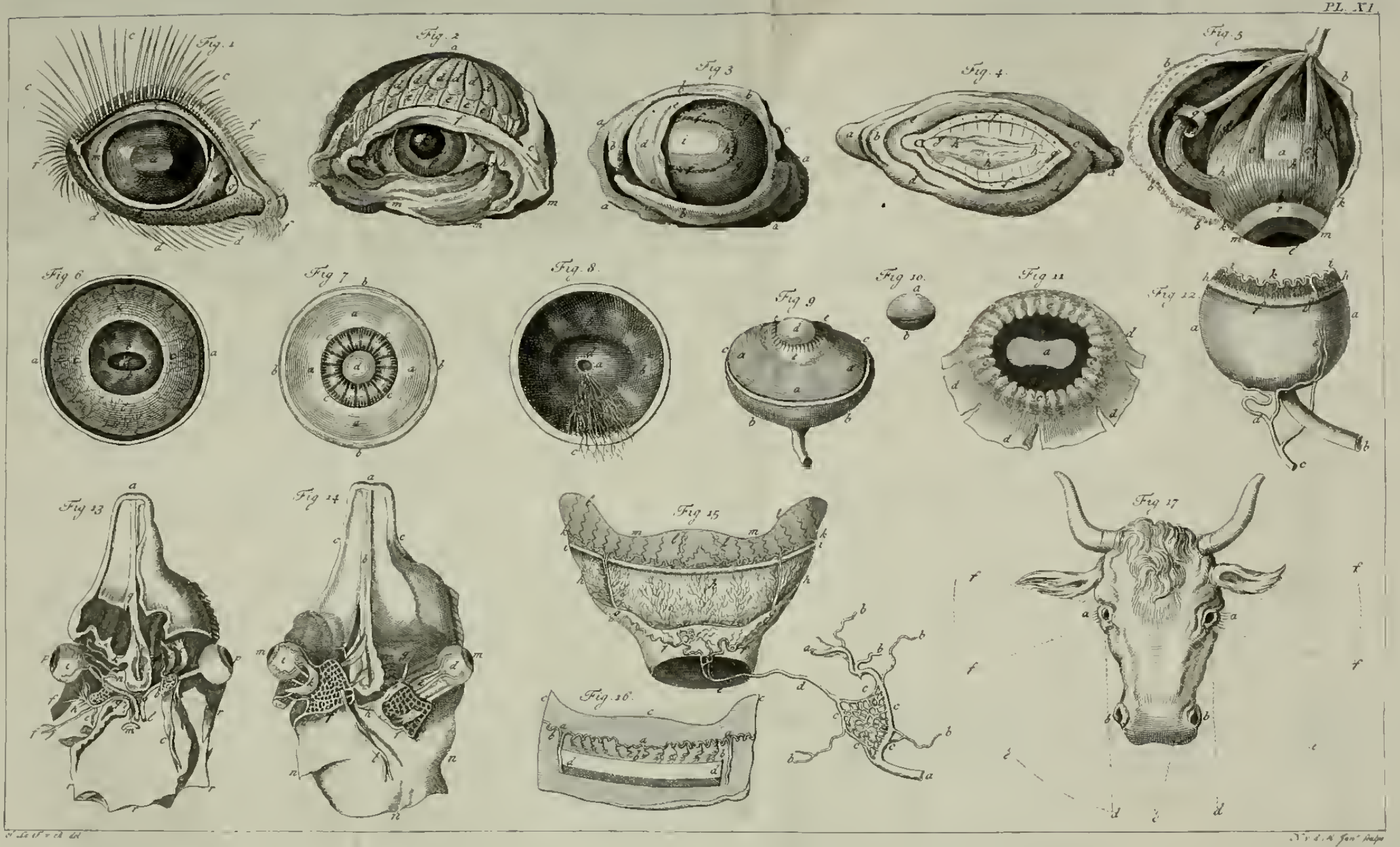





\section{TWEEDE AFDEELING.}

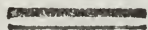

ZEVENDE HOOFDSTUK.

Ontyouswende en befchrijvende do bijzonso derheden yan de reukicelen der Koei. jen, met geheel nieuswe afbeeldingen.

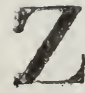

oo ingewikkeld als de begrippen omtrent de zintuigen van het gehoor en het RUNDves: gूezigt zijn, zoo zijn zij het insgelijks met opzigt tot den reuk der dieren. De Wijs- II. Afd. geeren en Ontleedkundigen kennen zeer wel Hoofdr. derzelver werktuigelijke deelen, en redeneren daar uit, tot zekere vatbare befluiten De reuls der vitwerking; mar eindelijk fituiten zij al jen. mede aan de kennis van het wegfluipend vermogen, het welk de zintuigelijke deelen, of op de denkingskracht der ziel, of op de bron aller zintuigen, de hersfenen namelijk, hebben; en zoo er eenig zintuig is, waar over ons vernuft ftilftaat in de ve:klaring van deszelfs uitwerking, is her voor- 


\section{NATUURLIJKE HISTORIE}

set namelijk de reuk en de rmank. Tier in koRUNDVEE. inen alle Wijsgecren overeen : zij ftellen, en II. Afu. rvij weten het, dat cen mensch leven kan,

VIt. die doof en blind is, a'thans die dit zintuig Hoofdit. niet volkomen tot zijn wil heef:; en het fchijnt zoo, of het is zoo, miţs men an ons het gevoelen vrij lote, namelijk, dat icmand, doof of blind zijnde, wel verminke is in het werlatuigelijke, maar niet in het inwendic denkbeeldige, vermits een duove of een blincie, alfchoon hij rict hoort noch ziet, evenwel door het gevoel en zekere leerizame teekenen bij zich zelve inwendig cen begrip kan vormen, wat zien, wat hooren is, en dat juist om dat hij inwendig, of zijne ziel, dat semis gcroelt, en om het ontbrekende zintuig wenscht.

Viaar bedenken wij nu cens, wat de reuk, de fimak on het gevoel is, dan valt er geen bedenking, om niet toe teftemmen, dat geen dierlijk wezen kan leven noch beftaan zonder wezentlijk gevoel, zonder fmaak, zonder reuk. Zonder gevoel is een mensch dood; zonder reuk heef de invioed van den fmaak geene werking, en zonder fmaak is alle voedfel cene cnnutte ftof tot onderhoud van het ligcham. Onzes bedunkens is dan on . der deze drie zintuigen de reuk eene der voornaamfte en edelite zintuigen des dierlijken levens; immera kan men geene voorbeelden annvoeren, dat eenis dier, zolfs in den faat yan verminking of gebrek aan de reukdeelen, zonder reuk is ; want iemand die de neus afgehouwen of afgefneden is, die 


\section{$\checkmark A N$ HCLLAND. 345}

die door verkoudhcid verifopt is, die verzweringen of neuspolijpen heêt, riekt door de inademing aan het varhemelic coor de fmaak, terwijl icmand, dic volftekt doof is, "zijn eigen geluid niet hoort, fchoon

hij gevoelt dat hij fprecki, noch een ftrekt blinde nicis zict, en evenwel et ftomme zijne fprak begript, en een volover redencert, en dus alleen werke door zeker begrip; manr de reuk werkt door ftoffelijke aanùoeningen; zelfs tor in de latefte oogenulikken des leveiss rickr cen ftervende het doodszweet; zoo dat men het zintuig des reuks, zonder aarzelen, als een deel moer annmerken, zonder herwelk geen dier leven kan.

Dit dan vastgefteld zijnde, is het niet minder wanachtig, dut elk dier, dierrje of gevoclig wezen, ik zoude ei de planten fchier bijvoegen, cen bijzonder geftel (organifa. tie zal ik eens fecllen) hebben, welks werking gefchikt is om de verfchillende uitwafemingen, dampen, geuren of zweet van allerlei foort te kunnen onderfcheiden en zich ten nutte te maken. Ik wil het, warde L.ezer! aan u door voorbecldeu vatbaar maken, om het des te beter op den reuk der Koeijen te kunnen toepasfen.

De Honden zijn het, welke men veron-Houden. derfteld den fijnften reuk te bezitten; het is zoo, een Hond kent de uitwafeming van zijn Meester, zelfs tor op de kleederen, die hij draagt; de voorbeelden zijn overbekend, dat cen Meester zijn zakçock, cabaksđoos, of ecnig ander tuig voorbedachtelijk wegY 5 ftope Ard Hookdit. - 


\section{NATUURLIJIE IISTORIE}

HRT ftopt en laat liggen, en, uren verre verwijRUNDVEE. derd, zijn Hond gelast om het re zocken; II. Afd. het dier riekt, vindt en kent onder vele

Hoofdit. zaken juist dat, hetwelk van zijn meester is. IUn fijne reuk, om op de jagt het wild te ontdekken, is ovcrbekend.

Reuk der De Vogelen ftelt men mede onder de Vogelen. dieren, welke den fjniten reuk hebben, nademal de Gieren, Adelaren, in één woord, dat alle Roofvogelen, uren verre den reuk der krengen rieken, en daar op azen.

Reuk der De Visfchen, de Rcofvisfchen, kunnen, Visfchen. naar hunnen anrd, zecr verre door de wateren rottende krengen ontdekken.

Reuk der De Infckten, de Vliegen, rieken insgelijks Infekten. fterk; de Bijen zwerven uren ver van hunne korven en honigraten op den reuk van de boekweit of tijmbloemen; de Nollendoodgraver (een zoogenamde Tor) riekt onder den grend den: reuk der doode MolIen.

Op deze en duizende dergelijke voorbeelden, oordcclien de Ouden, vooral ARISToTELES en bijzonder HERACLITUS, en meest allen na hun, dat de Mensch onder alle dieren het minst met het vernogen van te rieken begaafd was, ten minfte atat hij dit vermogen in mindere mate bezat: zij erkenden en bepariden een nog veel minder trap in de Parden en de herkaauwende dieren, en vooral in de Kocijen.

Deze ftellingen, die misfchien niemand zou durven ondernemen te betwisten, op te helderen, of liever te verbeteren, zal ik 
nu cens nader inzien, te meer; daar ik op het onderwerp van den reuk ontellijke waarnemingen in allerlei dieren gemaakt heb, en derhalve ook alle de af beeldingen van de reukdeelen der Koeijen door ons alleen en HET RUNDVEE: eigenhandig naar het leven naauwkeurig zijn afgebeeld op Plaat XII.

Docli eer ik tot derzelver verklaring over $\mathrm{ga}$, zal ik mijne aanmerkingen op het bovengemelde mededeelen. Dat een Hond, een Adelaar, een Roofvogel, een Honigbij of Infekt, van zeer verre of rieken kan, is niet te ontkennen, ja dat meer is, dac zulk foort van Dieren den Mensch in dit geval overtreffen, is insgelijks waar, maar dit bewijst niet, dat een Mensch of andere Dieren, als de boverigemelde, onvatbaar zouden zijn voor eenige aandoening der reukdeelen, waar voor de gemelde bekende Dieren, vatbaar zijn : het tegendeel is waar, want de graanof zaad-etende vogels, bij voorbeeld de Hoenders, zullen uit de paardendrek de onverteerde haverkorrels rieken en uitpikken: de Musfchen en Vinken tit een vermengde zaadhoop die zaden rieken en virpikken, welke zij noodig hebben: het onderfcheid van aas of deeg der visfcher's, leeraart den onderfcheiden reuk dezer Dieren, en elk, die maar eenigzins in de aangename nafpo. ringen der Infekten ervaren is, weet, dat elk Rupsje dat foort van bloem of plant of kruid verkiest, dat hem eigenaardig is: dat wijders elk kapelletje, uiltje, vliegje, torretje, mugje, motje, hoe klein en fchier

II. Afd.

VII. Hooldr: 


\section{NATUURLIJKE HISTORIE}

Hex onzigtbaar, in een beemd van kruiden, in EUNDVEe, ecn bosch vol boomen, in een hof vol

II. Afd. bloemen, juist en zonder misfag, dat kruid,

VII. die bloem, dien boom, dat zaadhuisje rickt, Foofdft. dat hij natuurlijk rieken en kennen moer tot zijn beftaan, gelijk deze Diertjes ook altoos dic ftreeken ontvlieden, alwaar tegenwerkende of voor hun walgelijke planten groeijen. Dus kan men ten aanzien van fijnen reuk of gewarwordingen van dierlij. ke of plantaardige uitwafemingen, zonder twijfel den reuk der Infekten nog boven het fijne reukvermogen der Honden ftcllen.

Maar als men nu eens onbevooroordecld dit ftuk overweegt, dan zal het, dit durven wij denken, blijken, dat elk bijzonder Dier, elk geflachtard, elk foort, van de kleinfte tot de grootfte toe, juist zulk cen trap van fijnheid van reuk heeft, als tot zijn beftuur en vernuft benoodigd is, en dar ook even daarom niet volgt, dat een Mensch of bijkomend Dier dat vermogen in minder mate zoude bezitten. Ik beweer het tegetsdeel; en durf, doch met cerbied, deze gezaghebbende Ouden beftrijden. Ik erken de bijzonderheid van fijnen reuk in vele Dieren, maar ik-ftelle ook, dat den Mensch zulk een vermogen zoude kunnen uitoefenen, ingevalle zijne nacuur, zijn aard en zijne overige vethevene zintuigen dit benoodigd hadden. Men legge een gezond Mensch honderd verfchiliende zaken voor, hij zal. dezelve door den reuk onderfcheiden. Men blinddoeke een ervaren Chimist, Drogist 


\section{A N HOLL A N D. 349}

of Apothekar, en legge hem duizend verfchillende drogerijen voor, hij zal dezelve RUNDVEE: door den reuk onderkennen. Een Minera- II. Afd. logist zal enkel op den reuk de metalen en foorten van aarde onderkennen. Bij voorVII. beeld, hij kent uit den pisachtigen reuk, door wrijuing, de Bolonifche Phosphorus en de Spaten, de zwavelreuk der pijriten of zwavelkies, het marmer, en zelfs door wrijving de harde keijen; een verftandig Graanhandelaar zal enkel op den reuk her graan onderfcheiden.

Dit, behalven meer, nu met bedaardheid gade geflagen, bewijst dat een Mensch, over het algemeen, het gebruik van den reuk, bij uitnemenheid, over allerlei zelfftandig. heden, boven eehig Dier heeft, dat is, om duidelijk te zijn, dat zijn geftel des reuks, alfchoon het in vele andere opzigten van dat in andere wezens verfchile, vooral in het uitwendig makkfel der neus, evenwel zoodanig is, dat hetzelve in de uitoefening der dierlijke varbaarheden, aller overtreft in het onderfcheiden der eigenfchappen van elk wezen door den reuk, en fchoon door de Ouden de fcherpheid van gezigt aan den kattenaardige $\operatorname{ly} n x$ de fijnheid van reuk aan de Honden, de fmak aan de Aapen, enz. werd toegefchreven, zoo worden niet to min alle deze bijzonderheden in fommige Menfchen insgelijks gevonden. Ten anzien van deze fijnheid van reuk, in fommige Menfchen, heeft de beroemde Gaubius, (een man, welke, ten dezen opzigte, allen geloof en tevens cerbied van mij en alle zijne 


\section{$35^{\circ}$ NATUURLIJKE HISTORIE}

HET Leerlingen verdiende) openlijk gezegd eene RundveE. Dame gekent te hebben, die op den reuk II. Afd of het gevoel van de dampkring, wist, of er viI. eene Kat in de kamer was, hij verhaalde, Hoofdrt dat hij opzettelijk had gezorgt, om de Kat met alle mogelijk geheim in eenig ander ver. trek te verbergen, doch zoo dra kwam de anders welgeftelde Dame, niet in de zaal, of zij rook de Kat en gevoelde eenig angstig zweet. Dit nu is zeker cen bewijs van den bijzonderen invloed der reuk op den Mensch gelijk op alle andere Dieren. Hier moet nog bij gevoeyd worden de bijzondere form en gedaante der neuzen, want gelijk de fijnheid van den reuk in de Honden veel afhange van het maakfel van den uitwendige neus, even zoo als in het gehoor de verfchillende oorlellen, zoo is het ook met de neuzen der IMenfchen, de oude Phijfionomisten erkende er het fchertfende vernuft en fijn oordeel van cenen PLAUTUS uit. - Het is ook niet vreemd dat men Menfchen vindt, die den reuk van laas, en zelfs van zommige anders aangename vruchten, zoo als perfikken, abrikoozen enz. niet kunnen verdragen. Het rieken van fchimmel of iets mufs, kan iemand zcer fterk aandoen, al hetwelk dan, zonảer vooroordeel befchouwd, onzes bedunkens aantoont, dat men in den INiensch de eigenfchap van fijn te rieken, in zulk ecne geringe mate, als de Ouden ftelden, niet kan ftellen, doch dat men daarentegen wel degelijk kan voordragen , dat de Mensch, naast hem de bloedrijke Dieren, en vervolgens alle levendige Schep- 


\section{$\forall A N H O L L A N D .351$}

Schepfelen, elk naar zijnen aard, het zintuig van den reuk hebben, zoo als noodwendig tot hun beftaan en levenswijs behoort, maar dat wat afdoet, is dat die fijne reuk aan alle foort van Honden niét algemeen eene eigen. fchap is, maar alleen an fommige geflachten, vooral aan de Brakken en Krulhonden : er zijn foorten, die op verre na niet zon fterk rieken, namelijk de Mopsjes, de Deentjes, de Dogjes en andere foorten; men vindt zclfs Honden, die bijna niets anders kunnen rieken dan dagelijkfche fpijzen, in één woord, alle geflachtfoorten der Honden, hebben een zekere trap van reuk, overeenkomstig hun ras en levenswijs, 200 als ook de Roofdie. ren: een Kat zal de Muizen en Ratten door den reuk ontdekiken, een Wezel of Fret de Hoenderkooijen en Konijnenholen, en dus ook alle andere Dieren naar hunnen aard, en wij zullen uit het reukgeftel der Koeijen trachten aan te toonen, dat in deze Dieren een allerverhevenfte blijk is van de wijsheid en grootheid des Makers, in het fcheppen van zoodanige reukdeelen, als noodzakelijk overeenkomstig waren met alle andere zoo zonderlinge Ledematen van zulk enn groot, en voor het Menschdom 200 nuttig Dier.

Het is dan ook hierom, dat men mec grond kan befluiten, dat de neus van een Koe veel breeder en fterker van bekleedfe. len is dan van eenig ander bekend Dier: daarenboven, dat het geheel inwendig reukgeftcl verfchilt van allerlei andere gevingerde Dieren, want in meest alle de herkaau

FET RUNDVREd II. Afd. VII. Hoofdif? 


\section{NATUURLIJKE HISTOR!E}

wende Dicren is het doorgans op dezclfde

nex wijze geformeerd als in de Koeijen. - Din, RUNDVEE. eer wij tot de befchrijving van de rcukdeclen II. Afd. der Koeijen overgaan, zullen wij eerst nog Vil, onderzoeken wat reuk, wat rieken, cigenHoofdrt. lijk wat het rieken, of de reuk der Koeijen is.

Bepaling Door den reuk of het rieken verftant men van de cen vermogen yan het zintwig, hetwelk ge-
reuk. fchikt is om de fubtiele uitwafemende getwren, of liever eigenaardige geesten yar elk wezen op te flurpen, in te ademen, yervolgens door de wegen der werktuigelijke reukbeenderen als 't ware gezift, yerfijut en onder Ccheiden te worden door den invloed, die alle dierlijke weanens op ecnert riekenden hebben, en dus kan men tcr nadere nitbreiding zeggen, dat, door middel van den reuk, alle de hoofditoffen der Elementen onderfcheiden worden, het zij dan nu eenig dierlijk riekend Wezen, deze tot vleeschetende, gene tot vischetende, anderen tot worm - en infektetende, wederom anderen tot ooft - en boomvrucht, nog andere tot graan, gras-, blocm - of kruidetende gefchikt zijn, allen bekomen zij door middel van den reuk, van dic opflurping der geestrijke uitwafeming, de kennis en onderfcheiding van ket voor hun noodwendig bijzonder voedfel, of ook van het gene hun fchadelijk is, terwijl de Mensch bij uitnemenheid alles door den reuk tor zijn voedfel kan onderfcheiden, en dat fcha-. delijk is, onderkennen, en wel darom, om' 
cat de Mensch over alle wezens als heerscht, ook door de reuk alles onderkent, en ten aan- RUNDVEE, zien der Koeijen en van het andere herkaau- II. Afd. wend Vee, zal blijken dat hun reuk en reukdeclen alleen voor hun geflachtaard en voor VII. geen anderen gefchikt zijn.

Eene Koe of Runddier is dan ook, ten annzion van den reuk, alleen gefchikt om langs en op de vlakte der aarde zijn nooddruft door den reuk op te fporen. Zijn aard en eigenfchap, zijn geftel, kan hem niet doen booren in de aarde, nog duikelen onder het water, noch zwerven over de zce en rivieren; neen! maar de afhangende valleijen der bergen, de tusfchenruimten der bosfchen, de vlakke velten, de effene beemcien, de grasrijke valleiien, de frisfche waterbceken zijn, zijn deel; hier kent het Dier door den reuk de klaver, de bo. terbloemen, de watcrlinzen, de grasfcheutoi tjes, in één woord, alle kruiden der vlaktens. Zijn, boven alle andere Dieren onder- Het bij: fcheiden, breeden neus en muil, zijn zon-zonder riederlinge tong en fmankeftel, doet hem onder ken der het grazen juist die kruiden al riekende opfpeuHoofdift, ren, die af bijten, die fmaken, die onder een mengfel van honderde aardgewasfen, door hem alleen uitgekipt worden. - Let eens, Lezer! let eens, Natuuronderzoekers! op het grazen cener Koe! let eens op het geblaas zijner neusgaten! gij zult overtuigelijk zien, dat hij geen kruidje, geen distel, doorn of hem fchaceliik kruid zal affcheeren; het fijne, het malschfte gras zal hij rieken, en af: 


\section{NATUURLIJKE HISTORIE}

HET afzonderlijk van cusfchen duizende kruider RUNDVEE. af bijten. Brengt eene Koe op een land vol II. Afd. distelen, of daar. in ons Holland het be. VII. kend heeremoes (cauda Equina), veel Hoofdit. klittenwortelen of fcheerling, vooral de distelen, het dul hanekam enz. groeijen, zij zal ze allen laten ftaan, en alleen het fijne gras of andere haar nuttige kruiden uitkip. pen, en niet dan bitteren nood of de zorgeloosheid van een' vrekken Boer doet haar uit honger nadeelige kruiden eten. Gaat des winters op de ftallen, ziet haar fchraal hooi, met distelen of onkruid vermengd, voorleggen, zij zal als dan nog het onkruid afzonderen, ja zelfs onderfcheid tusfchen koolftruiken en allerlei fchellen van knollen en aardappelen maken; zij zal zeker foort van appelen of peren gaarne eten, maar van anderen een af keer hebben; dit nu is de eigenfchap van haar aard, natuur en reukgeltel. Legt haar vleesch, visch of iets dergelijks voor, even zoo zal zij het wei. geren, ten ware bij nooddwang, gelijk men wil dat de Schotten en Ieren, die aan de zee wonen, hun vee wel met visch voeden, doch dit is ook oorzaak, dat het vee allerkleinst en ongans blijft; in één woord, de reuk der Koeijen is volftrekt gefchike om de zachtfte, de malschfte, de geestrijkfte kruiden te kunnen kennen. Dan, laat ons nu de deelen eens ordenlijk nagaan, om door derzelver geftel alles, wat gezegd is, op te helderen.

le dien einde, om aan dit ons ontwerp 


\section{* A N H O L A N D. 355}

re voldoen, is Plaat XII. ingerigt. Wij HET hebben het geduld en de moeite genomen, om, met toepasfing op den reuk, onder II. Afd. fcheiden af beeldingen te geven, en wel in Fig. I en 2 het geheele hoofdgeftel van een VII. Hoofdit.' Kalf, naar het leven tot op ruim een vier- plaat XIId de verkleind. Fig. I vertoont het hoofd Fig. $\mathbf{r}$. nitwendig, en Fig. 2 hetzelve inwendig en Het hoofd: doorgefneden; dus worde in Fig. I bij a een Kalf het opperbekkeneel ontbloot voorgefteld, met het bij $b$ is de vereeniging der hoofdfcheel- Reukftel, beenderen (Sutura Coronalis); bij $c$ de inlijving der gezigt-, reuk - en fmaakbeenderen aan het verhemelte; dit noemt men het voorhoofdbeen, den voorhoofdnaad, de zaagswijze groef (Sutura Sagittalis), kort op dit anduidfel is de inlijving van dat gedeelte naar het oogbeen $d$; bij $e$ is het bo- Boven: venneusbeen te zien, hetwelk eindigt even neusbeen, boven het ringbeen van den neus; 't welk dadelijk zal voorkomen; aan de achterzijde van het achterhoofd is bij $f$ het fteenbeen en het gehoorgeftel zigtbaar; bij $g$ de holligheid van het flaapbeen; $h$ teekent de benedengroef van her verhemelte, eigenlijk de verzamelplaats der kaauwfpieren; bij : is het achterhoofd; bij $k$ ziet men de oogbeenkas, waarin het zintuig van het gezigt bewaard wordt; maar bij $l$ beginnen de bij uitnemendheid in eene Koe kenbare reuk- Reuk? beenderen. Dus is bij $m$ het bovenneus- beendere been; bij $n$ het ringswijs neusbeen, dat in de bovenlip dringt; in deszelfs holte is de groote reukweg, die in de reukbuisjes en het fpons- 


\section{NATUURLIJIRE HISTORIE}

nEx: been zich nitbreiden; bij 0 ziet men de undvE. holle beenfleuf, warin de reukdeelen ook

II. Aft. tot den fmak en het voorverhemelte indrinVII. gen; cindelijk bij $p p$ de bovenkaakfche Hoofdit. beenderen van het uitwendig verhemelte, eindigende in de onderoogfche beenderen bij q; bij $r r$ is het jukbecn, of de knok der wangen, in de Koeijen insgelijks bijzonder uitftekende; bij $s$ zijn de bovenkiezen; bij t $t$ t $t$ is de onderkaak of het kinnebakken aan zijn invang om het jukbeen en het achzerhoofdfche uitftek; bij $u$ zijn de onderkiezen; bij $\boldsymbol{y}$ de voortanden; $\mathscr{W}$ is het voorverhemelte en de kwijlwegeri; $x$ het achterverhemelte.

Deze Figuur, alleen dienende om cenige algemeene aanwijzingen aan het hoofd, in verband met de rukdeclen, voor te ftellen, zij genoeg tot ons tegenwoordig oogmerk; anderzins zoude hier cene aanwijzing der zenuwen en zenuwgaatjes niet onnut geweest zijn; dan, vermits ook deze bijzonderheden in afzonderlijke afbeeldingen over de zenuwen zijn voorgedragen, laten wij dit hier onaangeroerd: dienende deze Fig. I voorts om Fig. 2 nader op te helderen. plaat XII. Men ftelle zich dan voor, dat op Plaat XII. Fig. 2. in Figuur 2 de kop, in Fig. I afgebeeld, doorgezaagd zijnde, in eene omgclagen te. genrigting inwendig vertoond wordt, waarin vooral de reukdeelen zeer zigtbaar zijn, en hicr, als het aanmerkelijkfte gedeelte van het voorhoofd beflaande, voorkomen; aanmerkelijk, zeggen wij, om dat in de Koeijen, 


\section{v A N H O L L A N D. 35 \%}

jen, volgens dezé Tiguur, de reuk-en Hzт fmaakdeelen ruim de helfe van het geheele RunDver: voorhoofd bellan, hetwelk blijkt uit de II. Afd. perpendiculare of loodregte lijn, die wij bij a $a$ a anngeftipt hebben, en midden door VII. Hoofdile het hoofdgeftel loop: : als men er nu op let, ziet men, dut de fijne reuk - zeef beenderen boven in de hersfenholte bij de finaken gezigtskameren niet alleen beginnen, maar zclfs over de gemelde middellijn in het ge. hemelte vervolgen, terwijl het overige gedeelte van het hoofd alleen de plaats der hersfenholligheden en de gehoorbeenderen omvat, hetwelk dan onze voordragt van het naauw verband tusfchen den reuk en den fmaak bevestigd; dan, om insgelijks eenig nader begrip van het geheel te geven, zijn deze volgende aanwijzingen vooraf noodig, om des te gemakkelijker de aanwijzingen van het bedoalde gedeelte der reukbeende. ren te verftaan,

Bij $b b b b$ dan is het bekkeneel, doorge: zaagd, zeer kennelijk met deszelfs inwen. dig fponsachtig en nog onvast gedeelte zigtbaar; bij c c c c c c c c c zijn de inwendige hol. ligheden en indrukfels van het hersfengeftel, of liever de korst der groote hersfenen; bij $d$ is het fijn en fchier doorfchijnend fchubsgewijs gebeente van het ooghol of de ooge kas; bij e e $e$ het doorgezaagd gebeente met deszelfs fponsachtige deelen en groeven van het gewelf van het verhemelte en de inlijvingen, zoo van het neusbeen, als van het yerhemelte: het luchtbeen, de flijm - en klier :

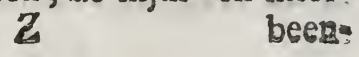




\section{$35^{8}$ NATUURLIJKE HISTORIE}

нгт beenderen der fimak, de tong-geledingen RUNDVEr. enz ; dit gedeelte malkt de groote bafis van

II. Afd. het hoofd der Kocijen uir, en is als de

VII. verzamelplaats van alle de onderite hoofd-

Hoofdit. fcheel-beenderen in het zoogenaamd veel-

Inlijving vormig nekbeen, wanrvan hier flechts bij der neus- $f$ een kleine doorgeznagde blijk is; bij $g$ beenderen. ziet men het binnengedeelte van het gehoorbeen, liggende in, en omvangen door het harde fteenbeen zelve aan het achterhoofd bij $h ;$ bij $i$ is de uitwendige gehoorweg zigtbaar; bij $k$ ziet men het gaatje, war door de gehoorzenuw in de hersfenen in. vloeit; bij $l$ het gat of ie opening van het hoofd, ter plaatfe daar het den eerfen wervel omvange, en daar aan draait; bij $m m m$ is de onderkaak; bij $n n n$ ziet men het bovenneusbeen (os Eithmoides), hetwelk als het dekfel van het onderlte is, in zijn eene helft, (zoo als het in Fig. I bij $e$ in zijn geheel vertoond is); hier aan ligt $\mathrm{bij}_{\mathrm{ij}} 0$

Rraakbee nig mid. delichot. het kraakbeenig middelfchor der beide neus kameren of neusbuizen: want men diene op te merken, (het geen ftraks duidelijk zal voorkomen,) dat er twce afdeelingen der neusbeenderen zijn, elk op zijn bijzonder neusgat links en regts betrekking hebbende; dit middelfchot is meerendeels kraakbeenig, in oude Koeijen wordt het beenachtig, doch altoos blijft het aan de uiteinden. van de neus eenigermate doorfchijnend: men noemt het in het Latijn Septum, zoo veel als middclfchot, de Mensch gevoelt het; in de Koeijen evenwel is het uitwendig min 


\section{$\checkmark A N H O L L A N D .359$}

zigtbaar, nog mincier in de Honden, maar zeer kennelijk in de Paarden, dermate, dat RUNDVEE. de Paarden-Doctors, in den droes der Paar- II. Afd. den op de doorfchijnendheid en den ftank van dit middelfchot lettende, hetzelve als VII. een teeken van veegheid aanmerken; men kan het uitwendig in de Koeijen zoo niet nagaan, om dat derzelver neusgaten en de bovenlip te ecltig en vast zijn : nogtans kent het de Boer op het gevoel, en in Veezickte let hij er op, of dit middelfchot, dat zij het fnotvlies noemen, wel zuiver is. Dit kraakbeenig middelfchot nu, bedekt in onze Figuur tot nog toe het bovengedeelte van de reukkokertjes, die mede op Plaat XII. bij Fig. $3,5,6,7$ enz. ontbloot en levensgrootte verbeeld zijn; doch daarentegen ziet men in deze Figuur 2 bij $p p$ de onderfte reukkokertjes, die gemeenfchap met de fmaak of de verhemelt-gebeentens hebben: eindelijk vertoonen zich bij $q q$ de groeven en holligheden van de fijne zeefbeenderen, fponsbeenderen (offa fpongio. Zeeffa), van den reuk, ter plaatfe daar de fijne beendereaw reukgeuren naar het hersfengeftel invloeijen, en als gefiltereerd de fijne geesten me. dedeelen; voorts bij $r \boldsymbol{r}$ de onderfcheidene fleuven, die de rolbeenderen bevatten. Alle deze beenderen nu hebben hunne bekleedfelen, omwindfelen en fpieren. Alle dezelve an te teekenen, zoude ons zeer verre af. leiden, iets evenwel moet er van gemeld worden, en wij zullen aandachtig zijn, om er bij elk beengedeelte of reukdeel aan te 


\section{NATUURLIJKE HISTOR!E}

GะT gedenken; in het algemeen gelieve men op te RUNDVRE. merken, dat, gelijk eene Koe door verfchil-

11. Afd lende fpieren zich bewergen kan, gelijk nok VII. de oogleden en de rong, dezclve bijzonder Hoofdit een eigenaardig vermogen heeft, om den neus en de neusdeelen te bewegen. Wij zien de fcherpriekende Honden de neusgaten bewegen en er mede fnuffelen: wij Menfehen kunnen de neustoppen bewegen; het optrekken en grijnzen der neus of neussgaten bij de die. ren, is menigmaal bij de Natuurkenners waargenomen, maar boven allen wordt de vreesfelijkfte grijns en fpalking der neusgaten den Stieren toegekond. Dus moldt ons viRgILIUS en ovidius van de vuurblazende Stieren, van het opfpalken der neusgaten, enz. Dit is zoo: men lette op de Koeijen en Osfen, zelfs als zij ftil ziin: men zal hen de neusgaten nu open zien fpalken, dan dezelve toeknijpen, en de neuslip geftadig zien bewegen, ja bij het toereiken van voedfel, zonder den muil te openen, zullen zij de neusfpieren uitrekken, en als een fnavel vooruiffteken, al hetwelk zeer zeker een buitengewone kracht in dit gedeelte bewijst; het is ook zeer wel te begrijpen, dat de natuurlijke aard van het dier zulks noodwendig moest hebben, want daar hetzelve geen boven - voortanden heeft, en de bovenlip dienen moet om, door inwendige aanhangfels van zenuwen, het gras of voedfel tot zich te trekken, en dit door den reuk te ontdekken, zoo volgt van zelve, dat het dit vermogen niet 
zoude kunnen uitoefenen, als deze bovenlip en de neusfpieren of zenuwen aan het cind van den muil niet 200 bijzonder werken konden, het welk dieren, die gefpleten bovenlippen hebben, bij voorbeeld de Hon den, de Katten, en ook het grasetend Haasje of Konijntje, ja ook de Kemelen, zoo fterk niet uitoefenen kunnen; de Mensch. nograns heef insgelijks de bovenlip zeer bewegelijk en ongefpleten, zoo dat dezelve die tegen den neus kan omkrommen en als een fnuit bewegen, waarom men dit wal eens bij een osfenmuil vergelijkt, evenwel verfchilt hav kracht merkelijk: men kan ook, fchoon in minderen graad, den neus en de bovenlip der Koeijen, en in zekeren zin ook die bij de Menfchen, vergelijken bij den fnavel der Elefanten, die men, eigenlijk gezegd, geen bovenlip toekent, om dat de neus of het uitwendig gedeelte de lip zelve formecrt, en in der daad, ik voor mij aar. zel niet, om in de Koeijen deze bovenlip den bewegelijken neus of fnuit zelve te nocmen.

Wat nu de inwendige reukfpieren betreft, zij zijn weinige, in vergelijking van her gehoor, ook minder fterk, maar daarentegen zijn de reukbeenderen, de reukwegen, overal als omwonden en ingewikkeld in zeer dun. ne vliezen, nlijmerige bekleedfelen en kraakbeenige geledingen, die zoo fijn, dun en teeder zijn, dat men dezelve zeer bezwaar. lijk in jonge Kalveren, naar orde, kan nagaan, even zoo min als de oneindig fijne

$$
Z_{3} \text { wee- }
$$

II. Afdi viI. Hoofditd 


\section{NATUURLIJKE HISTORIE}

нгт weeke deelen der hersfenen. In oude en zUNDVEE. volwasfen Koeijen evenwel gaat dit beter,

II. Afd. want in deze wordt veeltijds het kraakbee-

VII. nige, beenachtige, en het velachtige, kraakHoofdrt beenig, in zoo verre, dat her kraakbeenig Velachtig middelfchot als dan den naam van been bekraakbeen. koint, daar het anders mediaftinum os $\int e p$. tuim cartilagineum heette, nu feptusin os: fium genaamd wordt. Ondertusfchen laat ik dit onderzoek gaarne aan jonger lieden over; zekerlijk was hierin vrij wat te ont. dekken, maar wij vervolgen, en brengen thans Fig. 3 en 4 voor oogen, vertoonende de inwendige neusbeenderen en reukwegen, uit een Kalf genomen, en naar het leven gevolgd, zoo als dit gebeente zich opdoct, wan: neer het middelfchor, (zie Fig. 2. bij 00), is weggenomen, en tevens ontbloot van de opperuitwendige neusbeenderen (osfa Eth moides) in Fig. I. bij ee afgebeeld.

Aan het begrip van deze Fig. 3. en deszelfs andere zijde Fig. 4. ligt de geheele kennis van de reukdeclen der Kociien: wij dienen derhalve hier in velen opzigte, eenigzins af te wijken van de gewone onte leedkundige kunsttermen, en wel des te meer, om dat dit ganfche geftel geheel en al afwijkt van het maakfel der reukdeelen van meest alle andere Dieren, in diervoege, dat wij vertrouwen den Lezer geen" ondienst te zullen doen, om in dit gedeelte, zoo wel afbeeldingen als aanmerkingen mede te deelen, die wij vermeenen, tot nog toe niet 200 oplettend te zijn nagegaan. 


\section{$\checkmark A N$ HOLLAND. $3 \sigma_{3}$}

In alle de reukbeenderen, buiten die der Her herkaauwende Dieren, vindt men de voorfte RUNDVEE: reukbeenderen, eigenlijk de middelfchotten, II. Afd. reuk - en fnotwegen, doorgaans alle fijn ge viI. biaderd, en met vele middelfchotten, tus- Hoofdrt' fchen de kraakbeenderen en fnotvliezen in geplaatst: in de Honden is dit geftel zeer ftork kennelijk; maar ik heb waargenomen dat deze deelen in den zoogenaamden Zeehond ongemeen bladachtig en fijn gefloten wa. ren, in diervoege, dat ik daar uit befloot. dat dezc fijne en welvastgefloten affcheidingen, zeer zeker dit Dier moesten dienen, eensdeels, om onder water te kunnen rieken, anderdeels, om te beletten dat het vloeibaar water niet in den neus indringen kan; dit gevoelen is, meen ik, gegrond, nademaal de walvisaardige Dieren, die een tweehollig hart, en een uit - en inademing hebben, allen telkens moeten boven komen en door hunne neusgaten den invloed van het water uitblazen; dus is het reukgeftel dezer Dieren zoodanig geformeerd, dat zij door derzelver zamenftel en werking onder en boven water kunnen rieken, maar in de Koeijen vindt men de reukbeenderen van een geheel ander maakf $\epsilon$. Er zijn geene zulke fijne bladeren of zeer dunne naast en vlak tegens elkander geplaatfte middelfchotten: Er zijn geen allerfijnfte vliezen, neen! maar er is in het voorfte neusgeftel, als ' $t$ ware, eene vereeniging van buizen ( $t u b i$ ), in- wendig ingedraaide, als ' $t$ ware, als in een gerolde trompetten, die met geweld den reuk

$$
\mathrm{Z}_{4}
$$
in- 


\section{$3^{64}$ NATUURLIJKE HISTORIE}

ผะт infurpen en den fnot afdrijven. Deze buiQUNDVE. zen hebben eene gedaante als ineengeroldo

II. Afd. papieren, en men zoude dezelve volkomen

ViI. kunnen vergelijken bij obliewafelties. die Hoofdrt. men ineen rold, en naat wellie galijkenis wij niet aarfelen, om deze neusbeendcren obliebeen-oblicbeenderen te noemen.

deren.

Men zie dan op Plaat XII Figuur 3 . het geheele obliebeen. ontbloot van alle de fnot- en andere viczen: dadelijk zal men ontdekken, dat dit gedeelre cenc inrollendo gedaante heeft, vooral als men Figuur ?, 8,9 , I 1 enz. daar bij vergcijikt. - Men lette nu op onze eerfe ontleding, cn wete vooraf, dat dit geheel levensgroot gedeelte gezuiverd is van allen fnot, flijm en vliezen, hetwelk wel degelijk moet in acht genomen worden, om dat de in deze Figuur ontbloote beenderen, allen, hoe teeder, hoe fijn, hoe dun, door een zeker foort van zelfftandigheid omringd worden, die men wel vliezen noemt, doch van mij dien naar niet kunnen bekomen, alzoo dezelve nim. mer eenige vliesachtige uitrekking of aanhechting hebben, indien men dezelve flechts met een penfeel aamrakt of wrijft, fmelten zij weg. lk houde het daarom voor omkorstingen of aanzettingen van fnot en flijm. ftoffen, die alleen aan de fcheidingen van den neus'eigen $2 \mathrm{ijn}$, even als het oorfmout aan het oor, en de kwijl aan het gehemelte. snotftof. Deze fnotitof nu, is in de Koeijen overvloedig, zoo dat eene gezonde Koe altijd fnotterig is. Deze fnot nu formeert om alle 


\section{v A $\mathrm{HOLLAND}$ L 365}

alle de reukbeenderen der Koeijen een foort van aanzetfel of omkorsting : het vervult RUNDVEE. de holligheden der affcheidingen van de oblie. beenderen, en omringt grenoegzaam her geheel van het voorfte neus - en reukgeftel, I. Afd. VII. zoo als het bij Fig. 2. is na te fpeuren : maar nu is Fig. 3. van dit alles ontbloot, en dan doet zich eerst bij $N^{\circ}$. I. in het voorgedeelte de obliebeenderen op; bij No.2. in het achtergedeelte de zeefbeenderen, welke onderfcheiding wij hier voorftellen; er moet evenwel ons hier nier ontglippen, aan re teekenen, dat in oude Koeijen deze zeefbeenderen beginnen te verharden en aan te wasfen, terwijl de fnotvliezen vc" appen, het welk, naar ons vermoeden, de oorzaak is, dat de Koeijen, even als de bejaarde Menfchen, door den neus, dunner fnot loozen, hetwelk zekerlijk uit dergelijke oorza. ken ontitaat, als bij veritopping of verkoudheid, en dit is voorzeker onder de Koeijen zeer gemeen. Wij maken ook deze onderfcheiding van het voor - en achtergedeelte, om des te klaarder het geheel te bevatten, en vervolgen nu met onze gewone aanduidingen op Plaat XII. Fig. 3 .

In het voorgedeelte komt dan bij $a$ voor, het Pl. XII. voorfte gedeelte van het kraakbeenig uirftek Fig. 3 . van den neus, dat in den bovenlip der Koe eindige, op het einde van het uitwendig neusbeen (Os Ethmoides). Dit gedeelte is herzelfde dat men in den Mensch het puntje of tipje van den neus (cartilago rostriformis) noemt; dat is de fnuit, fnuitneus; in de Beesten Z 5 


\section{NATUURLIJKE HISTORIE}

FET de fnoet, de fnavel; dit gedeelte vereenigt RUNDVEE. met dat van het tegen over aanklevend ge-

II. Afd. deelte van de andere zijde, (bij Fig. 4. af-

VII. gebeeld) formeert den muil, den neus cener Hoofdr. Koe. (zie Fig. I4.) Het is zeer beweeg. baar en ontvangt alle de inlijvingen der fpicren en zenuwen, welke die wonderlijke beweging der Koeijen in het vermogen van den bovenlip of den fnuit, onder het grazen en herkaauwen maken. In den Mensch en in meest alle viervoetige Dieren, eindigt dit gedeelte fcherp rond, maar in de Kocijen ftomp plat, herwelk de breedte van den ftompen neus aantoont. ( zie Fig. I 4.) Aan dit gedeelte (Fig. 3. bija) volgt nu zekere inbuiging; bij $b$, die insgelijks kraakbeenig de form en fi* guur volgt van het uiterfte einde van het obliebeen; bij $c$ vind men het uiteinde van de snotkcm-groote fleuf der fnotkom $d d$, die aldaar bij $c$ weder een kleine inham maakt, alwaar de reukdeelen het cerfte worden opgeflurpt; deze kom of fleuf $d d$, formeert aan de uitwendige zijden, de groote of bovenfte fnotof rcukbuis; terwijl bij $e$ een kleine inham van dezelve is, waar in de reuk wordt op. geflorpt; onder deze fleuf ziet men de rug van een andere reukbuis $f f$, (die in de omgekeerde Fig. 4. grooter te zien is); insgelijks bij $g g$, de groote inwenteling van het obliebeen, (dat in Fig. 4. de grootfte plaats beflaat) in diervoege, dat, zoo men Fig. 3. befchouwd, men altoos maar het tegenover omgekeerde bij Fig. 4. vindt, even als of men een blad omkeerde, als zijnde beiden 


\section{$\checkmark$ A N H O L L A N D. 36 \%}

deze Figuren hetzelve gedeelte, doch het Hêt een van vooren en het andere van achteren, zoo dat, als iemand de zaak wel wil bevat- II. Afd. ten, hij altoos de eene Figuur met de àndere vergelijken moet, en dan zal ook uit die VII. vergelijking blijken, dat het bovenobliebeen, in Fig. 3. bij $h^{*} h *$, ene geheele andere wenteling bekomen heeft, als hetzelve bij Fig. 4: vertoont. Naar laat ons nu het achtergedeeite befchouwen; hier ontdekken zich dadelijk verfcheiden afdeelin. gen, alle bij wijze van fleuven en inhollin. gen onderfcheiden; deze zijn de omkleedfe. len van inwendige holle buizen, waar in cie renkademing om en om worde gevoerd, tof in de holtens van het zeefbeen, of eigenlijk in ontellijke buisjes en holtens van dat zelve been, in Figuur 4. ontbloot. Deze eerstopgenoemde afdeclingen, zijn nu bij wijze van cen doolhofpad, hetwelk gedu- Dsoliof. rig om en wederom gelegd is, wanrom he neusbeen. ook hier bij vergeleken wordt, vooral als men dezelve invendig opent; want alhoewel deze affcheidingen in Fig. 3. bij $h \hbar h h / 2$ zich uitwendig als afgefchciden vertoonen, door de fleuven $i$ i ii, zijn zij het in de daad niet, want inwendig zijn zij als eene buis, waar van de bogten flangsgewijze omlopen, evein als ecin omkrommende wa. terleider Deze fleuven ii ii, zijn nu de fnotwegen, en zijn altoos vol fnothijin; terwijl de buizen $h h h h h$ altoos zonder fnot, maar luchtledig voorkomen, en in de ontellijke ceilerjes var het fpons - fchuim - of 


\section{NATUURLIJKE HISTORIE}

нЕт zeefbeen uitloopen; achter de voornaamfte xundver. buis $k$, doet zich eene groore holligheid,

II. Afd. $l l$ op, omringd van eene groote fleuf $m$ :

vil. deze lleuf heeft in de inlijving van het neusbeen gemeenfchap met zekere opening aan de oogkas, waar' tegen dezelve ftuit: zij is doorgaans vol dunne flijm of fnot, en heeft dus, volgens het gevoelen der Ontleedkundigen, gemeenfchap met de traanklieren der oogen. Dit is zeker zeer aanneme. lijk, om dat men in de Koeijen al zeer al. gemeen, in de hoeken der oogen vrij zware uitvloeijingen der tranvochten heeft, die even zoo aankorsten als de fnorftof in den neus zelve; wijders is er bij $n$ een nog grooter kom, almede eene bewarplaars van fnot nijm; endeliik ontdekken zich bij 0000 Zeefbeen. de uitwendige buisjes van het zeefbeen ( 0 s cribrofum) zeer kennelijk, alle met hunne openingen en tusfchenruimtens, wendingen en regelmatige $\mathrm{i}$ igtingen; voorts is bij $p p p$ de aanhegring van het voorlie gedeclte van her neusbeen aan het achterfte zigtbaar, en dienc opgemerkt te worden, dat dit gedeelte, aan elk neusbeen, links en regts tegen elkander Suit. zoo dat de twee neusbeenderen, zoo wel het zeafbeen als het oblie- of ingedraaid been. hier aan vlak tegen elkander fluiten, en darenboven dour zeker middelfchot, nogmaals gefcheiden worden; welk

sanekam midtelfchot in den. Mensch crista galli of hunekam genaand word:; doch in de Koeijen is het rond, ftomp en kraakbeenig. Zie Figuur 4.

Ma25 


\section{$\checkmark A N$ H O L L A N D. $\quad 369$}

Maar nu befchouwe men dit gedeelte, нет in Fig. 3 afgebeeld, eens omgekeerd in Rundver; Fig. 4, dan ontdekt zich een verbazend II Afd. verfchil in het maakfel, zoo dat alle de fleu VII. ven, bulten en oppervlakten, die in Fir. 3 Hoofdit. voorkomen, hier als uitgehold en geopend plat XII. fchijnen, het geen echter zoo niet is: alles Fig. 4 . is zoo als de natuur het gevormd heef: met fchar of mes heeft men er niets aan gedaan, alleen door een fijn penfeel heef men dezelve van de flijin gezuiverd, zoo dat de kleinfte holligheid, het fijnfte fleufje in zijn natuurlijken ftuat hier wordt voorgelteld. Men gelieve nu deze Fig 4 eens bij de tegenovergeftelde Fig 3 te vergelijken, dan ziet men in Fig. 4, onder het vak $N^{\circ}$. I, al wederom het dun obliebeen $a a$, doch in eenen geheel anderen draai, en als gehecl plat, want daar het reukbeen als rondachtig omloopt, zoo is dit gedeelte plat, en drukt inwendig tegen het middel ichot van den neus, te weten, tegen dat gedeelte, dat men Septum of interfititium noemt, zoo als in Fig. 2 bij 00 hetzelve te zien is; aldaar maakt het flijmachtig bekleedfel van het neusbeen, als 'c ware, eene geul of holle goot, die van tusfchen het kraakbeenig middelfchot, tot tegren de uitwendige neusbeenderen (Os Ethmoidis), den voornaamiten fnot - of nijmweg maakt.

Dan, in deze fleuf, hier in Figuur 4 af. gefcheiden, ziet men bij $b$ wederom het kraakbeenig uitftek of de neuslel, doch in Neuslet. eene andere gedaante, $200 \mathrm{dat}$ de kom of bol. 


\section{$37^{\circ}$ NATUURLIJKE HISTORIE}

HeT holte, waar door de reukwafem in de fnotQ UNDVEE. wegen dringt, of liever waar de fnot uit-

II. Afd. vlocic, hier duidelijk bij $c$ te zien is; bij

VII. $d$ is insgelijks eene ingroeving, die de te. Hoofdrt. genzijde uitmakkt van den bult (in Fig. 3 Snotncuf. bij $b$ ); daarna vertoont zich in Fig. 4, bij $e$, de driehoekige holte; bij fff de groote middelleuf : deze fleuf wordt geformeerd door de inwentelende draaijen der obliebeenderen, welker omwentelingen hier zeer duidelijk onderkend worden; de bovenfte $f f$ is de platte wand van het ingerold been, (in Fig. 3 bij $h^{*} h *$ afgebeeld); bij $g g$ is de breede omflag van hetzelve gedeelte, (het welk in Fig. 3 bij $g g$ de onderfte fmalte des beens, was,) in dier voege, dat de fnothleuf of geul, die in Fig. 3 onder aan voorkomt, hier, in Fig. 4, in het midden is bij $h h$, alwaar eigenlijk den rand aan den indraai is; en 7.00 insgelijks de groo. te fnothleuf, die, volgens de verklaring van Fig. 3, aan het kraakbeenig deel van den neus in de invloeijing der neusgaten zijings uit. loopt: hier, in Fig. 4, als door een dunner geultje bij $i$ i omvloeit; eindelijk, daar in de voorzijde bij Fig. 3 de oblie - of rolbcenderen viak toe tot an de inworteling der zeef beenderen loopen, zoo is hier, in Fig. 4, aan de binnenzijde van hetzelve gedeclte, eere bijna drichoekige affcheiding tusfchen de obliebeenderen en de zeef heenderen bij $k k k$ : dit gedeelte is uitwendig altijd vol nijm, en de bafis van het velachtig fnot, dat dit geheele geftel omvat, even 


\section{VA $N$ HOLLAND, 371}

als het beenvlies (perioflium) de been- HRT deren.

In het gedeelte No. 2. nu, doet zich aller- II. Afd. heerlijkst zien het ganfche geftel van het zeef - en fponsbeen, aan den binnenkant: Hoofdr: dit gedeelte is hier der opmerking overwardig; men gelieve dan vooraf wel op te merken, dat alle de witte en vlakke gedeelten de eigenlijke fijne wanden of verhevenheden van de zeefbeenderen vertoonen, masr dat daarentegen al de $z$ warte uitdiepingen fnoten flijmkameren zijn, met welke de lucht. of reukkameren geene gemeenfchap hebben; dit verzoeken wij den Lezer en Naarvorfcher van onze afbeeldingen wel in het oog te houden, want, dit verwarrende, is alles in de war. Dus is bij $l l$ de ganfche witte vlakte, waar in de geheele groote kamer van den reuk ligt, die door ontelbare buisjes gefiltereerd wordt, en naar her reukzintuig in de hersfenen vloeit, zoo als in de divars doorgefneden Figuur 13 nader zal verklaard worden. Uit deze reukkas fpruiten nu al die zoo wonderlijke wanden, die zich als aderen bij $m \mathrm{~mm}$ doen kennen, tot zij in verfcheiden reijen van zeer fijne wegen bij $n n n n$ in dat zelfftandiger gedeelte 000 invloeijen, alwaar de reuklucht uit de ingerolde obliebeenderen verfijnd, nogmaals invloeijende door onbegrijpelijke wegen, als geraffineerd, gezuiverd en verfijnd, ja, ik zou zeggen, gedistilleerd wordt, even als een Chijmist, door middel van dangswijze bui • zen en door vele wentelkringen, de fijnfte wa. fem, 


\section{$37^{2}$ NATUURLIJKE HISTORIE}

HET fem, de vlugfte declen der geestrijkfte vochRUNDVEE. ten door distillatie, vangt en vergadert, zoo II. Afd. ook moet men deze fijne deelen der neus.

vIr. beenderen aanmerken als natuurlijke kunstHoofdat. tuigen, wier fijne distillatie en verzame. ling der géestrijke reukîtofen alle kunst. werktuigen der menfehen overtreffen, en in der daad in het reukgeftel der Kocijen al te klaarblijkelijk zijn, om hier in ook nict een grooten bovenmenfchelijken Kunstfchepper tc crkennen; en, wat is nu hier de wijsheid, waar is het vernuft, dat in het reukgeftel eener Koe, een dier, aan alle de wederwaardigheden van lucht en weder, maar vooral bij avond-en morgendaauw aan de nitdamping der aarde bloorgefteld, eene diepe verborgenheid van eene ondoorgrondelijke Scheppingskracht kan ontkennen? Befchouw, Lezer! bij $p p$ de groote fnotkom, wanr in zich de afgercheiden hersfenvochtige ftoffen verzamelen; befchouw bij $q 9 q$ kleinere hol. tens, die wederom bij $r r r$ invloeijen; befchouw eindelijk nog eens bij $n n n n$ die ongemeene fijne geulcjes, welker invloed eindigt om de geulen der oblie - of rolronde beenderen. Als gij dit nu wel opgemerkt hebt, zult gij, zoo ik hoop, wel bevatten, hoe wijs en zorgvuldig al die teedere, dunne, fchier onhandelbare affcheidingen ser fijne reukdeeltjes, juișt in een zacht, week, verkoelend flijm en fnot gewenteld zijn, die meer dan de kunftigfte Chijmist, met al zijn luteren of ftoppen, de allerfijnfte deelen des reuks, uit welk een element het 


\section{A N H O L L A N D. 373}

het zij, aan het hersfengevoel van het dierlijk leven, ja der zicle brengen, ja het geheele ziels - en ligchaamsgeftel is ontfteld, II. Afd. als deze reuk - en fnotdeelen door verkoud. heid en Catherale ziekten aangetast, in VII. hare gezonde werking belemmerd zijnde, veeltijds den dood aankondigen.

Men zie verder Plaat XII. Fig. 5. Hier Plaat XII: is de kast of het befchermbeen afgebeeld, Fig. 5 . hetwelk de fijne zeefbeenderen onvat, wier teedere dunne fponsachtige buisjes volftrekt geene de minste drukking kunnen lijden, ja zelfs minder dan eenige fijne zenuw - fpierof bloedvat-vezels hier tegen beftand zijn. In de inwendige holle kast van het jukbeen of het wangbeen, is dit teeder geftel ingekast; dit been is uitwendig hier in zijne natuurlijke grootte, uit een Kalf genomen, afgebeeld, en vertoond uitwendig niets dan bij a de zaagswijze inleding in de voorhoofdnaat, die men futura fagittalis noemt, dat is : zaagtands-voorhoofdnaat; wijders bij $b$ de holligheid, warin de bovenneusfpier in ingeliff; bij $c$ eene aanmerkelijke ope. ning, waar door zeker fmaakzenuwtje in de reukkast indringt.

- Maar nu keere men dit been om, en be. Plaat XII. zie het inwendig op Plat sII. Fig. 6, Fig. 6. waar men in deszelfs holligheid juist die Reukkass. aanmerkelijke indrukfels ziet, waar in de deelen van het zeefbeen fluiten en befchermd worden, even zoo als de weeke oppervlakten der hersfenen in het harde bekkeneel, den indruk hunner bultjes en rondigheden $\mathrm{A}$ a

be- 


\section{NATUURLIJKE HISTORIE}

מex behouden, indiervoege, dat het zeefbeen RUNDVEE, in Fig. 4 bii $k k$ tot $r r r$ afgebecld, vol-

II. Afd. maakt in dit been Fig. 6. nluit, en wel zoo

VII. fterk, dat men goede handen en voorzigtig Hoofdit. overleg noodig heeft, om hetzelve geheel en ongefchonden uit deze beenkas te ligten, nademaal het onder alle hoofdbeenderen niet alleen een der fterkfte, maar tevens het allervaste in de bovenkaak is inge. wricht. Men ziet bij a deszelfs dikte en groeven aan het jukbeen; bij $b$ de bogt van hetzelve tegen de oogkas, aan het jukbeen; bij $c$ de inbuiging der kask inwendig; bij $a d d d d d d$ luchtkommen; bij $e$ de groote luchtkom, en onder aan ziet men bij $f$ de fijne langwerpige luchtwegen, wier invloed op anderen betrekking hebben. Ditalles nu opgemerkt, doet ons zien, hoe dit teeder geftel befchermd en bewaard wordt, maar er is nog iets aan te merken, te weten, dat daar fchier overal de reukbeenderen van den voorneus door nijmige fnot en fnotvliezen omringd worden, hier niets dergelijks zich vertoond, hetwelk dan aantoont, dat in deze beenholligheden, tevens in her zeefbeen, en in deszelfs buisjes, niets dan de fijne wafem of de luche der reukftoffen, gezuiverd en verfijnd worden, juist ter plaatfe, alwaar de gezıgt - de fmaak - ja de gehoorzenuwen aan het hersfengeftel naderen, het green de Lezer in de verklaring van het hersiengeftel der Koeijen en deszelfs zenuwen, duidelijk zal kunnen nagann. 
Wij vervolgen met de befchrijuing van Fig. 7 en 8 , verbeeldende beiden op elkan der volgende deelen van den voorneus. In II. Afd。 vorige Figuren vertoonden en befchreven VII. wij alrede her kraakbeenig neusdeel, mits Hoofdr.  gaders de oblie - of rolbeenderen, doch hier Fig. 7. zijn dezelve afgefcheiden, zoo dat Fig. 7. het kraakbeenig gedeelte met deszelfs holle onderfleuf (waar tusfchen het obliebeen in Figuur 8 afgebeeld) in de natuurlijke zamenvoeging wordt omhelsd, aanduidt. Men ziet dus bij $a$ den beweeglijken kraakbeenigen voorneus ( vergelijk op deze Plaat Fig. 3 en 4.) $b 6$ is het vervolg van de bovenbuis, die den rug van het obliebeen uitmaakt, en dus de eerlte fnotfleuf; bij $c c c$ onder aan, is de onderfte fnotheuf, welker wanden als verlengd uit het kraakbeenig gedeelte van den beweegbaren voorneus $d d$ ontftan; deze fleuf is de onderfte van het geheele geftel, en tevens de langfte, als loopende van het neusgat af, tot achter aan het zeefbeen toe. (Vergelijk mede op deze Plaat Figuur. 3 bij $p p p$.)

'Iusichen deze twee verlengingen van de Plaat Xtr: neusgaten en den voorneus zelve, lige nu het Fig. 8. obliebeen, afgebeeld op Plaat XII Fig 8. en volkomen beantwoordende, vooreerst: aan de zamenftelling van het beweegbaar neuskraakbeen, gelijk bij $a$ duidelijk blijkt, en vervolgens 200 ook het ondergedeelte $b b$ volmaakt aan de geul of groef van het onderfte gedeelte, in Fig. 7. bij $d d$ aangewezen, en 200 ook het bovengedeelte $c c c$ in $\mathrm{Al}_{2}$

Fig. 


\section{NATUURLIJKE HISTORIE}

HEx Fig. 8 insgelijks aan dat, hetwelk in Fig. 7. R.UNDVE. bij $b b$ is angetoond: midden nu door dit

II. Afd. obliebeen loopt de middel - of groote geul
VIJ. lloofdit. $d d$, welke altoos vol fnot en vellen gevon: den wordt, en eigenlijk de groote fnotgeul is. De wanden dezer geul zijn het dan die inwendig aan beiden de zijden indraaijen en ineen rollen, zoo als gezegd is, bij wijze Rolbeen. van ineengerolde papieren: men kan het ook eren. ingedraaid, ingewenteld (injecta) noemen, zoo als dergelijk beentje in des menfchen reukgeitel bekend is, doch dit is op verre na zon ongemeen en bijzonder nict, waarom wij al wederom dit nog nader willen verklaren: p'aat XIr. Zno dan ziet men op Plat XlI. Fig 9, hetboFig. 9. venfe oblie - of rolbeen in zijne natuurlijke groorte, met deszelfs groote fnotgeul, waar van a a a de bovenwand, en $b \dot{b}$ de onderwant verbeeld, beidein als tegen elkander inrollende; bij $c c$ de onderwand van het rolof obliebeen: het overicre verklaart zich genoeg uit de vergelijking met het voorige, maar om nu deze draai regt te kennen, be-

Plast XII. ziet men Plaat XII. Fig. 10. waar men de Fig. 10. twee oblicbeenderen ziet, zoo als zij natuurlijk tegen elkander indraaijen: dezelve zijn levensgroote en dwars doorgefineden afgebee!d, zou dat nu deze kleine, doch fraaije Figunr volkomen die inrolling en kunstige in. wenteling doe zien, welke het reukgeftel in de Koeijen zon verbazend van dat in anderen dieren onderfcheid. Bij $a$ is de regter, bij $b$ de linkerdraai; bij $c c$ de wanden van het kraakbeen, en bij $d d$ de bovenvlakte van den neus, 


\section{A N H O L L A N D. 377}

neus: maar nu leere men het onderrolbeen kennen, deszelfs zamenltelling heeft buiren de ingedraaide gedante in den binnenwand, Ir. Afs. wanr san het ain het zeefbern nadert, eeni- VII. ge bijzondere holligheden, die als zeer kenHoofdr. nelijke affcheidingen of celletjes zich opdoen, en gemeenfinap met de laarfte draai der inwenteling hebben. Men bexie dezelve op Plat XII. Figuur I I. alwaal zij juist plaat XIL. onder de groote fnotfleut liggen. (Verge-Fig. $\mathbf{~}$ lijk hier mede op deze Plaat Fig 4.: Deze celletjes bij a $a$ a $a$ in Figuur $r$. nu zijn inwendig in her been $b b$ ingewikkeld; en nict zigtbaar, ten zij men een fchilfer van het reukbeen, zoo als hier, opligt en af1cheid; zij zijn altijd vol fnotftoffe, doch veel fijner en dunner, dan die in de geulen zich bevindt, wanruit ik befluit dat aldaar de fnot - en flijmftoffen gezuiverd, en in de draai gewenteld zijnde, eindelijk in de geul $d d$ uitvloeijen.

Ten einde dit nu nog eens op te helde-plat XII. ren, dicnt op Plat XII. Fig. I2, alwaar Fig. 12. insgeliiks dit gedeelte dwars doorgefneden. is afgebecld, en wel tweeledig, tc ween, beide deze foorten van beenderen zoo als derclve an beide de zijuen yan het geheel renkgeftel liggen: dus is bij a de regtiche wenteling, bij $b$ de linkfche, marr ook ter wederzijden vertoonen zich bij $c c$ de aanhangfels der zoo even bij Fig. Is belihreven geul.

Eindelijk, nm nu ook een begrip van Plaat XII. de doorfnijding der zeefbeenderen te beko Fig, I3.

$$
\text { A a } 3 \text { men, }
$$




\section{$37^{8}$ NATUURIIJKE HISTORIE}

yer men, dient al mede op Plaat XII. Fig 1?: undVEe hier is nu die overheerlike werktuirglijkII. Afd. heid der zeef beenderen (os/a Cribriforinia), vit. Sponsbeenderen (osfa Sporgioja), volkoHoofdrt. men opengelegd; ieder rondje, icucr affcheiDoorfnij- ding, is een ingerold buisjc, dat de fijue ding der reukdeelen zife, de fijne geesten distilleere zeef'sen. ceren. en afzonderlijk verfijnt (faturecrt), dat is, zuivert, tot de onbegrijpelijklte fibtiliteit der reukgecsten, of eigenfchappen der uitwafemingen, dic van elk bijzonder dier, plant, metaal of geestrijk voge, in onzen dampkring vermengd, aan het reukgeltel eener Koe gebragt worden, her zij dezelve door den mond ingeademd, of door den neus ingeflorpt, of cok door de gehoorwegen gemeenfchap hebben, of waar door het gevoel wordt angedaan. Bij dit alles erkennen wij eerbiedig en nederig, dat al ons vernuft, al onze kunst en wercnfchap, ftilftat, en dat alle onze aanmerkingen en al ons onderzoek niet verder tocreikende is, dan alleen om te befluiten, dat in alle deze onnagaanbare buisjes van het zeefbeen iets verborgen is, het geen wij even 200 min kennen, en nimmer zullen kennen, als ook niet het week gedeelte van het hersfenmerg: beide deze zakelijkheden kennen wij uit de overeenbrenging, die derzelver maakfel aan ons toeftaat te beredeneren, maar nimmer kunnen wij volkomen derzelver uitwerking beflisfen; het behoort tot die verborgenheden, die de groote Maker alleen voor en in zich beboudr, en warr bij alle menfche- 


\section{VA N HOLLA N D. 379}

lijk vernuft moet ftilltaan, en zeggen: $a \mathcal{F}_{2}$ - нет hovah! hoe groot zijn uwe werken! Gij RunDver. hebt we allen met wijsheid gemaakt! en II. Afd. ik vocg er bij: wie zal tot den einde toe VII. den Almagtigen kennen? Dwas en roeke. Hoofdit. loos zoude het derhalve zijn, indien ik u, geachte Vaderlanders! iets zoude willen uitleggen, waar voor mijn gevoel, rede, kunst en alle mijne werktuigelijke vermogens niets zijn dan dwarrelwinden, wier geruis in de doolhoven van ons vernuft omzweeft. Vergenoegt u dan met dit fchetsje bij Fig. I 3 : ziet daarin, bij $a a$, het miduelfchot der twee zeefbeenderen (Mediastinum), bij $66 b 6$ den rand van dit geitel, herwelk inwendig die zelfde buisjes, dwars doorgefneden, vertoont, welke gij mede op deze Plaat in Fig. 4 bij $n n n n$ zoo duidelijk uitwendig ziet: befchouwt vervolgens bij $c c$ ter wederzijden de holle luchtkommen, die relkens bij de vorige afbeeldingen befchreven zijn.

Meerder kan ik, zonder verwarring, niee afbeclden; ik acht het zelfs waarfchijnlijk, dat iemand, wiens zaak het niet is, oncleed'sundige figuren en derzelver aanwijzingen ' na te gaan, veelligt ook alle deze afbeeldingen met. ongeduld zal nafporen : het zij 200; maar, geëerde Vaderlanders! ik zal trachten $\mathrm{u}$ te voldoen; ik zal in de laatfe Figuur alle deelen bijeen brengen, dezelve aanwijzen, en wel zoo, dat ik vertrouw, dat de onkundiglte, de eenvoudigfte zal kunnen bevatten, wat het voortreffelijk reuk-

$$
\text { A a } 4 \text { ge. }
$$




\section{NATUURLIJKE HISTOR!E}

net geftel cener Koe is, waar van ik de dee'en u zoo vitvoerig en afzonderlijk heb getrach

II. Afd. te leeren kennen.

VII. Figuur I4, op Plaat XII, zal hier toe dienen, als ziinde in dezelve op de meest mogelijke proportie het gheel reukgeftel afgebeeld, zoo als hetzelve bij deelen al. reeds is voorgedragen, en dus, alhoewel naar het beloop van ons ontwerp kleiner in omtrek, echter de anciere afbecldingen duidelijk genoeg tot het proportioneel geheel kan brengen.

Plaat XII. Zoo dan vertoont Figumur is de geheele Fig. 14; Kalfskop vlak van voren, zoo dat alle de reukdeelen vereenigd in hunne ware rigting liggen, in diervoege, dat alle de reeds befchreven declen, van op zijde of van achte. ren in alle derzelver rigtingen vertoond, hicr vlak van voren voorkomen.

Wij beginnen met het ecrfe uitwendige, namelijk de neusftomp : dit gedeclte is bij $a b$ aangeduid en kennelijk genoeg; bij $b \vec{b}$ zijn de neusgaten: het geen in dit gedcelte nu de oplettendheid vereischt, is voorcerst de fterkte van den neus, mitsgraders derzel. ver ongemeene gerimpclde en als gefagijinde opperhuid, en ten tweecie, de affanden der neusgaten $b b$. welke zeer zcker aantoonen, dat de reukwegen der Koeijen niet 200 nabij en als tegen clkander geplaatst zijn, als in den Mensch, en in de Honden, Katten en andere dieren; waar uit dan onbetwistbaar volgt, dat beide deze neusga*en meerder gefchapen zijn, om ter weder- 


\section{VA N H O L L A N D. $\quad 3^{81}$}

zijden te rieken, dan wel vooruit, gelijk dit ook wegens het gezige is betoogd. De RUNDVBz: Menfchen, vooral ook de Aapen, ricken al- II. Afd. len met opgerigten hoofde; een Hond en foortgelijke dieren met een vooruitftekenden VII. fnuir; maar een Koc, of elk ander herkaauwend dier, ook een Paard en Ezel, die langs den grond grazen, riekt met gebukten hoofde natuurlijk naar zijn voedrel, en zoo deze dicren al met opgerekten muil naar de kribbe rieken, is het de Mensch, die hen dic leert, daar doch de natuur geene ftallen noch kribben hecft; eene $\mathrm{Koe}$ is er ook moeijelijk toe te brengen, te weten, om hoog nar eene kribbe te rieken, zoo als het Paard, wiens halswervelen hiertoe ge fchikter zijn; de aard en de natuur eener Koe eischt den vlakken grond, en hicrom ftrooit men op de veeftallen altoos her hooi en gras voor hare voeren op den grond; men drenkt haar uit eene geul of waterloop; een Paard, daarentegen, bemint het flurpen of drinken uit een emmer, en kan voltrekt niet flurpen, gelijk eene Koe tiit de platte geul cener Koeftal, zonder regen zija natull an te drinken ook is de lip en neus van een Paard meer gefchikt om uit eene ruive of rousterkrebbe hooi en gras te bezigen, dan eene Koe, een Schrap of Ram; zelfs fchijnt het deze eigenfchap meer dan eene Koe te hezitten. Dit alles wel opgemerkt wordende, is hier door nagenoeg het geftel van den fterken bovenlip en de neusgaten der Koe verklaard: voeg hier nu bij, Aa 5 Hoofdrt. 


\section{NATUƯRLIJKE HiSTORIE}

nex dat men duidelijk in de uitblazing der luche, RUNDVEE in de nitdamping in den herfst, wanneer

II. Afd. men de geconcentreerde lucht in alle dieren

VII duidelijk ziet uitademen, deze uitblazing in Hoofdf. de Koeijen altoos tweeleàig en zijdelings kan onderfcheiden, hetwelk integendeel in andere dieren zoo kenbaar niet gefchiedt.

Nog eene kleine aanmerking dient hier bijgevoegd te worden, te weten, over de har. ftoppels aan en om den neus der Koeijen. Men erkent in de fijnriekende dieren, als de Honden en Katten, zeer lange haartjes als knevels aan den neus; men ziet Menfchen en ook Paarden, die in de reusgaten zelve inwendig zeer kennelijke haren hebben: deze dienen zekerlijk om de uitwendige verdikkende in. ftuivingen des luchts te beletten, of wel de al te fterke uitvlocijing der fnot, mar opmerkelijk is het, dac de fornuizen of eerfte neusgaten eener $\mathrm{Koe}$, vooral eener jonge Koe, altijd kaal, glad en koud zijn; dit is insgelijks zoo in de Honden, vooral ook in de Hazen en Konijnen, hetwelk dan, wel opgemerkt zijnde, een zeker bewijs, ten minfte eenig vermoeden, aan de hand geeft, dat ook in dit opzigt eene Koe een bijzonder greftel heeft, en dat dan ook daarom de zware haarftoppels aan den neus en bovenlip meerder gefchikt fchijnen ter afweering van onnutte reukitoffen, dan wel tot het rieken zelve.

Wij ftappen hier af, en gaan nu het inwendig geftel nafpeuren: ten dien einde lette men in onze Fig. I4 op de aanwijzing bij 
$b \bar{b}$, boven op het reukgeftel; hier is de al- HEx gemeene affcheiding der tweederlei reukdee. RUNDVEE: $^{-}$ len, links en regts, doorloopende tot op 11. Afd. en aan het middelpunt der neuslip $c$, doch in bijzondere verdeelingen; dus is bij $d$ de VII. groote neuf, die het middelfchot uitmaake tusfchen de holligheden $e e$, welke het hersfengeftel vormt aan en om de wanden der omkrommende reukkameren $f f$; daarna vervolgt deze fleuf in de tusfchenfcheiding der beide zeefbeenderen, en is aldaar bij $g$ de plaats, daar in den Mensch de zoogenaamde Crista galli of het hanekambeentje is, doch die bier door twee aanmerkelijke holle beenderen bij $h h$ de fcheiding der zeefbeenderen uitmaken; vervolgens ontdekt zich bij $i$ i duidelijk het kraakbeenig middelfchot (medium finum), het feptum natum, hetwelk de oblie - of rolbeenderen wederzijds affcheidt, gelijk zich dan bij $k k$ de eerfte buis met zijn fnotlleuf opdoet; wijders zijn bij $l l$ wederzijds de groote oblieof rolbeenderen (osfa turbinata) duidelijk met hunne fnotgeulen bij $m m$; dit gedeelte makt de tweede verdeeling der reukbuizen uit; maar nu, doet zich bij $n n$ de oppervlakten op der fnotholligheden, die in Figuur 3 levensgrootte in het achtergedeelte bij $h h h h h$ zijn afgebeeld, en hier in Fig. i4 niet dan oppervlakkig kenbaar zijn, zijnde dus de derde affcheiding der fnot - en reukwegen; eindelijk ziet men bij $o o$ alle de opgemelde geulen, fleuven en rolbeenderen eindigen en uitvloeijen, aan en om Hoofdit: 


\section{NATUURLIJKE HISTORIE}

HET den kraakbeenigen neustop; zoo als die in RUNDVE. Fig. 3 bii $a$ is afgcbeeld en befchreven; alle II. Afd. deze deelen nu zamengevoeggd, hier voorgefteld VII. zijnde, formeren eigenlijk de voorneus beHoofdit. nedenwaarts, en worden gedekt door het bovenneusbeen (Os Ethmoides?, zie op deze Plaat Figuur I bij $e$; dan eindelijk nuipen alle deze beenderen van den voor of onderneus, in, en onder de holten, die de beide zeefbeenderen formeren en waar aan $z i j$ verknocht zijn, zie onze Fig. I 4 bij $p p$ : hier nu ontdekt zich duidelijk de boog, die het zeef been met zijn gewrigt formeert bij 9999 , en tevens al wederom de zij. lingfche fnotholten bij $r r$, gelijk ook overal hier de groote, gints de kleinere holligheden bij $s s s$ te zien zijn, en wolke al. reeds bij Figuur 4 van deze Plaat volko. mon zijn befchreven; alleenlijk dient men gade te flaan, dat bij tt zich nog twee aan. merkelijke fnotkommen opdoen, die in de zijlingfche afbeeldingen nict zigtbaar konm den zijn, gelijk men ook wel degelijk de geheele afbeelding van deze zeef beenderen nict anders moet aanmerken, dan als dezelfde holligheder, fleuven en reukbeentjes of derzelver wanden, die op deze Plaat in Fig. 4 zijdelings zijn afgebeeld, maar dezelve zijn in Fig. 14 in een anderen ftand, dat is, zoo als zij vlak onder het plat der koedol, eigenlijk het voorhoofd, liggen, onder de zaagswijze voorhoofdnaad; einde. lijk en ten laatfen zijn hier bij и и и и и и и и nog eenige fpiertjes aangeduid, die den neus be. 
bewegen, en bij $y \boldsymbol{y}$ de fterke lipfpie- $\begin{gathered}\text { HET } \\ \text { RUNDVE. }\end{gathered}$ ren.

Hier mede de befchrijuing der twaalfde Plant, en dit Hoofdituk over de reuk der Koeijen voleindigende, hebben wij er verder II. Afd. niets bij te voegen. Heeft iemand, welke niet ervaren in de ontleedkunde is, lust, met weinig kosten en moeite de hoofdzakelijke deelen nader te leeren kennen, als hij zich een Kalfskop, dat toch een tafellekkernij bij onze Natic is, laat opdisfen, hij fcheide dan de beentjes van den muil en neus voorzigtig af, en, zoo hij wil, legge hij onze Plaat XII. voor hem, als wanneer hij van zelve en vrij gemakkelijk, uit vergelijking, de voornaamfte neus - en reukbeen. deren zal kunnen onderfcheiden, en, bij het fmakelijk tafe1-onthaal, tevens zich een wijsgeerig vermaak verfchaffen.

Wij gaan dan nu over, om ook op der. gelijke wijze de declen van den fmaak, die der tong en der kaken te underzoeken in de volgende Plaat en deszelfs verklaring; maar laten hier nog eerst volgen eene korte verklaring van Plaas XII. 


\section{NATUURLIJKE HISTORIE}

HะT

RUNDVEE.

11. Afd.

VII.

Hoofdit.

\section{Verklaring yan Plaat XII.}

Fig. 1. Een geheel Kalfshoofd, in zi;n beendergeftel, naau wkeurig naar het Leven op een vierde verkleind.

$a$ de kroon of het opperbekkeneel.

b vereeniging der hoofdfcheel - of kroon. beenderen.

$c$ de geleciende zamenloop der reuk - en fmaakbeenderen aan het verhemelte, eigenlijk het voorhoofdbeen.

d oogbeen.

$e$ boven - neusbeen (Os ethmoides.)

$f$ het fteenbeen (os petrofa.)

$g$ de holligheid van het flaapbeen.

$h$ de benedengroef van her verhemelte, eigenlijk de verzamelplaats der kaauwfpieren.

$i$ het achterhoofd.

$k$ oogbeenkas, oogkas.

$l$ begin der reukbeendereu.

$m$ boven - neusbeen.

$n$ ringswijs neusbeen, of het topfnuitbeen.

0 holle beenfleuf of reukweg.

pp bovenkaakbeenderen.

$q$ onderoogbeenderen.

or het jukbeen (os jugale.)

$s$ de bovenkiezen.

tt t t de onderkaak.

u onderkiezen. 
VA N HOLIA A D. 187

y voortanden.

HET

भy het voorverhemelte.

RUNDVEE,

$x$ het achterverhemelte.

II. Afd. VII.

Fig. 2, vertoont hetzelve Kalfshoofd dwars Hoofdet: overlangs doorgezaagd. om deszelfs inwendige deelen te kennen.

a a a de inwendige doorzaging van de kroonnaad perpendiculaar.

$b b b b$ het geheele bekkeneel.

$\operatorname{coc} c \operatorname{ccc} c$ de inwendige holligheden en indrukfels van de groote hersfenen.

$d$ de fchubgewijze gebeenten van het oog. hol, of de weg der gezigezenuw.

eee het fponsachtig reukgebeente, of verhemelte, gewelf, enz

$f$ aanwijzing van het veelvormig been.

$g$ binnendeelen van het gehoor.

$h$ fteenbeen aan het achterhoofd.

$i$ de gehoorweg.

$k$ gaatje van de gehoorzenuw.

$l$ het hoofdgat, daar het hoofd an den eer-

ften wervel, of den atlas, draait.

$m m m$ de onderkaak.

$n n n$ bovenneusbeenderen.

. 0 kraakbeenig middelfchot.

$p p$ onderfte reukkokercje

$q q$ groeven van de zeefbeenderen, fponsbeenderen.

r lleuven der reuk - of fnuitbeenderen.

Fig. 3. inwendig, langwerpig neus - of Inuitbeen, levensgrootte, uit een Kalf, 


\section{NATUURLIJKE HISTORIE}

HET

RUNDVEE.

II. Afd.

VII. Hoofdit. aan de zijde van het middelfchot, dat hier is weggenomen, het obliebeen.

a het beweegbar kraakbeenig uitftek van den reus of fnuit.

$b$ inbuiging of kraakbeenig uitfek van het oblicbcen.

$c$ het uiteinde van de groote fleuf of fnotkamer $d d$.

$d d$ de bovenfte fnot - of reukbuis.

$e$ de kieine inham van herzelve, of reukopflorper.

ff reukbuic.

$g g$ de groote inwenteling van het obliebeen, onderwarts.

$h * h *$ de groote bovenwenteling van het oblicbeen, gemeenfchap hebbende met deszelfs fleuven, $i i i$.

$h h h h h$ uitcinden der leuven, $i i i$.

i i i zijnde tusfchenfleuven en fnotkamers, tusfchen de uitcinde van het obliebeen.

$k$ groote fnot of nijmbuis.

$l l$ holligheden onder hetzelve.

m lange fleur.

$n$ g, oote onderfnotkom.

o0 00 de uitwendige buisjes van het zeefbeen. $p P p$ aanhegting van het voorfte gedeelce des neusbcens aan het achterfte gedeelte.

Fig. 4. Het geheele geftel van het boven verklaard fnuitbcen, met het obliebeen aan de binnenzijde, levensgrootte.

a het oblicbeen omgekeerd, van binnen. 


\section{VA N H O L L A N D. 399}

$b$ de krakbeenige fnuit - of neuslel.

HET

$c$ de opening daar van.

RUNDVER.

$d$ ingroeving in de kraakbeenige fnuit.

$e$ driehoekige holte.

II. Afd.

VII.

fff de groote fnonleuf, of platte wand van lloofuts.

het obliebeen.

$g g$ de onderfte of ronde wand van het oblic. been.

$h h$ de rand aan den indraai.

$i i$ verfmallend geultie aan de zeefbeenderen. $k k k$ drichockige affcheiding van het obliz. en zeefbeen.

Il de vlakte wanr in de reukkamer ligt.

$m m m$ tusfchenwanden der fnotkommen.

$n n n n$ wanden en fleufjes van het zeefbeẹn.

000 de affcheidings - fleuf.

$p p$ de groote fnotkom.

qqq kleine fnotkommen.

rrr langwerpige holte.

Fig. 5. is de geheele kast of befchermbeen van het zoo wonderlijk zeefbeen in zijn natuurftand, uit de geleding van het jukbeen geligt, levensgrootte vertoond.

a zaagswijze inleding in de voorhoofdnaad, uitwendig.

$b$ holligheid, waarin de boven neusfpier is ingelijfd.

- c opening of gaarje, waar door zekere fmaakzenuw in de reukkast indringt.

Fig. 6, het opgemelde kastbeen aan de binnenzijde.

$\mathrm{Bb}$ 


\section{NATUURLIJKE HISTORIE}

พхт $a$ deszelfs dikte en groeve aan het jukbeen. ZUNDVEE. $b$ de bogt van hetzelve tegen de oogkas aan IJ. Afd. het jukbeen.

VIl. $c$ inbuiging of inleding aan de kaken. Hoofdit. $d d d d d d$ luchtkommen.

e groote luchtkom.

$f$ langwerpige luchtwegen.

Fig. 7. Het kraakbeenig middelifchot tus: fchen de rol-en obliebeenderen, levensgrootte afzonderlijk.

a kraakbeenige beweegbare voorinuit of neus.

$b b$ vervolg van de bovenbuis.

$c c c$ de onderbuis of lange fnotheuf. $d d d$ onderkraakbeenig gedeelte.

Fig. 8. Het obliebeen, eigenlijk rolbeen, geheel los en afgefcheiden, beantwoordende aan het kraakbeenig middelfichot.

a eind van het obliebeen aan de beweegbare neusfnuit.

$b b$ de onderkom of ronden indraai, $c c c$ de boven indraai.

$d d$ de groote fnotgeul.

Fig. 9. Het boven rol - of obliebeen af́zonderlijk met zijn draai.

a a a groote fnotgeul, de bovenwand.

$b b$ groote fnotgeul, van den onderkant, beiden tegen elkander inrollende.

$c c$ de onderwand van het rolbeen. 


\section{VA N H O L L A N D: 39r}

Fig. 10. Dwarfche doorfnijding van beiden nkr de rol - of obliebeenderen, mid- ${ }^{\text {Xundver: }}$ den door.

$a$ de regter omrolling.

$b$ de linker omrolling.

II. Afdeel:

VII.

Hoofult.

$c c$ wanden van het kraakbeen.

$d d$ bovenvlakte van den neus.

Fig. I1. Het rolbeen overlangs doorgefineden, mer deszelfs kameren.

$a$ a $a$ a fnotcelletjes.

$b b$ been, waarin dezelve zijn ingewikkeld.

$c c$ draai of uitloozing der fnot.

$d d$ de groote fnotgeul.

Fig. 12. De dwarsfe doorfnijding der rolbeenderen tegen het zeef - of fponsbeen.

$a$ de regtfe draai.

$b$ de linkfe draai.

cc aanhangfels der in Fig. II befchreven geul.

Fig. 13. Geheele dwarfe doorfnijding van het zeef- of fponsbeen.

a $a$ het krakbeenig middelfchot der zeefbeenderen.

$b b b b$ de bovenrand der gemeene kast, met alle de ontelbare buisjes van binnen. cc holle luchtkommen.

Fig. 14. Het geheele reukgeftel eener Koe regtftandig van voren, met de naastmogelijke proportie 200 van $\mathrm{Bb}_{2}$

been. 
SET

RUNDVE.

II. Afd.

VII.

Hoofdit. beenderen als fpieren, en verdiere deelen, uitvoerig afgebeeld, en de volkomen vereenigingen ' van alle de reuk - en neusdeelen.

$a a$ is de uitwendige muil, met hair bezet, of de neus.

86 de neusgaten.

$c$ het kraakbeenig middelfchot aan het be-

- gin der lip.

$d$ de groote fleuf van boven.

ee de luchtholligheden aan het hersfengeftel.

$f f$ de reukkameren.

$g$ de plaats der hanckam.

$h h$ de holle luchtbeenderen of ficheiding der zeefbeenderen.

$i i$ het kraakbeenig middelfchot.

$k k$ buịzen der fnotwegen.

ll de groote rol of obliebeenderen ( $\cos \sqrt{a}$ turbinata.)

$m m$ fnotgeulen.

$n n$ oppervlakte der fnotholligheden.

00 uitvloeijing der fnot in de neusgraten.

$p p$ de uiteindens van de rolbeenderen $a^{\prime}$

$\because$ het zeefbeen.

9999 het groote holle gewricht van het zeefbeen tegen dezelve.

or zijlingfe fnotholtens.

ss.s s kleinere binnen - fnotholligheden.

tt zeer kleine fnot-en luchtkommen.

и и и и и и и и beweegfpieren van den neus of muil.

y y. fterke lipfpieren. 


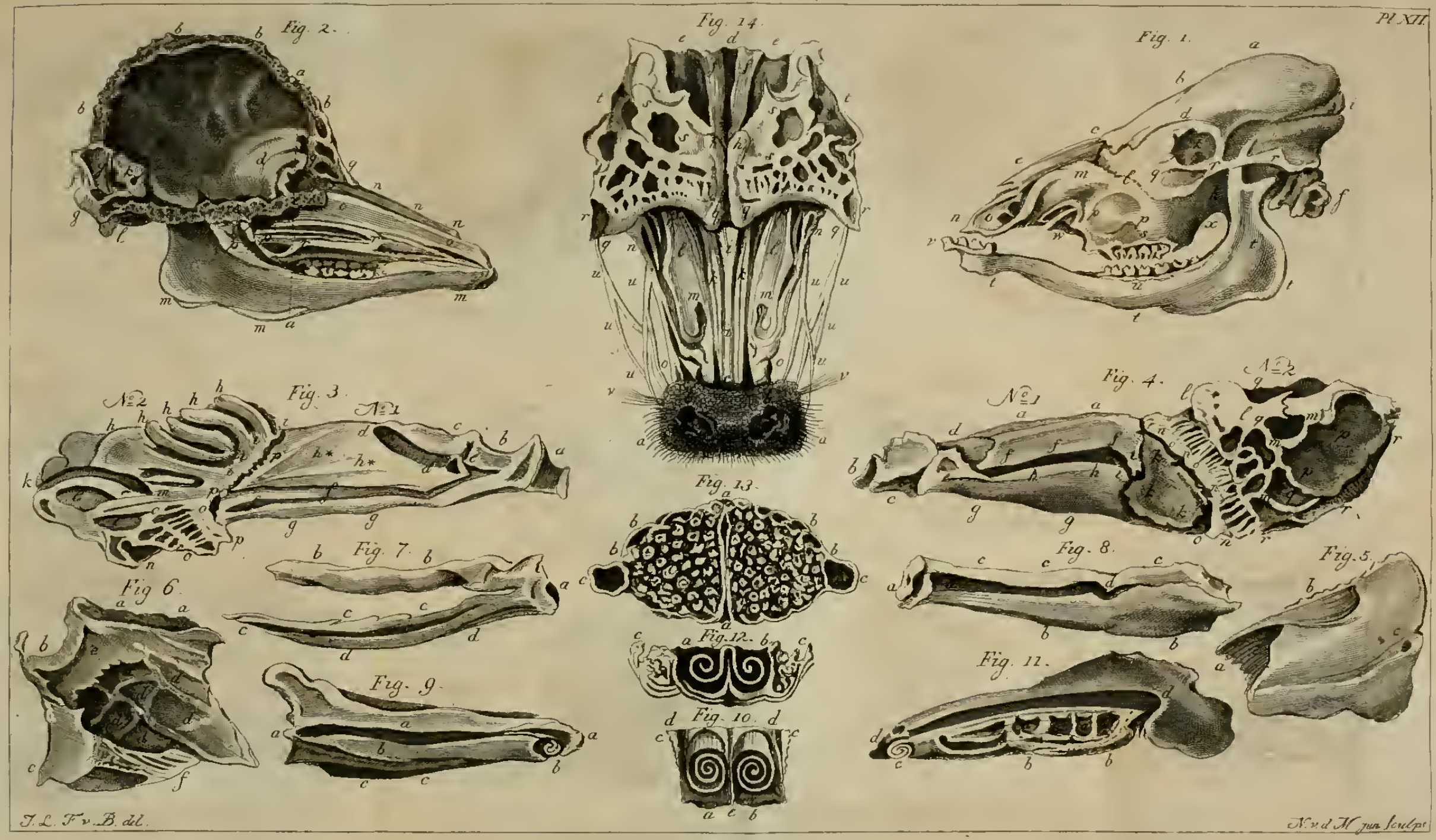




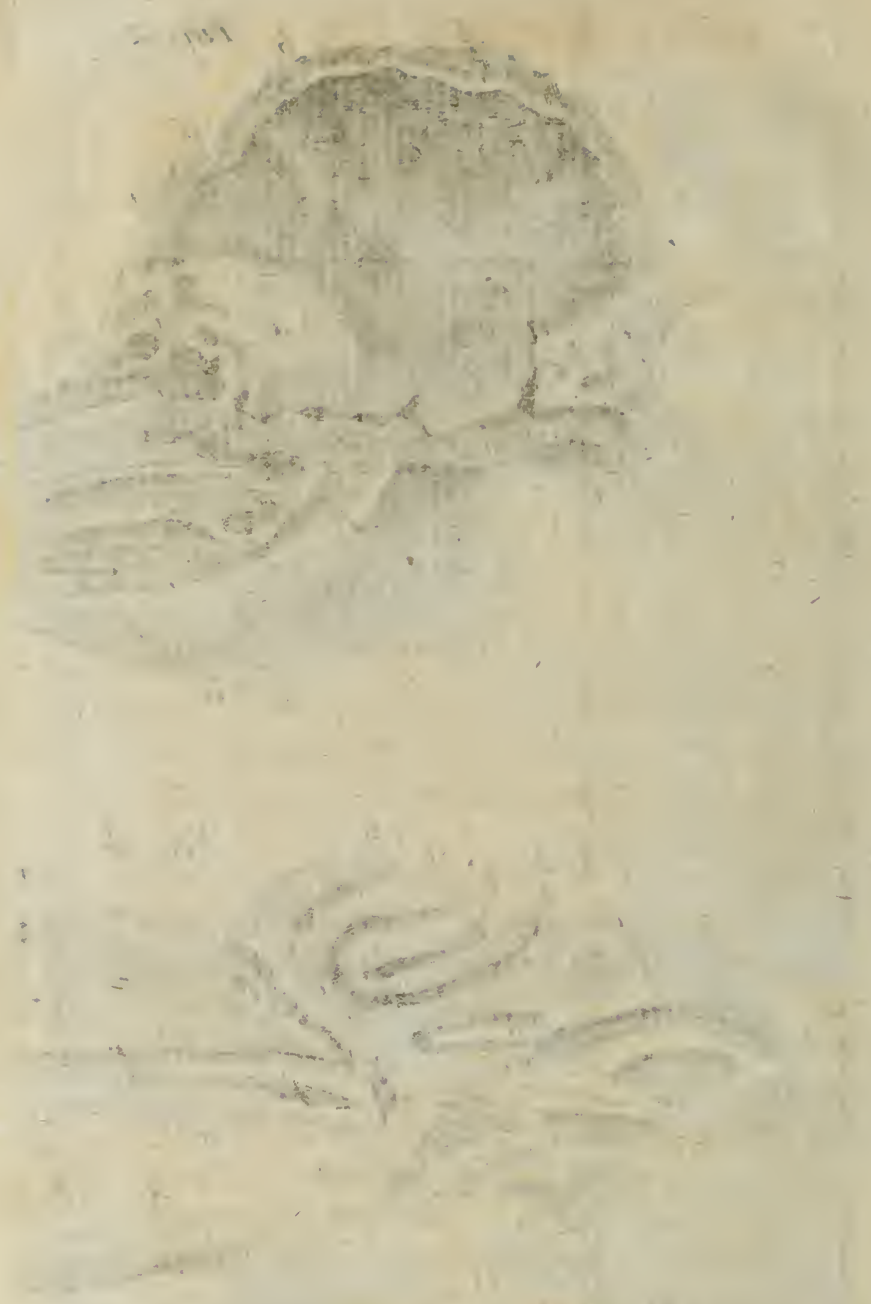

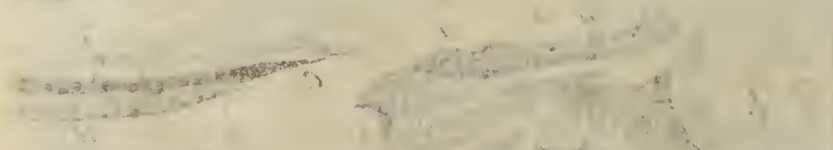

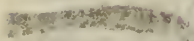

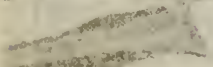

and
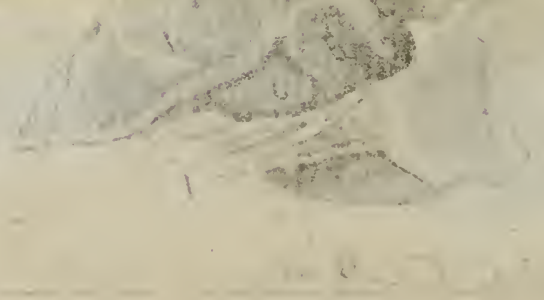
VAN HOL LAND. 393

\section{TWEEDE AFDEELING。}

ACHTSTE HOOFDSTUK.

Handelende over de zintuigelijke deeles yan den fmaak, der chijlmaking, het gebit, de tong en het verhemelie der Runderén.

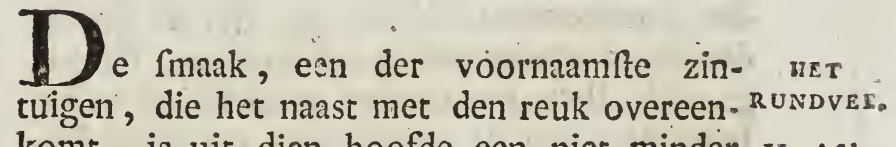
komt, is uit dien hoofde een niet minder II. Afd. onderzoekwardig onderwerp als eenig an. vilr... der zintuig; althans uic hoofde van de fchei- Hoofdes ding der chijl en der vochten in den mond en het gebit der Koeijen, waar van de kennis aan den Landman en Veehandelaar hoogst noodzakelijk is, om dat het onderzoek dezer deelen het meest kan toebrengen to de uiterlijke kunde van de teekenen der ziek ten of der gezondheid.

Vele en zeer diepzinnige denkbeelden zijn cr. over den finalk der Menfchen en der Dieren bekend, vooral over de wording der

$$
\mathrm{Bb}_{3} \quad \mathrm{chijl} \text {, }
$$




\section{NATUURLIJKE HISTORIE}

מxT chijl, of eigenlijk dat bijzonder vocht of w uNDver. fpeekfel, dat in den mond, aan de tong en II. Afd. de klieren altoos tegenwoordig is, en zonVIII. der hetwelk men geen fmaak noch prikHoofdr. keling aan de fimaakdeelen gewaar zoude worden, of eigenlijk dat de onderfcheiden fmakelijkheden, als zout, zuur, zoct, bitter, laf, heet of koud mededeelt, even zoo als in de reuk door de nlijm en de fnot. fcheidingen de bijzondere reukftoffen worden onderfcheiden, in 200 verre, dat en de reuk en de fmark, den eenen zonder den anderen niet werkt. In de Koeijen hebben wij de reuk, zoo wij vertrouwen, geheel en al genoeg verklaart, en derzelver reukdeelen, 200 als die bijzonder ann deze die. ren eigen zijn, befchreven; ten aanzien van den fmaak zullen niet minder bijzonderheden voorkomen: althans het zijn de fmaakdoelen en chijlwording der Koeijen, die het grootfte licht ter verdere ontdekking en be. fchrijving van de chijlmaking en fmakdeelen der Menfchen hebben aangebragt, gelijk uit de af beeldingen van STENON en BLAz:Us blijkt, waarom wij ook derzelver af beeldingen zullen mededecien, en die met onze eigen nieuwere voorftellen.

Dan, daar de gelegenhejd der maakdeelen, de tong, het verhemelte, de kwijlen chijlvaten en klieren, mitsgaders de longpijp en flokdarm, eene meer gemeenfchappelijke aandoening van dit zintuig gevoelen, dan wel de anderen, zoo is dit ook allerbijzonderst opmerkelijk in de Koeijen 


\section{A N H O L L A N D. 395}

in de reuk en den finalk werkzaam; er is door Hет ons te voren reeds gewag gemaakt, in hoe RUNDVE. verre een Mensch en de naast aan hem komende dieren, de werking van een of ander

zintuig, bij voorbeeld, het gehoor of ge. Hoosdit: zige misfende, door her andere kan geholpen worden of door zielsvermogende oefeningen dat gebrek te gemoet komen, en dus het leven behouden, maar in de reuk en den fmaak is dit geheel anders, dewijl beide dezen zonder elkander niet alleen niet kumnen werken, maar zelfs de Mensch zonder dezelve nier kan leven, om dat, wanneer de invloed van geestrijke voedende ftoffen op de fpijsverteering ontbreekt, dan ontbreekt ook het voedend vermogen, en gevolgelijk het levensonderhoud: dit is, onzes bedunkens, bewijsbaar genoeg uit de werking; die de reuk en de fmaak uitoefent in de natuurlijke begeerte naar, en de walging vant, eenige drank of fpijze: de voorbeelden zijn overvloedig onder ons Menfchen, dat iemand volftrekt de reuk van kaas niet kan verdragen zonder te walgen of flaauw te worden; de anders, voor vele, zoo liefelijke reuk en fmak der aardbeziën, is voor fommige menfchen een hoofdpijn - verwekkende fmart. Er zijn fommige fpijzen, bijzonder onder de kuolfoorten, welke aan den Mensch natuurlijk walging veroorzaken: aan mij zijn kinseren bekend geweest, welke zoodanigen afkeer voor roodekoolfoep met meel hadden, das zij, door de ouders gedwongen, dien te eten,

$\mathrm{B}$ b 4

\section{Afd. \\ Hoordlt:} (1) 


\section{NATUURLIJKE HISTORIE}

HET de ftuipen kregen, en het bloed in den neus RUNDVER. ontfprong; de Honden, anders gulzige die-

II. Afd. ren, zullen eer van honger fterven, eer zij VIil. iets eten, dat hun reuk en fmaak tegenftaat; Hoofdrt. de Zwijnen walgen van witte boonen; kortom, alle dieren hebben eene walging en natuurlijken af keer van voedfel, 't welk haar fchadelijk is, en dit zouden zij natuurlijk niet kunnen onderfcheiden, wanneer de zintuigen der reuk en van den fmaak door den wijzen Schepper van allen dierlijken nooddruft aan haar niet was ingefchapen. Hoe nu de reuk, door eene verkwikkende onderfcheiding van fpijze en drank, met den fmaak zamenwerkt om die verkwikking te fmaken, te proeven, op te flurpen, te kaauwen, te herkaauwen, en eindelijk aan alle de ligchamelijke zelfftandigheden het vleesch, het bloed, het merg, het gebeente, de zenuwen, klieren, in één woord, al ons beftaan te geven: dit behoeft hier geen ver deren uitleg, als behoorende elders tot de filijsverteering, en derhalve ftat ons hier alleen te bewijzen, dat en de reuk en de fmak onder alle de vijf zintuigelijke on. derfcheidingen de twee voornaamfte zijn, die op het eigenlijk ftoffelijk ligchamelijk beftaan betrekking hebben; - ftoffelijk beftaan, zeg ik uitdrukkelijk, om dat men de aandoening van het gezigt en het gehoor niet eigenlijk ftoffelijk noemen kan, want het licht of de lichtftralen, noch de dreuning van het geluid, deelen aan het lig. chaam geene zelfitandjgheden mede, dan het denk- 


\section{v A N H O L L A N D. 397}

denkbeeldige der ziele, en dus eigenlijk die andoening, welke men geyoel noemt, dat RUNDVEE. Enormen impetum faciens van HIPPOCRA- II. Afd. TES, en in onze dagen de Irritabiliteit, dat is, de aandoening van het gevoel. In Hoofdit. dezen zin zege men wel : het oor wordt verzadigd van hooren en het oog van zien; de wijsgeerige welfprekendheid kaauwt en herkaauwt; de verhevenheid der welfprekendheid van de Dichters en zanglievende ARIONS en SAPHO's voeden de ziel door welluidend fnarenfpel; de Koorzangen van het gevederd Koor weergalmen op den luchtadem van Echo; doch dit alles voedt het ligchaam niet; want voor den reuk van liefelijk gebraad en den fmaak van welbereide fpijzen, ja voor een bete broods en een korf boomooft, zal een wellprekend Wijs: geer, welluidend Citerfpeler en keurig $Z$ anger al zijn kunstvermogen opofferen. Dus deelen de reuk - en fmakdeelen, behalve deze prikkeling, eene wezenlijke voedende ftoffelijkheid mede, die dadelijk op de voeding en de ligchaams - nooddruft werkt; bij voorbeeld: de Mensch krijgt of door honger, of door flanuwte, de zoogenaamde geeuwhonger: men houdt hem ftraks een ttuk brood onder den neus, dadelijk verkwikt hij door den reuk en bekomt: hij bijt en hapt gulzig naar de bete broods en bekomt, zoo ook dringen de vlugge geesten van de vlugge zouten, aftrekfels van kruiden, en gedistilleerde wateren naauwelijks door den reuk tot ann het verhemelte, of $\mathrm{B} b 5$

VIII.

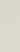




\section{NATUURLIJKE HISTORIE}

MET de fmaak en het gevoel wordt dadelijk opQUNDVEE. gewekt en verfterken de aêmechtigen; inII. Afd. tegendeel kunnen door den reuk en den fmaak vili. ftoffelijkheden worden medegedeeld, die Hoofdst. Mensch en Dier fchadelijk en doodelijk zijn; zoo als er ontelbare voorbeelden zijn van de fchadelijke uitwafemingen der dampen uit moerasfen, poelcn, wateren en fonteinen, die den reuk aandoen, den fmaak vergiftigen en pest veroorzaken; de zwavel. dampen in 't gemeen zijn aan de dieren fchadelijk, om dat zij door den reuk eene bedwelming aan het geheel zintuigelijk en gevolgelijk aan het levensgeftel der dieren veroorzaken, en zelfs ook de planten aandoen: immers eene Noorder-luchtftroom, door kwade dampen verzeld, flaat op ééns alle veldgewas doodelijk ter neder, waar over hare wolk drijft. Wanneer men een weinig zwavel under de boomtakken, waarop vogelen flapen, aanfteekt, worden zij dadelijk, door den reuk, de damp en fmaak der zwa. vel bevangen, en vallen half dood ter neder. De Boa, een llang in Indiën, doet door zijn adem de vogelen naast hem nedervallen. De uitwafeming der boonen-blocmen bevangen den reuk en den fmaak der Menfchen, en verwekken een dommelenden fmaak, waarom men zegt van iemand, die mijmert: hij is in de boonen. De kracht van het nieskruid, heulbloem, en vele andere zijn ook bekend: en zeker dit brengt ons tot de Koeijen, als zijnde deze de dieren des velds, die het meeste deel hebben 


\section{、 \ H O L L A N D. 399}

aan, of bloot ftaan voor den fchadelijken invloed van den dampkring, en bij welk dergelijke uitwafeming, op den reuk en den fmaak, en gevolgelijk op hun leven en beftaan' den meesten invloed veroorzaken.

Daar nu alle de ftoffelijke aandoeningen, door prikkeling en dadelijke mededeeling aan het voedfel, door den reuk en den fmaak aangevoerd worden, en, gelijk betoogd is, in het reukgertel die ftoffen door de reukkameren on fnotwegen, in de fnot zelve worden afgefcheiden, even zoo hebben ook de fmakdeelen eene bijzondere bereiding, waar door de opgeflorpte drank en de genuttigde en herkaauwde fpijzen door een natuurlijk chijl of flijm, dat men fpeekfel noemt, gekleinst en daar mede vermengd zijnde, eindelijk wederom van de groffte deelen gefcheiden worden, welke door kaauwing, wenteling om en door de tong en het verhemelto tot klompen, of, zoo men zegt, tot pillen gevormd, door den flokdarm naar de maag gezonden worden, als de groote kamer der fpijze en fpijsverteering, terwijl de fijnfte en vlugfte fappen, door de chijlbuizen, binnen den mond en aan het verhemelte, op eene wonderbaarlijke wijze worden ingeflorpt, en eene vol1treke afzonderlijke bewerking hebben, die alleen tot den fmak en gedeeltelijk den reuk beiden behoort, hetwelk ook de Natuur leert, nademaal geen dier, van wat aard of geflacht het zij, eenige fpijze zal genieten, zonder eerst daar aan te rieken, 


\section{NATUURLIJKE HISTORIE}

mET daar na te proeven, eindelijk te eten en te 2 UNDVER. fmaken; dan, hoe algemeen dit aan alle 1I. Afd. dieren eigen is, 200 is het verfchil van hetVIII. zelve zoo groot, dat er ook geen foort Hoofdrt. van dieren bekend is, hetwelk in het maakfel der fmaakdeelen, zoo wel als in dat der reukdeelen en in derzelver werking, volkomen aan een ander foort van dieren gelijk is.

Dit laat een ruim veld tot onderzoek en vergelijkende Natuurkunde open, waar in wij ook door de Ouden reeds zijn voorgegaan, 200 als voornamelijk in de werken van meergenoemde CASSERUS PLACENTINUS, fabritius, blasius, en in die der Franfche Anatomisten, wegens verfchillende viervoetige dieren, vogelen, visfchen en andere dieren bekend is, en waar in, buiten die der Menfchen, ook die der Koeijen, Paarden en Schapen, met de meeste aandacht behandeld zijn.

De kennis van de fmaakdeelen en chijlmaking is, behalve die van den omloop des bloeds, van het zenuwgeftel, de teeldeelen enz., mede het allervoornaamfte, het geen de Medicijnmeester moet kennen, een der grontfte kundigheden in het ontdekken van ziekten, is in het kennen van deze deelen gelegen; zoo dra de fpijsverteering, de fcheiding der vochten bedorven is, openbaart het zich in aanflag op de tong, in den verkeerden fmaak, bedorven reuk, ademftank, fnotftank, vertoonen zich dadelijk aan de gezwollen fnot - en chijlklieren; en doen de 
longeklep aan, dermate, dat zij prikkelen- nET de hoest verwekken : iemand kome in cen RUNDVEE. vertrek of huis, dat vol aanflag van rook II. Afd: is, dadelijk doet de inademing daar van den reuk en fmank aan, en zoo ook wordt de VIII. reuk en fmaak aangedaan, in de verte zelfs van Kalkovens, Runmakerijen, Leertoúwerijen, Lijm - en Traankokerijen, Vischgrom, Mestfaalten, en allerlei gestende ftoffen, die allen meer of min den reuk en fmank aandoen. Daar nu alle deze aandoeningen, zoo kennelijk op de deelen van den fimak werken, is het zeer zeker ook een cier: noodzake? lijkfte kundigheden, die men in de veeärtzenij behoort te kennen, en wel voornamelijk in het Rundvee, nademaal derzelver frmaakdeelen, even als die van den reuk, eene geheel bijzonder zamenftel hebben, aan geen ander Dier eigen, gelijk ook buicen dat, de uitwerking der chijl-en fpeckfelbereiding, van die der andere Dieren verfchilt, zoo dat het geen men in dit opzigt bij hẹt eene Dier voor ecn teken van ziekte erkent, dit bij den anderen daarentegen gezondheid aanduidt: de voorbeelden zijn bekend: bij voorbeeld: de Honden, Katten en alle verfcheu. rende Dieren, doen hun zièkten en ongefteldheid, ja dolheid, kennen door het ontijdig kwijlen en fchuimbekken, zoo dat men verzekerd is, dat deze Dieren kwijnen, en zelfs hun chijl vergiftig en fchadelijk is, maar integendeel herkent men de eerfte teekenen van ongansheid, ziekte en veepest bij de Koe, als dezelve niet kwijlt, of daar 


\section{NATUURLIJKE HISTORIE}

mEx an kwijnt; het kwijlen, bijzonder bij het RUNDVEE* herkaauwen, is een blijk van gezondheid:

II. Afd. niets ziet den Boer liever, dan dat zijne

vili. Koeijen gezonde heldere chijl of fpeekfel

Hoofdit. loozen, en de neus altijd vochtig is. De Schilders nemen dit ook waar, als zij ge. zond, tierig vee afmalen: het een en ander dan zamengenomen, kan genoegzaam zijn om de noodzakelijke kunde van dit zintuig, door uitvoerige befchrijvingen en figuren zoo duidelijk te doen kennen, als wij zulks van de andere zintuigen gedaan hebben, hetwelk in vele opzigten gemakkelijker door een Landman in de natuur zal kunnen wor. den nagegaan, dan wel dat van het reeds verhandelde over het zenuwgeftel, het gehoor, het gezigt en den reuk, om dat deze eene fubtile ontleding der ingewikkelde dee. len vereifchen, en de ontleding, althans der uiterlijke fmaakdeelen, gemakkelijker te doen is, en door een bezadigde behandeling kan verrigt worden; immers, het zal een Landman, een Koemeester, of ander onderzoeklievenden, weinig moeite kosten om zich een koe - of kalfskop met tong, ftrot en flokdarm te verfchaffen, en de kaken er af te fnijden: hij zal de tong, de kevels, het verhemelte, de congfpieren en chijlklieren duidelijk kunnen onderfcheiden, en die mer onze befchrijving en afbeeldingen vergelij. kende, zeer duidelijk, zoo wij vertrouwen, in dit ftuk onderwezen worden, zonder zelfs een ontleedkundige te zijn. Dit dan ons doelwit zijnde, gaan wij tot de befchrij- 
ving der fmaakdeelen, en verklaring van de HET daar bij behoorende figuren over, en wel RUNDVREa vooreerst tot die, welke op Plaat XIII. II. Afd. Fig. I is afgebeeld, en die wij van den kundigen STENON hebben overgenomen, als vilI. zijnde deze de voornaamfte ontdekker van het beloop der chijl - en kwijlvaten in de Koeijen, waar naar zoo veel nuttige verbeteringen in de befchrijving van die der Menfchen zijn gemaakt.

Plaat XIII. Fig. 1. fteld dan voor oogen P1. XIIrd de kwijl - en kliervaten, benevens de fmaak- Fig. $\mathbf{x}$. zenuwen, die de kaauwing en herkaauwing bevorderen.

Bij a a a a ziet men die klier, die onder het oor ligt, en daarom parotis genaamt, men noemt dezelve de hoekklier, (conglo- De hooks: meratis) om dat dezelve in den hoek en klies. aan den flaap van het hoofd legt. Deze klier moet een Koeijendocter en Landman volftrekt kennen, om dat deze dezelfảe uit. werking heeft, die in den Mensch van zoo veel belang is; het is die klier, die in zinkingen, in kiespijn en in hoofdpijn, den grootften invloed heeft, en de plaats, waar men de hoofdpleister, fpaanfche vliegen en ontbindenden oliën appliceert. Ik geloove hierom, dat men in de veeziektens er te weinig op gedacht heeft, om ook fpaanfche vliegen of afleidende middelen aldaar te leg. gen, te meer, om dat men in de beginfelen der veeziekten aan de zwelling derzelver klier, ook het eerfte begin der ziekte ontdekt, dat is, dat de Koeijen kwijnen, want 


\section{NATUURLIJKE HISTORIE}

GET als derzelver vaten en invloed op de chijl, RuNDVEe die in de herkaauwing in den mond uitII. Afd, vloeit, verftopt zijn, zoo ftelle ik voor mij

VIII. vast, dat daar uit die bedwelming en hoofd. Hoofdift. pijn en geheele kwijning der beesten volgt: doch hier van zal ik in het vervolg, bij de verhandeling over de Veepest, nader en uit. voeriger fpreken; het is, om dit nog in het voorbijgaan te zeggen, die klier, die den wortel der gehoorzenuw bedekt, zij heeft wijders op het geheele kakenbeen eenen algemeenen invloed, en hierom noemt BLAZIUS dezelve te regt de kaak, de kinnebaksklier (glandula maxiilaris). Wij gaan over tot derzelver verderen uitleg en die deger geheele Fig. I,

a $a$ a $a$ is de voorfchreven klier.

$\mathrm{Bij} b b$ is angeduid de voorhoek der opgemelde klier, die de ware parotis of hoekklier van BLAsius, en de zamengevoegde van STENON is, eigenlijk de verzamelklier der weivochten (Lympha).

Bij $c$ ziet men de verzamelplaats van dit vocht aangeduid, en al wederom moet ik van de noodzakelijkheid om deze plaatfing wel te kennen, fpreken, want de dolligheid der Koeijen, en de kolder der Paarden, houdt hier den zetel, en het is ook hierom, dat de Latijnen cen dol, een hersfenloos mensch, ecn ijlhoofdig mensch, een Lymphaticus noemden.

Bij $d . d d d d d$ ziet men de fpruchtels, zoo als dezelve uitwendig de chijl- of flijmE.: 


\section{A N H O L L A N D. 405}

vaten in den geleiweg of geul (ductus нer falivalis) bijeen doen vloeijen.

RUNDVER。

eee vertoont derzelver uitvloeijing in den II. Aft. mond en naar de tong.

ffff doet ons de bloednlagader zien in zijn Vili.

uitwendigen tak.

$g g g$ zijn de takken der zenuwen, die uit en om de gehoor - gezigt - en fmakzenuwen, de traanklieren, en ook de reukzenuwen ontfpruiten, ten minfte zich met dezelve vereenigen, en midden door den chijlklier loopende, zich bui ten dezelve in geheel afgefcheiden takken vertoonen.

hh vertooni derzelver fpruchtels en taksgewijze uitfpreiding.

i $i$ wijzen de zenuwrjes aan, die al mede uit den chijlklier ontfpruitende, de chijlvaatjes of buisjes vergezellen, en welke vergezelling ons al wederom brengt tot de opmerking, hoe naauw de alleruiterite gevoeligheid der zenuwen, aan deze oorhoekklier verbonden is, en daarom volftrekt moet in ache genomen worden in de ziektens der Koeijen, hat zij dezelve Epidemiek, ontftekend, of Chroniek, of kwijnende, zijn.

$k$ de neusgaten.

$l$ de longepijp.

$m$ het oor.

$n$ de van den kop tot ann den fnuit afgeftroop. te huid, albier omgeflagen vertoont. 


\section{NATUURLIJKE HISTORIE}

yet Gelijk dan nu, volgens stenon en BLAaunder. zius, de uitwendige liorsing van de kinne11. Afd. baksklier, en de geleibuizen der chijl, uitVII wendig vertoond zijn, volgen nu ook de Hoofdr. inwendige bij Fig. 2, waar omtrent men Kinne. heeft op te merken, dat dezelve in de Koeibaksklier. jen, gelijk ook in den Mensch, zoo wel Inwendi.het verhemelie als de ondertong, de kiee kwijl- zen, de kaken, de wangen en lippen inwenvaten. dig bevochtigen, en zij zeer kennelijk in de wanden van den mond uitfijpelen, waarom men dezelve ook daarna onderfcheiden benamingen geeft. In de Koeijon komt bijzonder in aanmerking die uitvloeijing der chijl ann en om de tong, die haar vooral dient om te lekken. De Honden hebben dezelve ook aanmerkelijker dan eenig dier. Bij de afbeelding der tonge zullen wij dezelve aanftippen: hier moet ik echter bij voorraad niet ovelflaan, dat de uitvloeijing der $\mathrm{kwijl}$ of het flijm, hetwelk uit deze klieren vloeit, in de Koeijen veel menigvuldiger is dan bij eenig ander Dier, en ook noodwendig zijn moet, nademaal deze Dieren vooreerst bij het grazen, het gras of ander voedfel nict kaauwen, maar door de tong en het verbemelte geholpen worden om het voedfel in de chijl als in een te kleinzen, en als ' $t$ ware te rol. Ien, zoo dat zij hetzelve als eane pil doorllikken, en her alzoo naar de mang zenden; waar van de haarballen, die de Koeijen door het lekken vormen, getuigen zijn.

Voor het overige behoeve ik voor den Luandzaat en den Hollandfchen Boer niet veel 
veel omnax, om hen te beduiden, dat de ret Koeijen zelfs veel meer dan de Schapen, Bok- Rundver. ken of Geiten, genegen zijn tot lekken en II. Afd. kwijlen. Wij hebben er ter loops al iets van gezcgd en ook afgebeeld: de Kalveren kwijVIII. len zeer fterk; ook gaac dit kwijlen of kwal1teren der Koeijen wel over tot een gebrek, vooral als zij aan de haarballen kwijnen, dan is dit therk kwijlen een zeker teeken van kwijning in de maag, en dan zegt men: de Koe of het Kalf is kwalfter of kwijlziek, ook wel fnotziek. Zie hier boven bii Snotkalf. Het een en ander dan overgebracht op ons onderwerp, zoo zullen dan de twee volgende Figuren, 2 en 3 , dit ophelderen; ten dien einde dienen men op te letten, dat de eene dezer Figuren moet aangemerkt worden als het tegenbeeld der andere, en men in beide deze Figuren de inwendige ligging der vaten, klieren en kwijlbuizen ziet, waar van wij na de verklaring dezer Figuren nader zullen fpreken.

Op Plaat XIII. Figuur 2. is dan afge- Pl. XIIt. beeld de klieren en kwijl - of chijlvaten in de Fig. 2 , Koeijen inwendig, zoo als dezelve in Fi- Inwendiguur uicwendig, dat is, aan de buitenfte ten, vande zijde der kaken, onder de huid vertoond fpierenge. zijn.

Bij $a$ a is de achterfte zijde der kaakklier (glandulus maxillaris).

$\mathbf{b} \mathbf{b}$ de ligging derzelve tegens de kaakfpier. $c c c$ de iprucheels of rakjes van de klierbuis (dustus falivalis) van achteren. 


\section{NATUURLIJKE HISTORIE}

Hะт $d d$ de worteltjes dezer fpruchtels.

RUNDVEE. $e$ de omgekromde buis, aan de zenuw er

II. Afd. tweeledige fpier oprijzende.

VIII. $f$ deszelfs wederkering en vereeniging in de voorfte klierbuis.

$g$ de gemeene kwijlbuis in zijne gemeene aanvoering.

$h h$ de dubbele fpier:

$i$ de uitloozing der opgenoemde kwijlvaten, naar de lippen en de tanden.

$k k$ de plaats der klieren, die aan de tanden uitloozen.

$\ell$ de bovenlip.

$m$ de longepijp.

$n$ de oogkas.

P1. XIII. Plaat XIII. Fig. 3 is eene afbeelding var Eig. 3.

de klier - en kwijlvaten omgekeerd, in tegenoverftelling van Fig. 2. zoo dat de Iongepijp - of ftrotten-ader (arteria as. pera) en de loop der vaten in eenen anderen ftand nederwaarts zich vertoonen, alfchoon het dezelve zijn.

$a \boldsymbol{a}$ is het achterfte deel der kwijlklier, geheel vrij van aanleggende deelen.

$b b$ is deszelfs opperfte en breede gedeelte, waarin de kwijlvaatjes zich ontlasten.

$c$ is de onderfte fpruchtel, zoo als dezelve van deze zijde den tweeledigen fpier intreedt.

d d de terugkeering van de takachtige fpruchtel, daar zij zich met de bovenfte vereenigt. 


\section{vA N H OLLA N D, 409}

$\epsilon$ de gemeene verlengde buis, of de groote $k$ wijlbuis.

$f$ de tweeledige fpier.

$g$ deszelfs inenting omtrent de ronde klier.

$h h$ de inenting der inwendige kaakfpieren

HET RUNDVERd

II. $\Lambda f d$.

VIII.

Hoofdf:

omtrent de fnijtanden of zoogenaamde tandachtige uitftekken in de onderkaak.

$i$ de inenting van de $k$ wijlbuis an zijn oorfprong, onder de punt der tonge, omtrent de fnijtanden.

$k$ de ronde klier an die van de kaken gehecht.

ll de tandwijze fcherpe lelachtige uitfekken van de onderkaak, omgeflagen buiten haar ftand.

sn de tong omgekeerd buiten zijnen ftand.

$n$ de amandelen of onderkaakklieren (Tonfiblate.)

0 de longepijp.

Uit de vergelijking dezer. Figuren blijkt Chijl • en dan, hoe en op welk eene wijze de chijl-kwijlva. en kwijlvaten en de bijliggende deelen ge- ten. legen zijn, en hoe dezelve uit hunne in. wendige buizen, tot aan de uitwendige dee. len toevloeijen: er mangelt nu flechts aan, om deze fubtiele ontleedkundige af beeldin. gen vatbaar te maken voor den Landman, den Veehoeder, of anderen, wier belang het $z \mathrm{ij}$, de uitwerking daar van ite kennen; ten dien einde hebben wij er de twee eigenhandige afteekeningen van het verhemelte, de tong, tanden, lippen enz. bijgevoegd in Figuúr 4 en 5. 


\section{AIO NATUURLIJKE HISTORIE}

нат In de eerfte, namclijk in Figuur 4, ziet sunDVEE. men nasuwkeurig en naar het leven afge11. Afd. begld het verhemelte eener Koe, of liever v'? van een halfjarig Kalf, zoo als hetzelve Hoofdit. Jigr tegen, en bedekt, alle de chijlvaten Het ver. van Fig. I en 2 , in welk verhemelte de bemelte. chijl - en kwijlvaten uitfijpelen en uitwafemen, zelfs door nog onnafpeurlijker fpruchtels, als het fubtielfte ontleedkundig oog toclaat te ontdekken; want ik houde voor vast, dat alle die doornachtige, zenuwachtige, tandsgewijze virftekken, wolke men in Figuur 4 bij $d d d d$ in de wangen, bij $c c c c$ in de ribswijze tandachtige reijen van het verhemelte, gelijk ook in het eeltig te. pelachtig gedealte van het voorverhemelte $e e$ ziet; alle onzigtbare buisjes en uitfijpelingen der chijl zijn, even zoo als bij den Mensch de fijne kliertjes der lippen, der ondertong, ja der tong zelve, hetwelk wij dikwijls gewar worden, als de chiil of het fpeekfel, vooral in het hartelijk lagchen, in toorn, of fchielijke beweging der knken, als met geweld ontfpringt en uitfpuit. Men ontdekt dit te duidelijker in het verhemelte der Koeijen, nademaal de gezegảe fcherpe uitftekken en derzelver ribsgewijze plooijen, geftadig de kwijl - of chijldrupjes even als parelijes uitpersfen, en onophoudelijk het verhemelte en de tong bevochtigen; war toe niet weinig helpt de poreusheid en klierachtigheid van het vetvlies in het ver. hemelte, in diervoege, dat men, even na den dood van eene Koe, of Kalf, of ook 


\section{VA N HOLLA N D. 412}

van een Schaap, als wanneer de uitvlneijing der $k$ wijl of chijlftoffe ftreme, als 't ware RUNDves. nog eene fijne zachre daauw of wafem op II. Afd. het verhemelte geftremd ziet, vooral in het achterfte geteelce bij $f f$, doch allerfterkst VIII. Hoofdfta en zclfs biina tot eene vereenigde confiften. tie bij $e e$; tot alle welke fijne en zuivere vocht en chijlfcheidingen het verhemelte van eene Koe zeer gefchikt is, en volftrekt verfchilt var dat van alle andere viervoetige dieren, die niet herkaauwen en weinig tanden hebben. Opmerkelijk is het echter, dat de Schildpadden an hunne tandelooze kaken, kiewen en flokdarm juist gelijke tandsgewijze reijen hebben; ook hebben de tandelooze Hagedisfen en fommige Visfchen el iets van.

Deze tandsgewijze uitftekken en ribswijze Pl. XII. tandachrige rijen, zijn zeer kennelijk in de Fig. 12 Koeijen, doch daar zij door de kleinheid en 13. in de proportie der Teekening van Fig. 4 en 5 op Plaat XIII, nier duidelijk konden afgebeeld worden, hebben wij op een open plaatsje in deze Plaat, bij Fig. I 2 en 13. twee ftukjes van deze tandwijze lellen afgebeeld, war van het eerfte, Fig 12. de afgepelde opperhuid met alle de holten der tepeltonden vertoond, en Fig. I 3 de tandwijze repels walke in deze holligheden fluiten, 200 als dezelve natuurlijk tegen het verhemelce der Koeijen liggen, en genoeg. zaam de geheele rand aan de kevels beflaan, tor aan de wanden der tong en lokdarm.

\section{C c 4}

Dic 


\section{I2 NATUURLIJKE HISTORIE}

H.T Dit zonderling geftel in de herkaauwende RUNDVRE. dieren overtuigt ons, dat deze opgemelde 11. Afd. tandlellen, (zoo zal ik dezelve eens noeVIii. me,) ecne ongemeene fijne en gezuiverde Hoofdrt. $\mathrm{kwijl}$ s en chijlfcheiding in de Koemaag en Tandle. Melkvaten bevordercn; waar uit men zeer len in den gegrond kan aflciden, dat hicr door ook die muil der zachte en voedzame fpijsverteering aan haar Koeijen. eigen is, en de fijne \{maak, die licfelijkheid in room, melk en boter, en cindelijk die malschheid in vet en vleesch bij uitnemendheid hier door bevorderd wordt.

$\mathrm{Om}$ dan de opgemelde tandachtige lellen en het gehecle geitel van het verhemelte nu verder te befchrijven, volgt hier de verklaring van Plaat XIII. Figuur 4.

P1. XIII, a a a a Zijn de wanden van de bovenkaak Fig. 4. en der lippen; bij de hovenite twee $a$ a zijn de eigenlijke voorlippen, vol kleine poriën en haarborstelcjes.

bb Vertoont de fcheiding van het achterverhemelte van het geribde en getande voorfte verhemelte.

cec c Duiden de ribsgewijze getande reijen aan, welker getal, tot twaalf zigtbare, in andere mindere zigtbare, bij $b b$ eindigt; ieder dezer getanden ribben vervangen zich beurteling in her midden, de een hooger, de ander lager, hetwelk wij in Fig. I 2 en 13 levensgrootte hebben afgebeeld. $d d d d$ Zijn ce groote tandachrige lellen, ter wederzijden aan de wangen tot aan de - kiczen uicloopende. 
se Is het eeltig en tepelig voorfte gedeelte van het voorverhemelte, welk hardachtig geftel in oude Koeijen bijna kraakbeenig II. Afd. wordt: dit gedeelre fluit dermate op de voortanden der onderkaak, dat hetzelve VIII. dient tot afbijten van het gras, en in der daad als een eenige eeltige tand is aan te merken.

ff Duidt aan het achterverhemelte, daar het aan het ftrottenhoofd on den flokdarm eindigt: in hetzelve ziet men door ftipjes angeduid de poriën, die aldarr de fijne fmaakvochten uit - en inflorpen.

$g$ Is de ingang tot den neus, waar door de lucht, uit de long, wordt ingeblazen. $h h$ De neusgaten

$i$ De fnijdende rand der voorlip.

Dus verre het verhemelte befchreven en Fig. 4. verklaard zijnde, eischt de naauwkeurigheid, om nu het tegुenwerkend geftel van de onderkaken, der tong en deszelfs Onderka: poriën aan te wijzen, om dat ook dit be-ken.

Ppiegelens - wan:dig gedeelte, het geen eene volftrekte betrekking tot den fmaak en de - herkaauwing heeft, niet vergeten worde: want, alfchoon de tandlellen, de poriën, en de tandsgewijze ribben van het verhe. melte, zulk een verbazend vormfel hebben tot het doen uitfijpelen der fmaak - en chijivochten, zoo kunnen dezelve volttrekt niet werken, zonder de de gefțadige fchuring en tegenwerking der tong en onderkaak, mitsgaders de uitvloeijing der fijne geesten tot C c 5 aan- 


\section{NATUURLIJKE HISTORIE}

HET aanprikkeling uit de tong en de onderkaakRUNDVER. fche tandlellen.

II. Afd. Ter verklaring hier van is Plaat XIII. vIll Fig 5 ingerige, door ons naar het leven Hoofdrt. afgeteekend, nademaal dit bij anderen, bij-

P1. XIII zonder bij scHNEIDER, zeer onnaauwkeurig Fig. 5. voorkomr. De Lezer gelieve dan deze Figuur oplettende na te gaan, en dezelve te vergelijken tegen de daar aan tegenwerkende deelen, in Figuur 4 afgebeeld en hier boven verklaard.

De kaak- a a Zijn de gewrigten en hoofden van de of kinne. bakbeenderen. eigenlijke kauk - of kinnebakbeenderen, die aldus genoemd worden, om dat zij als in een bak of bekken de tong en de ondertongfche deelen bevatten: deze kin. nebakken vereenigen zich in een centrum vooraan, acheren in de bekleedfelen der onderlip: in oude dieren kunnen zij na den dood veelal niet van elkander gefcheiden worden, maar zijn door beenvergroeijing vereenigd In andere dieren, wclke de kinnebakken langwerpig vooruic ftcken, zijn dezelven verdeeld, en liggen op de knekelvelden meest afgefcheiden; die van jongere Koeijen vindt men, na de verrotting der weeke deelen, ook doorgaans verdeeld; voorts worden deze been deren gevat in de groeven van het os temporum.

b $b$ Is de zijdelingfche ftrekking van de kinnebakken. 


\section{VA N HOLLA N D. 4I5}

c Het centrum der vereeniging aan de kin en de infnijding der kinnelippen.

HET

RUNDVEE:

$d d$ de onderlip met deszelfs borstelachtige haren, en daarin zeer zigtbaar de acht onder - fnijtanden in derzelver waren ftand.

II. Afd. VIII. Hoofdit:

$e e$ de tandsgewijze lellen van de onderkaken, die tegenwerken tegens die van de bovenkaken, (in Fig. 4 bij $d d d d$ afgebeeld) welke tegenwerking dusdanig is, dat de tandachtige uirftekken van beiden de kaken, in de werking der herkazuwing, in en op elkander fluitende, en door de beweging der kaken fchurende, daar door het geweekt voedfel fijner kleinzen, en altoos het fijngekleinsde en herkaauwde voedfel naar achteren drukken, waartoe dit wonderlijk geftel volmaakt gefchikt is; want deze tandlellen zijn juist in beide de kaken altijd naar achteren glooijende, in diervoege, dar de fijne chijl en her fap van het voedfel als van zelve en zonder veel moeite wordt doorgeflikt: deze zachte beweging, waar toe ook de tong veel helpt, kan men warnemen, als men de Koeijen in rust onder de herkaauwing - ziet nederliggen.

$f$ is de tong, zoo naauwkeurig mogelijk De tong: in het klein afgebeeld, zijnde dit genoegzaam om het bedoelde alhier te verklaren. De tong kan en moet men verdeelen in tweeërlei gedeelten, te weten, het dikke achtergedeelte, hetwelk tegenwerkt tegen het gladde verhemelte, in Figuur 4 


\section{NATUURLIJKE HISTORIE}

HET bij $b b$ en $f f$ vertoond, en in het voorfte en bewegelijkfte gedeelte.

II. Afd. $g$ vertoont het dikke achtergedeclte kenneVII!. Hoofdit.

lijk: hetzelve is zecr bol, vol porien, en doet over deszelfs ronde verhevenheid de gekleinsde fpijze over het ftrottenhoofd $m$ in den nokdarm gleijen, en bij de herkaauwing het gedeeltelijk verteerde, of liever geweekte, wederom in den mond komen. De kennis van dit deel, ten minfte de oplettendheid op deszelfs gezonden ftand, is van gewigt voor den Landman, nademaal de eerfte kenmerken van ongemak, ongefteldheid der maag, ziekte, kuch, longevuur en de blaar zich hierin opdoen, en dit deel zich gezwollen vertoond.

$\mathrm{Bij} h$ is het voorfte en bewegelijkfte gedeelte der tonge alzins bezer met zeer fijne porien, doch inzonderheid op zijde, alwaar ter wederzijde eene rij buisjes als tepeltjes zich opdoen, en waaruit fijne vochten vloeijen; men moet dezelve niet verwarren met de ondertongfche klieren (glandulae fublinguales). Deze liggen onder aan de tong, voornamelijk onder her diktte achtergedeelte, on ziin hier nier zigebaar; in de holten der kinnebakken zijn derzelver uitloozingen: bij de befchrijving van Fig. 6,7 en 8 zijn dezelve nader ontleed.

i $i$ ter dezer plaatfe, beftaan, onder de tong, en tusfchen de tong en de kiezen, de monden of buisjes die van de ondertongfche klie. 


\section{- A N H O L L A N D. 417}

klieren hunne uitloozing, in het ganfche bekken der kinnebakken verfpreiden, tot ${ }^{\text {RUNDVRE. }}$ aan en langs de beklcedfelen der kiezen II. Afd. en tanden, doch zijn hier, door de na- vill. - tuurlijke ligging der tong, niet te zien, Hoofdrt. maar door dezelve bedekr.

$k k$ duiden den waren ftand der kiezen aan. Il zijn de tongbeenderen, die onmiddelijk door eene menigte tongfpieren, hijzonder in de Koeijen, eene fterke beweging in de tong bevorderen, zoo dat ik gelove niet te dwalen, als ik ftelle, dat onder alle viervoetige dieren, er gene ziin, die meerder kracht met de tong oefenen, als de Koeijen. De Honden die fterk lekken, doen dit altijd met eene flappe tong. De Roofdieren, Tijgers en het KattengeNacht, hebben fcherpe gedoornde tongen, doch geene kracht om dezelve verre buiten den muil te brengen, om derzelver kortheid. De Koeijen daarentegen kunnen de tong verre uitrekken, zoo dat dezelve in, over en om den neus flingert. Als men op de ftallen kome, en de Koe wil vriendfchap toonen, rekt dezelve haar

. tong uit; iets dat weinig andere Dieren doen

we toont de liggging van het ftrottenhoofd tusichen de tongbeenderen.

Dus verre gevorderd zijnde dat wij de Het ftrotfmakdeelen en de chijlwerking van de tong tenhoofd. en het verhemelte der Koeijen hebben voor. gefteld, gaan wij over tot de juiste afbeel$\therefore$ ding 


\section{I8 NATUURI,IJKE HISTORIE}

หET ding van het zoo naauw verbonden geftel RUNDVEe. der fpicren en der tongbeenderen, vooral II. Afd. aan het ftrottenhoofd en andere declen; vilr. welke afbeeldingen nu achter den andeHoofdr, ren volgende, alleen door de eenvoudige verklaringen, volkomene ontleding zullen opleveren.

PlaatXIII. Nu komt dan voor Plaat XIII. Fig. 6. Fig 6. vertoonende de tong eener Koe, met alle deszelfs fpicren ontbloot, zeer duidelijk onderfcheiden in die uicwerkende vermogens, die de Koeijen in het bewegen der tonge bij uitftek eigen zijn: de letter a vertoont dan de top, tip, timp (apex) of het uit. einde ter tong, doorgefneden bij $b$. Uit deze timp, dat de regte Hollandfche naam is, (topje yan de tong, zegt men) fpruisfieren ten nu twee voorname lange fpieren, walder tong. ker vezelen regt nederloopen Deze fpieren ziet men bij $c c$ : dezelve beflaan de wanden van de tong ter wederzijde. Zij hebben het vermogen om de tong in te krimpen en uit te rekken, en oefenen de eerfe kracht in het grazen, dewijl hunne vereeniging in den timp of top der tonge eindigt, midden uit de opgemelde fpieren Ipruiten twee aanmerkelijke zijdelingfche fpieren $d d$, door denzelven is die bijzondere kracht aan de Koeijen eigeu, om onder het grazen de tong ter wederzijde te bewegen : zij zijn zeer fterk, en oefenen eene kracht, evenredig an het gebruik, dat deze Dieren er van maken, verre boven die van den Mensch of andere Dieren, die de. 


\section{$\checkmark$ A I HOLLA N D. 419}

dezelve wel hebben, mar òp verre na zoo fterk nier. Deze fterkce is in de Koeijen ook noodzakelijker, om dat zij door die II. Afd. kracht het gras links en regts kunnen affcheren, te meer, om dat de eigenlijke tonVIII. Hoofdit. ge, namelijk het geen men het fponsachtig gedeelte noemt, en bij $e$ aangeduid is, niet in ftaat is om te werken bij het grazen, maar alleen om de fmakdeelen op te flurpen.

Onder deze fpieren ontfpruiten nog de twee lagere zijdelingfche fpieren $f f$, welker werking is, om het achterite gedeelte der tong te befturen, tor plaasfe, alwaar de doorlikking of liever overglijding der gekaauwde en herkaauwde fpijze, deszelfs fmaak aan het verhemelte mededeelt: dit gevoel van den fmaak nu, wordi eindelijk verfijnd door nog twee kleinere fpiertjes $g$, welker inlijving uit her gaapbeen (os Hyoides) en de congbeenderen ontfpruiten, en wel aan het oppergedəelte derzelven bij $h$; maar nu hebben de gemelde gaap - of tong- Tong. beenderen in hunne kom, bij $i i$, insgelijks ren. $_{\text {ren }}$ spieren, die hetzelve helpen werken, en door die werking in het doorllkken fluiten en ontluiten, op dat daar door de gekaauwde fpijze, of de fappen daar van. niet in de longeklep dringen of overvloeijen als het dier ademhali, warom ook zelfs de horenen of beenen van her gaapbeenderge. ftel $k k$ altoos niet alleen $\mathrm{kraakbeenig,} \mathrm{masr}$ zelfs in het midden met buigzame geledin. gen zijn, terwijl onder derzelver boog, wederom fpierrjes $b$ zich opdoen, die op de lon. 


\section{4:0 NATUURLIJKE HISTORIE}

Het longeklep $m$ werken, en vooral op het RUNDVE. fchildvormige kraakeen $n n$ (CartilagoII. Afd. (cutiformis) van het ftrottenhoofd $r$ pas. VIII. fen, terwijl alle de tongfpieren, en de worHoofdit, tel der tong zelve, eindigen in de twee eigenlijke tongbeenderen, die beide geheel afgefcheiden van het frottenhoofd, bij wijze van twee verwijderde beenderfchenkelen bij 0000 te zien zijn; dan, ook midden aan deze zoo kennelijke en van de tong onaffcheidelijke beenderen, die men zelfs in de gerookte Koetongen erkenuen kan, zijn twee zeer fterke breede fpieren $p p$; deze fpieren zijn de voornanmfte, die de kracht der doorflikking ocfenen; zij zijn het, welker werking men in het herkaauwen der Koeijen uitwendig ziet; zij zijn het, daarenboven, welker gevoel de Koeijen buirengemeen beminnen, en er gaarne aan geftreeld worden; niets behangt deze dieren meer, dan dat men zachtjes met de hand tegen den ftrot op deze fpieren aanwrijft. De Koeijen fteken den kop vooruit, en laten zich vrijelijk aan deze deelen betasten, de wrijving hier aan maakt haar lodderig en gedwee. Zoo heeft de Natuur in deze groote forfche dieren dat teeder gevoel in deze ondertongfche fpieren gelegd; gelijk dan ook de twee zenuwen $9 q$, te weren, die van het zesde paar, juist an de plaats dezer gevoeligheid, door het fchildvormig kraak. been en het frottenhoofd invloeijen naar de tongdeelen; wijders is bij $r$ de annwijzing van het ftrottenhoofd; bij s s twee fpjeren, 


\section{VA N II O L L A N D. 42x}

liggende tegen den cerften ring van de lon gepijp, welke bij $t$ wordi anngewezen; alle welke ceelen nader bij de befchrijuing II. Afd. der ademhaling zullen voorkomen.

De declon der ondertong in hunne eerfie VIII. Hoofdet: rigting vertoond zijnde, vooronderftelt mén PlaatXIIr. nu in Figuur 7 van Plaar Xill, dat dezeive Fig. 7 . weggenomen zijnde, de tongfpieren in eene andere gedaante vooritellet.

a Is wederom de timp der tong: warineer van onder deszelfs punt de middellijn der tong van $b$ tot $c$ wordt afgefcheiden, van de fcheiding des ondertongfchen bekleedfels en de opgemelde lange bovenfpieren (van Fig. 6 bij $b$ en $c c$ ), dan vertoont zich cene anmerkelijke fleuf, van $b$ tot $c$; deze leuf nu ontvangt van wederzijden cene fpier, dewelke beiden afgefcheiden en bloot gelegen, als twee vleuge. Ien $d d d d$ zich uitfpreiden, doch in derzelver natuurlijken ftand, wanneer zij vereenigd zijn, de dikke en bolle vleeschachtige zelfftandigheid der tong maken, in zoo verre, dat deze vereeniging uitwendig onder an de tong ontdikt wordt, zoodanig, dat zij de zoogcinamde tong, of svermnaad formeren. De Boercn, en buiten deze vele anjeren, fpreken veel van den tongworm, als mede van den tongriem, zoo als men de kinderen hier van laat fuijden: deze tongriem of tongworm, zoo als men die gewoon worino is te noemen, is niet anders dan bet vetvlies of velachtig middelfchor, hetwelk tusfchen de fcheiding dezer fpieren gelegen is. Dd

Dit 


\section{NATUURLIJKE HISTORIE}

HET Dit middelfchot ontvangt de fmakzenuwen RUNDVER en blocdvaten van de onderkin en van

11. Afd. dic kracl, (nader in Fig. 8 te zien); de

VIII. Landleden kennen dit gedeelre, en doen Hoofdit. hetzelve door kwetfing met fchaar of mes wel eens bloeden, wanneer de Koe fterk kucht of flaauw herkaauwt. $Z$ ij noemen het dan, gelijk gezegd is, tonoworm: in der daad vindt men fomtijds Koeijen, welker tong aan deze fpieren zwaar gezwollen en meestal klierachtig is, hetwelk de Joden als een onrein teeken anmerken, voornamelijk an de twee zijdelingfche fpieren, gelijk aan die, welke in Figuur 6 bij $d d$ zijn afgebeeld, doch hier wederom in eene andcre gedaante omgeflagen voorkomen bij $e e$; deze fpieren bewegen insgrlijks de tong zijdwaards, inwendig met volle kracht op het gaapbeen werkende; waar achter insgelijks al wederom twee kleine fiertjes zijn bij $f f$, wier invloed op de achterfte buis der tong aan de longeklep werkt, tegen het kraakbeenig uitttekje $g$, waar van de wanden bij $h h$ nederglooijen, en vervolgens binnen derzelver kring het week vel der longeklep (Laryngs) beflui. ten; bij $i$ komt het ftrottenhoofd, en bij $k$ het fchildvormig kraakbeen, voor; bij Il zijn de fchenkels van de tongbeenderen: bij $n m$ derzelver hoofden, door welke tong. beenderen de tong aan de kaakbeenderen wordt ingelijfd, en dus de fterkte en de bewegingen der tong niet alleen onderfteunen, ssaar genoegzaam geheel en al de fteunfe- 


\section{$\checkmark A N H O L L A N D^{\circ}$}

len en bafis der tong zilit, dermate, dat door middel van deże beenderen de tong Rundves. der Koeijen eene zeer fterke kracht kan oe II. Afd. fenen, zonder van de medewerking vain het vill. ftrottenhoofd afhankelijk te zijn, te meer, Hoofdt. om dat de fpicren van dit ftrottenhoofd meerder gefchikt zijn tot het uit - en ina. demen en het geluid geven, dain wel tot het doorflikken en kerkaaumen, want in dit opzigt bekomen deze tongbeenderen met hun aanhechtonde fpiercn meer gemeenfchap met het verhemelte, warint zij fluiten, en dus tevens met de âanhechting des nokdarms, welke hier an verheeld is; $" n n$ zijn de beweegfuieren der tongbeenderen; bij oo ziet men de zanuwen, die door hee fchildvormig kraakben invloeijen; $\not p p$ duiden twee groote fpieren aan, wier werking tot het geluid betrckking heeft, gelijk ook de fpiertjes $q q$, tegen den eeriten ritig der longepijp $r$ annigggende:

Nu dient Plate Xill. Figuiu o voorna- pil xitto meijik om den invloed van den fmaak door Fig 8. het zenuwgeftel, en tevens de fijne vaatjes op de binnenfte pponsachige zelftandigheid Sponsacka der tong aan te toonen: deze zoogenaamde tigkeid. fponsachitige zelfitandiglicid en fijaheid van het vleesch, herwelk, als het ware, niet fpierachtig, maar zaangedrongen fchijnt, is overbekend op den Holwandichen disch, alwaar een fmakelijk fchijfje van eene fijn gezoute en gervokts Kostung, zelfs in den mond van tandelooze grijsards en jọn. ge kinderen, als wegfmele, en door de tong 


\section{NATUURLIJKE HISTORIE}

HET tegen het gewelf van het verhemcle als fijn RUNDVER genalen wordt. Dit fponsachig gedeelte,

II Afd. hetwelk voornamelijk de boventong beflaat, vili. vertoont zich hier binnen - en onderwaarts Hoofdift bij $b$, beginnende van de timp $a$, en ein. digende onderaan, in deszelfs heuf $c$ : hetzelve wordt wederzijds omvangen door de twee lange fpieren $d d d d$, ter wederzijden de figuur en form der cong uitniakende, gelijk die wok in Fig 6 en 7 zijn aangeduid, en hier insgelijks op de nok van de tongbeenderen zijn ingegroefd bij $e e$, maar, daar het in deze Figuur voornamelijk op aankomr, zijn de twee groote zenuwtakken $f f$, welker fpruchtels in de middellleuf van de fponsachtige zelftandigheid der tong indringende, het gevoel van den fmaak aandoen; zij worden vergezcld door fijne bloedvaatjes, en békomen voorts gemecnfchap met de chijlvaten, in deze onze Plaat bij Fig 1 , 2 en 3 zoo naauwkeurig afgebeeld: hier evenwel zier men hoe fijn deze zenuwrakjes zich verfpreiden, waartoe dan nog bovendien medewerken de twee zenuwtakken $g g$, dic bciden achter en om de gaapbeenderen invloeijen, terwijl al wederom nog twee anderen, welke door het fchildvormig kraakbeen en het frottenhoofd invloeijen, bij $h h$ te zien zijn. Eindeliik zijn hier wederom kenbaar de aangrenzende deelen en beenderen, in Figuur 6 en 7 telkens herhaald, en dadelijk bij de Figuren 9, 10 en I I gelijk ook bij het geftel der longen naauwkeuriger te verklaren; hier zul. 


\section{v A N HOLLAND. 425}

zullen wij lechts de annwiizing vo!gen der letteren. Bij ii zijn de fchenkelen van de RunDver. tongbeenderen, bij $k k$ derzelver opperein- II. Afd. den of hoofden, bij $l l$ deszeifs beweeg- VII 1 . fpieren, doch bij $m$ ziet men nog eene afHoofdit: zonderliike fpier, welke in de voorige $\mathrm{Fi}$ guren niet is angeduid, en die alleen gefchikt fchijne oin de onderfchenkelen van de tongheenderen te bewegen, gelijk de anderen het bovengedeclte; $n$ is het ftrotten. hoofd, $o$ het fchildvormig kraakbeen, $p p$ zijn al de fpiertjes tegen den eerften ring der longepiip leggende, en $q$ de eerfte ring van de longepijp. Alle deze Figuren nu, zamen genomen, maken, vereenigd met onze afteekeningen en aanmerkingen, nar ons inzien, een kort en vatbaar geheel uit van het zintuigelijke in den fmaak der Koeijen, benevens de chijlwording. Hoe nu de Koeijen verder de fmak tot dit of bijzonder onderwerp onderfcheiden, is voor ons onoplosłelijk, zoo dat men voor cen fpreekwoord houd: over de keus en den fmaak is nict te oordeelen.

Ondertusfchen daar de tong en fmaakdeelen, mitsgaders derzelver zenuwgeftel, zulk een naauw verband hebben met de longe. kleplpieren, en over het geheel met de deelen van den hals, de ondertong, de borst, en als 't ware, aldus de zintuigelijke vermogens te zamen voegende, die het leven, de beweging en de ademhaling bevorderen, zoo geeft dit ons cene gepaste gelegenheid om allenks tot dit onderwerp over te gaan,

$$
\text { Dd } 3 \text { war: }
$$




\section{AATUURLIKE MISTORIE}

xet waartoe wij dan ande:mal en ten laatifte uUNDVE: ons van de onvergelijkclijke fchoone afbeel-

II. Afd, dingen van CAsseri bedienen moeten, als V111. waar door men een volkomen begrip kan Hoofdit: vormen van het geheel inwendig zamenitel der binneilarkfche fpieren, varen, kiieren, longebuizen, fmitak -, fpraak - en geluiddeelen der Koeijen: voorwar geen klein ontwerp om ons ook de frank der fieren te bevijizen; de oneindige kunstrijken roeftel alleen tot deze vermogers, roepen ons tos, om, als 't ware, volgens jobs getuigenis, , de dieren des velds, de vagelen des Hemels, de visfchen der zee te vragen, en elk een van deze zal ons lecren dat de hand des Heeren, des wijzen Scheppers, dit alles doet, dit alles gemake heeft voor en naar den aard wa elk dier, herwelk tor zijne wijze doeleinden beftemd is."

Zoo gij dan, waarde Lezer! nog al meer wilt overtuigd zijn, zoo mijne arbeid uwe onderzoeklieverhid mag opwekken, vestig dan het oog op de overhecrli ke Figuren 9 , 10 en II op deze Plaat XIII. en welke naar die van den oplettende J. casSERI PLACENTINUS zin gevolgd Wij heb. bon dezelve in dit ons werk onontbeerlijk geacht en deelen die mede met derzelver verklaring.

piaat XYI. Plat SIII. Fig. 9. vertoont een Koei. Fir. 9. in. jenhoofd, rustende op de ftarre en het werdige voorhoofd, ao dat de huid, langs de kin fpieren tot aan den gorgel doorgefneden zijnde, de 


\section{VA N H O L L A N D. 427}

ligging der fpieren en verdere deelen duide- HET lijk aanwijst.

II. Afd.

a $a$ a $a$ is de huid van het hoofd langs de VliI. onderkin, tor aan het borstbeen toe, langwerpig doorgefneden en alhicr omge- van het vouwen vertoond, tevens met de vet - en Kociien. nlijmvliezen daar aan verknogt.

$6 b$ de beiden voorfte uitfiekken van de onderkaakbeenderen, of her kinnebakken.

cc De zeer bijzondere fpieren, welke van het uiterfte der kin af, tot an hot gaap. been ( 0 S Hyoidis) toe, door eene zeer bijzondere fchuire zamentrekking der fpiervezelen, dit gedeclte befturen, zonder ecnige betrekking tot andere fpieren, en dus als in een bijzonder certrum, overlangs tot het ftrottenhoofd zich vereerigen, om welke rede de Ontleedkundi. gen deszelfs werking in de modulatie der geluiden nog niet hebben kunnen bepalen. did Twee dergeiijke vezelige fpieren, die in de ronde omloopende, de beweging der tonge als in een gietvorm begunstigen.

$\varepsilon$ Her centrum der fpiervezeleil an het wit en kraakbeenig uitfek van het gaapbeen of den gorgel. Dit gedecite is in meest alle dieren, inzonderheid in de Koeijen, zoo bloot en vrij van bekleedfelen, het zij ver - of fpiervliezen, dat het zich altoos glad en viak vertoont, ten ware er eene geweldige afrukking van deszelfs eigen deelen plaats had.

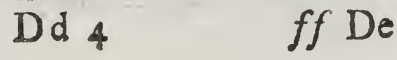


$\underset{\text { Rov }}{\text { het }}$ ff De fterke kaauw - of herkanwwipieren (Masfeteres), die allier zeer kennelijk II. Afd. derzelver inlijving in het binnen-bekkevili. neel en derzelver nederlooping an de Hoofdif. kaakeenderen aantoonen. Deze fpieren zijn in de Kocijen, gelijk in andere die. ren, zeer zwaar en fterk, doch, zoo ik niet mis hob, zijn zij in de Koeijen ronder en meerder centraal in derze! ver inJijving, zoo dat hier door de bewegingen ir hec herkaauwen losfer, en als het ware draajender zijn: welke aanmerking wel eens een rader en taanwkeuriger onderzock overwaardig is.

g.g 'Toonen de twee fpieren aan, die links en regts langs hec gaapbeen loopen. CASSER I merk $\mathrm{a}$ an, dat dergelijken in den Mensch niet gevonden worden, althans niet zco als in de Koeijen, waarin geen zenuwachtige zamenloopingen zijn; dan, hieromtrent merk ik aan, dat mecst alle fpieren, in welk foort van dieren het $z i j$, die namelijk in het ftrotenhoofd, de longeklep of de longepijp zijn ingelijid, nimmer eenige peesachtige zamenloop hebben; ja ik vertrouw niee mis te tasten, als ik flel, dat het gene men in het gorgelgefel kraakbeenig noemt, eigenlijk uit dezclfde zelfftandigheid beftant, als de peezen in de uitcinden der fpieren, want gelijk alle werkingen der fpieren en derzelver vezelen uit het zamentrekkend vermogen cer concentratic in de peezen beftaat, 700 is het gevolg warachtig, dat, de. 


\section{A N HOLLA N D. $4: 9$}

dewijl er geene zigtbare peezen in het ftrottenhoofd enz gevonden worden, dan ook zeer zeker de inlijving der fpierve. II. Afd. zelen aan die declen die werking geven, die anders de peezen in de Musculen VIII. Hoofdet. aan de beweging der beenderen veroorzaken: dan, ook dic laat ik wederom voor nader onderzoek over, ja merke ook dit aan 2 ls het verborgene, 't geen de Goddelijke Makor ons nier wil doen kennen, op dat de wonderliike geluiden der dieren zijne wonderen verkondigen.

thit Duiden aan de gemeenzaam werkende fpieren, welker inlijving in den top van hit borstbeen (fermm ) begint, en die wederzijds in eene twecledige verwijde rirg ant de longeklep of het ftrottenhoofd zich verdeelen, zoo dar deze fpie. ren volitiekt alle beweging van het openen en fluiren der longeklep, en vervol. gens de ademhaling bevoideren, ja die geheel befturen, en die dus zeer duide. lijk, als 't ware tweeledig, uit de andere rweeledige zich verwijderen, en de eene - tak zich inlijfe in het gaapbeen i os Hyoi. dis), en het andere in het fchildvormig kraakbeen (os ccrtiliggo Scutiformis)

ii Zijn wederom twee langwerpige fpieren, uit denzelven oorfprong der opgemelde fpier die insgelijks in het gâapoen zijn ingelijfd.

$k k Z_{i j n}$ de andere takken der opgemelde fpier, bij $h h$ befchreven, in den ftand waarin dezclve het fchildvormige kraak Dd 5

been 


\section{$433^{\circ}$ NATUURLIJKE HISTORIE}

игт been en de longeklep bewegen, zoo dat

Rundver. eigenlijk de aanduidingen van $h h, i i$ en

II. Afd. $k k$ tot elkander betrekking hebben.

VIII. $l$ Het kraakbeen van het ftrottenhoofd van Hoofde. voren.

In $m$ m De geheele longepijp, van bet ftrottenhoofd tor aan de longen bloor liggende, zoo als dit gedeelte in alle dieren bloot ligt, en zich volltrekt niet be. weegt, dan door zijne eigene tusfchenringige fpieren, die op eene bijzondere wijze de kraakbeenige ringen, waaruit dezelve beftaat, op en neder bewegen, za. mentrekken of ontlasten, naar mate do beweging der fpanning en ontfpanning der longen in de ademhaling werkt. Over. waardig is het, om hier over den beroemden CASSERI in te zien: ons beftek laat niet toe om alles, wat hier deswegens kon afgebeeld worden, voor te dragen, doch echter zullen wij dadelijk, zoo veel mogelijk, hier van nader fpreken.

$n n n n n n$ Wijzen aan twee zeer lange fmalle fpieren, welker incnting begint ter we. derzijden san de tepelsgewijze uitftekken van het bekkeneel, en loopen tot aan het borstbeen, waarin zij zijn ingelijfi, doch die in hun middelfte of dikfte gedeelte, als in eene omvouwende gedaante, in zich zelve eene draaijende beweging maken, zoo als duidelijk in de Figuur biijkt. 


\section{vA HOLLAND.}

0000 Zijn wederom twee lange fpieren, нвт onder en nass de opgemelde liggende, RUNDVRE. en welke mede in het borstbeen zijn in- II. Afd. gelifd, doch die niec tot aan de hoofd- vint. beenderen loopen, maar in en ann de uit- Hoofdrs. ftekken der wervelbeenderen van den hals ziin ingeënt.

pp Zijn insgelijks twee fpieren, die uit verbreedende vezelen van de geheele borse in ecn fmaller zamenvoeging eindigen, en mede in de uitftekken der nekwervelen zijn inge ënt. Deze en alle de opgemelde fpieren dienen om in de ademhaling de borst en het borstbeen te bewegen, te fpannen of in te binden.

99 Duiden de plaats en de gedeelten der fchouderbiacieren aan.

rr Twee gedeclten van tepelsgewijze fpier; vezelen, boven het borstbeen.

Dus verre deze Figuur van casseri verklaard zijnde, volgt de tweede, niet minder aanmerkelijke, zijnde bij ons op Plaat XIII. Fig. ro.

Ten aanzien van deze Figuur zijn wij verplige te melden het geen CASSERI er van PlaatXIIr. zegt, te weten, dat het fommigen zoude Fig. 10 . kunnen toefchijnen, dat in deze Figuur we-gel. derom dezelfde anwijzingen voorkomen, als in de voorgaande Figuur 9, maar de. wijl het zeer zeker is, dat men de werking en platfing van het eene deel, in eene regelmatige on regtchapen ontleding, niet dui- 


\section{NATUURLIJKE HISTORIE}

H: duidelijk aan het verftand kn brengen, zonRUNDVRE. der de aanduiding der-naast medewerkende

If. $A f d$. deelen, zoo zal dan deze Figuur, voor den visi. opmerkzamen, een zeer duidelijk licht verHoofdft. fpreiden over de voorgaande Figuur 9, en de nog volgende Figuur a $\mathbf{t}$, welke dieren moet om het keurig geftel van den gorgel der Kocijen te leçren kennen. Dus is dan vij

a a a a a wederom de omgeftroopte huid van het hoofd, met alle deszelfs daar aan verknochte vleczige en vezelige vliezen, eren als in Figuur 9.

b6 $\mathrm{Ziin}$ de kinnebakken, geheel bloot en van derzelver bekleedfelen gezuiverd.

c c Duiden aan de vezelfpieren, gedeeltelijk ...in de vorige Figuur 9 bij $c c$ verklaard: dezelve werken tot de doorflokking. $d d$ Zijn insgelijks de vezelige fpieren, in Fig. 9 bij $d d$ verklart.

- Is wederom het centrum der fpiervezelen aan het uitftekend gedeelte van het gaapbecn: zie deszelfs verklaring in Fig. 9 bij $e$.

ff De kaauwfpicren (Masfeteres), even als hier .voren Fig. 9 bij $f f$, doch met dit onderfchcid, dat dézelve hier geheel bloor liggen.

$\mathrm{g} g$ Is de plaats. waarin de kwijl-en chijl. fpieren, mitsgaders die der tong (hier voren belchreven) zich bevinden, doch hier waggenomen ziju.

$h \hat{h}$ Lijn twee piramidale fpieren, die in Fig. 
Fig. 9 niet zijn afgebeeld, doch hier een нEт bijzonderen aundache verdienen, om dat RUNDver; zij, wit het gaapheen ontfpruitende, in II Afd. de tong of her tongheen eindigen, $\mathrm{cn}$ aldaar volftrekt, nict alleen de werking der VIII. doorflokking en uitnokking van het herkaauwen bevorderen, maar ook het geluid en geloei door de beweging der tong moduleren.

$i$ Is het ftrottenhoofd, afgefikeiden van alle andere deelen, die hetrelve bedekken, dermate, dat hetzelve volkomen zigtbaar is. $k k$ Vertconen twee fpieren, die gemeenzaam de longeklep befturen, en in de klieren (Thyroides) van hetzelve ingewikkeld liggen, en ook het gaapbeen of hec ftrottenhoofd regeren

Il Zijn de twee takachige fpieren, die in Fig. 9 bij $h h$ zijn afgeheeld, en welkar onderfte gedeelten aldaar gedeeltelijk bedekt waren, doch hier geheel ontbloot zijn, zoo als dezelve uit het borstbeen ontfpruiten.

$m m$ De affcheiding en tweeledige fplitfing van beide deze fpieren, die hier dunner, niet te min langer worden dan het on. dergedeelte, wordende daarom tweebee. nig (biceps) genoemd.

$\{n$ De inlijving van de dikfte dezer tweebeenige fpieren, in en an de longeklep. en het ftrottenhoofd. zeer duidelijk verbeeld: zie ook Fig. 9 bij $k k$.

-00 De langite en dunfte dezer fpieren, (zie ook Fig. $g$ bij $i i$ ) die in een cen- 


\section{NATUURLIJKE HISTORIE}

HET

RUNDVEL.

II. Afd.

VIII

Hoofdit.

trum vereenigen, en zich inlijven in het witte bultje of uirftek van het gaapbeen, in Fig. 9 bij $e$, en hier door de boven. fte letter 0 aangewezen.

$\not p$ Ter dezer plaatfe zijn twee fpieren, of liever, naar onze gedachien, fpiervezelen, die geen centrum in cene peesachtige zamenloop hebben, maar alleenlijk in het fchildvormig krakbeen overdwars zijn ingelijfd, en eene bewegingskrache hebben, onafhankelijk van eenig ander gedeelte: deze fpiervezelen zijn dermate in het kraakbeen ingelijfd, en hunne aan klevingen daar aan zoo fibtiel, dat zeer vele leerlingen en in de ontleedkunde onbedrevenen dezelve niet alleen niet cens kennen, maar die ook te gelijk met het ftrottenhoofd uitnemen on overflaan.

$q$ Duidt de tusfchenringfpieren der longepijp ann: deze zijn alleen eigon aan el ken ring van de longepijp, en worder gezamenlijk door een taai vlies verecnigd: dic vlies kennen wij nog nict regt, maar ons vermoeden, rustende op veler. lei proeven, is dat dit geheele vlies, alfchoon het geene vleezige vezelen vertoont, echter in zich zelve enkel en geheel en al uit vezelen beltaat, die deze tusfchenringfpieren niet alleen, maar de geheele buis der longepijp befturen; al thans dit is zeker, en ik blijve borg voor de waarheid, dat, eer men in taat is om deze tusfchenringfpieren te onderkennen en het kraakbeen te zuiveren, men vole 


\section{A N H O L L A N D. 435}

volftrekt dit vlies niet anders dan als dradige vellen kan affcheiden. Deze aan-RUNDVEzd merking is dan wederom eene toegift van II. Afd. onze ondervinding.

r r Zijn twce fpieren, die het gaapbeen en hoofdit. de longepip ter wederzijde bewegen, en walke in Fig. 9. niet te zien zijn.

ss $\mathrm{Zijn}$ lange en breede fpieren, dewelke uit het bostbeen ontfpruitende, in de uiteinden der halswervelen ingelijfd zijnde, den hals en het beklseneel bewegen.

t t t t Twee zware fpieren, die in hunne oorfprong: zeer breed zijn, doch in hun uiteinden fmaller worden; deze worden uit het cerite paar ribben geboren, en eindigen zeer fnal, almede in de dwarfche uitfekken der halswervelen; deze bevorderen de bewegring der hals.

yy Twee andere gezellige fpieren, onder de opgemelde liggende a an en omtrend welke dezalve oor zijn ingelijfd.

$x x$ Twee dergelijke fpieren, onder de op. gemelde liggende.

yy Twee zeer zware fpieren die an de fchouderblacien verbonden zijn, en dezelve met betrekking tot het hoofdgcftel beweegen.

$\approx z$ andere fterke fpieren, die op de beweging der armen of voorvoeten betrekking hebben.

A A Gedeeltens van de borstfpieren in hun bovenfte ligging, die insgelijks op de beweging der armen, en in het gemeen op 


\section{$43^{6}$ NATUURLIJKE HISTORIS}

- at al het hals - en hoofdgrftel werken. D:rundver. ze zijn het eigenlijk, waraan de Koeijen II Afd. gaarne gefreeld worden, en die de geVIII. voeligheid in de Koeijen op het ganfche Hoofdit. zintuigelijk geftel van her hoofd veroorzaken, zoo als wij bij het fpreken ovçr den kosfem gazegd hebben; men ziet dezelve hier gedeeltelijk, doch zij verbreden zeer fterk naar onderen, to: in cien kosfem of çc borst zelve: zij omvangen aldaar in de vecklieren den zweferik.

P1. xirr. Gelijk dan in de voorige afbeeldingen op rig. 11. Plast XIII. Fig. 9 en 10, alle de fpieren en derzelver inlijvingen zijn afges Snieren beeld, zoo dat de bovenfle weggenomicn kaswen bevorde. ren, enz. zijnde, de onderfte te voorfchijn komen, zoo komen nu in Figuur I1. die fpieren te voorfchijn, door de voorige bedekt, en wij zullen nu eene volledige verklaring geven ten aanzien van de gruj. te kanuwfpieren (Masfeteres), van de fpieren van het fanpbeen (os Temporale), gelijk ook van die van het gaapbeen, korcon van die fpieren, die volltrek de krache der herhaauwing, doorflokking en adembaling bevorderen, en ook het itrottenhoofd regeren.

a a Toont zeer duidélijk aan den juisten ftand en de plaatfing der ache tanden.

$66 b 666$ is de omgeflagen huid mer het haar in de anhargeride deelen.

fc De onderkaken-beenderen. 
$d d$ Twee lange zeer fterke fpieren, die ter wederzijde in de kin, en van onder' in Rundver. het gaapheen eindigen. Deze fpicren be- Ir. Afd. wegen volftrekt de kin, en door hunne zamentrekking regeren zij ook het geftel VII'. van het ftrottenhoofd over het geheel, in dier voege, dat ik voor mij vastftel. le, dat de fterke kracht van deze fpieren, (welke men bij andere dieren, ten ware bij de Paarden, zoo fterk niet vindt) dat fchorre geloci en gebulk der Koeijen veroorzaken, om dat zij de kin alleen door deze fpicren befturen.

- is al wederom dat krakbeenig punt van het gaapheen, waarop alle fpieren van dit geflel concentreren, doch hier in deze Figuur van dezelve ontbloot.

If Dir zijn twee bijzondere vlerkgewijze vlakke fpieren, die, als het ware, het bckleedfel der anderen uitmaken, ten minfte bij wijze van een middelfchot, ter wederzijde van het gaapbeen on ftrottenhoofd zich in de breedte uitfpreiden, en daarna in een zeer fijne draadsgewijze pees zamentrekken, welke pézen eene draads - of wormsgewiize beweging hebbende, in de achtereinden der onderkaak eindigen, en aldaar tevens met de werking der kinnebakken, eene volftrekte . heerfchappij oefenen over het flokgeftel. g g Duiden zeer fterke fpieren aan, die in geene der voorige Figuren zichtbaar zijn, echter onmiddelijk op alle hier vooren E. Hoofdit, 


\section{NATUURIIJKE HISTORIE}

SHET

RUNDVEE.

II. Afd.

VIII.

Hoofdit,

befchreven fpicren van het frottenhoofd en de longeklep betrekking hebben. In hun oorfprong fchijnen zij vliezig, daar na worden zij volkomen fpierachtig en vezelig, vooral dane zij het ftrottenhoofd naderen: in han midden verdeelen zij zich in twee takken, volkomen vleezig, waar van de twee langfien ter wederzijde zich ook aan het gaapbeen inlijven, en in het midden cen zenuwachrigen ring formeren, welke men fpierkracht (robur musculorum) noemt: on zeker het is aan en door deze ringen, dat deze fpier zoo wel een bijzonder vermogent heeft in zijn bovengedeelte op de ademhaling en het geltrid, als op de herkaauwing en op de krache der ontfpanning van de borst en den kosfen.

hh Twee dwarsgeplante fpieren, dic de tong bewegen, en vooral in het horkaalwen, bij de doorzwelging en oprisping, de tong drukken.

ii Nog twee nederwaarts glooijende fpieren, die elk ter wederzijde insgelijks de tong behulpzaam zijn met betrekking tot de kaken en het oppergedeelte van het ftrottenhoofd.

$k k$ Twee dikke bolle fpieren, welker krachtdadige werking van de inlijving an het gaapbeen en ftrottenhoofd, tot aan den wortel of het achterfte zware gedeelte der tong zich uifftrekt.

ll twee voorname fpieren, die onder van 


\section{$\checkmark A N$ H O L L A N D. $\quad 439$}

de plaatfing der kaauwfpieren, tot in het faspbeen zijn ingelijfd, en voomamelijk RUNDVER. ie eerfte ka?uwing en kneuzing van her gras, ais mede ae herkauwing, bevorderen.

II. Afd. '1! I Hoofdn.

s $m$ Toonen ann die buitengewoone dikke en zware, als 't ware, ronde Ipieren, die in alle Dieren genoegzaam, zoo in - als uitwendig, de holte, die er tusfihen de kaken en de flagen van het hoofd zijn, vervullen, en die van zulk eene verbazende kracht zijn in het fluiten en ontfuiten der kaken, dat men met geen geweld dezelve. zonder den wil van het dier openen kan; men noemt dezelve de groote kaakfpieren of kaauw - en herkaauwfpieren ( $\lambda^{\prime}$ cisfeteres), om dat zij de kiezen in het kaauwen en herkaauwen helpen : hierom ook kinnebakfpieren (Mandiuulares) enz. ginoemd. Deze fpieren behoort ean Veehoeder vooral te kennen, zoo in derzelver figuur, als plaating, om dat zij aan eene verrekking of kramptrekking (hetwelk men de yijuer in de Paarden noemt) onderhevig zijn, cn hetwelk, vooral in de Koeijen, opmerking verdient, want ook in de ftroefheid of llipheid dezer fpieren, lige het kenmerk van de ongelteldheid en ziekte der Koeijen, zoo dat men door eene wrijving of anprikkelend middel, veel kan te weeg brengen tot derzelver herftel. Voorts zijn deze fpieren uii zulk een fijn vleesch zamengefteld, dat hier

$$
\text { Ee } 2
$$

a22. 


\section{NATUURLIJKE MISTORIE,}

HST

RUNDVEE.

II. Afd.

VIII.

Hooldit.

an de beruchte lekkernij van een grebradon kalfskop is toe te fchrijven, althans bij onze Hollanders is dit overickend.

$n$ Het gedeclte van het thottenhoofd, onder de fpieren zigcbaar.

o 0 Is de aanduiding van de ronde fpieren, die de ftror zijdelings befturen, in hun waren fiand.

$p p$ De kraakbecnige ringen van de longe. pijp, van hunne tusichenfpieren, (bij Fig. 9 en 10 be(chreven) gezuiverd, oin derzelver waren ftand te zien.

$q q$ De plats der ooren.

gr De oorell.

ss De hoornen en de kruin.

Door deze aanduidingen, vertoouwen wij, dat de ligging der declen in bet hoofd, op Plaat Xll1. in de drie Figuren 9, 10 en I I afgebeeld on daarbij befchieven, voor ecn ieder vatbaar zal zijn.

Tot hier toe, zoo kout ons beftek toc. lat, deze drie opmerkelijke Figuren 9, 10 en I I verklaard hebbende, valt het onzes bedunkens niet moeijelijk, deszelfs zamen. hang en betrekking op elkander te bevatten, althans wij hebben hier door leeren kennen en opmerken, hoe ook het wonderlijk geftel der herkaauwing, ademhaling en berveging der tonge, het ftrottenhoofd, mitsyaders de kaken en fmaakdeclen onderling, in dit ontzaggelijk Dier werken, in zoo verre, dat Plaat XIII. Fig. 1, 2 en 3 wel onderzocht zijnde, ten aanzien der zenuwen: 


\section{V.A N II O L L A N D. 441}

en kwijlklieren, gelijk ook die van den reuk, нвт den fmaak en der andere zintuigelijke dee- RUNDVER. len, als ook het verhemelte, de tong, de II. Afd. lippen, de tandgewijze lellen, mede op vir. Plaat XIII in Fig. 4 en 5 afgebeeld enz. Hoofdn. zoo zullen de drie Figuren 9, 10 en. II, vergeleken met Figuur 6,7 en 8 , ( al mede op Plaat XIII.) een volkomen licht geven aan het fpiergeftel van het hoofd, hetwelk hier volkomen in zijn ftand ligt, zoo als de gezonde ontleedkunde zulks vordert, en zeer zeker aldus nict kan blifven, als men de vaten, zenuwen en klieren afzonderlijk wil vertoonen, in wclke grevallen de fpieren en beklcedfelen moeten weg genomen worden.

Hier mede bevelen wij onzen Lezers en den naauwkeuriger Opmerker deze Figuren, terwijl wij, danr bij berustende, nu eenige aanmerkingen over, en de afbeelding van her ontbloot kaakbeen, van alle fpieren gezuiverd, zullen laten volgen.

Dus wordt dan op Plaat XIII. bij Figuur I 4 derkaken vertoont een bijna levensgroot onderkaakbeen uic een Kalf, hebbende zijne volkomen kiezen en tanden, waar door de eer. fe knaging van het voedfel bewerkt wordt: men telt in de kaken veelal vier kiezen: fommige tellen er vijf of zes, doch welke relling de regte niet is, om dat men meest acht geeft op de inwendige uitpuiling der liezen, en niet op derzelver wortelen, die in de groeven en holten der kinnebakken befloten zijn; want als men de kiezen uit de kaslen uitligt, bevindt men, dat de Ee 3 kroo- 


\section{NATUURLIJKE HISTORIE,}

HeT kroonen wel verdeeld fchijnen, en voor af RUNDEE. zonderlijke kiezen genomen worden, maar 31. Afd. ondercusfchen zijn de grootfe derzelven VIII. verenigd, en bijzonder zijn cle groote kieHoofdrt. zen van onder in drie, de rolgende in twee worcleinden verdecld, zoo dat, wil men his naar berekenen, dan hebben de Koeijun er acht, en juist beantwnordt dit getal ann de punten en uitftekken der kroonen, gelijk in Figuur 15, 16. 17 en I8 te zien is; evenwel, nademaal de kroonen veree. rigd zin, is elke kies met twee of drie wortelen man eenzelfde been, en dus tel ik er niet meer dan vier, met een kleine voorkies, waarmede her getal vijf is: evenwel laten wij anderen in hunne tilling vrij. Alle de kiezen liebben holle groeven en geulen, waarin het gekaauwde als gekleinst wordt; de kroonen zijis fcherppunig, en beantwoorden an de groeven der bovenkiezen : in de Kalveren zijn dezelve vrij puntig en fcherp, doch in oude Koeijen worden zij ftomper en gindder door de gedurige fchuring bij het herkasuwen, her geen in alle dieren, inzonderheid in de Parden, plaats heeft; de voortanden worden door den tijd zeer giad, vooral na de wisfe. ling, waar van wijuitvoeriger fpreken zullen bij de verhandeling over de voortteling en den wasdom der Kueijen : deze Figuren dienen bij voorraad tot dat onderwerp, maar hier bijzonder om de werking vaniden muil en het verhemelte (in Fig. 4 en 5 van deze

Plaat

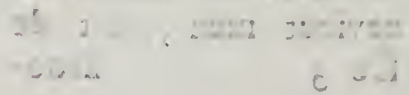



Plant XIII. afgebeald) nader op te hel- $\begin{gathered}\text { Het } \\ \text { deren. }\end{gathered}$
RUNDVE.

Fig. I4 dan vertoont een geheele Kalfs- II. Afd. kakbeen met de kiezen; in Fig. 5 bij $k k$ VIII. zijn dezelve in her klein anagewezen, doch hier in het bijna levensgrootte. Hoofdif. Pl. XIII, Fig. 14.

a a Zijn de uitflekken der kaak, die in derzelver groeven van de bovenkaken fluiten. $b j b$ Is de eigenlijke kinnebak, dus genaand om dat de kiszen in de holten van dit been als in cen bak liggen, galijk ook de fniitanden aan de kin.

cc Is dus de bak der kiezen.

$d$ De bak der tanden aan de kin.

$e$ De eerite groote kics, die maar een wortel heeft: zie dezelve levensgrootce in Fig. 15 .

$f$ De tweede groote kies, die een dubbele kroon en drie wortels heeft: zie dezelve in Fig 16 levensgrootte.

g De derde groote kies, met drie kroonen en twee wortels: zie dezelve levensgrootte in Fig. 17.

$h$ De vierdo grootc kies, met twee wor. tels: zie dezelve levensgrootte in Fig. 18. $i$ Een uitpuilend voorkiesje.

$k$ Vier der voorfte finitanden aan den muil, of hat halve gedeelte der kin of kaak : zie Fig. 2 en 5 , als mede dezelve in Fig. 19 levensgrootte.

Plaat XIII. Fig. I 5 verbeelde levensgroot- PI. XIII. te de achterfte kies met eene wortel, ge- Fig. 15. Ee 4 heel 


\section{NATUURLIJKE HISTORIE}

нет heel uit de kas genomen, warin men dan zundVE ook maar eene holle groeve ziet: deze

I'. Afd. groeve is in de natuur met een zeker foort

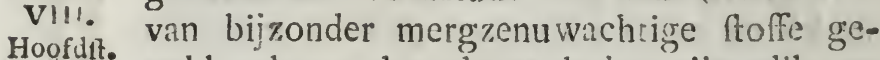
vuld; de randen dezer holte zijn dik en zwaar van been, glad als ivoor, en wordic van den boventand gefcheiden door een foort van dwarfchen ring of rand, zoo als dit in alle kiezen plaats heeft; dezen rand verbindt door fterke pezen de kiezen aan derzelver kasfen (Alveolae), ter plaatfe daar zij uit de kasfen vrij en open tusfchen de wanden der wangen en het verhemelte zich vertoonen; de top dezer kies, gelijk als alle anderen . loopt fpits toe met eene ronde fcherpte, bij wijze van eene hellebaard of fpierfe; derzelver randen krullen op zijde om, en formeren eene geul ter wederzijds, waarin de fappen van het gekaauwde en herkaauw: de uitvloeijen naar de keel en den flokdarm. Deze en de volgende kiezen ziet men hier aan den binnenkant, en dus moet men zich dezelve voorftellen als nier uit het kaakbeen, hetwelk in Fig. 14 verbeeld wordt, maar uit het andere, daar tegen overliggende, te zijn genomen.

a Is de wortel, met de groeve of geul in de kaken.

$b$ is de ring, die de bovenkies in de fluiting der kiezen - kas verbindt en vast. houdt.

C Is de fpits der kies.

$d d \mathrm{De}$ twee zijdelingfche geulen. 


\section{A N H O L L A N D. 445}

Plaat XIII. Fig. 16 is de groote dubbele kies, die aan den middenrand vereenigd is, doch onderaan in twee groote ingerol. de wortelen, en in her midden in een groote en eenige kleinere wortels eindigt. Het is op deze kies en die van de boven- Pl. XIII, kaak, dat het dier zijne ferkfte krache in Fig. 16. her kaauwen oefent. Deze kies ftaat in de kaken ook iers hooger dan de voorkiezen, welker rigting in de Figuren is in acht genomen, gelijk men zier; dat de kiezen Fig. 17 en 18 ook lager ftaan dan Fig. 16, zoo dat nooit de kiezen in eene gelijke horizontale vlakke rigring liggen, maar eenigzins bogtig, hetwelk verfchilt van de rigting der kiezen in vele andere dieren, behalve in de Elephanten, Kemelen, Scha. pon, Herten en Geiren, walker kiezen insgelijks zoodanige rigting hebben, herwelk doet befluiten, dat deze plaatfing ook bijzonder tot de herkaauwing gefchikt is, in diervoege, dat de twee voorite hiezen min'der fcherp en uitpuilende zijnde, gereedelijker tegen de tandsgewijze lellen van het verhemelte en de wangen kunnen medewer'ken, onder her herkaauwen.

a ca Zijn de diie fcherpe hoeken dezer kies, mede alleng; van de meest uitftekende achterfte naar voren lager ftaande. b6 Zijn de geulen of holten tusfchen de tandsgewijze uitftekken a $a$ a. \& De omgekrulde randen der kies.

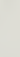




\section{NATUURLIJEE HISTORIE}

HET $d d$ De ring of de fluiting in het bovengeRUNDVE.' deelie der kas.

II. Afd. e De groote wortel, die met dubbele zeer VIII.

Hoofdit.

fierke beenranden als in een gerold zijnde, eene holle buis uitmaakt, warin he: kiezenmerg en de zenuwen liggen; in groote volwasfen en oude Koeijen is de. ze holic in hard en vast been verwandelt, en het is nict zeldzaam, cen aanwas van zijwanden als bijtakken daar aan te vinden.

$f$ Is een zelfde foort van. wortel aan den voorkant der kies.

$g$ Is eene vlakke fpitfe wortel, die uit het middelfchot fpruit: deze heeft geene holligheid.

$h h$ Zijn dirie tanden, uit de middenkioon fpruitende.

Plat XIII. Plaat XIII. Fig. IY verbeeldt de derde Fig. 17. kies: deze heeft twee holle wortelen, deszelfs toppen hebben flechts twee kleine geulen tusfchen beiden; men zict dat de pun. ten in drieën vcrdeeld zijn, en dar ieder derzelver eene infnijaing heeft, die de kroon als zespuntig maken; deze punten zijn rond. achrig ftomp; zij zin op verre na zoo fcherp niet als in de gróte kies, en dic. nen otm op de leldchrige tandien van het verhemielte tc werken, en inzonderheid bij het grazen als wanncer cene Koe terk met de tong werkt, dezelve niet te kwetfen, waarom het fchint, dat de natuur an dit 'it is

dier 


\section{VA N HOL L A N D.}

dicr geene flagtanden, fcheurtanden of hondstanden gegeven heeft, om des te gemakke. RUNDVEe: lijker het gras en het weeke voedfel te kun. II. Afd. nen kaauwen.

VIII. Hoofdito

a a a Zijn de drie verdeelde en ingefneden fpitfen der derde kies, 7.0o dat dezelve gezamenlijk zes tandjes uitmaken.

bb Zijn da twee wortelen, die, even als de vorige kiezen, ook als in een gerold zijn, en dus eene fleuf in de midden maken : wanneer deze wortelen in oude Koei. jen verharden, laten zij het kenmerk in het been na.

$c$ Is een klein middenworteltje.

d De zijrand, die tegen de groote kies (Fig. i6) aanfluit.

ee De holle fleuven der kies.

Plaat XIII. Fig. 18 is de vierde kies, Plaat XIII. die twee gladàe worteltjes en eene kleine in-Fig. 18. fnijding, welke rond neerglooit, heeft: deze Figuur, vergeleken met het gezegde bij Fig. 15,16 en 17, verklaart zich zeive.

Eindelijk zijn op Plaat XIII. Fig. I9 ver-PlaatXII. heeld vier der voortanden, in den rang zoo Fig. 19. als dezelve in den muil ftaan, levensgrootte uit cen Kalfskop genomen : in het ka. kenbeen (Figuur 1 4 ) ziet men die van de tegenzijde, zoo als ze zich op zijde vertoonen, dan hier ziet men die van den binnenkant, uit de kasfen van het andere c.... ka- 


\section{NATUURLIJKE IISTORIE}

нЕт kakenbeen genomen; zij zijn van $a, b, c$ RUNDVEE. tot $d$ allengs grooter, maar ftaan met hare II. Afd. frijranden echter waterpas in den onderVIII. muil, hetwelk op deze Plaar in Figuur 5 Hootult, zeer fraai te zien is, zoo dat wij er niet veel bij te voegen hebhen, dan alleen dac deze tanden midden in hunne lepels, zoo zal ik ze eens noemen, eene kleine holligheid heuben, die gemeenfchap heeft met het wortelmerg; in de jonge Kalveren is dit gedeclte niet zeer hard, maar na den tijd der wisfeling, welke binnen twee jaren gefchicdt, ziin zij harder; in de volwasfen en oude Koeijen worden zij harder als ivour, zoo dat men er goud, zilver en metalen mede kan polijsten, het geen bckend genoeg is; de randen dezer tanden zijn wit, doch het middenhol iets aschverviger; in oude Koeijen blijven die randen insgelijks wit, doch de holten der lepels worden dan veeltijds zwartachtig, ten minficn geel vuil. Gelijk de kiezen allengs naar voren verkleinen, zoo verkleinen de acht voortanden vier en vier naar achte. ren, gelijk uit de rangfchikking in Figuur is blijkt, zoo dat de wortel van den kleinften rand niet dieper in de kas der kaken inzinkt, dan de wortel der kleinfte kies.

Deze Figuren dan zich zelfs genoeg verklarende, wijzen wij den Lezer verder naar de lefchrijving van Figuur 4 en 5 in dit Hoofúftuk, terwijl wij over den groei en de wisfeling der ianden breeder zullen fpre. ken, 


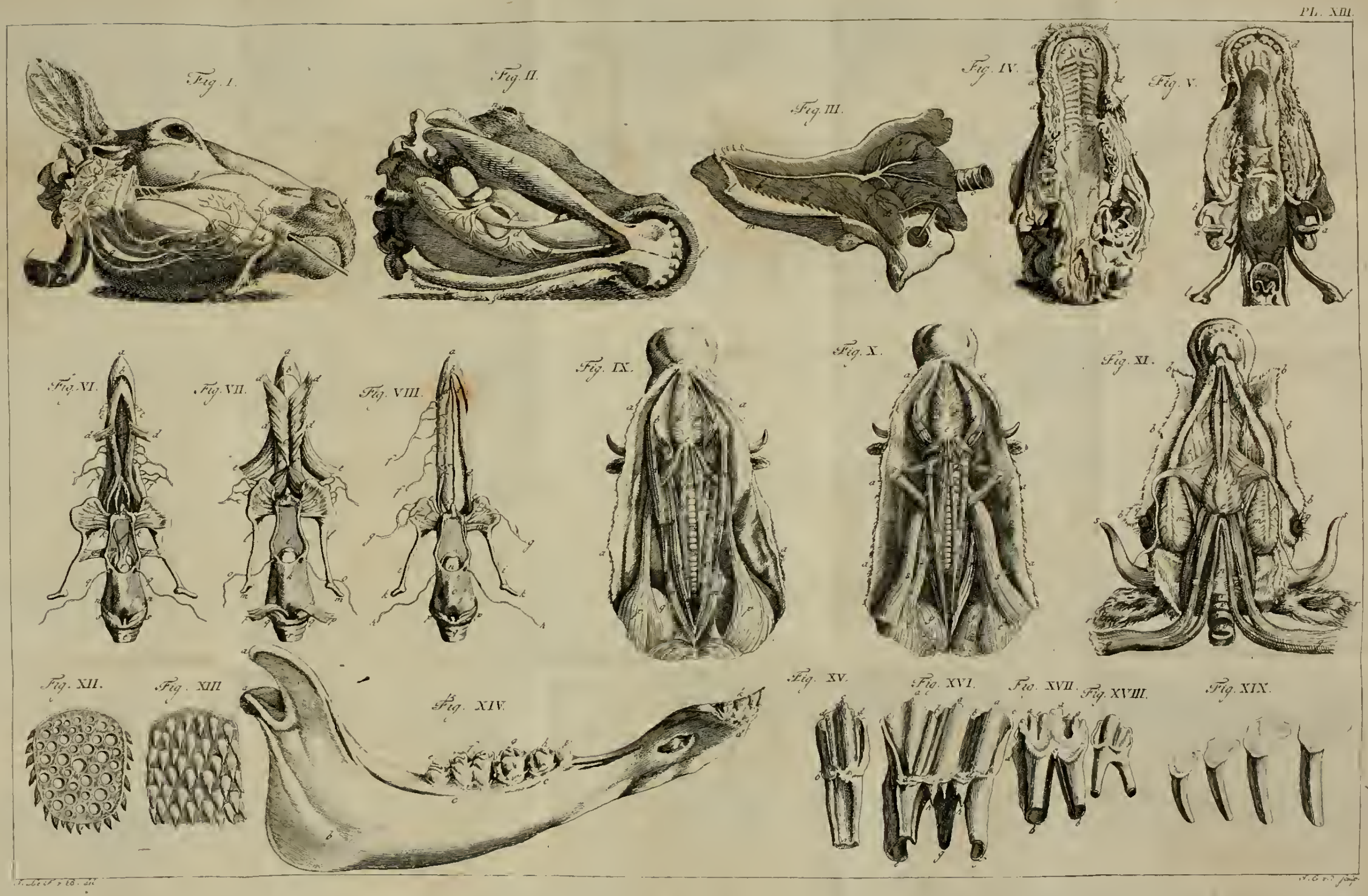




\section{VA N H O L L A N D. 449}

ken, als wij de Koeijen, van den baar. $\boldsymbol{H}^{\mathrm{x}} \mathbf{T}$ moeder af, tot de mrootfte volwasfenheid RUNDves. roe, in derzelver oudertom en kenteckenen II Af. zullen befchouwen, even zoo als wij dit VIrI. van de Parden gedaan hejben, en dus hicr Hoofult. dit Hoofdituk over de fmakkdeelen der Koeijen befluitende met cene korte aan. wijzing der Figuren op Plaat XIII, zullen wij overgaan tor de verhandeling over het gevoel. 


\section{$45^{\circ}$ NATUURLIJKE HISTORIE}

FET

RUNDVEE.

II. Afd.

VIIT.

Hoofdft.

\section{Korte Verklaring yan Plact XIII.}

De verklaringen der Figuren, op deze Plaat, zijn het geheele Hoofdftuk door naauwkeurig, van Figur tot Figuur, ann. gewezen, en dus hier overbodig; alleen zal cene korte aantlipping van her geen in deze Figuren wordt afgebeeld, hier niet geherl ondienstig zijn.

Fig. I. Verbeeldt de kwijlvaten, zenuwen en klieren, die ćen mond bevochtigen bij het herkaauwen en fmaken der fpijze.

Fig. 2. De kinnebaksklieren en inwendige kwijlvater.

Fig. 3. Verklaring van de klier - en kwijlveten omgekeerd, in tegenoverftelling van Fig. 2. met het be. loop der vaten tegen het ftrottenhoofd.

Fig. 4. Het geheele verhemelte, met de fnuit, de tandgewijze reijen, dé kieuwen, wangen en kiezen.

Fig. 5. Het onderkaakgeftel met de tong en onderkiezen, de fmaaktepels en tandlellen.

Fig. 6. De tong met alle deszelfs fpieren en zenuwen ontbloot.

Fig. 
Y A N H O L L A N D. 45I

Fig. 7. De tongfieren met hat ftrotten hoofd.

НET RUNDVEE.

Fig. 8. De invloed van den fmak in het II. Afd. zenuwgeftel, met de tongbeen- VIII. dercn.

Fig. 9. Een geheel Kocijenhoofd, van onderen omgekeert, vlak op de ftarre liggende, vertoonende overheer. lijk alle de fpieren en verdere deelen, die aan den gorgel en de fmnakdeelen zijn ingclijfd.

Fig. 10. Nadere verklaring der fpieren die onder de opgemelde liggen

Fig. I I. Derde verklaring van de ontbloote kaauwfpieren , fmaak-, tong-en andere klieren.

Fig. 12. Een ftukje van de afgepelde op" perhuid van het verhemelte, met de holten der tepelionden van de tandgewijze rijen.

Fig. 13. De tandgewijze tepels of lellen, welke in de holligheden (in Fig. I2 afgebeeld) fluiten.

Fig. I4. Het geheele kalfskakebeen van alle fpieren ontbloor, om de platfing der kiezen te zien.

Fig. $15,16,17$ en $1 \times$. De koeijenkiezen levensgroote, om de kroonen en wortels te kennen.

Fig. 19. De voortanden levensgroote. 


\section{TWEEDE AFDEELING.}

NEGENDE HOOFDSTUK.

Behelzende nadere bijzonderheden over

het zintuigelijk gevoel der Runderen, met yergelijkende aanmerkingen op dat yan den

Mensch en andere

Dieren.

\#ET In het geheele beloop dezer Natuurlijke zundver. Hiftorie van het Rundvee, en bijzonder in II. Afd. de befchrijving van het zenuwgeftel, is telix. kens melding gemaakt van het dierlijk geHoofdft. voel, en betoogd, dat alle gevocligheid Vergelij. van het dierlijk leven door het zenuwgeftel king van werkt, en in alle die oneindig fijne, aan het dierlijk het oog, ja aan alle onderzoek ontglippengevoel met de uiteindens der zenuwfpruchtels, eigendat der . lijk ook de onbegrijpelijke andoening van het gevoel der Dieren gelegen is.

In dit opzigt ftaat dus het foortgelijk gevoel der Dieren gelijk met dat der Men- 
fchen; voor zoo verre de Mensch in zijn нет ligchaamlijk geftel, tot het rijk der Dieren UnNveE: behonrt, en met uitzondering van het denk- II. Afd. beeld, herwelk de Mensch van de onfterfe- IX. lijkheid zijner ziel van zich zelve gevoelt. Hoofdits Wat de inwendige denkbeelden der Dieren betreft, hict van weet de Mensch niets, doch de uitwendige kenncliikheden en teekenen van gevoel in de Dicren, met die van zich zelve vergelijkende, moet men erkennen, dat ook de Dieren, zoo wel als de Mensch, de zintuigen van het gehoor, het gezigt, de reuk, den fmaak en het gevoel hebben; dat dus het dierlijk gevoel aan allen gemeen is; doch dat elk dier, naar zijnen aard, bijzondere uitwerking der zenuwen heeft.

Het gevoel, dus befchouwd, is eene prik- Bepaling. kelende gewarwording van alle ttoffelijke wat gevoel in - en uitwendige aandoeningen in en bui. ${ }^{\text {is. }}$ ten het ligchaam en men kan dit verdeelen in een lijdelijk, een willekeurig en een hartstochtelijk gevoel.

Het cerfte, namelijk het lijdelijk gevoel, Lijdelijk is dat levensgevoel, hetwelk wij niet kun. gevoslo nen beletten dan door zelfsmoord of baldadige verlanming: bet is dat inftinkt, 't welk wij lijden en gevoelen, zonder dat onzen wil dic kar beletten; als daar is, het gevoel van den omloop des bloeds, den poisflag, de ademhaling, en, met één woord, alle werktuigelijke werkingen des levens, al hetwelk aan den mensch en aan de dieren gemeen is, en dat door de Ontleedkundi- 


\section{NATUURLIJKE HISTORIE}

HET

gen motus fine voluntate, dat is, beweging zonder onzen wil, genoemd wordt, in te.

II. Afd. Genftelling van motus yoluntate, dat is, beIX. Houtdet. weging door onzen wil.

Wijders behoort tot het lijdeliik gevoel de invloed en aandocning van her luchegeftel en den dampkring, warin wij leven, en zonder welker invloed de dierlijke wezens niet beftaan, noch beftaan kunnen, en welker uitwerkfelen zij niet beletten kunnen te gevoelen, als daar is : hitce, koude, droogte, vocht, rijzen en dilen der verhevelingen, derzelver damp en nevelen, wind, regen en donderbuijen; mer ćén woold, al. les wat uitwendig op bet inwendig geftel, ook door tit - en inademing, werkt, doet het gevoel aan : laat ik er bijvoegen, de uitwafeming door zweeten en verftoppingen van de poriën der huid, waar voor de Kocijen meer dan andere dieren vatbaar zijn, als dieren zijnde, die in het open veld, zonder eenig dekfel of fchuilplaats, midden in den dampkring leven.

willekeu. Wat men door het tweede of willekeu. rig gevoel. rig gevoel te verftaan hebbe, verklaart zich gemakkslijk; dewijl wij als mensch waren, dat wij tot eenig gebruik van een of ander voorwerp willunte komen, hetzelve eerst betasten en vuelen of her hard, zache, week, vederachrig, wollig, droog of vochtig, enz. is; ook dar wij de zelffrandigheid van eenig dierlijk, plancaardig of delfftoffclitk wezen door het gevoel kunneu onderzotken, of wcl dit kitunen valuten: in wel. 


\section{VA N HOLLAND• 455}

welken zin wij dit gevoel ook kunnen overbrengen op de Kocijen, die ook naar ha- RUNDVEE. ren aard en inflinkt alle ztlke voorwerpen, 1I. Afd. die haar tot voedfel of in andere betrekkin- $1 \mathrm{x}$. gen kunnen dienttig zijn, voelen kunnen, Hooidito fchoon in minder vermogen dan de mensch.

Het derde of hartstochtelijk gevoel is Hartstochveel verhevener en voortreffelijker in den teijk ge. mensch dan in de dieren, en vooral is het ${ }^{\text {vosto }}$ verre boven dat der Koeijen verheven. Men kan her hartstocheclijk gevoel van toorn, gramfchap, liefde, haat, vrees, fchrik, geheugen, lennis van hun beftaan, in één woord, allerlei hartstochten en dierlijke vernuftdriften, in de groote dieren, wel niec ontkemen, maar de dierkunse leert ons echier, dat de Koeijen, onder dezclve, in dit opzigt, het minst vermogend zijn; want daar men vele dieren. inzonderheid de Honden en de Parrien, alleilei kunften kan leeren, zoo zijn de lioeijen en het herkaauwend Vee, over het algemeen, niet vatbaar noch gevoelig voor eenige kunstoefening of leerzaamheid: het eenige, waar aan men haar met moeite gewennen kan, is het trekken van den ploeg en het gareel eener trekwagen; en fchoon zij varbaar zijn voor her gevoel der zweepftriemen, ftokflagen en andere pijnen, fchijnen zij er cchter minder gevoelig voor te zijn dan de Paarden, welke dieren, fchoon mede aan de uiteriijke aandoeningen in den dampkring onderhevig zijnde, echrer veel aandoenelijker van geroel daar voor zijn, en het is om die min$\mathrm{Ff} 2$ dere 


\section{$45^{6}$ NATUURLIJKE HISTORIE}

nет dere gevoeligheid der Runderen, dat men RUNDVE. dezelve redeloos en dom noemt, en een

II Afd. mensch, welke een ftomp vernufi heeft, IX. bij cen dommen Os vergclijkt.

Daar nu alle voorgemclde aanmerkingen flechts tot eene aanleidende voordragt van de verfchillende denkbeelden over het grevoel dienen, zoo komen wij van zelve tot de bepaalder oorzaken van het gevoel der Koeijen, in tegenftelling van die der andere dieren, bijzonder die van den mensch. WVij hebben gezegd en verklaard, dat in de oneindig fijne uiteinden der zenuwen tevens de uiterlijke aandoening van het gevoel gelegen is. Deze alleruiterlijkfte aandoeningen nu liggen en eindigen in den huid der menfchen, en zoo ook in alle dieren, en wel door de in - en uitwafeming, of, zoo als men het noemt, door de opflurping en uic. drukking ( $a b$-en reforbentie), tor welke werking, behalve de poriën der huid, ook oneindig kleine tepelijes of fchubsgewijze ftipjes zich in de huid bevinden, in zeker onderfcheiden vlies, hetwelk men Epidermis noemt, en welk vlies zoo teeder en niet te min vast is, dat het, in zijne doorfchijnendheid, duidelijk de gemelde gevoelrepelcjes of itipjes vertoont.

De beroemde Leydfche Hoogleeraar в. s. ALBINUS heef dic ten volle bewezen, in de ontleding van deze fijne gevoeligheden. der huid, waar van de uitmuntende af beeldingen, door den kunstrijken J. en L. AD. 


\section{v A N H OLL A N D. 457}

MIRAAL vervaardigd, bekend zijn (*), en IRET ik kan niet nalaten deze afbeeldingen aan RUNDveE: te bevelen, om een begrip te vormen van Ir. Afd. de teedere gevoeligheid in de huid der menfchen, en dit vergelijkende bij die der dieren, te betoogen, dat narmate het gef:el, Verfchil het temperament en de fexe der dieren, ge- van het gevoegd bij het klimaat, waarin zij leven, folluen de verf́chilt, dat ook alzoo het gevocl in de verfchil huid verfchilt: als mede dat, naar mate de lendeland. uiterlijke bekleedfelen der huid verfchillen, arden en ook het gevoel in dezelve verfchilt; dus verfchilt ook de fijnheid van gevoel en zachtheid van huid onder de menfchen, en is zeer aammerkclijk tusfchen de blanken en zwarten, of Europeanen en Afrikanen. De huid der blanke Europeanen is zacht in het aanraken, maal die der Negers, bijzon. der die wolachtig haar hebben, nog zachter: in de fexe is het verfchil ook groot; de huid der mannelijke fexe, vooral die der fterk gefpierde en op de borst gehanide mannen, is zoo zacht, teeder noch gevoelig nier als die der vrouwelijke fexe, welke latite, over het geheel, eene zachtheid en fijnheid van gevoel in de huid bezit; en zOU-

(*) Van dit werk zijn ficchts zes ftukjes bekend; dan, deze getuigen niet te min, dat de eere der uitvinding om fijne ontleedkundige afbeeldingen in kleuren te drukken, aan de Nationale Amflecdamfche Kunftenaars behoort, en als nog overtrefien het geen thans door de Engelfchen in het vak van drukken in kleure gedaan wordt.

\section{Ff 3}




\section{$45^{8}$ NATUURLIJIE HISTORIE}

Rr. zoude ik wel te berispen zijn, wanneer ik; rundve als Natuurkundige, aan onze Nationale Hol-

II. Afd. landfche vrouwelijke fexe eene zeer fijne IX Howidf. teçerheid van inenfchelijk gevosl toefchreef? Bijna alle Wijsgecren, bijna alle Zede- of Minnedichters, onder de oude en nieuwe, maken melding van dit teeder gevoel, bijzonder in de vrouwelijke fese, en onze Nationale oorfpronkelijke Dichcers hebben hier in uitgenumr.

Sta mij derhalve toe, geachte Lezer! dat ik u hier op cenige verpozende liefalligheden van her zintugelijk en hartstochtelijk gevoel van mensch en dier onthale: laat ik op her voetfoor van CATS, HUIjGeNs, WESTERBAAN, en vooral van den Ridder P. c. HOoFT, die zoo vecl van deze gevoeligheden heeft opgezongen, en het zoo drok had van ftroken, freelen en vlejjen, laat ook mijn Holland, che corIDON de teedere gevoeligheid van zijne chLors eens opzingen, en op die gevoeligheid der menfchen en onze natie toepasfen.

Puikdichters! mild begaaft in teed're melodijen Van ziclsaantreklijkheid in 't froken, Areelen, vicijcn - Der vaderlandfche jeugd, en 't menfcheirjk gewoel, In 's levens prikling en 't zintaigelijk gevoel. Komt, troetelminnaars van de gỏ Fent onk het reer gevoel van cuLOKISJE, mijn fchoone, En oordeelt, of zij ook 't gevoel der godlijkheid

In de zelffandigheid heeft van de menschlijkheid? Ja of die bemelgaaf , al die anloklijkheden, Geen levensteek'nen zijn van welgevormde leden? 


\section{A N H O L L $\triangle$ N D. 459}

Beflis of mensch en dier, al wat op aarde leeft, KPT

Niet jeder naar zijn aard, gevoel van 't leven heeft? RUNDVre, Of al de aandoenlijkheid van tasten, zien en raisen, II. Afd. Niet in de zachtheid ligt van 't fireelen en genaken?

Zacht ftreelt een herderin der lamm'ren wolle vacht; IX.

Zacht frookt PALEMON ook zijn ftieren fterk van kracht ;

Zacht zijn de vlokjes van het dons der zwanenveder, Zacht is d'aantrekkelijkheid der bloemjes jong en teeder;

Zache is het wormgefpin van zijde en van fatijn;

Zacht is de poez'ligheid der fneeuwwitte Frmelijn; Men noem' het alles zacht, die teed're aantreklijk heden, Maar zacht en zachter zijn mijn CHLORIs poez'le 'eden: Zacht acsmt Zephir een koeltje in'tloof en fchomlend riet,

Maar zachter is een kusch, die chLnR Isje mij biedt: Malsch druipt de morgendaauw van muskadelle tipjes, Maar malfcher ambrozijn van chLoris rozelipjes:

Malsch is ' $t$ fluweel gevoel der purpere amarant . - Maar malfcher ftreelt en frookt mij chlozis lieve hand:

Malsch is al 't boomooft, al haar tuiltjes, al haar bloemen,

Maar ais een malf che maagd mag ik mijn cuLor Is roemen. Gansch teeder is ' $t$ gevoel van' $t$ kruidje roert mij niet. Gansch teeder freelen zich de vischjes in de vliet, Gansch teeder wil 't klimop den eikenftam omhelzen, De witte winde omvlecht de teedre wilg en elzen:

Ja! al wat teeder is, wenscht zich te zaam gepaard. Maar, chLoris in mijn arm, wensch ik niets meer op aard'.

Het af $t$ ijn moog' fomtijds dat teeder bijzijn krenken. Dan heeft het oogenlijhnog het gevoel van 'twenken, Ff 4 Ja! 


\section{NATUURLIJKE HISTORIE}

HET Ja! ondanks dat gemis, wordt door de denkingskrach

a. UNDVEF. Der ziele, her gevosl des ligchaams nog verzacht.

II. Afd. Komt aan dan, wie gij zijt, PHikdichters van DIONE!

ix. Zeg of ik in ' gevoel van chlor IsJE, mijn fchoone,

Hoofdf. Niet alles vinde, wat des leveris teederheid

Kan fchenken aan 't gevoel van dier en menschlijisheid? Niet alles vinde, wat het menfchelijk vermogen

In 't denkbeeld van 't gevoel der zicl houdt opgetongen?

Hij, die op mensch en dier het meer toepásfen wil,

Het ftaat den wijsgeer vrij, maar ik voor mij zwijg ftil.

Hoe men nu deze dichterlijke gevoeligheden wil befchouiwen, en mogelijk berispen, dezelve komen echter zeer wel bij dit onderwerp te pasfe, dewijl het ontegenzeggelijk is, dat het tcederfte, het aantrekkelikfte, ik zoude haast zeggen het fympathetifche van het gevoel, over het geheel in de huid, en in het bijzonder in de gemelde deelen, als de hals, de lippen, de handen, alierteederst in de toppen der vingeren en in do harlokken on liaard ge. legen is: dan, alvorens tot eene vergelijking hier wan, met het gevoel der Koeijen over te gaan, zal $\mathrm{jk}$ nog iets uit de theorie 'van her menfchelijk gevocl opmerken, mamelijk het verfchil van her gevoel in de verfchillende tijdperken van den ouderdom der menfchen, als in de eerite jeugd, in àe volwasfenheid en in den ouderdom.

Verfchil van het geHet gevoel is bij deszelfs cerfte ontwikvoet in de keling in het eerstgeboren kind zeer vatverfchil. baar voor den invlocd dos dampkrings; kout ler rie tijde
pe kendes de geboorte begint de huid met deszelfs ievens. 


\section{VA N HOLLA N D: 46 I}

poriën van hleur te veranderen : de huid wordt opgezet, reelal ceel, lort daarna RuNDver met een meclachtig ftof in fommige kin- II. Afd. deren als fchelferig) bezet; deze valt vervolgens af; daarna, en wcl in cen jaar tijd, IX. bekomt de huid die ongemeene zachtheid, cie bolle zachte uitpasning, welke zoo kennelijk dat tecdere op de wangen der kinderen veripreidt: deze gevoeligheden nemen van tijd tot tijd toe, en naarmate dat de wasdom toencemt en de ledematen zich uitzetten, wordt ook de huid meer uitgefpannen en de poriën en tepeltjes der huid worden gevoeliger, tot dat de wasdom volkomen is en de invloed der natuur zich in beide fexen doet geroelen, als wanneer het menf́chelijk (en osk dicriijk) gevoel in deszeifs messte kracht is. Hier nu vermindert de gevocligheid in mensch en dier naar mate dai de ouderdom nadert. Zoo dra de reedergevoulige mangd eene vrouw is en moeder zal worden, wordt dit teeder gevoel medegcdeeld an de vrucht, welke zij dragt; vervolgens geeft het gevoel, wanneer zij het eerstgeboren zogend wichtje san hareii boezem voedt, har eene ruime vergoeding yoor de fmarten, door haar, voor het kind ter wereld was gebragt, geleden; maar dan vermindert ook het gevoel, allengs als wegfneltende of verhardende; de huiszorg, het huiswerk en bedrijf, de toenemende vastheid der ledematen verininde. ren de eerfte andoenelijkheid van hetzelve: cindelijk genaakt de bevende ouderdom, Ff 5 c่ui- 


\section{NATUURLIJKE HISTORIE}

AET duizende wederwaardigheden, ziekten, pijRUNDVRE, nen, toenemende verharding der huid, verII. Afd. oorzaken dat dezelve ruuw en rimpelig en IX. gevolgelijk minder gevoelig wordt: hier bij Hoofdrt. komt verzwakking der andere zintuigen, als vermindering van het gehoor, verzwakking van het gezigt, verlamming der reuk - en fmakcieelen, minder aandoening in de vingeren en vereelte handen, eindelijk eene verharding in de huid en de gewrichten, een loomhicid in de lendenen, kortom, eene vermindering van kracht in alle de zintui gen en in het algemeen ligchamelijk gevoel (Senforium commune); dan is het gedaan met die zachte teederheden, welke wij van CILLoRIS en CORIDON zongen: de Dichters veranderen van toon; hoor den Dichter p. C. Hoort aan zijn DEUFILO het verminderen en verwelken van het gevoel zoo ei. genaardig als kunstrijk afmalen:

\section{Wilt rekeninge maken, \\ Dat deze rozekaken \\ En deze lipjes vars, \\ Die gloeijen als een kars,}

En die nu ieder wenscht te ftreelen en te ftroken, Eens zullen met er tijd verflenzen en verftroken:

De diepe rimpels, met

Er tijd, dit voorhoofd, net

En glad, heel zal onthegten;

Deez' lodderlijke vleggten,

Die nu met ftrikjes zijn zoo geestiglijk vertuit, Die zullen ' $t$ gulden kleed allengskens trekken uit, 


\section{$\checkmark A \times H O L L A N D . \quad 463$}

En't geen gij voor fijn goud hicld mogelijk voor dezen, HET Zal zilver blijken en nechts fchijnen goud te wezen: Rundver:

Deez' vlugge vardigheid,

Daar griize alwaardigheid

Gaat zonder recn op gnorhen,

II. $\mathrm{Afd}_{\mathrm{a}}$

IX. Hoofd:

Die zullen met er tijd de vleugels dapper korten:

Dan is het al re laat, als bet'ren tijà ontbreekt.

Zie daar door onzen Vaderiandf hen Hoofdpoëet het menfchelijk gevoel, als natuurlijke eigenfchap, afgefchetst, van de kracht des levens en aan den hoogen ouderdom, tot daar alle zintuigclijke aandoeningen en met dezclve het gevoel eindigt, on welke vermindering van gevoel 200 ongevoelig toe - en afneemt, dat men het niet kan merken, 200 als de Dichter H. к. Pоoт zegt:

Als de bevende ouaderdom,

Die al vast op wolle fchoenen

Aanfluipt, onze jeugd verbeilt,

Eer men't wanen kan of merken.

Tot de dieren overgaande, zoo is ten Overgang annzien van die dieren, welke men gevin-tot het ge"gerde noemt, en het naaste aan den mensch voel der komen, aan te merken, dat fommige, als dieren, bijdaar zijn de Curang Outang en andere Aap-der Kor foorten, wel eene zekere fijnheid van gevoel jen. in de vingeren hebben, mar op verre na zoo niet als de menfchen; dat dit in de naast aan hen -volgende foorten van dieren allengs vermindert, als in de Honden, Wolven en Vosfen, wier vingeren kort, ftomp 


\section{NATUURLIJKE HISTORIE}

๓eT ftomp en hard zijn; in de Kattenaardige RUNDVEE foorten krimpen de nagels op, en worden

II. Afd. op zachte kusfentjes der voetzolen ingetrnkHoofdr. ken, naarmate zij deze dieren tot gevoel moeten dienen, en bezitten ook cene groote gevoeligheid in het haar van de huid.

Eindelijk tot het gevoel der Koeijen overgaande, zoo ftaat aan te merken, dat dezelve dit gemeen hebben met den mensch, in deszelfs eerfte jeugd, dat zij gaarne aan fommige deelen. geftreeld worden en aan dez.elve het aandoenlijkfte zijn, als aan den hals, aan de kosfem of borst, achter de kruin aan de nok en aan de oxelen, gelijk wij dit bii de befchrijving van deze deelen reeds gezegd hebben; dan, wat het fijn gevocl in de vingeren der menfchen betreft, hier in zijn de gehoefde dieren, en dus ook de Koeijen, verre achter, alzoo bij haar de eigenlijke nitcinden der gevoelzenuwen eindigen en zijn opgefloten in eene hoeve of klaauw, waarin de Paarden zulk eene fterke ongevoeligheid bezitters, dat zij daar aan, zoncer merkelijke aandoening, het affchra. pen en fchroeijen met ijzers gedogen.

Hoe ongevoelig de Koeijen ook an de klaauwen zijn, zoo veel te aandoenlijker zijn zij ann derzelver kroon, te weten daar, waar het viterfte einde der huid aan de voetklaauw eindigt en zich daar mede vereenigt, ja, het gevoel hier an is zoo teeder en aandoenlijk, dat daar door het zoogenaand klaauwzeer, hoorn- en hoeffchurft ontftart; de Koeijen worden fchier dol door het 


\section{VA N H O L L A N D. 465}

het fteken van oneindig kleine infekten en torreties, welke zich aan deze kroon der voetklaauw vast zetten, en men ziet haar daar door, in de weiden veeltijds met de pooten ftampen; wijders hebben deze dieren eene geneigdheid om met de pooten in het water te ftaan, ten einde het kittelende gevoel te bekoelen. Deze teedere gevoeligheid in dit gedeelte is ann do Landlieden zeer wel bekend, en in de Vee-artenijkunde is de kennis van dit gevoel der kroonklaauwen eene der gewigtigfte onder alle de noodige kundigheden, waarom wij ook dit onderwerp, bij de verhandeling over de ziekten der Koeijen, uitvoeriger zullen behandelen.

Wat het eigenlijk gevoel in de huid der Koeijen betreft, deze is veel minder dan het gevoel in de huid der Menfchen, en dat juist daarom, om dat de huid der Koeijen veel vaster en digter is als die van den Mensch, en zelfs lederachtig; in zoo verre zelfs, dat men deze lederachtige huid als een onderfcheidend geflacht-kenmerk op de Runderen toepast: ook is van alle viervoetige dieren (den Elephant, Rhinoceros en Hipputamus of Rivierpaard uitgezonderd) de huid der Runderen het hardfte en lederachtigfte, zelfs zonder eenige bereiding door de Leertouwers ondergaan te hebben; derzelver huid kan ook zoodanig verharden door afruijing, de blaar en de pof, dat dezelve zich kaal, glad en lederachtig vertoont, en ycor het geveel van zweepllagen en de be-

HET RUNDVEE: II. Afd. IX. Hoofdet: 


\section{NATUURLIJKE HISTORIE}

HET ten der infekten onaandoenlijk is. De huid Rundver. der Parden is meer gevoelig, ten zij de. II Afd. zelve door ouderdom ongevoeliger wordt, IX. of door zweepllagen verdoofd is. De poHoofdt. riën in de huid der Kocijen zijn ook meer. der gefloten, zoo dat zij minder cigenlijk zwerten, dan andere dieren, fchoon zij ech-

- ter fterk uitdampen; de gevoeltepeltjes en uiteinden der zenuwen verharden fpoedig, en zoo wordt de huid vatbaar voor zooda. nige verharding, dat men er vast en ondoordringbaar leder nit bereiden kan: al hetwelk ontegenzeggelijk bewijst, dat dic ook als oorzaken van minder gevoel in de huid kan worden aangemerkt; dan, hoe zeer ook deze mindere gevoeligheid in de huid der Kocijen kenbaar is, zoo bezirten zij echter ecne mecralere of mindere aandoenlijkhcid, welke van de onderfcheidene lucheftreken en den aard dezer dieren afhangt, zoo dat de huid der Runderen, welke uit de Afrikaanfche on Aziatifche gewesten tot ons gezonden worden, en die der Europefche, ten aanz:en der hardheid verfchilt; en onder de Luropefche verfchillen die uit Holland, Vriesland en Groningen bij die, welke uit andere gewesten van Europa komen: dan, hoe zeer men deze meerdere of mindere gevoeligheid gadeflaat, 200 is er wederom iets, hetwelk integendeel haar, zoo wel als den ivjensch en an. dere dieren, eigen fchijnt, namelijk eene zekere natuur - eigene jeukerige prikkeling in het huidvlies, dat door die andocning, 
welke het zweet, het bloed en de uitwa- нет feming veroorzaakt, de huid geftadig aan-RUNDves doet, zonder dat eenige uitwendige oor- II Afd. zaak hier toe medewerke, maar welke jeu- IX. kerigheid men onderfcheiden moet van die Hoofdrt. toevallige jeukte, welke door huidziekten of het fteken der infekten veroorzaake wordt.

De jeukerige gevoeligheid, welke hier bedoeld wordt, is geheel iets anders : het is eigenlijk die prikkeling, welke mensch en dier, van de teedere jeugd af aan tor den ouderdom toe, gevoelt op het hoofd, in de haren, en in alle de gewrichten, waar de meeste uiteinden der zenuwen zijn, ook aan de fchouders, op de borst, en vooral langs de ruggegraat, van den nekwervel af tot aan den uiterften lendenwervel toe, en dus ook in die platefen, waar de oorfprong der zenuwen uit her hersfen - en verlengde merg is: en dat aan de haren en haartoppen een zeer fijn, ja zelffs hartstochtelijk gevoel is toe te kennen, kan men genoeg afleiden uit de aandoeningen van toorn en fchrik, als wanneer in den Mensch de hoofdharen oprijzen; in de dieren, als in de Honden, Kattenaardige geflachten enz., rijzen de haren van den kop en de lendenen.

Wat de gevoeligheid van het hoofdhaar der Koeijen betreft, in vergelijking van dat der Menfchen, hieromerent ttaat aan te merken, dat hun hoofdfchedel vooraan plat en beenachtig is, en de horenwortel het vermogen bezit om de voorhoofdfpieren en de daar in gewortelde haren te bewegen; dat ook 


\section{NATUURLIJE HISTORIE}

Het ook de gevocligheid der haren op die plants van het voorhoofd of de kol veel verfchile

II. Afd. bij dat van den Mensch, maar dat daaren-

IX.

Hoofdit. tegen die gevoeligheid der haren fterker is aan het achterhoofd tegen de nek en aan den hals; hier is het, dat de Koeijen, en vooral de Stieren en Osfen, bij de minfte aandoening, de haren oprigten.

Wegens hunne eigenfchap om zich den hals, ja het geheele voorftel tegen een boom, paal. of fchot te fchuren, om de natuur - eigen jeukerigheid (waar van boven gefproken is) te verzachten, hier van zul. len wij nader fpreken bij de befchrijving van de weiding en ftalling der Runderen.

Alvorens te eindigen, kan ik niet voorbij om melding te maken van het gevocl, hetwelk verre de meeste dieren in de knevels en fprieten der lippen hebben, en hetzelve te vergelijken met dat, hetwelk zich in de zoogenaamde ftoppels en haren aan den muil der Koeijen bevindt.

De Natuurondedzoekers ftellen eenparig, dat aan de zoogenaamde knevels, welke men aan den muil en de lippen der Katten en van genoegzaam alle gehaarde en bloedrijke dieren vindt, eene zekere gevoeligheid cigen is, van alle overige aandoeningen van het gevoel, ja zelfs van het hartstochtelijk gevoel, onderfcheiden; dat dic gevoel aan die dieren (ook aan de vogelen, welke zoodanige haren aan de fnavels hebben, visfchen enz., welke gevoelfprieten bezitren) alleen eigen en als ingefchapen en aan dezelve 


\section{A N HO L L A N D. 46ुg}

dienftig is, om daar door de alleruiterfe HET gewarwordingen van het gevoel, elk naat ${ }^{\text {Rundves。 }}$ zijn ard en eigenfchap, tot upfpeuring van II Afd. zijn voedfel of afwering van fehadelijke aan- IX. doenirgen te kunnen gebruiken, on cus de Hoofdlto uitgeftrektfie vermogens van het zintuigelijk gevoel, zelfs in vereeriging met alle de overige zintuigelijke andoeningen, uit te oefenen.

De Kosijen nu zijn met zoodanige lange haren, fprieten of roelers an den muil en de lippen niet voorzicn, maar integendcel zijn de haren aan den muil, fruit en bovenlip der Kocijen kort, hard, borstelig en ftomp, zoo als men in onze afbeelding der reukdeeien op Plaat XII. Fig. I 4 duidelijk ziet vertoond, zoo dat deze groote dieren, tegen de meeste kleine vergeleken, geene zoo groote gevoelfprieten en haren aan de lippen hebben, hetwelk ons al we. der opleid tor bewondering der wijsheid van den Schepper, die, gelijk wij van alle de andere zintuigen eerbiedig hebben opgemerke, ook hier onze aandacht opwekt, om te betoogen, dat het gebit, de muil en de lippen der Koeijen natuurlijk gefcha : pen zijn, om kort op de vlakte der aarde het gras en de kruiden af te bijten, en als fchuivende langs den grond voort te grazen. Aan haar zouden dus zoodanige lange knevels, fprieten en voelers hinderlijk zijn, en zij zouden het gras zoo kort niet kunnen afbijten en afgrazen als zij nu doen, of zij zouden teffens hare knevels, fprieten

\section{$\mathrm{Gg}$}

of 


\section{NATUURLIJKE HISTORIE}

нет of voelers afbijten, ten minfte zich zelRUNDVEE, ven pijn aandoen: al herwelk ook is toe

1i. Afd. te pasfen op alle kort langs de aarde gra'x. zende beesten, als Schapen, Geiten, Her. ten, Paarden enz.; terwijl aan deze dieren het gemis der lange knevels, fprieten en voelers, aan den muil, en het daar in liggende gevoel, fchijnt vergoed te worden door de gevoeligheid en beweging, welke zij in de oorlellen en oorharen bezitten, en hetwelk men in de Koeijen duidelijk ziet werken ter afwering van infekten en vliegen, wanneer zij ftil en gerust grazen of liggen te herkaauwen.

Verdere befpiegelingen over het zintuige. lijk gevoel nalatende, zoo befluiten wij dit Hoofdituk en teffens de verbandeling over alle de zintuigen der Koeijen, in vergelijking met die van den. Mensch, alsmede dit Stuk dezer Natuurlijke Hiftorie yan het Runa'vee, terwijl het volgende Stuk, be. vatcende de verhandeling over de inge. wanden, nu ftaat te volgen. 




$$
\begin{aligned}
\text { SPELIAC } & 78-B \\
& 340^{24} \\
& \checkmark 5
\end{aligned}
$$




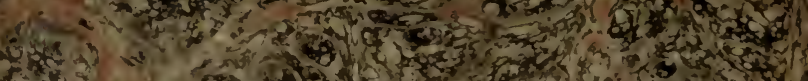

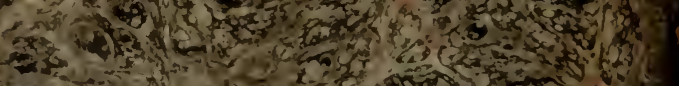

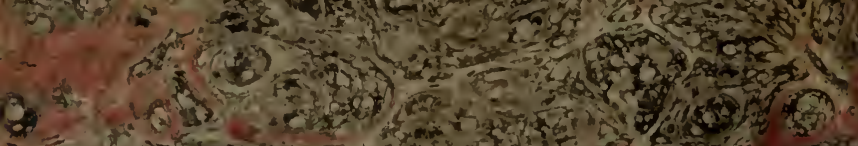

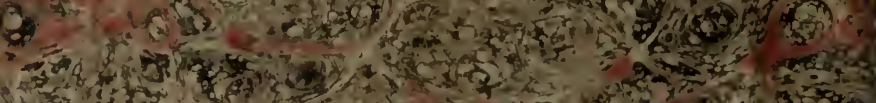

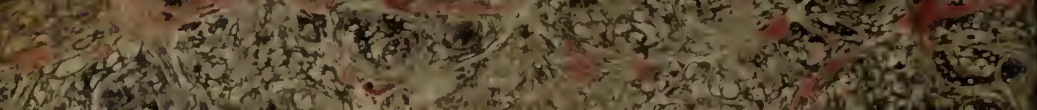

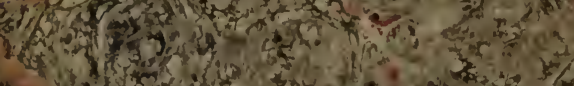

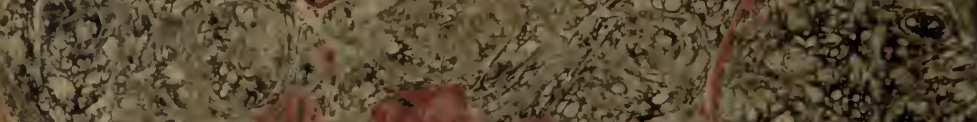

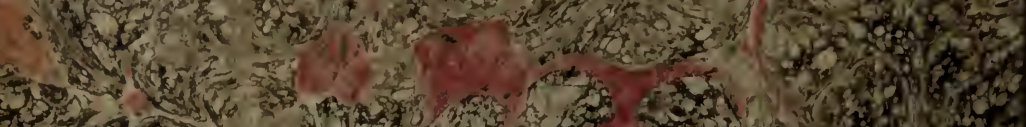
3.

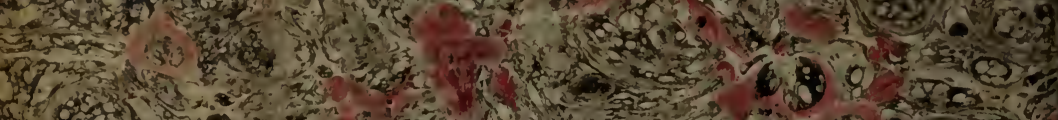

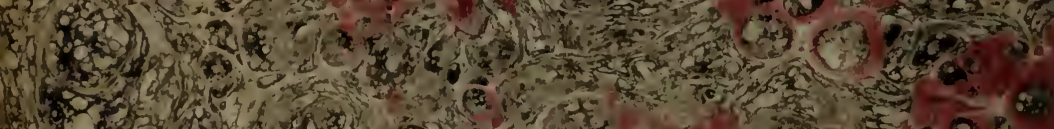

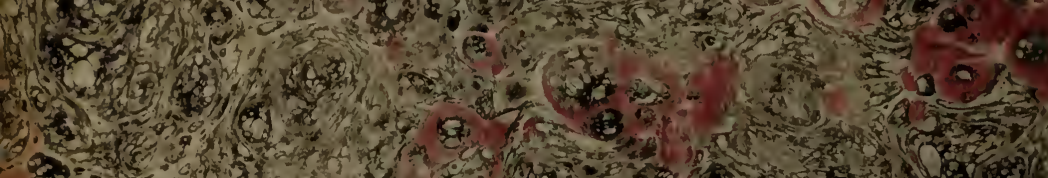

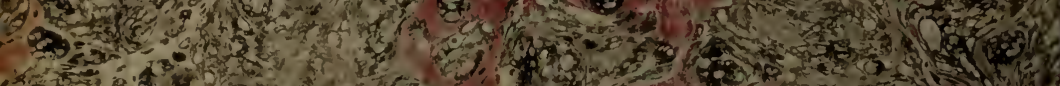

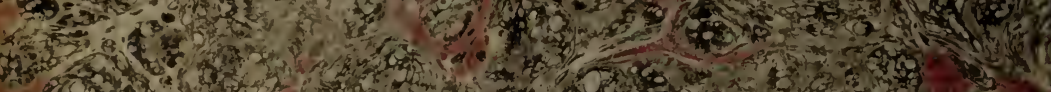
(3)

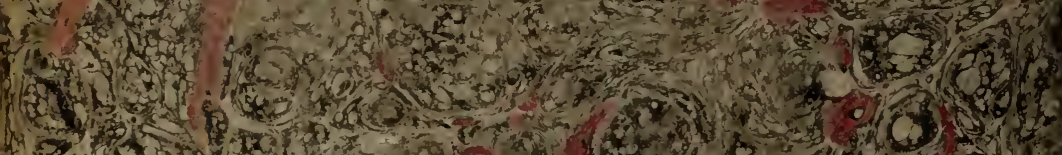

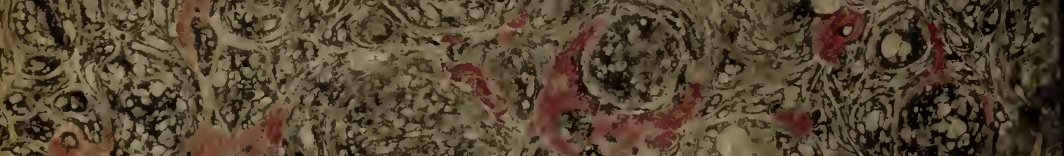

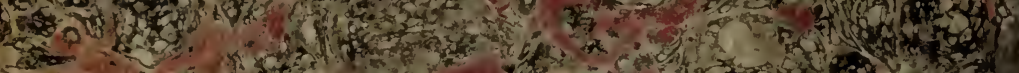

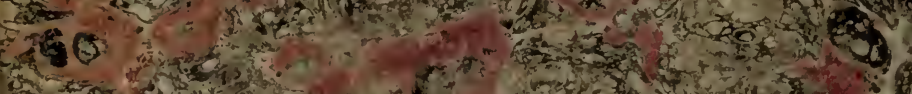

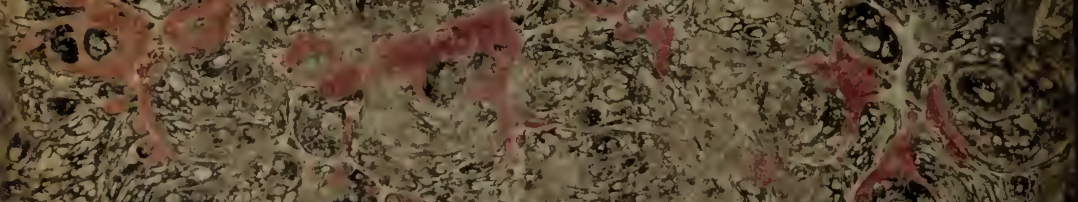

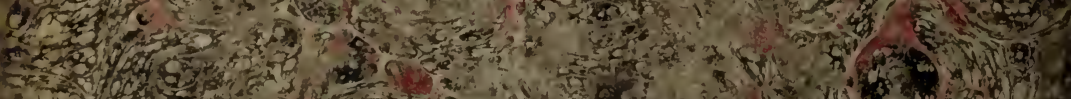
(3)

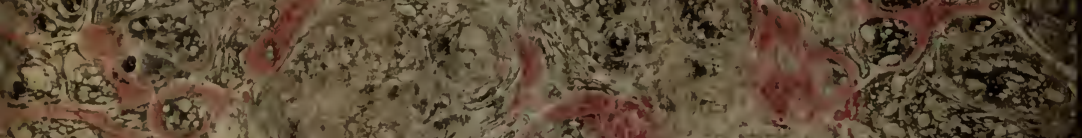

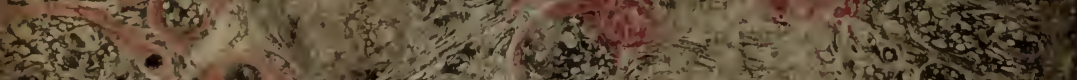

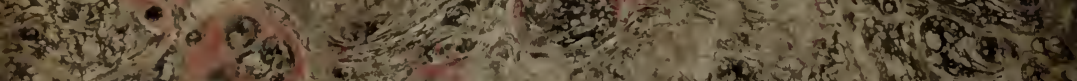
$00^{2}$ 4.t.

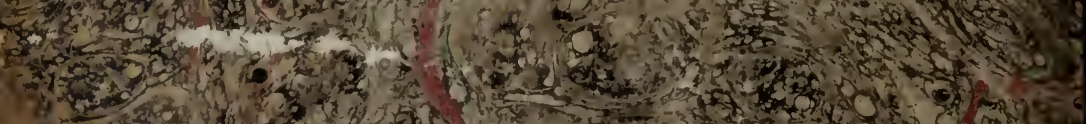

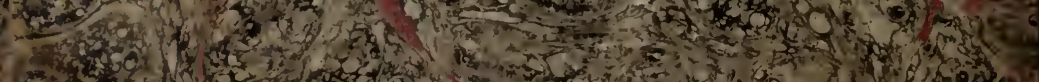

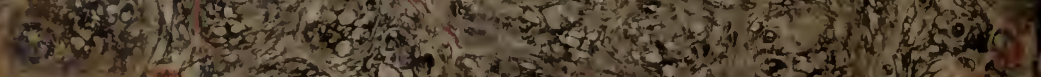

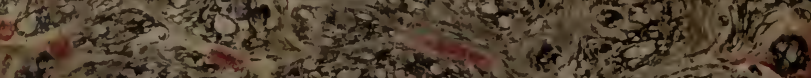

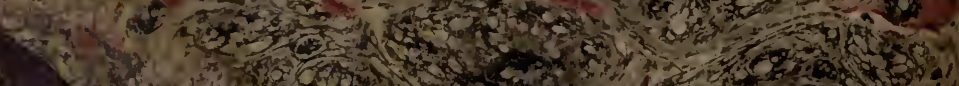

